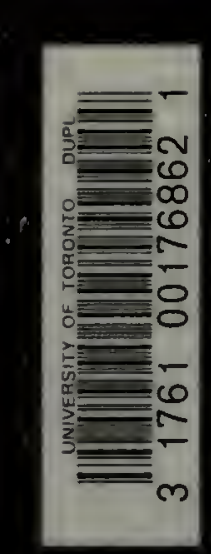



Digitized by the Internet Archive in 2007 with funding from Microsoft Corporation 


THE

LIFE, LETTERS AND LABOURS $\mathrm{OF}$

\section{FRANCIS GALTON}




\section{CAMIRIDGE UNIVERSITY PRESS \\ C. F. CI,AY, Maxager}

TLOHדH: FETTER LANE, E.C.

EDilturgf: 100 PRINCES STREET

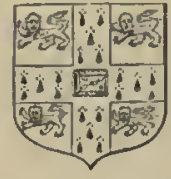

IIonton: H. Li. LLWIS, IBG GOWER STREFT, W.C.

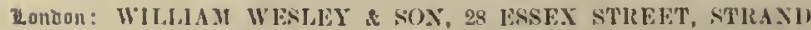
Brrlin: A. ASEIER AND CO.

Zeipgig: $Y$. A. BROCKHAUS

pew Rork: G. P. PUTNAM's sows

bombav and (alcutta: MACMLIhAN ANI) CO., LTH.

Toronto: J. M. DEXT ANI) SONS, LTIr.

Tokño: 'TH: MART\%EA-KABLSHIKI-KAIRHA 


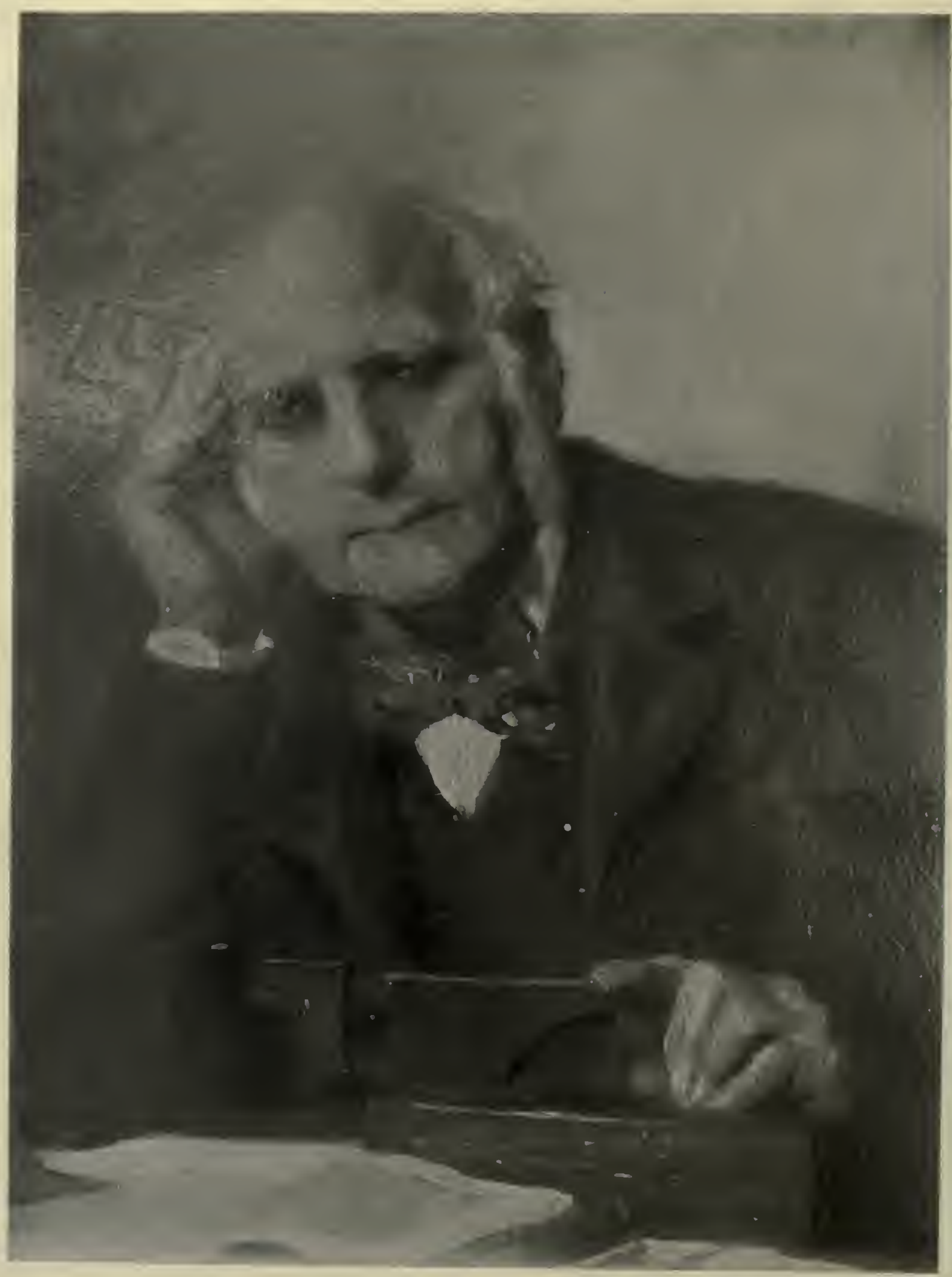

FHANCIS GALTON in 190:?.

From a photngraph by the Author of the untinished picture by C. W. Furse at Claverdon. 
THE

LIFE, LETTERS AND LABOURS

$\mathrm{OF}$

\title{
FRANCIS GALTON
}

\author{
BY \\ KARL PEARSON \\ GALTON PROFESSOR, UNIVERSITY OF LUNDON
}

VOLUME I

Birth 1822 TO MARRIAGE 1853

Cambridge :

at the University Press

1914

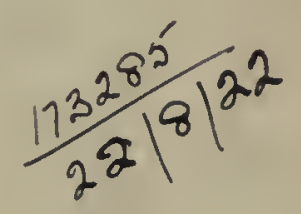




$$
\begin{aligned}
& Q \\
& 143 \\
& G 3 P_{4} \\
& V .1
\end{aligned}
$$

$$
\begin{aligned}
& \text { Cambrioge } \\
& \text { PHINTED BY JOIN CLAY, M.A. } \\
& \text { AT THK UNIVERSITY PRESS }
\end{aligned}
$$

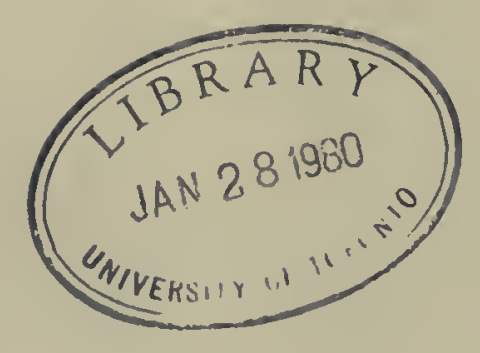




\section{PREFACE}

THEE delay that has attended the issue of this Life of Francis Galton, of which even now only the first volume appears, is largely due to three caluses. In the first place the writer lias so many other duties that the time to sort out, peruse and abstract the large amount of available nnaterial has only been obtained in odd holiday intervals or by postponing the claims of students and workers in the Galton Laboratory on his attention and energy. I trust that they will for the sake of this account of the life of the manl, to whom we alike ove so much, pardon the delays, which have so often been inflicted on the publication of their own researches. Secondly I had hoped that some postponement of the date of issue might lead to the discovery of more material bearing on the "Fallow Years" 1844 to 1849. This hope has not been fulfilled, and nothing has reached me ${ }^{1}$ which in any way supplies the place of the material, which appears to have existed at the date of Galton's death, judging by his own index to his letters. Hardly a letter to him of this period, which would have fixed his habitation and occupation, or have suggested his thoughts and reading, has reached me. The whole of his letters home from Egypt and Syria have perished, and the letters to him from his sisters, which would have told much, have been destroyed. The first realisation of this loss so depressed me, that I almost determined to give up the portraiture of a life, which could thus never be adequately exhibited in sone of its most momentous phases. The five ycars which follow most men's University careers are the most developmental of their lives. No other quinquennium is one of such marked growth, for men usually in this period will start to think and act definitely for themselves; they must then fice the fundamental problems of life relying on their own powers. Here I can tell nyy reatder little or nothing of Francis Galton, and 1 would merely say that the absence of information is not due to want of

1. I have endeavoured in vain to trace what has happened to letters written 60 to 70 years ago to College friends-all long dead. 
searching. It was only the feeling that, at least in one or two aspects of Francis Galton's later life and of his scientific work, I could perhaps put his contributions to hunnan knowledge more adcquately than possibly onc or another who niight takc up the task, if I resigned it, and who would hirrdly grasp the bearing of that long and intimate scientific correspondence between Galton, Weldon and myself, that I persevered in my endeavour to give some account of a life, wherein an important chipter of personal development must remain largely unrecorded.

'The last source of delay has been the difficulty of collecting the illustrative material, with which I deternined from the start to accompany this work. The records had to be collected from many sources, and it was soon clcar to me that I was collecting as much information bearing on the family history of Charles Darwin as on that of Francis Galton. It seemed desirable to place the two men to some extent in contrast in nly volume, showing in ancestry, in methods of work and in outlook on life what they had in common and how they diftered. Twenty years ago, no one would lave questioned which was the greater man. To-day the work of Darwin is being largely undermined by a new view of hcredity. We are told that "the transformation of masses of population by imperceptible steps, guided by selection, is as most of us now see, so inapplicable to the facts, whether of variation, or of specificity, that we can only marvel both at the want of penetration displayed by the advocates of such a proposition, and at the forensic skill by which it was made to appear acceptable even for a time ${ }^{1}$." Foremost among such advocates were Charles Darwin and Alfied Russel Wallace. If the judgment given above be correct, Darwinian evolution is only a fallacy supported for a time by "forensic skill." Its propounders must belong to a school which will leave no permanent mark on human thought. T'he last twenty years have scen a continual progress, not only in the expansion of the methods initiated by Galton, but in the recognition of the purposes to which he desired their application; above all we have approached much closer to the conscious study of what makes for race efficiency - to the application of Darwinian ideas to the directed evolution of man. If Darwinism is to survive the open as well as covert attacks of the Mendelian school, it will only be because in the future a new race of biologists will arise trained up in Galtonian method and able to riticise from that standpoint both Darwinism

${ }^{1}$ P'roblems of Gienclics, by William Bateson, p. 248, New Haven, 1913. 
and Mendelism, for both now transcend any treatment which fails to approach them with adequate mathematical knowledge.

If this view be a true view of the evolution of biological thought in the near future, then any comparison of the relative grcatness of the two men becomes superficial. Darwinism necds the complement of Galtonian method before it can bccome a demonstrable truth; it requires to be supplemented by Galtonian cnthusiasm before it can excrcise a substantial influence on the conscious direction of race evolution. Man has been directly endeavouring for a few thousand ycars to improve himself ly improving his environment. Galton's lesson-over and over again disregarded by those who profess to be his disciples - was that little could be achieved this way, that the primary method to elevate the race was to insure that its physically and mentally abler members, not only had the unrecognised advantage of natural selection in their favour, but were directly and consciously encouraged to be fertile by the state. If my view be correct, Erasmus Darwin planted the seed of suggestion in questioning whether adaptation meant no more to man than illustration of creative ingenuity; the one grandson, Charles Darwin, collected the facts which had to be dealt with and linked them together by wide-reaching hypotheses; the other grandson, Francis Galton, provided the methods by which they could be tester, and saw with the enthusiasm of a prophet their application in the future to the directed and self-conscious evolution of the human race. It is unprofitable to discuss relative greatness, and in this work I have made no attempt to do so. I see one family which has done much for our national worth, and every fact which bears on its history and its characteristics is of interest to us all. Those who know the real history of the one occasion on which Galton and Darwin disagreed know how loyal Galton was to Darwin-loyal with a loyalty far rarer to-day. Galton would not have wished inc to put him in the same rank as his master, but the reader who follows my story to the end may possibly sec that the ramifications of Galton's methods wre producing a renascence in innumerable branchcs of science, which will be as epoch-making in the near future as the Darwinian theory of evolution was in hiology fiom 1860 to 1880 , and which has encountered and will encounter no less ligoted opposition from both the learned and the lay. 'To work for that Galtonian renascence has been the writer's main aim in life as it was also that of his chief colleague and friendW. F. R. Wcldon. I can only hope that these volumes will contribute 
to the due appreciation of what Galton laboured to do and what he hoped in the future might be done in this field.

It is only fitting that I should put on record here the ready help 1 have received in imnumerable ways from Francis Galton's relatives and friends. For letters, papers and the reproduction of illustrative portraits I have in the first place to thank Mr Edward Wheler Galton of Claverdon; to his sister, Mrs T. J. A. Studdy, I owe also much in the way of facts and portraits. Mrs M. G. B. Lethbridge, Sir Francis Galton's niece, did invaluable work in placing in order and indexing the letters to her uncle from 1860 onwards. To the three sons of Charles Darwin, Mr William Erasmus Darwin, the late Sir George Howard Darwin and Sir Francis Darwin, I owe much information and many letter's. Without their ever-ready and generous aid it would not have been possible to put before my reader's so completely as I have done the ancestral history of Charles Dar'win. To Mr Francis Rhodes Darwin and to Colonel C. W. Darwin I an much indebted for particular's and photographs of the Darwin portraits at Creskeld Hall, and to Larly George Darwin for kindly help after the reath of her husbanrl. The Rev. Darwin Wilmot placed at my disposal most valuable manuscript material as to his grandfather, Sir Francis Sacheverell Darwin, as to his great-grandfather, Erasmus Darwin, and as to the family history of the Darwins. Mrs William Wavell, great-granddaughter of Erasmus Darwin, allowed me to see her Darwin portraits and manuscripts. Several other members of the family also have most kindly shown me illustrative matcrial, or provided me with data. Many friends and correspondents of Francis Galton have allowed me to take copies of his letters, which will find dne acknowledgment in my second rolume, where thesc letter's are used.

In the heavy pedigree work of this volume I have reccived continual assistance in search work from my colleague Miss Amy Barrington and in the laborions drafting of the pedigrees for engraving from the Hon. Secretary of the Galton Laboratory, Miss H. Gertrude Jones. My heartiest thanks are due to them both for the patience which they have brought to their tasks, and the invariable suavity they have shown to a frequently overworked and occasionally irascible taskmaster. 'To my friend and colleague Professor' W. Paton Ker' I am very grateful for a variety of suggestions and corrections during proof. 
I am fully aware that the indolent reader will find much in this work which he does not want and which has but little interest for him. It is intended fundamentally as a permanent memorial to the Founder of the Galton Laboratory, and embraces material which may easily perish or be ultimately lost sight of. If the said reader will only wait a few years, I have little doubt that my material will be strained of its more solid content and presented to him in that light and cheap form, which we are told is a first necessity of the morlern book market. My ubject is a different one, namely to issue a volume to some extent worthy of the name of the man it bears, — which may be studied hereafter by those who wish to understand him, his origin and his aims, rather than to furnish an evening's amusement for readers however numerons, who would just as readily study any other biography as that of Galton, if only it chanced to be entertaining. I have been told that the genealogical section of my book will weary its readers and narrow its public. I would reply that this work is not written to gain a public, but piam memoriam prodere conditoris nostri and is intended especially for those who have known and loved Francis Galton in the past, or who may in the future desire to understand and honour hin.

K. P.

Tine Galtoy Laboratory,

UNIVERSITY OF LONDON.

April \&, 1914.

P. G. 



\section{CONTENTS OF VOLUME I}

CH.P.

I. FORFWORD . . . . . . . . . . . . 1

II. Tile Ancestry of Fraxcis Galton . . . . . . . 5

III. Chithimoon and Bortioon . . . . . . . . . . . 62

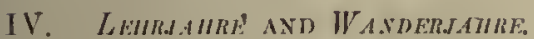

Part I. Medical Studies and the Flight to Constantinople . . 92

Y. LWIIUAIIIE AND WANDERJAHRE.

Part II. Mathematical Studies and Cambridge Pleasures . . 140

VI. FALLOW YFARS, 1844-1849. . . . . . . . . 196

Yit. 'The Rawakfanf: Screntific Exploration . . . . . 211

ApPFindix:

Note I. Pontraits of tile Dariwin Family . . . . 243

Notf II. On the Howarn Ancestry of Chartas Darwin. . 244 



\section{ILLUSTRATIONS TO VOLUME I}

Fromtispipse. Franeis Galton in 1903. From $a$ photograph by the anthor of the infinished picture by C. W. Furse at Claverdon.

PLATH

1. Ficsimile of a Letter of Charles Darwin to Franeis Galton on the pullication of the latter's Hereditary Genius, Dec. 23,1869 belieeen pr. 6 and $i$

I. Facsimile of the Reply of Francis Galton to Charles Darwin's letter of Dec. 23, 1869. . . . . . . between $\mathrm{pm} .6$ and 7

to fuce prage

III. Frasmus Darwin. From a print after a picture by Rawlinson of Derby 13

IV. Linsmus Darwin and his father, Dr Ernsmus Darwin, at Chess. From a sillouette at Claverdon in the possession of Mr Wheler Galton .

IV bis. Elizabeth Darwin (née Collier) and Dr Erasmus Darwin, Derby, 1800. From silhouettes mounter on opal glass in the possession of their great-granddaughter, Mrs T. J. A. Studdy . . . . .

V. From the MIS. Boyhood of Sir. Francis Sacheverell Darwin in the possession of Mr Darwin Wilmot. Mechanical Ferry designed by Dr. Erasmus Darwin for crossing from his honse in Fell Street, Derby, to his orchard. Francis S. Darwin as a ehild in the hoat, 1789

VI. Rolert Darwin of Elston (1682-1754). Father of Erasmus Darwin and great-grandfather of Charles Darwin and Francis Galton. From a picture at Creskeld Hall loy Riehardson, 1717 . .

I I his. William Alvey Darwin (1726-1783). Brother of Erasmus Darwin. From a photograph in the possession of Mr W. E. Darwin of the picture at Creskeld Hall

I'I lev. Robert Waring Darwin (1724-1816). Brother of Erasmus Darwin anrl author of Principia Botanica, or Introrluetion to the Sexual liotany of Linnaeus. From the picture at Creskeld Hall painterl by John Borridge, 1775

VII. Llizalnetl Hill (1702-1797). Wife of Rolert Darwin of Elston and mother of Dr Erasmus Darwin. From a plotograph of the portrait at Creskeld Hall in the possession of Francis Darwin, Esq.

VIII. Thohert Waring Darwin, F.R.S. (1766-1848). Wather of Charles Darwin. From a mezzotint of the painting in the possession of Mr William E. Darwin. (The mezzotint was engraved before the painting was eut down.) . . . . . . .

IX. Susamalı Wedgwood (1765-1817). Mrs Robert Waring Darwill, nother of Charles Darwin. From $a$ niniature in the possession - of Mr Willian E. Darwin . 
X. From the MS. Boyhoor of Sir Francis Sncheverell Darwin, who, being bitten by a dog, produced a stampede by barking as a dog to mimic hyrlrophobia. Mrs Darwin (Elizabetl Collier), the surgeon, the two Miss Palkers, Violetta Darwin (afterwards Mrs Galton) and Emma Darwin are seen on the stairs, while Dr Erasmus Darwin comes ont of lis study to ascertain what is wrong . . .

XT. Poem to Mrs Pole (Elizahetlı Collier), afterwards Mrs Erasıus Darwin. From a manuseript volume of poems by Dr Erasmus Darwin in the possession of Mrs William Wravell. Words altered and eraserl ly Sir Francis S. Darwin . . . . . . . . .

XTI. General Sir David Colyear, afterwards Lord Portmore (circe 16501730). Grandfather of Flizabeth Collier. From the portrait lyy Van rler Banck formerly at Arthingworth Hall . . . .

XITT. Charles Colyear, second Earl Portmore (1700-1785). Father of Elizabeth Collier. From the picture loy Reynolds formerly at Arthingworth Hall . . . . . . . .

NIV. Catherine Sedley, Countess of Dorchester, afterwards Tady Portmore (1657-1717). Grandmother of Elizabeth Collier. From the picture by Kneller formerly at Arthingworth Hall . . .

XV. Sir Henry Savile, Scholar (1549-1622). Maternal grandfather of Sir Charles Selley and a direct ancestor of Francis Galton. From a print in the possession of the anthor of the portrait hy Mareus Gheraerts the Younger . . . . . . . .

xVT. Flizabeth Collier (174i-1832). Mrs Pole, later Mrs Erasmus Darwin, with her son Sacheverell Pole. Painterl in the year 1770. From a picture in pastel loy Wright of Derby in the possession of $\mathrm{Mr}$ Wheler Galton at Claverdon

XVIT. Elizaheth Collier (Mrs Pole, later Mrs Erasmus Darwin) with her dog. From a silhouette at Claverdon in the possession of $\mathrm{Mr}$ Wheler Galtom. Underneath, facsimile of her signature.

XVtII. Sir Francis Sacheverell Darwin (1786-1859). Uncle and godfather of Sir Francis Galton. From a portrit by Haynes in the possnssion of Sir Francis' granddangliter, Mis Willian Wavell .

XIX. From the MIS. Boyhood of Sir Francis Sacheverell Darwin. Faneis S. Jarwin and George Bilshorow while engaged in slooting pigs with arrows are disturbed by a mad dog, which commmnicates hydropholia to the pigs and a horse. It is eventually killert by the mob. 1796

xX. Tlure portraits of Franees $A$ mo Violetta Darwin (Mrs Tertius Galtom) $(178)-1874$.$) :$

(a) In the year of ler marriage, 1807. From a niniature by Thompson in the possession of her granddangliter, Mrs T. J. A. Sturdly . 
PLATE:

XX. (6) The mother of Francis Galton, aged 75. Fom a portrait in the possession of the Galton Laboratory . . . . . .

to fuee praye

(c) Mrs I'ertius Galton. From a photograph taken when she was 79 years of age

XXT. (a) Sir Jiwen Canneron of Lochicl (1629-1723). Great-great-greatgrandfather of Fancis Galton. From a print in the possession of Mr Wheler Galton

(b) Sir Charles Sedley, Poet (1639-1701). Great-great-great-grandfather of Francis Galton. From a print in the british Mnseum Print Room, which is from an original picture formerly in the pussession of the Ducless of Dorset

XX1I. David Barclay of Youngsbary (1728-1809), Philanthropist and SlaveEmancipator. Uncle of Mrs Samuel Galton (Lucy batrelay), greatuncle to Tertius Galton and to Mrs Fry, and graudfather to Hudson Gurney. From a print in the British Muscum Print Room after the picture by Houghton.

XXIII. (a) Ury. The home of the Barclays. 'The Friends' Meeting House on the right. 'The Gotlic window with shutters on the first floor is that at which Lucy Barclay worked her sampler. Photograph from a water-colour sketch .

(b) Elston Hall. The original home of the Darwins, from a pen and ink sketch in Mrs Wheler's MS. "The Galton Family" . .

XX1V. (a) Captain Robert Barclay-Allardyce (1779-1854). From a painting formerly at Ury, slowing linı on his 1000 mile walk in 1000 hours. Captain Barclay was half-brother to Lucy Barclay .

(b) Robert Barclay, M.P. (1731-1797). Father of Lucy Barclay (Mrs Samucl Galton) and of Captain Rubert Barclay-Allardyce. Great-grandfather of Francis Galton. From in print in the pussession of $\mathrm{Mr}$. Wheler Galton after the picture by Racburn.

XXV. Simuel Galton, the Younger (1753-1832). Firom a portrait by Jangastre at Claverdon in the posscssion of $\mathrm{Mr}$. Wheler. Galton

XXVI. Tluee portraits of Lucy Barclay, Mrs Samuel Galtun (1757-1817):

(a) From a miniature takcn about the time of her marriage (1777)

(b) From a silhouctte taken at Bath in middle life . . . .

(c) From a portrait in later life in the possession of Mrs 'I. J. A. Studdy .

XXVIT. Photographs of Lucy Barelay's sampler, proving her presence at Ury when seven yenrs of agre . . . . . . . .

XXVIII. Irs Samuel Galton (Lucy Barelay) (1757-1817). Fron a pastel portrait by Langastrc at Claverdon in the possession of Mr Wheler Galton . 
XXlx. The Homes of the Girltons, being the title-page to "The Galton l'anily," an Ms'. history by Elizabeth Anne Wheler ("Sister Bessy"), 1883.

XX.X. Duddeston House, the lnome of the Sannel Galtons, fither and son. From a sketch by Emma Sophia Galton in the possession of Mrs 'I'. J. A. Studly . . . . . . . .

XXXI. Great Barr. 'I'he eountry home of Samuel Galton, jun. (17851799). Favourite ineeting place of the Linnar Socicty. From the photograple of a witer-eolour clrawing in Mrs Wheler's MLS. "The Galton Family"

XXXII, (a) The Galton-Farner house, later the Galton bank, in Steelhouse Lane, Birningham, now a shop

(b) Friends' Meeting llouse in Bull Street, Birminghan, where the two Samuel Galtons with their wives attended and were ultimately buried.

IXXI11. Samuel Tertius Galton (1783-1844). Father of Francis Galton, and husband of Violetta Darwin. From a painting ly Oakley in 1838. "Tertius Falton, who is a demi-semi Quaker in religion, a demi-beau in dress, and loves wonders and varieties in Seience, aud by profession a Whig:" Letter from Dr Parr, 1812, deseribing his guests at dinner, Coke of Norfolk, p. 126 .

XXXIV. Tertius Galton, with his children Adele, Erasmus, Emma and Bessie, 1837. From in silhouette by Edouard in the possession of Mr Wheler Galton at Claverdon.

XXXV. Unele and Aunts of Franeis Galton:

(a) Theodore Galton $(1784-1810)$

(b) Aclele Galton, ML's J. K. Buoth (178.1-1869) . . . 5.1

(c) Sophia Galton, Mrs Charles Brewin (1782-186:3) . . 51

(d) Mary Anne Galton, Mis Schimmelpenminck (1778-1856(6) . 51

XXYYI, (a) Theolore Gialton, frem a miniature . . . . . 51

(b) Adile Galton, ML's J. K. Booth, fiom a photograph . . 5.

XXXV11. Couparison of Charles Darwin, aged 51, and Francis Galton, agcel abont 50, from photographs . . . . . .

XXXV11I. Nangoro, Fing of the Ormpo, from the first exlition of Fincis Galton's Tropical South Africet. In illustration of Francis Galtou's sense of humour . . . . . . .

XXXIX. Francis Galton, aged \&. From a sillonette in his mother's MN. History of the Childhood of her son, 1830 . . . .

XL. Facsinile of the first page of Violettil Galton's aceount of the Childhood of Francis Galton, written in $18: 30$ 
XLI. (a) Charkes Darwin in early manhood. From a portinit in Mrs Wheler's MS. "The Galton Family" . . . . .

(b) Charles Darwin in later life. From a photograph by his son, Major Leonard Darwin

XLII. Erasmus Galton (1815-1909). In his uniform as a "middy," agred I3. Silhouette in the possession of Mr Wheler Galton at Claverdon. "My second brother, Erasmus, then a boy of twelve or thirteen, showed himself to us in his uniform, with the dagger or 'dirk' that was part of it." Francis Galton, Memories of my life, p. 16

XLIII. Breadsall Priory ("Happiness Hall"), The later home of Erasmus Darwin and afterwards of his willow (Elizabetl Collier, Mrs Pole). This is the house where the joyous visits of tho young (ialtons to their grandmother were made. From a pen and ink sketch of the garden frout

ILIV. (a) Breadsall Church. From a sketch. This church contains the tombs of Erasmus Darwin, his widow and other menbers of the Darwin family

(b) Brculsall Priory. Purchased hy lirasmus Dinwin the Yomnger, and bequeatlerl by him to his fatleer, Erasmus Darwin the Elder. From a water-colour sketeh at Claverdon . . . . .

XLV. Plan of the Larches, the birthplace and home in boylood of Francis Galton, with two inset aspects of the house. From a plan by Violetta Galton (néc Darwin) . . . . . . .

XLVI, (a) Erasmus Darwin (173I-1802). From a painting by Wright of Derby

(b) Darwin Galton (181t-1903). Eildest brother of Flancis Galton. From a picture by Oakley at Claverdos

XLVII. 'Three great-grandchildren of David Barclay of Cheapside:

(ci) Hudson Gurney

(b) Margaret Gurney (Margaret Barclay)

(c) Mrs Fry (Elizabcth Gurney). All second cousins to each other and to Tertius Galton

XLVIII. Francis Galton. From a portrait by Uakley of 1810 (Galton Laboratory, University of London)

XLIX. Sketch by Francis Galton of the Bishop's Gateway at Liége, visited 1838

L. (a) Emma Sophia Galton (181I-190t), "Sister Peminy." From a silhouette at Claverdon

(b) Elizabeth Anne Galton (1808-1906), "Sister Bessy," Mrs Edward Wheler. From a painting by Powles in $189 \mathrm{I}$ at Claverdon.

L bis. Elizabeth Anne Galton (1808-1906), "Sister Bessy." From a painting by Euston of 1844 in the possession of Mrs '1. J. A. Studdy .

P. G. 
LT. Sketches from Galtor's Cambridge Lutters:

(a) The fire-place in Galton's rooms with the foils, Smyrna pistols and native lance. . . . . . . . . 150

(b) The sitting-room before the remoral of the sofa to the fire-place 150

LII. Sketches from Galton's Cambridge Letters:

(a) Pcn and ink sketch of Ely Cathedral, 1842

(b) Pcn and ink sketch of King's College Chapel from the Ficld ly the Mill, 1843

IJII. From Francis Galton's skctch-book of the German tour in 1843 :

(a) Enma Galton anck Julia Hallam . . . . . . . 180

(b) "Sister Emma". . . . . . . . . . . 180

LIV. Last Days in Cambridge. Sketches from letters:

(a) Letter of Francis Galton to Tertius Galton announcing his degree

(b) The last meeting of the Caseo-Tostic Club, 1843

LV. Francis Galton. From two ealy photographs in the possession of $\mathrm{Mr}$ Wholer Galton . . . . . . . .

LV bis. Francis Galton's sisters. From early photograplss on glass (before 1860) in the possession of their niece, Mrs T. J. A. Studdy :

(a) Emma Sophia Galton (1811-1904), "Sister Pemmy"

(b) Milicent Adèle Gaiton (1810-1883), "Sister Delly".

LVI. Sketches from Galton's African Diaries:

(a) Rough water-colour sketch of gun set as a trap for a lion

(b) Samplc page of a diary sketcl1-book showing pencil "snapshots"

LVII. Sketches from Galton's African Diaries:

(a) Karupi, an Ovampo . . . . . . . . . 216

(b) Tclapupa's wife and Tchapupa, natives of Damaraland . . 216

(c) Omutchikota, the small lake in Ovampoland, where Galton's name was found in 1907-8

LVIII. Sketches from Galton's African Diaries:

(a) The Captain of the Hottentots, Jonker Afrikaner, walks off witl Galton's Law Code under his arn

(b) Facsinile of Jonker Afrikaner's promise to keep the peace in Damaraland .

LIX. Sketches from Galtou's African Diaries:

(a) Nangoro, King of the Ovampo, original sketch of June 7,1851 ; his majesty crowned with the theatrical tinsel crown

(b) Galton's favourite hack in Damaraland 
PIAITE

I.X. Francis Galton and his Wife (Louisa Jane Butler). In early married life. From a plotograpl in the possession of $\mathrm{Mr}^{\mathrm{r}}$. Wheler Galton at

LXI. Francis Galton and his Wife (Louisa Jane Butler). In middle life .

LXII. Pictures at Ncwnham Grange:

(a) ? William Alvey Darwin $(1726-1783)$ as a young man . . 243

(b) Robcrt Darwin of Elston (1682-1754) . . . . . 243

LXIII. Thomas Foley (1617-1677), Founder of Old Swinford Hospital, from the engraving in Nash's Ilistory of Worcestershire after the painting of 1670 by William Trabute. A direct ascendant of Charles Darwin

LXIV. Heydon Hall. The home of the Earles, now of their descendants through the female line, the Bulwers. From an old engraving by W. Ellis of a drawing by F. Repton . . . . .

LXV. Erasmus Earle (1590-1667), Own Sergeant to the Cominonwealth. Great-great-grandfather of Erasinus Darwin. From the picture by Zoest at Heydon . . • • . . • ' . .

LXVI. Thomas Earle, Brother of Anne Earle, the great-grandmother of Erasmus Darwin. From the picture by Zoest at Heydon. . 246

In the text:

Erasmus Darwin's visiting card. Tailpicee to Chapter V . . . 195

The three children of Erasinus and Elizabeth Darwin, Edward, Emma and Violetta Darwin (Francis Galton's mother). Tailpiece to

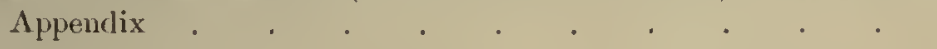

\section{PEDIGREE PLATES A'T' END \\ (In Pocliet of Cover)}

\section{PLATE}

1. Immediatc Ancestry and Collaterals of Sir Francis Galton.

B. Pedigrce showing connection of Barclays with Noteworthy Ancestors.

C. Pedigrec illustrating Relationships of Freanues, Barclays and Galtons.

D. Pedigree of Alorahams, Farmers and Galtons.

E. Pedigree showing connection of Charles Darwin with Noteworthy Ancestors. 


\title{
RESUMÉ OF THE LIFE AND LABOURS OF FRANCIS GALTON
}

\author{
CHIEF EPOCHS IN THE TIFE OF FRANCIS GALTON
}

Bom February 16, 1822. Hied January 1T, 1911

A. "Apprenticeship"

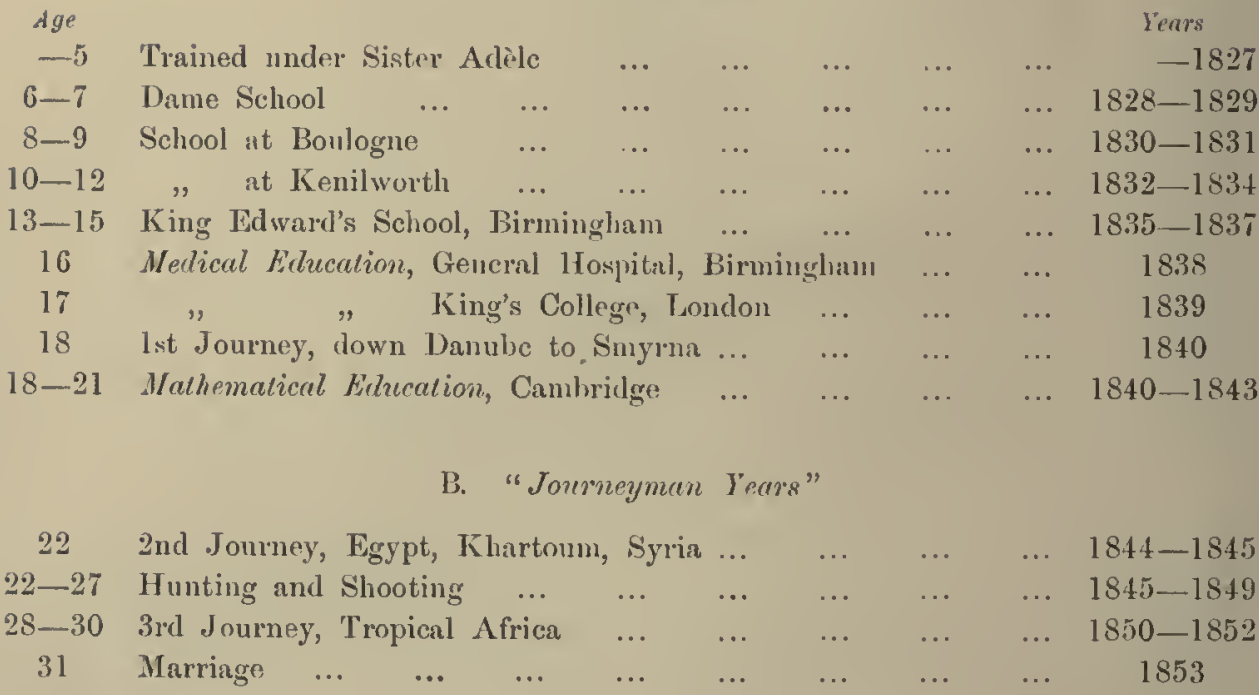

C. "Master" Craftsmun"

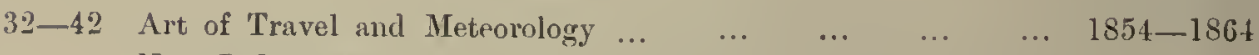
New Influcnees:

(a) Quetelet's Lettres sur la théorie des mobabilités appliquée aux sciences morales et politiques ('Translation, $\begin{array}{llllllll}1849) & \ldots & \ldots & \ldots & \ldots & \ldots & \ldots & \ldots\end{array}$

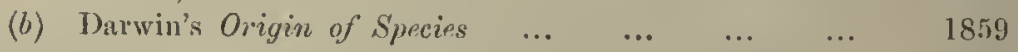

43 First Research in Hercdity (Hereditary 'Talent and Character) 1865

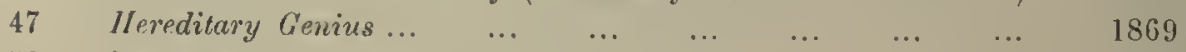

50
Statistical Enquiries as to Prayer 
Résumé of the Life and Labours of Francis Galton xxi

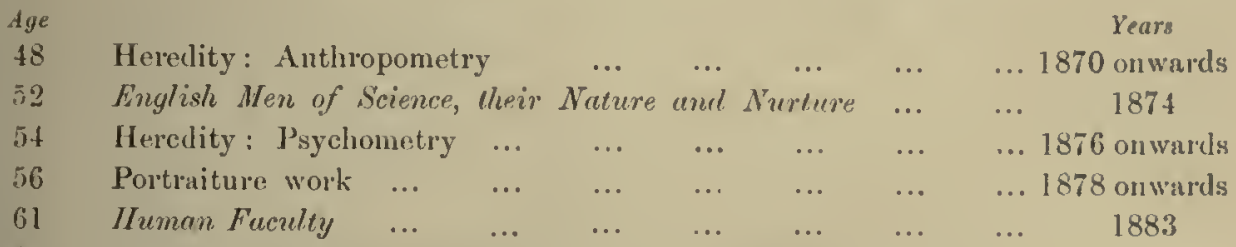

66 Personal Identification (arising form inquiry as to fremanency

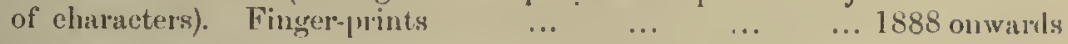

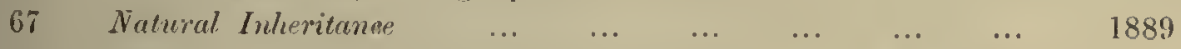

[Correlation and its applications. This was the starting-point of the Biometrie School.

72 First acarlemic Lectures on Variation and Correlation aceompanied by Laboratory work starterl at University CollegeOctober 1894. Start of Biometric Laboratory ${ }^{3} \quad \ldots \quad$...

74 Measmement of Plants and Animals Committer, Royal Socicty

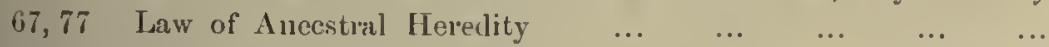

79 Biometrika foumled. Galton writes a preface and hecones con-

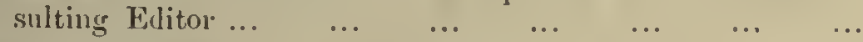

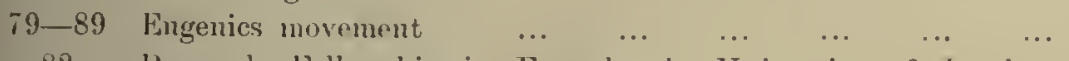

82 Research Fellowship in Eugenies in University of Jondon. "Ëlıgenics Oflice"

85 Transformation of "Eugenics Oftice" into the "Eugenies Laboratory" and its assoeiation with the Biometrie Lahoratory

89 Denth and by bequest Foundation of the Galton Professorship and Endowment of the Laboratery of Eugenies in the $\begin{array}{lllllll}\text { University of Loudon } & \ldots & \ldots & \ldots & \ldots & \ldots\end{array}$

\section{Chinf Posts and Honours}

Royal Geographical Society, Gold Medal (Member of Council for many years)

Fellow of the Royal Society (Gold Medal, 1886; 1)arwin Medal, 1902; Copley Medal, 1910; Member of Couneil, 1865-6, 70-2, 76-7, 82-4)

Pritisle Association (Sectional President, three times, (teography 1872,

Anthropology 1877, 1885, and General Seeretary 1863-7, Member of Council; twice asked to be President)

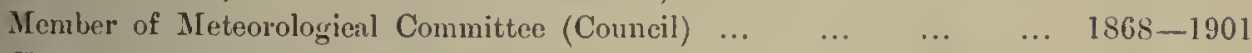

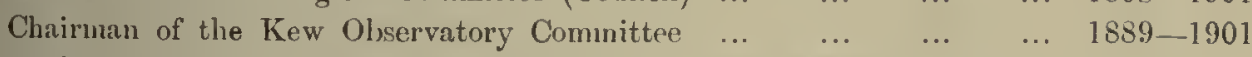

Antliropological Institute (President, 1885-9; Huxlcy Medal, 1901)

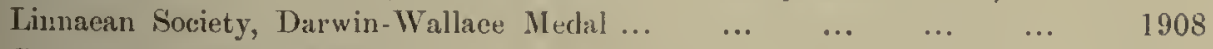

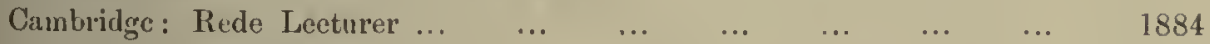

$\begin{array}{lllllllll}" & \text { Honorary D.Se. } & \ldots & \ldots & \ldots & \ldots & \ldots & \ldots & 1895\end{array}$

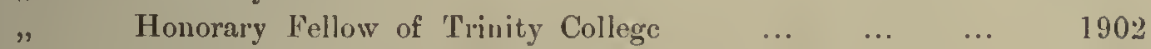

Oxford : Honorary D.C.L. $\ldots$.

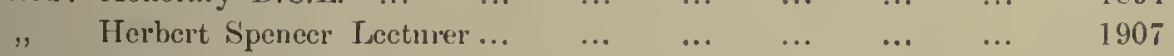

1 The Laboratory existed from this date; the name Biometric was given to it after the naming in Novenber $\mathbf{1 9 0 0}$ of Biometrika, when the term Biometry was invented, see Life of Weldon, Biometrika, vol. v, p. 35 . 


\section{ANALYSTS OF FRANCIS GALTON'S WORK}

Y.ears

I. Travel. (i) Practise $\quad$.. $\quad \ldots \quad \ldots \quad \ldots \quad \ldots \quad$ 1840, 1844, 1850-2

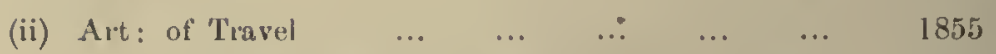

of Campaigning (Lectures at Alewrshut camp) 1856

$\begin{array}{llllll}\text { Vacation Tourists } & \ldots & \ldots & \ldots & \ldots & 1860\end{array}$

Last Memoir $\ldots \quad \ldots \quad \ldots \quad \ldots \quad \ldots \quad \ldots \quad 1881$

(15 memoirs, etc.)

II. Mhysics. Meteorology : (12 memoirs) chiefly $\quad \ldots \quad \ldots \quad \ldots \quad 1861-1873$

Design of Instruments $(12$ menoim) $\quad \ldots \quad \ldots \quad \ldots \quad 1850-1906$

IIT. Heredity.

First Paper: Hereditary Temperament and Character $\quad \ldots \quad 1865$

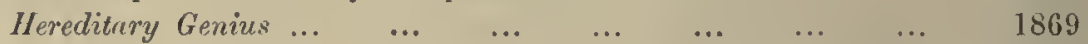

(i) Physical Characters, Anthropo- (ii) Mental C'haracters, Eaperimental metry, $1873-1894$

Influence of Town and Country (1873). Mensurement of the Senses, Auditory Anthropometry in Schools (1874). (1876), Muscular (1883), Visual (1884), "Nature and Nurturc" (1876). An- ctc. etc.

thropometric Laboratory (1882). Al1- Anclysis of Mental Processes, Frer will thropometric Instruments $(1877-89)$. (1879), Visions and Imagery (1879Records of Families (1884), etc. etc. 82), Arithmetic by smell (1894), etc. (over 30 memoirs).

(18 memoirs!

(iii) Iruman Faculty (1883). (Life. History Allum, and Recorrl of Family Faculties, 1884.)

(iv) Portraiture:

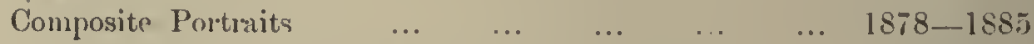

\begin{tabular}{llllll} 
Just perceptible Differcnces & $\ldots$ & $\ldots$ & $\ldots$ & $\ldots$ & 1878 \\
\hline
\end{tabular}

$\begin{array}{lllllll}\text { Plrotographs of Pedigree Stock } & \ldots & \ldots & \ldots & \ldots & 1898\end{array}$

$\begin{array}{lllllll}\text { Numeraliser Profiles } & \ldots & \ldots & \ldots & \ldots & \ldots & 1910\end{array}$

etc. etc. (12 memoirs)

(v) Direct Experiments and Observations on Heredity:

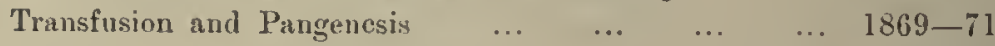

$\begin{array}{llllllllll}\text { Twins } & \ldots & \ldots & \ldots & \ldots & \ldots & \ldots & \ldots & 1876\end{array}$

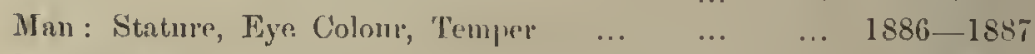

$\begin{array}{lllllllll}\text { Sweet Poas } \ldots & \ldots & \ldots & \ldots & \ldots & \ldots & \ldots & 1886\end{array}$

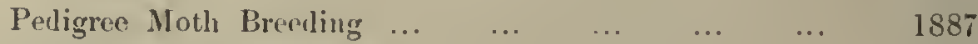

$\begin{array}{lllllll}\text { "Evolution" Committer? } & \ldots & \ldots & \ldots & \ldots & \ldots & 1896\end{array}$

$\begin{array}{llllllll}\text { Bassett Hounds } & \ldots & \ldots & \ldots & \ldots & \ldots & \ldots & 1897\end{array}$ etc. etc. (10 memoirs) 
Rérumé of the Life and Labours of froncis Galton xxiii

IV. Development of Stalistical Theory:- Years

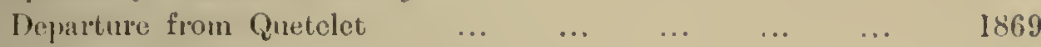

$\begin{array}{llllllll}\text { Statistical Scales } & \ldots & \ldots & \ldots & \ldots & \ldots & \ldots & 1870\end{array}$

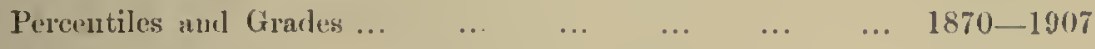

$\begin{array}{lllllllll}\text { Ogive Curves } & \ldots & \ldots & \ldots & \ldots & \ldots & \ldots & \ldots & 1875\end{array}$

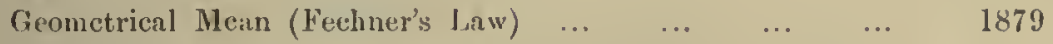

$\begin{array}{lllllllll}\text { Reerression } & \ldots & \ldots & \ldots & \ldots & \ldots & \ldots & \ldots & 1885\end{array}$

$\begin{array}{lllllll}\text { Currelation and its Mcasurcment } & \ldots & \ldots & \ldots & \ldots & 1889\end{array}$

"Ranks" and the Correlation of Ranks _.. . . . . 1889

First and Second Prizes, i.e. relative value of extreme ability 1901

(16 memoirs)

V. Application to Theory of Hevedity:

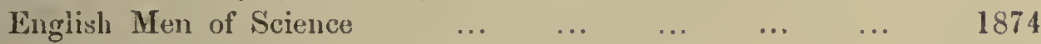

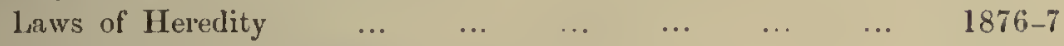

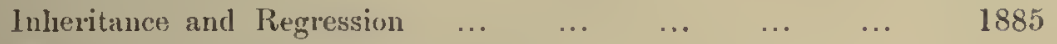

$\begin{array}{llllllll}\text { Kabural Inheritunce } & \ldots & \ldots & \ldots & \ldots & \ldots & \ldots & 1889\end{array}$

[Point of Departure of Biumetric Sclool]

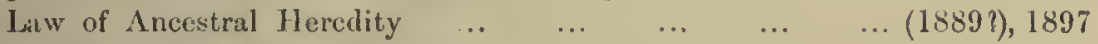

$\begin{array}{llllllll}\text { Notewortly Families } & \ldots & \ldots & \ldots & \ldots & \ldots & \ldots & 1906\end{array}$

(36 memoirs and books, etc.)

V1. Frm the measurement of characters for inheritance naturally aruse the problem of their permanence:

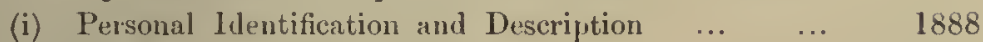

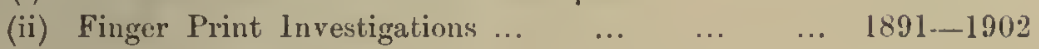

(13 memoirs, etc.)

V11. Application to IIuman Affairs: Eugenics:

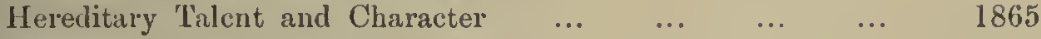

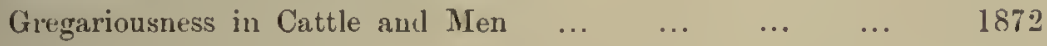

$\begin{array}{lllllll}\text { Hereditary Improvement } & \ldots & \ldots & \ldots & \ldots & \ldots & 1873\end{array}$

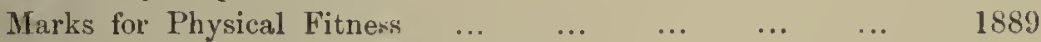

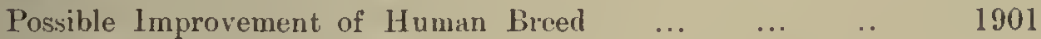

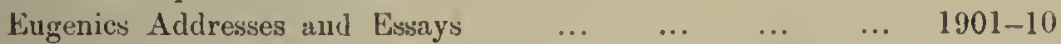

(17 memoirss, etc.) 
I am inclined to agree with Francis Galton in believing that education and environment produce only a small effect on the mind of anyone, and that most of our qualities are innate.

\section{CHARLES DARWIN.}




\section{CHAPTER I}

\section{FORFWORD}

To more than one reader of this biography the death of Francis Galton, following within five years that of one of the keenest of his friends and lieutenants, Walter Frank Raphael Weldon, meant not only the loss of a revered leader, but of another personal friend and counsellor. Some of my readers will remember quite recent visits, and fertile talk in the white-enamelled, sunlit drawing-room at Rutland Gate, with its collection of Darwin, Galton and Barclay relics; the table at which Erasinus Darwin wrote, alongside the easel with its powerful, if unfinished, portrait by Furse, telling - as the highest phase of art alone can tell-why and even how Francis Galton inspired men. To such visitors anything written here must appear incomplete and onesided; the atmosphere of a really great man - and such unquestionably Francis Galton was-cannot be reproduced in words; the tones of voice, the subtle sequences in phases of thought, the characteristic combinations of physical expression and of mental emphasis, which make the personality, can only be suggested by a great master of words, or at best outlined by a famous craftsman; the student of science, unless he be endowed with a poet's inspiration, must fail to provide even such adumbration. Nor again is it easy to portray the essential features of a man who is at least one generation older than yourself. There are in life two barriers between man and man more marked, perhaps, than any others, the reticence of age to youth, and the reticence of age to age. The friends we have grown up with from our youth, whose emotions and beliefs have been moulded under like physical and mental environments, we may perhaps truly know; we have caught their individuality before age laid constraint on its fullest expression. But the fiiends of adult life have no common mental history-the community of like growth fails them; they stand to each other even as great civilised nations whose culture and art may be revered and understood, whose knowledge and customs aid but do not replace home

$$
\text { P. } \text { c. }
$$


growths. In youth friends are as primitive tribes, they raid each other's preserves botll to destroy and to capture what they do not themselves possess; they mould each other's mental growth by friction and combat, rather than by peaceful interchange of commodities; the barrier of age to age, or of age to youth is wanting, and we actually know our friends in the very making of their characters. The friendships of age and age, and of youth and age possess many factors which fail the friendship of youth and youth; there is probably no wiser gift a parent can wish for a child than the rare friendship of youth and age, and this even if it verges on hero-worship. But neither such friendship, nor that of age with age, is the one which best fits the biographer for his task of measuring the circumstances which lave influenced a life, or of portraying the mental evolution of what he has only known in its ripest form. Francis Galton was seventy years of age before the present writer knew him personally, although the written influence began five years earlier; he was seventy-five at least before intimacy ripened into a friendship which grew in closeness with the years. This, and the age difference of between thirty and forty years, might disqualify, and indeed do disqualify the writer for any attempt at what he understands by genuine biography-from a portrayal such as Arnold gives us of Clough, or Hogg of Shelley-the intense reality which springs from a personal and intimate knowledge of youthful development. But to be drawn in this sense we must die young, before at least our contemporaries have lost the will and power to wield the pen ; and there are but few who achieve and die young in the field of science. Francis Galton, and therein the Fates were kindly, was not one of these. He was over fifty years of age before much of his best work was done; he was sixty-seven when his Natural Inheritance was published, the book which may be said to have created his school. For although his methods were developed in papers of the preceding decade, that book undoubtedly first made them known to us, and found him the lieutenants who built up the school of modern statistics. Other work of the highest value and of permanent usefulness in many branches of science Galton achieved before he was fifty, but the first central fact of his life is the relative lateness of much of his most inspiring work. His greatest contribution to method was published after he was sixty; his greatest appreciation of what that method might achieve for man was hardly pressed on public attention before 
he was eighty. How then shall one, who knew him-however intinately-only in the last years of life portray the mental evolution which was proceeding stage by stage for fifty years before firendship began? A very slight introspection tells each one of us how complex was the scaffolding by which the structure of our own intellectual opinions has been reared; how many attempts, how many failures, how many moulding men and things have contributed their part! How little of this do even our life-long intimates know, how little finds its expression in diaries, letters or the printed word! Could such things enable one to understand the whole nature of a man, the present writer, owing to the extreme kindness of the relatives and friends of Francis Galton, wonld have small need to lament the failure of his task. But the sense of failure has grown as these pages took form. The man of strength and character, who knew what he wished to accomplish and carried it through; the leader who inspired us is there-even as we read him in Furse's portrait-but the evolution of the man-the story of the mental growth, which should be the aim of every genuine biographer-is seen but darkly and from afar; it is but faintly shadowed in the written word and screened to dimness by those barriers of which the author has spoken. For reasons such as these he can only hope to place before his readers some phases of Francis Galton's life and some aspects of his scientific work. The real story of that life, the steep ascents, leading to wider horizons, won as all victorious minds have won them by struggle with earlier opinions and with a less developed self, the arduous final acceptance of new ideas as triumphant certitudes; these things the writer can but trace as they appear indistinctly to him; others will and must interpret in their own way, and will doubtless reach different view-points.

Galton of all men would not have desired this biography to be a panegyric. To be of service it must be, as he would have wished it, the life of a real man, of a man who makes mistakes, who has wandered from the path, or stumbled, who has striven after the wholly illusiory, or towards things beyond his individual reach. The difference between the ordinary mortal and the one of subtler mind is not that the former strays, and the latter does not, but that the deviations in the one case lcave no pcrmanent impress, while in the other they are coined into a golden experience, which forms the wisdom marking the riper life. Hundreds of men have failed to reach distinction or gain immediate 
profit by their school education, by their college careers, by their professional training, or by their early travels. There was a period when Galton's fate seemed to hang in the balance, when it appeared as if he would becone an English country gentleman, whose pleasure lay in sport and whose aim in life was good comradeship. Then the instinct for creative action mastered his nature, and every apparent failure of the past seemed to have borne, not bitter fruit, but a golden experience essential to labours, which the reaper had never foreseen when he garnered his harvest. 'That conception is the key to the first thirty years of Galton's life. It will be found, we think, a clue to the lives of many men of power, who strive in turn towards numerous goals, before they have learnt to realise their fitting sphere of achievement. Such apprenticeship with all its possible bungling, such Lelir- und Wanderjahre, can only be reckoned as idle when the matured journeyman fails to produce his masterpiece.

Of one thing we are certain, that the reader, who will follow patiently our hero through the great and the little, through the apparently trivial and the apparently vital incidents of this story, cannot fail to fall in love with a nature, which met life so joyously, and from childhood to extreme old age was resolved to see life at its best and be responsive to its many-sided experiences. Because Galton was a specialist in few, if any directions, because he appreciated without stint many forms of human activity, he was able to achieve in many spheres, where the established powers with greater craftsmanship but narrower outlook had failed to recognise that there were still verities to be ascertained. In the "fallow years" Galton wandered joyously through life, but he had been and he had seen, and he was thus trained, as few specialists are trained, to achieve in a marked degree. 


\section{CHAP'TER II}

\section{THE ANCESTRY OF FRANCIS GALTON}

IT is only fitting that an early chapter of the life of Francis Galton should be devoted to some account of the ancestry of a man, who did so much to make the world at large appreciate the value of a good series of forbears. To some it may seem that Francis Galton in his Memories may have said all that is needful on the point of ancestry; to others the mere statement that he was a grandson of Erasmus Darwin and a half-cousin to Charles Darwin may appear to account for his ability and for the directions of his scientific work. 'To a third group of persons, which has been much in evidence of late, the doctrine that mental characters are inherited appears to be not only absurd, but a sign of mental depravity in its upholders; they would probably consider without investigation that both Charles Darwin and Francis Galton were intellectually the product of their environments, and that all further inquiry was wasted energy. Because there are so many able men whose ancestry is insignificant, the group to which I refer has never mastered the paradox that, while ability is inherited, a majority of able men have not had a noteworthy ancestry. Pairs of exceptional parents produce exceptional sons at a rate more than ten times as great as commonplace parents, but because exceptional parents only form about one-half per cent. of the community exceptional men as a rule have not had a noteworthy ancestry.

It is peculiarly fitting in this place to turn to the question of ancestry, because if there is one point in his work that Francis Galton laid emphasis upon it was that the mental aptitudes are hereditary. His three chief works, IIereditary Genius, English Men of Science and Inquiries into Human Faculty were essentially devoted to the thesis that mental characters are inherited in the same manner and at the same rate as the physical characters. Even in his Natural Inheritance, Galton's fourth great book, he writes:

"We may therefore conclude that the same law...which governs the inheritance both of Staturc and Eye-colour, applies equally to the Artistic Faculty" (p. 162). 
And again in the Fortnightly Review for 1887 :

"I shall have fulfilled my object in writing this paper if it leaves a elear impression of the great range and variety of temper among persons of both sexes in the upper and middle classes of English society; of its disregard in Marriage Selection; of the great admixture of its good and bad varieties in the same family; and of its being nevertheless as hereditary as any other quality."

Or lastly in 1904, writing in Nature (August 11) of his investigations into "Natural Ability among the Kinsfolk of Fellows of the Royal Society," Galton says :

"The result of this inquiry is to prove the existence of a small number of more or less isolated hereditary eentres round whicls a large part of the total ability of the nation is clustered, with a closcness which rapidly diminishes as the distance of kinship from its eentre inereases."

'T'o these and many other published statements of Francis Galton could be added many memories of private talks. But perhaps the memorable letter of $1869^{1}$, in which Charles Darwin acknowledges the receipt of Galton's Hereditary Genius, may suffice to demonstrate how early Galton taught the heredity of the mental characters. It runs as follows :

\section{MY deAR Galton,}

Down, Beckenhas, Kext, S.E. Dec. 23 (1869?).

I have only read about 50 pages of your Book (to the Judges), but I must exhale myself, elsc something will go wrong in my inside. I do not think I ever in all my life read anything more interesting and original. And how well and clearly you put every point! George, who has finished the book, and who expresses hiniself just in the same terms, tclls me the earlier clapters arc nothing in interest to the latter ones! It will take me some time to get to these latter chapters, as it is read aloud to me by my wife, who is also much interested. You have made a eonvert of an opponent in one sense, for I have always maintained that, excepting fools, meu did not differ much in intellect, only in zeal and hard work; and I still think tliere is an eminently important difference. I congratulate you on producing what $I$ am convinced will prove a momorable work.

I look forward with intense interest to each reading, but it sets me thinking so mucl that I find it very hard work; but that is wholly the fault of my brain and not of your beautifully clear style.

Yours most sincerely, CH. DARwin.

The point to which Charles Darwin was converted was the principle that intellectual ability is hereditary. That much of that ability consists in the faculty for hard work is a further principle with

1 The letter is so eliaracteristic, that I have reprodueed it here followed by Galton's reply on the day of reeeipt: see Plates I and II. 

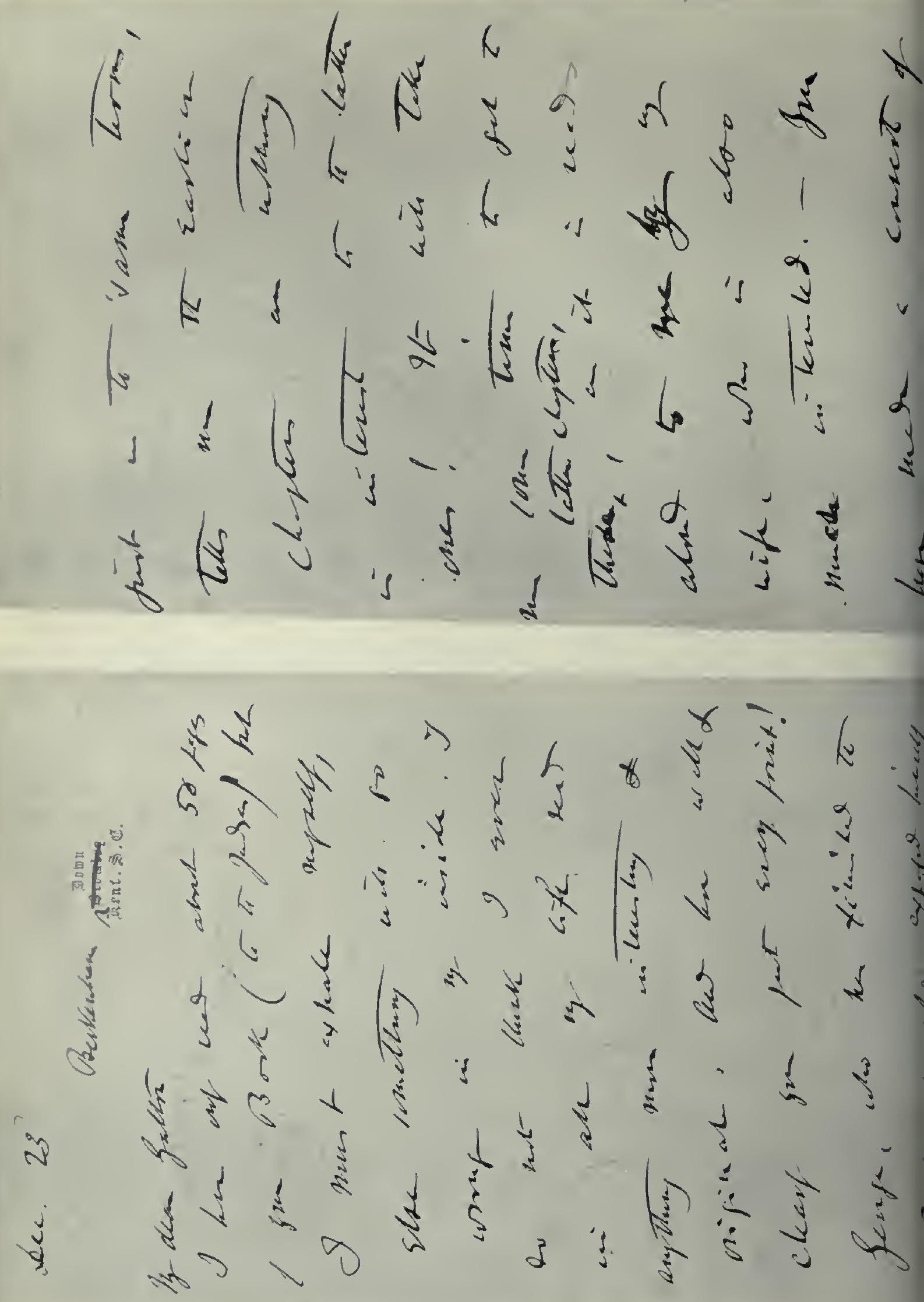

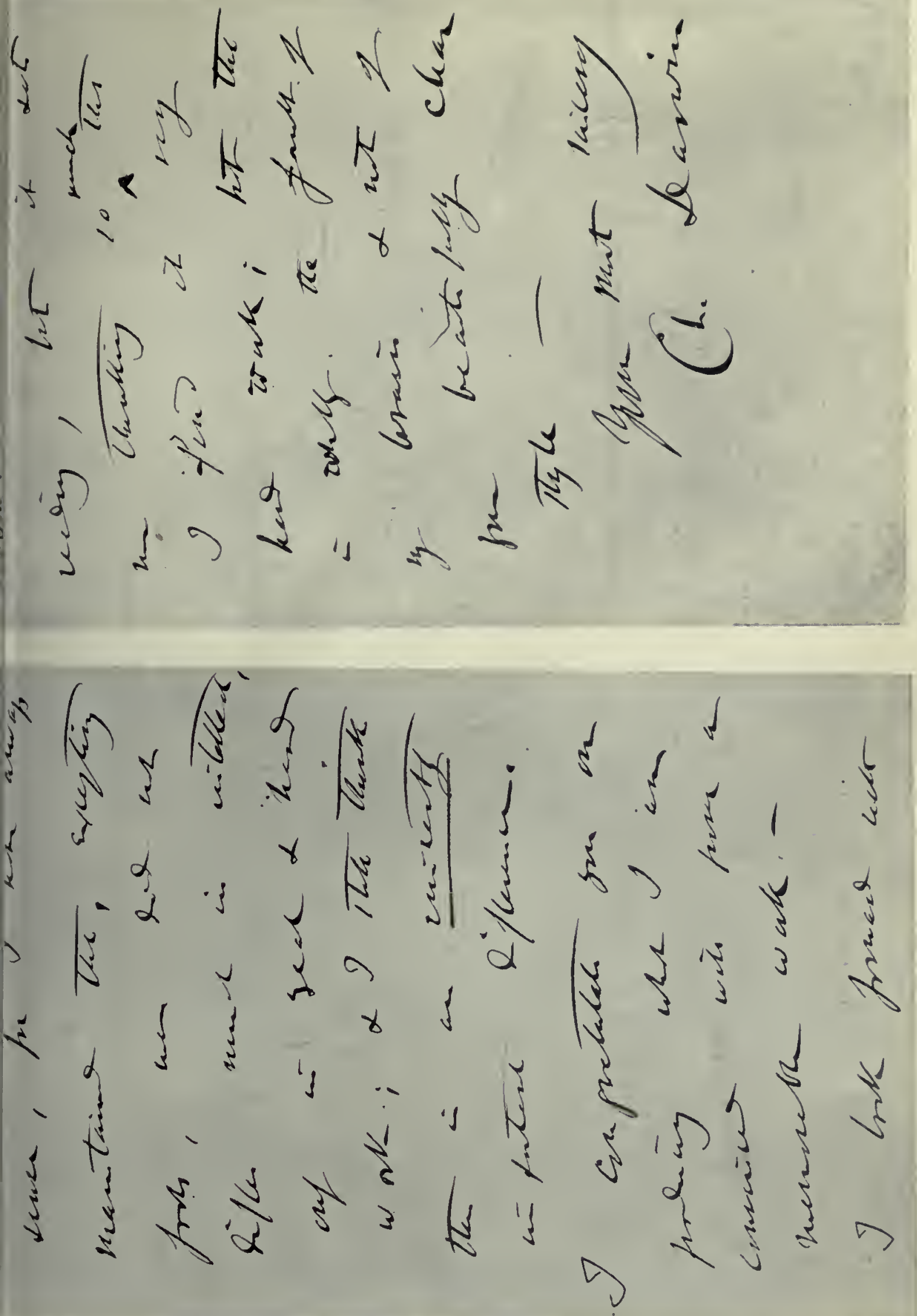



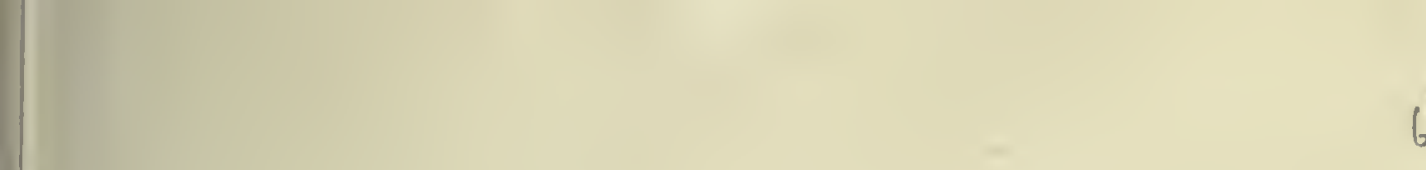
ts.

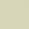

$$
\text { ts. }
$$

s.

.




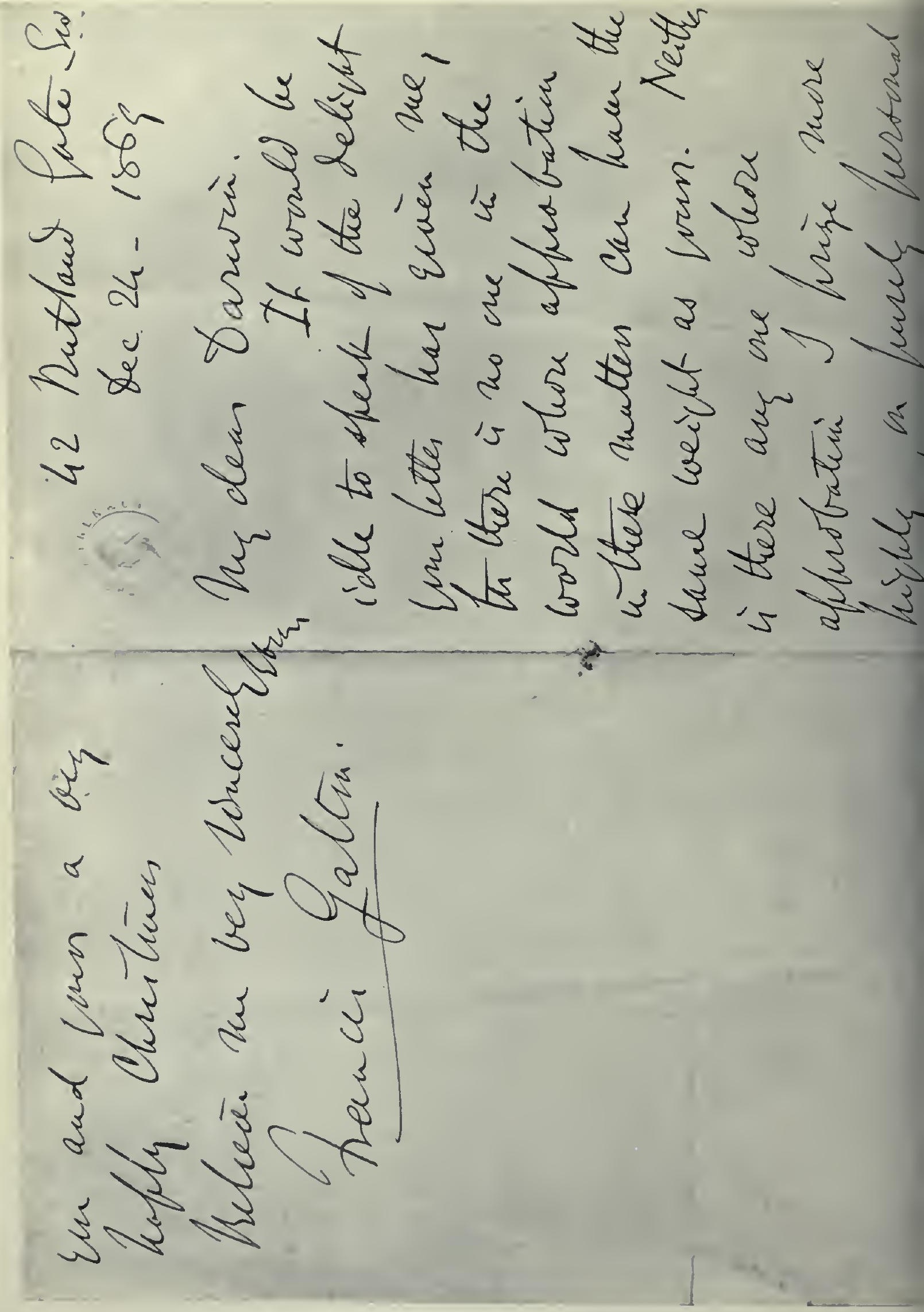



which most of us would also agree with Darwin-not the least Galton himself-with the proviso, that that mental faculty also is largely subject to hereditary control.

And Darwin did not hesitate to give expression to his conversion in The Descent of Man published two years later (Ed. 1885, p. 28).

"So in regard to mental qualities, their transmission is manifest in our dogs, horses and other domestic animals. Besides speeial tastes and habits, general intelligenee, courage, bad and good terupers, etc., are certainly transmitted. With man we see sinilar finets in almost every family; and we now know, through the adinirable labours of Mr Galton, that genius which implies a wonderfully complex combination of ligh faculties, tends to be inherited; and, on the other hand, it is too certain that insanity and deteriorated mental powers likewise run in families."

The chief conclusion of Galton's work, the most fixed principle of his teaching, was the like inheritance of the mental and physical characters. Many passages in his writings show that he fully appreciated the modifications introduced by environment, but these modifications can be for any character plus or minus in effect, and on the average the hereditary factor comes out as the main controlling feature.

It seems only a few months ago that talking with him over the almost bitter feeling which the work of the Galton Laboratory on environment had called forth, he said: "I wish they (the critics of that work) would study the subject of twins," and referred to his investigations of 1875 . I wonder how many of those critics have studied Galton's papers on twins! Had they done so, would they have supposed that the contrast of Nurture and Nature was a new fad of the Director of the Eugenics Laboratory, and had not been recognised and rendered definite by Francis Galton himself. Let such study the section in Hereditary Genius entitled "Nature and Nurture," and its words:

"When nature and nurture eompete for supremacy on equal terms in the sense to be explained, the former proves the stronger. It is needless to insist that neither is self-sufficient; the highest natural endowments may be starved by defective nurture, while no carefulness of nurture can overcome the evil tendencies of an intrinsically bad plysique, weak brain, or brutal disposition. Differences of nurture stamp unmistakable marks on the disposition of the soldier, clergyman, or scholar, but are wholly insufficient to efface the deeper marks of individual character" (p. 12).

How did Galton try to solve the relative strengths of "nature and nurture" - this "convenient jingle of words," as he terms it, which

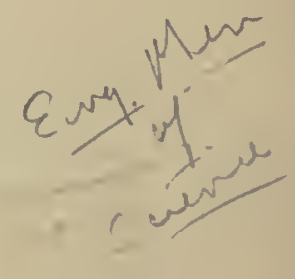


"separates under two distinct heads the innumerable elements of which personality is composed"? He noted that twins are of two kinds-those born physically and mentally alike, and those born as unlike as ordinary brother's and sisters. He proceeded to determine how far like twins were differentiated by unlike environments, and how far unlike twins were rendered like by their common nurture. He discovered that whatever the environment like twins remained alike and unlike twins remained unlike, even as they were born. 'Thus he sums up his History of Twins, as a Criterion of the Relative Povers of Nature and Nurture:

"There is no escape from the conelusion that nature prevails enormously over nurturo when the differences of nurture do not exceed what is commonly to be found among persons of the sanie rank of society in the same country. My only fear is that my evidence seems to prove ton much, and may be discredited on that account, as it seems contrary to all expeetation that nurture should go for so little. But experience is often fallacious in ascribing great effects to tritting cireumstances. Many a person has amused himself by throwing bits of stick into a tiny brook and watching their progress; how they are arrested, first by one chance obstacle, then by another; and again, how their onward course is faeilitated by a combination of circumstances. He might ascribe much importance to each of these events, and think how largely the destiny of the stick has been governed by a series of trifling accidents. Nevertheless all the sticks succeed in passing down the current, and thcy travel, in the long run, at nearly the same rate. So it is with life, in respect to the several aecidents which seem to have had a great effect upon our careers. The one element, which varies in different individuals, but is constant for each of them is the natural tenclency; it corresponds to the current in the stream, and inevitably asserts itself." (Joumal of the Anthropological Institute, 1875 , p. 391 , etc.)

Such work as the Galton Laboratory has done was to give quantitative definiteness to this conclusion of its founder. And, in view of it, would it not be idle in this biography to pass over the nature-the ancestral factor-and spend our time chiefly on the nurture of Francis Galton? To those of us who believe in alternative inheritance, to those again who favour its more fashionable Mendelian phases, there is nothing marvellous in transcendent intellectual power being associated with one member of a Darwin or with one nember of a Galton fraternity. To those who put their faith in nurture as the controller of mental characters, it must be a standing miracle that brothers reared under identical environment should fail to show the same ability, or showing the same ability should be so diverse in their physical attributes or in other mental characters! 
So much then can be said in favour of the study of Francis Galton's ancestry. While he himself has told us in broad outline what he owes to the strains which were mingled in his blood, there is much that he has not referred to, that possibly he could not refer to, either from modesty or ignorance. I lave lieard him speak with keen appreciation of his Quaker forbears; but I doubt if he knew, or if even we now know all they suffered for their faith. Besse's record, in his Collection of the Sufferings of the People called Quakers, is little more than a list of fines, imprisonments, and deaths, yet it occupies two large folio volumes, and the present writer, from a study of the Yorkshire records alone, knows how incompletely it represents all that occurred. Of that other wider side of his ancestry-which indeed helped the Apologist Robert Barclay to lighten the grave oppression directed against the early Society of Friends by actively soliciting his royal kinsmen in their favour-of this side of his ancestry Galton rarely if ever spoke. Yet it is one that we cannot pass over.

As one who has dealt with many family pedigrees, chiefly of the professional classes, the writer's experience has been of the following kind. In ascending backwards we pass, perhaps through the squirearchy, eventually into the yeoman class. Here there is no hope of going further than the cluurch registers (say to 1600) will carry us, or perhaps the wills a hundred years further. We leave the family on the soil, and we have no trace of further distinction or knowledge of its ever being anything but autochthonous. If a member reached, before that date, celebrity by marked ability, he was either an ecclesiastic who left 110 offspring, or he and his family were raised to the noble class. Once reach the yeoman class, and there is little hope of going beyond the data in the deeds of the yeoman's chest. A second method of terminating our ascent is to reach a bar-sinister, beyond which in more recent times there is only perhaps feeble family tradition, or in early times little screened disgrace, or even much pride. Lastly we may find ourselves passing into a noble or royal family, which for generations las maintained its position by its physique and mentality. And here, perhaps, we may recognise a distinct difference between what this means now and what it meant before 1700 . From our earliest knowledge of European history, till something like the 17th century, there was a continuous and most stringent selection of all noble and royal stocks. To retain your head on your shoulders and yet rise to

P. G. 


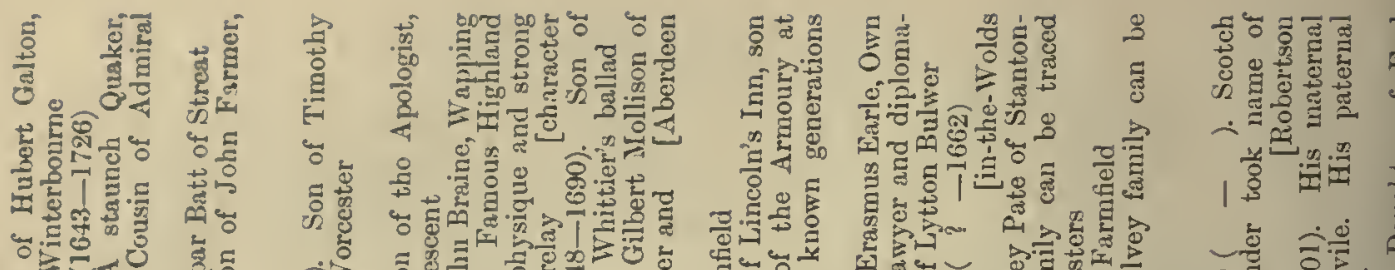

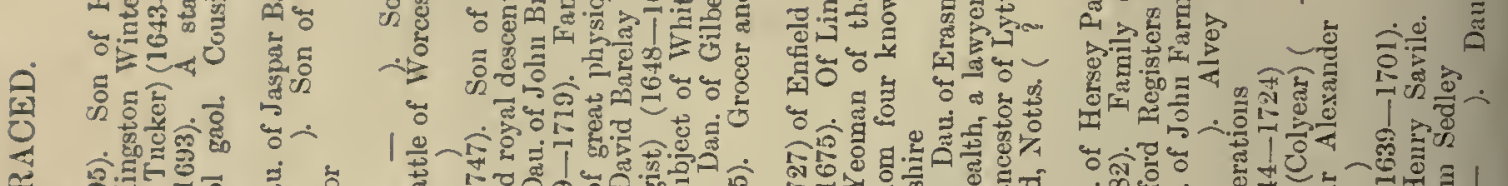

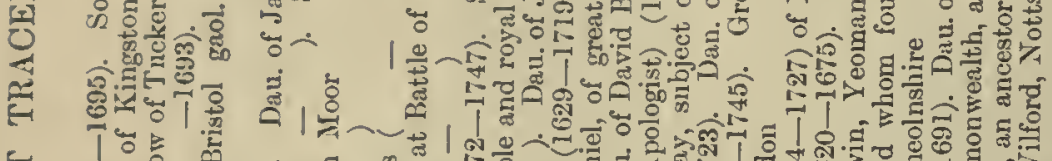

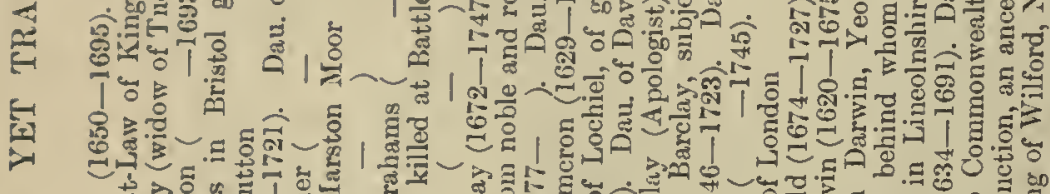

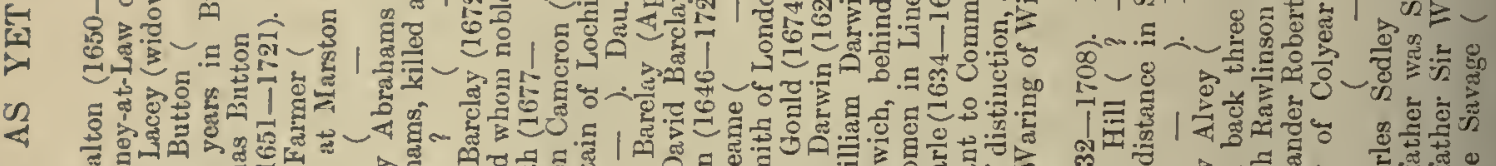

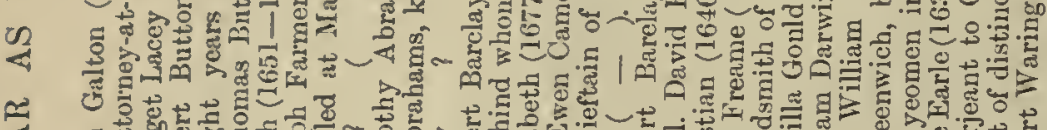

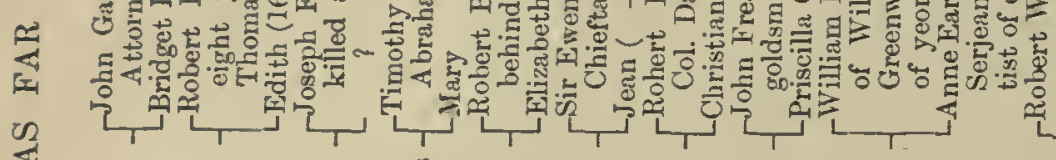

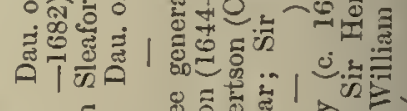

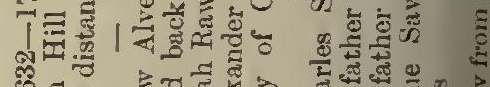

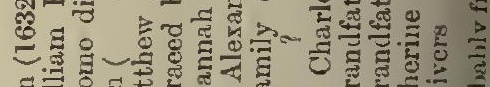

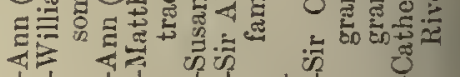

है

噌

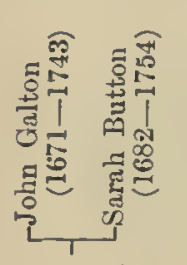

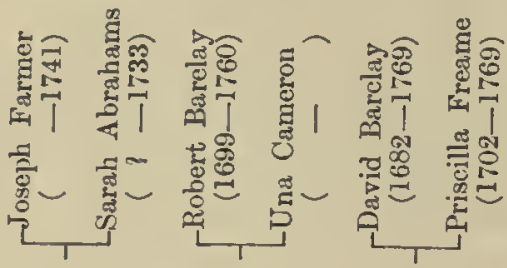

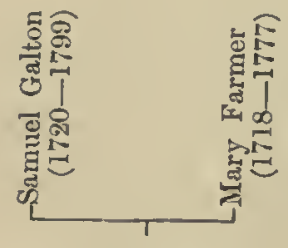

봄

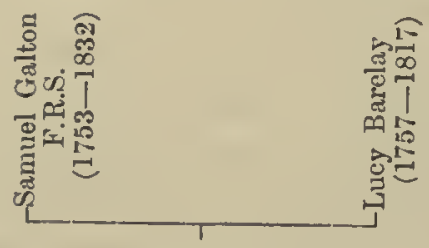

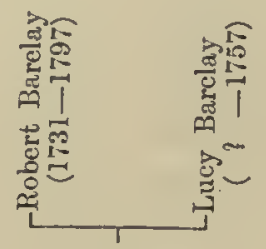

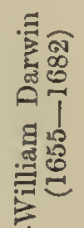

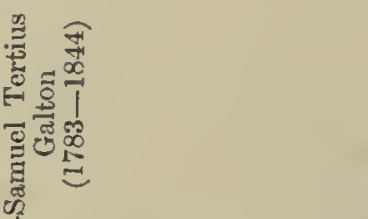
है, है
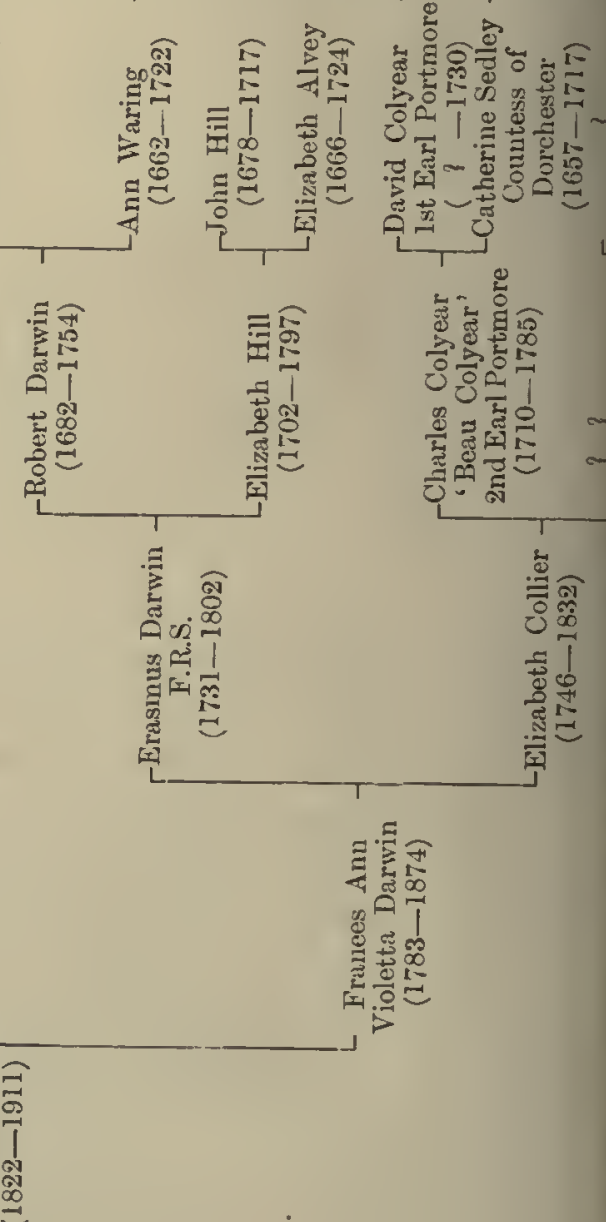
distinction in your country meant inmense resource, activity and mental ability. Men like Alfred the Great, Friedrich Barbarossa, or William the Conqueror, were kings because they were essentially men preeminent in ability in their days; and to show in the male line a continuous descent of ten generations, as the de Bruces did, signified that the family had craft to gain and strength to hold the acquired. The game at politics meant death to the checkmated, often destruction of their stock and forfeiture of their land. Thus it came about that royal and noble blood, from early mediaeval times almost to the close of the Stuart period, really signified stocks of physical and mental strength; and the earlier we go back the more certain is this truth. To anyone whose ancestry carries him to such noble or royal lines, there will be little difficulty in linking on to most of the great names of early European history.

To follow step by step backwards the pedigree of one man like Francis Galton till we can go no further, but find all our lines fail us, is perhaps the most instructive lesson in history that is possible. The biographer has learnt more history, social and political, in the present inquiry than he had ever done before. One sees not only our own times linked up with great names in the past, but one feels that yeoman, squire, noble and king form a more homogeneous whole than we have hitherto appreciated with our narrow class distinctions; and we realise that the stocks which led to famous men of old may exhibit them to-day in methods more in keeping with our social ends.

It seems to me that the pedigree showing the noteworthy ancestry of the Barclays is in itself a full reply to those who think it suffices to say that Francis Galton was a grandson of Erasmus Darwin! Francis Galton owed much to his Darwin descent, but he owed not less to other strains, and notably to the firmness, conviction, toleration, and business aptitude of those Quaker strains of Galton, Button, Farmer and Barclay which formed nearly half his heritage.

I trust that Pedigree $B^{1}$ may show the reader reason enough for taking a wider view than Galton himself has given us of his past family history; for indicating as he himself has indicated that it is neither to be wholly neglected, nor summed up in any one line of descent. The nurture of comfortable homes, good schools and our leading universities was provided for both Charles Darwin and Francis Galton, but it was

\footnotetext{
${ }^{1}$ See end of this volume.
} 
provided also in like measme for literally hundreds of their contemporaries. If nurture could produce such mental characters as we find in both, then we should count such men by the tens instead of by mnits. Nurture indeed! Let us listen to what Galton himself says of his school-the King Edward's School at Birmingham :

"The literary provender provided at Dr Jeune's school disagreed wholly with my mental digestion. The time spent there was a period of stagnation to myself, whieh for many years I deeply deplored, for I was very willing and eager to learn, and could have learnt inuch, if a suitable tencher had been at hand to direet and encourage me." (Memories, p. 21.)

Or, again, try Darwin! Writing of Shrewsbury, his school, he says : "The school as a means of education to me was simply a blank," and again of his course at Edinburgh :

"The instruetion at Edirburgh was altogether by leetures, and these were intolerably dull, with the exeeption of those on ehemistry by Hope; but to my mind there are no advantages and many disadvantages in leetures compared with reading." (Life, I, p. 36.)

At Cambridge both cousins took Poll degrees. Darwin says that his three years at Cambridge were "wasted as far as the academical studies were concerned, as completely as at Edinburgh and at school.", Galton wondered at the narrowness of Cambridge, "for not a soul seemed to have the slightest knowledge of, or interest in, what I had acquired in my medical education, and what we have since learnt to call Biology" (Memories, p. 59).

Undoubtedly their Cambridge time gave Darwin and Galton much - friends and the leisure to develop on their own lines. But in neither case was it nurture moulding the men, it was nature making the best use of an uncongenial environment.

It nay be said that the nurture was not that of school or college, but the nurture of the home. Both men were the exceptional members of generally able stocks. That in many respects their home-conditions wcre sympathetic goes without saying, but these home conditions were similar to those of others of their own stock and of many contemporaries. It may be said that their common grandfather was a man of distinction, and that although his writings were open to the world, Charles Darwin and Francis Galton, although born after Erasmus's death, came by family tradition more closely in touch with his teaching.

Yet here is what Charles Darwin wrote of his grandfather's chief work; he is speaking about his Edinburgh acquaintance with R. E. 
$12^{a}$

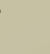

$$
2^{a}
$$

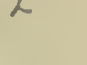

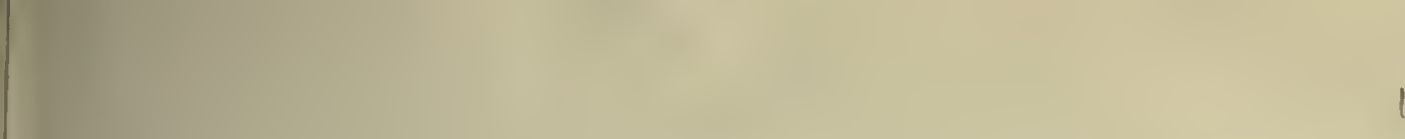




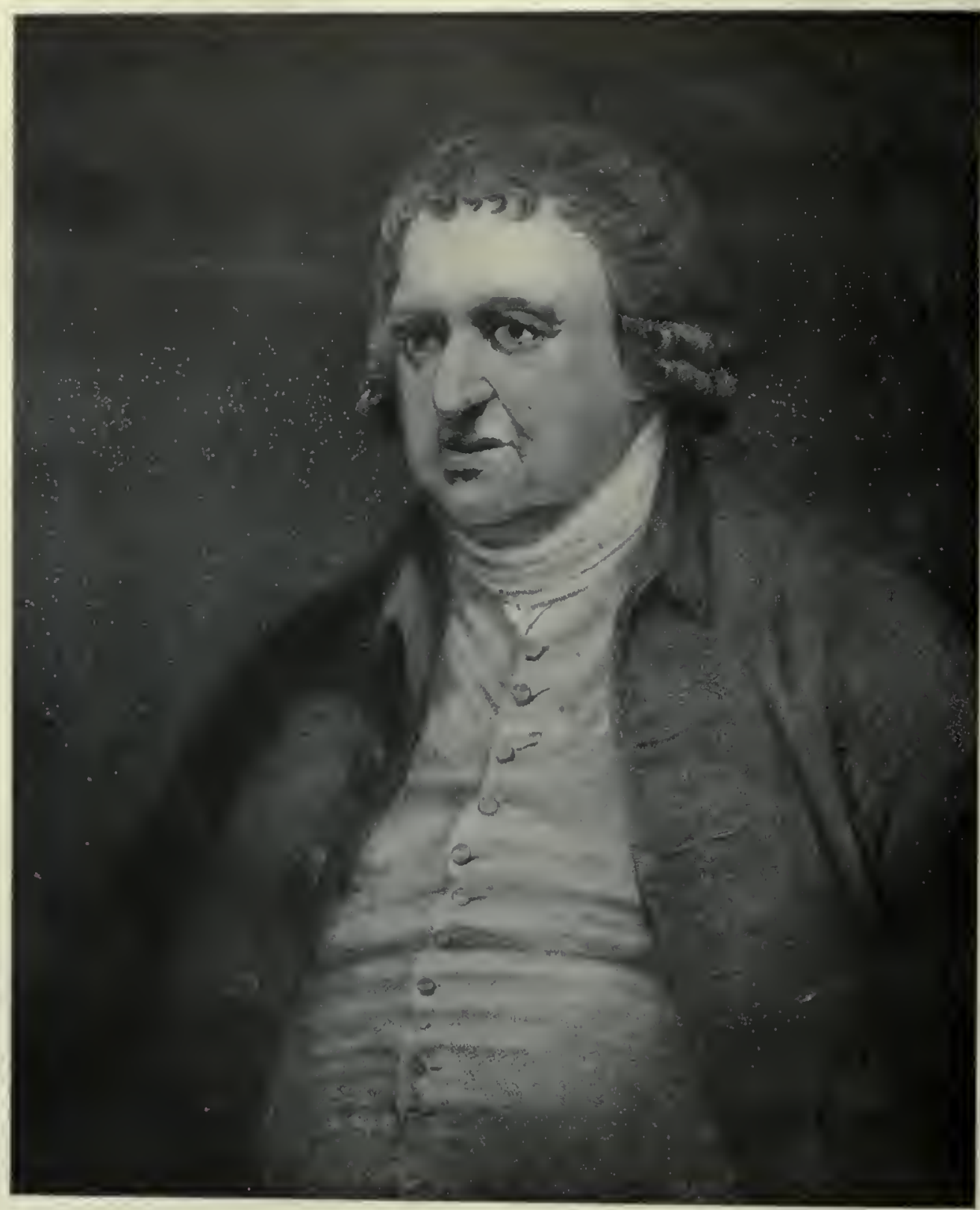

RRASIITS DARWIN (1731-1802).

from a print after a pieture by Rawlinson of Derlyy. 
Grant, afterwards Professor of Comparative Anatomy in University College, London, to whom that College owes its fine Grant Library:

"I knew liim well; he was dry and formal in manner, with much enthusiasm beneath this outward crust. He one day, when we were walking together, lonrst fortl in high admiration of Iamarek and his views on evolution. I listened in silcnt astonishment and as far as I can judge without any effect on my mind. I had previously real the Zoonomia of my grandfather, in which similar views are maintained, but without producing any effect on me. Nevertheless it is probable that the hearing rather early in life such viows maintained and praised may lave favoured my upholding theur under a different form in my Origin of Species. At this time I had admired greatly the Zoonomia, but on reading it a second time after an interval of ten or fifteen years, I was much disappointed; the proportion of speculation being so large to the facts given" (p. 38).

In a letter to Alphonse de Candolle written shortly after Charles Darwin's death in June, 1882, Francis Galton says :

"Thank you very much for your interesting brobure on Charles Darwin, analysing the causes that contributed to his success. It has been a great satisfaction in all our grief at his loss, to witness the wide recognition of the value of his work. He certainly as you say appeared at a moment when the public mind was ripe to receive his views. I can truly say for my part that I was groaning under the intellectual burden of the old teleology, that my intelleet rebelled against it, but that I saw no way out of it till Darwin's Origin of Species emancipated me. Let me, while fully agreeing with the views expressed in the pamphlet in all important particulars supply a few minor criticisms which it might be well to mention."

After a reference to economic matters Galton cites the words of de Candolle that the descendants of the "poete physiologue" had certainly read at the right moment the works of their grandfather, and continues :

"I am almost certain of the contrary in every case except Charles Darwin (and I doubt whether he had) - [as we liave seen, he eertainly had read the Zoonomia]. To myself the florid and now ridieuled poetry was and is intolerable, and the speculative physiology repellent. I had often taken up the books and could never get on with them. Canning's parody The Loves of the Triangles quite killed poor Dr Darwin's reputation. It just hit the mood of the moment, and though my mother never wearied of talking of him, his life was to me like a fable only half believed in. That much the same was the case with some of Charles Darwin's sons, I ean I think affirm."

Without being, perhaps, as hard on "poor Dr Darwin" as his grandson, I think we must admit that it was the hereditary taste or bent of the Darwin stock that Erasmus transmitted to his grandchildren and not an environment or even a sympathetic tradition. In studying the works of Erasmus Darwin, it is indeed difficult not to be 
repelled by the florid language or the want of reasoned inference drawn from marshalled facts. Part of this is due to his date, but not all, for his timc carries us to the Wollastons, Young, Kerwan, Priestley and Smeaton, some of whom were close intimates of Darwin himself, to say nothing of the great continental physiologists, naturalists and mathematicians. Darwin's defects were partly due to his environinent, the incessant occupation of a most popular physician, which hindered the possibility of a life wholly devoted to science, the smaller interests and the want of friction with the best minds which must often occur in narrow provincial circles-though the neighbouring Birmingham was in those days a centre of considerable mental activity. Yet beyond all this there was somcthing of the prophet about Erasmus Darwin. He had thrown off the old telcological dogmas and was seeking a new theory of life, and he had inspirations even if his poetical representation of them wearied his grandsons and in no lesser degree wearies a still more modern reader. To start examining the characters of living forms not with a view of seeing in them evidence of design, but of testing their utility to the owner and how he or his stock might have acquired thcm, was a real step forward. Had Erasmus Darwin been by calling a man of science and not of medicine, doubtless many of his inspirations would have perished under his own analysis. Others would have stood his trained criticism, and been established by marshallerl facts-as true scientific knowledge. As it is we regard him as a most interesting personality, almost as a man of genius; but rathcr as evidence of the general ability of the Darwin stock, than as a powerful environmental or traditional factor influencing the development of either Charles Darwin or Francis Galton'.

With our present views on heredity, we look upon Charles Darwin and Francis Galton as drawing their ability from the same reservoir as Erasmus Darwin did, but we realise that it only flowed from him to them in the sense that he was the conduit, not the source of the ability.

1 This view was fully reepted by Franeis Galton himself. Writing of men of scienee in his Mereditury Genius (1869) he says: "The number of individuals in the Darwin family who have followed some braneh of untural history is very remarkablethe more so lieeause it so happens that the tastes appear (I speak from private sourees of knowledge) to have been more personal than traditional. There is a strong element of individuality in the different nembers of the race which is adverse to traditional influence." 
Plate IV $14^{\circ}$

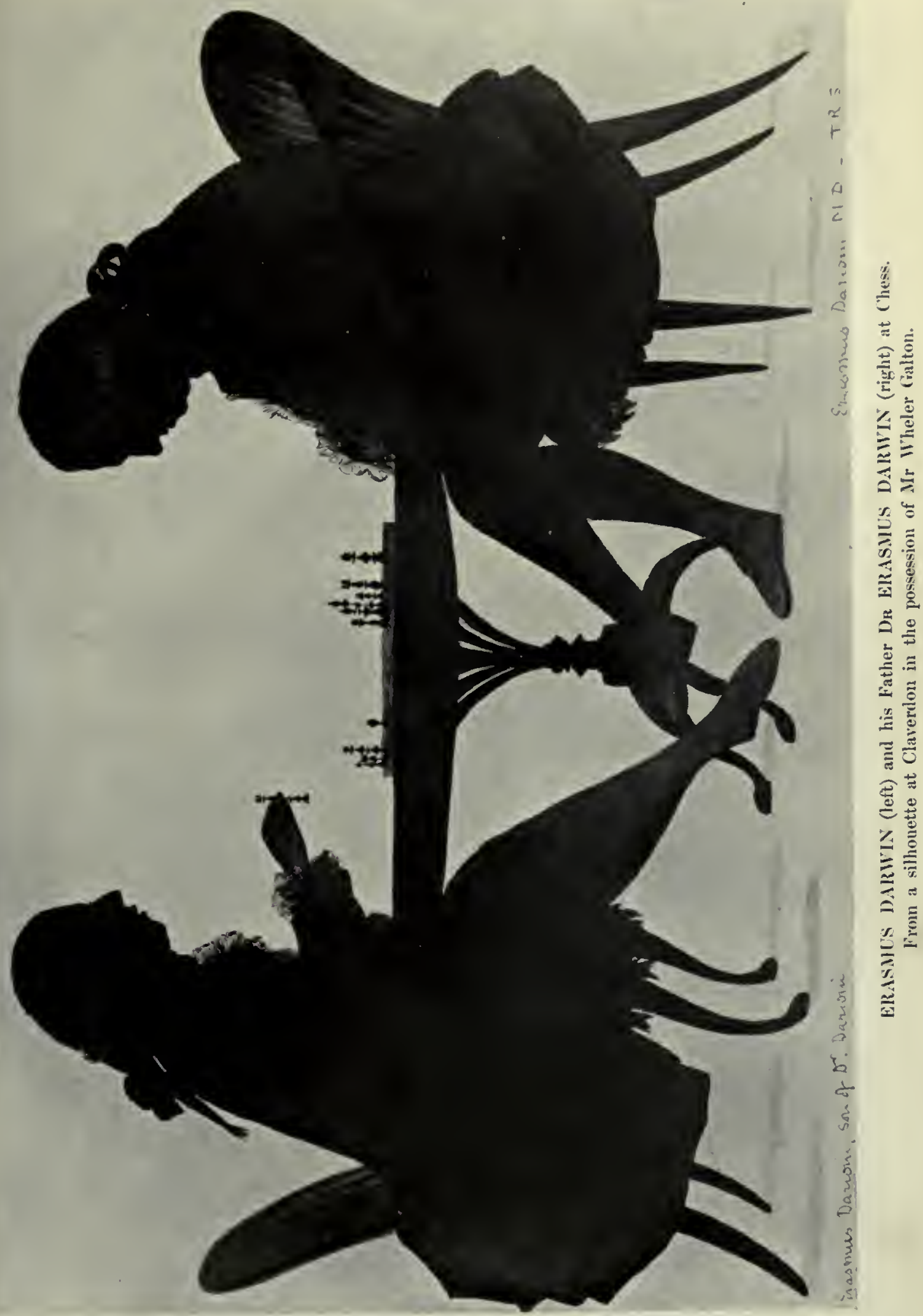




It is worth noting here that we cannot, when judging of the ability of the Darwin stirp, confine our attention to Erasmus and Charles. Erasmus Darwin's brother-the elder Robert Waring Darwinpublished a Principia botanica or Introduction to the Sexual Botany of Linnaeus. The present writer is not able to judge its merits, but it ran through several editions, and illustrates at least the taste and bent of the stock. We note how the scientific work of the Darwins begins de novo in this generation with the two brothers Robert Waring and Erasmus ${ }^{1}$. The sons of Erasmus by his first wife were Charles, Erasmus and Robert Waring, the father of the greater Charles the younger. It is difficult in this case to separate out the personality of Erasmus the elder from that of his sons. Yet I think there is evidence that there was independence. Charles died from a dissection wound at the early age of 20 , and a prize essay of his on pus and mucus and his proposed doctor's thesis were afterwards edited by the elder Erasmus. In the prize essay we find a number of experiments, in the thesis a round of clinical observations discussed in moderate and straightforward language. Only occasionally, as in the peroration of the thesis, do we feel sure that we read the words of the father, Erasmus himself :

" $\mathrm{T}$ heg, illustrious professors, and ingenious fellow-students, that you will recollect how difficult a task $I$ have attempted, to evince the retrograde motions of the lymphatic vesscls, when the vessels themsclves, for so many ages, escaped the eyes and glasses of philosophers; and if you are not quite convinced of the truth of this theory, hold, I entreat you, your ninds in suspense, 'till ANATOMY draws her sword, with happier' omens, cuts asunder the tenets which entangle PHYSIOLOGY; and, like an augur, inspecting the immolated victim, announces to mankind the wisdom of HEAVEN?".

In the same manner it is not possible to judge fairly of the thesis of Robert Waring Darwin which was published at Leyden in 1785, and afterwards in the Philosophical Transactions, 1786. The author was at the date of publication only 19, and Charles Darwin asserts that it was written by Erasmus. It largely reappears in the Zoonomia, but contains more appeal than the elder Darwin usually

1 I hardly think we can class Robert Darwin their father in this category; see however Life and Letters of Charles Darwin, I, p. 3.

2 Even the printing of Heaven in smaller capitals than the Sciences is characteristic of Erasmus Darwin's muse, although when reprinting the essay in his Zoonomia, Vol. I, p. 512, he secms to have become conscious of the difficulty and transposed the sizes! 
makes to experiment ${ }^{t}$. 'The second son of Erasmus the elder, Erasmus the younger, seems to have been in character more like his nephew Erasmus Alvey Darwin, the brother of Charles and friend of Thumas Carlyle and his wife. He is reported to have been interested in statistics, and although we do not lay much stress on this point, it deserves notice with regard to later developments of ability in the Darwin fanily. Erasmus Darwin the elder seems to have had distinct meehanical ability, and physical tastes; he was ingenious in mechanisms - as perhaps the sketch of his ferry at Derby, taken from a brief autobiography of his son, Sir Francis Sacheverel Darwin, will indieate (see Plate V). He was also in constant touch with a number of men working with distinction at mechanieal problems. He invented a windmill to grind colours ${ }^{2}$ for his friend Wedgwood, which after approval by Watt was not only used, but continued to be used till a steam-engine by Boulton and Watt replaced it. To Darwin again Watt first imparted under pledge of secreey his plan for improving the steam-engines. Indireetly also we find Darwin intelligently interested in astronomical and physical matters, such as the returns of comets predicted by Halley, the nearest approach of comets to the earth as discussed by Bode, or the experiments on mixing colours and on the nature of primary colours by his friend Samuel Galton-his grandson's paternal grandfather. 'On the whole we see in Erasmus Darwin most of the scientifie tastes which have been developed with greater thoroughness by his children, grandehildren and great-grandchildren.

When we look at these four generations of scientifie workers, the variable nature of their work-medical, biological, mathematical, mechanical-the wonder is not that ability has been maintained, but

' Erusmus himself, in 1788 (Botanic Garden, Part 11, p. 262), certainly approves the attribution of the memoir to Dr Robert Darwin. The paper dealing with "ocular spectra" is an interesting one, the earliest as far as I know which drew attention to the "contrast colour" seen by an cye fatigued by looking at a given colour.

"Metcyard, Life of Josiah Wedguood, Vol. II, pp. 29 and 447.

3 Owing to the kindness of Mr Darwin Wilmott I have been able very fully to examine the commonplace book of Erasmus Darwin; it gives the reader a far more favourable opinion of Erasmus than his poems-designs for various meehanisms alternate with accounts of medical cases, and with suggestions for experimental treatment. It is a most interesting and valuable book from both the historical and social aspects. His originality was shown in his attempt to inoeulate against measles; this made his son Robert rery ill, and his daughter Elizabeth is reported by some to have died as a resuit. 
Plute V

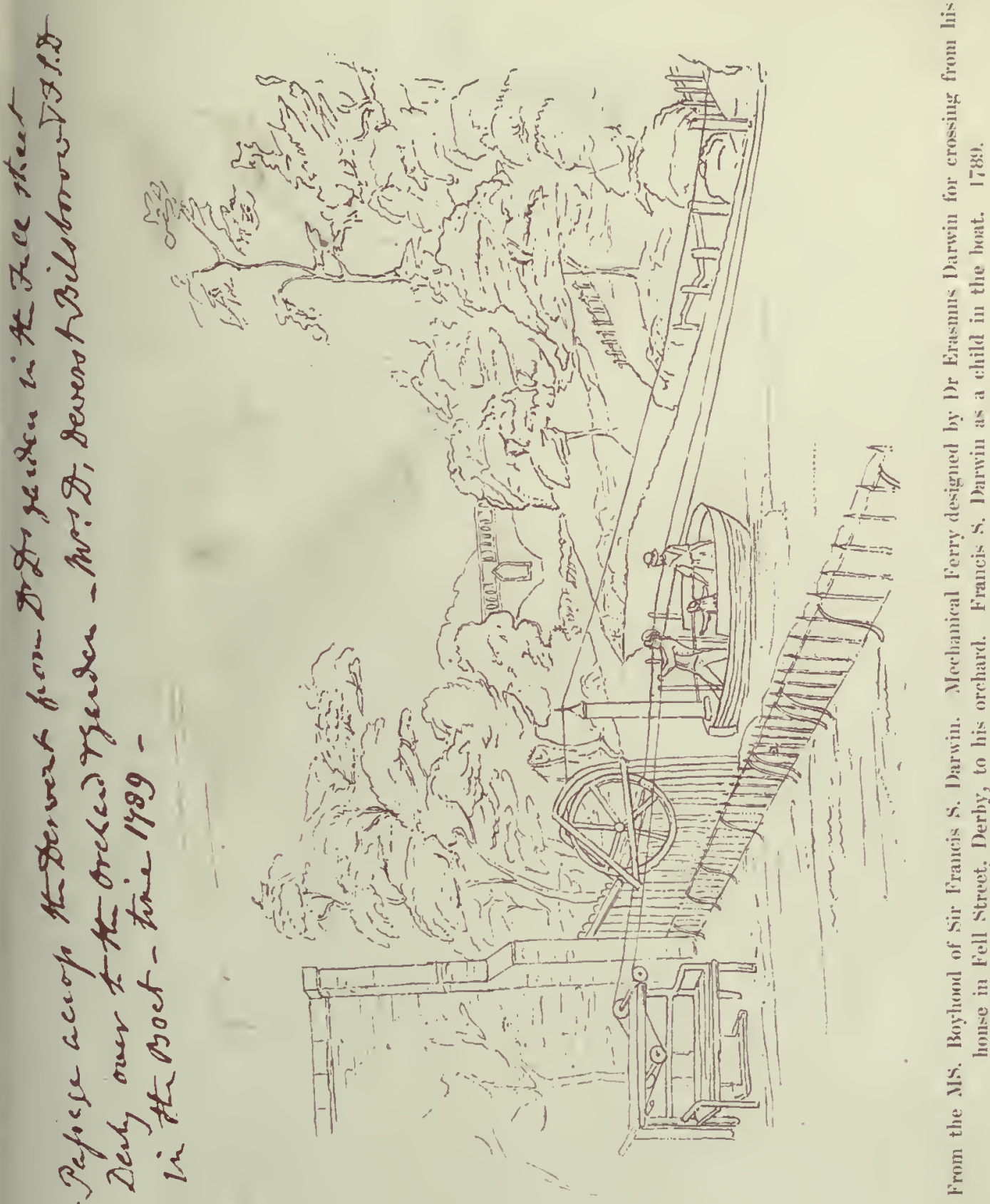



Plate VI

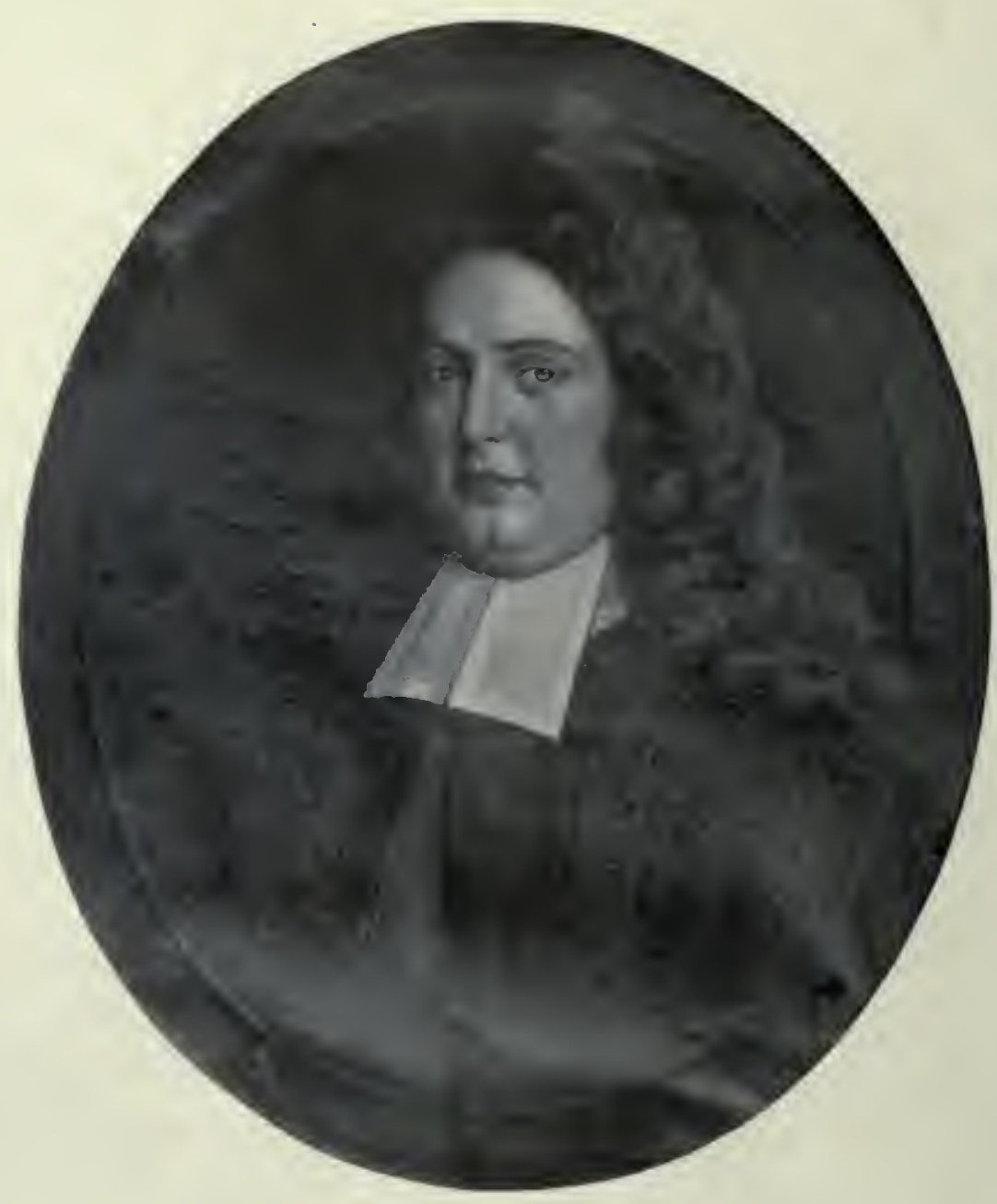

ROBERT DARWIN of Elston (1682-1754).

(ireat-grandfather of Charles 1)arwin and Francis Galton. From the portrait at Creskeld painted by Richardson about 1717 . 

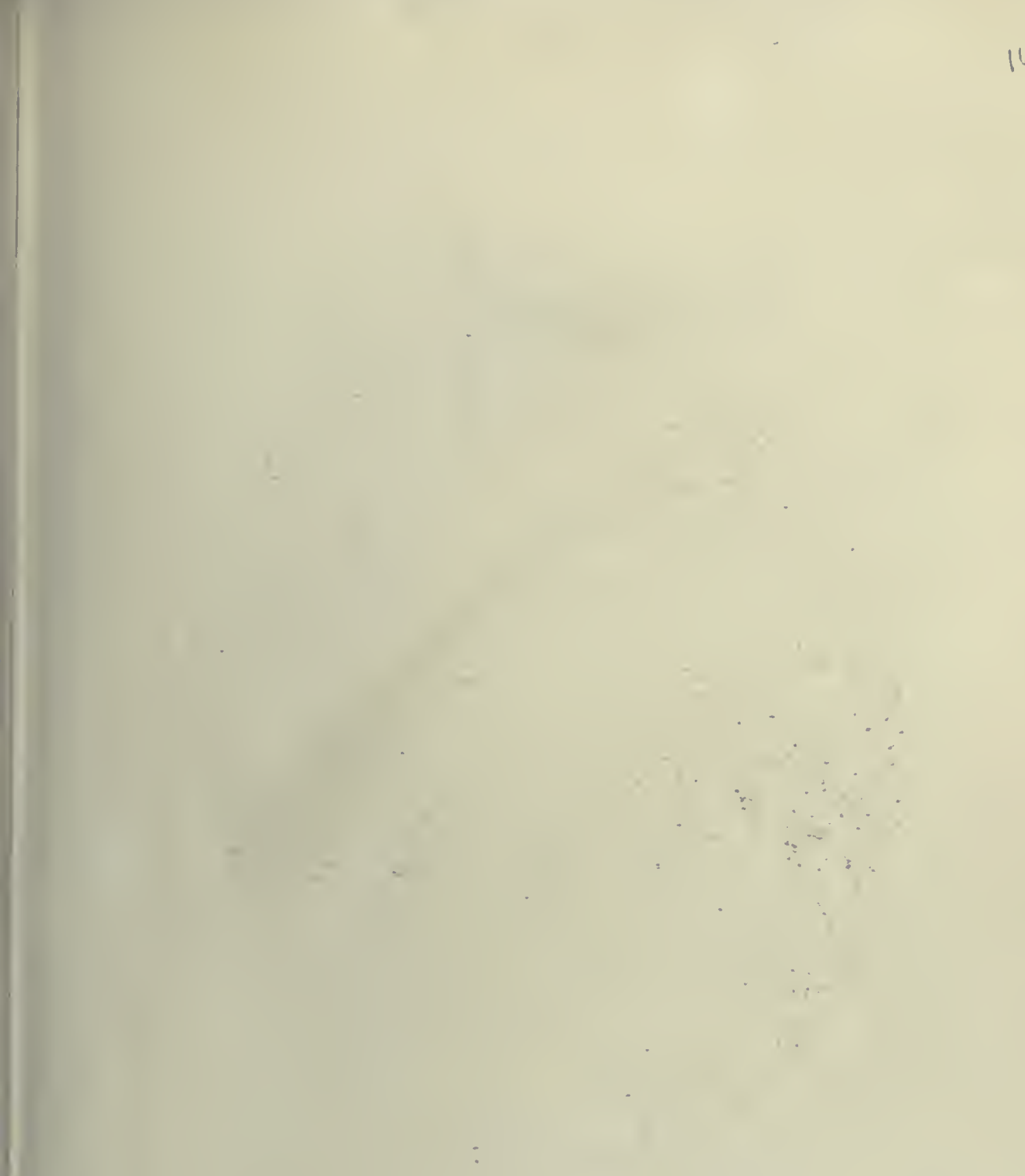


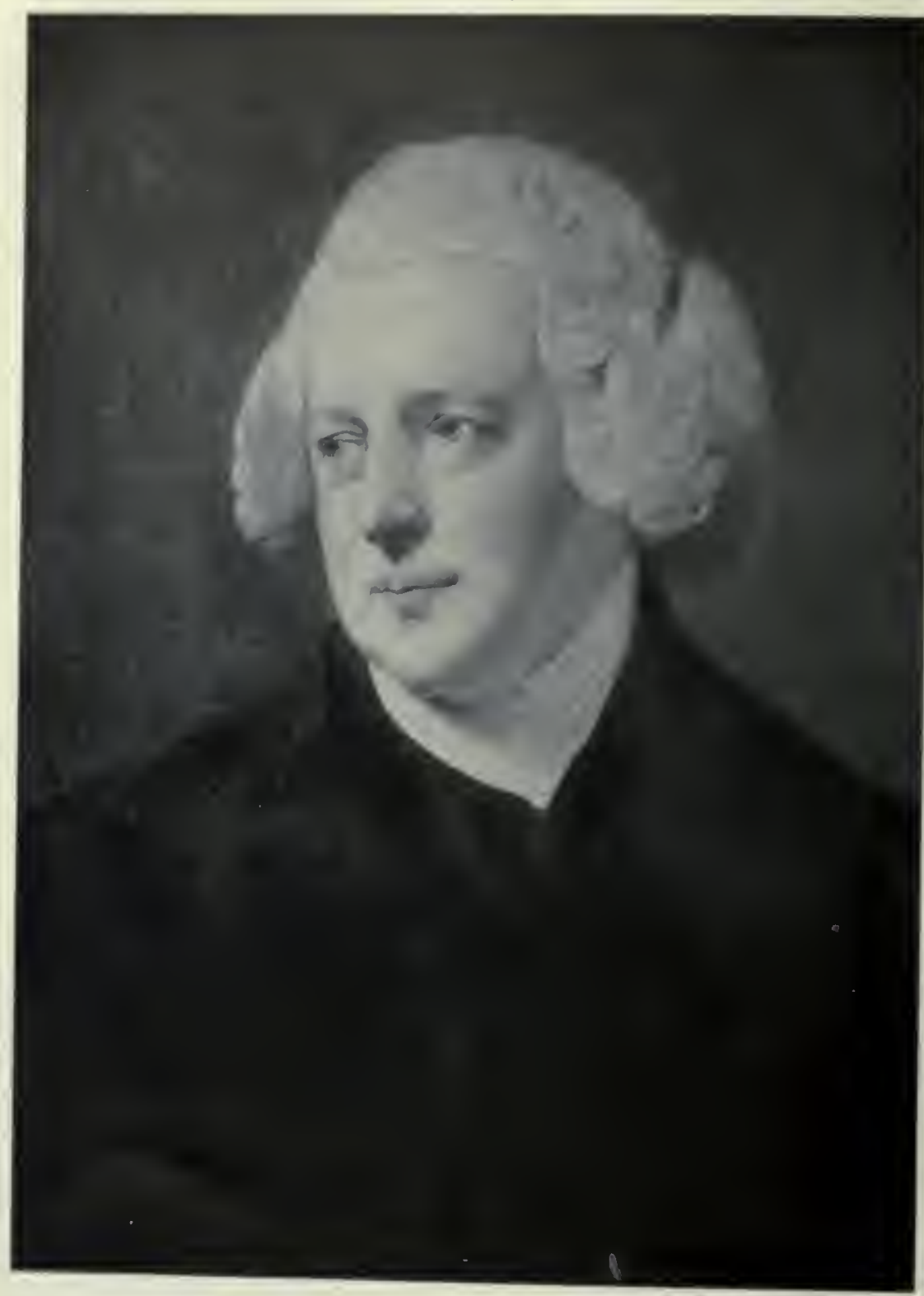

WHALAM ALYWY I)ARWIN (1726-1783).

Brother of lirasmus l)arwin. From a photograph in the possession of Mr William E. Darwin of the picture at Creskeld. 

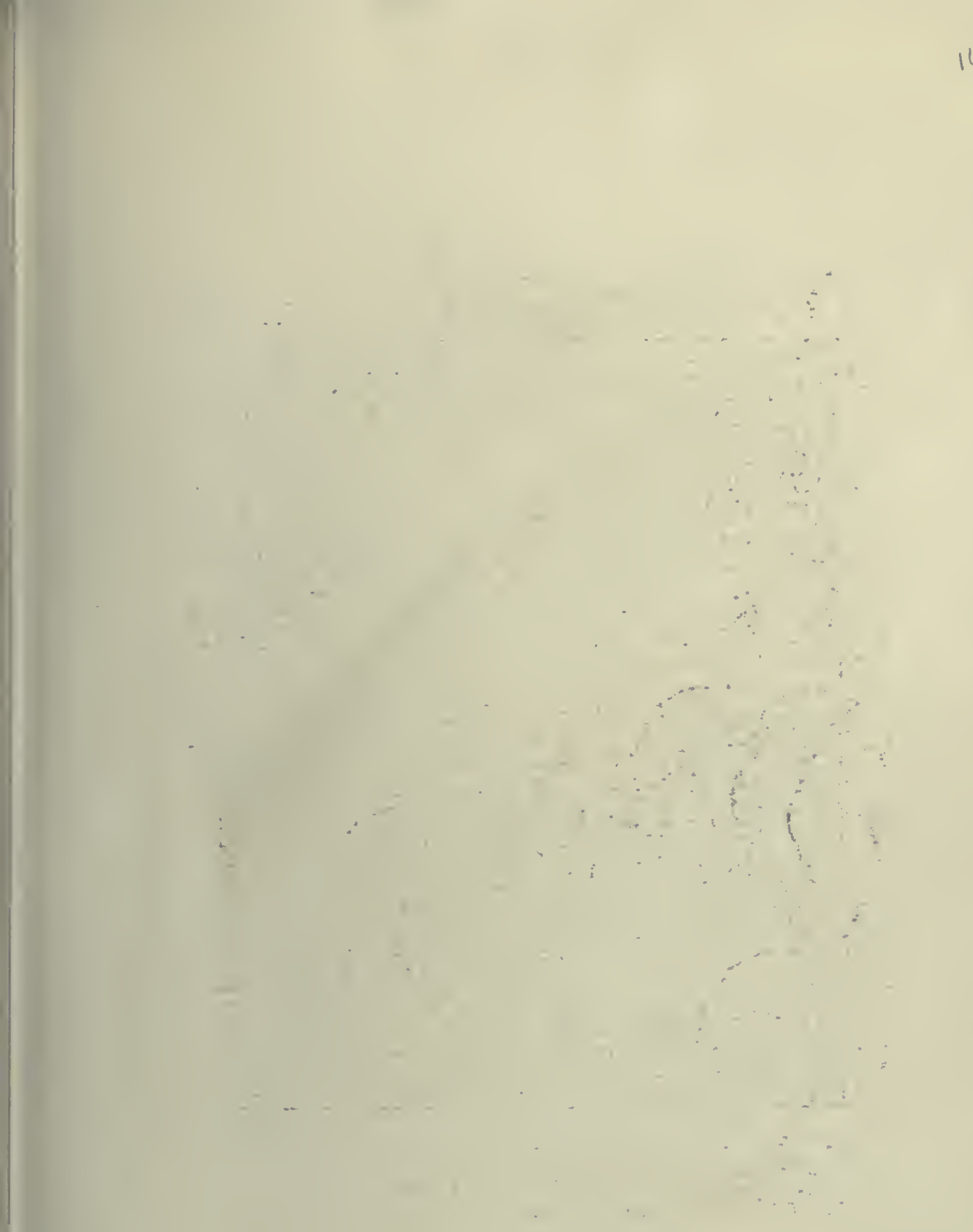
Plate VI ter

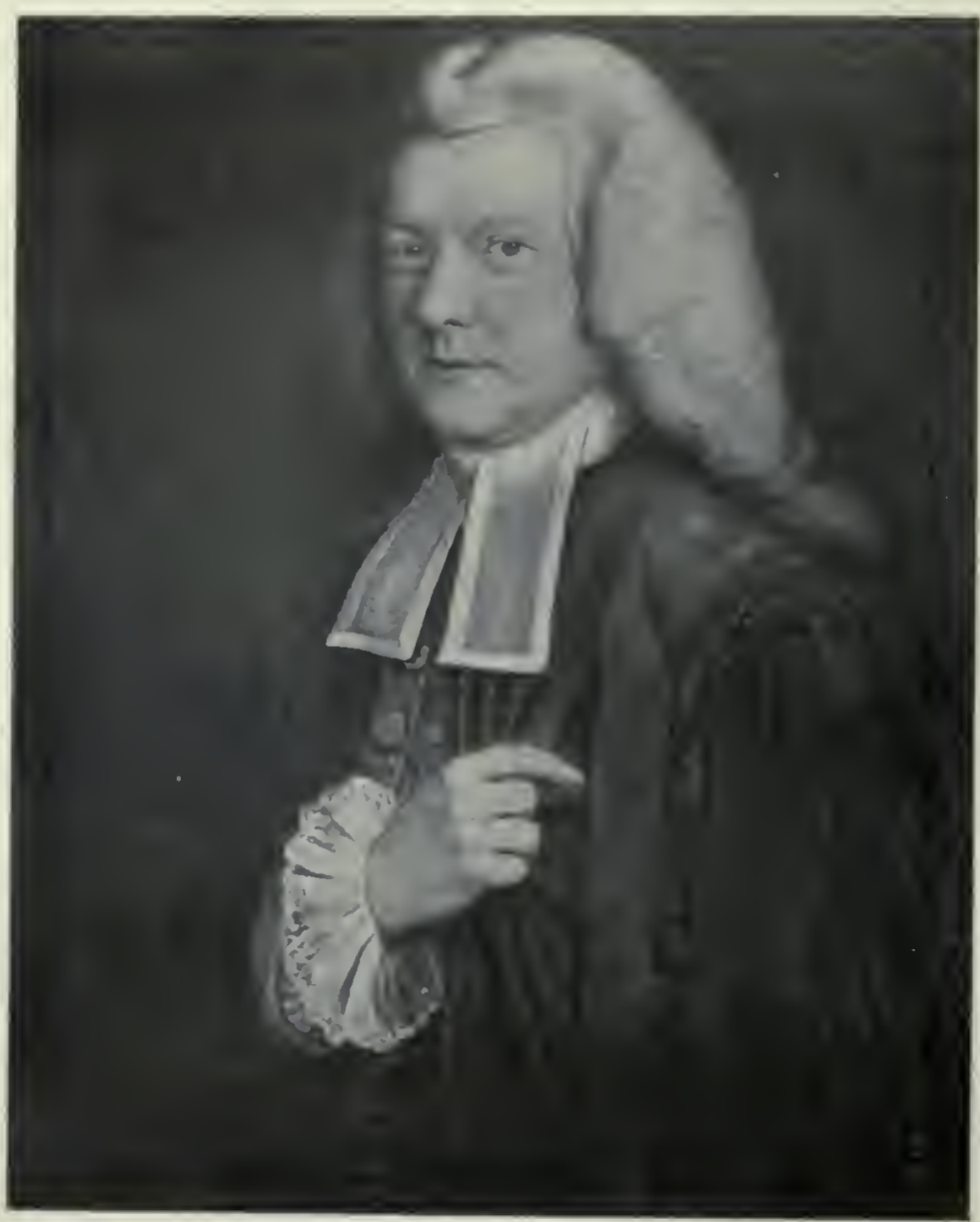

ROBERT WARING DARWIN (1724-1816).

Brother of Dr Erasmus Darwin.

Author of the Principin Botunica, or Introduction to the serual Botnmy of Linnarus. Aged 51 from the picture at Creskeld painted by dohn Borridge, 1775. 


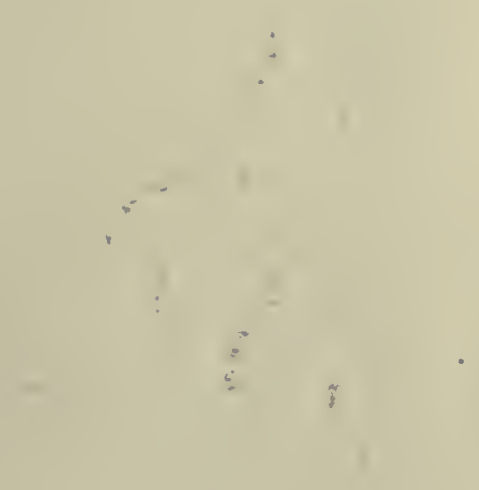




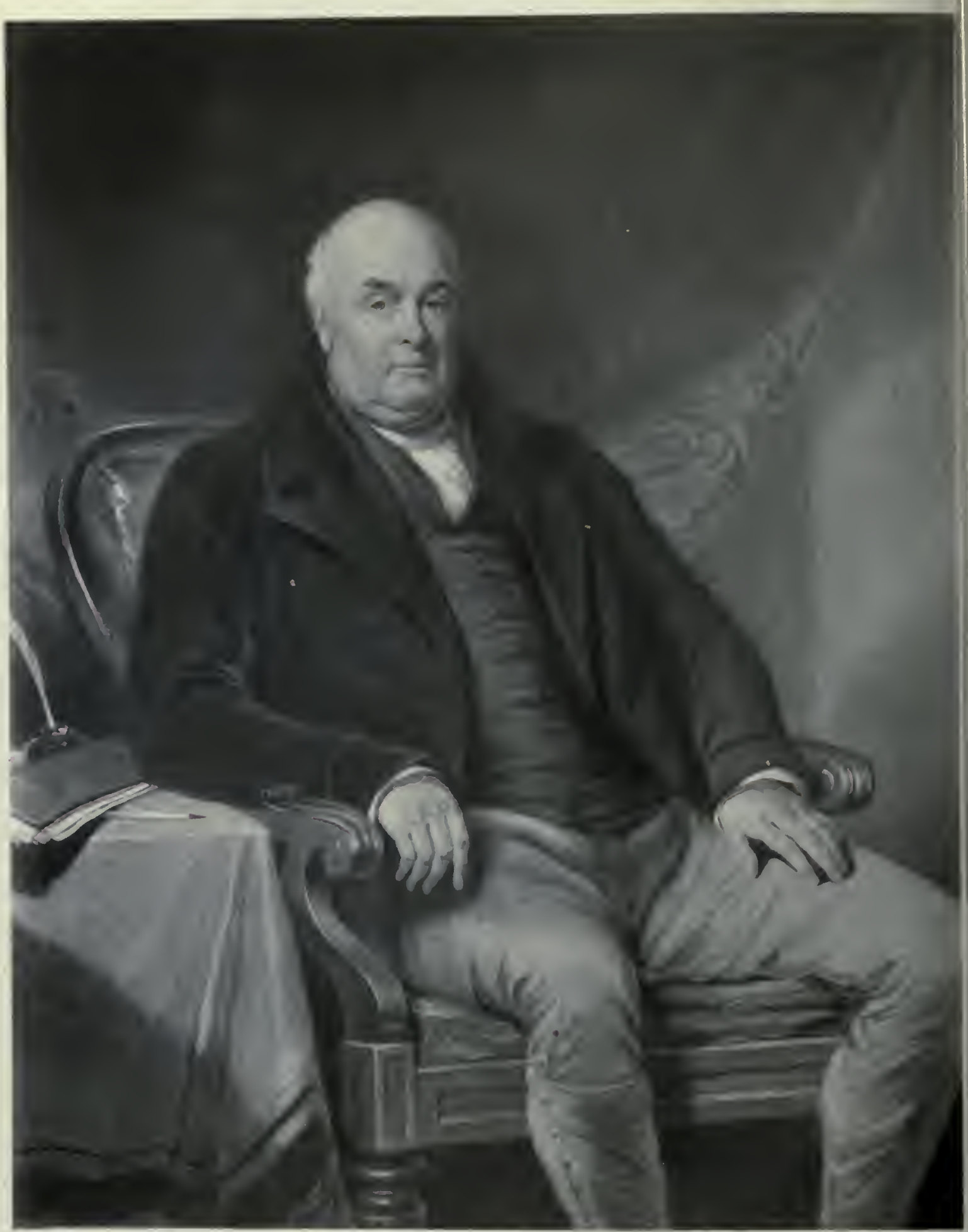

IROBSERT WARING DARWIN, F.R.S. (1766-1848).

Vather of Charles Darwin. From a mezatint of the painting in the possession of Mr William Erasmus Darwis. ('The mezotint was engraved before the painting was cut down.) 


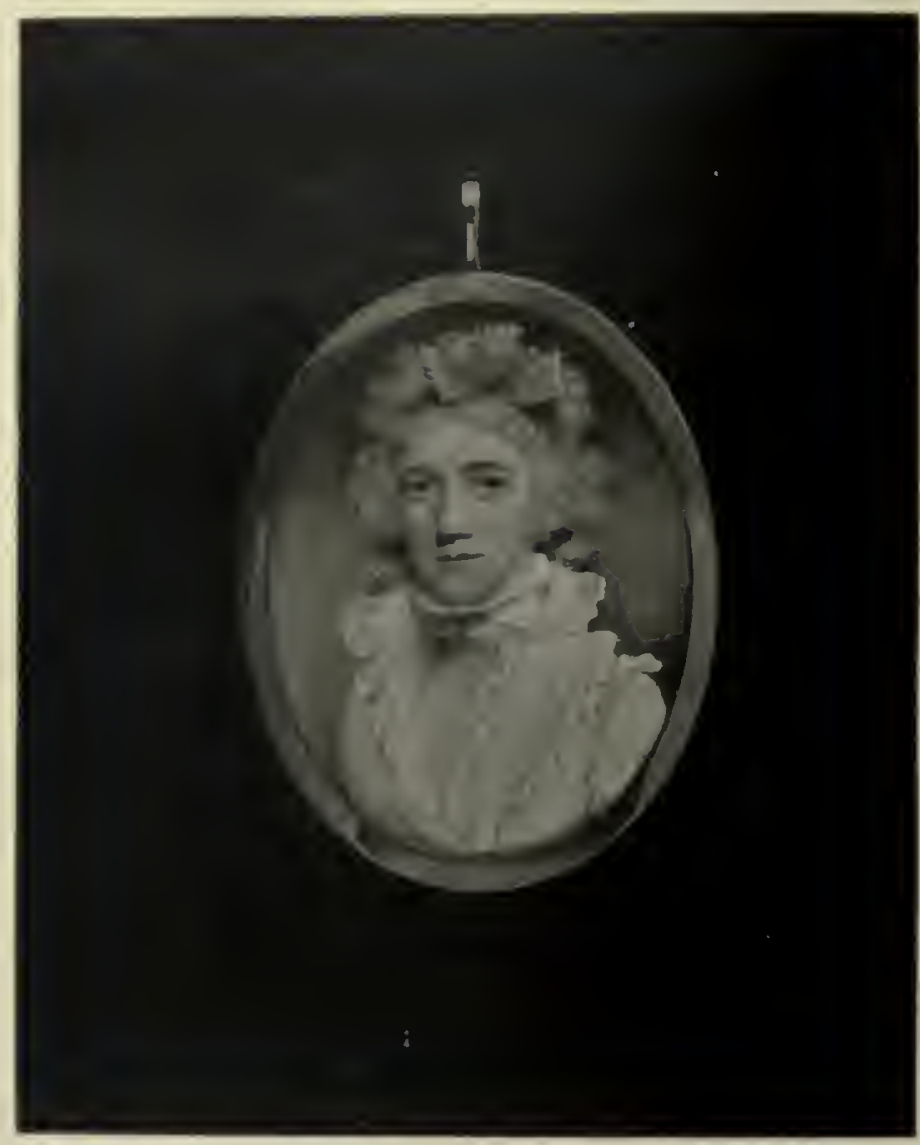

SUSANNAH WEOGWOOD $(17,5-1817)$.

IIrs Robert Waring Darwin, mother of Charles Dinwin. From a miniature in the possession of Mr William Erasmus Darwin. 
that we can find so little trace of it in the generations of Darwins before Erasmus. They belonged more recently to the smaller squirearchy and ultimately to the yeoman class. As far as a full pedigree has yet been traced the Darwin stock is linked by the marriage of Erasmus' great-grandfather William Darwin with Ann Earle to a stock of considerable ability. Am's father Erasmus Earle (whence ultimately the name Erasmus) was "Own Serjeant" to the Commonwcalth, a lawyer and diplomatist of some distinction, fiom whom through the female line the Lytton Bulwers or Bulwer-Lyttons trace descent (see Plate LXII). There is no evidence, however, of any member of the Earles having had scientific ability, and such distinction of the more literary kind as might come from this family must have laid dormant for two generations. Until the pedigree of the Hills is more fully worked out, I an inclined to think that Erasmus Darwin's mother, Elizabeth Hill of Sleaford, may have brought some of their exceptional ability into the family. Her portrait (see Plate VII) shows her to have been a lady of much character and her husband Robert Darwin (see Plate VI) is reported to have composed the verse:

\footnotetext{
"From a morning that doth shine, From a boy that drinketh wine, From a wife that talketh Latine, Good Lord deliver me!"
}

where the third line is suggested by Charles Darwin to have had some relation to the learned character of Robert's own wife !

So far we have kept to Charles Darwin's line of descent in the Darwin family, i.e. that connected with Erasmus Darwin's first wife Mary Howard (see Note II, Appendix). It seems likely that a certain delicacy, but possibly also a certain increase of sympathy and gentleness, was brought into the Darwin stock by this lady; she died at 30 years of age.

For eleven years Erasmus Darwin remained unmarried", then at

' I have examined all the available wills of the Sleaford Hills and the church registers in the hope of linking up Erasmus Darwin with Sir John Hill, the botanist, who sprung from Lincoln, but I have found no link so far.

2 From the standpoint of heredity it is of interest to know that he had in the interval two natural daughter's whom he educated; he set up a school and wrote a book on female education for them, and provided his own later daughters as pupils. One of these ladies afterwards married a doctor and her son became a distinguished surgeon. This lady and her future husband are shown in the "hydrophobia" staircase scene from the MS, autobiography of Sir Francis S. Darwin's boyhood: see Plate X.

P. G. 
50 he married the widow of Colonel Edward Sacheverel Pole. This lady, Elizabetlı Collier by name, was fanous for her wit and beauty ; Darwin made passionate poems (see Plate XI) to her even before her husband's death, and when she was ill he is reported to have spent the night outside her chamber window. Elizabeth Collier (see Plate XVII) must have been a noteworthy beauty in her day and had many younger suitors when Erasmus Darwin won her after only six months of widowhood. In old age she was a striking figure to her grandchildren, spending lier days wholly outdoors supervising her gardeners and labourers at Breadsall Priory, and her house was visited by her grandchildren with the greatest enjoyment. Of her ancestry we can piece together but little, and that tradition, not certainty. Family tradition states that she was a natural daugliter ${ }^{1}$ of Charles Colyear, second Earl of Portmore (see Plate XIII). Lord Portmore was a very well-known social figure in his days. He was one of the leading men on the turf in its early period, and his name occurs repeatedly in the old form of racing-namely, matches between two horses, agreed for a certain date between two owners. First as Captain Colyear and then as Lord Portmore from 1720 to 1760 we find him engaged in such matches with the Duke of Leeds, Sir Nathaniel Curzon, Lord Godolphin, etc., all notable figures in the early horse racing and horse breeding world. It was a world which centred chiefly round Newmarket Heath, and was largely self-contained. When Peregrine, the Duke of Leeds, dies, his widow Juliana marries Lord Portmore ; their daughter, Lady Caroline Colyear, marries Sir Nathaniel Curzon, and the son of Peregrine, Thomas fourth Duke of Leeds, marries Mary Godolphin in 1740, and ultimately comes into possession of GogMagog House (with the grave of the Godolphin Arab) near Cambridge. In such environment we have to look for the inother of Elizabeth Collier, who is reported to have been the governess to the Duchess of Leeds' daughters, Lady Caroline and Lady Juliana. It is significant of the higher sense of responsibility of those days, combined as it was with much greater looseness of morals, that we find in the family records that the natural children were often brought up in touch with members of the legitimate family and provided for in much the same way. Thus we

'She was brought up in good society under the charge of a Mrs Mainwaring of Farnham, of whom Elizabeth Collier always spoke with great affection, and whom slie occrsionally visited. 
Plate $\mathrm{X}$

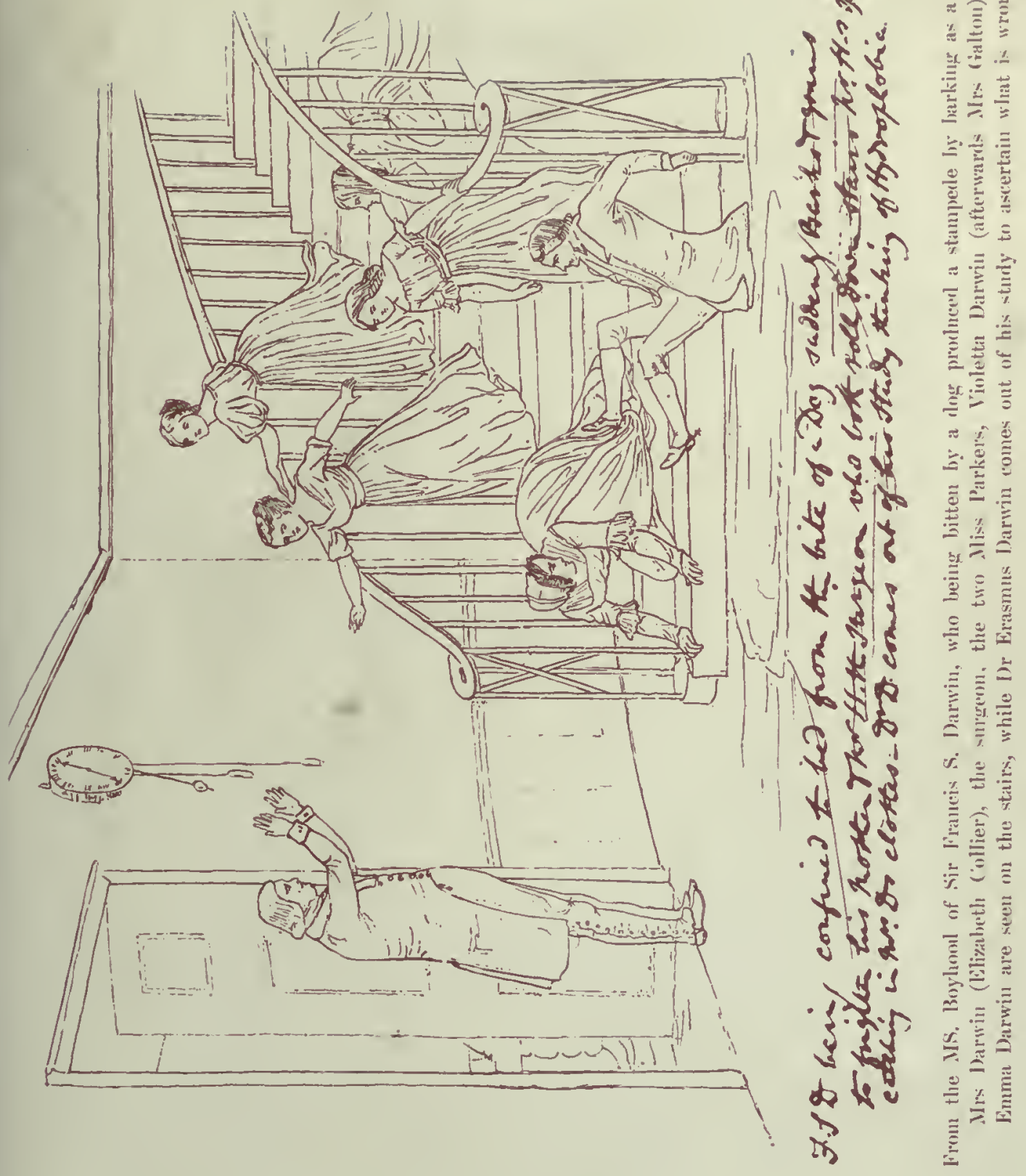





\section{Letter $X$}

PCoronic equistle to a moximied Sadry.

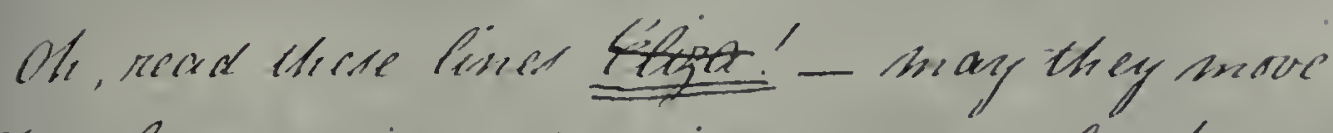

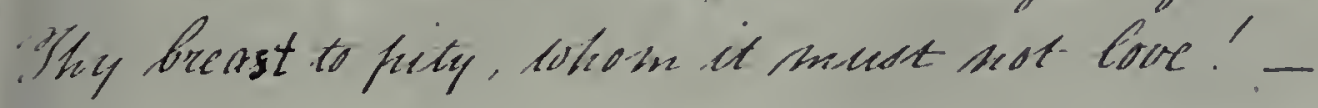

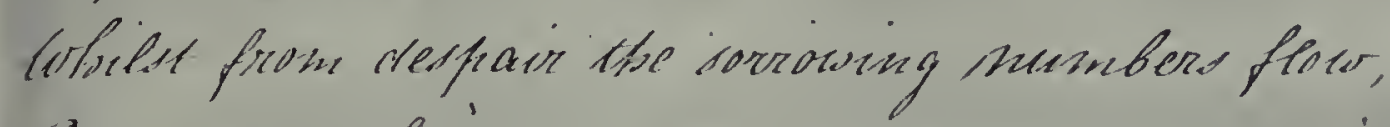

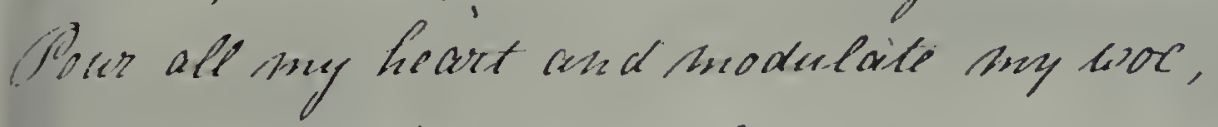

- To Cowlegs wish, neo dubiout worde shale rise, But Truth shall tume thense, Yintue's self chiastise

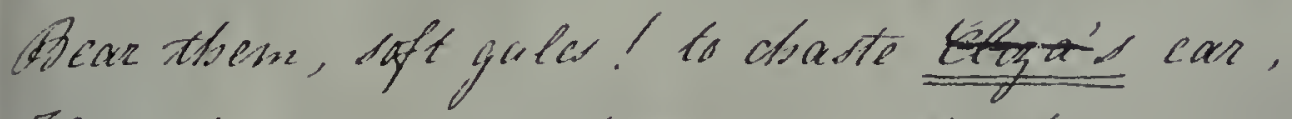
Herself may read them, - or her husband hear.

If brigher scenes from other's frills extend, If ther's wales more friagrant flowers defond,

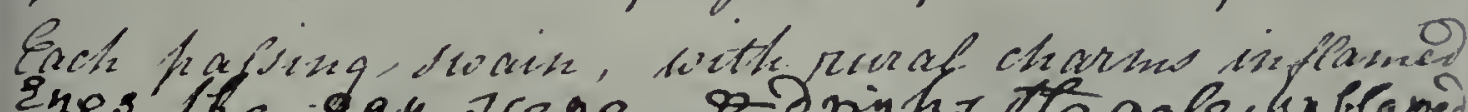

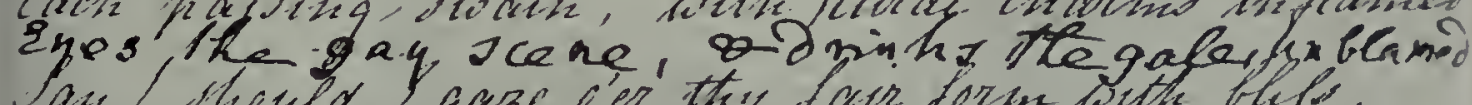
say! Shoved gaze ber thy farr form both blefe, ir ask the baimy rafuture of a kige,

Pore wo the reval mects her sistor-guset,

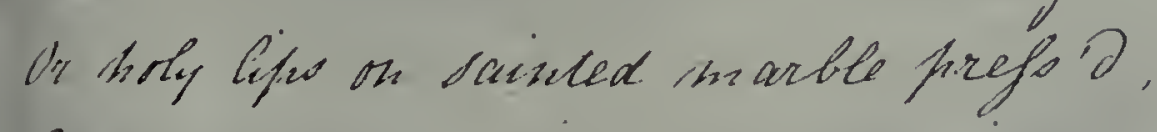
could buth, could insocence, on virtue flame? 



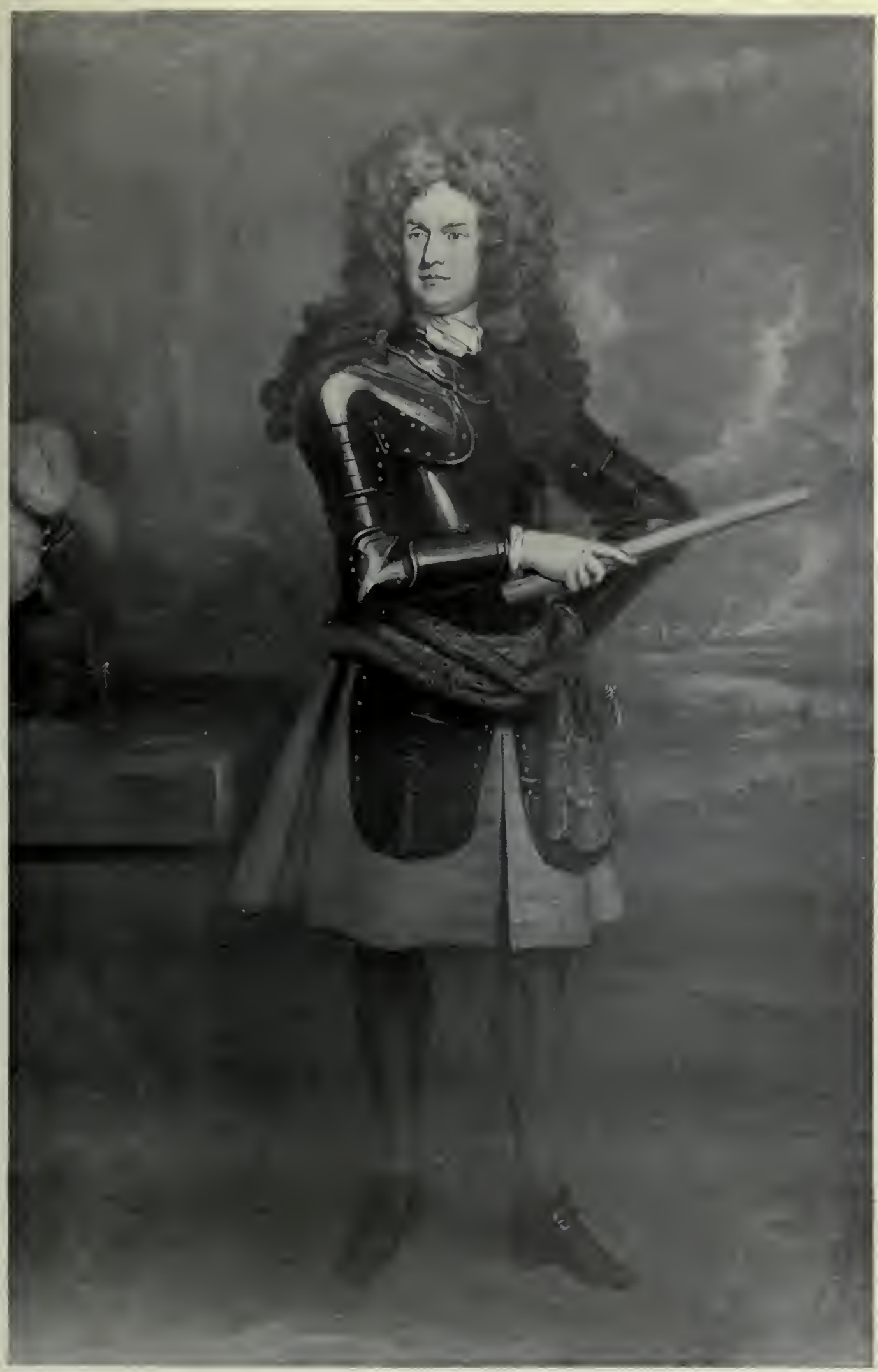

GENERAL SIR DAVID COLYEAR, afterwards Lord Portmore (cirea 1650-1730). From the portrait by Van der Banck formerly at Arthingworth Hall. 
$\therefore$

$-$

-

4 


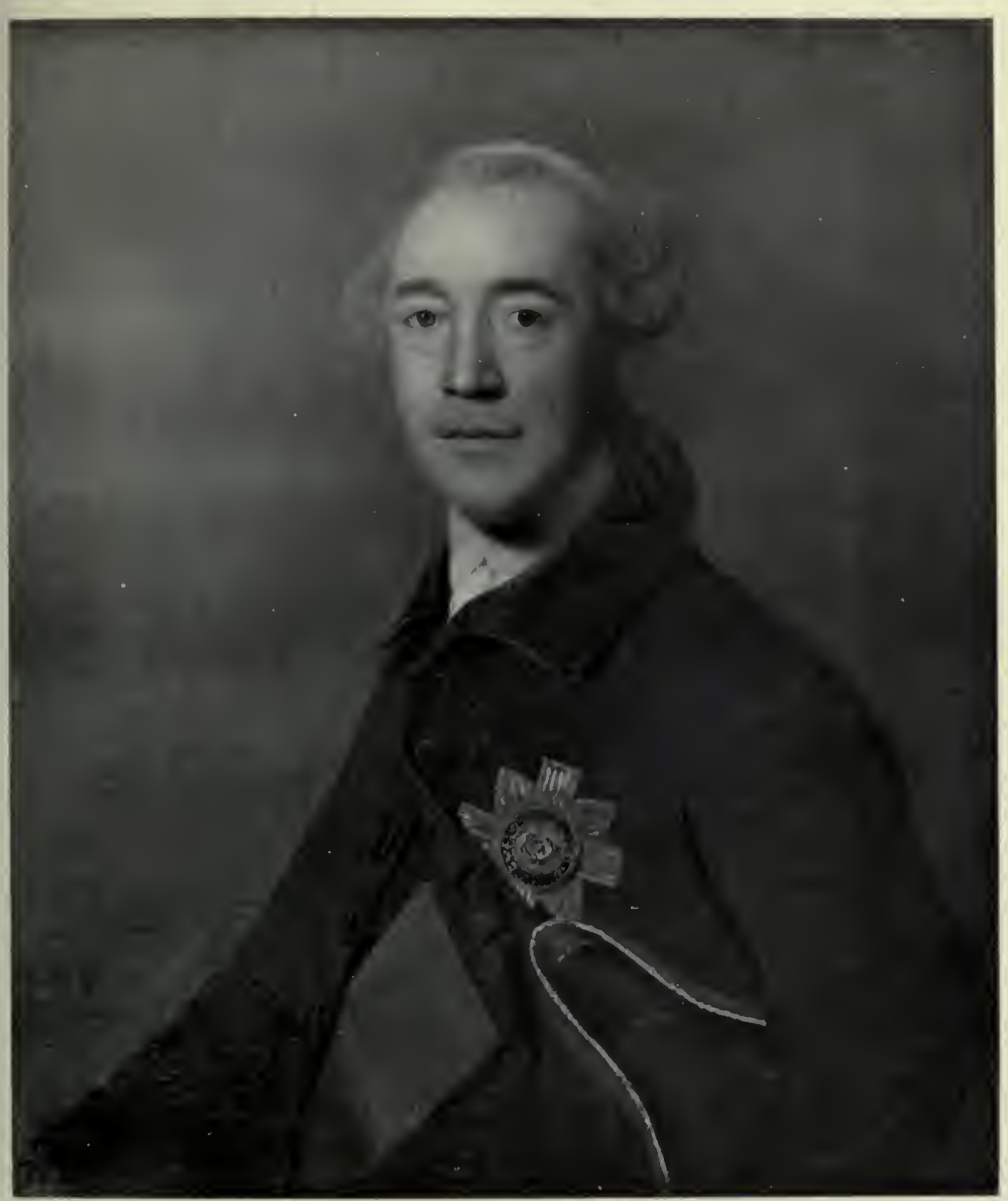

C'IARLES COLYEAR, Seconl Earl Portmore (1700-1785). From the picture by Reynolds formerly at Arthingworth Hall. 



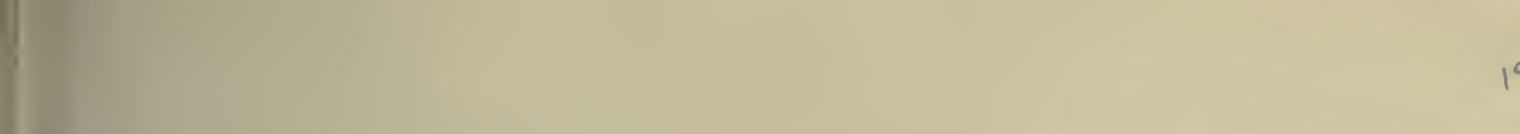

.

.
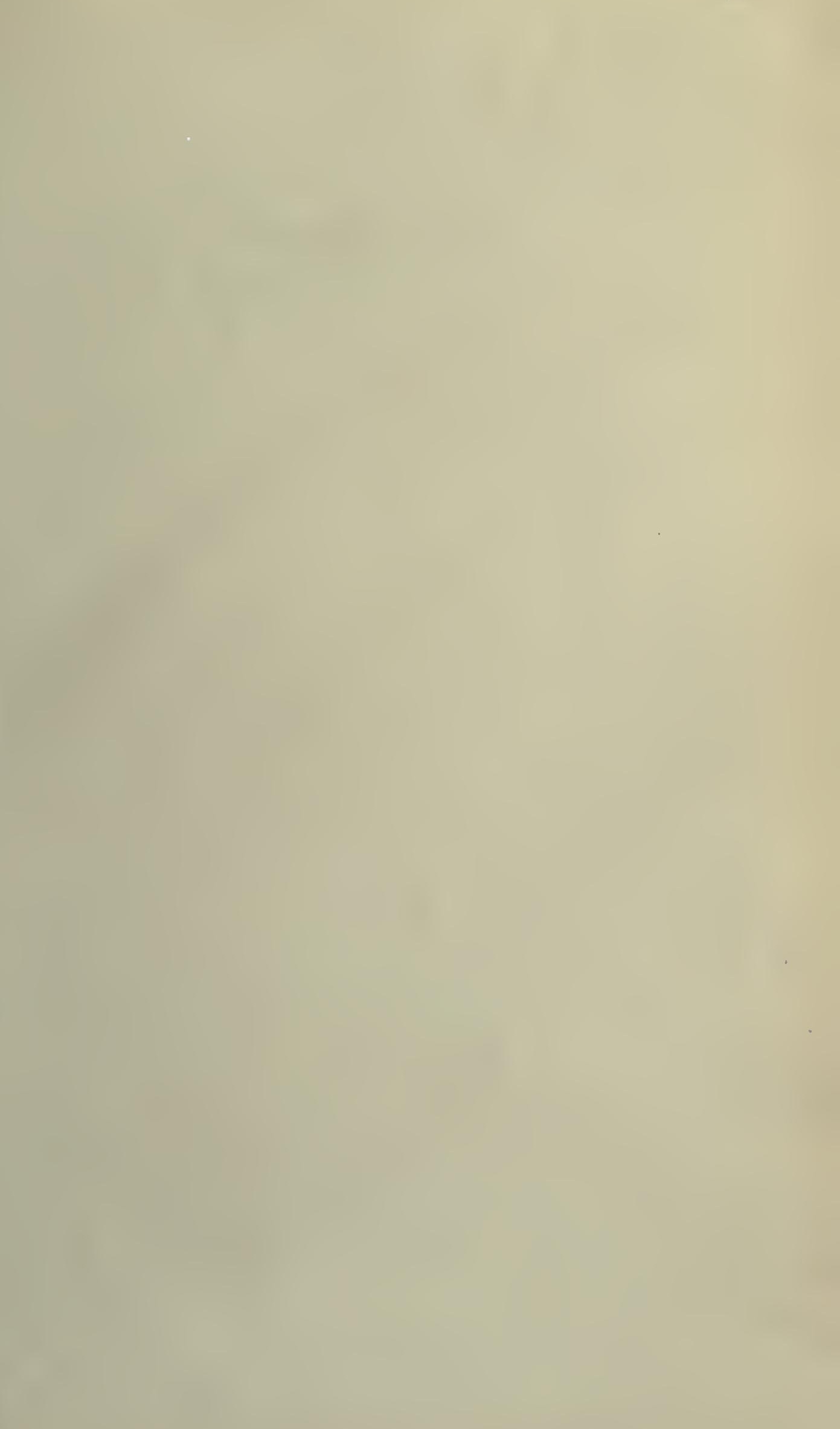


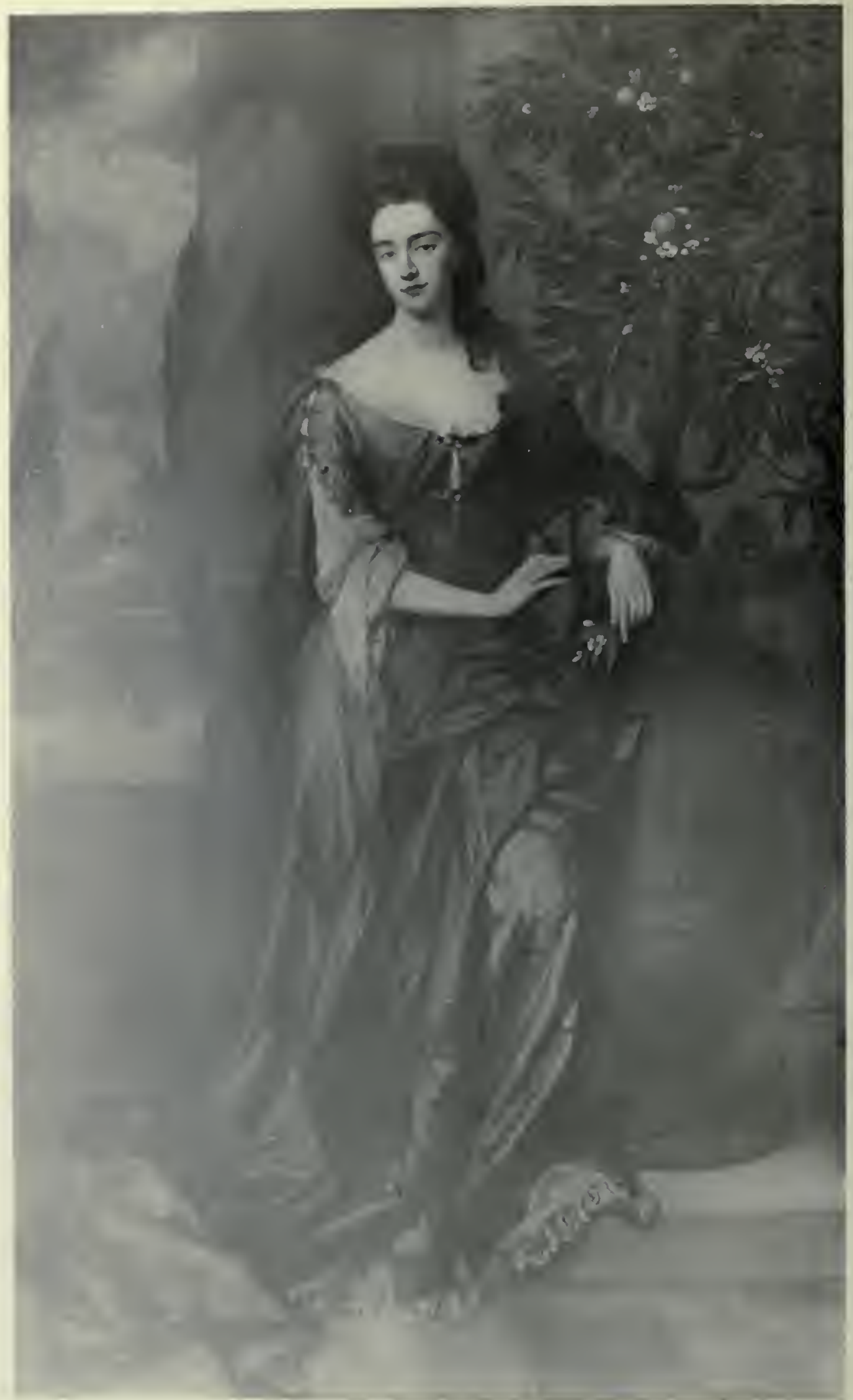

(AIHERINE; SEDLEY, Countess of Dorchester, afterwards Lady Portmore (1657-1717). From the picture by Kineller formerly at Arthingworth Hall. 
find Erasmus Darwin's natural 'daughters were intimates of his family'; Colonel Edward Sacheverel Pole gave the family living to a natural son who bore the name of Pole and was beloved by Darwins, Galtons and Poles alike. Our first knowledge of Elizabeth Collier is her marriage on April 10, 1769, to Colonel Pole in the little church at Radbourne. Why should a natural daughter of Lord Portmore appear in Derbyshire? We think there is no doubt that the true explanation is to be found in the fact that the Curzons were next neighbours to the Poles, and that Lady Curzon, formerly Lady Caroline Colyear, would be halfsister to Elizabeth Collier. She brought her natural sister with her to Derbyshire, and there Elizabeth married. In tracing the parentage of Erasinus Darwin's second wife to Lord Portmore, we have linked up Francis Galton's grandmother with a number of names of great historical interest.

Charles Colyear himself-commonly called "Beau Colyear"-a name justified by the portraits I have seen of him, was chiefly celebrated for his horses and his equipages. But his father (see Plate XII) was a man of great distinction. He served as a soldier of fortune under William of Orange and came with him to England, afterwards serving in Spain and Flanders-

"one of the best foot officers in the world, is very brave and bold; hath a great deal of wit; very much a man of honour and nice that way, yet married the Countess of Dorchester"

writes a contemporary of him. Catherine Sedley, his wife, had been mistress to James the Second ${ }^{2}$. Portmore was a soldier of fortune raised to the peerage by his achievements in the field. Catherine Sedley, whatever we may think of her morals, was undoubtedly a woman of very great character and of great wit. A sample of this is provided by her astonishment at the intensity of the Duke of York's passion for her: "It cannot be my beauty," she said, "for I have none; and it cannot be my wit, for he has not enough to know that I have any."

The portrait of her by Kneller ${ }^{3}$, till recently at Arthingworth Hall

1 There are frequent visits and letter's to and from these Miss Parkers, and theyare two out of the four children in the sketch of the staircase at Dr Darwin's house : see Plate X.

${ }^{2}$ Catherine Sedley was a kinswoman of the Churchills, whether through the Drakes or not, I have been unable to ascertain. Thus she was probably related to Arabella Churchill, and possibly to both Barhara and Elizabeth Villiers-a subject which would form a fitting study for a thesis on heredity.

"Sold at Christie and Manson's in 1913. 
(see Plate XIV), does not support the view that she was entirely lacking in beauty. It is not wholly unlike Wright's portrait of Elizabeth Collier (see Plate XVI), and we think in the youthful Violetta Darwin and in other members of the stock descended from Elizabeth Collier and Erasmus Darwin we may find traces of Catherine Sedley.

And if we are to judge a royal mistress, we must turn to her time and parentage! Her father was one of the lewdest men at Charles Il's cour't, and even Pepys, by no means himself an ascetic, was shocked at his profligacy. Yet he was a man with real literary power, his prose style is "clear and facile," and his plays and poems had such a contemporary reputation that Charles II said of him that "his style, either in writing or discourse, would be the standard of the English tongue." Later in life Sedley somewhat redeemed himself by parliamentary activity and his advocacy of William III'. He will ever be remembered by his lyrics:

"Love still has something of the sea,

From whence his mother rose";

or :

"Phillis is my only Joy,

Faithless as the Winds or Seas,

Sometimes coming, sometimes coy,

Yet she never fails to please";

and these at least settle that he knew how to handle his mother tongue. His portrait from a print in the British Museum is given in Plate XXI.

Sir Charles SSedley's wife was Elizabeth Savage, who came of a distinguished line, and his mother was the Elizabeth Savile, of whom Waller wrote :

"Here lies the learned Savile's heir,

So early wise and lasting fair,

That none, except her years they told,

Thought her a child or thought her old."

Thus we link up with Sir Henry Savile (see Plate XV), the most scholarly Englishman of his date, the founder of the Savilian professorships of geometry and astronomy at Oxford, tutor to Queen Elizabeth, Warden of Merton and Provost of Eton. On the other hand Sir William Sedley², Sir Charles' paternal grandfather, founded the Sedleian

' He is reported to have said that if King James made his (Sedley's) daughter a countess, he had been even with him in courtesy by making James' daughter a queen!

'I lave not been able to discover in Oxford any portrait of Sir William Serley. 


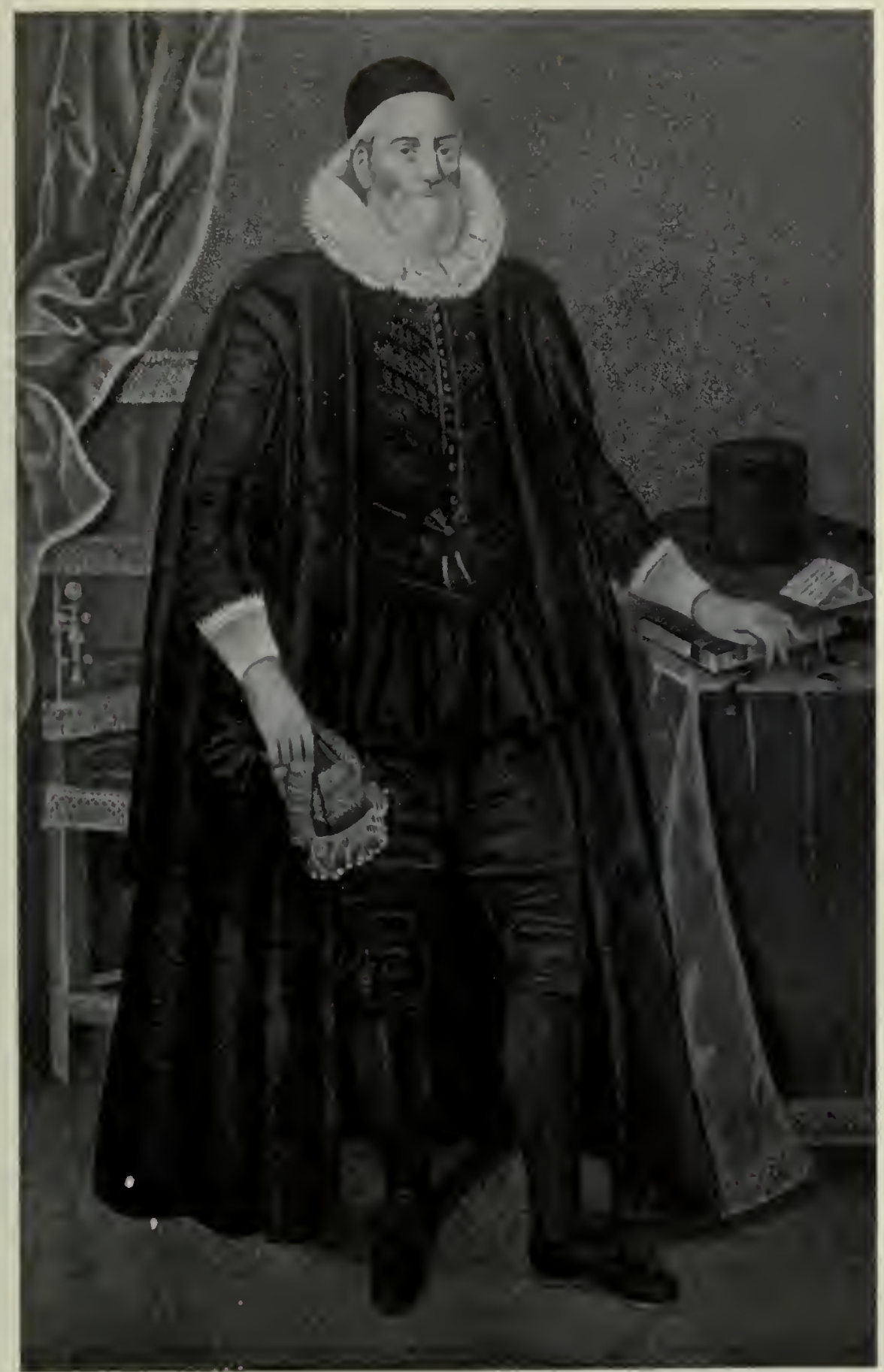

SIR HENRY SAVILE, Seholar (1549-1622).

Maternal graudfather of Sir Charles Sedley and a direct ancestor of Francis Galton. From a print of the portrait by Marcus Gheeraerts the Younger in the possession of the author. 



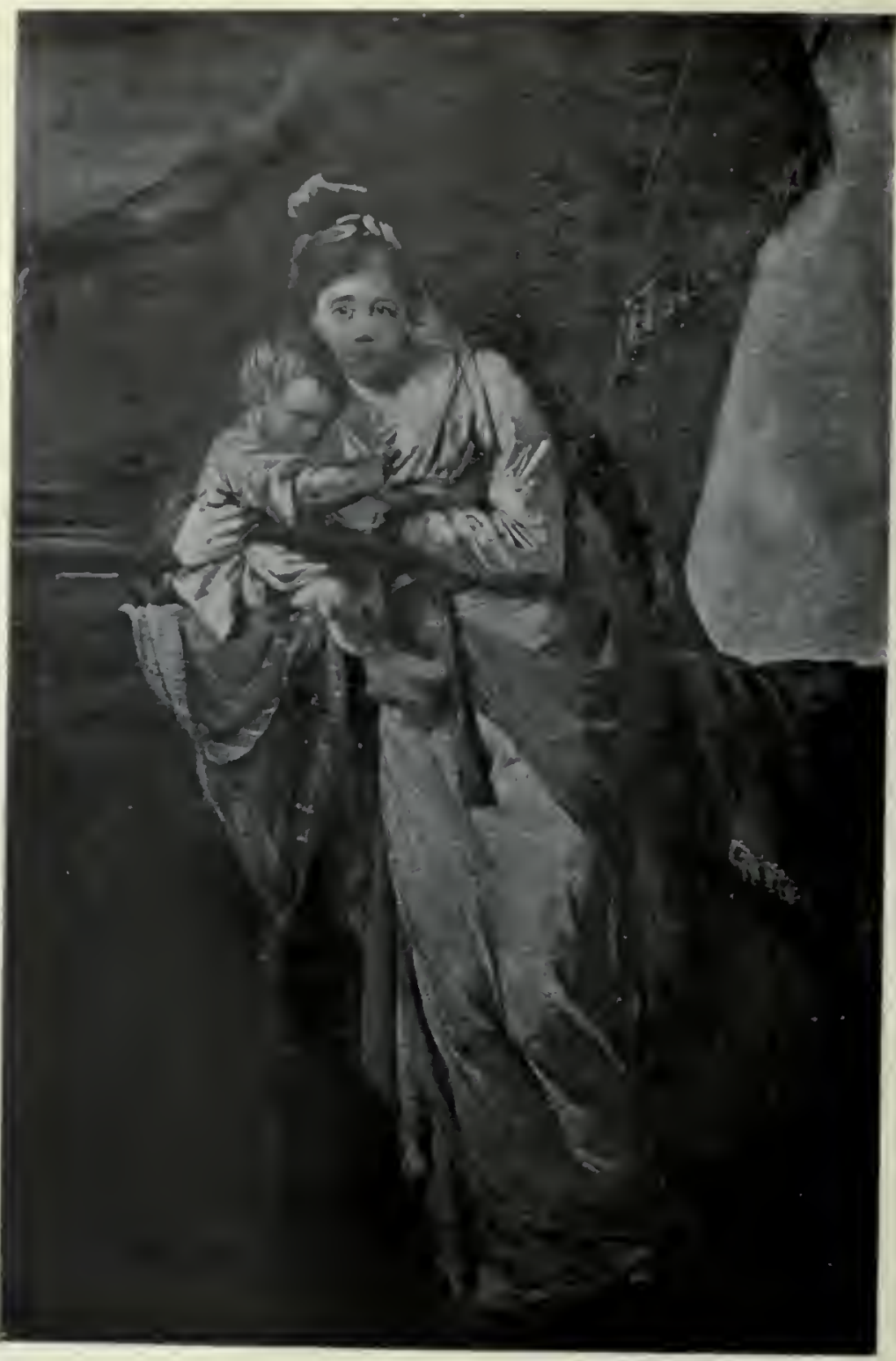

ELIZABETII COLLIER (17+7-1832).

Mrs Pole, later Mrs Erasmus Darwin, with her son sicheverel Pole. Painted in the year 1770. From a picture in pastel by $W_{\text {right }}$ of Derby in the possession of Mr. Wheler Galton at Claverdon. 


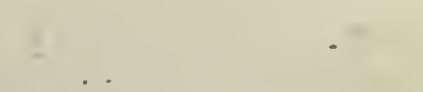



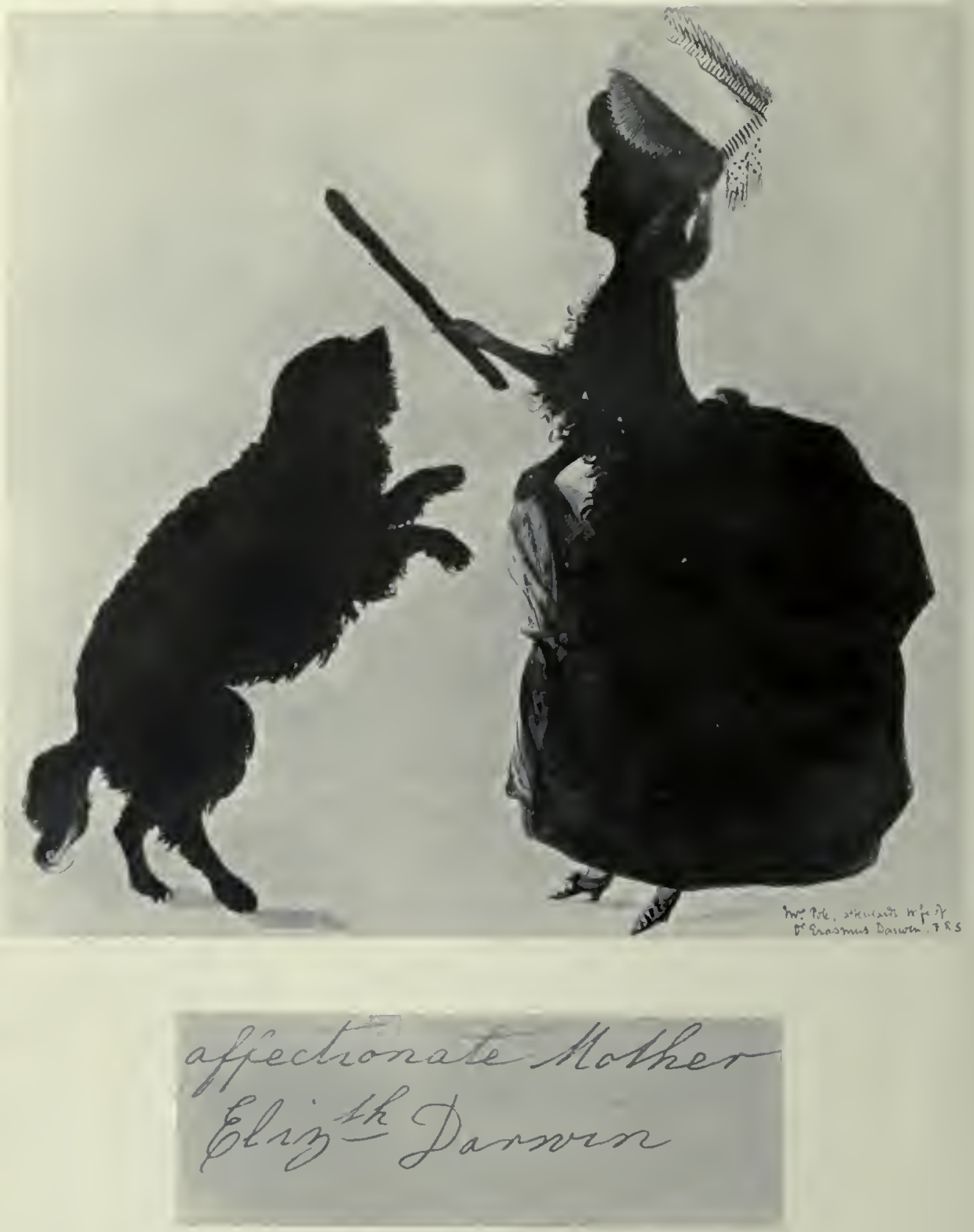

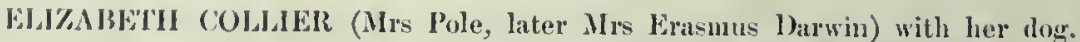
from a silhnuette at Chaverdon in the possession of Mr Wheler Galton. 
professorship in Natural Philosophy at Oxford. It is not without interest that the grandson of Savile and Sedley in the sixth degree should have founded a professorship in his turn.

One of the most noteworthy points connected with this branch of Francis Galton's ancestry is the tendency to die out in the male line. Sir Henry Savile left an only daughter, Sir Charles Sedley an only daughter, the Colyears ceased to be in the male line, the Darwin family springing from the Darwin-Collier marriage has ceased to be in the male line, and this is true whether we follow it in either Galton or Darwin branches. The women of the stock have children, but their sons again are childless or nearly childless. This is far too widespread a phenomenon to be the result of chance; we nust probably conclude that childlessness of the male is a definite heritage of the Savile-Sedley ancestry. It provided keen wit, courtly manners, literary power, and love of adventure, but handicapped the sons with this fatal dower.

Of Elizabeth Collier's mother I am less able to speak definitely. I have sought for families of Collier which would be at all likely to be in touch with the racing circle of Godolphin, Leeds, and Portmore. The only one I have found was next neighbour to Gog-Magog House, a yeoman family of Collier associated with the villages of Stapleford and Stow-cum-Quy, but a few miles from Cambridge and from Newmarket. Here a certain Elizabeth Collier was born in 1713; she is not married till the year after Mrs Darwin's birth, but no trace of the registration of that birth has been found ${ }^{1}$. I suspect, but cannot prove, that she was the mother of our Elizabeth Collier, and that shortly before 1745 , she came as governess into the household of the Dowager Duchess of Leeds, then wife of Lord Portmore, whose stepson two or three years earlier had married Mary Godolphin, the daughter of Lord Godolphin of Gog-Magog House, Stapleford. Should this be correct, Francis Galton would be a descendant of a member of a family which has produced men noteworthy both in literature and medicine. He would probably be a direct descendant of the father of Jeremy Collier, the famous non-juror. Collier's writings are described as "clear, brilliant and incisive," the work according to Macaulay of "a great master of sarcasm, a great master of rhetoric." Almost singlehanded Collier purged the

1 That birth is not recorded in the church registers at Weybridge, the home of the Portmores. 
English stage at the close of the 17 th century by his courageous attack on Dryden, Congreve, D'Urfey, and the school of licence in his Short View of the Immorality and Profaneness of the English Stage (1697)'. It is one of the weird phases of human history that if our suggestion be correct Elizabetl Collier should be a kinswoman at the same time of the licentious playwright Charles Sedley and the courageous and indignant non-juring bishop Jeremy Collier! One thing both her kinsmen possessed in common-sarcastic wit and a fine command of English -and that is a heritage which is so rare that none can disregard it.

A few words must be said here of the descendants of Liasmus and Elizabeth Darwin. Of the seven children of this marriage, Edward Darwin the elder died unmarried at 47 . We have few details of his character or ability. John Darwin, Rector of Elston, died unmarried at 31, Henry Darwin died as an infant, Emma died unmarried at 34, Harriet married Admiral Maling and died without issue at 35. Thus for our present purposes the family reduces to two: Francis Sacheverel, afterward Sir Francis S. Darwin, and Violetta, afterward Mrs Galton. Sir Francis Darwin (see Plate XVIII) is for us a most interesting figure. In the first place he was godfather to his nephew Francis Galton. In the next place, like his godson he was trained to medicine. A brief autobiographical account of his boyhood illustrated by his daughter Violetta is still in existence, and it shows him as an adventurous, lather wild boy (see Plates X and XIX). Like his godson he soon ceased to pursue medicine as a profession, but in 1808 , at 22 , he started with four others, one of whom was 'Theodore Galton, a younger brother of Francis Galton's father; on a tour through Spain, the Mediterranean and the East. Travelling was not then what it is now, and we come in contact with war, robbers, privateers and the plague in the diary of this two years' tour in the East. Of the five who started, only Dr Francis Darwin returned alive! The diary of the tour shows a keen antiquarian taste gratified under many difficulties, and we recognise that Francis Dar'win not only loved adventure for its own sake, but was a born naturalist also, whose ready pencil followed a keen eye, where rock and mineral, plant and

'I have followed Macaulay (Essays, ed. 1874, p. 588, and IIistory, ed. 1876, v. p. 85), but I have not done so without examination of the originals. Jeremy Collier's Short View does not suit the public taste of to-day, but the question is whether we do not need a second lustration. 
Plite XVIII

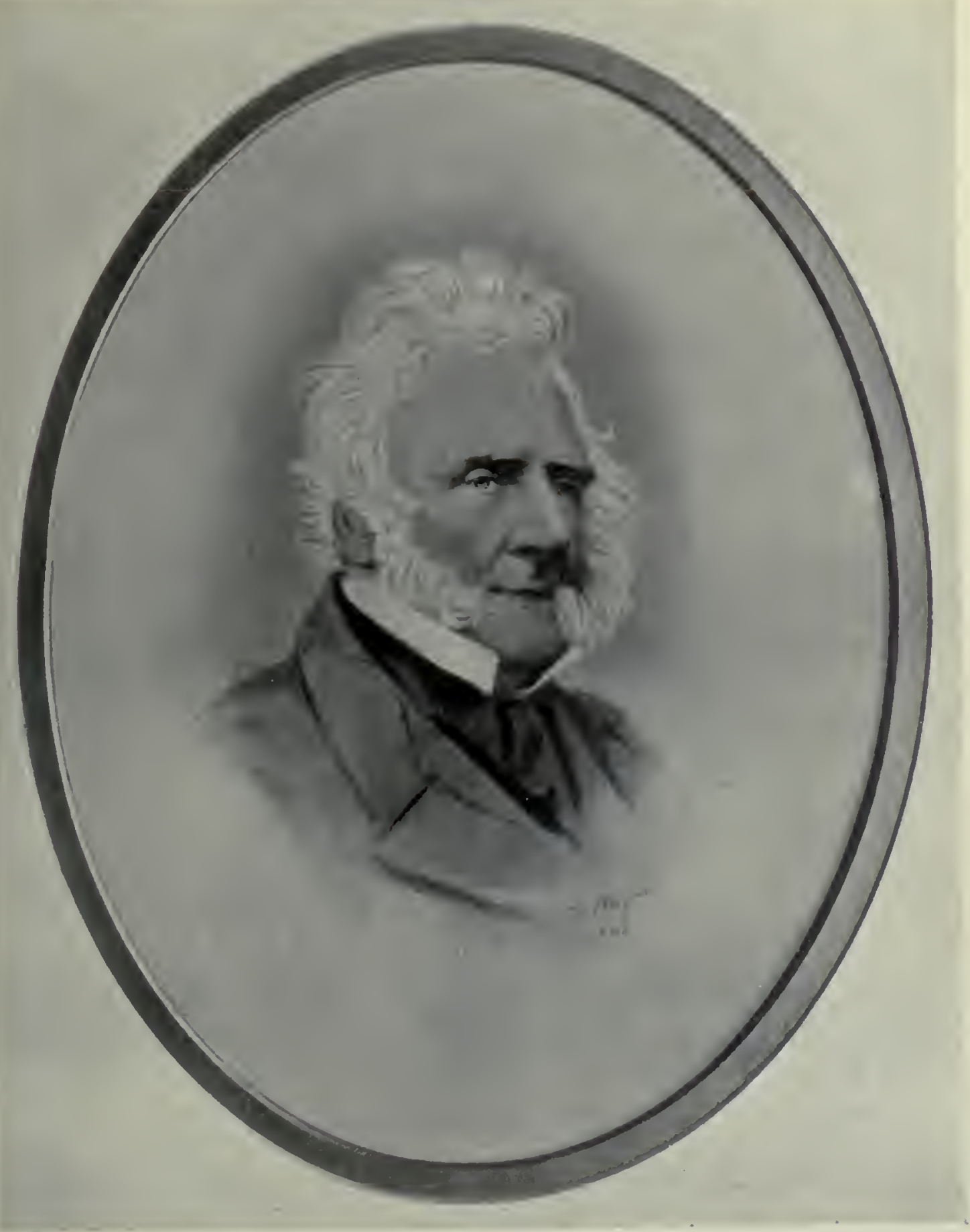

SIR FRANCIS SACIIEVEREL, DARWIN (1786-1859).

Uncle and godfather of Francis Galton. From a portrait by Haynes in the possession of Sir Francis' granddaughter Mrs William Wavell. 



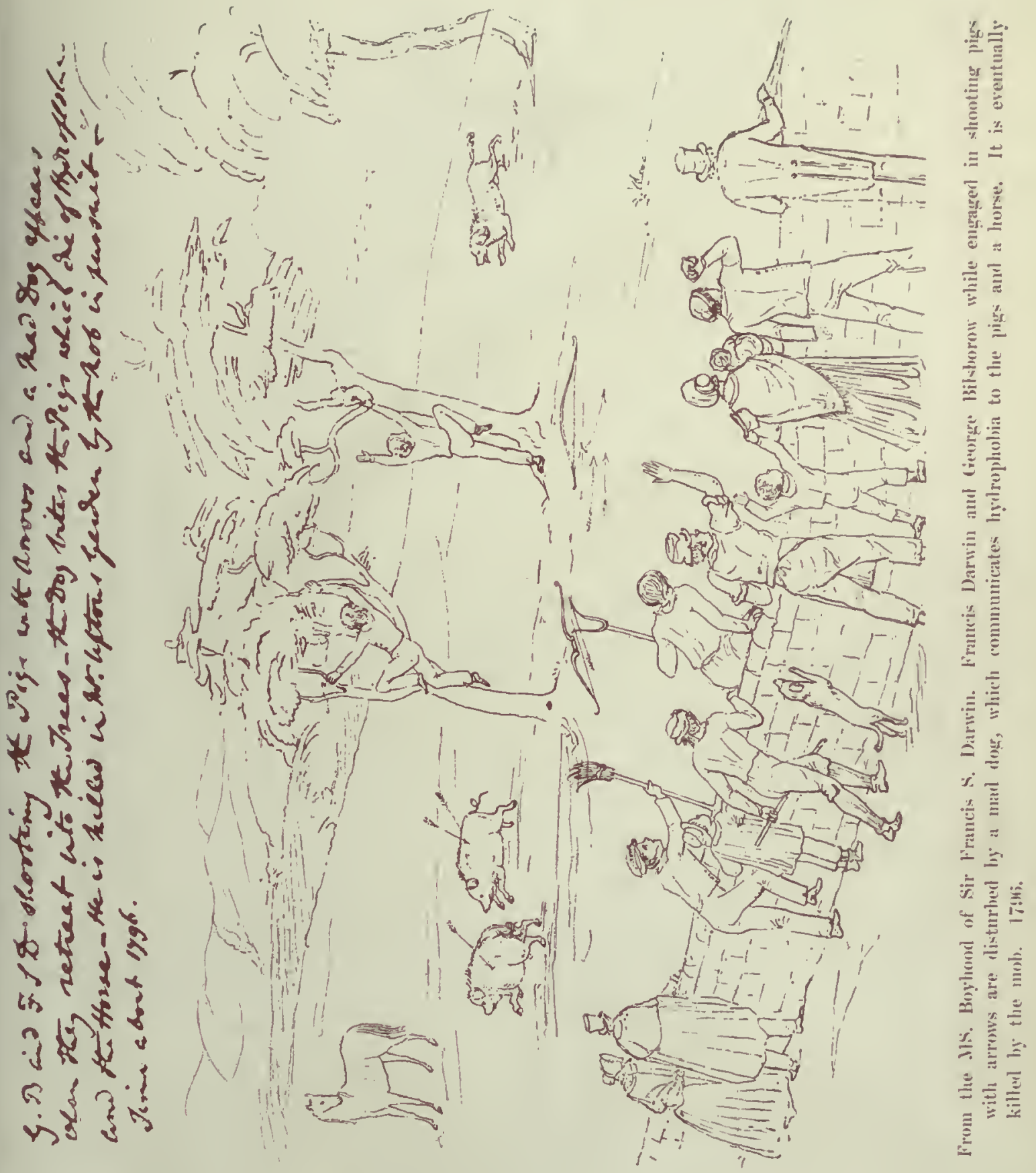



beast were concerned, as readily as when it portrayed an archaeological novelty or displayed the costumes of Greece or 'lurkey. 'T'ypical of the man is the account lie gives of the plague in Smyma; instead of flying from the place, he remarks :

"On the 2nd day we again found ourselves at Smyrua amongst the plague, which had increased, 400 persons having dicd in our absence. I had now an opportunity of watching the progress of this disorder in several English sailors, who having been on shore, had caught the infection. I also visited the Armenian and Greek hospitals, where numbers were dying daily of the plague" (p. 55).

At Smyrna also we hear the tale of a gun discharged immediately under the window, which their host informed them was the shooting of another cat by a soldier posted to shoot the cats coming out of the next house where everybody but the baby had died of plague; the cats being the chief transporters of the infection. Darwin, wanting more experience of the plague, on another return to Smyma undertook by invitation of the native physicians charge of several hospitals, of which the Greek and Armenian contained euch 120 patients.

"This," Darwin writes, "was a good opportunity to become conversant with the diseases of the cliniate, and from constant observation I found the plague was frequently checked by an active practice of which the Medici of the East were totally ignorant. Intermittent fevers and the Lepra Graecorum are very peculiar in the Levant. Hard eggs and salt fish being the hospital diet, phthisis is most prevalent."

During the tour Darwin visited Tangiers, Tetuan, and attempted to get into $\mathrm{Fez}$, not then visited by Europeans, but was not permitted to reach that closed centre of Mahommedanism. The strange element in Sir Francis Darwin's life is that he returned home, and after a short practice in Lichfield, settled down in a wild out of the way part of Derbyshire, and spent his days in studying archaeology and natural history without ulterior end ${ }^{1}$; his place was full of animal oddities; there were wild pigs in the woods, and tame snakes in the house. Possibly his son Edward's keen power of observation of the habits of animals as exhibited in his Gamekeeper's Manual was developed under this environment. But the fragmentary knowledge we have been able to gather of Francis Darwin suggests marked character and

1 There is a marked tendency, almost an instinct, in many members of the DarwinGalton stock to lead a leisurcly country life, which completely masks their scientific interests. It bccame dominant for a time in the life of Francis Galton himself. 
ability, which somehow failed of full fruition. Francis Galton's sister writes in her Reminiscences of the year 1826 :

"Wo then went on to my uncle Sir Francis Darwin at Sydnope, wlio sent a pair of horses to help ours up the steep lill to the house. It was a wild plaee, lut very. anusing to visit. The six elildren slept in hammocks and kept pet snakes."

The love of adventure, the scientific and literary tastes of sir Francis S. Darwin lead me to associate him closely with his godson, and it is strange that of all his Darwin or Galton uncles, Francis Galton in personal appearance seems to me to resemble most closely Francis Darwin. This leads me to emphasise a point which I think is of some importance: the Darwins were not by nature born travellers. Charles Darwin it is true went on the memorable "Beagle " voyage, but probably not because he derived immediate pleasure from travel for its own sake.

"I trust and believe," he wrote, "that the time spent in this voyage, if thrown away for all other respeets, will produee its full worth in Natural History; and it appears to me the doing what little we ean to inerease the general stoek of knowledge is as respeetable an object in life as one ean in any likelihood pursue." (Life, I, p. 205.)

Those are not the words of a traveller for the joy of travel, but of one who travels to obtain an end, not from innate Wanderlust. Some of my readers may know that joy in passing on into the unfamiliar, in spending each day under new conditions, - an unknown mortal mid unknowns! The Wanderlust is a fever which seizes the non-immune, mostly in youth, but may be in the blood, unquenched even in age. Both Francis Galton and Francis Darwin had marked touches of it, and in two ancestral lines-other than the direct Darwin line-we reach men who wandered and fought, and in an earlier century we have little doubt our Francises would have joined another Francis and have reached fame as Elizabethan buccaneers. This love of travel sprung, not from Darwin, but from Colyear and Barclay ancestry; it is manifest even in the scientific work of Galton. Both Charles Darwin and Francis Galton were pioneers in science, but the nature of their work was essentially different. Darwin invaded a new continent with the idea of settling in it. He planned great roads through it and he largely built them, and organized the country. He left traces of his pioneer work on the face of the land which must remain as his memorial for all time. Galton also discovered a new world, but he rushed from point to point of it making his hasty maps and ever eager 
to see beyond. He never waited to see who was following him, he pointed out the new land to biologist, to anthropologist, to psychologist, to meteorologist, to economist, and left them to follow or not at their leisure'. He left others to settle and develop; his joy was in rapid pioneer work in a wide range of fields. If the world did not understand and accept, he would leave them thirty or forty years to consider it, until after many other wanderings he came to that land again to find an altered state of scientific knowledge and of public opinion. This love of travel for its own sake, the Wanderlust, which for many of us was largely the secret of Galton's power, was hardly Darwinian, we believe it came partly through the Colyears-which explains its appearance in a lessened form in Francis Darwin-but partly through the Barclay-Cameron and Button strains, as we shall indicate later.

The second child of Erasmus Darwin and Elizabeth Collier-sister. of Sir Francis Darwin - who comes especially under our ken is Frances Ann Violetta, shortly Violetta Darwin, the mother of Francis Galton (see Plate XX). She inherited many qualities from her mother, Elizabeth Collier, and although she bears the name of Darwin we must not look upon her as a pure Darwin. Much of her joyous unconventional nature was undoubtedly from the ancestry of Elizabeth Collier. She was by no means a Quaker by instinct, and the Quaker, Samuel Tertius Galton when aged 33, seems to have been baptised as an adult (Jan. 18, 1816) at Radbourne Church-probably owing to her influence. Her pictures as a young bride show her to have possessed

${ }^{1}$ Francis Galton himself realised this to the full. Thus he writes as follows in his Inquiries into II uman Faculty:

"My general objeet has been to take note of the varied hereditary faeulties of different men, and of the great differences in different families and races, to learn how far history may have slown the practicability of supplanting inefficient human stocks by better strains, and to consider whether it might not be our duty to do so by such efforts as may be reasonable, thus exerting ourselves to further the ends of evolution more rapidly and with less distress than if events were left to thcir own eoursc. The subject is, however, so entangler with collateral eonsiderations that a straightforward step-bystep inquiry did not scem to be the most suitable course. I thought it safer to proceed like the surveyor of a new country, and endeavour to fix in the first instance as truly as I could the position of scveral cardinal points" (p. 2).

Six years later in the Natural Irheritance (p. 2) he again describes his work in much the same spirit, that of a pioneer building a high level road into a new country, affording widc views in unexpected directions and casy deseents to novel and not yet mapped districts. 
marked good looks, more Collier than Darwin; she had considerable artistic faculty, and we are inclined to think that possibly the initials V. G. may be found on the graceful bookplate of her husband. Through her too came longevity into Francis Galton's stock from the Colliers. She lived to be 91 , her mother Elizabeth Collier to be 85 , and Elizabeth Collier's mother to be $96^{1}$. Francis Galton's brother Erasmus lived to be 94, his brother Darwin to be 89, his sister Emma to be 93 , his sister Bessie to be 98 , and Sir Francis himself lived to be 891 This again is not a Darwin characteristic. It was also a longevity associated with persistent freshness of intellect-the sole condition under which longevity is of personal or social value. Violetta Darwin (see Plate XX) seems to have been a woman of much character, for thirty years after her husband's death she was the centre of a large household, with excellently kept records, and accounts. She did not permit liberties ${ }^{2}$, but was warmly loved by her children; in fact, she had an essential feature of lovableness which she handed down to her son Francis in a marked degree. No servant, no subordinate, ever attempted to take liberties with Francis Galton, and yet no man was more loved by relatives, friends, members of his expeditionary force and of his household ${ }^{3}$. To Violetta Galton we owe a quaint little biographical account of her son Francis' childhood, of which the first page and the silhouctte arc reproduced later:

Passing now to the paternal ancestry of Francis Galton we find ourselves at once in a sterner atmosphere. If we look through the list

'Francis Galton says so himself in his Memories, p. 7. But we lave not been able to rerify the statement. There is possibly confusion with Elizabeth (Hill) Darwin.

2 Slie wrote a quaint Advice to Young Women upon their first going out into Service published in Derby, and dedicated to Miss Harriet Darwin "for the nse of her school for poor children." As an extract I take: "When you speak to upper servants, always add Mr or Mrs before their names, it is a respect due to thcm; and whenever you happen to meet a Lady or Gentleman, in any part of the House, always courtesy oul passing them, as you should rcmember to be civil."

${ }^{3}$ This lovable side of his nature is so truly expressed in a letter from onc of his great nieces, that I venture to cite her words here:

"I expect we all see our friends differently; if I were to write a memoir of Uncle Frank I should just say what a pet he was, and how good tempered and full of delightful naive sayings, and that everybody wanted to kiss him! I should not bother about his intcllect, which did not come my way."

These sentences give a picture of Francis Galton, which all his intimates know to be true, but which it woull be hard to express so well. 

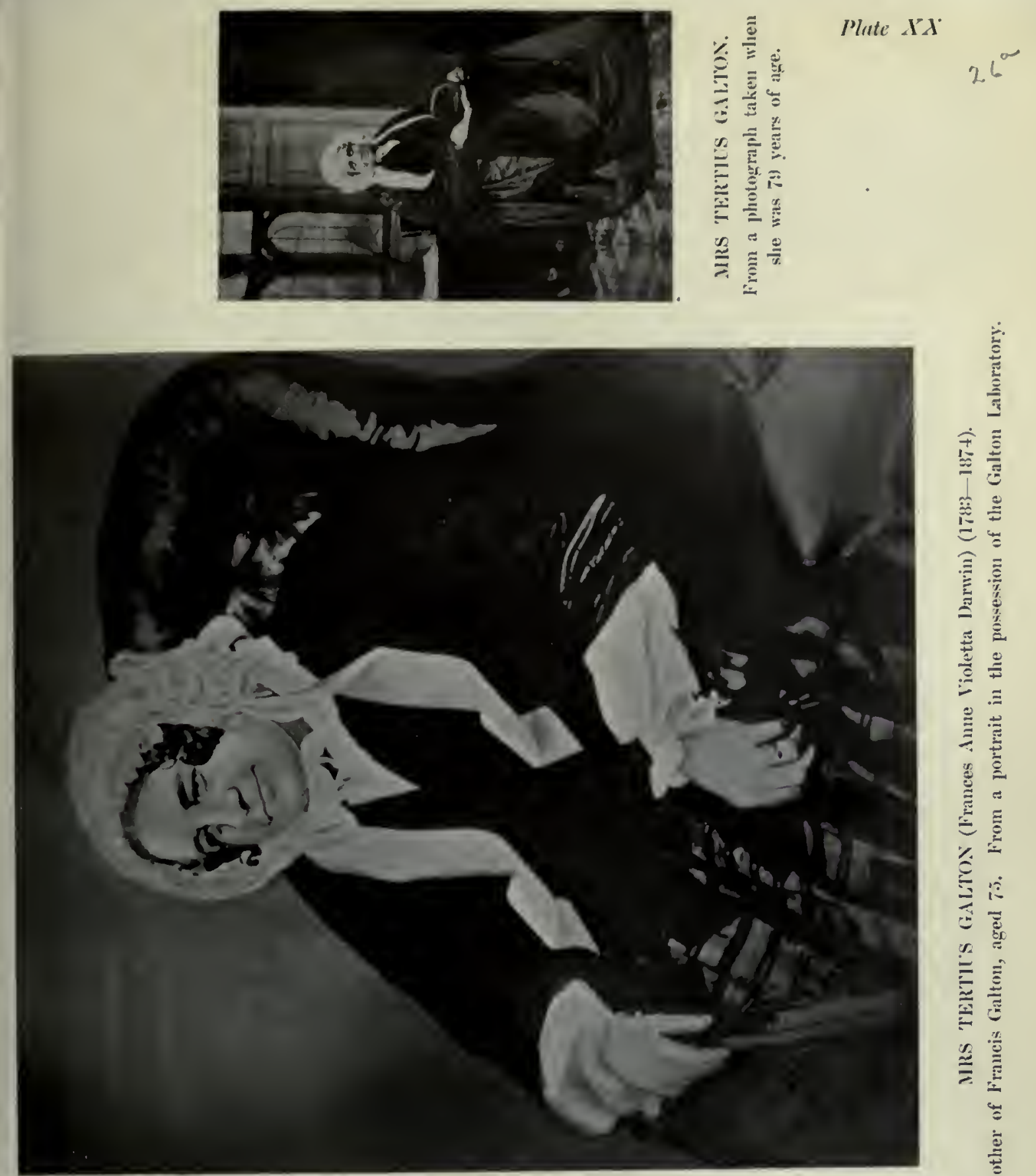

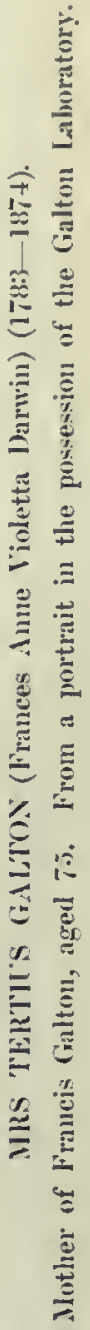
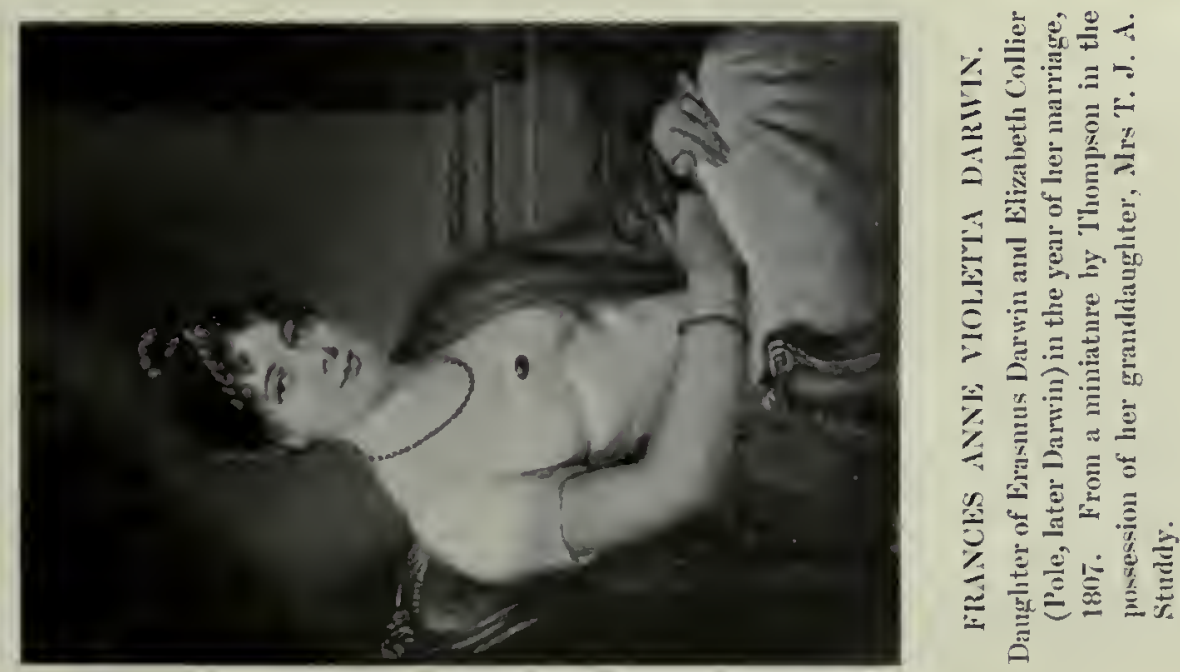

$26^{1 s}$

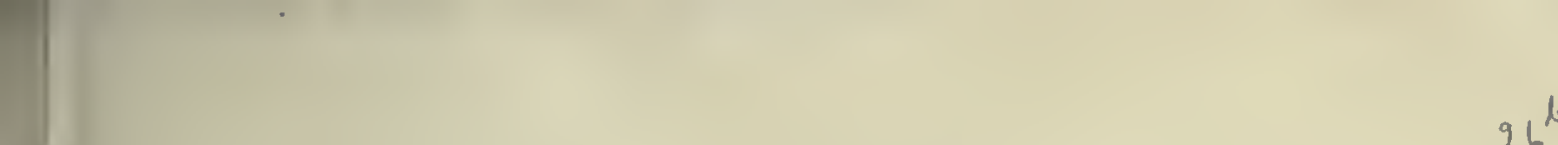




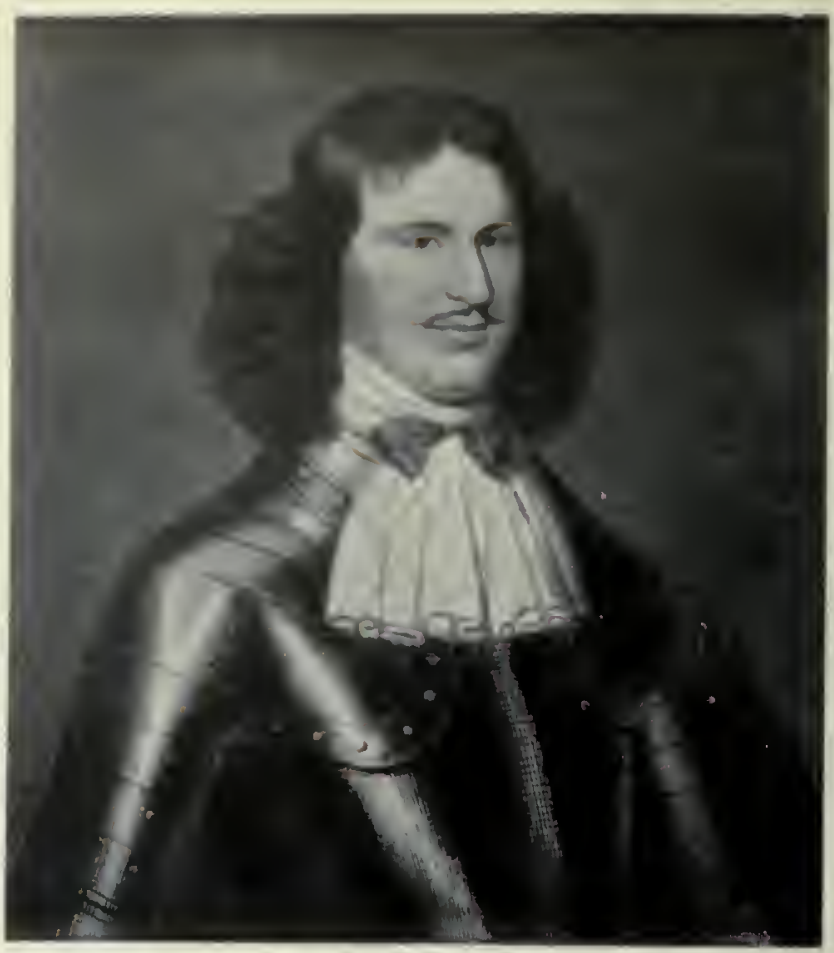

SIR FWEN CAMERON of Lochiel (1629-1723).

(ireat-great-great-grandfather of Francis Galton. From a print in the possession of $\mathrm{Mr}$ Wheler Galton.

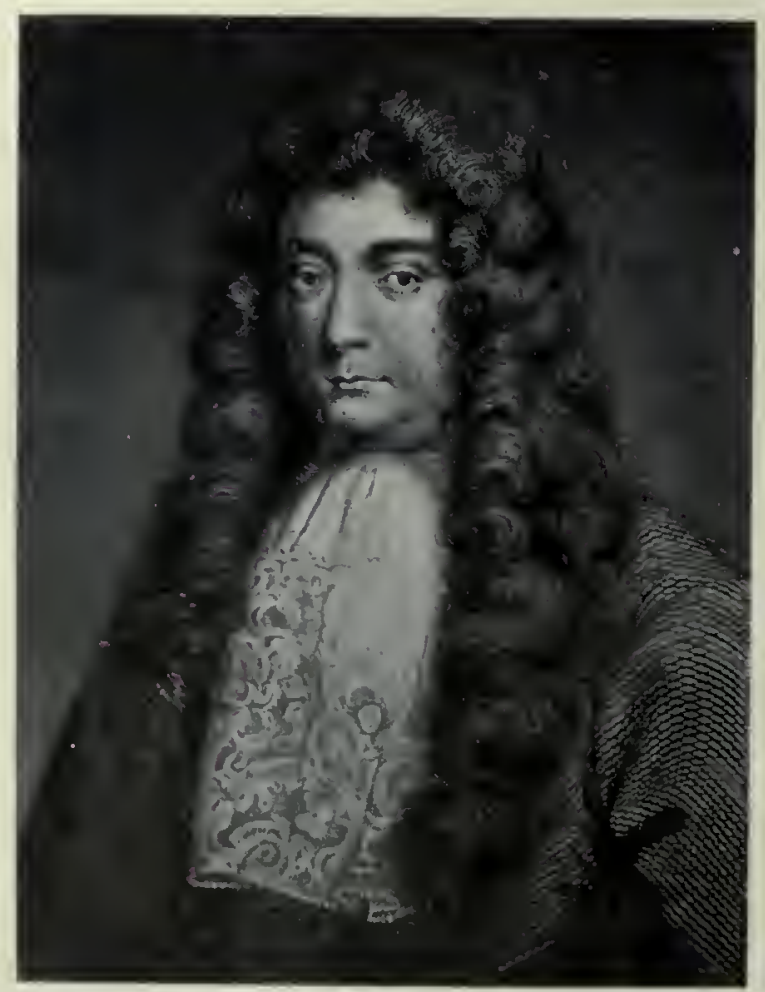

SIR CIARLAS SEDLey, Poet (1639-1701).

(iveat-great-great-gramdfather of Francis (jilton. From a print in the British Museum I'rint Room, which is from an original picture formerly in the possession of the Duchess of Dorset. 
of Galton's 16 great-great-great-grandparents on the paternal side (see p. 10), wc find that 11, possibly 13 , were early nember's of the Society of Friends. Another, Sir Ewen Cameron, is famous as one of the last of the Highland chieftains, a man who summoned his clan and fought at its head (see Plate XXI). It is at first sight strange to find him marrying a daughter of the Quaker David Barclay, the sister Jean of the Apologist Robert Barclay. But the Quakers were never opposed to the Stuarts in the way the Puritans were. Rober't Barclay himself was a direct descendant of the Stuarts in morc than one line (see Pedigree Plate B). At the instigation of George Fox, Barclay appealed to James II, to check the persecution of the Quakers, and his kinship to the Stuarts gave him easy access to the King. He believed in James' zeal for liberty of conscience being sincere; and in his Vindication of 1689 he says: "I love King James and wish him well." But as a Quaker he was a man of peace, who preached obedience to every established government and unlike his brother-in-law Cameron of Lochiel took 110 part in the Jacobite movements. His influence with Lochiel was probably great, and in 1688 Lochiel accompanied Barclay to London that the latter might use his influence with the King to settle a dispute between Gordons and Camerons. Barclay's mother was Catherine Gordon. Of Robert Barclay himself we must all acknowledge that he will ever remain one of the great masters of the English tongue. He formulated as a scholar and a rhetorician the doctrines of the Society of Friends in a way that was impossible for the uncultured George Fox. We nnay not agree with the doctrine of immediate revelation as it was developed in the Apology; that the inward testimony of the spirit in each man telleth him of the true will of God is a teaching which had led the Anabaptists to terrible catastrophe, but held in check by such quietisin as we find in the mediaeval mystics and in the early Quakers it has done little harm and much good. Above all it led directly, since the inward spirit alone dictates religious knowledge and there is no formal creed or recognised outward authority, to the doctrine of universal toleration. We do not all realise how much we owe to the Quakers, and not least to Robert Barclay, for proclaiming this great doctrine, and, what is more, ultimately establishing it by their passive but stubborn resistance. Papist, Lutheran, Calvinist, Anabaptist, Anglican had not got as far as Robert Barclay when he wrote: 
"This foreing of men's conseicnees is contrary to sound Reasone, and the very Law of Nature. For Man's Understanding eannot be foreed, by all the Bodily Sufferings another inan can inflict upon him, especially in matters spiritual and supcrnatural: 'T'is argument and evident Demonstration of Reason, together with the Power of God reaching the Heart, thut can change a Man's Mind from one Opinion to another, and not Knocks and Blous, and such like things; which may well destroy the Body, but can never inform the Soul, which is a free Agent, and must either accept or reject matters of Opinion, as they are born in upon it by something proportional to its own nature. To seek to foree minds in any other manner, is to deal with men, as if they were Brutes, void of understanding; and at last is but to lose one's labour, and as the Proverb is: To seek to wash the Black-moor white. By that course indeed, men may be made Hypoerites, but can never be made Christians." (Apology, 4th Edn., p. 497.)

This may serve as a sample of Barclay's opinions, and of his command of our tongue. With his father, Colonel David Barclay, Robert had to suffer much for his faith. Colonel David Barclay had been a soldier of fortune, serving under Gustavus Adolphus through many fierce carnpaigns, and again in our own civil wars. Then between 50 and 60 he tells us that having served many others he made up his mind to enter the service of God, and looked around him with the greatest anxiety and earnestness, to know, in the midst of so many pretenders, what society of Christians to join with. Ultimately in his perplexity he found refuge in the Society of Friends. He resolved in the year 1666 to suffer indignities and injuries for conscience' sake and to exhibit his bravery in a new field. He established the Quakers' meeting at Ury and henceforth prison, public mockery, fine and distraint were his lot. He has met his reward in the noble ballad of Whittier ${ }^{1}$ :

1. "Up the streets of Aberdeen, By the Kirk and College Green, Rode the Laird of Ury;

Close behind him, elose beside, Foul of mouth and evil eyed Pressed the mob in fury.

2. Flouted him the drunken ehurl, Jeered at him the serving girl, Prompt to please her master; And the begging earlin, late Fed and elothed at Ury's gate, Cursed him as he passed her.

'John Greenleaf W'nittier, Poetical Works, London, 190t, p. 35. 


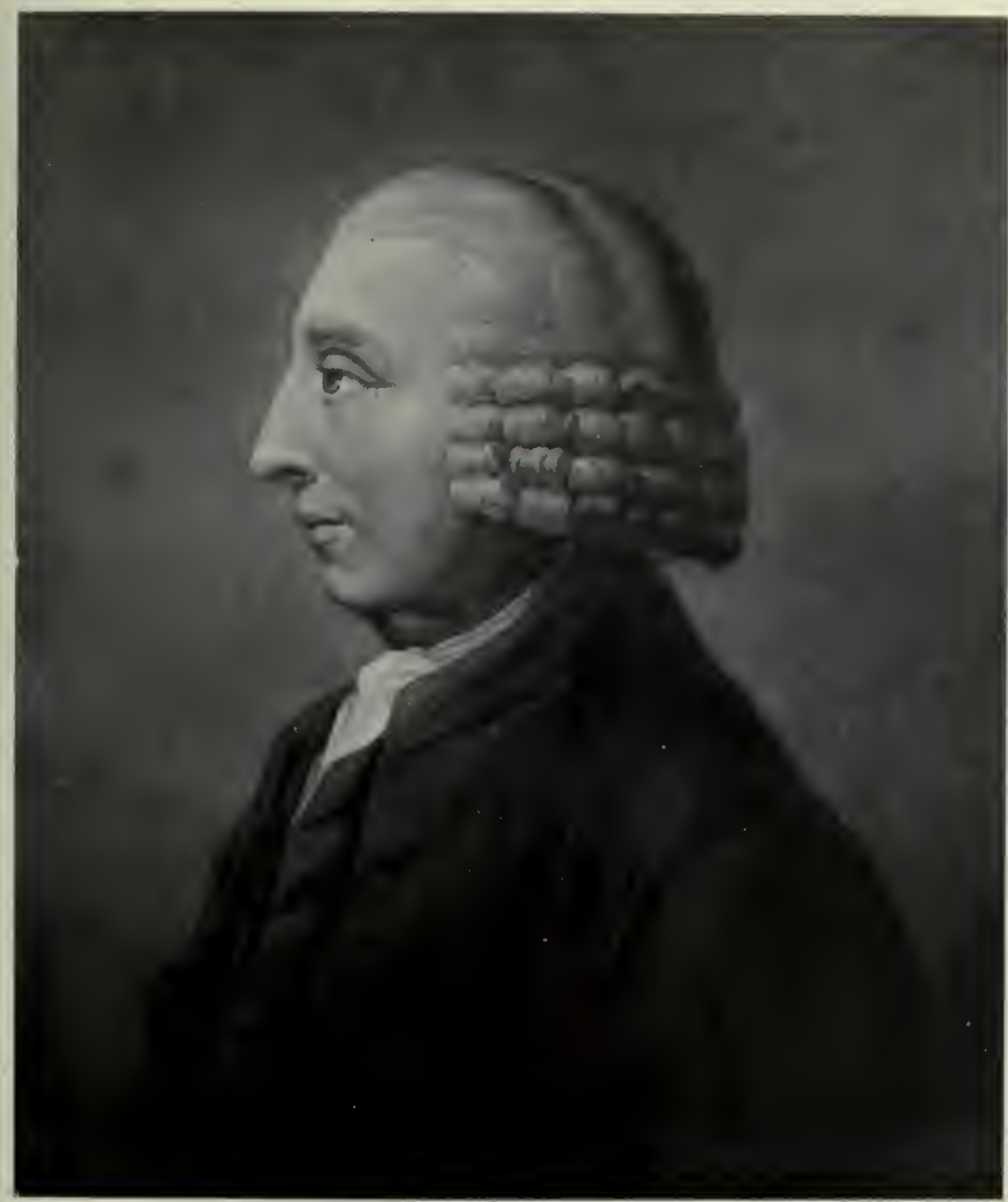

1)AVI1) 13ARCLAY of Youngsbury (17:28-1809).

Philanthropist und Slave-Emancipator. Uncle of Mrs Samuel Galton (Lucy Barclay). Great-uncle to 'lertius Galton and to Mrs Fry, and grandfather to Hudson Gurney. Fron a print in the British Museum l'rint Room after the picture by lloughton. 

3. Yet with calm and stately mien,

Up the streets of Aberdeen

Came he slowly riding;

And to all he saw and heard,

Answering not with bitter word,

Turning not for chiding-

4. Came a Troop with broad-swords swinging,

Bits and bridles sharply ringing,

Loose and free and froward;

Quoth the foremost 'Ride him down!

Push him, prick him through the town

Drive the Quaker coward '"

5. But from out the thickening crowd

Cried a sudden voice and loud,

'Barclay! Ho! A Barclay!'

And the old man at his side

Saw a conrade, battle-tried,

Scarred and sunburnt darkly.

6. Who witl ready weapon bare;

Fronting to the troopers there

Cried aloud: "God save us!

Call ye coward him who stood

Ankle deep in Lutzen's blood

With the brave Gustavus?'

7. 'Nay, I do not need thy sword,

Comrade mine,' said Ury's lord;

'Put it up I pray thee;

Passive to His Holy Will

Trust I in my Maker still,

Even thougl He slay me." "

Galton had as much to thank his Barclay ancestors for as his Darwin descent; it was not less, possibly more notable (see Pedigree Plates A and C). And Galton knew it; writing in the summer of 1906 he says ${ }^{1}$ :

"It is delightful to hear that you are so pleasantly placed among old Quaker associations. They-the Quakers-were grandly (and simply) stubborn."

'That stubborn persistency was a wonderful asset of nearly half Francis Galton's immediate ancestry. David Barclay, younger son of the Apologist, walked from Ury to London, and, commencing life afresh,

1 Letter to K. P. 13/7/206. 
built up a big buisiness, and the Barclay house in Cheapside received visits from three King Georgcs. From thence spread also that wonderful nctwork of business families which is summed up in the names of Barclay, Hoare, Bevan, and Gurney.

Mr Hudson Gurney'1 (1775-1864), himself son of Agatha Barcliny, a granddaughter of David Barclay of Cheapside, and husband of anothcr Barclay, remarks in discussing the Barclay pedigree?: "Query : T'aking the moral Pedigree from 913 to 1913 in all human probability may it not stand:

(1) Powerful and highlyconnected Nobility.

(2) Provincial Squirealty.

(3) Utter Beggary.

(4) Norwich Tradesmanship.

(5) Sectarian Opulence.

(6) Underbred Assumption.

(7) Bankruptcy and Dispersion.

Ending this queer and chequer'd history sans land, sans goods, scens brains, sans everything."

When we recollect that Francis Galton's grandmother was a greatgranddaughter of the Apologist; that she was the woman-herself of marked character as her portraits show-who handed down Barclay persistency and Barclay physique to Francis Galton-then I think we need not fear that the Quaker Barclays have ended unworthily. The Cameron-Barclay strain was a splendid strain, physically and mentally. Francis Galton's great-uncle, Captain Barclay (see Plate XXIV), the last Barclay of Ury (see Plate XXIII), was a famous pedestrian, an athlete who when over 70 could lift a man of 12 stone on the palm of his hand from the floor to the table, and who walked 1000 miles in 1000 hours, one mile to each hour. His father (see Plate XXIV) was also a mian of strength, who took up and threw a trespassing donkey over a hedge as he would have done a football. The traditions of strength go back to Ewen Cameron and his generation. Francis Galton himself says that from "the Barclay blood he received a rather" unusual power of enduring physical fatigue without harmful results." (Memories, p. 11.)

Distant as may seem the comnection between Francis Galton and the great names of mediaeval history (see Pedigree Plate B), the

1 Second eousin of Tertius Galton : see Pedigree Plate C.

"Hudson Gurney's remarks are taken from an MS. aeeount of the Barelay family. He was dealing witl a 1000 years from the last Carlovingian Emperor and looking into a future half-a-eentury ahead. 


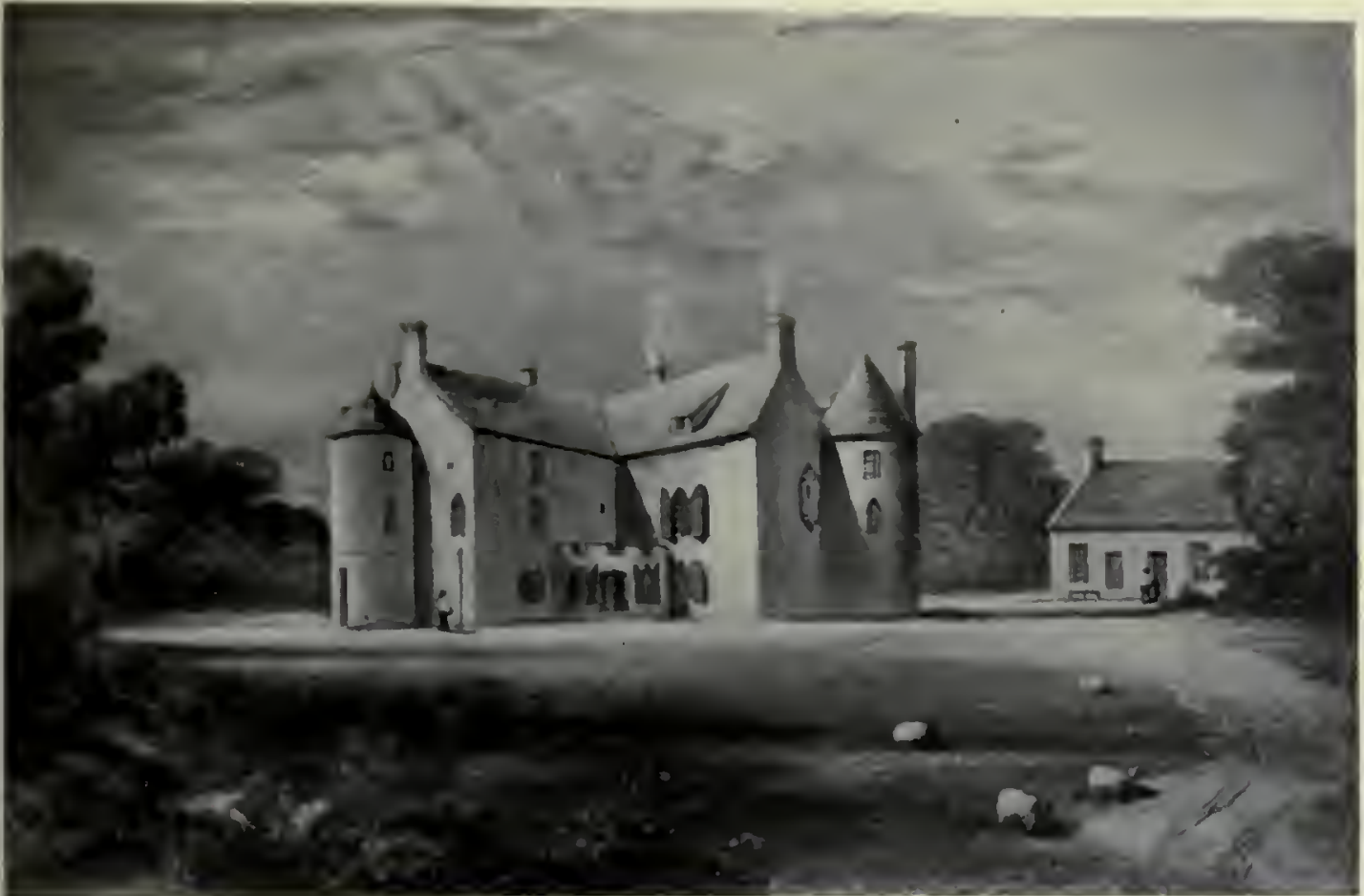

URY.

The home of the Barelays. The Friends' Meeting IIouse is seen on the right. 'The Gothic window with shutters on the first floor is that at whieh Lucy Barelay worked her sampler. Photograph from a water-colour sketch.

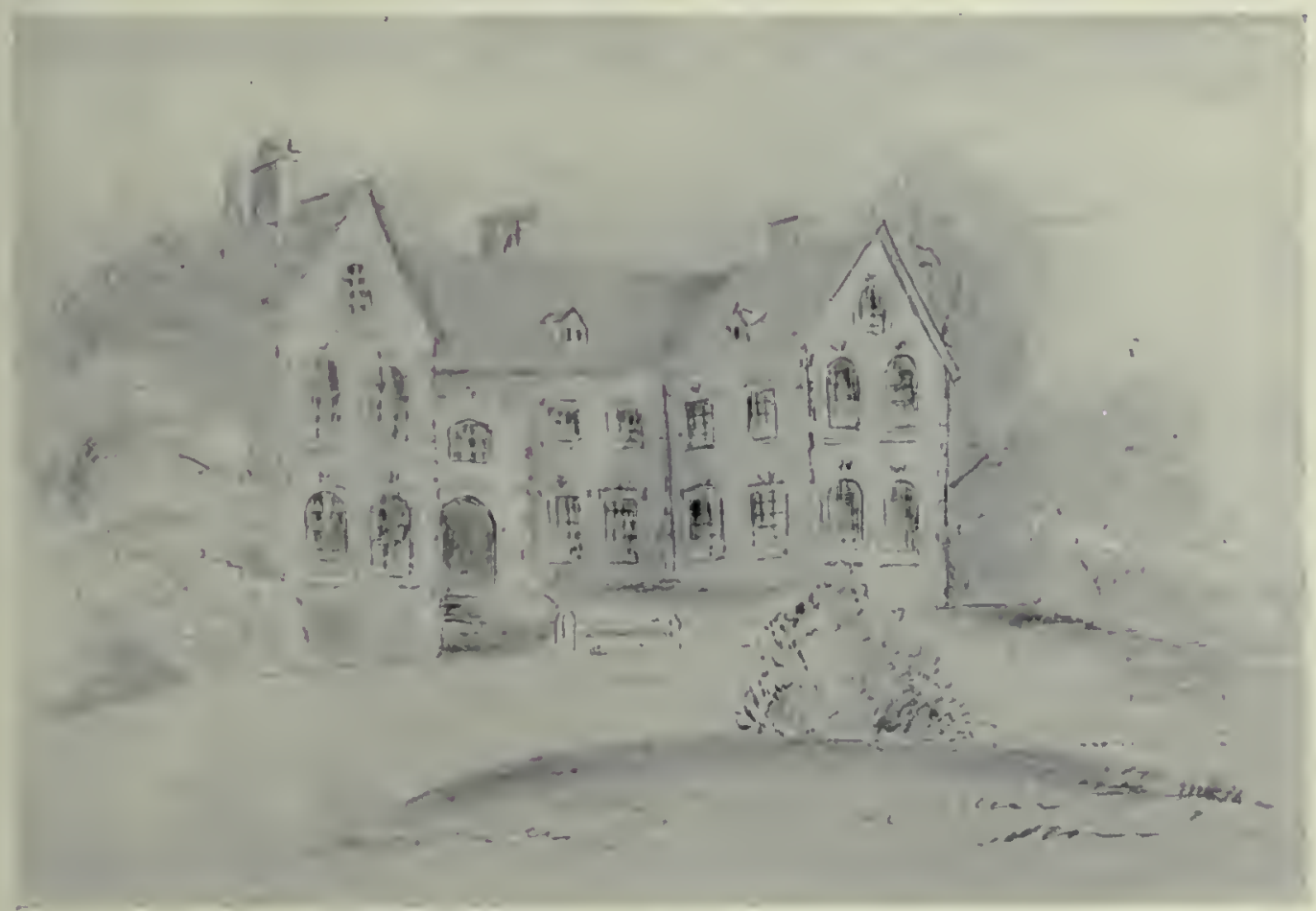

ELTTON HALl.

The original home of the Dawins, from a pen and iuk sketch in Mrs Wheler's Ms. "lhe (ialton Family." 

Plute XYIV
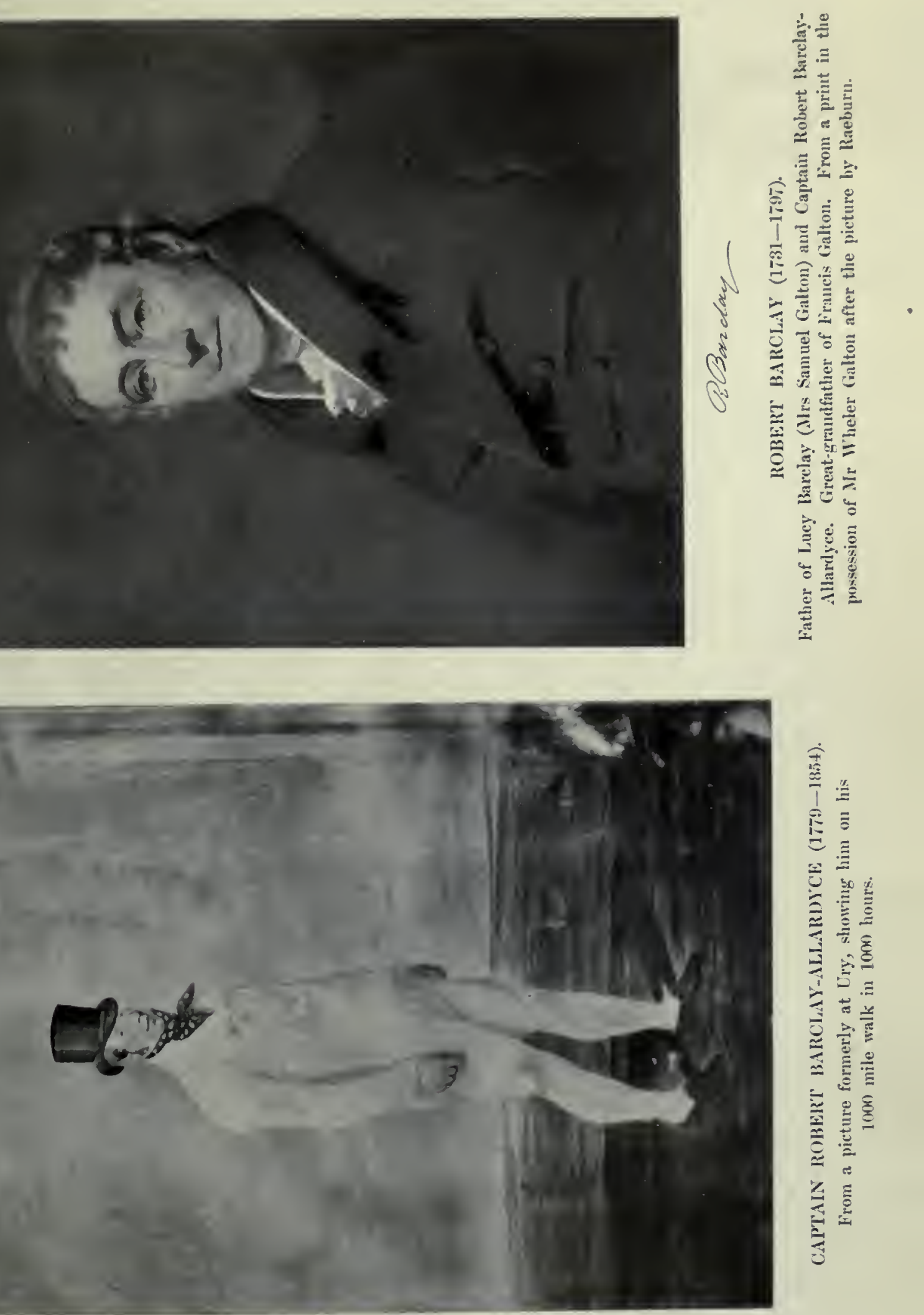

stubbornness and physique we find in the Barclays were almost certainly the factors which in earlier generations made their ancestors great in the land. The reader may think that the bond is slender, but it is strange how often we find the great linked to the great in history. And let us remember that, although we have traced the Barclays up to many great names, we have not followed those names downwards again to all their descendants who may have been famous. Our pedigree is directed only to one such man. If the reader believes that time and patience would lead any single individual to find in his ancestry names great in history, then will that reader assuredly find himself in error. In nine ancestral lines out of ten we find a stock which, if we can carry it back beyond 1600 , lands us in a yeoman fanily. There we end in the soil, and there probably the ancestry has remained from Anglo-Saxon times.

If we turn back to the fifth generation of Sir Francis' ascendants, we find ourselves very near to that yeomanry stage at least in a moiety of the branches. Actually, in some of the branches, we have to deal with the younger sons of yeomen who had come into the towns as traders. The Galtons - supposed to have sprung originally from Galton in Somersetshire-are described in the church registers as yeomen and husbandmen. They send sons into the law and the church, but we have no record of any member of the family being of note. Look at the other names, as far as it has been possible to trace them. Robert Galton, the brother" of the second John (see Pedigree Plate A), started as a "Haberdasher of Smallwares" in Bristol; the Farmers were "Ironmongers" there; the Freames were grocers in Aldgate, but later goldsmiths as well; the Braines were Tobacconists of Wapping, but carried on a variety of other trades in Whitechapel and Ratcliffe, even to bakers and butchers. But in many cases we can show that they were the sons of yeomen or squires who came into the towns to trade, just as the younger sons of yeomen do to this day. Much more was this the case in the days of the religious persecution of the Quakers. To be a member of the Society of Friends in the latter half of the 17 th century demanded splendid courage, and the being, as Galton phrases it, "grandly and simply stubborn"; but it demanded more; it needed marked industry and persistency in carrying on a business, and supporting a family under repeated fines and imprisonments. Stringently selected, as the early Quakers were, their rules of intermarriage led to a splendid breed of men and women. If the reader wants to realise how a particular 
type, even among mankind, can be relatively easily reached by selection and intermaririage, he has only to study the history of the Society of Friends. Great businesses were established by them, and the banking interests of the country were largely in their hands. We are concerned here only with their energy, persistence and industry. They did not apparently always follow the highest dictates of their faith. While in Yorkshire nembers of the Society were ejected, because they had shares in merchant vessels which carried a gun to protect them against privateers, the Galtons and Farmers set up a gun-factory in Birmingham which supplied large quantities of muskets to the Government. But the business had much wider ramifications; there were large transactions in Lisbon, and on one occasion $£ 54,000$ of slaves were handled in America. ${ }^{2}$ Ultimately in the time of Samuel and Tertius Galton it developed in association with the Farmers into a banking enterprise. Generally with the Galtons as with others we pass from the country to retail trading in the towns, then to large mercantile concerns built up under the new conditions of industry, where the Quaker characteristics produced their full return.

Let us look a little into some of these other Quaker ancestors of Francis Galton. The Freames spring from Robert Freame of Cirencester ${ }^{2}$. The pedigree illustrates the three stages, yeomanry, town traders, and ultimately mercantile houses. Thus the brothers Robert and John of Aldgate were grocers, but John was a goldsmith as well. John Freame of Bushhill, Edmonton, married Priscilla Gould, and his sister Hannah married Thomas Gould, probably her brother. Of Robert Freame's children by his first wife the most interesting is Thomas, who went to Philadelphia. He married in 1725 Margaret Penn-daughter of William Penn by his second wife Hannah Callowhill of Bristol-and their daughter, Philadelphia Hannah Freame, became Viscountess Cremorne. It was into the business of the Freames, and indeed into their very household, that David Barclay of Ury came, when he walked up to London. Like the apprentice of romance,

' On the other hand David Barclay of Youngsbury, Tertius Galton's great-uncle, who had come into the possession of $£ 10,000$ of slaves for a business debt, carried thein to New York, taught them crafts and then, when they could maintain themselves, emancipated them. This David Barclay (see Plate XXII) was one of the finest claracters of his timc, a true humanitarian and a worthy descendant of the Apologist.

${ }^{2}$ I think this Robert may be the son of Richard Freme (? Freame), mayor of Gloncester, whose pedigrce can be further followed in Ilarleian Publications, Vol. xxr. 
but at a much later age, he married his master's daughter Priscilla. In conjunction with his brother-in-law, Joseph Freame, the business was developed into a large banking and mercantile firm ${ }^{1}$. Lucy Barclay, the great-grandmother of Sir Francis Galton, was a child of this marriage.

But the Freame and Barclay intermarriages are by no means thus exhausted. Sarah Freame, Priscilla's sister, married David Barclay's son James, by his first wife, Ann Taylor. James Barclay and Sarah Freame had three clildren, two sons who left no issue and a daughter Anne, who married James Allardyce. Their daughter, Sarah Anne Allardyce, was the second wife of Robert Barclay (1731-1797) and mother of Captain Robert Barclay Allardyce (the pedestrian, and last Robert Barclay of Ury) and of Margaret Barclay, Mrs Hudson Gurney, the great-aunt, and kind hostess to Francis Galton's sisters and himself. Robert, Margaret and Lucy Barclay, who married Samuel Galton, were thus directly half brothers and sisters, but in addition their mothers were granddaughter and great-granddaughter of David Barclay of Cheapside, and granddaughter and great-granddaughter of John Freame of Lombard Street! Captain Barclay, the pedestrian, and Mrs Hudson Gurney were thus much closer in blood than greatuncle and great-aunt to Francis Galton ?. Lastly another sister of Priscilla Freame, Mary, married Thomas Plumstead of London, and their daughter Priscilla married James Farmer of Bingley, the partner in Birmingham of Samuel Galton, the first. Their daughter in turn became the wife of Charles Lloyd, who was the managing partner of a large Birmingham bank. Thus Priscilla Farmer and Lucy Barclay were cousins, and this no doubt brought Lucy Barclay the second into touch with Samuel Galton, and led to their marriage. According to a memorandum of Samuel Galton, he met Lucy Barclay at Hertford in 1776 for the first time, and married her in Oct. 1777, shortly after his mother, Mary Farmer's death. The pedigree (Plate C at the end of this volume), in which a very large number of collaterals are omitted, will

${ }^{1}$ It should be noted that the goldsmiths were largely bankers in the 17 th century. The firm was Freame and Gould in 1698, and Freame and Barclay in 1736; the business seems to have been a continuation of that of Pepys' goldsmith Stokes: see Hilton Price, Ilandbook of London Bankers, pp. 10-12.

2 Anotlicr daughter of David Barclay married a Gurney, and his famous daughter, Elizabeth Fry, a worthy niece to David Barclay of Youngsbury, was second cousin of Tertius Galton and also a feature of Francis Galton's hoylood.

P. G. 
serve to elucidate the complex relations of Freames, Barclays, Farmers and Galtons. Thus Samuel Tertius Galton was second cousin to Hudson Gurney, and Sir Francis himself great-nephew to Mrs Hudson Gurney, Margaret Barclay, the sister of the pedestrian! It will be seen how the Freaines, if not among the persecuted Quakers, were associated with some of the most industrious, zealous and noteworthy of the Quaker stocks.

Of the Braines, tobacconists of Wapping, we have been able to piece together less information. The two brothers, James and John, and the sister, Elizabeth, were all married between 1670 and 1677 , James to Elizabeth Graeme in 1670; John to Elizabeth Hutchins of Ratcliffe in Jan. 1672-3, and Elizabeth to Henry Fiegensnow of Limehouse in 1677. Of James Braine we know that in 1681, for refusing to take the oath at a coroner's inquest, his goods were taken by distress; and again, in the winter of 1684, the Quakers were kept out of their meeting at Ratcliffe by a guard of soldiers, but they held their meeting constantly in the yard or street. For doing this they were fined, and James Braine again had his goods taken by distress. William Braine and Thomas Braine suffered also imprisonment and fine-they were doubtless relatives. Where the Braines originally came from I have not succeeded in finding out. Some of the records point to Somerset and Gloucestershire, and the name occurs in the Gloucestershire Visitations and in the Registers of Little Deane as that of a family of some distinction. In London they lived in Stepney Parish, and the various Quaker Braines belonged to Wapping and Ratcliffe. The family must, however, have been commercially of some weight, or we should hardly find them in touch with the Barclays. The birth entries in the registers (the spelling varies) are:

To John Braine of Wapping, Parish of Stepney (Tobacconist), and Margaret ${ }^{1}$ (in one entry there is by a slip Mary) his wife: Thomas Braine, b. 12/11/1674; Margaret Braine, b. 13/5/1676 (married 14/7/1699 at Devonshire House, Abraham Coleman ${ }^{2}$ of Wapping); Elizabeth Braine, b. 20/12/1677 (married 6/6/1696 Robert Barclay of Scotland); Francis Braine, b. 23/11/1679; Farley Braine, b. 17/1/1682-3;

1 If Elizabeth Hutchins be not a slip for Margaret Hutchins, John Braine's first wifo must have died in her first year of marriage.

"The name suggests Anno Coleman, cruelly flogged as a Quaker at the cart tail through New England. Sewel, History of Friends, Vol, I, pp. 431-4. 
John Braine, b. 24/5/1684; Mary Braine (b. ? ), dau. of John and Margaret Braine, late of Ratclifte, Stepney, married 11/7/1707 John Midford of London.

The sons we have not been able to trace further. It is noteworthy that Robert Barclay of Ury must have married Elizabeth Braine when his brother David was only 14 years of age, and accordingly it is unlikely that David was the link which brought Robert to seek a wife in commercial circles in East London. His father, the Apologist, made several visits to London, and was in touch with Friends in London; one of these visits in April, 1683, was to place his son Robert at school in Theobalds, 12 miles from London; or the link with the Braines may have been through the latter's maternal grandfather, the merchant Mollison ${ }^{1}$ of Aberdeen, who would probably have business connections with Wapping, then almost the port of London.

Another strenuous Quaker was Jaspar Batt. He came originally from Street in Somersetshire, and must have been among the earliest converts to the ductrines of George Fox. As early as 1657 he had his goods seized, and in the same year he was fined for refusing to take an oath. In 1660 he was sent to prison; in 1663 we find him in Ilchester gaol, from which he wrote a letter with Matthew Perin, who was his daughter Edith Batt's second husband. In 1667 Batt was imprisoned in Taunton Castle; in 1678 others were fined for listening to his preaching. In 1683 he was arrested for preaching, and later in the same year he was again seized and put in prison. In a letter to George Fox, 1683, he describes how his "dear wife" and he lay on the boards of the floor because they cannot "with safety receive or keep any goods or bedding in our house," owing to repeated distraints. In 1684 he was again before the court; in 1685 he was in trouble about tithes, and in 1686 we learn that he had already spent 2 years 4 months and 19 days in gaol for his conscience' sake. It might be supposed that Edith Batt's experience of her father's difficulties might have prevented her selecting a mate of like stubbornness! On the contrary she found in Robert Button a husband who had spent no less than eight years of his previous life $(1664-1672)$ in gaol for conscience' sake?

1 Gilbert Mollison was brother to the famous Colonel Mollison, who signalised himself in the defence of Candia besieged by the Turks.

${ }^{2}$ Bosse's Sufjerings of the People called Quakers, Vol. II, pp. 42-4. He was discliarged from the county gaol for Wiltshire in 1672 with Walter Penn. 
The Buttons are descended from an old Glamorganshire family, and there are several distinguished men of this name. Robert Button, who married Edith Batt, was a near relative of Admiral Sir Thomas Button, probably first cousin or first cousin once removed, but the evidence is traditional and I have as yet no proper pedigree worked out. Sir Thomas Button, however, was clearly a stubborn old fighter, much of Robert Button's type. He was one of the earliest to seek for a North-west passage in 1612, and although he did not discover it, he for the first time, amid great hardships in the ship Resolution with the pinnace Discovery, explored the coasts of Hudson's Bay. Button's Bay and Isle, Resolution Island and Nelson River (called after the master of his ship who died there) still remind us of Button's voyage. Later he was Admiral of the Irish seas, busily engaged in repressing the numerous pirates of those days. As in the case of most strenuous men, he succeeded in quarrelling with officialdom, but the charges raised against him were absurd, were easily disproven, and probably only raised to avoid paying his salary, which remained unsettled at his death.

When Robert Button married on his release from gaol Edith Batt in 1672 , he is described as of Taunton, Somersetshire, and by trade he was a grocer. They had eleven children, of whom no less than eight died in infancy. The youngest, Robert, born 1693, married twice, first (March 1716) Mary Ellis, and second Martha Vickris ${ }^{1}$ (October 1719). Both died within ten years of their marriages. Ellis, the child of the first, married a cousin, another Mary Ellis, but does not appear to have had any children; he died aged 40. His father, the second Robert, died aged 33 in 1726 .

Those who survived were Elizabeth $(1689-1754)$ and Sarah (1682-1754), who married John Galton of Yatton in 1703. Elizabeth married (1723) Joseph Gifford, of Wellington, who settled at Taunton. Three daughters died as infants, one son only, Joseph Gifford (b. 1724), survived, but did not marry and died in 1801, suspicious of all his relatives. His father died in 1730 .

The mortality of the Buttons" is remarkable, and doubtless points

A well-known Quaker name.

adith Button (née Batt) was 42 years old at the death of her husband. In the following year sho married Matthew Perin, the companion in Ilchester gaol of her father Jaspar Batt. Perin was then 60 years of age, and died three years after. His widow marricd a third time a year later Edward Watts, fifteen years her junior. There was no issue of either of these marriages. 
to some weakness in the stock, probably on the Batt side. But we have to realise that during the 20 years of the marnied life of Robert and Edith Button, Robert spent additional time in gaol. George Fox visited 'Taunton in 1656 and 1663, in which year Street was visited. Fox's meetings in Bristol were very frequent, and he married Margaret Fell there in 1669; his last ministry there was in 1677. There can be little doubt that Robert Button like Jaspar Batt came personally into contact with George Fox. John Galton must have been already a Friend in 1700 , when he married Sarah Button, but we do not know at what date or under what influences. Originally he had been apprenticed to William Wake of Shapwick, a gentleman grazier of Dorset (d. 1705) and father of Archbishop Wake. He moved from Yatton to Taunton" on the day of his marriage,- which he tells us was "a sunshine day,"-and his children were born and he died there. Probably the great mortality of the Button family opened some field of activity for him in Taunton. His sons Robert and John moved to Bristol, where their widowed mother also resided. But the worst persecution of the Friends in the West was over before the date of John Galton's marriage (1703). The severest years were 1682 and $1683^{2}$-the former

1 Yatton is 12 miles from Bristol, Taunton 45 miles, and Street, near Glastonbury, about halfway between Bristol and Taunton.

2 Probably the Grace Button who was fined with Elias Waymouth, an innkeeper of Taunton, and 20 others in 1670 for being at a meeting was a relative of the then imprisoned Robert (Besse's Sufferings, Vol. 1, p. 607).

In 1678 we find Robert Button is confined again in Ilchester by Justices' warrant for contempt in not appearing at the Bishop's Court on processes for tithes at the suit of Robert Collier, Priest of Cliard. He and other Friends were confined in a place called the Friery, and it would seem that he had been there since 1675 (Besse's Sufferings, Vol. I, p. 612).

In 1683 we again find a record of imprisonment for Robert Button.

"On the 12th of the Month called August, Henry Walrond, a Justice of the Peacc and Cap ${ }^{t}$ of the Militia, came with some of his soldiers and a Constable to a Meeting at Gregory-Stoke where Jasper Batt was preaching. After some time he was silent, and they scornfully bid him Go on; He answered, It is not meet to cast Pearls before Swine. Then the Capt took thcir names both men and women. He let the Women go, but committcd the Men to the Constable's Custody cxcept four, viz. William Calbreath, John Powel, John Crocker and Robert Button, whose words he took to appear at his House next day, rcquiring the Constable to bring the others also thither at the samc time......(p. 637). Next day those four who had promised to appear, went to the Captain's House, who set one of them at liberty, fined William Calbreath and John Powel 10l. 10s. each and cominitter Robert Button to prison" (Besse, Vol. I, pp. 626 and 627). 
being the year of birth of Sarah Galton (née Button). In Bristol all the men in these ycars were put in prison; then the women kept up the mectings and they also were seized. 'Then the Friends' children were left alone with the servants, and the children under 16 kept up the meetings. Notwithstanding that the law could not properly reach them nineteen of them were carried to the house of correction and threatened with a whipping. Most of the Friends committed to prison were traders and craftsmen, and they endeavoured to carry on their trades in gaol, but were not permitted. It was a time of stringent selection and many children suffered, but it brought the "grandly stubborn" into a community, and gave Francis Galton a factor of his ancestry, which is too influential to be passed over.

We now reach the Farmer and Abrahams families. In both of these we find an ancestor killed in the Civil Wars (see Pedigree Plate D) : probably but not certainly on the Puritan side, for the sons of both became Friends. Two sisters, Sarah and Abigail Abrahams, married two brothers, Joseph ${ }^{1}$ and Thomas Farmer, in 1711 and 1713 respectively.

Again in 1686 :

"On the 12 th of the Month called April this Year, Robert Button, a Grocer of Taunton, being Overseer of the Poor, appeared before the Commissioners of Enquiry into the Rebels Estates upon Summons. They would have admiuistered an Oath to him, which he refused to take, mildly telling them, that he should do his Duty as faithfully as those who did Swear. One of the Conmissioners upon this began to examine lini : When he had been at Chureh and when he took the Sacrament? To which Robert answered, That he thought he was not summoned here for that, and that he did not come to accuse himself. Whereupon the Commissioners required the Mayor and another Justice present to tender him the Oath of Allegiance, which they did, and on his refusal to take it, eommitted him to Taunton Bridewell, where he was confined about two weeks" (Besse, Vol. I, p. 648).

It will be seen that Robert Button was obviously a man respected in his own district, for he was Overseer of the Poor, and he was clearly recognised as a leader, for when others are fined he is sent to gaol. In England, I think, few were more frequently or longer in gaol than this father-in-law of John Galton of Yatton. Yet those who will read the history of $\Lambda$ dniral Thomas Button's fight with the $\Lambda$ dmiralty, will understand that Robert Button was not "grandly stubborn" because he was a Quaker, but a Quaker because he came of "grandly stubborn" stoek.

1 This Joseph appears to be the man referred to in a deed of 1720. Joseph Farmer, Ironmaster of Birmingham, entered into artieles of agreement with Joshua Gee of London, William and Thomas Russell of Birmingham, Ironmasters, John Ruston of Woreester, Ironmaster, and Stephen Onion of Brewood, Stafford, Ironmaster, to purchase land in Baltimore County in 1720 (March 17), and also gave direetions to John Copson to purchase other lands in Ceeil County, convenient for navigation into 
Abigail Farmer, after the death of her husband in 1725, married Arthur Jephson of Bristol, and from this Abrahams' marriage was descended John Henry Shorthouse the author of John Inglesant. The commercial links between Bristol and Birmingham were very strong, and we are inclined to think that Joseph Farmer, the father of Joseph and Thomas, may have been a Bristol man. 'There are Joseph Farmer of Cary's Lane, Bristol, who died in 1755 , and his wife Sarah, who died in 1722, and these may well have been the parents of our Joseph and Thomas. Anyhow, we find the son Thomas of Thomas Farmer is an ironmonger of Bristol, and marries there in 1743 Mary Jephson, almost certainly a relative of his mother's second husband, Arthur Jephson $^{1}$. It is in Bristol, rather than Birmingham, that we must look for the link between the Galtons and Farmers. Robert Galton, son of John of Taunton, appears in Bristol as a "Haberdasher of small wares," and there in 1734 he marries Hannah Farmer"; this is the first Galton-Farmer marriage. Hannah was daughter of Thomas Farmer and Abigail Abrahams and sister of Thomas the ironmonger in Bristol. It is quite probable that Thomas Farmer and Robert Galton both dealt in Birmingham hardware, and from this basis started the common mercantile interests of Galtons and Farmers in later years, Bristol being then largely the port of Birmingham. Robert Galton lived in King's Square, Bristol, and there his last child, Sarah, was born in 1743, and she died and was buried in 1745 . Shortly after this he appears to have gone to Boston in New England, probably on business matters, and there he died in 1746 , or according to some accounts in 1749. It is hardly likely that he settled there as his wife and children remained in Bristol. It is possible that his mission had something to do with the large consignment of slaves valued at

the Bay of Chesapeake, near to the Ironstone Mines, where they would erect their forges and furnaces. Thus Farmer seems to have been one of the pioneers in establishing the iron-industry of America and the Galtons' connection with the Farmers and their dealings in slaves seem to point to the reason for Robert Galton's visit to New England in 1743-1745. [The deed above referred to was in the possession of Mcssis S. and E. Coleman of White Hart Lane, Tottenham, in July, 1913, and was most kindly purchased and presented to the Galton Laboratory by Mr Edmund Wheler Galton.]

1 Tertius Galton's physician at Leamington, Dr Jephson, was probably also a relativc.

2 There were only four children of this marringc, three died in infancy, one only survived to twenty and died then. 
$£ 54,000$ to John, Robert and Samuel Galton to which I have already referred. His wife Hannah Galton (Farmer) died in 1767 at Bristol and was buried in the Quakers' Ground at Redclif. The youngest brother, Samuel Galton, born in 1720, also started life in Bristol' ${ }^{1}$, where he paid for his freedom in 1742. In 1743 his stock, he tells us, was worth £1144. In 1746 be married Mary Farmer, the daughter of Joseph Farmer of Birmingham, and thus cousin of Hannah, his brother Robert's wife. He received $£ 1600$ as marriage portion, and definitely becomes assistant to his brother-in-law, James Farmer. This probably took Samuel to Birmingham where his brother John was already established at Duddeston. In the next year, 1747, he is admitted partner with James Farmer for a quarter of his stock for $£ 2500$. In 1753 he is equal partner with Farmer. James Farmer's cousin Benjamin Farmer, son of Thomas, was a merchant in Lisbon, and James had very large ventures there in 1755 . The earthquake of that year appears to have involved the Farmers in great losses, and James Farmer was bankrupt in this year. The partnership was dissolved and the estates at Duddeston, Saltley, etc. were assigned to Galton. Samuel Galton renewed the partnership with Farmer in 1757, and from an agreement of 1766 the shares of James Farmer and Samuel Galton are placed respectively at $£ 13,862$ and $£ 22,281$. Meanwhile by the death of his mother, Sarah Button, in 1754 , an estate had accrued to Samuel at Taunton. By the death of his brother John in 1775 , several other estates in Somerset-Edgmead, High Ham, Allermoor, Bridgwater-were inherited by Samuel ${ }^{2}$. This brother John had married Hannah Alloway and settled at Duddeston on the outskirts of Birmingham as it then was. He, however, had no children, and his property passed to his brother. When Samuel Galton died in 1799 aged 80, the Galton business held in equal partnership by himself and his son Samuel was valued at $£ 139,000$.

We have gone into these details as they are illustrative of the Quaker stubbornness turned to successful commercial achievement.

' The connection with Bristol was kept up, for Samuel's sister Mary died there in 1789 and his daughter Hannah in 1773.

${ }^{2}$ In 1776 Samuel Galton states in his memoranda that he sold the estate at "Beer Hill." This proves that the Thomas Galton of Beere who appears in the Registers of Winterbourne-Kingston in 1617, and who was probably the Thomas baptized Jan. 7, 1580, was an aseendant or relative of the Joln Galton of Yatton. 
A very appreciative notice of Samuel Galton the first appears in the Gentleman's Magazine for 1799 (p. 63):

"A sound and acute understanding, a quick and clear conception, extended views and a mind active and firm, joined to the habit of unremitting industry, commanded success with regard to the improvement of his fortune. The sine talcnts were ever ready to be comployed in giving advice and assistance to thoso who asked and in forming and directing churitable institutions."

After referring to his local charities and general beneficence, the writer continues :

"These excellcnt qualities were accompanied with great hospitality, and their effect improved by the urbanity and courtesy of his manners, by an agreeable, well-formed person, and a countenance expressive of the intelligence of his mind and the clieerfulness of his disposition. He encountered the various accidents of life and the infirmity of old age with uncommon dignity; the energies of a strong and powerful nind enabling him to support those trials which related to himself, without relaxing in his attention to the distresses of others. The same firmness of character accompanied him in death."

Surely much of this characterisation might be directly applied to his great-grandson Francis Galton. Unfortunately no portrait of him appears to have been preserved". Nor were "the various accidents of life" which the first Samuel encountered slight in character; besides the bankruptcy of his partner a more personal distress arose from the

1 A pleasing pen-picture of this typical Quaker is given by his granddaughter Mary Anne Schimmelpenninck (see Hankin, Christiana C., Life of Ifury Anne Schimmelpenninck, Vol. I, Autobiography. Pt. I, 1778-1787, pp. 45-53. Iondon, 1858).

"Of all the pleasures of my childlood, by far the greatest and the swcetcst in recollection were the visits, whether of days or weeks, to my dear grandfather at Dudson. I can hardly saly how delightful to me was the quiet, the spirit of love and order and peace which characterised his household. The family, as I remember it, consisted of my grandfather himself and of Iizzie Forster. She harl formerly superintended the education of my aunts, my father's sisters, but, after the cleath of my grandmother and my aunts, Lizzie Forster continued her post as liead of the establishment. My grandfather himself presented so striking a likeness to Wm Penn in West's picture of the Treaty with the Indians, that I never knew any person who had seen both, who was not struck by it. He was very cheerful, orderly, active, acute as a man of business, and most kindly in his consideration and thought for the welfare and happiness of all about hin. While my nother bestowed out of her benevolent heart, like a noble benefactress, ny grandfather gave in a benevolent, considerate, and lusincss-like way; with brotherly kindness he ascertained what would and to the wellbeing of his people, and supplied the want kindly, beneficently, yet not lavishly, witl a completeness that showed his pleasure in giving, yet with an orderly economy. He considcred himself as a responsible steward, and as his fortune had been the fruit of God's l, lessing on his industry, he clesired, remembering the labour of his youth, to 
early deaths of his children. It would seem that the short-livedness of the Button stock was handed down to the third generation. His eldest daughter Sarah died at 13 ; his second cliild James at one year; his

reward industry in others, and to make as many hearts as he could, light and grateful to Gorl the Giver, never seeking to fix the eye of the receiver on himself....

"Well do I recollect my dear grandfather's eheerful voiee, as, at about six o'clock, on a bright summer morning, he would call me to aeeompany him on his walk, or if he wero suffering from the gout, to walk by his wheel-chair in the shrubbery. First we nserl to visit the little garden he had given me, and watch the growth of the seeds and roots I liad planted there under his direction. Then we proceeded to the hothouso or conservatories, where my grandfather affixed to various bunehes of grapes or pines the names of invalid friends or others, to whon they might be a comfort. If $\mathrm{I}$ had been a good child, lre would let me affix the tickets, and would teaeh me to print the names on them or perhaps allow me to be the bearer of his gifts. And then he liked to visit his bees in their glass hives, whence he drew many a lesson on industry. He was likewise a great florist, and delighted to visit his greenhouse, his auriculas, and otler clroice flowers. Then we proceeded to the pond, or rather, perhaps, lake, since the stream on whieh Birmingham stands runs through it. This lake occupied eight or ten acres, and was of considerable length. It was truly beautiful; its borders indented and clother with the finest willows and poplars I ever saw. The stillness was delightful, interrupted only by some sparkling leaping fish, or the swallow skimming in circles over the water, the hissing of the swans from their two woody islets, or the eries of the wildfowl from the far-off sedges and bulrushes. It used to be a delight to me, when standing near my grandfather in a rustic fishing-house at the farthest end of the pool, he applied to his lips a little silver whistle (such as now, sixty-six years after, I wear in remembrance of him) and immediately the surface of the lake seemed instinct with life. Waterfowl, of all descriptions, rose from their coverts, and hurried towards us: the heavy Muscovy ducks, Sheldrakes, Burrow ducks from the Severn, sea-gulls, Canada and Cape and tall Peruvian geese, and the little moor-hen and teal, half-sailing, half-flying, with six majestic swans all drew near to be fed. How well do I remember my grandfather then saying to me "Thou canst not do much good, and canst feed but a very few animals; yet low plensant it is to do even that! God, the Father of all, opens His hand, and all $\mathrm{H}$ is creatures on the faee of the wide earth are filled with good. How blessed is He!' Then my grandfather would visit his mill, whieh was near the lake; there he inquired after all his workmen, went to the cottages of any that were ill, and was sure to leave some substantial evidence of his visit, besides the kind word whieh aeeompanied all his gifts. Plensant were his friendly calls on some infirm or aged person, or sickly child, and sure were those who diligently attended his school of a reward.

"On our return to breakfast, my grandfather would make me partake of his little ration of toast and clotted erean, and then came the pleasure of throwing open the window and spreading eorn with salt on the large pigeon-board...... How eagerly I listened when my grandfather pointed ont to me the deep attaehment of the carrier pigeon to her home, of the queest to her nest, of the turtle-dove to her nate; that they eould only flomish upon corn and all their food seasonerl with salt. He also showed me 
$42^{\circ}$

42 
Plate $\mathrm{K} / \mathrm{YV}$

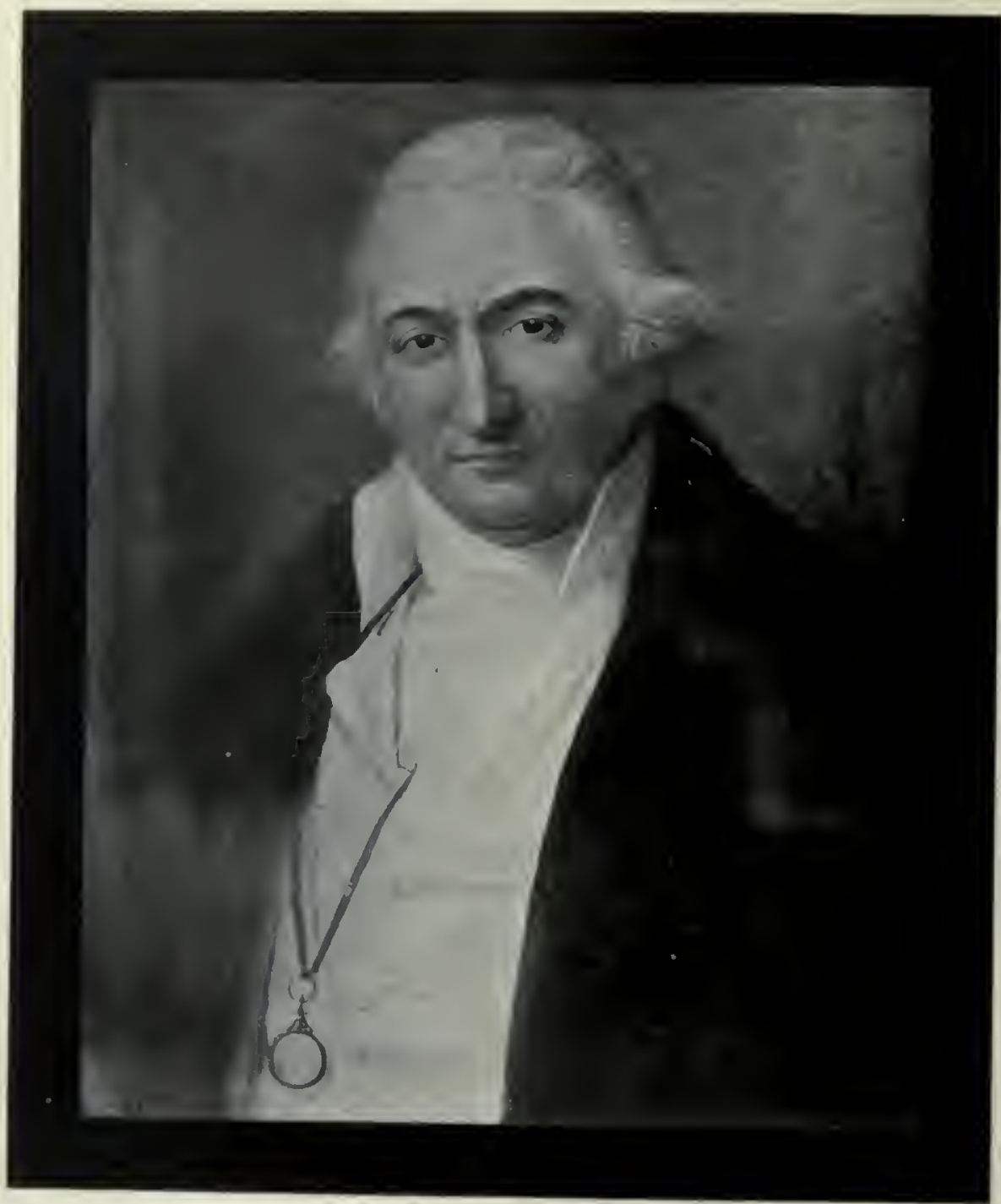

SAMUEL GALTON, the Younger (1753-189:2).

From a portrait hy Lomgastre at Claverdon in the possession of Mr. Wheler Galton. 
fourth child Mary at 28; his fifth Edith in the first year of life; his sixth Elizabeth at 21 and his youngest Hannah at 14! Only his third son Samuel survived to carry on the line ${ }^{1}$. To anyone who has studied the pedigrees of families in the 17 th century this immense mortality will not seem wholly exceptional. Of its great influence on national life and character there can be small doubt.

The death of his brothers and sisters all previous to that of his father, meant that Samuel Galton the second became, on the death of his father in 1799, a man of large wealth and considerable estates. His portrait (see Plate XXV) seems to indicate a man very similar to the verbal description given by the writer in the Gentleman's Magazine of his father. In the family he was often spoken of as Samuel John or John Samuel, but he was not so registered at birth; it seems probable that the name was merely adopted to distinguish him from his father. Born in 1753, Samuel Galton the second went in 1759 to school at Bristol-a fact which shows how the Bristol connection of the Galtons was still maintained. In 1760 he was transferred to James Fell's School at Worcester, which he left in the following year. In 1768 he

their beautiful but sober plumage, and pointed out, when they soared up aloft, how briglit their iridescent culours appeared in the sun...... l loved, too, to assist my grandfather in arranging old letters and papers from friends of his youth, or of his ancestors......

"One more anecdote respecting my grandfather. He was most kind to us his grandehildren, but I believe yet more espeeially to me, who was three years and a half older than any of the others, and who from delicate health always preferred the quiet society of those older than myself, to children's play. It was his custom to give each of his grandchildren a guinea on the day of their birth, and on every birthday add another; paying us also interest on the former. When we were seven years old, he made us keep the accounts ourselves. This was to go till each attained the age of twenty-one, when he intended the whole sum as a little present; besides this, he frequently gave me money, sometimes half-a-crown, sometimes a guinea. He gave me also a little accountbook in which he desired I should set down accurately everything I received and expended. This was contrary to my natural taste and habits; it was also very different from my dear mother's magnificent manner of spending and aeting in all that related to money: but one day my grandfather called me to him and said: "My child, thou didst not like when I advised thee, the other day to save thy sixpence, instead of spending it in barberry drops and burnt almonds..... We cannot be self-denying wisely till we know the real value of what we give up; that is why I wish thee to keep exact accts.'"

1 Their mother, Mary Galton, died at the Swan Inn, Tewkesbury, on her way from Cheltenlaam to Birmingham in the presence of the two Samuels and lier daughter Mary"my exemplary and dear mother," as tho younger Samuel expresses it. 
went to the Warrington Academy, where Dr Priestley taught. Here he came, for the first time probably, into touch with this man of commanding scientific ability with whom he remained a close friend during life. Priestley was the second name in 1785 of those ${ }^{2}$ on Samuel Galton's certificate for fellowship of the Royal Society. Nor was the friendship one-sided. Whatever the mob may have thought of Priestley, when they fired the Unitarian meeting-houses, burnt Priestley's private house, wrecked his laboratory and destroyed his manuscripts and books, for sympathising with the French revolutionists, Galton and Wedgwood maintained their friendship for him. There is a fine letter from Samuel Galton to Priestley still preserved which runs (Sept. 7, presumably 1791):

"I have this moment only received your farour by $\mathrm{Mr}$. Wm Priestley, and rejoice most sincerely in the idea of seeing you. If you incline to come to Birmingham, which I think much better and more honorable, pray inform me the hour you expect to arrive and where, for $I$ will meet you at the Coach and aceompany you in your perambulations about the town, lappy in an oecasion to arow the most explicit attachment to a Pcrson, whose friendship does me the greatest honour. If you leave the eonelı at what was onee your house, I will meet you there. It shall never be said that Dr Priestley was not reeeived with open arms by one on whom he has conferred such obligations. The idea of fear Mrs Galton ${ }^{3}$ and myself equally despise, nor do we really think there is any dangel; but if the alternative were that we should lose our house or our esteem for ourselves, we would not pause for a moment"."

There is a good deal of the old Quaker spirit of the Barclays and

1 It should be noted that John Wedgwood and Malthus were both at Warrington somewhat later 1782-3, and this College link of Wedgwood and Malthus to Priestley, Darwin and Galton should be borne in mind.

2 The names are Richard Kirwan (1733-1812), the "Nestor of English Chemistry," and Copley medallist in 1782 for his papers on cliemieal atlinity, "an accomplished linguist, a brilliant talker, and an adept in Italian music "; Joln Smeaton (1724-1792), the great engineer, builder of lighthouses and bridges and originator of the Institution of Civil Engineers; Josiah Wedgwood (1730-1795), the keen business man, the strenuous potter and the inborn artist; T. Lane (1734-1807), the inventor of graduated medical measures and of the diseharging eleetrometer' and Sir William Watson, M.D. $(1744-1825)$, another distinguished medical man of the time. It would have been difficult at that day to have a group of six smpporter's more weighty or more varied in tlucir talents.

${ }^{3}$ Lacy Barclay : see Plate XXVIII.

+ Marsh, G. F., Transactions of the IIistorical Society of Lancashire and Cheshirc, Vol. vi, p. 69. "On some correspondence of Dr Priestley, preserved in the Warrington Museum." 
Plate XXVI

$44^{a}$

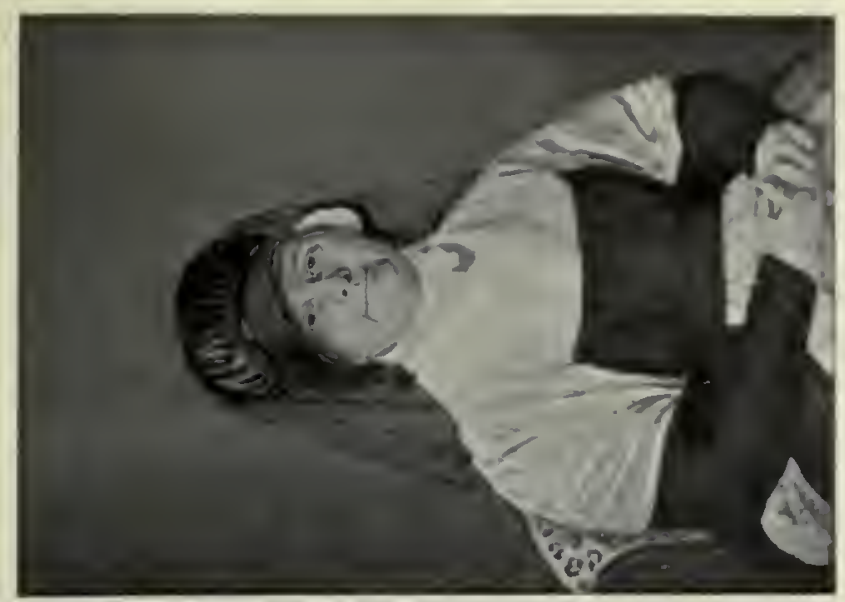

$\stackrel{\varrho}{=}$

$\Xi \stackrel{\circ}{\circ}$

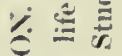

言

E $=$

$\div \div$

至

कू चै

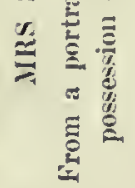

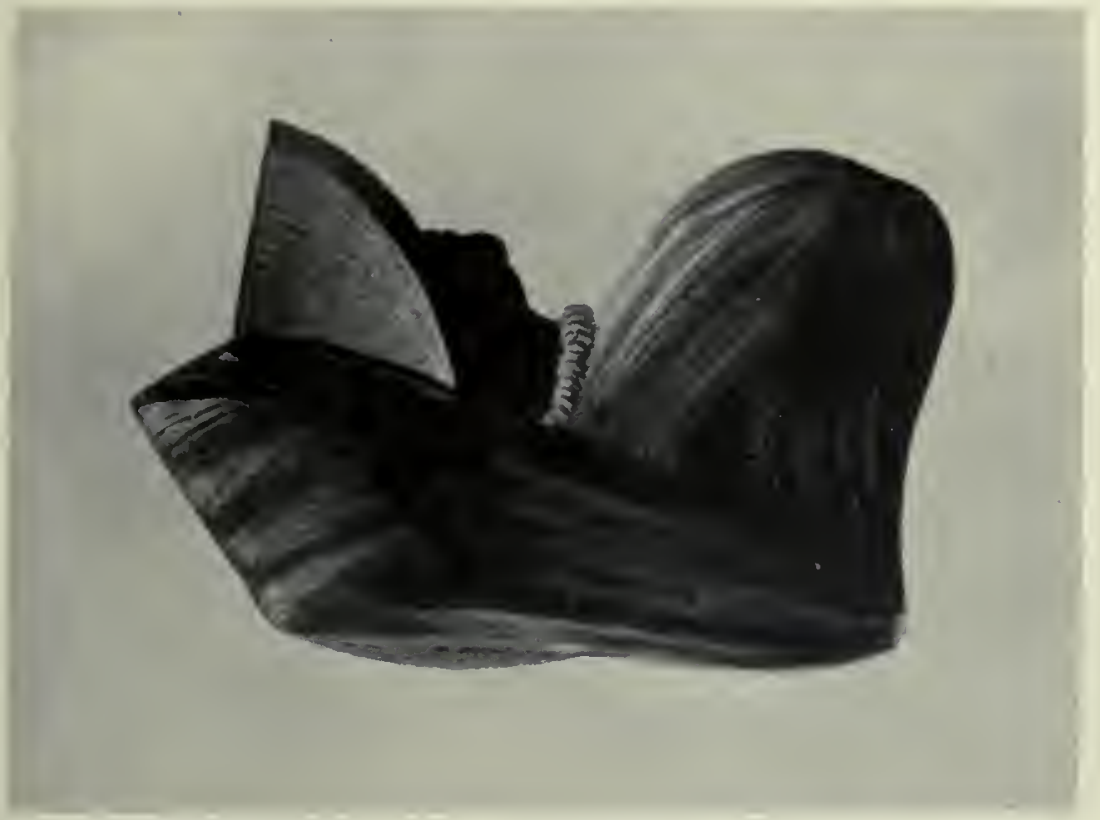

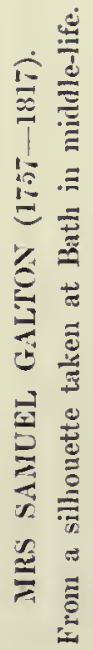

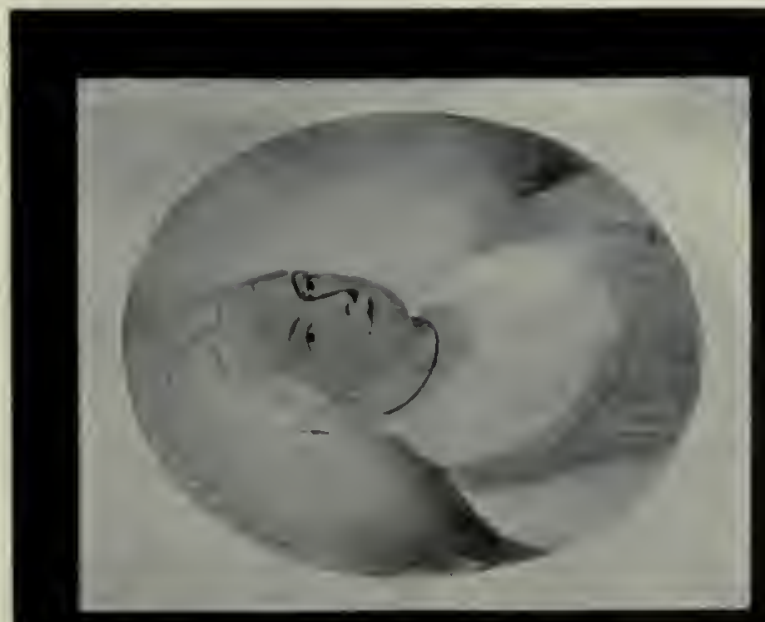

言节

ब

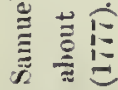

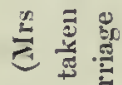

二

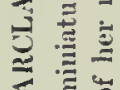

突范

壳 

Buttons in this letter of Samuel Galton the second, and although Priestley did not venture, perhaps for the sake of his friends, to face Birmingham, Sanuel Galton continued to give an anmual benefaction towards the cost of his researches.

The fact that Samuel the first sent his son to the Warrington Academy - while absolutely consistent with the toleration prcached by Robert Barclay-indicates that he had already departed somewhat from the religious teaching of the Society of Friends. He also had been concerned in the gun-trade with James Farmer. But in 1795 Samuel Galton was formally disowned by the Society of Friends "for" fabricating and selling instruments of war," after the matter had been for several years agitated. Galton entirely disi'egarded the disownment and went on attending the meetings until his death in 1832 . The position of the Society was, I think, only consistent with their doctrines, but the disownment ought to have come nuch earlier-even to Samuel the first. If the statement be correct, that the Society continued to receive Samuel Galton's donations, then the disownment was certainly of a very specious character. Both Samuel Galton and his wife Lucy (Barclay) lived and died as Quakers and were buried in the burying ground attached to the Quakers' meeting-house in Bull Street (see Plate XXXII). There is little doubt, however, that both Samuel the first, and Samuel the second, the friend of Priestley and Erasmus Dar'win', had progressed from Quakerism a considerable way towards

${ }^{1}$ In the British Museum is an interesting tract by Samuel Galton, "To the Friends of the Monthly Meeting at Birmingliam"1795. It puints out that for 70 years his grandfather (i.e. Farmer), his uncle (John G.) and his father (Samuel G.) had been engaged in the business without animadversion on the part of the Soeiety, that the trade had devolved upon him as an inheritance. That to be eonsistent no member of the Society ought to pay taxes to a Government which prepared for war, or for preserving the peace in case of riots. Men were not responsible for the abuse of what they manufaetured. He deelines to give any pledge to the Society with respeet to abandoning his business; when he did witldraw, it should be from spontaneous sentiment and not from external influence. All is in excellent common sense and full of charaeteristic stubbornness, but his position was undoubtedly a false one judged by Quaker prineiples. Actually he gave up the gun business eight years later, three years after lis father's dcath.

2 Erasmus Darwin was regarded as ahmost an atheist by Anna Seward, and Mrs Sehimmelpenninek, referring to Dr Darwin, says: "I was thus in a state of mind to receive evil from a new and hurtful influence which now approached our family eircle" (Life, p. 126). And again, "I had been much in the soeiety of freethinkers" (p. 441). 
Unitarianism, or Deism. The next generation was to return to the Anglican or to the Roman Catholic Confession.

'The Warrington Academy has led to this digression on Samuel Galton's relations to Priestley. On leaving Warrington, Galton entered when 17 years of age the counting-house of Galton and Farmer. His diary reveals rapid progress in business success and continuous scientific tastes. In 1775 , his father transferred $£ 10,000$ to him; in 1776 , he first saw Lucy Barclay' (see Plate XXVI), in 1777 he married her, and his mother, Mary Farmer, died. In 1778 he became equal partner with his father, and took a house in Five Ways, Birmingham. In 1783 he was worth $£ 35,716$. In 1785 he went to live at Barr, and bought cows and followed agricultural pursuits -in the winters he came into Birmingham again. In 1788 he was worth $£ 43,049$. In 1792 we find him interested in canal development; in 1794 he bought Warley for $₫ 7300$, an estate he aftcrwards presented to his son John Hubert Barclay Galton. After the death of his father in 1799 , he went to live at Duddeston, and in 1803 he was worth more than $£ 180,000$, and latcr than this we have repeated investments in and development of landed estates. At death his fortune was upwards of $£ 300,000$. Among interesting evidence of the intimacy with Dr Erasmus Darwin are the fees paid to him, 10 guineas in 1787, 100 guineas for a visit to Margate in 1793, when Mary Anne the eldest daughter had a dangerous fever, and 40 guineas for a visit to Bath at the time of the illness and death in 1799 of Samuel Galton the elder. Other items of general interest are 80 guineas for four years to Dr. Priestley in 1798, and a further subscription in 1803.

Of Samuel Galton's own development after he started business we may say a few words. He was a nember of the Lunar Society, a local society the members of which dined at each others' houses at time of

1 There is an absurd tale in the first edition of Cassell's IIistory of England, only referred to here in case anyone should ever revive it, that Lucy Barclay was a daughter of George IJI and Hannah Lightfoot, a young Quakeress. The story is disproved by: (1) the marriage certificate of Hannah Lightfoot to Isaac Axford in 1753, four year's before Iucy's birth; (2) the inarriage certificate of Robert Barclay to the first Lucy Barclay on June 3, 1756, which in 1860 was in possession of Mrs Brewin; (3) the birth of I.ucy Barclay at Bushill in the Quakers' records on MIarch 22, 1757; (t) the dcath of her mother, Lucy Barclay, at her birtlı or one day afterwards-according to family tradition by her bed taking fire: the Quakel rccords say she died on March 23 and was buried at Winchmore Hill on the 29th; (5) Lucy Barclay's visits to Ury (sco Sampler, Plate XXVII); (6) Robert Barclay's bi-annual visits to Great Barr to sec his daughter and her husband, whom he ultimately made one of his executors. 

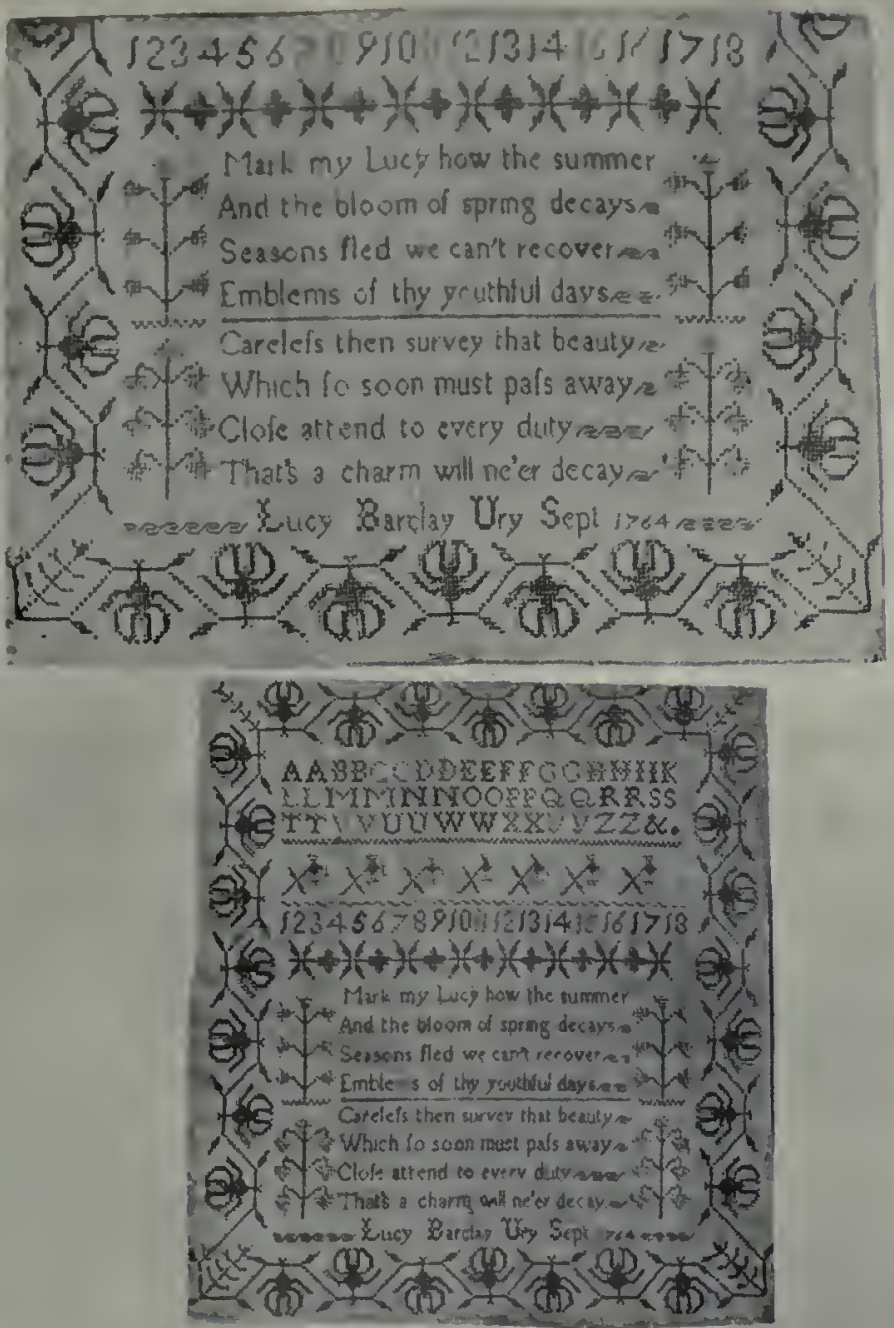

Photographs of Lucy Barclay's sampler, proving her presence at Ury, when seven years of age. According to the MS. riary of linueis Galton this sampler was worked at the gothic window with slutters on the first floor (see Plate XXIII), and he gives a sketeh of the recess inside the window where lis grandnother sat. A pane of glass broken by ler during this weary task was still pointed out in 1839 . 



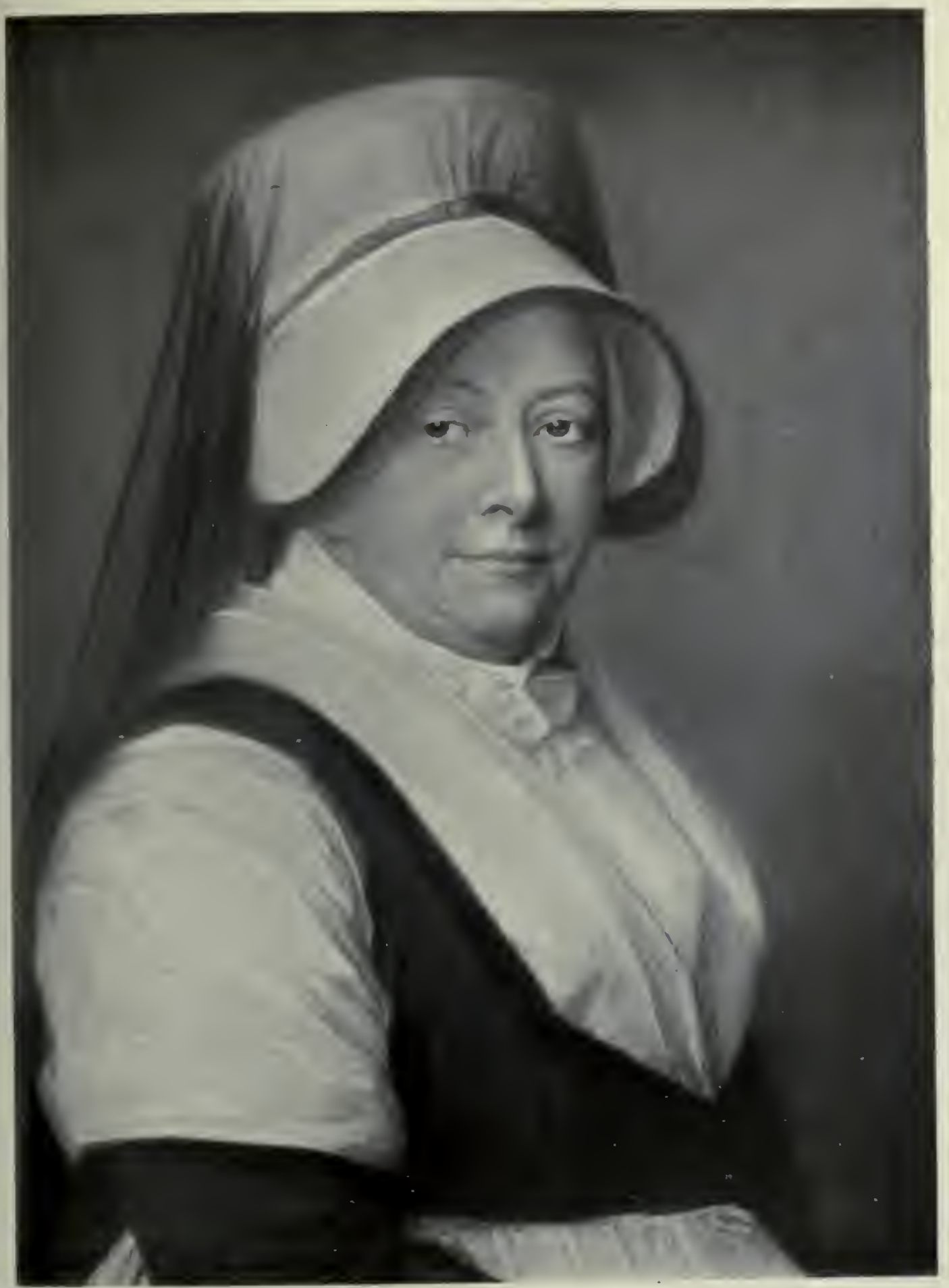

MRS SAMUEI, GALTON (Lucy Barclay) (1757-1817).

From a pastel portrait by Langastre at Claverdon in the possession of Mr. Wheler Galton. 

full moon, and which included many names of note ${ }^{2}$, e.g. Erasmus Darwin, William Withering (1741-1799) (a notable physician and distinguished man of science of his day), Baskerville (the famous printer), Wedgwood', Boulton and Watt, Thomas Keir (a very able chemist), Day (the author of Sandford and Merton, an eccentric, but of some power), Edgeworth and Small ("a man of delicate sympathy, keen perceptions, and suggestive energy ${ }^{3}$ "). Galton was also a member of the Linnean and Royal Societies.

The atmosphere of Birmingham in those days was one of progressive commercial development based on intimate relations to science, and Samuel Galton was one of the strongest links in the chain. His selfculture went on throughout his busy life. At 19 he attended Harris' lectures on oratory; at 21 he began to form a library, at 23 he attended Walker's ${ }^{4}$ lectures on gases, and he heard Walker again at 28. In 1799, at 46, he attended Bankes' lectures on philosophy, and in 1811 he assisted in founding the Birmingham Philosophical Society. In 1781 he bought a microscope for $£ 10$; in 1782 Nairn's electric machine; in 1783 Buffon in 16 vols.; in 1786 a reflecting telescope by Watson, and optical apparatus; in 1789, a camera obscura, and in 1818 he paid $£ 42$. $6 s$. Od. for an orrery, which his great-grandson, Mr Edward Wheler Galton, has recently presented to the Eugenics Laboratory. Of Samuel Galton's published contributions to science there are few to record. Dr Erasmus Darwin's long note on Galton's colour mixing experiments in The Botanical Garden', 1791, seems to suggest that he did some remarkably early work in this direction, which must have antedated that of Young (1801), whom Clerk-Maxwell places first in the field as the originator of the idea of three primary colours. The first publication by Galton himself of his results occurs

' Beside these men witlı whom he was very intimate, we must add Jean Ancle de Iuc (1727-1817) and Joseph Berrington.

2 Wedgwood was a frequent attendant, if not an aetual member.

'See Meteyar'l's Life of Josiah Wedywood, Vol. II, pp. 208-9.

4 Probably Adam Walker (1731 -1821), a sueeessful popular seienee leeturer, " pioneer of what is now "University Extension." He was a friend of Priestley, who may have brought him to Birmingham. I have not been able to identify Harris, and the only possibility for the third leeturer ("Bankes") would be Sir Joseph Banks--who was eertainly a frieud of Samucl Galton's, but I am not aware that he ever leetured, even on natural philosophy.

${ }^{5}$ See Additional Notes, note 2, p. 6, Edn. 1791. 
in the Monthly Margazine for August 1, 1799. They show that Samuel Galton was not only a careful experimenter, but a man of very considerable originality. Young was himself a Quakel' and was as a boy brought up in the house of David Barclay of Youngsbury'; herc he was educated with Hudson Gurney, and must have come in contact with Samuel Galton, who married Lucy Barclay in 1777. It seems probable, therefore, that Young knew Galton's work. Possibly his memoir took originally the form of a communication to the Lunar Society. The purchase of optical apparatus in 1786 is suggestive as to the date of these researches. Samuel Galton, as we have seen, was largely interested commercially in canals ${ }^{2}$, and in the Annals of Philosophy, Vol. Ix, pp. 177-183, 1817 is a paper by him On Canal Levels. He also published a book on birds ${ }^{3}$ with quaint colour illustrations, which was quite good for its date; according to his grandson Francis he had a decidedly statistical bent4. There is ample evidence to slow that Samuel Galton had he not been a "Captain of Industry" would have been a noteworthy man of science; his energies-even like those of Erasmus Darwin--were diverted from science to more monetary pursuits. But when we look at the strong facc shown by the portrait of Samuel Galton, when we examine the record of his scientific friends, and appreciate his tastes and abilities, we find it hard to assert that Erasmus Darwin was the only source of Francis Galton's scientific ability.

When we examine the four grandparents of Francis Galton, it is difficult to give precedence to any one of thein as more noteworthy than another. Lucy Barclay has been described by one of her granddaughters as "a very clever, beautiful woman, very dignificd and Queen-like in her manner." She possessed great talent and refinemcnt,

\footnotetext{
'Sec Memoir of the Life of Thomas Young, M.D., F.R.S. [By Hudson Gurney], p. 10. London, 1831.

${ }^{2}$ Erasulus Darwin favoured also the construction of canals and formulated some forcible and some rather quaint argunents in favour of them. His great-grandson, Mr E. Wheler Galton, has in his possession an interesting manuscript of Erasmus's dealing with this matter. An argument in favour of eanals was the provision they made for a reserve of men suited for the navy.

3 The Natural IIstory of Birds containing a Variety of Facts selected from several Writers and illustrated with upvards of One IIundred Copperplates. In three volumes. No date, Johnson, St Paul's Churchyard.

4 There are remarkable graphie charts of his ineome and louscholrl cxpenditure, length of service of his servants ete., ete., still cxtant.
} 
$48^{\circ}$ 


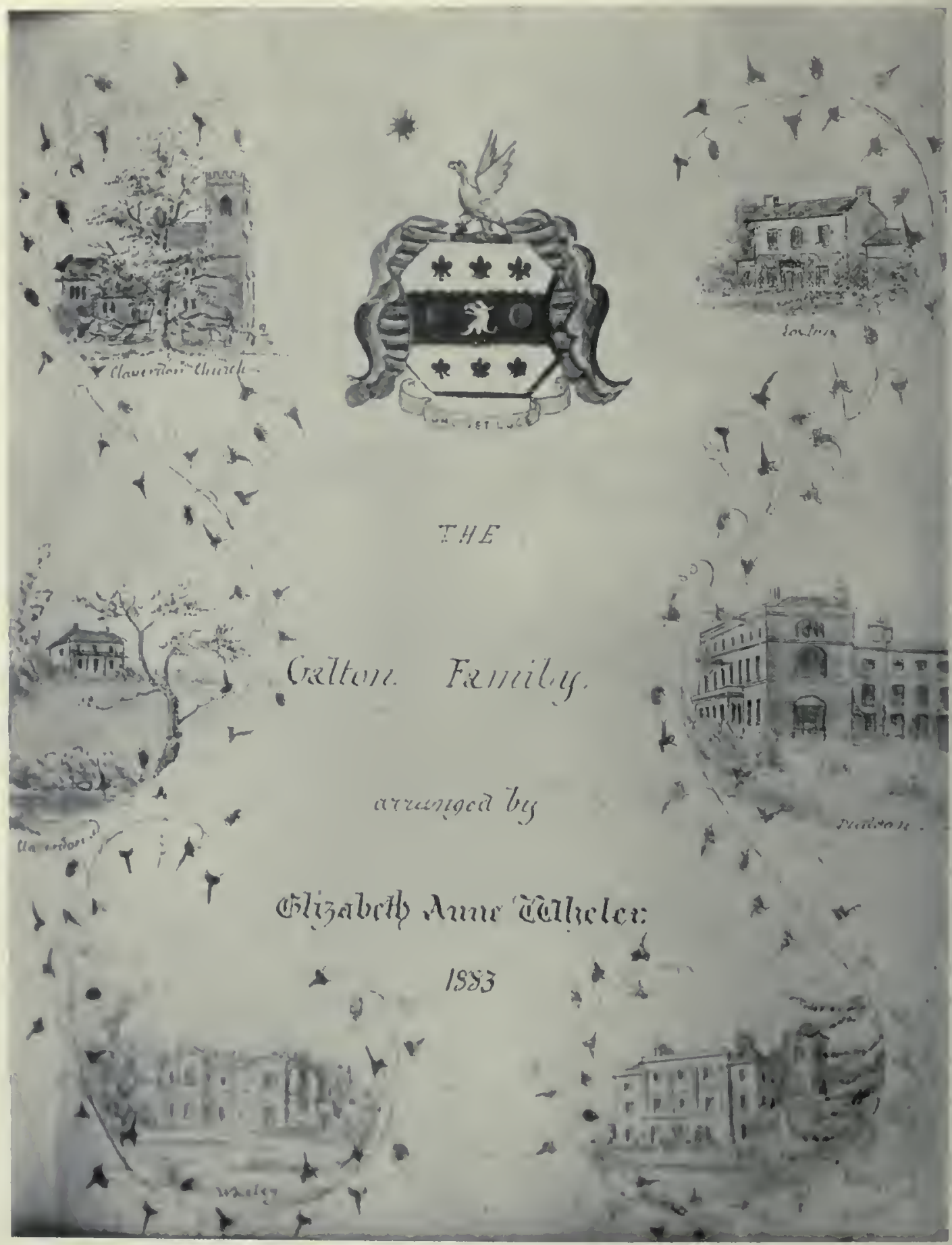

'Title-puge to Mrs W'heler's (Flizabetl Anne Galton's) MS, account of the Galton Family, showing sketches of Claverdon House; Claverdon Chureh (where franeis Galton is buried); loxton, the liome of Brasmus (ialton; Dudson, the home of the Simuel (baltons; Whaley, the home of llubert Galton, and Ilarloor, the hrome of Hownrl Galtous. 


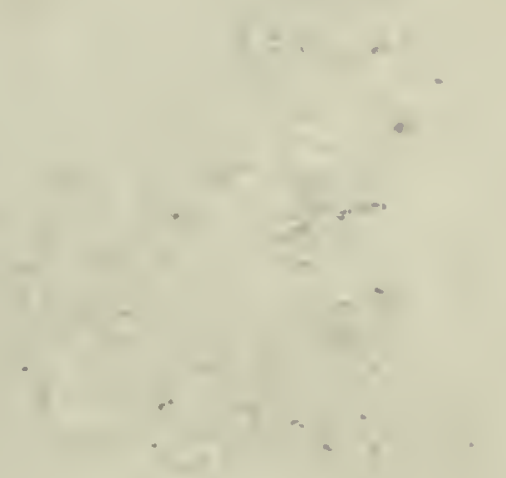


Plate XIX

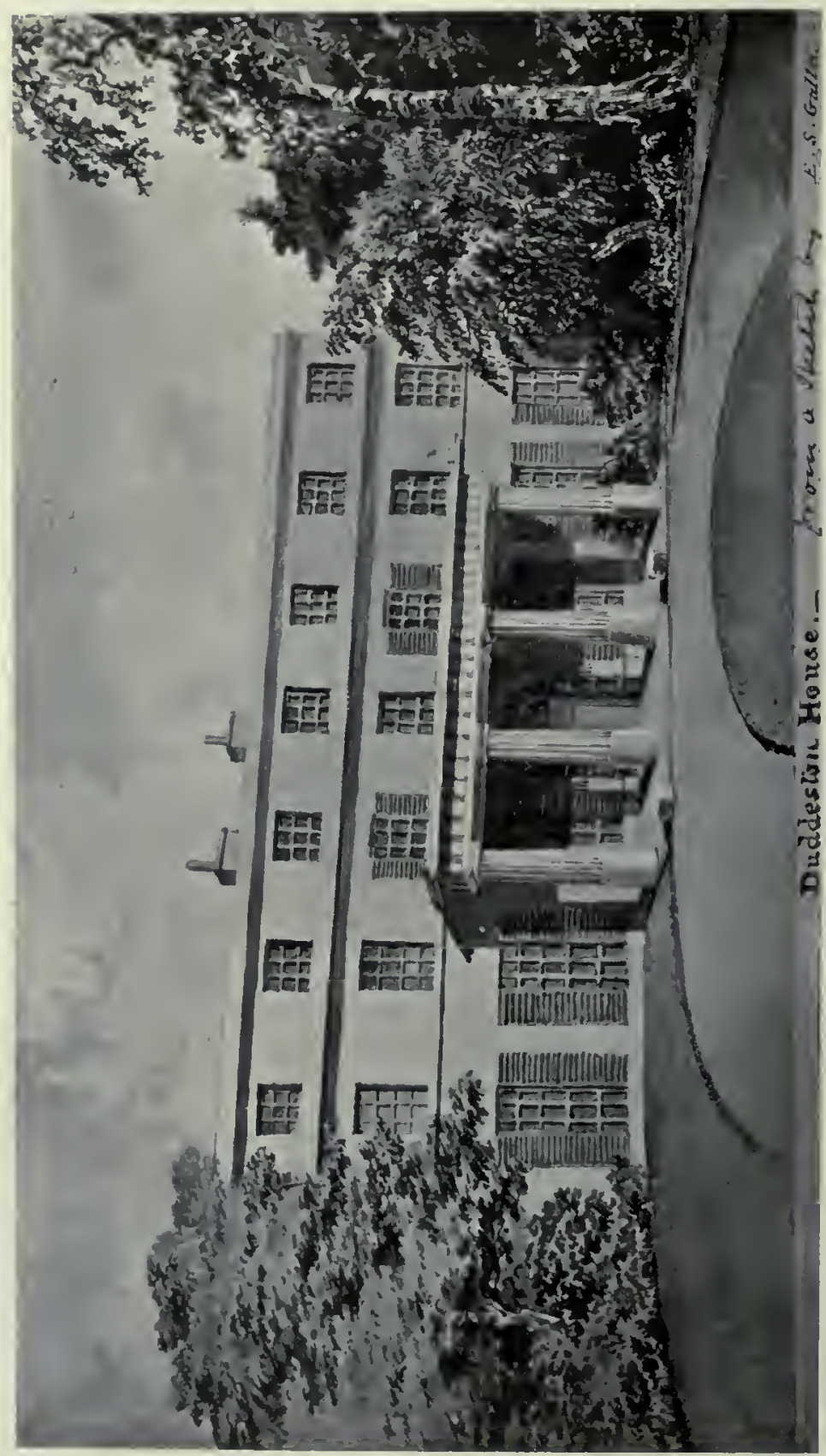

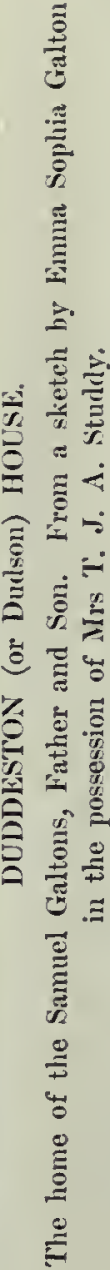




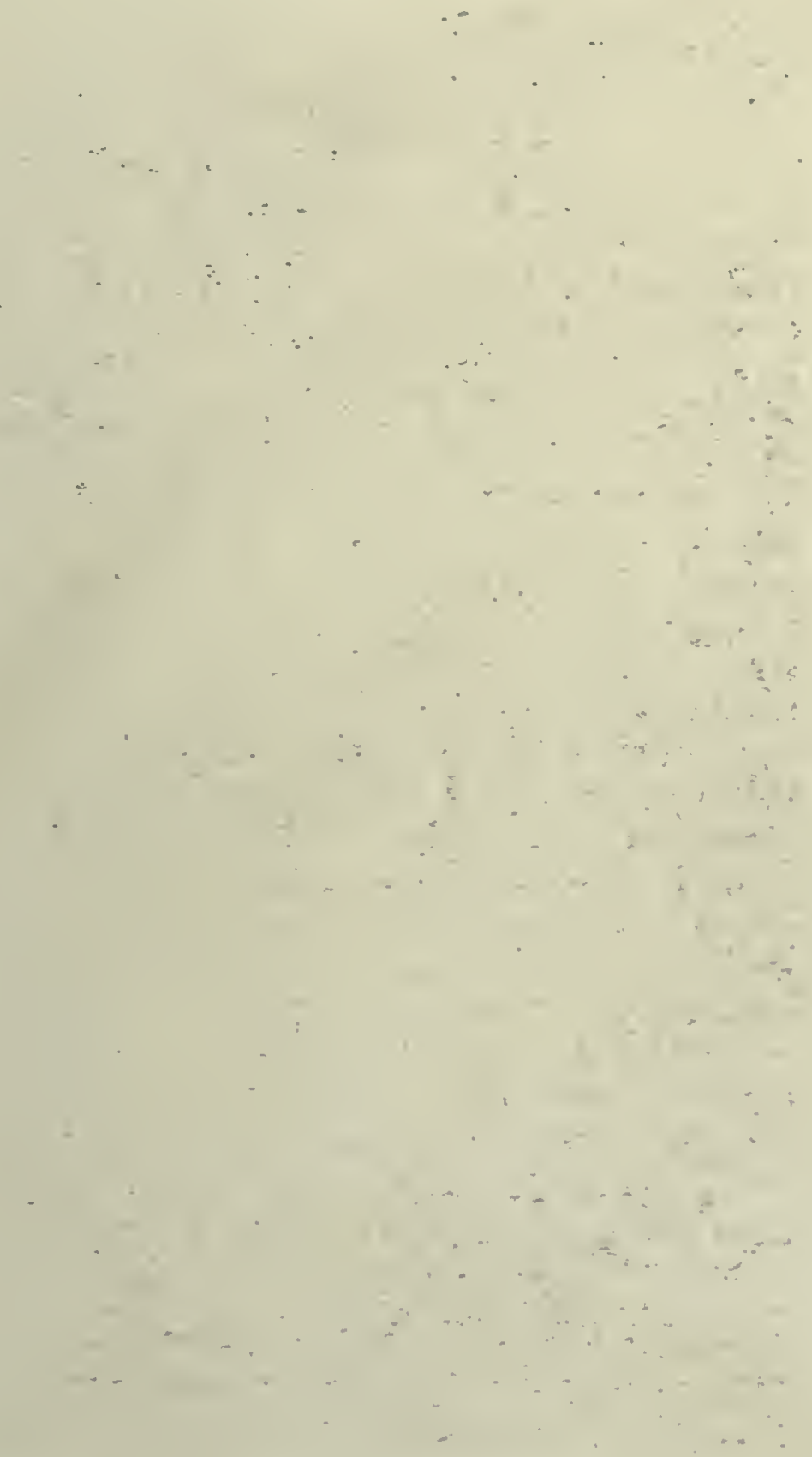




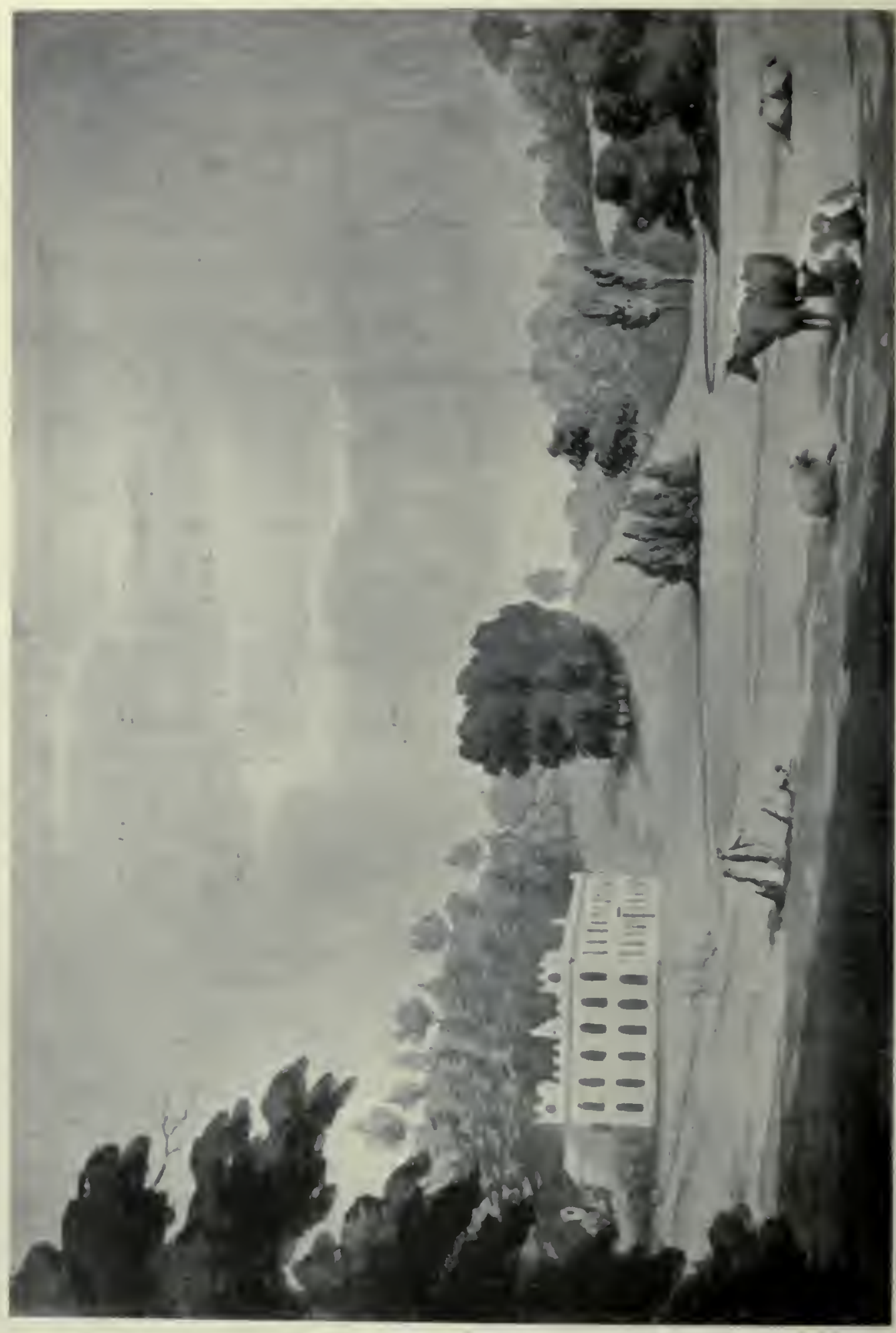


and she studied history and literature of every kind to educate hei children. She brought the physique of the Barclays and Camerons, and something of the courtly bearing of the Stuarts, and the ability of their greater ancestors into the Galton stock. Samuel Galton himself contributed determination, industry and a strong elcment of Quaker stubbornness-but at the same time wide public and social sympathies, and a distinct scientific bent. Elizabeth Collier of more slender figure than Lucy Barclay was not behind her in beauty. She supplied an artistic instinct, a joyousness in life, an appreciation of form and expression which are less usual among the Society of Friends; in her ancestry we trace in addition both love of adventure and love of learning. And last, but not least, we have Erasmus Darwin, who presented his descendants with that great gift, the scientific imagination-the match which may light a strong fire if the solid fuel of other characters be provided.

Before we pass to the children of Samuel Galton the second, a word may be added here about the Galton houses in Birmingham and elsewhere (see Plate XXIX). We have already noted the partnership of the Farmers and Galtons (John and Samuel) originating in Bristol. When John went at first to Birmingham he took a lease of Duddeston, and this house at his death was taken over by his brother Samuel, and passed in 1799 to his nephew Samuel the second (see Plate XXX). He enlarged it in 1800 and went to reside there in 1801. Samuel soon after his marriage had bought a house in Five Ways, Birmingham, and added the next house to it. But in 1785 he went to live at Great Barr', a large country house about four miles out of Birmingham, spending the winter in various houses in Birmingham.

In 1702 the shop of Joseph Farmer was in the corner of Bull Street and the Minories in Old Square, Birmingham. He was an ironworker, who became a successful gunsmith. He lived in the Square till 1735 when he moved to the house in Steelhouse Lane, known afterwards as Farmer and Galton's house and subsequently still as Galton's Bank (see

${ }_{1}$ This house, of which we give the photograph of a water eolour (see Plate XXXI), was a frequent meeting plaee of the members of the Lunar Soeiety. An interesting aceount of the meetings at Great Barr in her ehildhood is given by Mary Anne Galton (Mrs Schimmelpenninck). There is a paper in the Birmingham and Midland Institute Archaeological Section, Transactions, 1890, pp. 79-84, by H. C. Bolton, on the Lunar Saciety with references to Grcat Barr.

P. 6. 
Plate XXXII). Joseph Farmer died in 1741 and his son James succeeded him. In 1746 Samuel Galton married Mary Farmer and went to live at 13 Old Square. When James removed to London, Samuel left the Square to live in the Steelhouse Lane house. He appears to have remained there after James' bankruptey and his return to Birmingham, for the latter then went to live at Bingley House, which afterwards passed into the hands of the Lloyds. The Galton-Farmer house bore the initials J. F. in monogram over the doorway, and this fine old house, scarcely recognisable, still exists. In 1782 Galton rented Duddeston ${ }^{1}$, he took a 99 years' lease of it in 1789 and his grandson purchased the freehold in 1820. Samuel his son lived immediately after lis marriage also in the Steelhouse Lane house, he then went to Hagley Road, Edgbaston, and afterwards to Great Barr, finally settling at Duddeston on his father's death. Thus in Francis Galton's childhood from 1822 to 1832 Duddeston was the much frequented home of the grandfather ; it was superintended by a highly respected Quaker housekeeper, Lizzie Forster, after the death of Lucy (Barclay) Galton in 1817. When in $180 t$ the gunsmith business was wound $\mathrm{up}^{2}$, the Farmer-Galton house was converted into a bank, possibly at the suggestion of the Barclays. In this bank Samuel and Samuel Tertius were partners with Paul Moon James, and later Hubert Galton, a younger brother of Tertius, also became a partner. In 1825 there was a general panic in the money market involving a run on the banks throughout the country. Hubert Galton, going up to Barclay's in London to borrow, found no less than ten partners of the Gurney banks come up for the same purpose. The run lasted about a week, but the strain on Samuel Tertius Galton was very great during the crisis-a crisis indeed which he had actually predicted in his tract of 1813. His friends, however, stood firmly by him during this trying period $^{3}$, and the bank weathered the storm well. The strain, however,

1 A Mr Freame appears to have rented Duddeston from 1757-1780, I am uncertain whether a rclative of the Freames discussed above.

${ }^{2}$ It would appear that Samuel Galton the second determined on his father's death to wind up the gun-factory (at one time producing guns at the rate of onc a minute!) and start the bank. Whether this change was due to altering economic conditions, or to a religious scruple, reaching freedom of expression on the death of his father, we cannot say.

${ }^{3}$ Onc fricnd collected 1000 sovereigns in a bag and threw it on the counter with a loud chink at the height of the crisis before the clamouring depositors asking the partncrs to takc carc of them for him, a most seasonablc kindness. Mrs Whelcr's Reminiscences. 


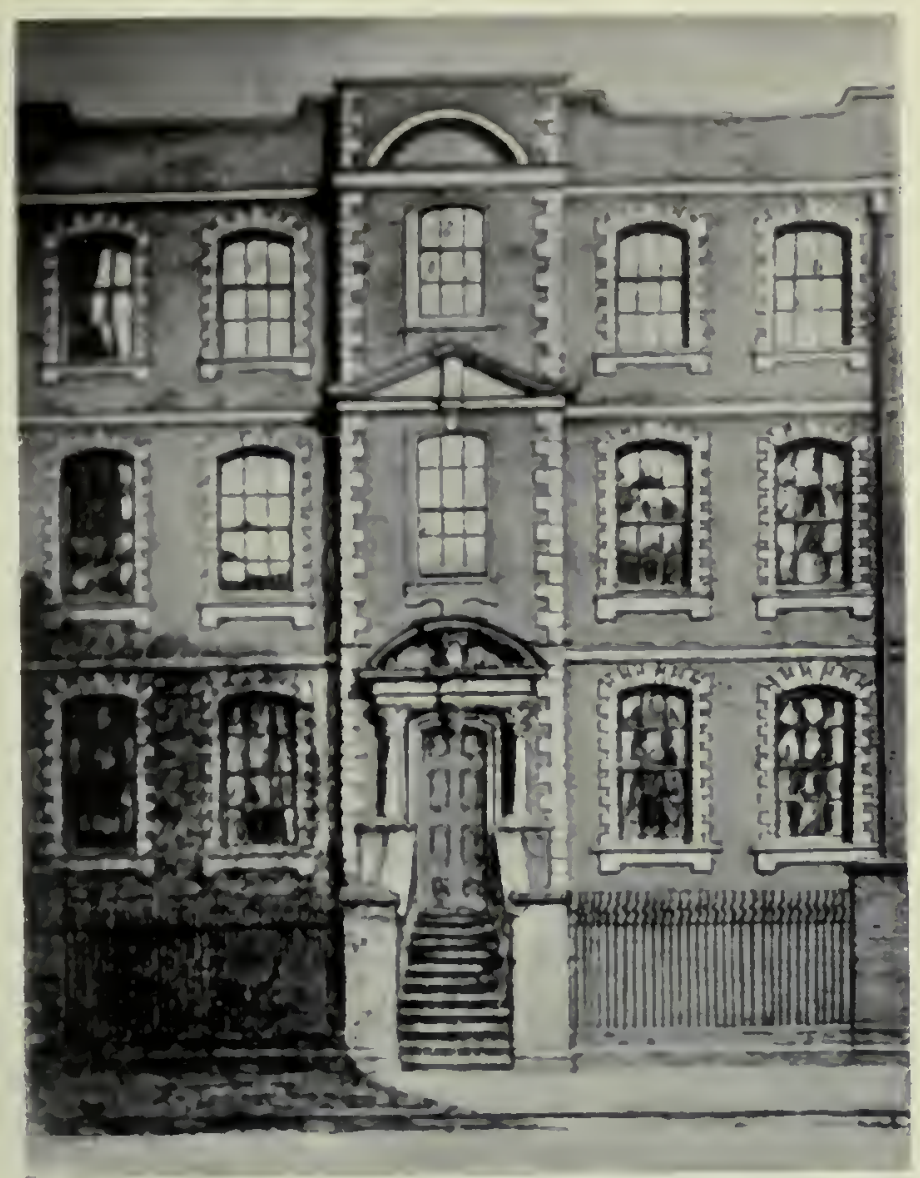

The Galton-Farmer house, later the Galton Bank, in Steclhonse Lane, Birmingham, now a shop.

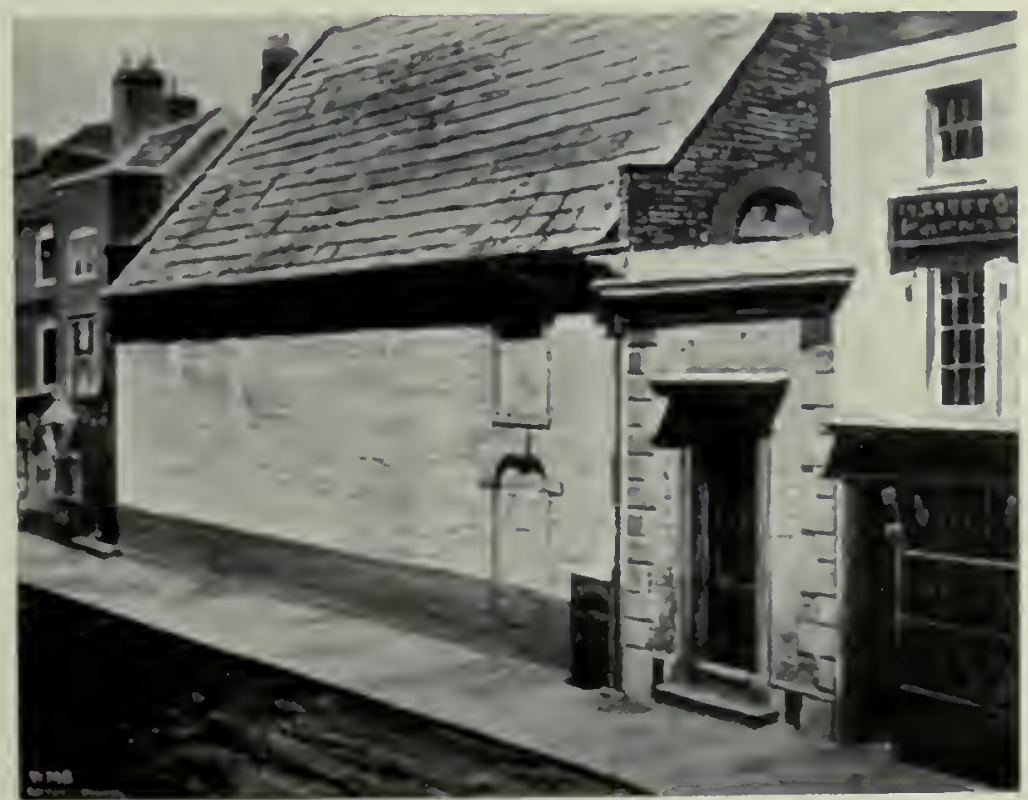

Friends' Meeting House in Bull Street, Birmingham, where the two Samuel Galtons with their wives attended and were ultimately buried. 

induced Samuel Tertius gradually to close the bank, which was accomplished in 1831, without the majority of people knowing anything about it until nearly every account was paid off. The Galton Bank in Steelhouse Lane afterwards became the Polytechnic Institution, later a Children's Hospital, and afterwards (1897) was the house of a medical man. It is now converted into a shop. In 1831, the Galtons' business relations with Birmingham ceased, and Samuel Tertius retired to Leamington in 1832. He had never lived at Duddeston, although he purchased the freehold of it in 1820 for $£ 8000$, and it became later a most valuable building estate. After his marriage, he lived at Ladywood, then a mile from Birmingham, and here all his children were born, except Francis who was born at the Larches (see Plate XLV), one mile from Birmingham on the Warwick Road. This house had been Dr Priestley's, being then called Fair Hill, and it was the house burnt in the Birmingham Riots to which we have already referred; nothing was left but one room and the laboratory over the stables$^{2}$. There was a good garden and three fields, and here the children used to scamper about on the two small Welsh poniesScamper and Fenella-to which Charles Darwin refers in his letter of 1853 :

"I should inuch like to hear something of your brothers Darwin and Erasmus: I very distinctly remember a pleasant visit at the Larches, now many years ago, and having many rides with them on ponies without stirrups."

Of this visit of Charles Darwin to the Larches Mrs Wheler writes as follows in her Reminiscences:

"My Uncle, Dr Robert Darwin, was a tall, very large man, weighing more than 20 stone, but wonderfully active for his size and very fond of his garden. $\mathrm{He}$ was extremely cheerful and agreeable, full of amusing anecdotes and considered a very clever doctor. His son Charles was a very pleasant lad; when about 15 , he was staying with us and went out with my Father to practise shooting; on his return we asked if he had been successful. 'Oh,' said my Father, 'the birds sat upon the tree and laughed at him.' Some time after my Fathers and Brothers went to Shrewsbury. My Fatler had hardly sat down, when Charles begged him to come out on the lawn, where he threw up a glove and hit it shooting, without missing, two or three times."

In 1824 Samuel Tertius purchased Claverdon", an estate near Warwick, which, at first a summer residence, became later almost the

1 It was rebuilt and occupied by Withering the botanist.

2 It is now in possession of his grandson, Mr Edward Wheler Galton, and contains a valuable collection of Galton, Darwin and Barclay pictures and manuscripts. 
family centre. Samuel Tertitis and Francis Galton and many of the family are buried in Claverdon churchyard. The earlier Galtons were buried in the yard of the quaint little Meeting House of the Society of Friends at Birmingham, a photograph of which is here reproduced.

Of Samuel Tertius Galton (see Plates XXXIII and XXXIV) we have many accounts from his children ${ }^{1}$. Francis Galton describes him as "one of the most honorable and kindly of men and eminently statistical by nature?."

"When we children quarrelled," writes Mrs Wheler, "and went to my Father or. Mother to complain, he used to send one into one corner of the room, and the otlier into the opposite corner, and at the word of command, each had to rusl into the otlicr's arms. This made us laugh and ended the dispute. My Fathcr was a true peace-maker, lee always turned the matter off playfully. He was fond of science, and took much interest in all new improvements. He liked measuring hills and mountains with his portable barometer, which we always took on a journey and which required great carc not to break."

The scientific instruments, however, with which he amused and instructed his children appear to have been chiefly those purchased by his father. Samuel Tertius does not seem to have been a man of quite the vigour or originality of his father, but he inherited his father's public spirit and much of his business capacity. He was High Bailiff of Birmingham in 1814, and took up the addresses from that town to the Prince Regent on the restoration of peace and on the marriage of Princess Charlotte. This public work was continued as magistrate and deputy-lieutenant after his removal to Leamington. He was called upon to act in numerous arbitrations owing to the widespread esteem for his good sense and judgment. It is reported that he never kept a poor man waiting, always saying "Time was money to the poor." While he suffered, as his father and grandfather had done, and his sons

${ }^{1}$ He was educated at Dr. Valpy's Scliool, Reading, and was entered in 1799, aged 16, as a pensioner at Trinity College, Cambridge. His father's account-book would seem to show that he went into residence, but he did not matriculate, and wc soon after find him in a commercial office in Liverpool.

"His only published work: " $\mathrm{A}$ Cliart exhibiting the Relation between the Amount of Bank of England Notes in Circulation, the Ratc of Foreign Exclianges, and the Prices of Gold and Silver Bullion and of Wheat, accompanied with Explanatory Observations," Loudon, 1813, is a graphical consideration of what we now term the correlation of thcse variates. It is a strong attack on an inconvertible paper circulating ınedium, and predicts disastrous consequences as invariably following such a system. It must have becn quite useful in its day. 


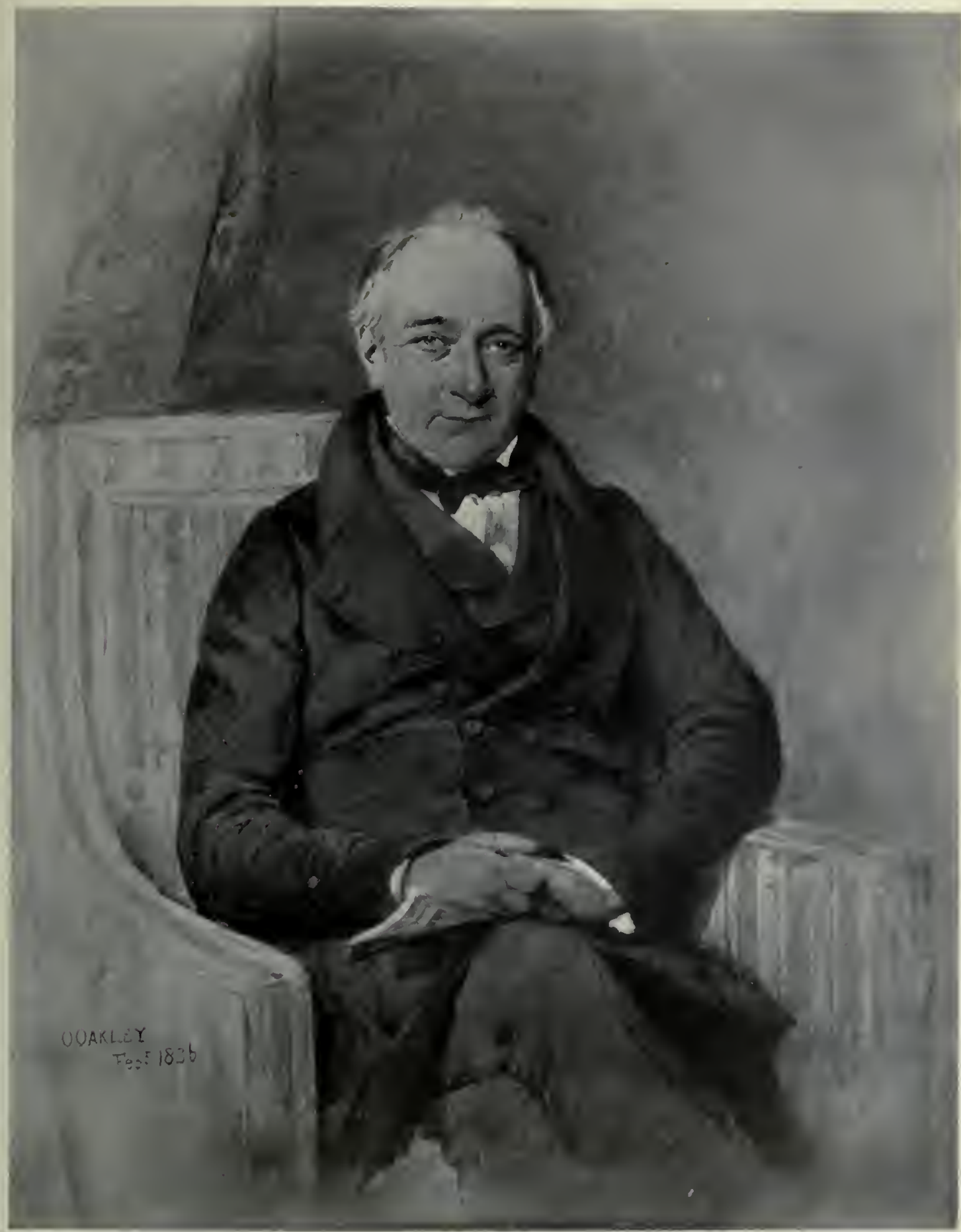

SAMUEL, TERTIUS GALTON (1783-184t).

Father of Francis Galtou, and lusband of Violetta Darwin. From a painting by Oakley in 1836. 

Plute YXXIV

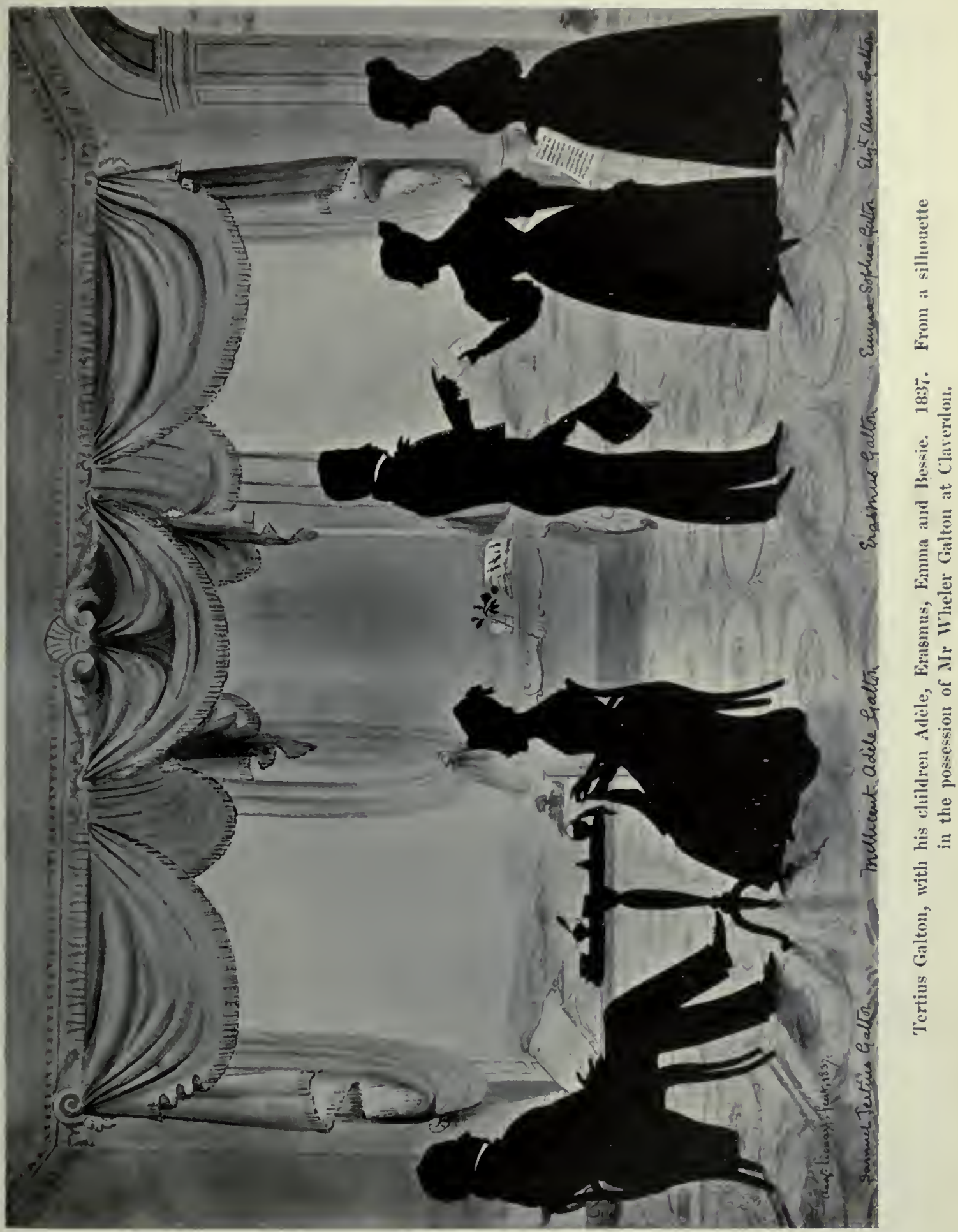



Hubert and Francis did later, from asthma, he yet inherited something of his Barclay ancestors' power of walking, and would walk all day without fatigue. He was not a man of that kind of note which finds its way into biographical dictionaries, but he did-what many of us everyday inortals fail to do-the usual work of the everyday world and he did it well ${ }^{1}$. As a result he was respected by all who knew him and beloved by all his children, who found in him on every occasion their best friend. He died at the relatively early age of 61 , and left his sons each sufficient fortune to follow their own bent apart from a profession.

Like Samuel Tertius, his two brother's John Hubert Barclay Galton (1789-1864) and John Howard Galton (1794-1862) married into able stocks, the first married Mary, daughter of Robert Barclay, Banker of London, and therefore a multiple cousin; the second a daughter of Joseph Strutt and ultimately his heiress. Miss Strutt was a granddaughter of Jedediah Strutt (1726-1797), the partner of Arkwright in establishing the spimning jenny, and himself an inventor of no mean order. Her father was not only the benefactor of Derby, but an intimate friend of Thomas Moore and Edgeworth. John Hubert had four children, three died quite young and the fourth left no issue. John Howard Galton's is the only line by which the name of Galton has been preserved. His second son Sir Douglas Galton (1822-1899) reached fame in a variety of ways: as a Royal Engineer he did much good, especially for the Commission on the Application of Iron to Railway Structures (1848); he was General Secretary and afterwards President of the British Association and the third of his name to obtain fellowship of the Royal Society. He was Assistant Inspector-General of Fortifications (1859-1862), Assistant UnderSecretary of War (1862-1870) and Director of Public Works and Buildings (1870-1875); and generally an able chairman of committees and of very considerable inventive ability. His achievements mark the scientific and business capacity of Galton and Strutt stocks, apart from the scientific imagination contributed by the Dar'win blend. Of Tertius Galton's sister's ${ }^{2}$ the most noteworthy was Mary Anne (1778-

${ }^{1} \Lambda$ shorthand diary of Tertius Galton for the years 1829-1844 (Eugenics Laboratory) testifies to his multifarious duties and his genial nature.

2 Of the remaining brothers Ewen Cameron died as a child of nine, according to family tradition from the rough usage he received from the elder boys at Dr Valpy's 
1856), who married Lambert Schimmelpenninck. She was a woman of very considerable literary power and made a special study of Port Royal; her works, The Theory and Classification of Beauty and Deformity, 1815, and Select Memoirs of Port Royal, 1829, had considerable vogue in their day. Francis Galton has said all that need be said on her separation from her family. Members of the same family are at times mutually incompatible and it is a fact, not perhaps easily explicable, but none the less demonstrable that such incompatibilities often reappear generation by generation. Of the two other sisters of Samuel Tertius, Sophia (1782-1863) married (1833) Charles Brewin-his grandfather Charles Lloyd was first cousin of Charles Lloyd who married Mary Farmer-and Adele (1784 -1869) married Dr John Kaye Booth (1827). Neither of these marriages made relatively late in life had issue. Of his Galton uncles and aunts, Mrs Booth in face resembles most closely Francis Galton, and she has more resemblance to Samuel Galton, her father, than Mrs Schimmelpenninck or Mrs Brewin, who are more like Lucy Barclay in their portraits. But in mental characters-strong sense, excellent memory, business aptitude and fondness for natural history-Mrs Brewin had much that was akin to her nephew Francis, and perhaps she is with the exception of Sir Francis Darwin the nearest of any uncle or aunt to him in character (see Plates XXXV and XXXVI).

Of Francis Galton's own brothers-Darwin Galton and Erasmus Galton-little need be said here. Erasmus entered the navy, but soon retired. Both brothers took their places as country gentlemen, and did their duty to their neighbours and to their shire. This was a life to which much of their ancestry, both Darwin and Galton, had been accustomed. On the one side had intervened the Quaker movement, followed by mercantile success, on the other, the exceptional appearance of Erasmus Darwin. But the younger generation, whether we consider the offspring of Violetta Galton or Francis Darwin, followed a sort of natural instinct and returned to the land. Their love of wild life and nature may have been great, but it did not lead them to the interpretation as well as to the observation of living forms. For a time it seemed that this native bent would master Francis Galton. Like his school at Reading. The other brother Theodore, a young man of much ability, died of fever at Malta (1810) when returning homeward with Francis Darwin-the fourth death in the party. 


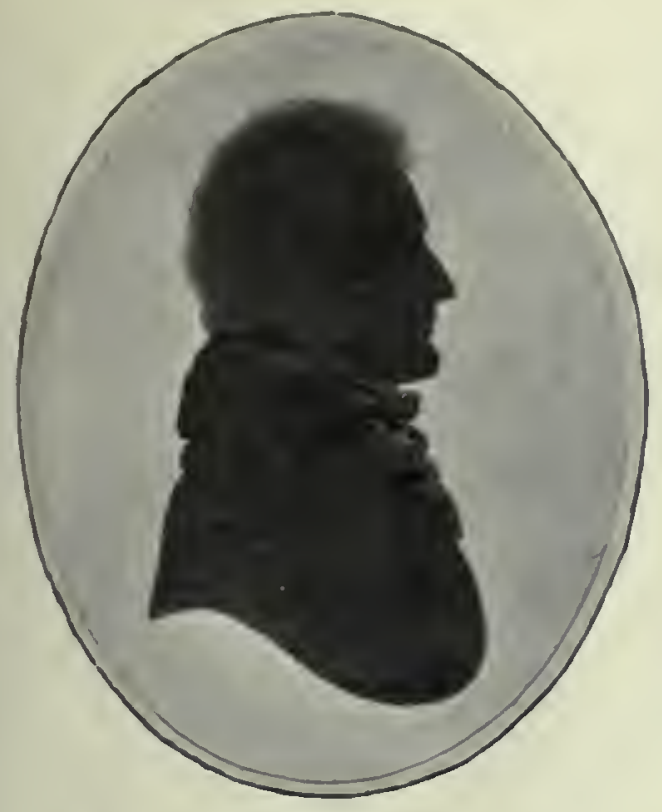

THEODORE GALTON $(1781-1810)$. Uncle of Francis Galton.

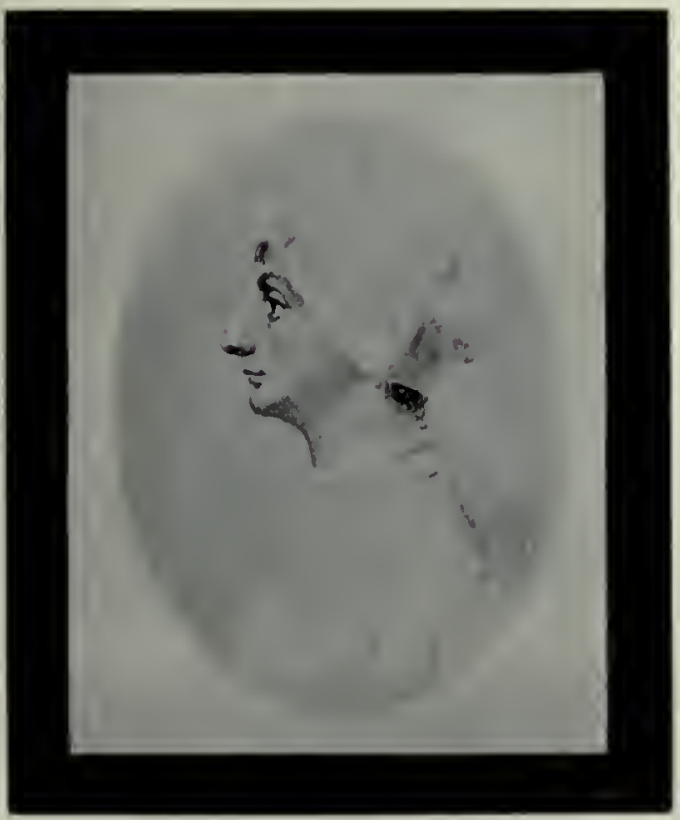

SOPIIA GALTON (1782-1863).

Mrs Charles Brewin, Aunt of Francis Galton.

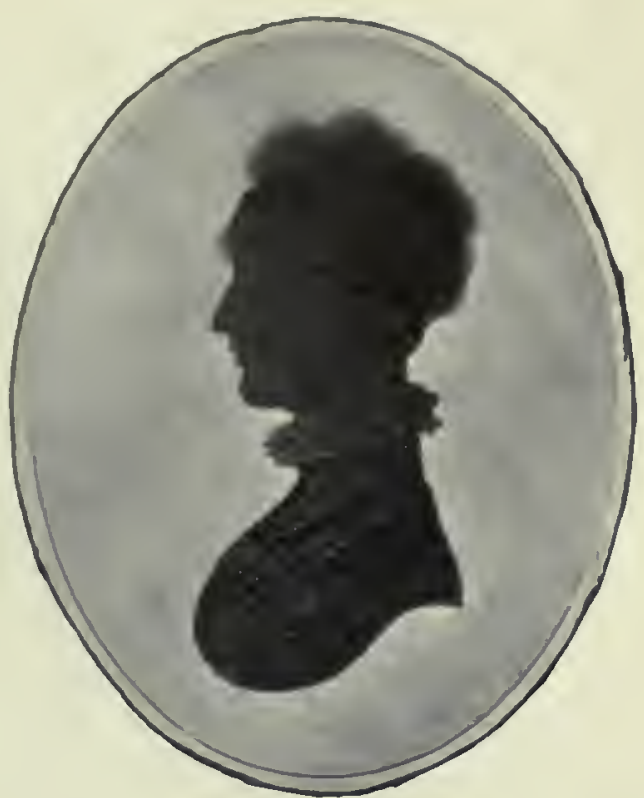

ADÈLE GALTON (1784-1869).

Mrs 'T. K. Booth, Aunt of Francis Galton.

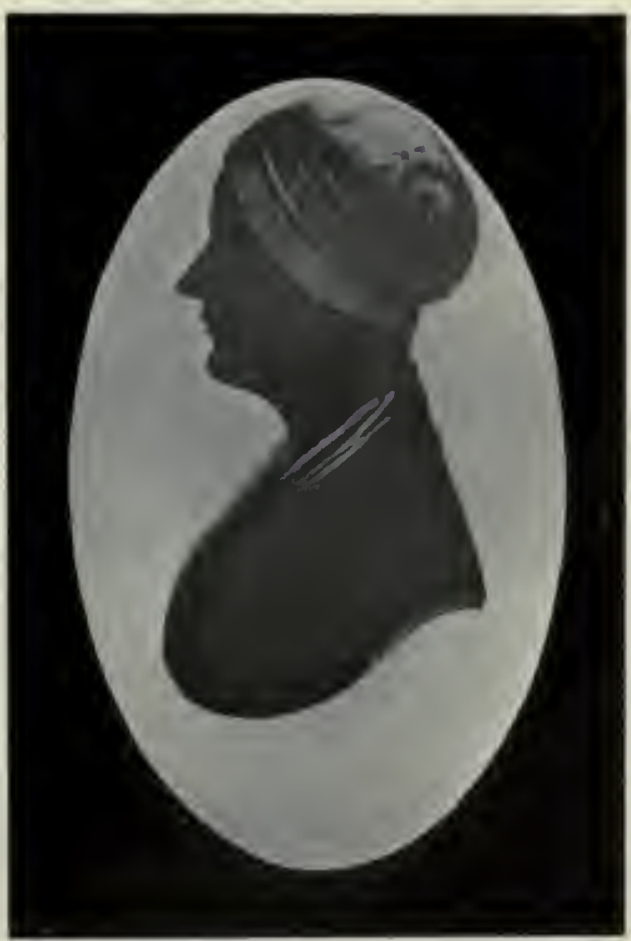

MARY ANNE GALTON (1778-1856).

Mrs Schimmelpenninck, Aunt of Francis Galton. 



\section{Plate $\mathrm{XXNY}$}

$\div 4^{85}$

\section{Mhte}

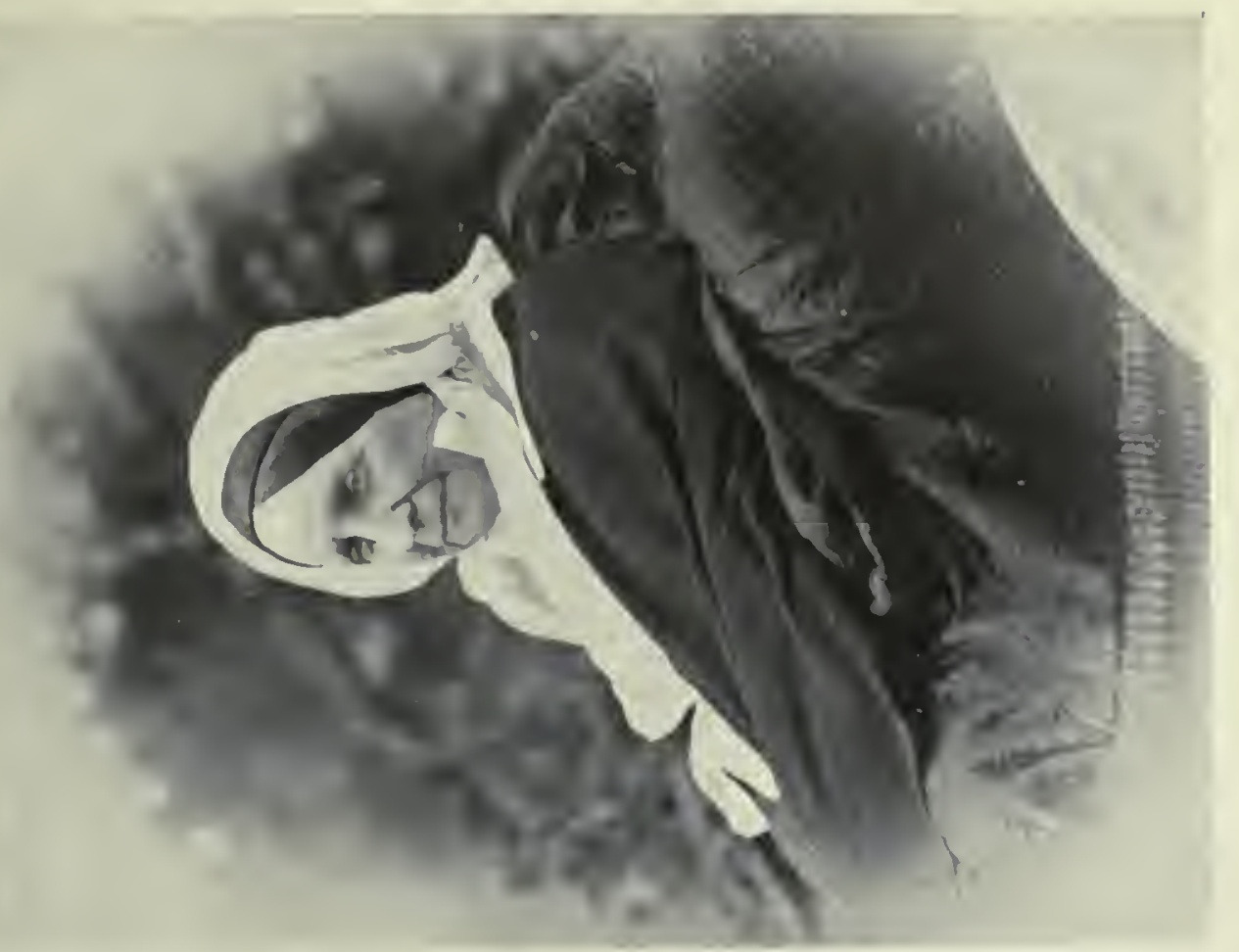

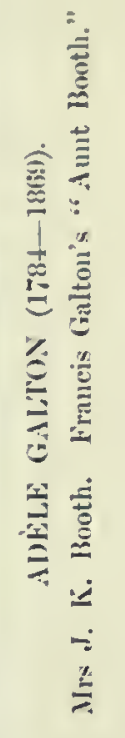

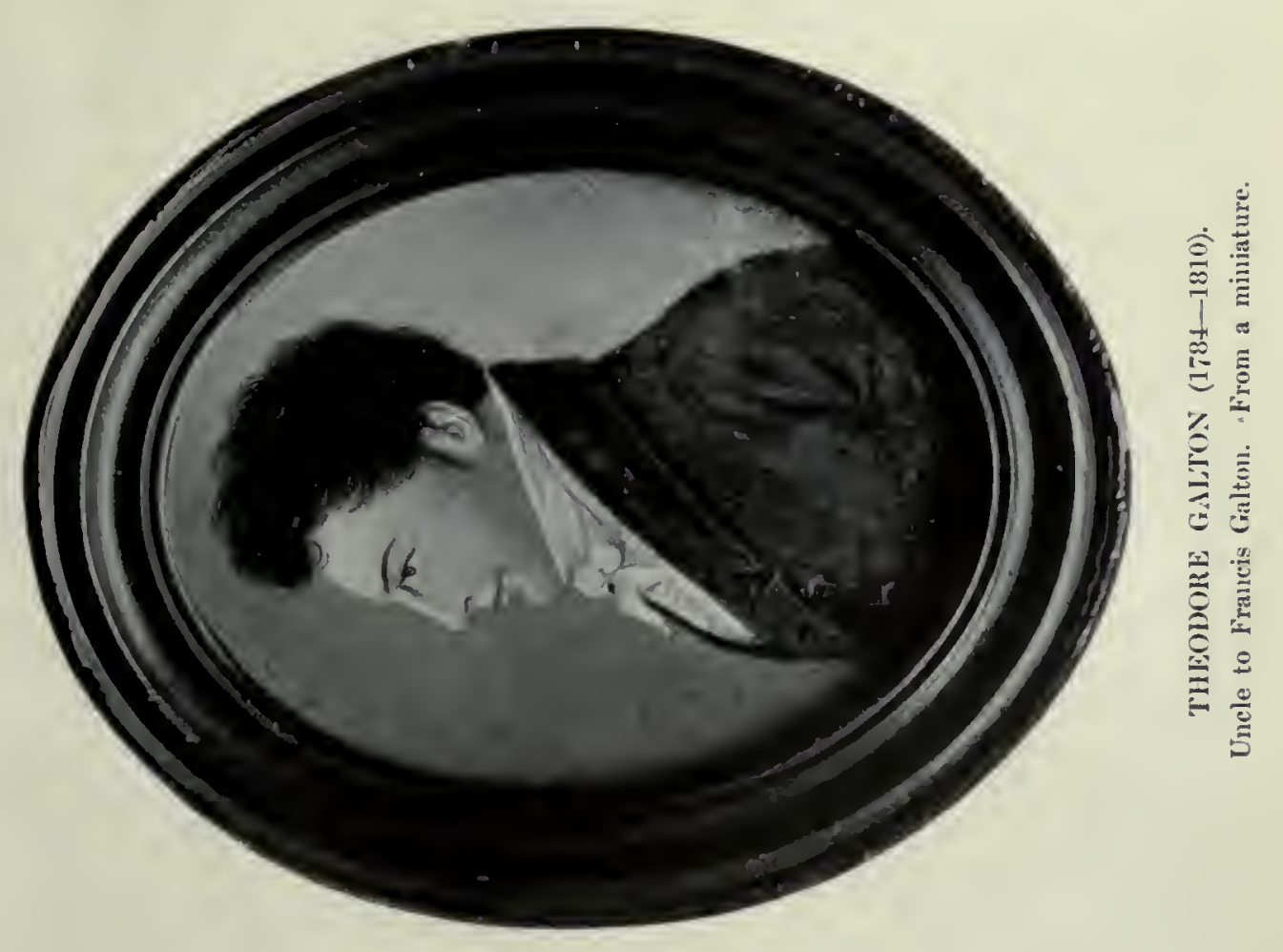



brothers he was in a position to become a country gentleman, and he himself says that, when aged 24 he returned from Syria,

"I was conscious that with all my varied experience I was ignorant of the very $\mathrm{ABC}$ of the life of an English country gentleman, such as most of the friends of my family had been familiar with from childhood. I was totally unused to hunting, and I had no proper experience of shooting. This deficiency was remedied during the next three or four years. Under the advice of my eldest brother, I bought a hunter and a hack, and began to hunt at the rate of about three days per fortnight in Warwickshire and at neighbouring meets" (Memories, p. 110).

But something else mastered this ancestral instinct. Galton was not to revert to the land and after six years the Wanderlust again sent him forth on his travels. If we knew the little difference which divides one man from another, even within the same family, we should have the key to most of life's riddles. Of one thing we can be certain, it is not slight variations of environment; it is the individuality of nature not of nurture.

If we endeavour to sum up the fairly detailed account we have given of Francis Galton's kinships, can we attribute to their different sources some of the chief physical and mental characters we note in him ? The following may be emphasised as marked features of Francis Galton:

Physical. (a) Marked longevity. (b) Very considerable physical strength and power of endurance. (c) A well knit figure somewhat above the average height and not tending to corpulence. (d) Regular features, with nothing unfinished, or at all unkempt about the person, generally what are described as "good looks." (e) Blue eyes and light hair. $(f)$ Ailments, asthma and deafness. $(g)$ Good digestion.

Of these physical qualities the marked longevity seems to have come from Elizabeth Collier; the physical strength from the Camerons and Barclays; the well-knit figure and good looks possibly from Beau Colyear', though Samuel Galton the second possessed them in a marked degree. The blue eyes and fair hair were again probably a Barclay heritage ; the asthma, and also possibly the deafness, a Galton character-both Samuel Tertius and his father Samuel suffered badly from asthma. Thus we realise that in most of his physical characters Francis Galton was not a Darwin; Darwin physical characters have

1 Of Sir Henry Savile it was said that he was "an extraordinary handsome man, no lady having a finer complexion." 
appeared in more than one of the descendants of Samuel Tertius and Violetta, but the most close of the Darwins to Francis Galton was his uncle Sir Francis Darwin, who also has the Collier strain. And in several of the physical features which seem to differentiate Francis Galton from many of his Galton kin, they seem to resemble more than he did the Darwins. If we take portraits of Charles Darwin and of Francis Galton in middle life, we may perhaps detect some resemblances in the rather firm lips, the strong chin, the heavy brow and luxuriant eyebrows, the slightly receding forehead and the apparent absence of marked occipital development (see PlateXXXVII). But taking physique as a whole, Galton.was in popular language, "not a Darwin." It is to the mental characters we must turn for likeness.

Méntal. (a) Even temper. (b) Great sympathy. (c) Ascetic rather than sensuous. (d) Strong mechanical bent. (e) Keen delight in numerical evaluation and symbolic expression, two factors hardly to be put, perhaps, under one heading. $(f)$ Strongly emphasised power of observation and appreciation of observation-what we might alınost speak of as the " clinical instinct." (g) Marked love of adventure, the roving lust. ( $h$ ) By 'no means a student or collector in the usual sense, neither a wide reader of books nor a worker in museums. Galton rather observed and collected to answer a problem he had a priori proposed to himself, than studied material with a view to the discovery of some hidden secret. (i) Continuous concentration in reading or analysis was liable to lead to. "mental fag," and on two occasions in his life led to a breakdown. ( $j)$ An instinct almost amounting to a moral sense that the end of science was not so much knowledge for its own sake, as social utility and increased human efficiency. (k) Much steadfastness of purpose accompanied by a considerable power of controlling others and inspiring them to fulfil his planned ends. (l) A noteworthy sense of humour. $(m)$ A great appreciation of the need for clear expression in science.

We believe that several of these features are markedly Darwin, but others just as certainly come from different strains.

Power of observation, the "clinical instinct" that we have referred to, was essentially Darwin. Probably also much of his sympathetic

${ }^{2}$ Francis Galton himself has said that he had a quick temper only gradually brought under control by excreise. If this be so, the power of control was probably hereditary. 

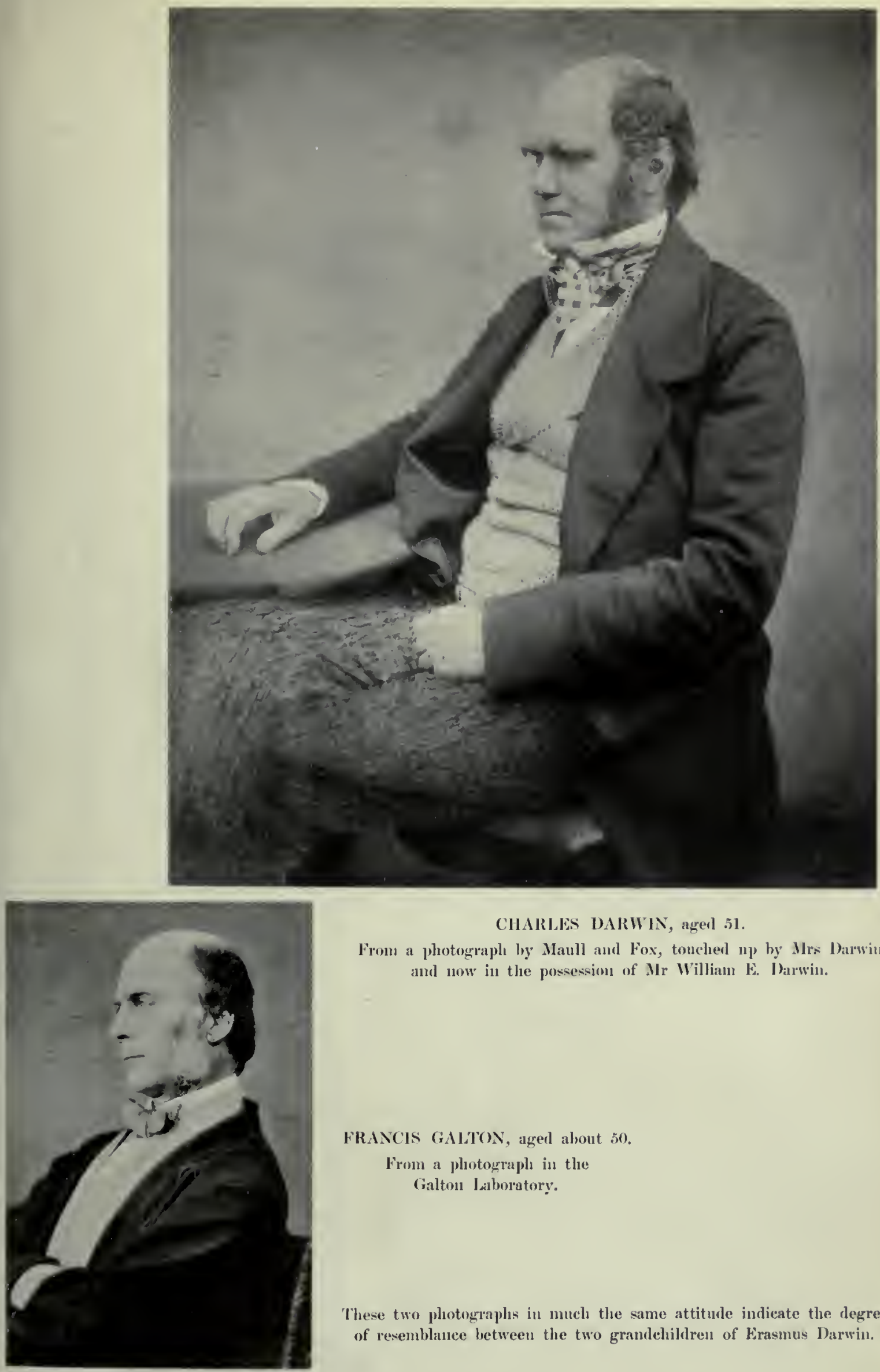

CHARLLS DARWIN, agerl 51.

From a photograph by Maull and Fox, touched np by Mrs Darwiu and now in the possession of Mr Willian ki. I Barwin.

FRANCIS GALION, aged ahout 50.

From a plotograph in the

Galton Isiboratory.

These two photographs in much the same attitude indicate the degree of resemblance between the two grandehildren of Erasmus Darwin. 

nature arose from the sanie source. Although a most distinguisherl mathematician has appeared in the Darwin stock, and it is stated that Erasmus Darwin the younger was statistically minded, there was no trace of it in Erasmus the elder, and it may be safely said that statistics were almost distasteful to Charles Darwin himself. On the other hand Samuel Tertius Galton, as we have already seen, published a statistical tract, and he and quite a number of his family delighted in numerical and statistical representation. There is hardly a doubt that this was in Francis Galton an emphasised Galton heritage, not wholly unassociated with considerable power of fine draughtsmanship, which we also find in other members of the family. During many years of friendship with Francis Galton, his present biographer never saw him handle the pencil nor had any reason to believe he had special aptitude in this matter; and yet examining his earlier notebooks and diaries we find them full of sketches which show that he had equal capacity with his sisters in draughtsmanship. When we read also the accounts of the work of his Galton ancestry in Birmingham, the manner in which they not only built up a great business, but also were continually engaged in public and charitable work, we must again place to their credit the passion Galton exhibited to turn all his work to public service-to regard all science as subservient to human progress. He was not content that the Eugenics Laboratory should produce merely scientific memoirs; he repeatedly urged its members to place their results in a popular form before a wider public. He disliked technical terms, and demanded the expression of results in language that all men can understand. Probably he and the present writer were not quite at one on this point, partly because the latter believed that new technical terms are needful in every progressive branch of science, partly because the writer thought that Biometry and Eugenics must in the first place establish themselves by the production of work especially appealing to the scientific world. Francis Galton pulled his way, and his biographer pulled in the opposite, both, perhaps, with something of Quaker stubbornness, but never with the least personal friction, and in the end came the compromise which marks the publications of the Galton Laboratory and the directions for its guidance in his will. Reference is made to these matters here because it must be fully realised that the social utility of his work was not a secondary but a primary motive in Galton's character. Charles Darwin thought that to add to the sum of knowledge i. (i. 
was perhaps the most respectable object a man can have in life, and this desire to increase knowledge amounts in some of our greatest inen to the equivalent of Spinoza's Amor dei intellectualis; in the case of Francis Galton it was rather an "intellectual love of man" which was the motive force in his work. Charles Darwin collected facts bearing on selection without any theory and on a wholesale scale. $\mathrm{He}$ made his systematic enquiry and then searched for a law ${ }^{1}$. This Baconian method was not Francis Galton's. He had formed his problem, and he devised his experiments or recorded his observations so as to give a definite answer yes or no to his questions. It was rather the economy of a business instinct. The inspiration came first, but he did not put it down as possibly his grandfather Erasmus would have done without array of reasoned and well-marshalled facts. $\mathrm{He}$ made just the limited observations which confirmed or refuted it, and in almost all Galton's work we see observations collected to answer an individual and relatively closely defined issue. We cannot fit diverse types of mind into rigid categories, but roughly we may say that Erasmus Darwin, Charles Darwin, and Francis Galton all possessed in a high degree scientific imagination. Erasmus put down his inspirations without due demonstration or effective self-criticism. Charles Darwin collected his facts before he allowed his imagination to play on them, he followed his inspirations by self-criticism and due demonstration. Francis Galton used his imagination to find his problem, then narrowed it to a small issue, and tested its truth by experiment and observation before publication. To a certain extent the difference in method is that of Bacon and Newton-possibly that of the biological and mathematical temperament. Something of the difference in Charles Darwin and Francis Galton was hereditary, and marked the concentrated business instinct which Galton inherited from Farmers and Freames, Braines and Barclays, as well as his own name-stock. It was that business instinct applied in science. Perhaps also the danger of "mental fag," a heritage which we are inclined to think came from the Farmers-was influential in guiding Galton in the matter. $\mathrm{He}$ was never a great collector or a mighty reader as his cousin Charles Darwin undoubtedly was.

In the roving lust again we see Cameron, Barclay and Colyear ancestry rather than Darwin, and, as already hinted, this influenced ' See Life and Letters, Vol. I, p. 83. 


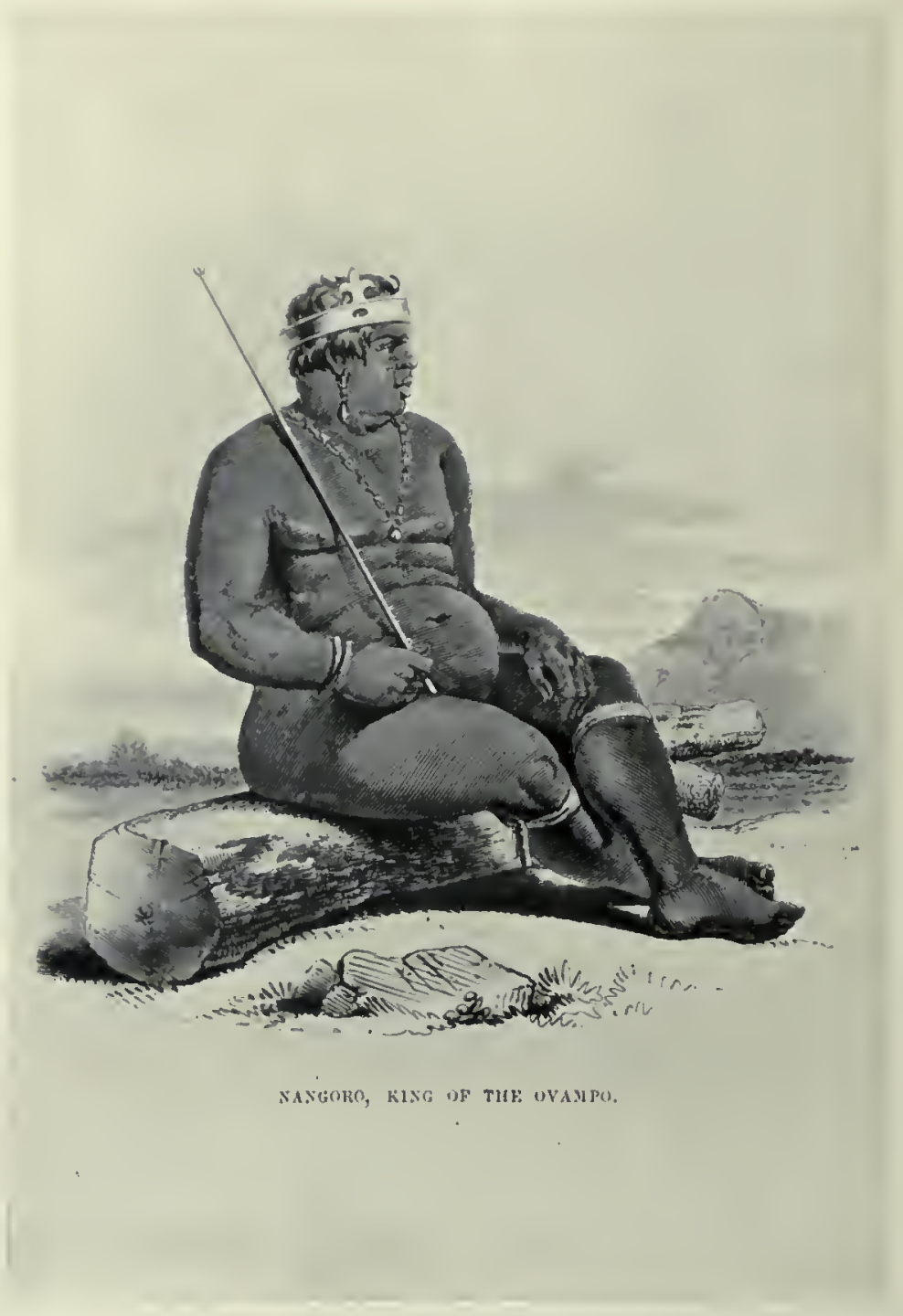

Lugraving from the First Elition of Francis (ialton's Tropicul south Africa. 'Tle king of the (Ovanjo crowner by the explorer. In illustration of Francis (ialton's senke of lumour. 
Galton's attitude in science; he delighted in inroads into unexplored territory, or even into what his neighbours considered as their special preserves.

The incursions of a pioneer mind, unfetterer by the orthodox opinions of a specialised group of workers, however irritating to the established hierarchy, are undoubtedly of the highest service to science, if that mind has exceptional insight and marked novelty of method. Both these Galton possessed in the highest degree.

Steadfastness of purpose-may we not credit something of this to Robert Button and Jaspar Batt with their many years of gaol experience? power of control and of inspiring others may be sought legitimately also in that more distant ancestry of great names to which I have but briefly referred (see Pedigree Plate B).

From Barclay, from Sedley and possibly from Collier came the desire for terse expression, the demand for simple language. But I doubt whether the wit of Sedley was akin to the humour of Francis Galton. Speaking of his father, Samuel 'Tertius, Galton writes:

"He was devoted to Shakespeare, and revelled in Hudibras; he read Tom Jones through every year, and was gifted with abundance of humour ${ }^{3} . "$

'The humour of Samuel Tertius was certainly manifest again in his son?. Many will remember the numerous personal anecdotes told by Francis Galton with keen appreciation of subtle humour, and never with touch of malevolence. But those who were not thus favoured will recall the famous incident of his desire to impress a Hottentot captain, who might prove dangerous, and how, with this end in view, he rode in a red hunting coat on an ox up to the captain's hut, thrusting the ox's nose into the very doorway of his abode. Or again, having sufficiently impressed a negro chief with his visitor's weight and importance, he then led him outside, and to emphasise the negro's own worth he proceeded to decorate his sable majesty with a paper crown of gold tinsel. The picture of the resulting figure published in the first edition of his Tropical South Africa, p. 220, and reproduced here (see Plate

1 Memories, p. 8.

${ }^{2}$ It is of importance to emphasise this because the late D1. John Beddoe declared in a sliort notice of Francis Galton (Man, 1911, p. 34) that "Humour was the only quality we could conceive as lacking in hin; and we know it is apt to be so in the Quakers." Humour is incapalle, perhaps, of definition, and the above statement is of marked interest as indieating how big personal equation can be in its appreciation. 


\section{CHAPTER III}

\section{CHILDHOOD AND BOYHOOD}

Francis Galton was born on February $16,1822^{1}$, at the Larches, near Sparkbrook, Birmingham. We have already noted the features of that house; how it was built by the botanist, Dr Withering, after the mob had practically destroyed the whole of Priestley's residence, one room only surviving. The site is now marked by a tablet to Priestley; it would be fitting to add to it some commemoration of the relation of the site to another Birmingham worthy, who has been as great a leader of scientific thought.

Writing sixty years after the event a birthday letter to her brother Francis, Emma Galton thus recalls the day itself:

"My dearest Frank, We shall think of you tonırrow, and wislı you and Louisa [Mrs Francis Galton] very many happy returns of the day. What a blessing you have been to us, and how proud we all feel of you. How wonderful a thing memory is! It seens but the other day that Mis Ryland had called with her 4 horses, and walked in the garden by my mother's garden chair. A ${ }^{t}$ Booth [Adèle Galton, Mrs Booth, Franeis Galton's aunt] dined at our house, and in the evening you were borm about 9 o'elock. And the importance Darwin, Erasmus and nyself thought of the Dudson carriage and pompous coachman coming carly on the following morning (Sunday) to take us to spend the day at Dudson [Grandfather Samuel Galton's house]. And we worried the servants by every now and then standing on a ehair to make us high enough to reach the call-tube in the Library to inform them: 'Mama had a Baby, and it was a Boy!' But we then little realised what a comfort you would be to every one of us. We should have vegetated and had green mould much thieker upon us had it not been for you." [Letter from 5 Bertie Terrace, Leamington, Feb. 15, 1882²].

${ }^{1}$ He was baptised on Mareh 20 following at the Church of St Martin, Birmingham. As we lave already noted his father Tertius Galton had left the Soeiety of Friends and reeeired adult baptism in 1816 at Radbourne.

2 Another aceount is given by sister Adcle herself 42 years after the event: "How well do I remember Aunt Booth dining with us on that day and she and my mother coming up in the white room to sit with me that evening; my mother being taken ill nt 8 o'clock; $M_{1}$. Hodgson being sent for and his coming to awake me in the iniddle of the night to tell me that a 'fine boy' was born. How well can 1 remember seeing you 
Plate XI

Francis Galore.

Ton of Sam - Vertices, Vislecta Gallon k Grandee of Erasmus Darwin. A. D. FR.S. author of Loonomian, Phytotogia, Butane Garden te te kc te war form the 16 February 1822 - Ac war the gong child of the family, having four Series a two Brothers older that hams ely - k the gounquit of then being six gears older than ne waw, it is not surfing that from hit bitt, he should have excited great interest, attention, se affection in the family - His the rd tester (Addle bon $21^{\prime} \mathrm{fuly} 1810$ - being an Imatid from her chunder occasioned by great

Simple page of Violettit Galton's Life IIistory of lirancis Galton, written by his mother on her son's departure for school at Boulogne, 1830. 
Francis was the last child in a family of nine, of which two sisters, Agnes and Violetta, died as infants. The youngest of his four surviving sisters was eleven years older than Francis, and his brothers, Darwin and Erasmus, were respectively eight and six years his seniors, and thus too different in age to be very companionable. Fancis had therefore all the temporary disadvantages which arise from being the late and somewhat solitary member of a large family. But these disadvantages often result in permanent advantages, if a child be of marked character. It is thrown on the one hand more on its own resources for amusement, and on the other hand may receive special attention from parents and elders.

"On the 16th February,"-writes Mrs Wheler [Elizabeth Anne Galton] in her Reminiscences, - "my youngest brother Francis was born, lie was 6 years younger than the youngest of us and never was a baby more welcomed. He was the pet of us all, and my mother was obliged to hang up her watch, that each sistcr might nurse the child for a quarter of an hour and then give him up to the next. He was a great amusement to Adéle and as soon as he could sit up, at five or six months old, he always preferred sitting on her couch to be amused by her. She taught lim his letters in play and lic could point to them all beforc he could speak. Adèle had a wonderful power of tcaching and gaining attention without fatiguing. She taught herself Latin and Greek, that she might teach him. She never made him learn by heart, but made him read his lcsson bit by bit, eight times over, when he then could say it. He could repeat much of Scott's Marmion, and understood it well by the time he was five." [MS. Reminiscences.]

For early training and companionship - her room was his nursery - Francis depended largely on this invalid sister Adèle, afterwards Mrs Bunbury. From the couch to which she was confined by weakness of the spine, she directed his early studies, and, whatever might be thought of her methods now, she undoubtedly encouraged both Francis' literary and scientific tastes.

In a little history (see Plates XXXIX and XL) of her son Francis, Violetta Galton gives numerous instances of his literary aptness. Thus at the dame's school to which he went when five years old one of his schoolfellows was writing to his mother at Madeira, as he had just heard that his father was in danger of being shot on account of Don Miguel's usurpation. "What shall I say to my mother about my

next morning, such a red little thing-and how wc all loved you, and then how wc used to quarrel for the honour of holding you in our arms, ctc. But to return to scculars..." (Lctter of Adèle Bunbury, Feb. 23, 1864.) Mr Horlgson was sixtcen years later the helpful friend who assisted Francis Galton at the start of lis medical studies. 
father," he asked Francis; "I have said I am very sorry." Francis immediately replied from Walter Scott, "I think this would do:

'And if I live to be a man

My Father's reath revenged shall be.'"

"Thank you," saicl the little boy, and added it to his letter.

And again, in the first year of his going to school at age five, the maid who went to fetch him home found at group of boys teasing him. Francis kept them all at bay with his arm straight out:

"Come one, come all, this rock shall fly,

From its firm base, as soon as I."

Another day about this same time his mother took him into a field where the servants were trying to catch some geese. Francis immediately ran amongst them and seizing the old gander by the neck brought him to his mother, muttering to himself the lines of Chevy Chase:

"Thou art the most couragcous knight

That ever I did sec."

On another occasion Francis fell off his pony into a very muddy ditch, and, as he was dragged out by his legs, he sputtered out halfchoked with mud to his brother Darwin the lines of Hudibras:

\section{"I am not now in Fortune's power}

He that is down can fall no lower."

As his mother depicts him for us in the first half-dozen years of his life Francis was a boy of mettle, full of strangely assorted knowledge, but naturally rather shy. A pretty story is told in Mrs Wheler's Reminiscences, which brings together two noteworthy English characters. Mrs Fry (see Plate XLVII) was a second cousin of Hudson Gurney, whose wife, Margaret Barclay, was a great-aunt of Francis Galton. Hudson Gurney was himself son of Agatha Barclay, first cousin of Lucy Barclay, Francis Galton's grandmother'. Aunt Gurney's house in St James's Square was the centre from which the young Galtons became acquainted with London life, and here they met Mrs Fry - "a very striking person, tall and dignified and yet so kind and motherly, one felt one could open one's heart at once to her." In 1824 Mrs Fry came to Birmingham and went to stay with

1 Mrs Fry was also a granddaughter of Catherine Barclay, who was sister to the first Iucy Barclay and to David Barclay of Youngsbury (sce Peligrec Plate C). Thus she was second cousin to Tertius Galton. 
Grandfather Samuel Galton at Duddeston, where a large party was asked to meet her.

"She told my mother," writes Mis Wheler, "that she would like to see Franeis, then a year and a half old, as her youngest child was about the same age. My mother said she would feteh him, but he was so shy, she fearcd, he would not makc friends with her. Mrs Fry said, 'Oh, never anind, I think he will,' My mother brought him into the room, where seeing so many people he hid his faee on his mother's sloulder and would not look up. She sat down by Mrs Fry, who took no notice of him; soon after she took a little box full of comfits out of her pocket, and held it ont towards the child but looking the other way, and talking to the company. My mother whispered 'Look, Francis,' and the child sceing no one obscrved him, sat on my mother's knee looking at the comfits. By and bye, he slid down, seized a comfit and ran back; Mrs Fry took no notice, and he soon stood by lier helping himself. She then gently lifted him upon her knee, taking no notice, when he soon began talking to her hinself."

His sister Adc̀le's education, besides providing him with modern English poetry, taught him to appreciate the Iliad and Odyssey. Leonard Horner, paying a visit to Tertius Galton in 1828, would frequently question the little Francis about points in Homer. At last Francis grew weary of the cross-examination, and one day when the usual questioning began, replied: "Pray, Mr Horner, look at the last line in the twelfth Book of the Odyssey"," and ran off.

So excited did he grow over the Iliad, that as a partizan of the Greeks he was known to burst into tears, when he came to the part where Diomed is wounded by Paris.

Probably apart froin poetry his sister Adèle - a child berselfrather forced the pace. He knew his capital letters by 12 , and both his alphabets by 18 , months of age. He could read a little book Cobuebs to catch Flies when $2 \frac{1}{2}$ years old, and could sign his name before 3 years. I have before me his actual signature on January 10, 1825, as witnessed by his sisters Adèle and Emma. From his fourth year a laconic letter ${ }^{2}$ has survived:

1 "But why rehearse all this tale? For even yesterday I told it to thee and to thy noble wife in thy house: and it liketh me not twice to tell a plain-told tale." Butcher and Lang's version, p. 206.

2 A similar letter to his father, dated Sept. 26, 1826, thanks him for the gift of a toy. There is also a quaint little paper book containing two paper pages stitched in blue paper; the first, second and part of the third side arc occupicd by two seripture texts written by Francis when four years old, but the remainder of the third and fourth side are filled in the same round hand with the remark: "Papa why do you call my books dirty that coine $\mathrm{f}$ rom the Ware-house? I think they are very clean."

P. G. 


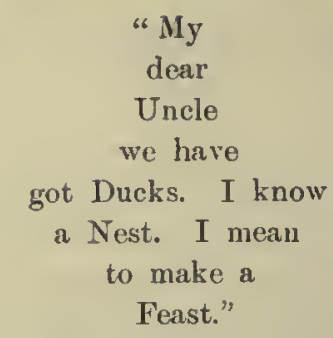

It is written between pencil lines in a round liand, and there is an endorsement by his mother Violetta, saying that Francis wrote and spclt it entirely himself.

The day before his fifth birthday he wrote a letter to his sister Adèle. The handwriting is now much more formed and the ruled lines have disappeared. He writes:

My dear Adetee,

I am four years old and I ean read any English book. I can say all the Latin Substantives and Adjectives and active verbs besides 52 lines of Latin poetry. I can cast up any sum in addition and can multiply by

$$
2,3,4,5,6,7,8,[9], 10,[11] \text {. }
$$

I can also say the pence table. I read French a little and I know the Clock.

\section{Francis Galton.}

Feb ${ }_{\wedge}^{\mathrm{r} u a r y}-15-1827$.

The only misspelling is in the date, which is corrected as indicated. The number 9 has been carefully erased with a penknife and the number 11 has a small square of paper pasted over it! Little Francis was evidently conscious that he had claimed too much, but as experience shored that penknife erasure tore the thin paper, the pastepot was used to obliterate the second unjustly claimed multiplier !

In a letter written by a visitor to the Larches on December 28 , 1828, we read:

"We are both delighted with the girls particularly the two eldest-they are so pleasing and unaffected, and so very amiable. The youngest child Francis is a prodigy. He is 7 next February, and reads and enjoys Marmion, The Lady of the Lake, Cowper's, Pope's and Shakespeare's works for pleasure, and by reacling a page twice over, repeats it by heart. He writes a beautiful hand, is in long division, has been twice througl the Latin grammar, all taught by Adéle. Bessy and Lucy are very modest girls with a constant habit of being employed."

It is pleasant to catch this impression of an onlooker as to Francis Galton and his relatives written 85 years ago!

When he was in his fifth year his sister Adele thought it 
desirable, as he had no children to play with at home, that he should go to school. He was accordingly placed under the care of a Mrs French who kept a school for 25 little boys about a mile from the Larches'. Here Francis distinguished himself from the beginning by being headboy, although there were many several years older than himself. $\mathrm{He}$ remained at this school for three years, until he was eight years of age, and in the last half-year had daily private instruction from the Rev. Mr Clay, master at the Birmingham Free School. The good dame at the head of his school reported very highly of little Francis, and once added, "the young Gentleman is always found studying the abstruse sciences." This was probably a protest on his part against the over emphasis of Latin in small boys' education - a matter on which Galton wrote very strongly later (see p. 88). When he left this dame's school at $8 \frac{1}{2}$ years of age, he had read and learnt the following books : Eton Latin Grammar, Delectus, Eutropius, Phaedrus' Fables, Ovid's Metamorphoses as far as the Medusa incident, and threequarters of Ovid's Epistles.

His mother, writing indeed of her Benjamin, in 1830, when he was leaving Mrs French's school, says:

"Francis from his carliest age shewed highly honorable feelings. His temper, although hasty, bore no resentment and his little irritatious were soon calmed ${ }^{2}$. His open candid disposition with great good nature and kindness to those boys younger than himself, made him beloved by all his schoolfellows. He was very affectionate and even sentimental in his manners. His activity of body could only be equalled by the activity of his mind. He was a boy never known to be idle. His habit was always to be doing something. He slowed no vanity at his superiority over other boys, but pitied them, and said it was a shane their education should have been so neglected"."

1 The school was at Balsall Heath House, and four communications to Tertius Galton from his son have survived - a rough drawing of a suspension bridge with a ship passing under it, a more tidy drawing of a wooden shed or house, and a neat little painting of dccorative swect peas, and lastly a dated letter, June 1st, 1830, stating that the holidays would conmenee on the 19th, that he thought he had much improved in his Latin and Greek with Mr Clay : "I shall soon be in Greek Delectus and Sense verses, for you know that I have nearly done with Nonscnse verses."

"His mother once said to him at a somewhat later age: "Francis, how can you keep your temper as you do?" "I don't," he answered, "but I've found out a capital plan. I go to nyy room as soon as I can get away, and I beat and kick my pillow till I'm tired out, and by the time I've finished, my temper's all gone." He continued metaphorically "to beat his pillow" under" great provocations in later life.

${ }^{3}$ This is aptly illustrated by his grent concern on going to Mrs French's because he thought that his mother would not let him remain at that school-the boys were so commonplace they had never heard of the lliad or Marmion! 
Such testimony from a mother might mean little had it been written when her son had reached distinction. But Violetta Galton appears to have written only thus of one son, and of him only before he was nine years of age. Did she see in her youngest son something of her father, or did her acquaintance with many men of marked intellectual ability enable her early to appreciate nascent signs of remarkable power?

It must not be thought that Adèle's scheme of education had not a modern side. Seeing how fond Francis was of natural history, she taught him a good deal of entomology, a study he became particularly fond of; and soon the boy's perseverance and activity in collecting insects were noteworthy ${ }^{1}$. He was also fond of studying the history of birds. Geology he was deeply interested in, and when he went with his mother on his second visit to Ramsgate in 1829, "he would entreat her to let the post-boy stop whenever he saw granite, or chalk or any mineral showing itself in the hills."

Some idea of Francis' pursuits and interests can be found in a will he made, boy fashion, some few months before his departure to a school at Boulogne. It runs :

I, Franeis Galton of the Larches near Birmingham make this my last Will and Testament-I give to ny dearest sister Adèle for her great kindness in teaching me all my English Books, my Watch, and all my Compound Money and Collection of Beetles-

${ }^{1}$ It is interesting to find in this very year when Adèle was teaching Francis entomology a notice in the records before me of Charles Darwin. MIrs Wheler writes: "In Septembcr (1828) Lucy and I were invited to Osmaston for the Derby Music Meeting, but when the time came Lucy had one of her rheumatic attacks, and Emma went in her place. Catherine Darwin came to us from Shrewsbury and we travelled together. Charles Darwin joined us at Osmaston, and we were a merry party of cousins... William Fox was making a collection of butterflies, and Charles Darwin immediately began to do the same, and this was the beginning of his interest in collecting. He and William Fox struck up a friendship which continued all their lives." MS. Reminiscences, p. 113. Mrs Fox was tlue daughter of William Alvey Darwin, a brother of Lrasmus Darwin. Clarles Darwin was at this time 19 years of age, and in his Autobiography he tells us that his passion for collecting had bcen developed before 1817 (Life and Letters, 1, p. 27). At that time Darwin was leaving Edinburgl and just going up to Cambridge, and he was already familiar with many men studying natural science. On the other hand Mrs Wheler's ineident confirms what Darwin himsclf tells us (l.c. p. 51) : "I was introduced to entomology by my second cousin W. Darwin Fox, a clever and most pleasant man, who was then at Christ's College and with whom I became extremely familiar." 


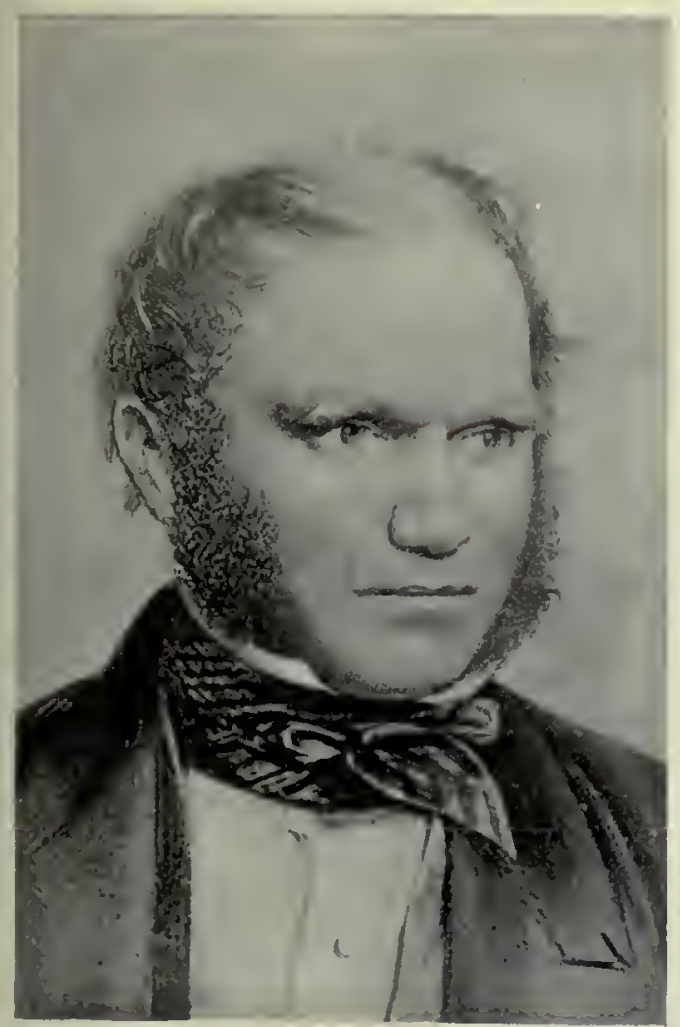

CIARLAS DARWIN (1809-1882).

In enly manhood. From a print in Mrs Wheler's IS. "The Galton Family."

(IIARLES IOARWIN (1809-1882).

In later life. l'rom a photograph by his son Major Lenum l)arwiu.

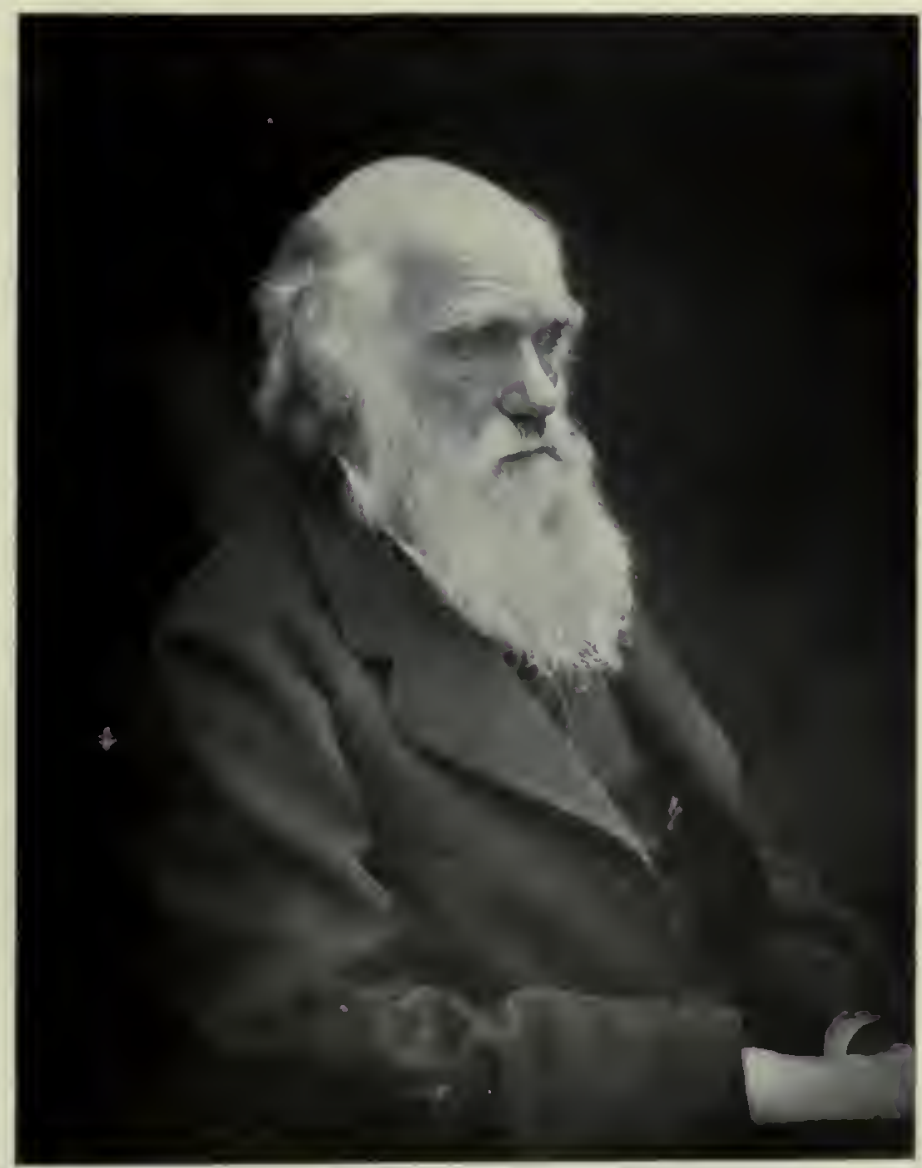



$6^{8^{b}}$

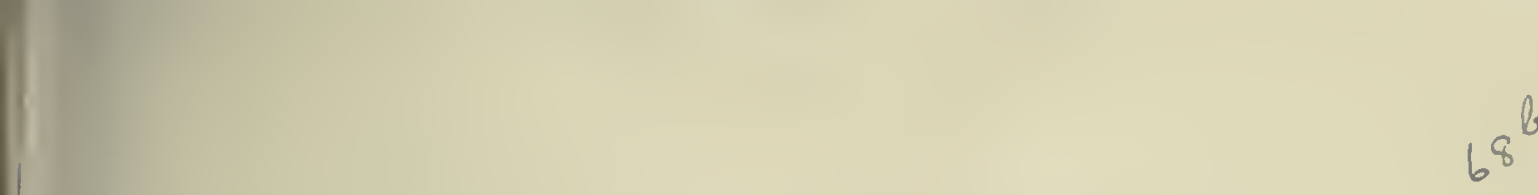

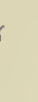




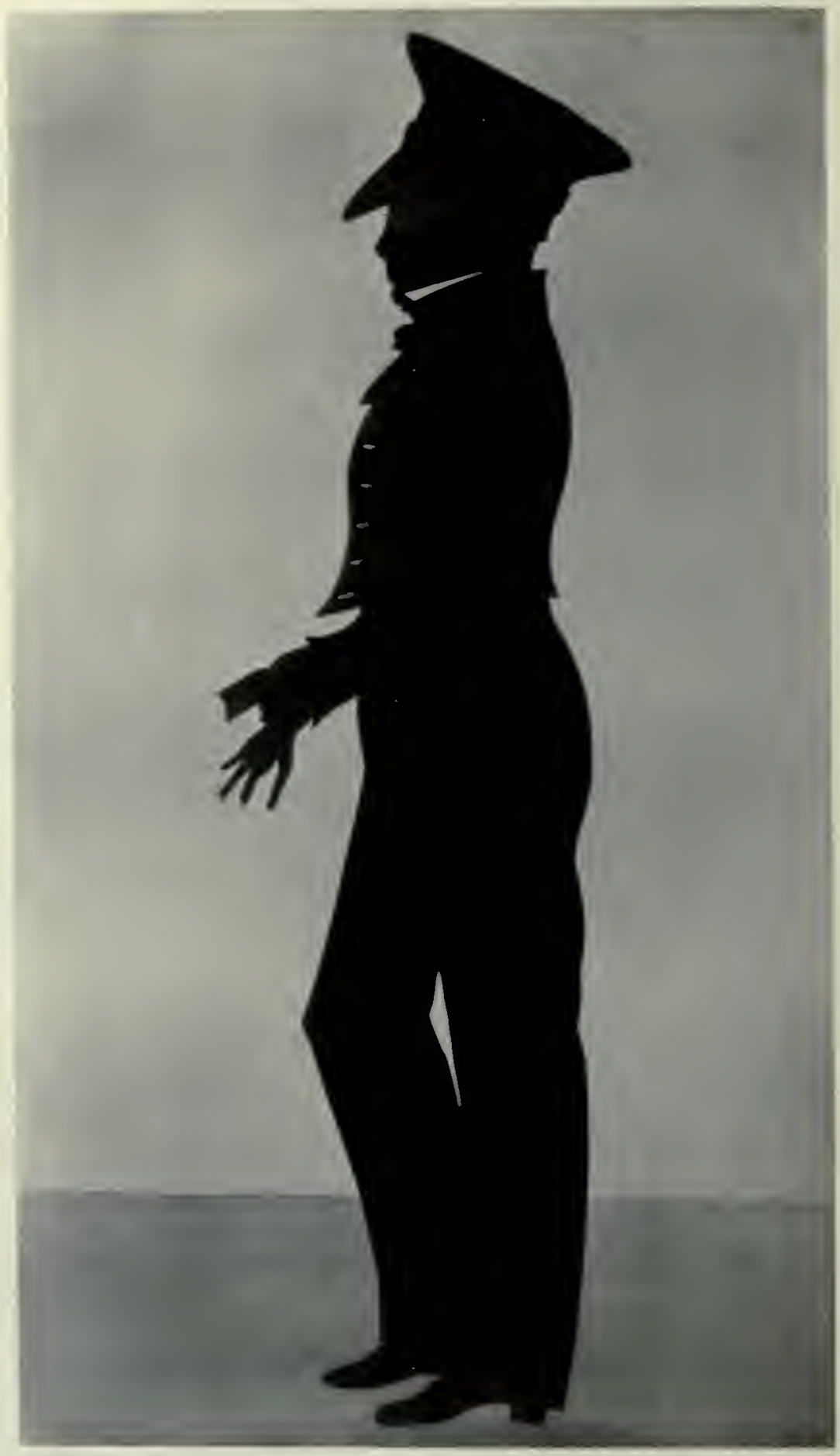

ERASUUS GALTON (1815-1909).

In his uniform as a "midly," aged 13. Lilder lorother of lirancis ( Memoriex, 1. 16. Silhouette in the possession of $\mathrm{Ml} \mathrm{r}$ Wheler Galton at Claverdon. 
To Bessy, my Minerals and Shells-To Lucy my Hygrometer and Desk-To Emmn my Medals - To Darwin all my parehment and my share in Aab and Poss [? ponies]-To Erasınus my Bow, Arrows and Steel Pens-'To Edward Levett Darwin ${ }^{1}$ [his cousin, son of Sir Franeis Darwin] my Skates and latin and greek Books-I make ny dearest sister Adèle my Executrix.

Signed, sealerl and delivererl by the within named $\left.\begin{array}{l}\text { Francis Galton on the } 14 \text { th day of February } \\ \text { One thousand eight hundred and thirty }\end{array}\right\}$ Frascis Galtos.

Witness S. Tertius Galton Violetta Galton.

Francis Galton himself feared that the educational efforts of his sister Adèle might have had a disastrous influence:

"In middle life," he writes in his Memories, p. 14, "I feared that I had been an intolerable prig, and cross-questioned many old family friends about it, but wus invariably assured that I was not at all a prig but seemed to 'spont' for pure enjoyment and without any affectation; that I often quoted very aptly on the spur of the moment, and that I was a niee little clild."

As a rule the presence of elder brothers and sisters, ready to do a little hustling and teasing when occasion requires, suftices in most cases to check any priggishness in the youngest member of a family. But there is another point from which the matter may be judged. Galton suffered in later years from occasional mental weariness, the effect of over-strain, and there is just a sad note in an answer his mother has preserved for us, given to his fither who had been examining him in arithmetic when he was five years of age. Asked if he was not tired, he replied : "I am not tired of the thing, but of myself." It is possible that with an ambitious, mentally active boy", such as Galton unduubtedly was-a boy who was easily ahead of his compeers in his first two schools-a little holding back would have been the more judicions course. There is a plaintive note too, with perhaps a deeper meaning

1 Edwurd Darwin went to sehool with Franeis at Mrs Frenel's.

2 When four years old Fruneis was observed to be very careful of every penny that he receiverl, and upon being questioned what ho was saving for replied: "Why, to buy honours at the University." Ho mee also told his father on heing asked what he would like most: "Why, University honours to be sure." The influence at work is not elear, the Galtons themselves dicl not spring from acalemically minded stoek, and the University careers of his uneles Charles and Rohert Waring Darwin wero of the distant past. His cousin Charles land not yet gone to Cambridge. 
in the phrase he used to mutter, at four years old, when his sister called him to lessons:

"Oh stay thee, my Adela stay,

She beckons and I must pursue."

Still there is another side to the picture, and we note that at three years and a quarter the small Francis was able to trot, canter, and gallop upon a large Galloway. The Galtons certainly encouraged outdoor sports and exercises.

In 1830 a great change came over Francis' life. Although only eight and a half years old his father determined to send him to a large boarding school at Bulogne kept by a Mr Bury. It is difficult to appreciate now-a-days the motives which induced parents - in an age when the child death-rate was appalling even in the upper middle classes-to place quite young children in distant boarding schools. Francis Galton himself (Memories, p. 16) suggests that he was sent to Mr Bury's to acquire a good French accent. "What I did learn was the detestable and limited patois that my eighty schoolfellows were compelled to speak under the penalty of a fine," and the final judgment he gives on this school with its apparently poor feeding, frequent birchings and bad supervision runs as follows: "The school was hateful to me in many ways, and loveable in none, so I was heartily glad to be taken away from it in 1832."

Violetta Galton in her little record endeavours to assure herself of the happiness of Francis. He had left home on September 3, 1830 with his father; they had slept in London that night, and they had visited St Paul's and its dome next day. At 11 o'clock they em. barked on the "Lord Melville" steamer for Calais, where they arrived late at night. The next day they went by "The Telegraph" to Boulogne, and in the evening, after seeing the sights, his father left him at the school in the old Convent, close to what is now the Cathedral. Tertius Galton waited a week in Boulogne

"to assure himself of the dear child's perfect happiness. He did not shed a tear, or scem at all uncomfortable at parting with his father, but to the last repeated how happy and comfortable he was, and how kind Mrs Neive, the housekeeper, and everybody was to him."

So Violetta Galton tried to console herself, but she sat down and wrote the little record of her son which las been preserved to this day, and she placed at the front the silhouette, which I have reproduced- 
the earliest portrait of Francis Galton. Before her also she doubtless had two of the three little packets which lie on my table as I write this: the first is entitled, "Baby's Hair," a fine golden shade, the second "Baby's Hair, Fras. Galton" was preserved by his sister Emma Sophia, and is of a paler shade and probably earlier, and the last "Francis' Hair, $18: 9$ (?)," a bright light brown, must represent him much as he was in Boulogne.

At the school he was placed in a high class, although the boys' ages ranged to fifteen. A collection of eight letters written from Boulogne were copied into a notebook by his sister Adèle, and the originals of five of them have also been preserved. These letters are boyish letters, referring to the animals at home, his garden patch, the doings of his sisters and brothers, and of his grandfather at Duddeston. The letters are probably not quite cliaracteristic, for I shrewdly suspect they were supervised by the master, who occasionally adds a footnote of his own, and in one case cross-writes a good deal of the note. Most of the letters begin with a statement that Francis is very happy at the school, but in later life Galton always spoke of his unhappiness there, and the reiterated statements of happiness and the kindness of the other boys do not seem spontaneous. Here are samples of these boyish letters:

My deAr Adéle,

$$
\begin{aligned}
& \text { Boulogne sur Mer, } \\
& \text { Saturday, 30th Oct., } 1830 .
\end{aligned}
$$

I am very happy at School. The Boys are all pretty kind to me. I am growing very tall, and in better proportion, for I am just able to clasp my wist. I am invited out every Sunday which I like very much. I was put in the third class a littlc while ago, because I was not able to keep up with them in lessons. I au l'eading a French book called Robinson, for I have just got out of the Granmar. I do Florilegium which I think is very hald in some places for they are taken out of the end of the Delectus, but some are very eusy. I have not begun to learn cither fencing or dancingbut I think I soon shall begin. Tell Emma to take grent care of my garden, and to see that nonc of the sisters take any of iny Hollyocks up, else I shall be in a most terriblc ragre when I come home. I like Cowper's Poems very much for there is at the end a very entertaining account of some Hares. I lope that the Pigs, Dogs, Horses and Cows are quite well. Pleuse don't feed Ringwood so much if you think it will make him a bad Dog. Give my best love to Papa aud Mama, Sisters, and to Grandpapa and Aunt Sophia,

\section{And belicve me always,}

Your most affectionate Brother,

Fraxcis Galton. 
A month later Francis writes:

\author{
Boulogie sur Mer, \\ Nov. 30, 1830.
}

MY DEAR MAMMa,

Thank you for your nice letters, but in your last letter you have no need to praise me for mine, for I had put nothing in it hardly, for I had but a quarter of an lour to write it in. When I said I was put in Robinson, I meant Robinson Crusoe, which I like pretty well. I hope you will come over soon here for I should like to see you, and to go out with you, for I miss dear Papa's greengages, which he userl to give. me when he was hcre..... Tell Papa to bring at least two bottles of caustic, for what. you will hardly believe when I tell you that I have one hundred and forty-two little warts. Unfortunately I have had a cold which kept me from going out yesterday, and even I am now in the sick-room whilst I am writing this letter. I have been ill once before, last Saturday I could hardly speak, and yesterday which was a going out Sunday, I was kept in bed all day. I am getting on with my Latin pretty well, but now I must end iny letter for its getting very dark. Good bye and believe me always

Your most affectionate son,

Francis Galton.

In the next letter; we learn that little Frank, as he was called at home, had spent his Christmas vacation as he did the following Easter holidays at Boulogne. Nor had there been a parental visit. After the usual phrases about liking the school and the kindness of the boys, and spending the holidays very happily, Frank continues:

"Please to tell Emma and Bessy to take the greatest care of my carnations, and other flowers, for when I come home, I shall expect to see about twenty roots-and pleasc take up all the weeds that you can...... All my warts are gone off-except one that is remaining. Thank you for saying that you would keep a bit of caustic. My flannel drawers and waistcoats are very comfortable. I am very glad that you hare left off being a Banker', for you will have more time to yourself and better health. I must now leave off; so good bye, and believe me

Always your affectionate Son, Francis Galton."

'The next letter preserved follows the Easter holidays, and Francis thanks his father for buying five shillings' worth of flower seeds for his garden. He notes also that it now will not be more than three months to the Midsummer holidays - when the precious garden and all the domestic pets from dogs to Alderney cows would again be actualities.

1 The Galton Bank was closed on May 31, 1831, and Tertius Galton removed at the cnd of this year from Birminghan to Leamington. 
Frank returned home on June 30 , and had only a clear day at home. On July 2 he went to the Colonnade House, Worthing, for the holidays. On August 31, Tertius Galton took his son up to London to join $\mathrm{Mr}$ Bury for Boulogne.

In a letter three weeks later (Sept. 20, 1831) Francis announces his safe return to his mother. After the usual phrases as to the happy character of the school, Francis continues:

"I arrived here very safely. It was very ealm indeed I think, but all the other people thought quite the contrary. There was a very fine Newfoundland Dog, but ho was very tame indeed. Almost all the women were scasick. I lost my Berth, but even if I had not, I would not have slept in it. When I was asleep we past the Heetor (the ship in which Captain Parry sailed to the northern regions), but when I awoke I found myself just opposite Gravesend. There were many Brigs and Frigates. One of them fired two guns, which I suppose was a salute. I did not see Shecrness, nor any threedecker's anywhere up the Thames. We past the Wellesley and the other ships at the Downs......"

The boy of nine was developing into a good traveller. The last letter but one of the Boulogne series may be given in full:

\section{1 th November, Boulogne,}

1831.

\section{MY dEAR MaMa,}

Please will you send the desk' whieh you gave me, by somebody that comes over here, or in anyway that you can, furnished well with wafers, sealing-wax, a gimblet (fol mine is broken), a turn-screw, good paper like that which you write on to Erasmus and a little packet containing about twenty nails, and the same number of screws, with a file. All the wire is come off that chain which Adèle bought me, so I am obliged to tie my keys to the buttonhole of nyy jacket by a piece of string. I have got the key of my playbox, which I quite forgot to tell you in my last letter. My Greek Lexicons have not become of great use to me, but I think they will soon, but I am always wanting my Classical Dictionary when I do my Virgil. I am quite well and I hope that you are also. I get better notes a great deal than I did last half-year, and am much happier. One of the Masters saw nıy candle in my desk which I brought last half, and he slyly took it away and put it on his desk, intending as I thought to keep it, but as soon as he was gone to the other end of the room, I sneuked it up and took it away and put it in my cap,_but alas! he found it out, and I do not think I shall get it agrain; so please add a Taper to the various articles and a pretty seal. Desks are so much in fashion this half, that there is hardly any big Boy that has not one. Send a quantity of pounded gum arabic, as I cannot manage to get it here. Scnd in any desk

1 In the following letter he writes: "I an so desirous of liaving my desk, tlat I am making a very nice plaee to put it in, where no Boy can get, and I am always thinking of it."

P. $\mathbf{G}$. 
witl the other articles a great quantity of impressions of different seals, for a great many Boys arc always asking me to give them the seals of my lettcrs (as I have the most) for gum seals, which indeed are very pretty. I quite long to see my gallant desk arrive. Edward Fisher is not come to school. Schonswar is very kind to me, and he always gives me wafers when I want them, but now in the Even" we are not allowed to stir from our places, and in the norning he is doing French.

So good bye, and believe me,

Your affectionate Son, Francis Galton.

The last letter undated is written two weeks before the Christmas holidays, again to be spent away from home. Clearly Frank had heard of the coming change to Leamington. "I wish very much indeed "- he writes to his father-.." just to go to Birmingham again and to see the Larches and Dudson-and other parts of Birmingham again." In the following year, when Frank came home for his holidays in June, he left Boulogne for good. But besides the change of home to Leamington, other marked changes occurred for the Galtons in 1832. Towards the end of January Grandmother Darwin-Elizabeth Collier -became ill and died on the fifth of February. She had always been a marked feature of the Galton circle. The visits to Breadsall Priory (see Plates XLIII and XLIV) were frequent, and Grandmother Darwin's visits to Birmingham were much appreciated; thus her death was a source of great sorrow to her grandchildren. She had had 12 children, 41 grandchildren and 28 great-grandchildren and at her death 60 descendants survived her. On the 10th of June of the same year Grandfather Galton also died; he was buried in the Quaker ground at . Bull Street. Thus the visits to Duddeston, made by the grandchildren hitherto two or three times a week, came to an end, and the influential Quaker element ${ }^{2}$ disappeared from their lives. With the death of his father Samuel, Tertius Galton-already a fairly wealthy man-became more so, and the future independence of the members of his family was assured. It was largely the wealth acquired by his grandfather Samuel Galton the second, that freed Francis Galton from any necessity

1 Francis with his father, mother and sisters had had a very happy visit there in 1827. One evening they got up a country dance, their grandmother Elizabeth Collierthen in her 80th year-joined in and heartily enjoyed it.

2 The influences were of an intellectual kind also. The drawing room and dining room at Duddeston were large rooms, three sides of the latter and part of the former were lined with books of history, botany, natural history, poetry, etc., and the grandchildren had the advantage of being allowed to borrow any book they liked. 


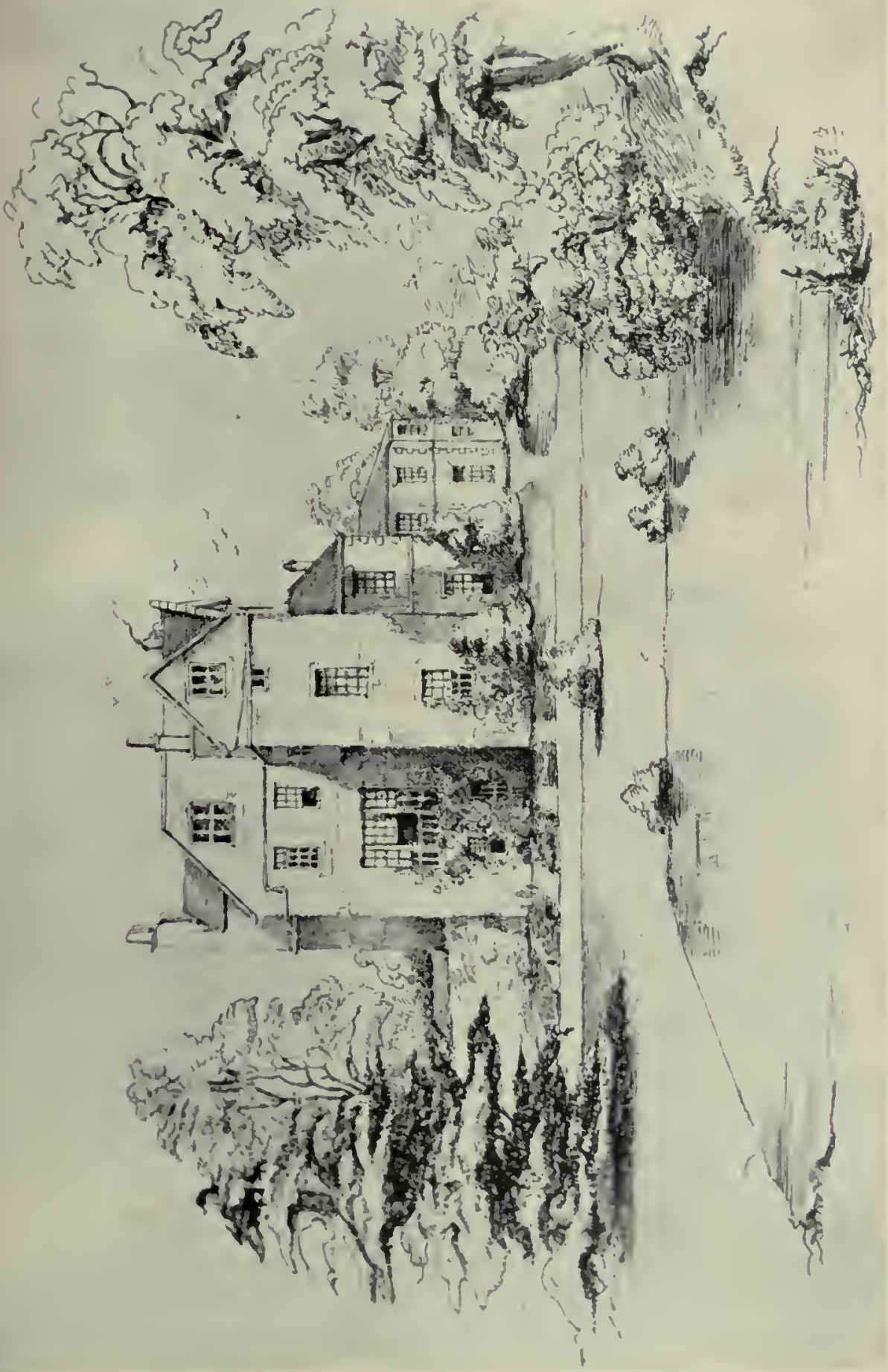

है

$\stackrel{2}{2}$

这

$=$

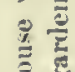

三

$\cong$

$\therefore$ 岁

竞

产兰

$\therefore \bar{E}$

焉

ב

总

娄

들

敢

气

况

$\div \cong \frac{\mathscr{a}}{\Xi}$

항

战

突

롱

$\equiv$

震

O

总

牙

कै

气.

胥

$\stackrel{2}{=}$ 



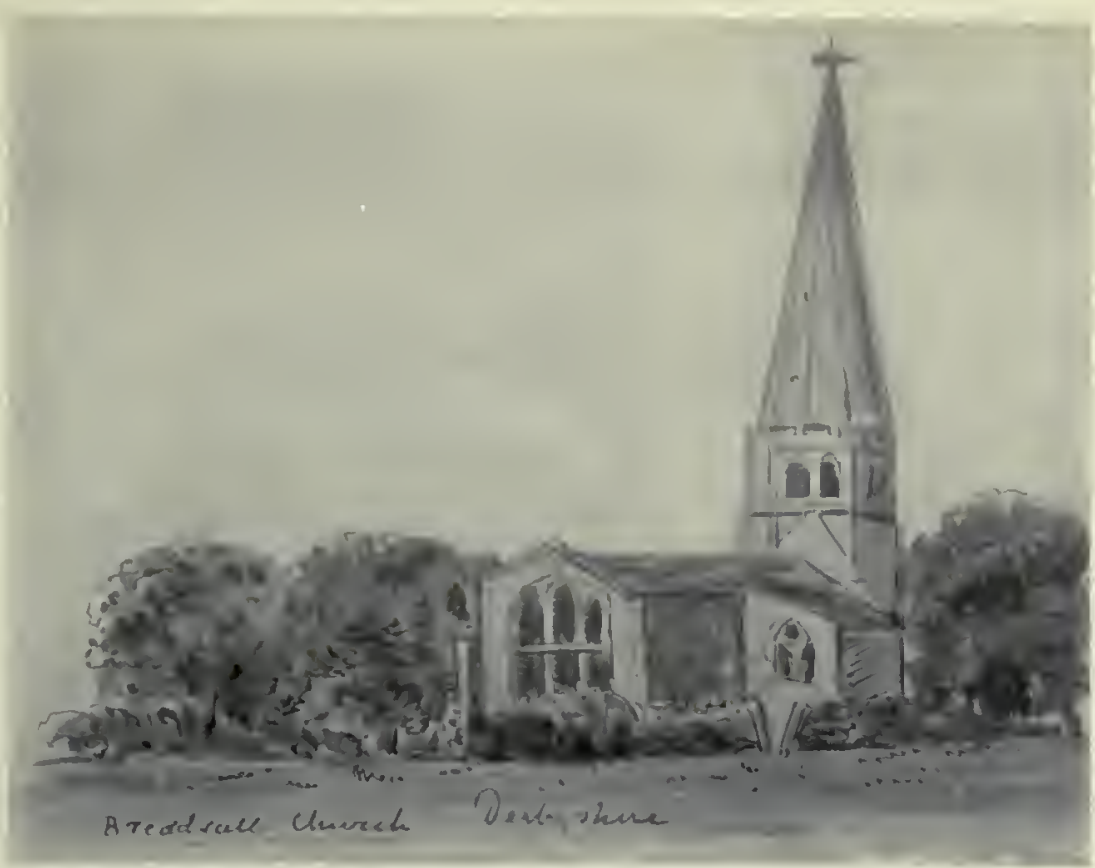

\section{BREADSALL CIIURCII.}

From a sketel. 'This (hureh contains the tombs of Erasmus barwin and his widow (Elizalheth Collier) with those of other members of the Darwin family.

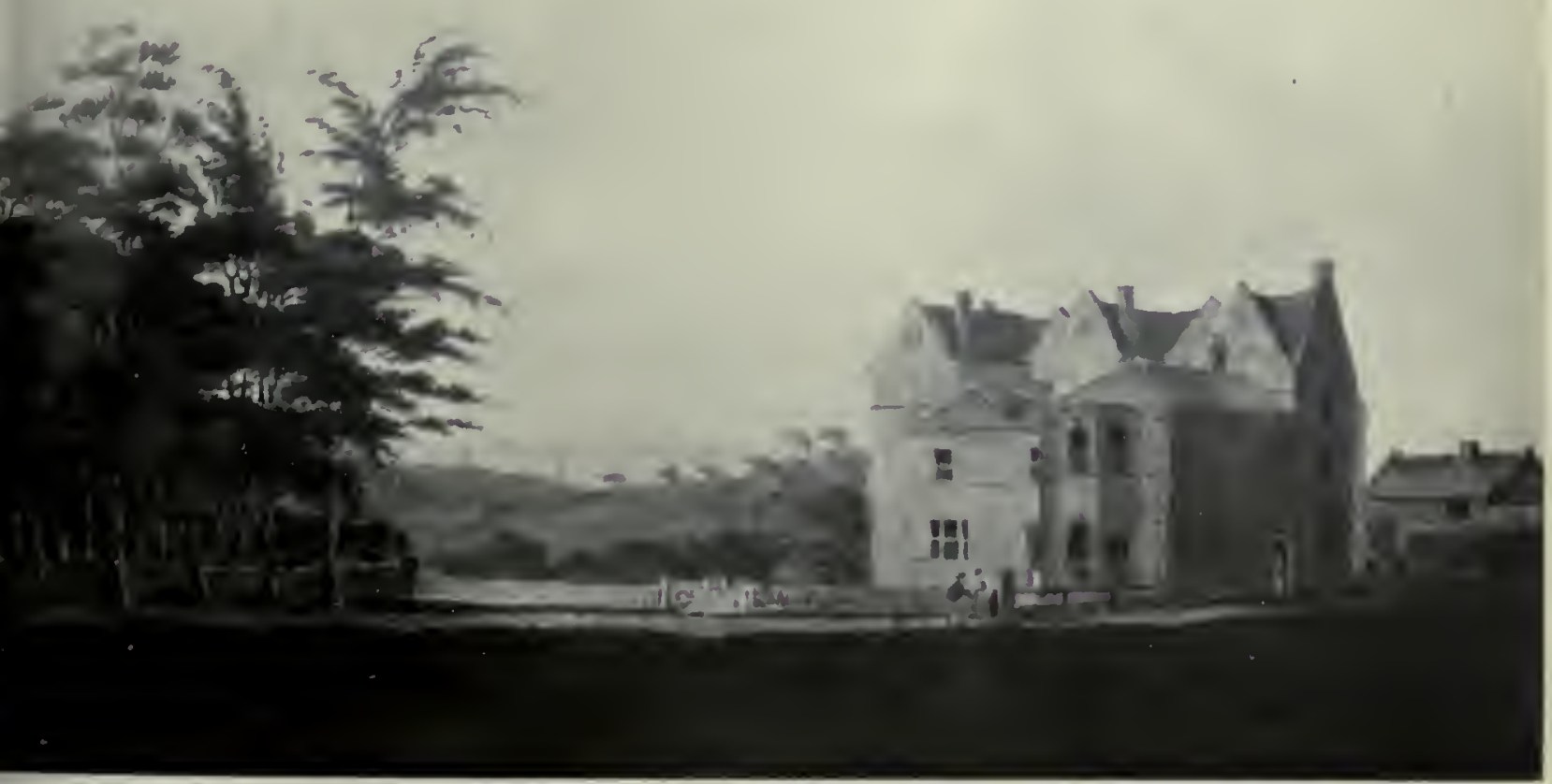

BREAIDSALL PRIORY.

Purchased by Easmus Darwin the Younger, afterwards ocenpied by Lianus Darwin the Elder, and later by his widow. From a water-colour sketsh at Claverdon. 

$74^{\circ}$

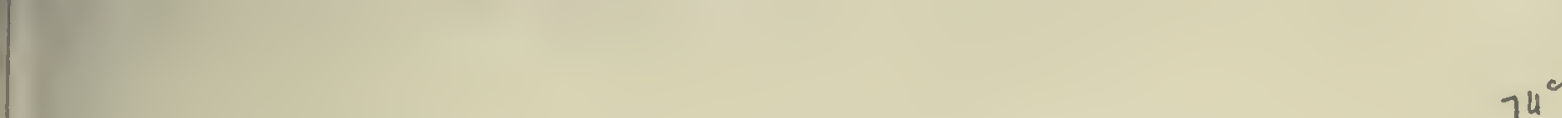$$
\text { . }
$$ 
Plate $\mathrm{YLV}$

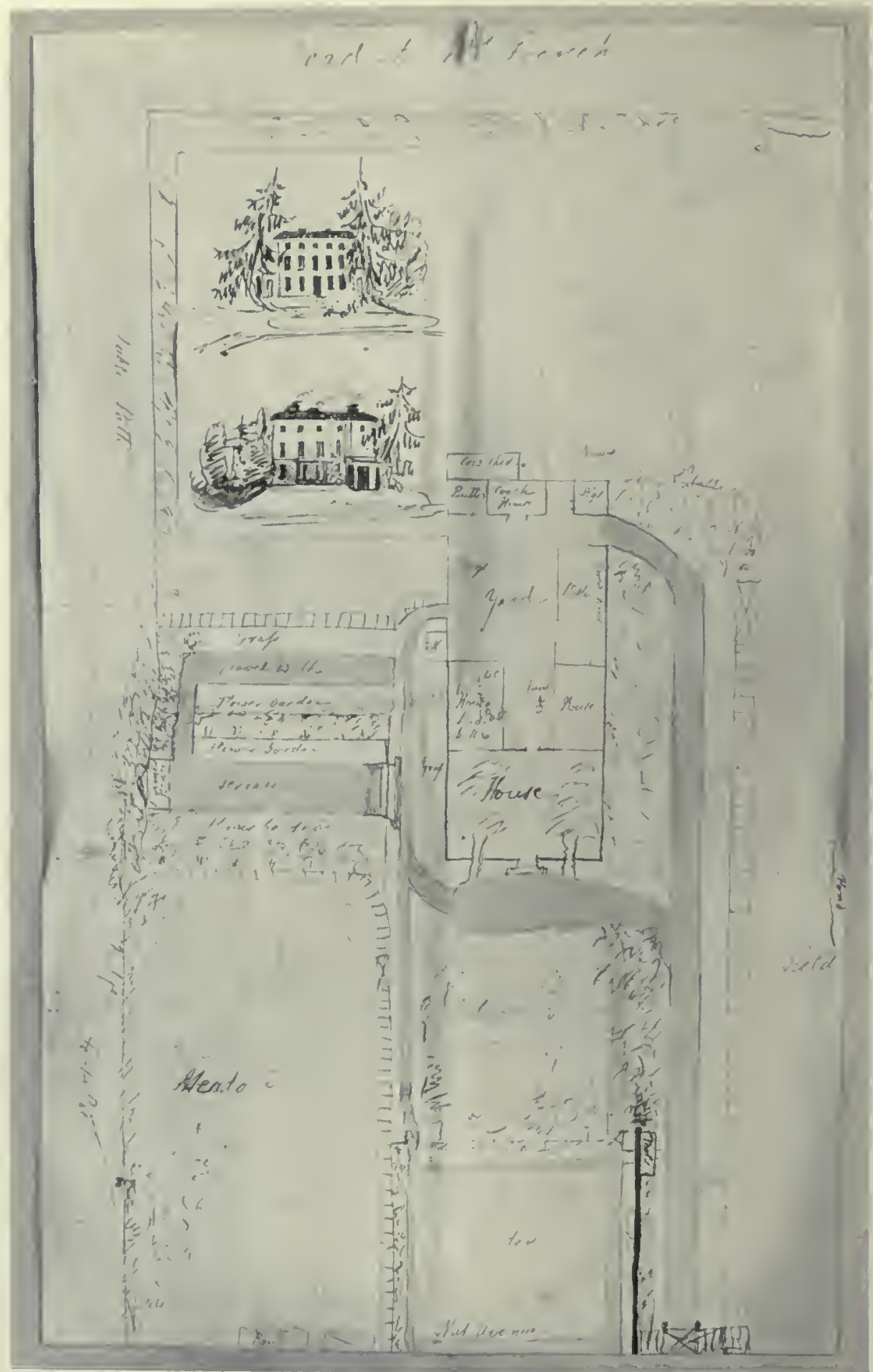

I'lan of The Larehes, the birthplace and home of Francis Galton's boylood, with two inset aspects of the house. From a plan by Violetta Galtun (née Darwin). We see the road to Mrs lrench's sclnol and the meadows where Charles Darwin rode and shot with the Galton loys. 
for following a profession, and knowing Samuel Galton's character as we do we may feel confident he would have approved his grandson's final disposition of a large portion of it.

With his return from Boulogne the first period of Francis Galton's life closes; his childhood is over and his boyhood begins. The letters we have quoted from these early years may appear to the reader to contain little of note. They are indeed just what a healthy normal child would write, but it is that very fact that makes them essentially buman documents and gives them their fundamental interest. We rejoice to see that men who have laid their mark on their age are in constitution just such human beings as we ourselves and closely akin to the childworld with which we are all so familiar. Need we attempt to see signs of exceptional ability or to discover foreshadowings of future achievement in the outpourings of healthy childhood? I do not think we can say more than that Francis Galton was a normal child with rather more than average ability, and that possibly only his mother, Violetta, realised instinctively that he was not just like the rest of her children.

From plans and sketches of the Larches drawn by Violetta Galton and her daughters Bessy and Emma we are able to realise the home of Francis Galton's childhood, which appeared to him so delightful, not only from the distance of Boulogne, but from the distance of later life. The house was a spacious one three storied in front and five-windowed across, two tall larches overtopping the roof stood as sentinels right and left. Two wings went out from the rear, that on the left faced a garden with terrace leading to a summer house. This wing had a bay window, and made the house on this side also three storied and five-windowed across. The right-hand wing ran back to the stable and brewhouse, which had once been Priestley's laboratory. At the back of the house was a large yard terminating in poultry-, coach-, and pig-houses, with cow sheds leading directly to the fields, where the boys used to scamper about on their ponies. We see the very spot where "Ringwood" and his fellows were kept, and the archery ground, and wonder which out of the many flower borders was the patch tended by Frank, where his beloved hollyhocks and

1 See pp. $43-48$.

${ }^{2}$ Mrs Wheler in her Reminiscences says these trees were among the first larches brought to England. 
carnations flourished. Undoubtedly it was a spacious, pleasant home and one round which many childish memories would grow up still more spaciously and pleasantly (see Plate XLV).

It is in the essence of childhood to have but one real 'home' and we may question whether Galton ever felt to 44 Lansdowne Place, Leamington, as he felt towards the Larches.

Francis, as we have seen, carne back at the end of June to England, and on July 11 following, a month after his grandfather's death, we find him on what was probably a last visit to Duddeston:

\section{My dear Papa,}

Last night I caught four perch and this morning I had much better luck for I caught in about the same time three perch and four roach. When I was coming to Nole a carriage arrived just before in which was a Lord; as the servants werc handing his wife out all of a sudden she fell on the pavement and was hurt very much indeed. I and Adèle made a very good dinner on the biscuits which I brought with me. Good bye. Aunt Sophia sends her best love to all.

F.

Were the birds (see p. 41) still on the lake as Francis caught his fish? Francis' reputation as a fisherman seems to have been a family joke, and two years later provoked a retort in sketch caricatures of a shooting expedition of his brother Darwin (see Plate XLVI).

"DEAR DAR, so I hear that no horses were strained to death in carrying your game, but however I send you some caricatures below."

The sketches are somewhat crude, giving little sense of Francis Galton's later power with his pencil. They open with Darwin giving instructions to Ben to provide a waggon with four strong horses to bring the game home, then we see Darwin in a gig with keeper and guns and three dogs. Thirdly comes the death of one dog, and the partridges' mocking flight, "Hee, Hee, Hee!" Fourthly the arrival of the waggon and waggoner "I have brought the waggon and four stout horses." "Why I have only been able to kill my dog," says Darwin; "however buy 1 hare and 6 brace of partridges and put them in the cart." The last picture represents the return of the sportsman to the family circle: "Well, what news?" says Mamma. "Why, I couldn't kill anything but the dog, it must have been the fault of my gun; but at the end I murdered 6 brace and 1 hare." Chorus: "Hum, bad Carpenters always complain of their Tools." Papa: "Who was it I saw buying partridges for one Darwin Galton?" 


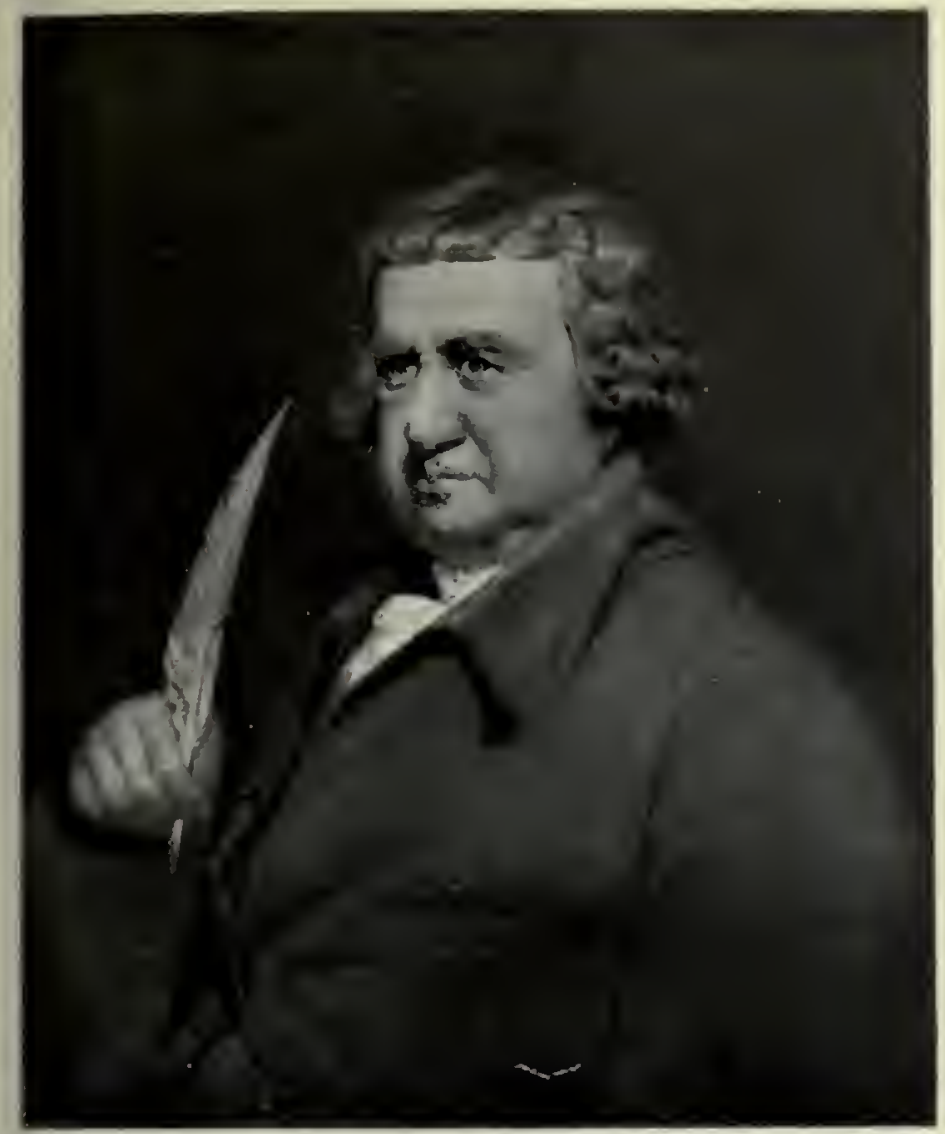

ERASAITS DARWIN (1731-1802).

(irandfather of Charles Darwin and frameis (ialtou. From a painting by Wright of I) (noliny.

DARWIN GALION (1814-1903).

Eldest brother of Francis Galton as sportsman. From a picture by Oakley at Claverdon. See 7.75 . 

"You see it is now tit for tat, the birds are not more afraid of you than the fish are of me. Hope Delly ${ }^{1}$ is well, give my love to all. Good bye.

$$
\text { F. GaLton?"." }
$$

After the home was transferred to Leamington, Francis was sent to school at the Rev. Mr Atwood's, who was Vicar of Kenilworth. 'This was a small private school with about half a dozen boys. Atwood was a relative of the inventor of Atwood's machine, a man who, to quote Galton's own words, "without any pretence of learning, showed so much sympathy with boyish tastes and aspirations that I began to develop freely?"

At this school Galton came in touch with the two Boulton boys, Mathew P. Watt and Hugh William, grandson of Boulton of the Lunar Society and the close friend of Samuel Galton, Wedgwood and Erasmus Darwin. Mathew Boulton became an intimate friend of Francis Galton, and one of the inspiring influences of his life. At Atwood's school carpentry and turning appealed to Francis' special and boyish instincts. Bird trapping, slings, archery, cricket helped to fill up the time. But he had got even beyond this, the summer holidays had been spent at Aberystwith and he had shot with a gun for the first time.

Half a dozen Kenilworth letters have survived. The first shows us that Mr Atwood did not fail to mingle a spice of theology with his other teachings:

\section{MY Dearest Papa,}

December 30, 1832.

It is now my pleasurc to disclose the most ardent wishes of my heart which are to extract out of my boundless wealth in compound ${ }^{5}$, money sufficient to make this addition to my unequalled Library

The Hebrew commonwe alth by John

A Pastor advice

Hornne's commentaries on the Psalms

Paley's eridence on Christianity

Jones' Biblical Cyclopoedia

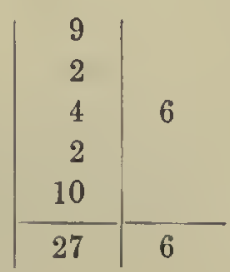

All books much approved of.

1 Adèle.

3 Memories, p. 19.

- This and the reference in the Will, p. 68, suggest that Tertius Galton had put by certain monies for Francis at compound interest.
${ }^{2}$ Letter to Darwin Galton, Sept. 8, 1835.

' l.c., p. 20. 
Francis' spelling and writing do not improve, and this confirms my view of much supervision at Boulogne; but all things become freer and more natural. On February 7, 1833, Francis writes:

\title{
Deakest Pater,
}

I wish you would send me as soon as possible three boards just like those which you gave me to carpenter upon on for very particular circumstances and send them as quick as possible. I intend to direct the letter to Adèle for fear if Pater should not be at home you may keep it for him the directions for the size are about 1 inch in thickness and a foot in breadth F. G.

[Miss A. Galton, No. 44 Lansdowne Placc, Leamington.]

When capitals and all stops disappear that boy is full of his own ideas and supremely happy! The Boulogne statements as to "happiness" have wholly vanished, and Francis is really happy. Again :

My dearest Father,

I have enclosed this note to Mrs Yard (?) as you desired me and I also hope that you will put its direction on it as I do not know it. Please ask Dely to send one rat

of those stoel iron traps like the one in which you caught your fingers with teeth and tell lier I will discharge the immense sum of $1^{s}, 3^{d}$ at the Easter Holidays.

And again :

Francis Galton.

\section{My dearest Pater,}

Please would you let me stay here till next Tresday because $I$ think that I could [learn a] deal more at [? from] Mr Churchill than otherwise for he teaches famously. I have no more time to write so Good bye,

\author{
Francis Galton, \\ alius \\ Snog, Lord Torment \\ and \\ Tease.
}

When a boy asks to stay longer when the Christmas holidays are arriving in order presumably that he may "learn a deal more" all must be well with him! Who Mr Churchill may have been, I don't know ${ }^{1}$, but no man ever received a higher testimonial to his teaching.

The Christmas holidays of 1833 had been memorable in the Galton annals. An attempted robbery was made at Lansdowne Place, only to be consummated some weeks later. Francis Galton gave an account of the event 65 years afterwards:

3 Possibly a teacher of chemistry, for according to another memorandum Francis began to study chemistry at this time, but the teacher is said to be French. 
"I was at home during the Christmas Holidays when an uttic was my bedroom. A waking one morning before daylight, when a faint light cane from the street lanps, I saw vaguely, the dark form of a man, standing by iny leedsicle, but saw very clearly the white blurs unde by his face and lands, for he was on the side opposite the window. Still it was impossible to be sure of the reality. I was but a small boy, in so great a terror that my tongue refused to articulatc properly, whien I tried to speak. Thell with a great effort, I sprang out of bed and puslied at the figure. My hand eame against the body of a man. Forthwith I pulled the bedclothes over my head, expeeting every moment to be stabbed through the counterpane. Thus I lay in agony until the day broke and light eoming through the clothes made it seem safe to look out. When I told my story at breakfast, I was laughed to scorn, they said it was a nightinare, but I knew better ${ }^{1}$. The robbery took place a few days later, when I had returned to school and the attic was empty. The thieves gaincd aecess through that room, entering through the window from the roof and leaving the dirty marks of the slippers they wore all about the floor. The servants then said that similar marks but fewer of them, had been seen the morning after my adventure. My conclusion was that the man by my bcdside, was a reality and no dream, and that he had entered, it might be merely to prospect the premises, believing that the attic was vacant, more probably that he eane with the intention of making the theft, but finding the attie occupied and fcaring an alarm, he decamped, to return on another ocension, when assured that the oecupant of the room was gone. He doubtless heard through an accomplice servant that no eredit had been given to my tale.

Francis Galton, Sept. 2, 1898."

In this robbery at Lansdowne Place Francis lost his watch ${ }^{2}$, and the accompanying letter received March 1, 1834, reminds his mother that a year has sped without a new watch.

\section{My dearest Mater,}

I now write this letter to you on particular business to remind you of something which although you may have forgotten is still as fresh as possible in my memory which is that a few days after the robbery (the day of which was yesterday) you did, for the purpose of solacing and conforting me on account of the watch, faithfully promise that if that said article was not discovered another exactly similar to that

1 An almost identical incident veeurred to the present writer as a child of nine, except that the man-lunatic or sleepwalker-was seated on the edge of the bed and visible in the moonlight that fell on him from the open window. I recollect keenly to this day, the effort to test the rcality and the solidity of the man, then the hour's of torture under the bed-elothes, to be told it was a nightmare, but I too knew better, though no demonstration of its reality ever came to justify me!

${ }^{2}$ In the police advertisement : $£ 50$ Reward, Robbery of Jewels etc., February 23, 1833, we read among other things: "a small silver French Hunting Wateh, supposed to have F. G. engraved upon the Back." It is probable that this watth was a present from Francis' grandfather Samuel, from whom a nice letter is still extant to his son Tertius; this letter eovered a draft to purchase watches for the grandchildren. 
should fill up my watch-pocket and as the aforesaid articlc has not been found in the hands of anybody I do assuredly hope and expect that the next time iny foot shall cross the threshold of No. 44 a silver watch shall be given into the hands of me. Ilerein fail not.

I have becn going on with my chemistry very hard and please give a thousand

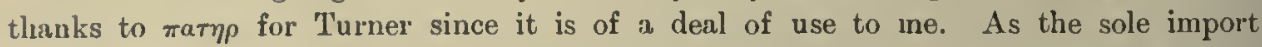
of this letter is to remind you, mammy, of the watch I have nothing else to say so good bye

Tut Squagdc.

One more letter, written to his sister just before the summer vacation to be spent at Weymouth, and the happy days at Kenilworth come to an end.

My deAr AdèLe,

[Before June 12, 1834.]

I think that when you write to me you might possibly remember to put where you live for the lettcr that you last sent to me had not the direction in it so that when I come to Weymouth I shall not know where to go unless you write. (Please don't read the following loud but let it be secret. Coax Pater as much as you can to get me a gun and ask him when he is not at all in a.black humour and I leave the rest of it to yourself.) I hope that Foddy has quite recovered her fright and is much better and I wish I had been there to enjoy the fun ${ }^{1}$. I wish that you had not gone to Weymouth for you said in your last letter that it was a large place which makes it as bad as even Brighton. Try and get a great many eggs of rare sorts but not of the common for I have a great many of them and cover them with rather weak gum and water instcad of blowing them and try and learn their names. I am coming on the 19th and are there many places for fishing Atwood is gone out for three days and Hugh Williams gocs on the 12 th. Good bye and remember what I asked you.

Frank Galtox.

Fishing, birds'-nesting, possibly I fear shooting sea-birds, such were the occupations of Frank's summer holiday. Soon after his return home a new school was found for him. Tertius Galton retained the Quaker dislike of public school education and he still held to the Birmingham tradition. Had the former been based on the perception that a classical education was idle for Frank, it had been justified, but he sent him into the centre of a big town-to obtain a suitable education as its justification? No! to obtain precisely the classical drilling which at least he would have obtained under healthier environment in several public schools. It is remarkable to look now on the

2I think this must refer to the following incident: Mr Galton lad purchased horses for his daughters to ride, and when two of them were out passing the barracks, the drums began to beat, and one of the steeds bolterl with its mistress into the barrack yard and took its place at the head of the regiment-it was an old troop-horse. 
intellectual activity of Birmingham, on Priestley, Watt, Boulton, Samuel Galton, and their association with the Wedgrwoods and Darwins, and realise that no attempt was made to free Birmingham from the trammels of mediaeval education. Samuel the first had indeed sent his son to Warrington Academy to study under Priestley and Enfield, but the younger generation, the sons and grandsons of the men, who had made Birmingham and their great fortunes out of Birmingham, fell back into the old theological and educational ruts. It is one of the most interesting chapters in the life of Francis Galton to read on the one hand the letters of Dr Jeune, headinaster of King Edward's School, Birmingham ${ }^{1}$, then called the Free School, to Tertius Galton, and compare his views on education with those of his pupil Francis Galton, a boy in his teens! Galton lived in Dr Jeune's house at Edgbaston, and walked daily through a mile of streets to school and back. He started with ill luck, for some weeks after going on Jan. 26, 1835 to the school, he was invalided home and the attack proved to be one of scarlet fever. Francis had been in the doctor's hands in the previous Christmas vacation and was possibly specially receptive, and the attack undoubtedly left him languid and inert. The epidemic was a severe one, for the headmaster wrote that he felt convinced by his late fatal experience that however disguised it might be by other symptoms it would turn out as in every recent instance an attack of scarlet fever. "It is a subject of congratulation rather than of regret that he should have undergone the trial, as the complaint I understand never returns." Little Johnny Booth, stepson of Galton's aunt, Adèle Booth, who had been at Boulogne with hin, and then gone to the Free School died from the fever. The life of another boarder was despaired of for some days. We have indeed to remember that we are back in the days when healthy children were put to bed with one that had the measles, in order that they might "get through them." When Francis got back after Easter, he was far behind his classmates and he was removed from the second into the third class at his own desire. Probably he never properly recovered from this

'Dr Jeune afterwards became successively Dean of Jersey, Master of Pembroke College, Oxford, and Bishop of Peterborough. He was a man of distinction and had a distinguislied son. He was only 28 when he went to Birmingham, and he remained thero from 1834 to 1838 just the time of Galton's career in the school. At Oxford he was a reformer, and, perhaps, his experience at Birningham was of value to him later.

P. G. 
throw-back in his school work. Writing before the attack to his father on February 2, 1835, for his foils, he appears fairly cheerful :

"I an very happy here, and we have everything almost we eould wish. We do an immense deal of work but nevertheless I should like to fenee as we should have quite 3 quarters of an hour to ourselves after feneing for an hour on half-holiclays. All this week there have been only two hoys eaned and none flogged they are in sueh eapital order, but the rules are pretty striekt [sie!] and the Doetor does not allow us to make a mistake in our Graminar."

But this tone of commendation very soon ceased. Of the rest of this year we have no further records in letters, but we know that the summer vacation was spent at Castle House, Aberystwith-the second visit to that place; that the mode was shooting-in which sea-gulls and water wagtails met their fate. Here too Dr Jeune was invited to come for a few days' change-not wholly to the satisfaction of Francisand the family learnt how a very clever man may be ignorant of everyday customs:

One day in July the family was alarmed by hearing that a mad bull had got loose and was tearing round the town. He had tossed a small man onto the top of a fish-stall.

"We all went out in front of our house, which was enelosed and so quite safe, to wateh. "Just under our wall was a flight of six or eight steps, and some ehildren were seated on them. The bull rushed by, elearing the whole steps, children and all, without liurting them, and rushed towards the sea, the men following him with pitehforks only made him worse, and he darted into the sea and swam away. The butcher not wishing to lose him got a boat and rowed after him. The poor beast thoroughly tired, allowerl them to put a rope round him and tow him baek, when he dropped down on the sands unable to stir. The buteher went to get something to put an end to him, when, on his return, the bull jumped up and eharged him. Away seampered the man and it was some time before the bull was eaught, I think he was shot at last for no one dared go near him. Franeis drew a carieature of 'All the Taffies put to flight by one John Bull,' and showed it to our Welsh eook, who was very angry with him. She harl offended him by throwing away some rooks he had shot, instead of making them into a rook-pie, so he had taken this means of punishing her" (Mrs Wheler's Reminiscences, p. 192).

Returning home Darwin drove Francis back in a "dogeart outrigger." The servants went by coach, which was overturned at Bewdley

1 Franeis went to Aberystwith in May-probably to reeuperate-and we find him on May 20, 30 and June 1 sending with brief letters to Dr. Jeune long translations from Cieero, Greek exereises, translations of the Medea, Latin verses, ete., and asking the Doetor to forward his Donnegan, Ainsworth, and Lemprière. Clearly the terrible Doetor and his classieal torments followed him into his Welsh holiday! 
Bridge, the maids escaping but the butler being injured. 'The family usually posted, somctimes in their own carriage'.

It is worth recording that the first incchanical design of Francis that has been preserved dates from July 17, during this Aberystwith stay. It is entitled: "Francis Galton's Aerostatic Project, 17 July, 1835." It represents a flying machine with five passengers, a pilot and (?) an engineer. It was apparently designed to work by rather large flapping wings, with a sort of oscillating steam-engine. The mechanism of the flapping indicated in two additional rough sketches is not very clear. I do not know how far it was suggested by his Grandfather Erasmus' lines on air-ships 2.

The only record of the autumn of this year is a letter from Dr Jeune of August 26, reporting the narked throw-back in Francis' educational progress due to his illness. He reports him, however, in excellent bealth and spirits with a good appetite, and notes that his vigour in cricket and football promise well for the continuance of his health. From the beginning of 1836 , however, we have a small pocket diary. It is full of the frank outpourings of a very healthy boy, who has clearly 110 one to guide his tastes and sympathies. I shall give a few extracts :

Saturday, Jan. 2. Took Pincher with a cord and Crab and Gane a walk. Darwin came back from Brum. I went to the Younge's party, pretty good tuck.

Monday, Jan. 4. Went to shoot at Cla verdon, killed a partridge. Went to Wood's party.

Friday, Jan. 7. Invited to Mrs Proby, did not go. Went hunting, pony fell over mo and hurt my leg; they had a run of an hour and 10 minutes.

Wednesday, Jan. 13. Thawed. Went to Mr Curtis who gave me some feathers, and taught me a good deal about artificial flies.

Thursday, Jan. 14. Had a dinner party ; the $\mathrm{D}_{1}{ }^{\circ}$ cane here, much against my liking.

Wednesday, Jan. 20. The old Dr went away with Dar to Brum. I walked out with Jones to tire my cannon.

1 Earlier when Grandfather Galton took his family to Tenby, in Wales, he used to hire the only two hackney carriages in Birmingham to take part of his party.

8

"Or on wide-waving wings expanded bear

The flying-chariot through the fields of air.

Fair crews triumphant, leaning from above,

Shall wave their fluttering kcrehicfs as they move;

Or wartior-bands alarm the gaping crowd,

Altd armies shrink beneatl the shaclowy cloud."

The Botanic Garden, Canto I, 1. 291.

"There seems no probablc method of flying conveniently but by steam or some other explosive material, which another half century may probably discover." Note to 1. 254.

${ }^{3}$ Dr Jeune. 
Monday, Jan. 25 is called "black Monday" and framed in black border, because of return to school.

I'uesday, Jan. 26. The Dr flogged a chap. The Dr's father was buried.

Friday, Jan.29. Got 50 lines of Virgil for going down to school in the evening without

Earp's' permission, which he called an insult to his dignity.

Saturday, Jan. 30. A bit of a row at school got 30 lines from Gedge" for throwing chewed paper at the fellows' heads. The dame's tremendously cruss.

Sunday, Jan. 31. The dame pretends she's half dead with a headache.

Monday, Heb. 8. Got an imposition for knocking down an umberella (sic!).

Tuesday, Feb. 9. The Dr in a tremendous rage, because I let a chap copy his exerciso from me.

Wednesday, Feb. 10. The Dr came upstairs after we had gone to bed and cauglit us making a row; gave the chaps he caught tremendous impositions.

Thursday, Feb. 11. Got half the syntax to write out for not being able to say my lesson. Dr very sulky.

Friday, Feb. 12. Dame receired a valentine, which told her that she liked a pot of beer, which I think is pretty true.

Friday, F'eb. 19. Saw a stuffed cat with 6 legs 4 ears 2 tails and one eye.

The rest of February, while well filled with notices of imposition and "tremendous rows" with the Doctor and Earp, is also noted by young Jeune and another boy getting the small-pox. Most of the boys went home, but

Thursday, F'eb. 25. Saw Pater who told me I was not to go home, which I did not much like only 2 left (?) in the 1st class.

March shows the same round of severity :

T'uesday, March 15. One boy was expelled and another flogged.

Thursday, March 17. Dukes was expelled.

Saturday, March 19. Took a walk to Edgbaston park. Earp bought a swing for us, to put which up we had to cut away some shrubs; we expect a row.

Sunday, March 20. Foe preached. The Dr made a tremendous row about the swing and said that it should be taken down.

Monday, March 21. The swing was taken down. We set up some leaping posts.

Tuesday, March 22. The Dr caught us looking over our books at school, a tremendous row. One of the blagards gave __ ? a crack in his face 4

Saturday, March 26. Bought a cat's gallows. Got caned.

Monday, Mar: 28. Got caued.

Good Friday, Aqril 1. Wc were made to fast, but we went over to the grubshop and got plenty.

Sieturday, April 2. The Ductor did not go round with his cane.

1 Presumably an usher at the Doctor's house.

"Francis' form master. ${ }^{3}$ Presumbly the matron.

- There werc continual fights with the strect boys of the roughest kind. 
Wednesday, April 6. 'I was examined hy Gedge in mathematics, the exaniners were Cramer, Johnstolle and Meryvale (?).

Thursday, April 7. Was examined in chassies. I was 2 nd in elass. Tom l'riee got the prize. Bates and Holmes accesserunt. Came home.

After return to school the rather unedifying life begins again:

Monday, April 18. I knocked a fellow down for throwing a briek at me.

Tuesday, April 19. I thraslied a snob for throwing stones.

Wednesday, April 20. One of the boys bought a lalf-erown trumpet which made at tremendous row.

Thursclay, April 21. We bought a bireh pro bono publieo for 15 shillings.

Friday, A pril 22. A tremendous row in the streets, on aceount of a blaguard thrashing one of our boys.

Monday, April 25. Saw the 1st swallow this year.

Tuesday, April 26. Got 30 lines of Virgil.

Wednesday, April 27. Got 20 lines of Virgil.

I'uesday, May 3. Got the syntax to write out for drawing a pieture of a race.

Sunday, May 8. Arnold preached. A fellow gave me a thrashing in the street.

During the period May 2-20 measles broke out in the school, and Galton appears to have been ill and some days staying away from school. Possibly he had a mild attack. On the 20th "mater" wrote to ask for Francis to come home for Whitsuntide. But he is soon back again at the old round:

Thursday, May 26. Got an imposition in algebra to do for Gedge.

Monday, May 30. Turner became a day boy, because he had not suffieient attention shewn lim.

Truesday, May 31. A complaint in the Journal on aceount of the Dr sometime ago, setting a boy 100 lines for talking.

Friday, June 10. The Dr took away a knife which I had bought with Pater's tip the day before.

Thursday, June 16. Fleteher knocked the erieket-ball into the ivy and lost it. The Dr was black as eharcoal.

Friday, June 17. Had to bring up a tremendous imposition to the Dr.

Thesday, June 21. The Dr stayed at home, so we eould not have any bolstering or fighting. Came home by the Regulator.

The summer holidays seem to have been spent at home; the weather was very hot $-85^{\circ}$ in the sun. Darwin had bought a pony, and the new pony and the old were driven tandem. Francis went to stay with his sister Lucy (Mrs Moilliet), and shot thrushes and even a swallow ("1st shot"), and caught perch and other fish. Later in the holidays he is shooting rabbits. This holiday also records:

Monday, July 18. Went to Stourbridge in the gig with Pater to see the locomotive engine. 
Wednesday, July 20. Went to lienilworth to sce a new school opened, and electrified the cat and girls. Friduy, July 22. Went with Limma to Kenilworth to sketcli:

On August 8 Francis goes back to school, and the old state of warfare is resumed. On the 11 th the impositions begin; then the boys go to bathe in the canal, but the Doctor stọpps it, and they go to Ladywell bath. August 22 and 23 there are further impositions; on August 24 Hawkins gets thrashed. Sept. 1st Galton took a walk in the evening by French leave, but was seen by the servants. Sept. 7 and 10 there are impositions, and on the 9 th Galton is nearly thrashed by the Doctor for not knowing his lesson. Sept. 12 there is another imposition, but perhaps consolation in the record that the cat has run away with one of the partridges presented to the Doctor !

Saturday, Sept. 17. Walked out, had an imposition. Dr in a black humour.

Sunday, Sept. 18. Had eider for dimner. I think the Dr is getting rid of it, for it tasted very sour.

Tuesday, Sept. 20. A row between Hawkins and the blackguard; had two chases after him, but at last lost him.

Wednesday, Sept. 21. Lines missel for the 1st time sinee he [? the Dr] has come to the sehool.

Thursday, Sept. 22. Was too late for school got an imposition.

For change on Sept. 27 there was a "regular row" with the dame, and so through the months of October, November and December we have the usual round of boyish pranks and punishments, interspersed with touches of more general interest, e.g. Oct. 20 "The gas was lighted for the first time," and Oct. 21 "The gas all of a sudden went out. Got 40 lines." While on Oct. 22 "We walked to see the railroad; had some fun, was not in time for breakfast."

On the 27th of October Francis sends a very piteous letter to his sister Adèle :

MY dEAR AdÈLE,

Thanks for the paper. I have not been able to write on aecount of the hard work and many impositions I have lately had-30 one day and 10 pages of $\mathrm{Gk}$. grammar to write out, the next 40 , and the next 40 , so that I have not had the least time. Another boy has left and is believed to be in a eonsumption. Indeed I never knew such an unhappy and unlucky sehool as this ; 2 more will leave at Christmas, and $\mathrm{I}$ would givo anything if $\mathrm{I}$ eould leave it too. There has been a great row about some cliaps getting looks from a neighbouring eirculating library, one book the Dr eribbed and another Earp threw into the fire, and some of us were called into the study, and he aceused us, telling the greatest story possible but luekily le was found out in most of 
them (sic). I do not like the Dr taking our class at school, he expeets the grammar said more perfectly than we can, \& thrashes the lower part of the elass for every inistake they make in construing; this morning he thrashed 11 fellows in 8 minutes!! So wo have no peace at home tlirough Earp, and no perce at school through the Dr. I wislt Papa liad taken me away at the Holidays, but of course lie won't; he has no reason tliat, I know of cxcept about chenging schools, as forgetting that I an not getting on the least and every clay is a clay wasted. How is it then expecter that if I leave school at 17 as Pater has tolk me, I shall know enough to pass examination at collegge and again, as you know how easily Latin and Greek are forgotten am $\mathrm{I}$ to turn away wholly from classics to doctoring, which of course [will] confuse me and make me forget the greatest part of what little I have learnt. How much hetter it woulcl be to remove me before it is too late. But, lowever, I suppose Papa will not chinge, and therefore I must bear the consequences. Good bye, and believe me, Your affectionate brother, F. Galtos.

Adèle, like a good sister, sent Francis' letter on to her father with a postscript added :

"I. have just reccived this lettcr and send it on for your perusal in ease you should like to make any inquiries, as poor Francis appears much downcast...."

Tertius Galton must have shortly afterwards communicated with Dr Jeune, for there is a letter of the latter's dated Dec. 7, $1836 . \mathrm{He}$ thanks Mr Galton for his frankness and confidence, and promises to communicate with him if he considers a change requisite in the course of Francis' education, or if a public school instruction is really not calculated to form his mind. Dr Jeune saw that Francis had great powers, and believed that if he would apply them he would hold a very distinguished position both in his school and later in the world. .He then states that he had that very evening been struck with the vigour of a translation from Cicero which Francis had sent up to him, and that, although there were undoubted inaccuracies in the exercise, it still proved that he possessed a mind of no vulgar order. Dr. Jeune is sure that Mr Galton will second his exertions by paternal advice.

The letter is one of a conscientious man who has not the least insight into the wants of such a nature as Francis Galton's. Here was a boy of immense physical and mental activity, longing for employment of hand and head, and no occupation is found for him but a drill in grammar with imposition and cane as sanctions! The harshness of treatment is no doubt modified now in many of our schools; the warfare of master and boy is not so continuous. But is the workshop, the laboratory, and the field expedition, the combination of observation and physical exertion universally provided even now to meet the needs of such natures as Galton's? Have we even now-a-days any true test 
for ascertaining whether a man has real insight and sympathy with boyish growth - any other test than a brilliant degree in classical or other studies-before we appoint him to be headinaster of a school, where quite unconsciously he inay make one boy after another miserable? I very gravely doubt it, and because I doubt it I have quoterl much from Francis Galton's cliary, and must now give a letter written a few months later (February 22, 1837). In the interval, i.e. since the letter to Adele, the Doctor had been apparently trying to treat his boys more as men, but the general scope of his method remained clearly the same :

MY dEAR PAPA,

Thank you very much for your kind letter and allowing me to take mathenatieal lessons from Mr Mason. I have come over to your opinion that Classies are of the greatest use in training the mind, but I feel eertain that I do not get on as I ought to do here. But even not counting that; there is a thing whieh you must own is of almost cqual importance with classies, and that is extensive reading in English, both History and Poets ${ }^{1}$. Now although the Dr says he approves of that kind of reading, yct when he comes in in the evening and sees us reading any book besides a elassieal one, he always says to us "Have you done your lessons?" Then, if we say Yes, he makes us say them; then if we do know them perfectly he tells us to look over what we have done before, ete. In faet although nominally he approves of it, yet really he tries to put a stop to it.

Also on thinking it over, it seems to me that 6 books of Euelid arc very little for 2 years? ${ }^{2}$. Now there was one thing which I forgot to say about English reading, that iny time of life is the one to make the most use of hereafter, and can any person get on anywhere without having read eertainly a great deal of English? When T rearl now I am obliged to read under the table at meals, or pick up time as I ean which amounts to very little in the end. As for my Classics I certainly am not getting on. If at Easter we arc made part of the Doctor's class we shall be put baek and the old round of impositions and hard work will eome again as the Dr himself has assured us more than onee. If we remain on the other hand in Gedge's elass, I shall keep where I am. I ask you in this letter to remove [me] not because I am unhappy here, for crrtainly we have muel more liberty and are treated more as men but beeause I feel I am really not getting on. I an not going down in my elass, but then my elass is

' On Dec. 14, 1836 his diary tells us that he "bought Lord Chesterfield and some pomegranates." In Oet. 1837 he thanks his mother for sending him money to buy Southey, but Southcy being unproeurable, lie had purehased Crabbe.

${ }^{2}$ I think Franeis had learnt in mathematics a good deal morc than this-perhaps partly with Mr Mason. Thus there are from the year 1837 fragments of algebraic notes on homogencous produets and limiting ratios. On a slip of paper recording work done, we have not only the 6th and part of the 11th books of Fuclid, but Algebra Part I and Part IT, cxeept eubics, biquadraties and theory of equations ; Staties and velocities of hodies, Dynamies, oscillations, projectiles, ete.; Hydrostaties and Hydraulies, and a "very little Diflerentials." 
remaining where it is. I leave it to you to do as you think best; but I must say I think I have good ground for what I have said. Goodbye and believe me your affectionate son Francis Galton.

Although effective reform of the Free School did not come during Francis Galton's school time, I cannot help thinking that his attitude of protest, to some extent directly and more perhaps indirectly through his father, produced real changes. The Doctor writes to Tertius on Oct. 23, 1837, that he is studying Edinburgh schools, and that the Governors have determined at Christmas to add to the establishment a Mathematical and an English master, and further, at the beginning of 1839, teachers of French and Drawing, and one more of English. The final report which the Headmaster gives of his pupil is characteristic, but shows the influence of the boy notwithstanding the constant warfare with the masters. Mr Gedge reported that he went on well with his mathematics, displaying much mental power and increasing daily in accuracy. The Headmaster confirmed this judgment, remarking that Francis

"found it irksome to tie down his attention to the exactnesses and niceties which distinguisl a good classical scholar. It is generally the case that boys dislike nost what is most needed for their peculiar turn of mind. He will I think do well, for though he does not entertain all the horror of false quantities or all the admiration of Greek accents which are felt by some of his fellows, he is docile and willing to submit to occasional defeat."

Such the opinion of the Master of the Boy; in his Memories Sir Francis gives the opinion of the Boy on the Master:

"I retained Dr Jeune's friendship until his death, and it was impossible not to recognise his exceptional ability and educational zeal, but the claracter of the education was altogether uncongenial to my temperament. I learnt nothing and chafed at my limitations. I had craved for what was denied, namely an abundance of good English reading, well-taught mathematics and solid science. Granmar and the dry rudiments of Iatin and Greek were abhorrent to me, for there seemed so little sense in them " (p. 20).

Galton had been anxious and willing to learn, but he had been given stones instead of the bread that he hungered for, and thus his chief school years were years of stagnation. It is curious to find him uttering in 1908 , when 86 years of age, the very opinions he had given in 1837 , when a boy of 15 ! I have spent long over this school period because it is not only interesting from the standpoint of educational history, but it is possible that some few parents reading these lines may save another boy from a like period of depression and stagnation, for I sadly fear its possibilities have not for ever vanisherl.

r. r. 
The summer of 1837 had been spent at Worthing with expeditions on the Downs to Cissbury and Chanctonbury Rings. Frank was studying fishes, making sundials, and riding with his sisters and Darwin. In the preceding Easter he had projected a tour to Bangor", to attend cathedral service there, since he "had never heard it chaunted," then to Snowdon, Beaumaris, and back by Liverpool and Manchester (Letter to Tertius Galton, March 26, 1837'). I am not certain whether the tour came off. Perhaps it was postponed till the Birmingham and Liverpool Railway was opened. This happened on July 4, and in September Tertius Galton, his daughter Emma and Leonard Horner, travelled from Birmingham to Liverpool, by what is now the London and North-Western Railway, to attend for the first time by train the meeting of the British Association.

Francis lingered on at the King Edward School for the first half of $1838^{2}$, but he knew that his time was over, and that freedom and more congenial pursuits were soon to come ${ }^{3}$. His father had arranged that he should enter the General Hospital, Birmingham, at midsummer as House Pupil. The proposal was made at the Weekly Board, December 8, 1837, Rev. John Garbeth, Chairman, "Resolved: That the Secretary do write to Mr Galton informing him that his son will be admitted a Pupil at the Hospital at Midsummer next at the rate of 200 guineas per annum." It was afterwards arranged that he should postpone his medical studies till October. His appointment was confirmed by the Weekly Board, December 29, 1837, R. 'T. Cadbury being Chairman. Dr Booth, the husband of his aunt Adèle, and Mr Joseph Hodgson, who had seen him into the world, seem to have acted as his medical sponsors. This was the bridge, not a very direct one, but of great import in its influence, by which Francis Galton passed from

1 This letter is of eonsiderable interest. Francis discusses quite freely with his father his work in mathematies and his ehance of being second in the class. He also discusses with his father the proposition as to the equality of the triangles with two sides of each equal and two not ineluded angles.

${ }^{2}$ A boyish poem on the Spanish Inquisition has survived from March of this year. Without any definite evidence, it seems to me to show signs of the study of Erasmus Darwin's verses. Galton never attained any power as a poet, but from sixteen onwards to the end at least of his Cambridge days, he was very fond of making occasional verses.

${ }^{3}$ In his last school letter to his father, chiefly about the medical man he was to live with in Birmingham, and his gratitucle for the new educational departure, Francis notes that the Doctor is "sworn in to-day at Jersey"; he, too, was leaving the field of battle. 
$90^{\circ}$ 

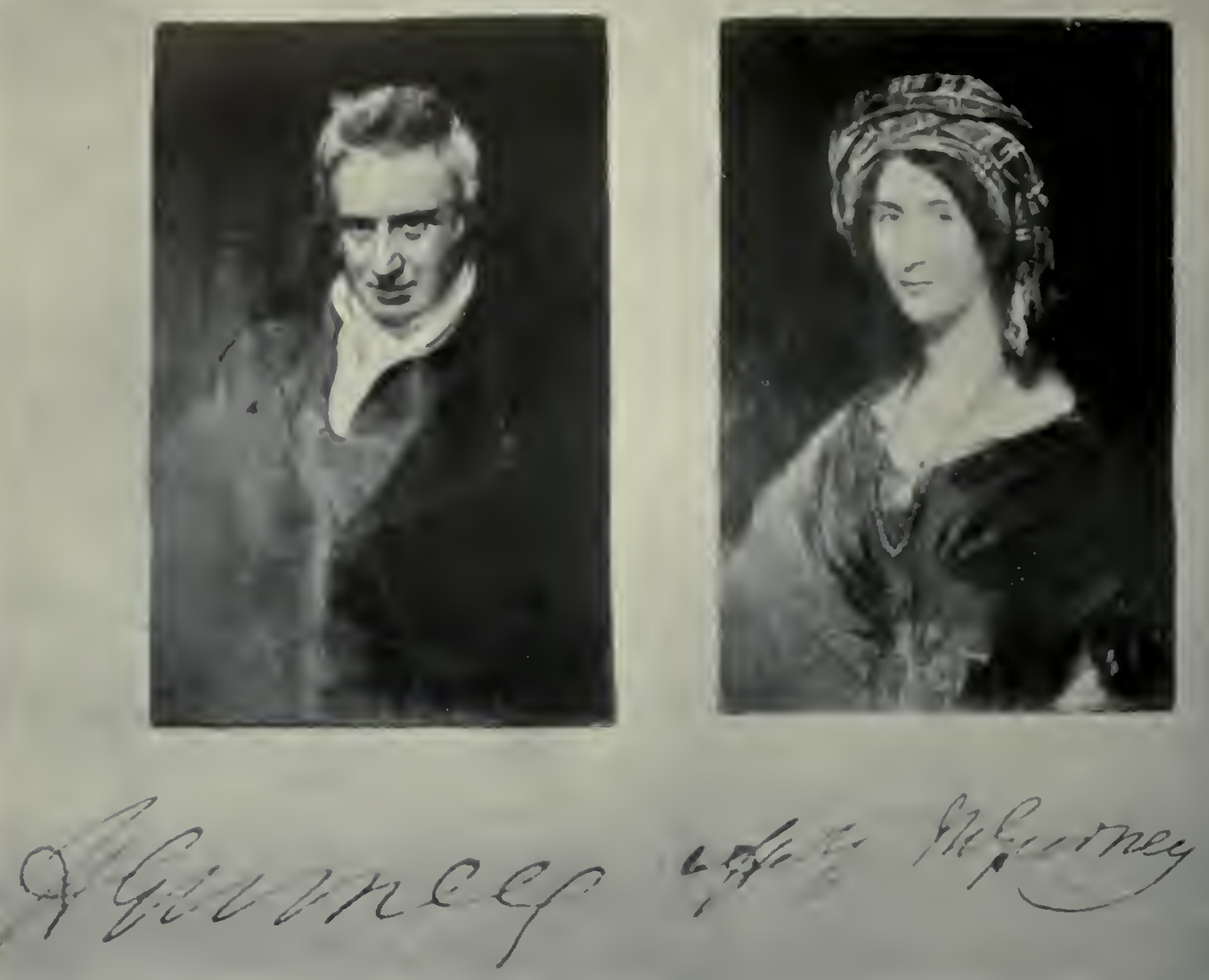

IUUDSOX GURNEY aml MAMGARET GURNEY (Margaret Barday), sister of ('aptain Barelay.

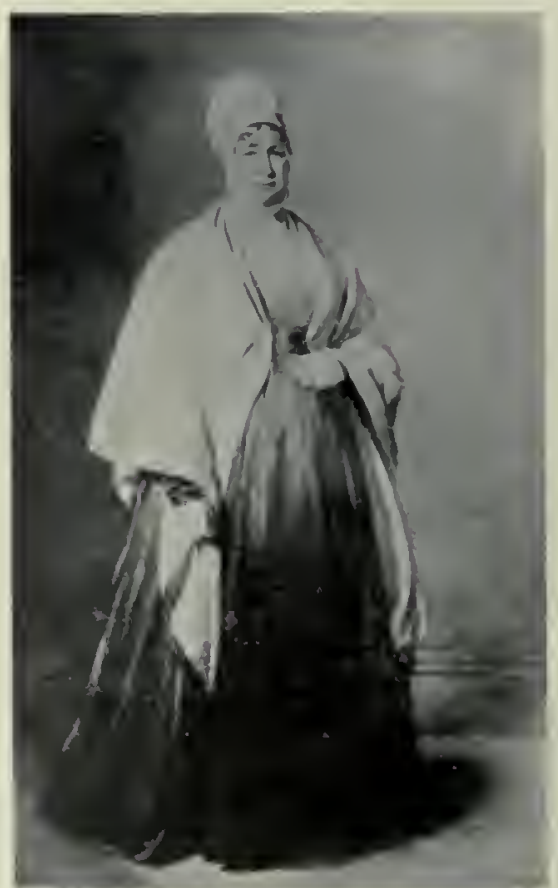

NIRS FRY (Silizalheth (iurney).

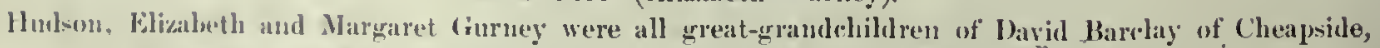
and secoml rousins to each other and to Tertius (ialton, another great-grandchild. 
the harsh discipline of a classical school into the fiscinating field of scientific observation?.

But the year was to be memorable in other ways. The house at Claverdon, the country liome of the Galtons, was taken in hand. In June the Coronation of Queen Victoria took place. On the 26th Francis Galton went up to London to stay with Darwin in his lodgings, and spent most of the time with his sisters at the Howard Galtons in Portman Square. It was his first long stay in London, and his friends took him out each day sight-seeing. Every house had thrown out balconies, and scaffolding, and galleries, covered with crimson cloth, had been built for spectators. 'I'he Hudson Gurneys (see Plate XLVII) had obtained a ticket for Sister Bessie in the Abbey itself. Uncle Howard and Sister Emma were at the Reform Club, Darwin at a Mr Collins', the Hubert Galtons in St James' Street, and Francis got a seat in Pall Mall for $30 s$. Sister Bessie (Mrs Wheler) describes the excitement both inside and outside the Abbey very vividly for us, the crowds, the illuninations, the ceremony and the feelings of the day itself.

I have frequently thought that Galton's idea of carrying, when in a crowd, a block of wood or a brick in browll paper which he let down by a piece of string and stood upon, as well as his "hyperscope," a simple tube with two parallel mirrors at 45 degrees to its axis, were devices impressed upon hin by his experience at these coronation festivities; they satisfied his desire to see over the heads of a mass of people. Unfortunately no letter of Francis himself, describing the events, has been preserved. But the formal beginning of the new reign was the formal beginning of Francis Galton's adolescence. Henceforth he was no longer a boy, but an apprentice, starting his craft ; rather early, it is true-at sixteen years of age-and rather old-fashionedly, but he was strong in character, and given freedom, he could and would absorb all that his active mind needed for its sustenance.

1 There is an excellent letter, dated Leamington, December 9, 1837, from Samuel Tertius to his son, announcing the mcdical appointment. He writes:

"I really believe, if you turn the opportunities you will have at the Hospital to the best account and avail yourself of the advantages of explanation that my medical friends there will be disposed to give you, if they find you willing to profit by them, that you will bcgin your medical career very propitiously. You must be careful to avoid low company and not be led astray by any pupils there that may not be equally well disposed - but I have great confidenee in your wish to do what is right, and when we meet at your approaching holidays, wc will talk over all your plans and arrangements in good earnest and partieularly in referenee to your masters and studies whilst at the Hospital." 


\section{CHAP'TER IV}

\section{LEIRJAHRE AND WANDERJAHKE'}

\section{Part I. Medical Studies and the Flight to Cunstantinople}

BeFore Francis Galton started work at Birmingham, a delightful trip for the sixteen year old boy was arranged in July, 1838. He travelled across Europe with two young medical men, Bowman and Russell, who were going on a tour combining pleasure of travel with inspection of continental hospital practice. The link with Bowman is pretty clear; he was the son of John Eddowes Bowman, a naturalist and banker of Wrexham. He had been a pupil of Joseph Hodgson and then house-surgeon to the General Hospital, Birningham; in the previous year he had gone to London to study at King's College, and he was later well known to fame as Sir William Bowman, the ophthalmic surgeon. Of Russell the only knowledge I possess is that conveyed by Galton himself in his long letters to his own father.

\section{My dear Govenor [sic]}

Wednesday Night 25 of July, 1838

\section{Old Humuss}

First of all the things that $I$ send are those that are over and above what I want; there is mueh grumbling about the size of my carpet bag. Now to my history. I arrived at the Coventry Station house at about 9. Aeeordingly I looked about Coveutry till it was $\frac{1}{2}$ past and retumed and took my station on the steps; at 25 minutes to 10 the train came up-prominent out of one of the carriages was a pale jaundicy face, to which face was attached a most indescribable proboscis across which glittered a pair of speetacles. Before even the train stupt the mouth of the foresaid face was engaged at bawling out the name of "Galton" in such a tone that the passengers of the other carriages simultaneously popped their heads out of the windows expecting some awful calanity. I accordingly, most awfully ashamed for the police oflicer had taken up the hue and ery, and Galton was the burden of the song, elbowed my way to where the yellow faee was bawling, introduced myself, Russel's ${ }^{1}$ eyes glistened through

\footnotetext{
' 'The spelling varies of this name.
} 


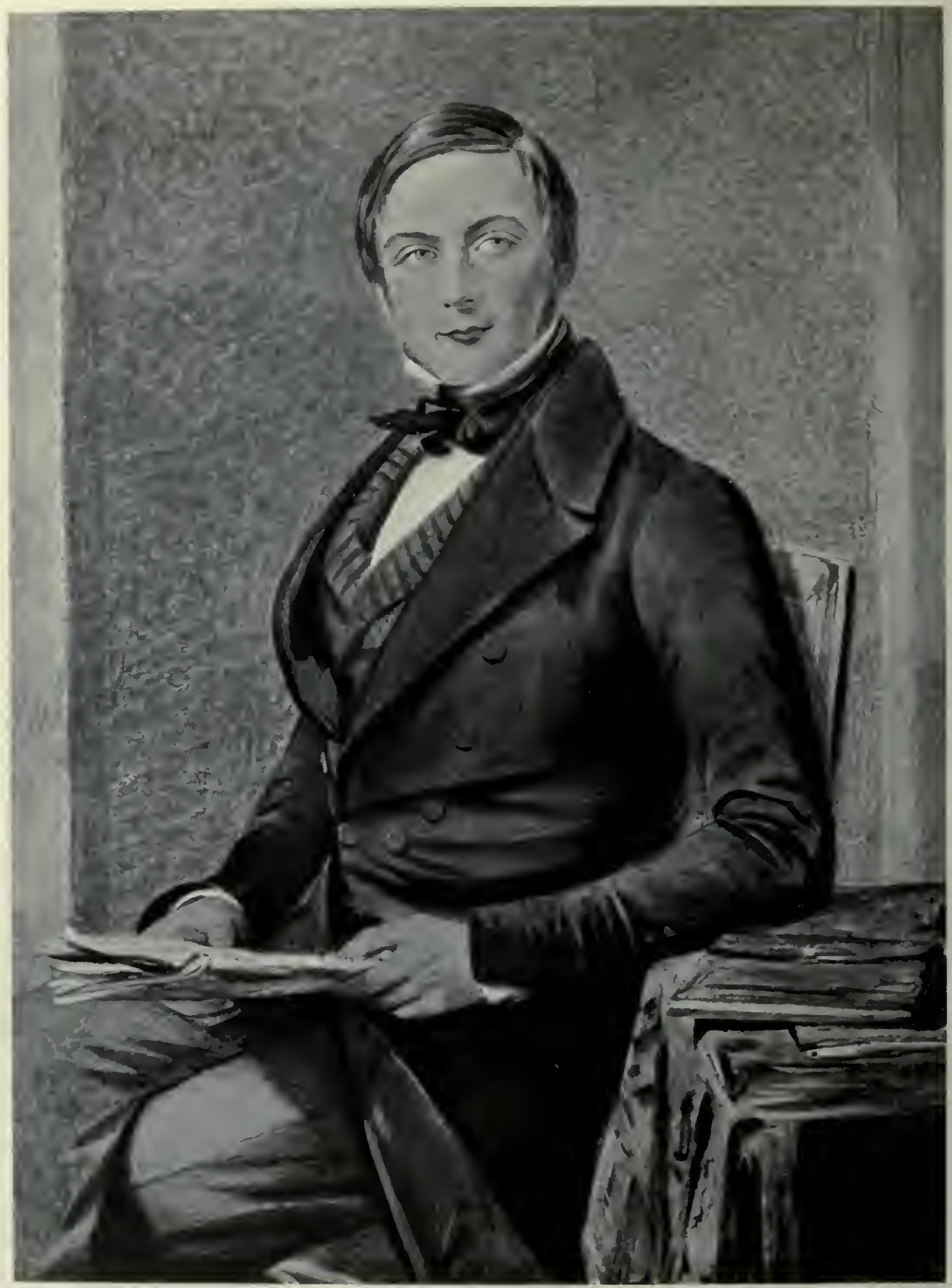

RRANCIS GALTON.

From a portrait by Oakley of 1840 . (Galton Laboratory, University of London.) 
his spectacles with joy having at last found me, and fairly out of brcath reseated himself. We went on to Rugby, where we were turned out into coaches, which were very bad ones, and so got to Denbigh Hall, where we got into the train again and reached London. Cabbed to the Old Hummums - went to Bowman and arranged plans for the next day.

Next day there were passports' to be got and viséed. Francis went to Barclay's for his letter of credit. Then he went down to dine with Barclay at Leyton and to stay the night, there being sixteen persons to dinner, all Barclays or Gurneys but three. Among other details of his two days in London Galton reports :

"I was magnetiscd to-day; it had not so much effect on me as last time; the Baron" said that he was quitc exhausted. We set off tomorrow. Bowman will press on to the top of thc perch, I cannot displace him, Russel and I are fighting for the next place."

We can picture the three young men, Bowman 22 years old, Lussell 20, and Galton much as we have him in his portrait, all ready and fit for their fiolic; Galton somewhat shy, and probably more boylike and sensitive to appearances than lis conlades (see Plate XLVIII). He was still in the stage, when to be unusual, e.g. carry a parcel through the streets-or look singular-was really painful to him. This was a matter in which travel would aid him and did, for while no man was inore careful of social convention than Galton, even in his later years, he did not allow it to become a tyrant and overrule comfort or convenience. I have heard him almost directly tell a caller to be gone, if he wanted to talk business, and the following anecdote communicated by his niece Mrs Lethbridge, witnesses how far in later years he had advanced from the boy of 16 , who felt shy when his name was bawled through Coventry station:

"I have an amusing recollection of a little trip to Auvergne which he and I took together in the summer of $1904 \ldots . .$. . The heat was terrific, and I felt utterly exhausted, but seeing him perfectly brisk and full of energy in spite of his 82 years, dared not for very shame, confess to ny miserable condition. I recollect one terrible train-journey, when, smothercd with dust and panting with heat, I had to bcar his reproachful looks for drawing a curtain forward to ward off a little of the blazing sun in which he was revclling. IIe drew out a small thermometcl' which registered $94^{\circ}$, observing, 'Yes,

1 Galton's passport dated July 24, 1838, and viséed by police and consuls and burgomasters in alnost evcry place he came to is now before me, a curious relic of this journey.

2 Query: Was this "animal magnetism" and the "Baron," Baron von Reichenbach 
only $94^{\circ}$. Are yon aware that when the temperature of the air exceeds that of blood lieat it is apt to be trying?' (I eould quite believe it!) By and bye he asked me whether it would not be pleasant to wash our face and laands? I certainly thought so, but did not see how it was to be done. Then, with perfect simplicity and sublime disregard of appearanees and of the astounded looks of the other occupants of our compartment, a very nuch 'got-up' Frenchman and two fashionably dressed Frenchwomen, he proceeded to twist his newspaper into the shape of a washhand basin, produeed an intinitesimally small bit of soap, and poured some water out of a medicine-bottle, and we performed our ablutions. I fear I was too self-conscious to enjoy the proceedings, but it never seemed to occur to him that he was doing anything unusual!"

It needed African travel to enable Francis Galton to throw off a certain self-consciousness; I have heard acquaintances, who knew perhaps little of his true simplicity and his width of toleration when intellectual values were under consideration, speak of him as conventional. He belonged, indeed, to an old-fashioned school, which liked good manners, which preferred its women to be pretty and diess gracefully, and which appreciated without worshipping the conveniences of wealth. But these conventional things were for him but grease to the wheels of life, to be put aside, whenever they interfered with the greater aims of existence. He might not have found it as easy as W. Kingdon Clifford did, to call in at the butcher's and walk home with a leg of mutton under his arm, but assuredly if "Universe" were to be solved on the homeward walk, he would have kept Clifford company regardless of the joint. Francis Galton's conventionality in boyhood and youth was largely shyness and self-consciousness-in manhood it was a traditional courtliness not without its protective advantages, and wholly disappearing before the warmth of his affection, when acquaintance had liperied into intimate friendship.

Our youthful travellers voyaged down the Thames and across to Antwerp, thence to Brussels, Mechlin and Liége (see Plate XLIX). Many of the letters to his father 'Tertius tell us of the usual travellers' sights, the churches, the pictures and museums, but occasionally we pass to things more suggestive, as the ornithological and geological collections at Brussels, and then to the first pleasures of the Rhine, and of the strangeness of foreign life.

"I really am quite full of obligations to you for letting me take this trip. I have been as happy as possible. You must exeuse my writing longer letters, as after being out all day, coming into the eoflee-room tired, you are stupefied with baecy smoke puffed out of the mouths of some 60 people. Then writing a long journal, it is rather tiring." 
Plate XLIX

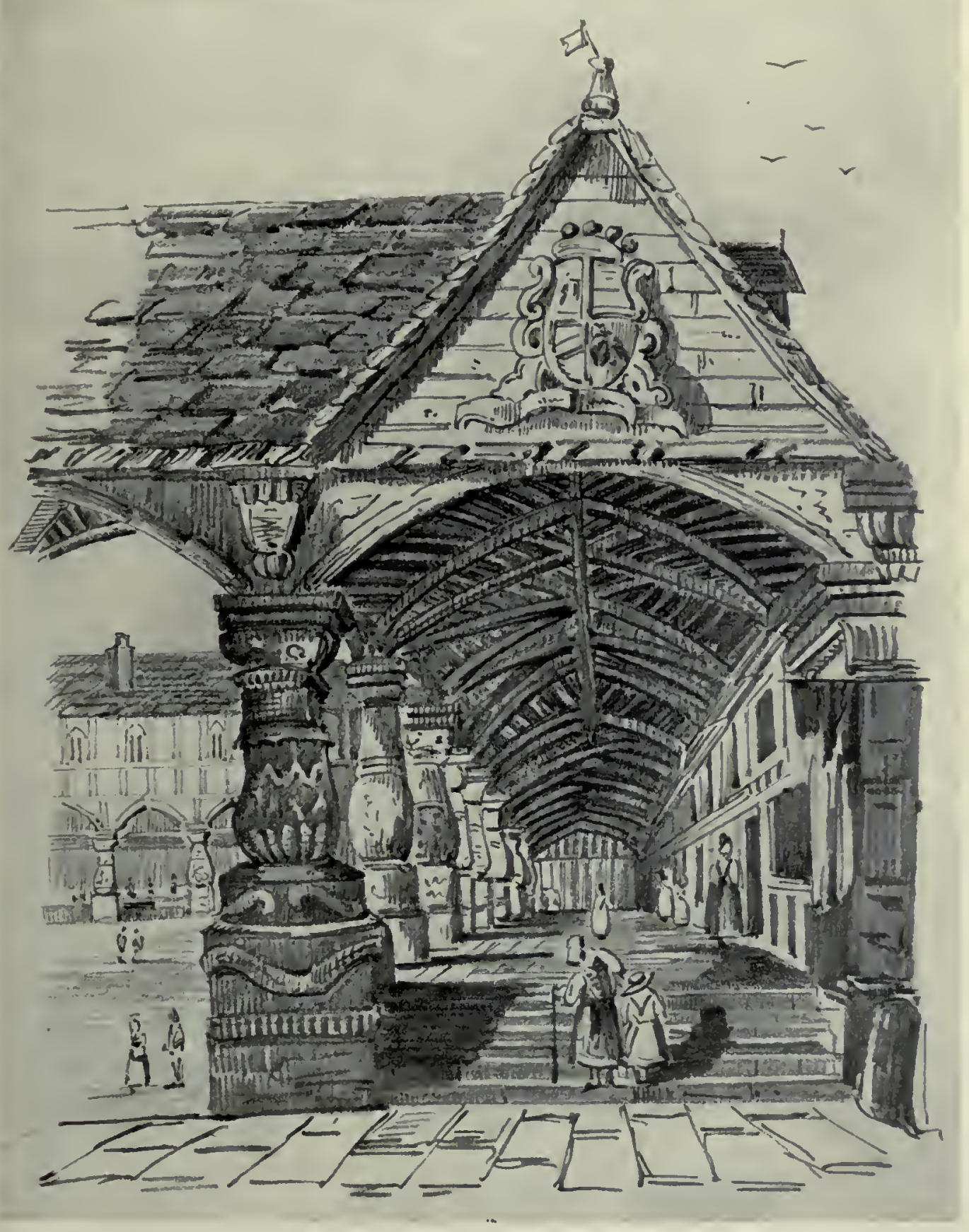

Sketeh by Francis Galton of the Bishop's Gateway at Liége. Visited 18338. 

The "tags" to his sisters (see Plate L) follow as usual:

"Dear Eman, sinee I wrote the first part of this letter I have been sketehing most tremendously-I took $\mathbf{3} 3$ drawings in the spaee of 4 lours or so in going from Bonn to Coblentz. I have taken also a great many other's. I am so very tired, that goorl bye and believe me ever your affeetionate F. Galton. Dear Bess, I have duly kept your preeepts in mind alout the immeasurable superiority of Englishmen. I have not lookerl out yet for vellum for you, beeause of earrying it sueh a distanee. Dear Delis, I am very glad I did not hother my head with Dutch liugo. Get 20 phrases in your heal, and in a few weeks you will speak German like a house on tire. Give iny love to Erasnus and Darwin. Good bye, Francis Galton."

In several towns the hospitals are visited. In Frankfort we read:

"They say that this is a very elean hospital, but I never fully appreeiated the value of fresh air till I found myself without its wards."

\section{Then followed Darmstadt :}

"Looked up the Museum; the jawlone of the Dudotherium and all that sort of fossil nonsense (!)"

Then to Heidelberg and on to Stuttgart and Augsburg with the Danube and Vienna as goal. Francis writes very patriotically; he is thoronghly enjoying himself, but his mind is expanding:

"There is eertainly nothing more useful than travelling. The more you see the more you are eonvineed of the superiority of England. However nothing ean be so admirable as a German or Frenehman who loves his eountry; it must be a great and genuine patriotism to be able thus to prefer it....... w wish you were there to see all the beautiful seenery we have passed through. The views were by far the most splendid I have ever seen. The arehiteeture is very eurious there is a great deal of the old Roman style. I have never seen a perfeet building of that style in England."

And again of Cologne Cathedral, "it is most splendid...I never" saw anything like it in England." Francis had yet to learn that the existence of patriotisin is not contingent on the possession of the best! In Heidelberg there was also experience of first class medical ability:

"Tiedermann a top-sawyer of the medieal line and a whole quantity of others. There was also a Dr Cobalt to whom we had letters of introduetion, a doetor who has made himself celebrated by transferring a wax eandle (without the wiek)from a eandlestiek into some holes in a skull i.e. as M.D.'s would eall it, injeeting the veinous system of the bones with wax (I think that is the phrase)."

In a letter from Munich we see that Francis has now to excuse his coming conversion to Bessy.

"Dear Bessy, I always keep your preeepts in mind, but after all the Germans are not so bad. Remember that as you told me the Hanoverians are our eousins, and the other states are brothers to them, and so they are relaterl to us. Also smoking is not 
their natnre-for had it gone by blood, it would have descended through the female line which is not the case..."

Then after attributing most of their faults to smoking, Francis continues :

"So evidently their nature is good but unfortunately much spoilt. And their Filwagen-their jolting is awful. N.B. (Don't read this aloud) I have got one boil and two blisters in such nwkward positions that when sitting back $\mathrm{J}$ rest upon all thrce; when bolt upright on two, and when like a heron, I balance myself on one side upon one!!! My feet are in a worse predicament having 3 blisters besides two agricultural crops. This is all from their Eilwagen or Jiligences. Next time I go abroad, I shall most certainly get my mackintosh double behind and blow it up likc an air cushion.... I am getting more contritc about not leaming the lingo. I certainly shall ncxt time."

Then from Munich through the Tyrol, and the Bavarian light blue and white colours - "trop tendre" for national colours as a Frenchman observed to Francis-are replaced by the yellow and black, the "awful Austrian stripe."

"But it was to be gone through, accordingly the coach stopped before the bar, when out popped an Austrian officer with nustachios likc sweep's brushes looking thunder and lightning. 'Kein Tabac' growled or rather roared the officer in interrogation (Tobacco is an imperial monopoly). Three 'Kein Tabacs' followed each other uttercd in a most submissive tone of voiee from us, like the echoes of Oberwesscl. 'The officer's eyes flared. He pointed to the luggage, down in the twinkling of an cye it came and was opened. He looked awful at my green bags with black strings, in which two or three dirty shirts werc esconced, and terrible at the other luggage; he made signs that every thing must conie out, when in the moment 3 Zwanzigers (a coin about $10 d$. ) toucher his hand- $\Omega$ galvanic shock seemed to thrill his whole system. The sour of his disposition, like the acid in Volta's pole scemed only to incrcase the change. The flare of his eye changed in an instant to a twinkle, the baggage was shut up and the officer fell into a 'paroxysm of bows' and away we drove. Got into Linz at 3 in the morning of the 26 th and at 7 we were steaming down the Danube in one of the carly voyages of stemers on this part."

Again there is a fraternal "tag" to this first Vienna letter:

"DeAr Brssy, You will be glad to hear for the honour of our country that the steamers on the Danube like those on the Rhine are all worked by English Engineers, and the orders all given in English."

In Vienna Dr Seligmann took our travellers the round of the hospitals' and museums:

In his letters from Vienna Francis does not mention the incident of the young and buxom female lunatic, who, on a visit to the asylum fcmale ward, rushed forward and clasped him tightly to her bosom as her lost Fritz! (MPmories, p. 25). He was probably too shy to record it then. 
$9 b^{\sigma}$

Plate I.

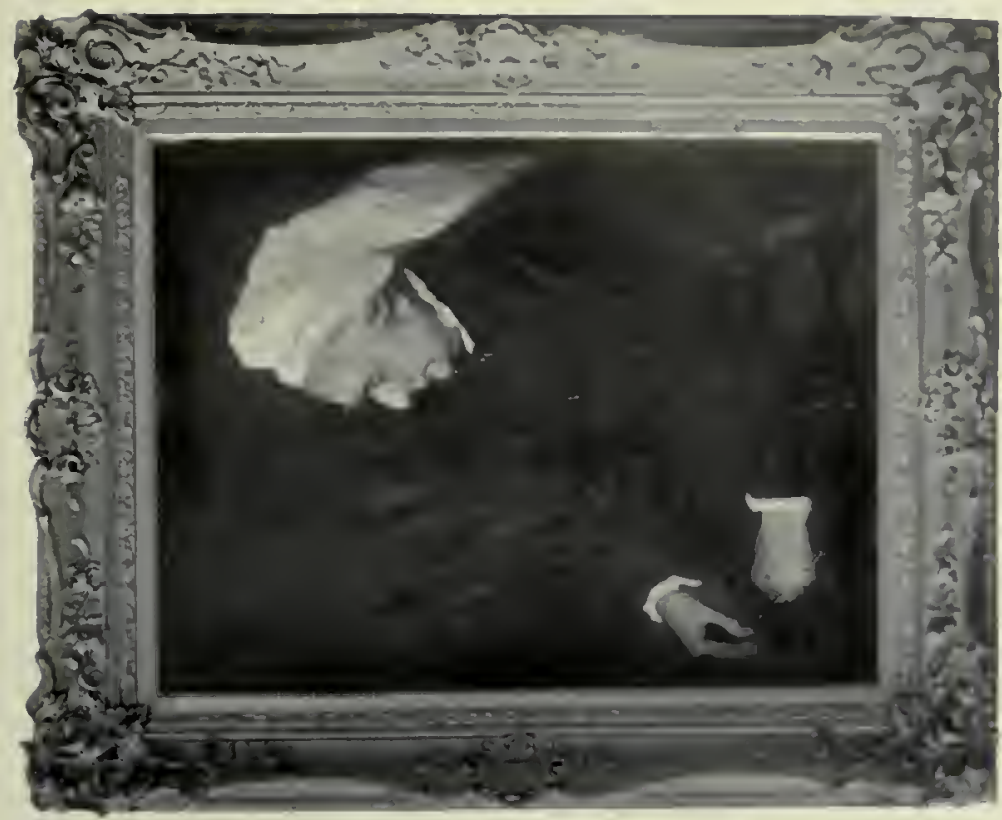

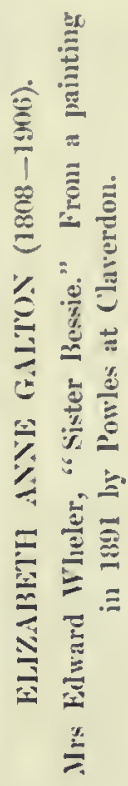

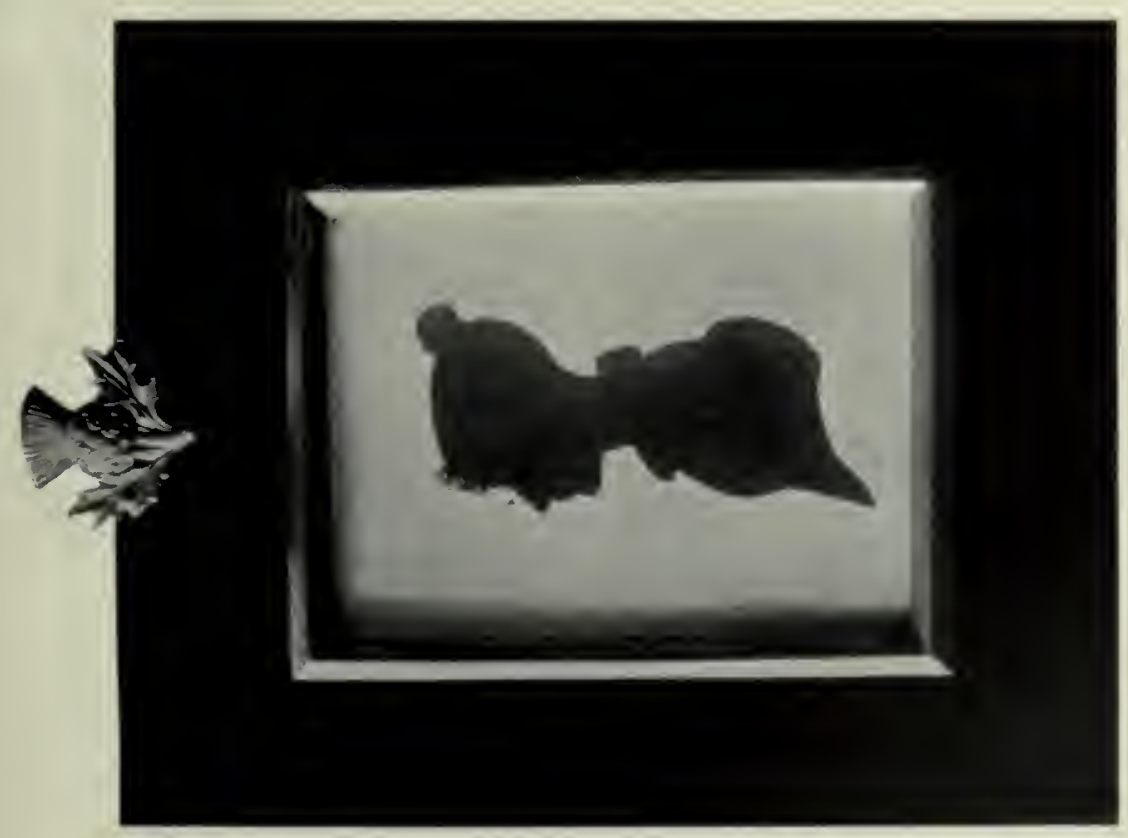

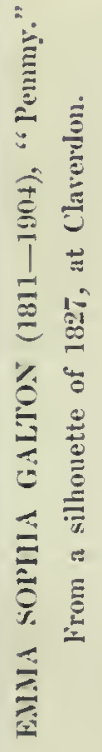



Plate I. bis

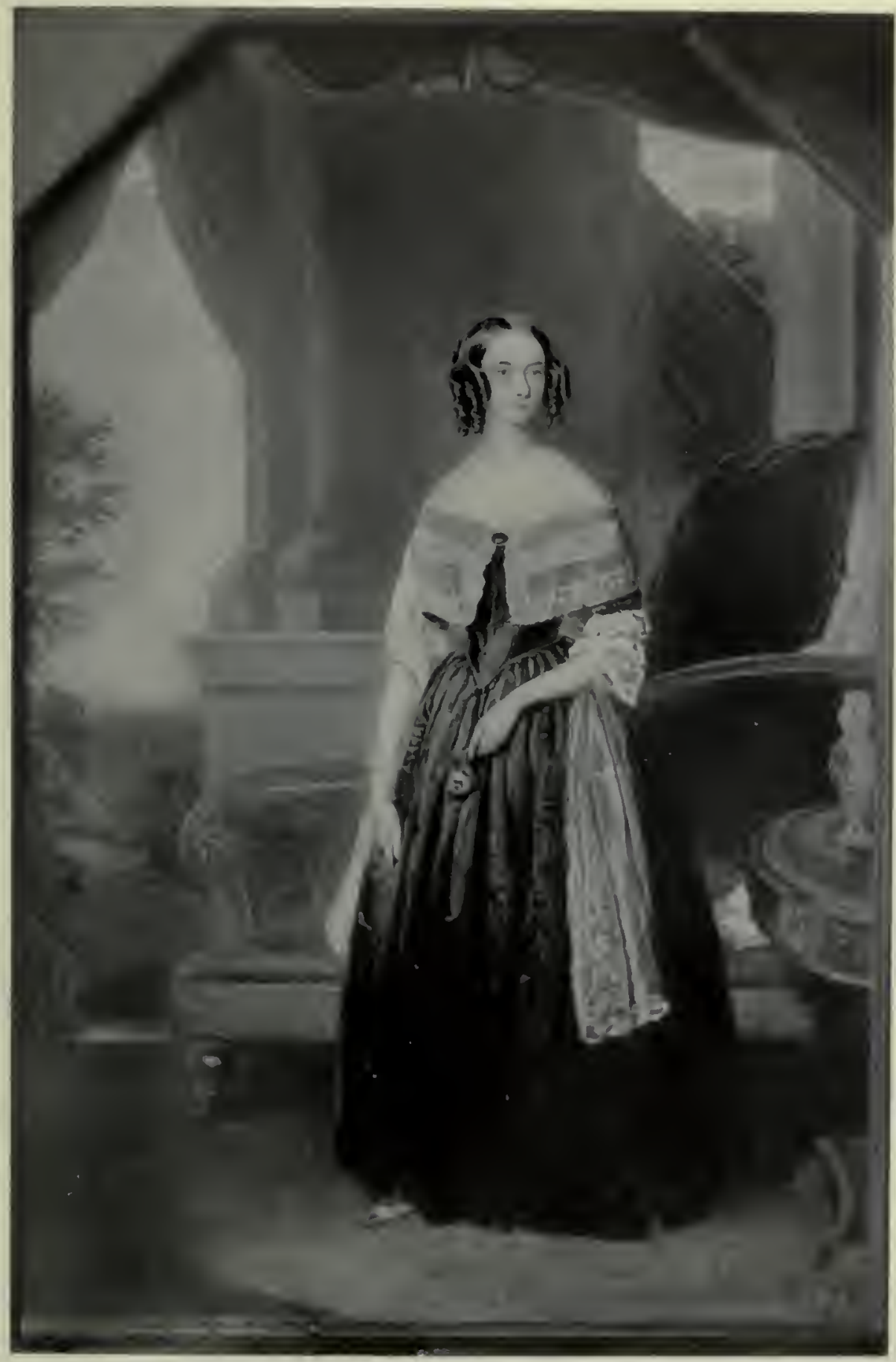

ELIZABETH ANNE GALTON (1808-1906), "Sister Bessy."

From at painting by Easton of 1844 in the possession of .Irs 'T. J. A. Studly. 

"He lias shewn us everything. 'Tell Bessy that after all some of these Germans are not a bad sort of fcllows."

The route now turned northwards to Prague, Dresden and Berlin. Saxon Switzerland was a disappointment as the Danube had been. From Berlin he gives Sister Bessy a quaint account of his medical comrades :

"Dear Bessy, The boils have subsided without the salt water, but thanks for the reccipt. However I must tell of some specimens of professionality in my two companions. My foot has been unfortunately exactly like Erasmus' at Weymouth; that is the nail of the large extremity thereof (which I will call eot for the same reason that you designated part of my fishing tackle $t u g$ ) most perversely grew in the side causing infammation. I happened to mention this to them; a smile of conscious professional power illumined the face of one, a grin of delight that of the other. Botls reaclily profferred their services, and as a backer Russell whipped out a bag containing 2 lancets, 1 spatula, a pot of ointment, a pair of surgical scissors, bandages enough and to spare for any compound fracture, 2 boxes of blue pills, lint, and a sewing up needle. $\mathrm{He}$ deposited these in succession on the table, adjusted his spectacles and smiled serencly. However as my foot pained me dreadfully, I made up my mind, and contrary to Gil Blas, accepted the Senior hand of Bowman. liussell disappointed retreated. Well, at last I found mysclf seatcd, the sick member was bared, Bowman, slceve tucked up, advanced scissors in hand. The reflected light from the instrument looked awful. He made a most beautiful circular twist of the hand for what earthly reason I do not know, and brought the scissors to their former place. He then examined my eot, shook his head, ejaculated: 'Bad,-very. Russell, have you a pair of forceps?' 'No' was the response. The two heads were now brought together to discover a substitute for the instrument in question; at last a bent pin was found to answer. Accordingly Russell had to hold the flesh back, and away went Bowman,-wrenching up the nail, then cutting it snip-snap all round, I writhing. However I could not help laughing at the opcrators. It was a splendid sight. And to do them justice all pain has gone away" [Sunday Sept xvi. 1838, Berlin].

Galton came home via Hamburg and Hull and his letter to his father from Kirk Ella where he paid a flying visit to the family friends, the Broadleys, may be cited at length :

$$
\begin{gathered}
\text { Tuesday }[\text { Sept. }] 25,1838 . \\
\text { KiRK ElLA. }
\end{gathered}
$$

\section{MIY DEAR Governor,}

I had not room in my last letter to tell you all the news so I will now commence. Aftcr lcaving Hamburg where we saw old costumes, old canals, cathedrals etc., etc. we had the screws of the boilcr get wrong, which caused a dclay of about 3 hours. We were then just too late for the tide and stuck on a sandbank where we had to wait for the ticle. We accordingly got the ship's boat and rowed to the Danish shore where we rambled about four hours. After that we werc too late to be able to sec our way at the mouth of the river, wherc we had to spend the night. Ncxt day we

P. (:.) 
passed Cuxhaven and Hclgoland, and had a long passage to Hull. We also got stopped by the Humber fogs, and could not proceed for a long time, making on the whole 31. dnys and 4 nights. I was dreadfully seasick and although like a true Briton nobody" (when on terra firma) can enter more fully into the spirit of "The Sea, the sca etc." or "On the glad waters of the dark bluc sca," yct my cnthusiasn dies within me, or rather like Bob Acres" courage "oozes out," but unfortunately not like his "out of the palms of his hands," but...... I arrived at Hull at 9 o'clock on MLonday. The time of absence from England was determined at 60 days. I was absent 60 days all but a quarter of an hour. After custom house etc. at Hull I set off for Kirk Ella and took the Broadlcys by surprise, who have been lionising me all about. Mrs Broadley unfortunately is not able to leave her room; Anne \& Charlotte are the only ones at homc. I shall escort Anne to Lucy so as to be at Moor Hall ${ }^{1}$ at 5 on Saturday and at Birminglaim about 6 or $\frac{1}{2}$ past. I shall then go to the Hospital, if I cannot get leave of absence. Please to tell all about what I am to do. Accounts etc. I will settle thell. I am very sorry that I could not come to see you, but I wished particularly to call on the Broadleys, if possible and accordingly went round by Hull. They are most kind and good natured to me, and Anne sends her love etc. Kirk Ella is a most comfortablc looking placc, surrounded by a colony of Sykes, their houses looking like towers to the ramparts of their garden walls. The weather is rather foggy. However tell Bessy that Yorkshire is not such a very bad place after all. The Humber is muddy - awfully - but anything looks well after the Elbe. And as for the English Hedge Rows and Green Lanes you cannot appreciate them till after having been abroad. Tell Bessy that if possible I am threc times as loyal as ever! The reason of this unreadable writing is the very uncomfortable length of my pen. I have marked the length below.

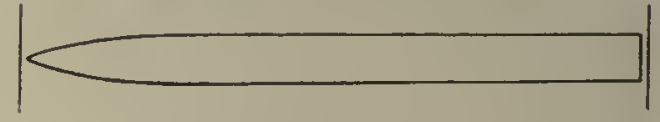

Good bye and believe me ever your affectionatc son, Francis Galton.

There are a few lines from Anne Broadley herself to Sister Bessy telling of Francis' bright face:

"The surprise as well as joy were very nearly too much for my wcak licad, and I was in a bewilderment the whole day, and still I cannot help looking at him with a sort of feeling as if it were a dream, and it cannot be true that Francis Galton is actually seated opposite to me at home. Mama is nearly as happy as I am to have a Galton at last under her roof. He looks very well and is just the same clarming boy as ever; not a bit spoilt, full of cnthusiasm on all he has seen and giving a most agrceable account of his most agreeable tour. Mana thinks I have not said enough about him before...... I feel proud not a little of his coming to sec me."

Francis escorted Miss Broadley to Moor Hall, a delightful cavalier, but if we read his letters from the early days at the Larches to the end of his Cambridge career, we feel impelled to point to this continental tour as the dividing line between boyhood and manhood. Francis is no longer a charming boy.

1 The home of his sister' Lucy, who had married James Moilliet in 1832. 
Returned to Birmingham Francis Galton plunged at once into his medical studies. 'The dozen pages in Galton's Memories which deal with this first medical experience are perhaps the most fascinating in that book, not only for the picture they throw on lospital life in the first half of the 19th century, but also for the indication they give of the great advantage clinical experience was to Galton himself. I do not propose to reproduce what Galton has told so well, but merely to supplement his account from letters written to his father Tertius during this period.

A first letter of Oct. $10^{1}$ deals with the supplementary studies Francis was planning.

Wednesday [Oct.] 10th, Lennington.

\section{My dear Governor,}

I have just returned from Birmingham where I dincd yesterday with Dr Booth and the day before with Hodgson. Hodgson advised me now to read some medicine and Dr Booth has lent me the book, but when I mentioned that I intended to go on with German whilst I was at Leamington, he said that I had certainly better not, but give up my time to Pharmacy. Accordingly I have not called upon the Pole, as I know that you wish me to knock under to Hodgson in everything of that sort. $\mathrm{He}$ and the Dr were both very good-natured to me. I was sorry to hear from Hodgson rather differently to what I had before understood. His words were "that I must expect every possible annoyance both in society and in continual interruptions; that I shall never have a minute that I can call iny own," and he spoke very strongly on the subject.......By the bye Hodgson says that my masters must be German and Mathematics twice a week, and he will inquire about them. Not drawing; he says that I sliall have quite sufficient to do with these.......

Ten days later Francis again writes of his mathematical and German studies :

"I will see if Mr Mason can give me lessons or not in mathematics.......Mr. Jones is spoken of as the best German Tutor....... Would you be so kind as to send me my German Grammar and Elementary Book and Klopstock and a few Tracts. Adèle will do this. Also please ask Emma to put out from my knick-knack cupboard a little instrument for boiling water, it consists of a cylindrical copper vessel-a sort of boiler with a bent pipe running out of it,-and a spirit lainp. [Picture.] There is a hospital seat at St Paul's which I attend. Tomorrow there will be an amputation of the leg, when I shall see how I can stand fire....... am rather anxious to begin dressing myself, as it is a bore sceing some pretty little operation going on where you cannot be the performer. By the bye would you tell me if I am to dress for Mr Hodgson or not as I really do not know what you have fixed on in that way. All the 'higher powers' are very good-

\footnotetext{
'Scnt to his father who was staying at Hadzor.
} 
natured etc., but snobs. - the Dispenser is not at all a blackguard, but you do not become intimate with him, which I am glad to sec as I slall be muclı under him."

On Nov. 10 we have an amusing account of work in the Hospital :

"Therc is an immense deal of work licre. It docs not come in one long pull but in a series of $j \in r k$ s of labour between intervals of rest, like playing a pike with a click reel. I will give you a sort of diary of the ovening of the day beforc yesterday. $\frac{1}{2}$ past 5 p.m. went round all the wards (No joke I assure you)-made up about 15 prescriptions. $\Lambda$ wful headaclie etc. Entered in the Hospital Books records etc. of patients; writing in my case book etc., hard work till 9. Supper. Went round scveral of the warls again. Accident came in-broken leg, had to assist setting it. $\frac{1}{2}$ past 11 , liad to read medicine etc. 12, very sleepy indeed, lighted my candlc to go to bed. A ring at the Accident Bell ; found that it was a tremendous fracture. Was not finished till $\frac{1}{2}$ past 1. Went to bed and in the arms of Porpus. 3 a.m. in the morning: a tremendous knocking at the door; awful compound fracture, kept me up till 5. Went to Bed-up again at 7 o'clock.-Ratlier tiring work on the wholc, but very entertaining. Attended a post mortem and dissection 2 days ago-Horror-Horror-Horror! I do not know when I shall get over the impression. It was a woman whose wounds I had assisted to dress. I made her medicine and prescribed once or twice for her. My first regular patient died also, yesterday morning. However as it was a burn, my mind is perfcctly casy. Don't tell this it won't sound well. I shall set up a case of instruments soon. I can write prescriptions splendidly, and moreover begin to understand all the humbug of medicine, which is not a little. I am very sorry that you lave got the gout, if I were at home I would prescribe for you with great pleasure. Tell Bessy that I have some valuable receipts - such as splendid Tootl-Powders-Glorious Perfumes-Beautiful Varnishes. Also Lucy's Biscuit Pie Crust answers very well.

I cxpect to cut Gil Blas quite out. I can hardly refrain from sending you a splendid receipt for cure of the Gibberish.

Good Bye and Believe me ever,

$$
\begin{aligned}
& \text { Your affectionate Son, } \\
& \text { Francis GalToN. }
\end{aligned}
$$

......Please send my Delphin Horace, and Ainsworth's Dictionary, and Schrevelius' Lexicon."

In November we find Galton busy with his German and Mathematical instructors; he is sending for Snowball's Trigonometry. $\mathrm{He}$ has had "what they call a grand field-day, six important operations." "The M.D.s are really most good-natured to mc. I am allowed to spend a Sunday every now and then out." A letter of Dec. 5, 1838, deserves reproduction in its entirety-it is so characteristic of Galton's varied interests, of his fund of quiet humour and of his liability to overwork himself! 


\section{Dec, 5, 1838. Birmingiram Grameral Hospital.}

MY DEAR Goverior,

I should have written before but I was waiting for my instruments, to sce if my funds were sufficient. They have not yet come, so I write to you at once. 'Thank you for your lctter. I am vcly glad to hear you are flourishing. Now for business. My Matliematical Master comcs at 7 o'elock Tuesday Evening-my Gelman at $\frac{1}{2}$ past 6 on Friday Evening. My time is distributed as follows: Up by 8. Breakfast de. until $\frac{1}{2}$ to 9 . I then go round the House with Mr Baker; afterwards at about $10 \mathrm{I}$ "postmortemify" should there be a subject, sometimes operations take place etc.; if not, I dispense should there be many out-patients: otherwise I read Medical Books, and go round with the Surgeons and sometimes Physieians (who by the byc arc aвомrably unpunctual). However it is impossible to regulate that part of my time, but my hands are full with the above occupations until 2. Not forgetting by the bye 5 minutes ats the clock strikes 11 which are invariably employed by me in swallowing a Digestive P'ill. Well, at 2 o'clock I dine etc. till $\frac{1}{2}$ to 3 , I then read Medieal Books etc. till $\frac{1}{4}$ past 5 . Then take tea till $\frac{1}{2}$ to 6 . Then Mathematics till $\frac{1}{4}$ to 8 . After that I write in the rogisters I have to keep and [dispatch] a few other little hospital jobs; also go round a fow of the wards etc., and read Horace and Homer on altcmate days till $\frac{1}{4}$ past 9, wlen supper is ready. After supper (at $\frac{1}{2}$ past 9 ) I read German an hour or so according to the state of my headachc. I walk out when I can-about 2 or 3 times a week, generally between 3 and 5 . When I dine out I read Mathematies from 2 to 5 and return to the Hospital at $\frac{1}{2}$ past 8 (if with Dr Booth); only just show myself at supper, so I get $\frac{3}{4}$ of an hour of medieal reading from $\frac{1}{4}$ to 8 to $\frac{1}{2}$ past 9 and then as before. I also always make this law : slonld an accident oeeur sueh as a fractured leg which takes sometines 2 hours to set, such as finding splints, making pads etc., I do not continue my studies in my other branches as if nothing had happened, but divide my remaining time between all that I lave not done that day. I like Mr Abbot my Matliem. Master very much; he adviscs me not to read the Calculus until I have read a little of other branches. I have read in the last fortnight the greater part of Analytieal Trigonometry, I have got some way in Conie Sections, which I like very much. I expeet to have finished them in about a month or 6 weeks, and then for the Calculus. Ask Bessy not to row me for this writing beeause I really do generally write better, but I cannot make my pen mark and I have no knife in my pocket. Good Byc and believe me ever your affectionate Son,

\section{Francis Galton.}

P.S. You ought to see me vaceinate I do so piteh the laneet into the children's arms. If $I$ take wine $I$ should be the only one that does so at table; aceordingly I cannot do so.

But the rushlight was not merely burning at both ends, it was in the oven itself; and Francis Galton was soon to feel the effects of this overstrain. A letter of Dec. 22 postpones his Christmas home visit, a dresser was ill and he could get more experience by staying:

"Tell Bessy that I am fully awarc how wrong it is to violate old eustoms etc., espeeially that of meeting on Christmas day, but it can't be lielped. Really now that 
I an turned 'Doctor' I find that I ean deeide on nothing beforehand; this is not ny first disappointmont. I do not know if I told you what a public charaeter I have beeome. Four distinct times in walking in Bull Street and New Street have I been surromded hy rarious jurenile members of the Rag-Tag and Bobtail division of the inhabitants and addressed not with hurrahs, but with 'I say ould chap, gie us some medicine,' also 'There gocs the Doetor' and other phrases pointing to my profession."

On January the 8th, 1839, Galton is still at his post, and his experience is increasing! He reports to his father his first experiment in dentistry :

"I tried my hand at toothdrawing the other day. A boy came in looking very deplorable, walked up to me and opened his mouth. I looked awfully wise and the boy sat down in perfect confidence. I did not manage the first proceedings well, for first I put in the key (that is the tooth instrument) the wrong way, then I could not cateh hold of the right tooth with it. At last I got hold. I then took my breath to enable me to give a harder wrench; one-two-three, and away I went. A confused sort of murmur something like that of a bee in a foxglove proceeded from the boy's mouth, he kicked at me awfully. I wrenched the harder. When, hang the thing,-crash went the tooth. It really was dreadfully decayed-and out eame my instrument. I seized hold of the broken bits-the boy's hands were of course over his mouth and eyes from the pain, so he could see nothing - and immediately threw them on the fire and most unconcernedly took another survey of the gentleman's jaws. The tooth was snapped right off. Well, I pacified him, told him that one half the tooth was out and I would take out the other (knowing full well that he would not let me toneh it again) and that it was a double one. But, as I had expected, he would not let me proceed. Well there was another tooth which he wanted out and against whieh $I$ took proeedings. I at last fixed the instrument splendidly and tugged away like a sailor at a handspike, when the boy, roaring this time like a lion with his head in a bag, broke away from me and the sawbone that was holding his head, bolted straight out, eursing all the Hospital Doctors right manfully. So much for my first tooth-drawing."

\section{To his sister Adèle he writes under a fortnight later:}

"I have been rather invalided and was sent off for a few days to Moor Hall to recruit. I shall look you up at Leamington some of these fine days, but not just yet. Hang it, it is now past ten in the evening and a car is just rolling up to the door, so I must finish, perhaps it may be a broken leg, so Good bye, ete."

The next day he adds a postscript :

"It was only a bad seald. This morning Hodgson gave me a letter from the Governor to him, and in reply, first of all my arm is all but well, it was an old sorc which I had forgotten when disseeting, it broke out of eourse and then subsided; about a week or ten days after that it broke out again, and gave me some trouble. Then as to my general healtli iny headaches are bettcr than they were onee-a great deal better, and I have of course a little hospital fever ac., but that is all. About my mind which Luey attaeks I shall not say much, exeept that it is werry uneomfortable, but I shall soon get over all hospital horrors, ete., ctc. I am in a great hurry as I want to get a 
walk out now, not having had one on aceount of the weather for the 3 last dings. Of course I have nothing to tell you, as the merlical world is quite a little world of its own and its proceedings $\mathrm{I}$ should inagine are not very interesting to the eivilised one. Oh Donner und Blitz! here is another aeeilent. T must look sharp for my walk, if not kept long by this clouble ealamity both to me and patient. I am calling out-Coming-tartar-

Fras. Galton."

So the months went on-far too much work and too little playnone of the sports and pastimes of our own medical schools. At Easter there was again no holiday:

"Can't come-quite impossible. Patients increased-awful number. Cut a brace of fingers off yesterday and one the day before.-Happy to operate on any one at homeI am flourishing - wish I could say same of my Patients. Love to all. Bye-hye.

Fras. Galtow."

But by July a change was really needful. Francis is planning a tour and mentions as possible companions his cousins Theodore Galton and Edward Darwin. His last letter from the Hospital to his father runs as follows :

$$
\text { July 10, 1839. Gexeral Hospital. }
$$

\section{MY dear Governor,}

I have been waiting before I wrote to you, to see whether Mr Hodgson would have recommended anything for me, but as he has not, I will tell you what he has done. He called me asidc and asked me if I felt unwell or not, I told him that I was,-gave syinptoms ete. When Mr Hodgson asked what $\mathrm{I}$ had intended to do about this trip that you proposed, $-\mathrm{T}$ replied that I had but just heard of it, and that I did not think that I could spare my time. To which Mr Hodgson agreed, said it was a foolish plan \&c., dc. (N.B. He was in a bad humour because an operation of his for cataract had not exactly sueceeded), and after saying other things of the same import, tooled off. He did not prescribe for me. However I shall do very well. There is capital fun going on here-only think of Dr Booth. Amongst other performances of his when he led the police into the Bull Ring, the pcople swearing, throwing stones at him etc., ctc. The Dl' (it being dark) coolly rode to the nearest Lamp Post, put his hand in his pocket and pulled out his Barnacles, inserted it again and lugged out the Riot Aet and read away most edifyingly! By the bye about Mr Abbot-I have had 30 lessons, a brace in November-do. in June and regularly in the intervening months'. His banker is Taylor and Lloyds, and he wishes to have it directed for the Rev. J. Abbot, Free School. Our Matron has lad a tremendous epileptic fit; she is in bed still and very unwell. Quite sorry to hear alout your Asthma, but you must I suppose console yourself with the Aphorism of the Cook on the Eels- "Nothing when you are aceustomed to it." By the bye I liave been on the stage with Van Amburg-took up

1 This proves that Galton had never taken a week's holiday sinee he started at the Hospital ! 
his whip and shook it (it is a common horse hair one, but very large, not heavy), and helped to draw the Lions' Cages off afterwards. I am rather badly off for soap. My Books cost a wee and there is my British Association fee $£$ l (I have kcpt regular Accounts !!) Amongst others of my entrics is one: Various Charitics 4d. I must look you up some of these fine days. T have got no news watsumever. So bye bye.

Your affcctionate Son,

Fras. Galton.

P.S. Mr Thomas Knott the Editor of Aris' Gazelte has dicd suddenly of apoplexy.

Of Samuel Tertius Galton it must be said that he knew what his son Francis could stand. The summer trip did come off and what is more Francis did not return in the autumn to the Birmingham General Hospital.

On September $2^{1}$, Francis started with his father and Sister Bessy via Coventry to Liverpool and thence by packet to the Clyde and Dumbarton. The tour went through what is now very familiar country, Loch Lomond, Loch Long, Loch Katrine, Oban and then across to Aberdeen, and Ury, the home of the Barclays. Francis' diary of the tour is still extant, and it comes to an abrupt end on Sept. 10, apparently because he had already filled in the bulk of the remainder of the book with sketches. We know from these that the party were at Inverlochy Castle on Sept. 17th and at Ury on Sept. 21st. There are no less than six unfinished sketches of Ury, three of the outside of the house, one of the chapel and burial ground of the ancestral Barclays, one of the wall-a tremendous looking structure-over which Captain Barclay's grandfather is reputed to have thrown a bull, and lastly the inside of the gothic window above the porch-with the deep window recess showing the thickness of the walls-where Francis' grandmother, Lucy, had sat to work her sampler, according to the custom of the fanily. Ury must have been a fascinating spot to those whose ancestry had dwelt there, and thus Sister Bessy describes it:

"Wc left Inverness at six o'clock in the morning passed Forres, where the witches met Macbeth, arrived at $A$ berdeen at 7 o'clock, drank tea at the Inn and then came on to Stonehaven where we slept. After breakfast we drove up to Ury which had belonged to the Barclays for some centuries. Margaret Barclay showed us over the curious old house (now blown up and a modern house built by the Bairds), she showed us the Mceting House of the Quakers, close to the house, which all Quakers when travelling in Scotland, came to see; a tiny closet, out of the large sitting room, is where my

1 The British Association met in Birmingham this August; and there is evidencc from Galton's accounts that he attended it-it was probably lis first meeting. 
great-great-great-grandfathcr Barclay wrote his famous 'Apology for' the Quakers.' We went up a small hill at the back of the house to the chapel where all the Barclays aro buriel. Then into the garden, where my great-grandfather pushed a bull over the wall, 60 feet down. We went over the farm with my uncle Barclay, and walked through "a wheatfield, the stalks higher than our hearls'. In the sitting-l'oom we saw an noveablo panel, behind which was a secret elamber to hide in. Margaret Barclay showed me a lock of Prince Charles' hair and after much urgent entreaty, I got her to give me the one hair I lave. She also showed me a miniature of Queen Aıne set with diamonds, which Queen Anne gave to my ancestor. She gave presents to many of the Jacobite fumilies, it was supposed with the hope that they would espouse her brother's claims to the throne after her cleath." (Mrs Wheler's Reminiscences, Sept. 1839.)

Francis went back with his father and sister to Leamington, and on Oct. 3rd the lengthy letters to his father start afresh. We find him at New Street, Spring Gardens, established in the house of Richard Partridge, Professor of Anatomy at King's College, London. Here Galton had two or three fellow pupils all attending the medical lectures at King's College. These were a distinct advance on the Birmingham system of education. There was preliminary training in anatomy (under Partridge with Bowman and Simon as directors in the dissecting room), in physiology (under Todd, a man whose encyclopaedic works can still be studied with occasional profit) and in chemistry (under Daniell, of battery fame). For the first time Galton came into a more or less modern scientific atmosphere, and a microscope became a necessity. Forensic medicine also was a subject of delight:

"It had a sort of Sherlock Holmes fascination for me, while the instances given as cautions, showing where the value of too confident medical assertions had been rudely upset by the shrewd cross-questioning of lawyers, confirmed what I was beginning vaguely to perceive, that doctors had the fault equally with parsons of being much too positive." (Memories, p. 42.)

In his first letter Francis expresses pleasure with his environment, his fellow pupils are "two scamps" and one seemingly very nice fellow. In his second letter he gives a more detailed account of his surroundings :

$$
\text { October 12, } 1839 .
$$

\section{My dear Fatuer,}

17 New St., Spring Gandiss.

Thank you very much for your letter-uncommonly so for its contents, which I have got duly receipted. This is a very comfortable house and I certainly have many extra opportunities of reading. Our sitting room is quite respectable, well lighted,

' Captain Barclay was not only a famous pedestrian, he was also a great agricultural reformer, anrl did much for Scottish agriculture.

1. G. 
ditto carpetted ; firo ete.; furnished with a most eapital library, about 10 skeletons, ete., a loyal east of St George and the Diagon, and a bust of Harvey, and I don't know what else. A view from the window of the Admiralty with a telegraph at the top eontinually working and attitudinizing like a skeleton learning gymnasties; the Horse Guards ete. My bedroom is sinall and a garret, but the most eomfortable one possible not too large nor too small, with bookshelves and a reading desk where $\mathrm{I}$ stew away most comfortably.......

King's College is a very niee place. I am there from 9 till 4 attending leetures and disseeting. There is a sight there which a Frenehman would give his ear's to see, viz. a most splendid eolleetion of large green frogs all alive and kieking and eroaking too, kept, however, for Dr Todd's Physiologieal Experiments. Thank you for the mieroseope it was just the thing; tho shirts too were werry aceeptable'.

I was quite surprised to hear that you got home without sueh an amiable personal as nyself. I am glad that the tartans were properly appreeiated. Good bye ete. Fras. Galton.

Dfar Pesmy-I want you to be in the vely best humour possibly and the reason is this : in my bedroom there is a yellow wall $12 \mathrm{ft} . \times 5$; now this does not aeeord witl my notions of beauty but-remember you are a eapital Pemmy-if there were two watereolour pietures to relieve its monotony, it would be most reputable. Now there is not a single engraving that will do in all London, they are all either too large and too expensive or too small and good for nothing. Now if you would lut paint me two pietures, eaeh about the size of a novel and send them up by some pareel or other I eould get them framed in blaek for 1 bob apieee. I should like something in a Prout style, not three Turks smoking their pipes in a triangle, with one blue hill in the distance and a white river between them, and something on the hill with two uprights and a eross bar like a gibbet only intended for the ruins of an old temple but some building or other well touehed up witl Indian Ink and reerl pel1. I shall take such eare of them. Now remember the "aspeet" of the room is this: pretty well-lighted, 1 window not opposite the wall,

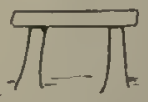
whieh is yellow. The frame will be blaek. You will now know what sort of things will suit. Tell Bessy that the paws are improving. Hair rery bad. Nails middling but better and that "sinutty" week is not quite passed. Good loye-You are, at least will he, a niee Pemmy. Love to all.....

Postscripts and other addenda refer to the presentation of his first cheque at Barclay's Bank. It is clear that Sister Pemmy provided for the artistic element, and Sister Bessy supervised Francis' neatness of attire and personal appearance. Although there are no letters bearing on Francis' . transfer from Birmingham to London, it is clear from the next letter I shall quote that his career-a year in London followed by Cambridgernust have been practically settled before he left Birmingham.

1 I have retainer any intentional wrong spelling, the unintentional slips are somewhat numerous, they would eomfort other sufferers, but I have thought it best to remove then. K. P. 
Sundey Oct. $16^{\text {th }} 1839$.

17 New SPRing Gardens,

Lonvon.

\section{My deAR Fathelr,}

Thanks for your letter. I have been thinking over about another year's Londonizing, and, having crammed up "Whewell's University Education," I certainly think that it would be better to give it and the Laboratory up altogether. $\Lambda$ s the Dissecting season is over about June (I forget exactly when) my hands will not be full for three months or so beforc going up to Cambridge, in which time I shall hope to get up my first part of Mathematics well, and a fair proportion of the Classies that Mr. Blakesley has mentioned. I think it would be as well at that time not to toucl cither Mechunics or Conic Seetions, but to exhaust Merridew's shop in seribbling paper for working equations ete. I am as well as possible, getting thorough exercising twice a week at Angelo's either at Carte and 'Tierce, or else in pitehing into a huge Life Guardsman, six feet and a lialf high in lis slippers, or rather in his pitching into me with single stick. I have no lieaduches or anything of the sort and disseeting inereases the appetite wonderfully. I don't send any accounts as there is nothing particular to put down. As for those I sent last time, I only sent the General not being very fond of Double Entry, though I have the particulars safe in my account book. For instance I did not write 2 ounees of Epsom Salts-2d., liaving included that in the Washing Bill, sinee it was most undoubtedly for a cleaning out that I bought them, and so for the rest'.

Pemny, you are a most dutiful sister. Pictures splendid, the framemaker nearly broke his windows when he sterted back in admiration; they are hung up with my littlc Ariadue betwcen them. Are they real seenes? However, don't ask me whether I admired the perspective. And now in return I will show you what a deal of attention I bestow on them; I will just nnake a caleulation. I am, on an average, 5 minutes dawdling in getting up, 10 minutes ditto in going to bed. During this time I must necessarily look at one side of the room or the other, and as the room is bare on the other side that can be no attraction in looking there. Therefore at least $\frac{2}{3}$ or 10 minutes will be daily spent in looking at your pictures, besides this I am always awake about $\frac{1}{4}$ of an hour before getting up, when I cannot help seeing them as they are just before my nuse, that makes 25 minutes a day, or 12 hours nearly a month or 156 hour's or $19 \frac{1}{2}$ days of 8 lours each yearly:

Dear Bessy, I did not receive your missal ; of course it was an accident. I didn't ask for it by letter, as I knew you would draw it intuitively; it will look so pretty, especially as it will be about the size of Emma's pictures, rather larger perhaps but same shape. Paws vastly improved, but horrors! about a week ago a huge crimson boil appeared a little to the left of my nose; it was as large as a fourpenuy piece and seemed

1 Samuel Tertius Galton was most partieular as to his son's aceounts, and we find specimen accounts with various methods of keeping them sent to his son Francis. Hc endeavoured to inculeate thorough business habits in his children, while at the same time he was most liberal in his remittances and preserved to his death the most intimate confidence and friendly familiarity of his son Francis. 
to increase "wisibly aforo my werry eyes." What eould $\mathbf{l}$ do? Partridge sail it was a earbuncle, but I knew better. For I had as soon as I had seen it, read 12 diflerent authors on that point, and thus prepared, I was detcrmined to fight vigorously. I pitched a lancet into it, poulticed it all night, swallowed a fearful dosc of blue pill and colocyuth, and an ounce and a half of salts next morning. They felt very aggravating in ny stomach, but at 3 p.m. the boil was almost colourless and gone down wonderfully. Tuesday, fast improving, laneet cut healing. Wednesday, all but well, left off stiekingplaster. Thursday, cured. Extreme cases, require extreme measures. Plcase write and tell me when the Gurneys come. How of ten ought I to call on the Horners-ditto on Chas. Darwin, who left his card here the other day. I drink tea with Mr Janies Yates $^{1}$ tomorrow. Good Bye, love to Maminy, Delly etc.

Tell Darwin that I have lots of tales to tell him. Partridge [sends] complts.

In the next few letters we find the question of future education still prominent. Clearly Tertius Galton was emphasising the importance of laboratory work, especially in chemistry, and there appeared little chance of it at Cambridge. Francis' social side was having considerable claims made on it, and he was working and playing hard at the same time. Again, as at Birmingham, the rushlight was doubled up and burning at both ends.

Nuv. 5, 1839.

\section{My deAR Father}

I was invited to tea by the Horners, very kind invite, but unfortunatcly signed Anne (I think) Horner. Now as I had not the slightest earthly idea whether" there was such a person as Mrs Horner or not, I did not know whom Anne meant, and therefore I eould not answer, so as soon as I had time I set off to eall. But they liad direeted their note Bedford Street, Russell Square, and when I got to Russell Square, I could find no such plaee. I went to B. Street, Bedford Square, Upper B. Place and knocked at, every No. 2 in the neighbourhood. At last I ealled a consultation of three polieemen, who after some debating gave over my case as hopeless; what could I do? Their name was not down in the Court Guide. The next day I made an expedition to 2 other Bedford Streets, but no go. Then came the day 1 was to take tea with them, and it suddenly struck me that the numbers in Lower B. Place might be different from those in Upper B. Place. I tooled there and luckily it was right; the Lyells were there, and one of the Horners liad just returned from Germany, St Petersbury etc. they werc very kind to me. Mr Horner was in the Nortl. I shortly after called upon Cliarles Darwin ${ }^{2}$, who was most good-natured ete., he has been unwell. I called upon Mr. James

' The well-known Unitarian and Antiquary of Lauderclale House, Highgate, and founder of the Yates Chairs at University College, London.

"Charles Darwin had returned from his voyage in the "Beagle"; had been married in January of this year (1839) and was living in Upper Gower Street. 
Yates. I am as wcll as possible. Cartwright charges awfully, viz. for 1 coat 1 waistcont $2 \mathrm{pr}$ trouser's $£ 9.19 .6$. I have morcover begun fencing at Angelo's Rooms. The charges are high but as for exercise etc., I think it was about the best thing I could do, 3 hours twice a wcck for the season, almost the whole year, at fcncing, single stick or whatever I like, $£ 11$. These two have bcen my great expenses, but luckily they don't come again. The way I spend my time differ's a good deal according to tho dissection

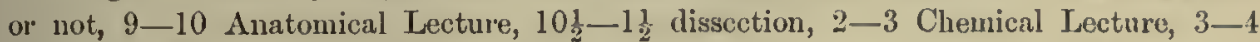
Physiological Lecture, 5-6 read or walk or fence or something of the sort; 6-7 dinner; doze $\frac{3}{4}$ of an hour, often a wee more, then tca till 8. Read and microseopize till 1 and amuse myself till 2 or $3 \frac{1}{2}$ according as I am lazy or not. Sleop till 8 . So I eat 2 hours, sleep 7 , attend lectures 3 , read hard $3 \frac{1}{2}$, nic roscopize 1 , dissect 3 , amusc mysclf 3 , dress etc. ctc. $1 \frac{1}{2}$. This is something of the way I spend my time. Now for the way I spend my money; this is not cxact to sixpences-though N.B. I keep accounts :

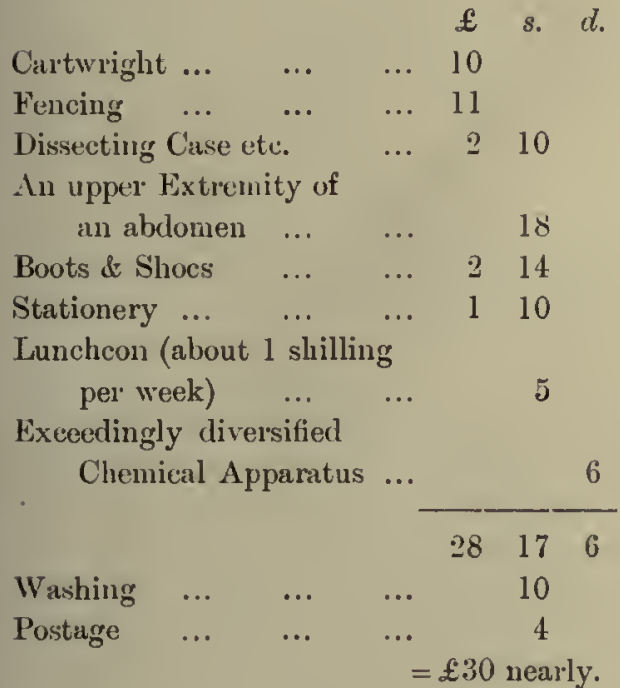

Tell Pem-that she is a nice Pent. Thliank Delly for letter. Your microscope is very uscful. Mr. Partridge has let me have the use of his very splendid one, value $£ 60$. But $I$ use your one commonly. Tell Mater that I thought of her and the Pig. I am afraid that the Pork Pie is not quite worth the carriage, although made out of a Claverdon Pig. Loves to all. Tell Bessy that paws arc improving though I have got a cut on them.

Fras. Galton.

Daniell's Experiments are most beautiful. He froze some Carbonic Acid Gas thc other clay by first condensing it to a liquid and then letting it suddenly free, the abstraction of Heat for Lateut froze it at a temperature of $130^{\circ}$ Falns. below the freeziny Point, it could be held up as the Carbonic Acid Gas being given off in evcry direction from it keeps it from actually touching the hand. I swallowed a picce, queer taste. Some mercury was frozen with it in no time.

'The next letter is of special interest not only for the advice it contains from Charles Darwin, but for the picture of the young medical student, who trusts his sister's home recipes in preference to his own knowledge! 
December 6, 1839.

MY DEAR GoverNor,

I hope that you won't consider me guilty of disrespect in sending you such a disreputable letter. But as I am at King's College ${ }^{2}$, and lave not any other by me, and moreover as in these happy days of $\frac{1}{2}$ ounce fourpennies anything in a decent envelope will do therefore--here goes.

I should have written before but I waited for Mr Hodgson, but as he won't come I wait no longer. I have spoken to Charles Darwin about Cambridge, who recommends next October and to read Mathematics like a louse on fire; thinks I lial better go as soon as possible for these reasons: that I camnot take my degree of B.M. until 5 years after matriculation, if not 6 . A medical education takes 3 or 4 years, of which I shall have had 2, and after taking an M.A. degree I shall have 2 norc before I can pass as Doctor. Now if I delay matriculation I shall defer the possibility of tuking a physician's degree for a corresponding length of time which may be an inconvenience. Again he thinks it certain that when at Cambridge I slall forget all the theoretical part of Medicine, I mean $\frac{1}{2}$ of Plyysiology, $\frac{3}{4}$ ths of Surgery and $\frac{4}{5}$ ths of Medicine, to say nothing of Anatomy Lectures, on the two last of which I shall attend next year and will be time tlurown away.

Now about reading Mathematics, he said very truly that the faculty of observation rather than that of abstract reasoning tends to constitute a good Physician. The higher parts of Mathematics which are exceedingly interwoven with Chemical and Medical Plienomena (Electricity, Light, Heat etc., etc.) all exist and exist only on expcrience and observation $\therefore$ don't stop half-way. Make the most of the opportunity and read them.

I quite agreed witlı all he said. Again, if after Cambridge I return to K. College, I should necessarily feel much greater interest in chemicalizing than I do now, not being able at present to compreliend one half of the fundamental principles which are mathematical, Light especially. This would be a great convenience with regard to the Laboratory, for were I to enter there now, I should be able to go there and tool about when I do not dissect (which I anı afraid will be very often as there are hardly any subjects), and work regularly after Cambridge, when I could finish my medical education at King's College. Bowman thinks ditto and he is a great man now, and he also says that every high mathematical M.D. that he knows has got on well. Dr Evans and Dr Blakiston of Biruingham, and Dr Watson of King's College, etc., etc. Please write and tell me what you think. Should I enter into the Laboratory, there is no time to lose. We shall have a week or ten days at Christmas, though, perhaps, it will scarcely be worth while to come down for so short a timc. Good Bye etc. Fras. Galtos.

DEAR BEsSY. Thanks for your letter and missal forthcoming. But don't please [give] any advice in the middle (even though it's an ancestor's) for I an sure I have had enougl, it's quite as eternal and does me no more good than Dr Sangrado's Warm Water.

O, Bessy, Bessy...... I have had another boil exactly by the side of the former which has partially reappeared. The new one is mountainous, but alas! not snow-capped like Ben Nevis, but more like Ben Lomond covered with scarlet heather. I shall have

" 'Iliroughout this letter and for two months previously Fr'ancis invariably spells this " colledge"! 
a complete Snowdonia of them soon and my mouth is rather sore. Paws rather improved.

(1) When a note of invite is sent unpaid by the twopenny post, may I answer it by ditto or how'?

(2) Ought I to call at St James Square ${ }^{2}$ before these boils go away and take the chance of more not coming, or not? N.B. the 2nol is just the size of and exretly like those purple polypuses there were at Weymouth.

(3) When the Iforners invitc witl a note beginning with "My dear Francis" how anI I to answer it?

Give my love to all. Ask Emma what I can do for the boils.

Diet. Breakfast, 1 large cup of tea.

$$
1 \text { round dry toast. }
$$

Luneheon, not always, Bread and Chcese.

Dinner, 1 or 2 times of meat, vegetables, melted lutter. 3 glasses wine. Pudding or Tart. 1 glass of water.

Tea, several small cups, bread and butter.

This is my full diet. Please Emma tell me what sort of low diet will do. T have fearful indigestion, sleepiness, variable appetite ete., etc.

Good Byc, Fras. Galton.

Possibly the very Spartan diet had more to do with the boils than Francis imagined. But he was soon to be home for the Christmas vacation and he was preparing for it. To his father he writes on Dec. 15th:

"I have agreed with Erasmus to spend a week in looking him up at Loxton, the time of travelling inclusive. Erasmus came yesterday to London. I introduced him to the Dissecting Room, from which he seemed rather glad to bolt. Would you ask Mater to see that my gun is in perfect endition, and as clean as a peeled potato, 2ndly to see that my powder flask, which $I$ think is in a Bank Box in my room, is gunpowder tight; if not to let the hole be soldered up. I want now to ask you abont the state of my wardrobe."

'Then follows a very complete account of Francis' wardrobe, the morning coat which will "do for the Strand, but not St James Square," the dress-coat "not exactly a perfect fit," the "two pair reputable trousers," etc., etc.

"What am I to do? Cartwright has no conscience, he has chargerl £15. 18. altogether.

Would you also send me word how many moming eoats you and Darwin wear yearly. My consumption would be 3 per year about. Please write soon as I am going to a ball at Horners next week. Moreover I have no great cont which is rather unplcasant in a London Fog."

1 On the introduction of general lettcr post, it was eonsidered as rude to prepay a letter, as it is now to leave it unstamped.

${ }^{2}$ Great-aunt Mrs Hudson Gurney (Nargaret Barelay, sister of Captain Barelay). 
Francis is undoubtedly growing into a bit of a beau, although he makes fun of lis needs throughout. The letter concludes with his accounts, the terrible tailor, "washing bill (not salts)," "medicine, a fearful quantity for indigestion, boils, carbuncle etc." 9s., "Luncheon and Dinner" Gs., "Head and Neck" $8 s .9 d$., etc. To those who study the developinent of human character it is of extraordinary interest to watch the cross currents working at this time in the young man's mind. There is the social current with the love of country pursuits which had dominated several of Francis' near relatives and collaterals; there is the observing "clinical" inclination, which had carried other relatives and collaterals into medicine and natural science, and then there is the love of mathematics and physics, which was again to manifest itself in other kinsmen. I doubt whether anyone watching the youth closely or reading his letters of those days would have been able to predict whether Francis Galton would end as a social leader, a country gentleman, a doyen of the medical faculty, or a noteworthy man of science. Tastes inherited from Beau Colyear, Erasmus Darwin, and Samuel Galton-wit and literary instinct, scientific imagination, power of organisation, with not a little Barclay tenacity were fermenting in a youthful mind, and none could have foretold with which victory would remain, or how they would ultimately be balanced. Examine Francis Galton's letter's in these Lehrjahre superficially, and they amuse as their lumour and boyish freshness necessitate. But behind this, those who can read between the lines will find a most instructive study in character development, one in which we seem to see not environment but innate tendencies contesting for mastership, and the environment itself is changed as each reaches control. None but the most careless reader could deny that the mind was seeking and making its environment, and not the environment moulding the mind.

When Francis Galton got back to Spring Gardens after the Christmas vacation we find one of his rare letters to his mother:

$$
\text { Jan. 6th, Monday [1840]. }
$$

\section{My dear Mother,}

I have been a wise person, that I have! Run away with Darwin's Dress Coat and left my own. Please send me mine by return of coach as in case of a party I have nothing to wear. I am full of contrition, etc., etc.

Now as I am writing I may as well tell you how I got here. As I got into the Coventry and Leamington Omnibus I saw at the other end in pair of thundering 
moustachios, cvidently part and parcel of Capt. Sayers. However nobody spoke a word and I fell fast asleep as usual, but before arriving at Coventry we found out that we each had to wait till $\frac{1}{2}$ past 12 for trains, he for the Birminghim and myself for the London train. So there being no coffee room we took the same sitting room and chatted away, balls, etc., etc., he complimented yours very much. He is a great African traveller; wears a beard, which he showed me, down to his waist and which he hilles under his shirt and stock and sports it in travelling and in fancy dress balls. He showed me how to makc a turban of my plaid, ete., etc., and was most agreeable.

Set off for London at $12 \frac{1}{2}$. Got there $5 \frac{1}{2}-$ Victoria Hotel-and an now at Partridge's.

Good bye. Loves, etc.,

Fras. Galton.

Writing on the 12th of January to his father, Francis says:

"I cannot say that I agree in what Hodgson says", but as I have written so often to you on this subject, giving my own reasons and those of others upon the question, it is scarcely necessary to repeat them. I will work likc a trooper whilst I am here, and when I get to Cambridge and to Mathematies, which for the last three or four years it has been my principal wish to study, I am confident that I shall not lose time.

Please thank Mater for sending my coat. Tell Pemmy that I thought of her and the balls on Wednesday and Saturday."

On January 21 Francis reports to his father the loss of his puise:

"I am as angry with myself as possible; the only thing that consoles me is that everybody is scrved out similarly, even you, e.g. your gold watch at the Spread Eagle. Catch me putting anything above 5 shillings in my coat tail pocket again. Hang the rascals. I shall have to pay Cartwright's bill for a great coat and frock coat which I ordered from Leamington and which together will be about $£ 11$. So could you send me another cheque which I will take the same care of as a passport in Austria.

Everything clse going on prosperously. I have just reccived your letter, and will certainly call on Lizzie Forster ${ }^{2}$ as soon as I easily can (this week or so). Your Sliding Rule is in continual use. Thank you very much for writing for my rooms at Cambridge......"

The next letter is written three days later:

My dear Goverior,

Hurrah! not been piekpocketted after all. Purse and Door key slipped through a loole in pocket of my old Reading Coat into the lining, where I found them last night. I cxpect a regular good rowing blowing-up letter from you to cross this on the road, which will do me lots of good.

$$
\text { Tar, Tar. }
$$

Fras. Galton.

Thanks innumerable to Delly for cardcase.

${ }_{1}$ Prcsumably Hodgson was not in favour of the mathematical interlude in a medical carcer.

- Lizzie Forster was the Quaker lady who had becn housekeeper at Duddeston after the death of Mrs Samuel Galton (Lucy Barclay).

P. a. 
In February the question of Clubs arises. Francis had met his Uncle Howard at the Hubert Galtons, and the relative advantages of the Oxford and Cambridge, the Athenaeum and the Parthenon had been discussed. Uncle Howard had promised to get him proposed and seconded for the Athenaeum, the Library being mentioned as a chief advantage. Actually it was not till fifteen years later, in 1855, that Galton, then distinguished as an African traveller, was elected under Rule II to the Athenaeum. He always spoke with great pleasure of the friendly meetings with many different minds at that Club, and already at 18 he had directed his thoughts towards it.

We have seen that Galton had started his College career with Anatomy, Physiology and Chemistry. He appears during this term to have worked more definitely for preliminary science, adding more Chemistry, some Botany and apparently Forensic Medicine to his studies. But the exact range of subjects he took up and the nature of the "matriculation" to which he frequently refers are not clear from the letters. In March we find plans being made for a visit to Paris with Sister Emma and his father-thus in a letter of the 28th:

"I have got my passport drawn out, but they will not give it me until I get from you a certificate stating that I go abroad with your approbation, I being a minor; so please send me one, couched in the following manner:

This is to certify that my son, Francis Galton, is leaving England for France with my entire approbation.

S. Tertius Galton.

Only think of the man's insolence in requiring one; it was almost saying: 'Does your motlier know you're out.' 'To get your passport you must attend once yourself and can represent the family. The times of attendance are between one and threc, No. 6, Poland St., Oxford St. You must tell me however the day before you appear as I must get a ticket to fill up. Just come crammed full of information about Names, Height, Eyes, Hair, Complexion, Ages, and all that sort of thing which you know of Emma and Stone. Perhaps the 'Varmints' will waut me next to write you a certificate ccrtifying my approbation. The passports are 'free, gratis and for nothing,' as they say to the hospital patients. 'The Viséing I kuow nothing about as I have no passport to Visé yet. I am almost surc I can do that. Hodgson has just made his appearance, says he saw you and Darwin the other day-he looks very ill.

Now then for accounts."

'The letter concludes with the usual summary of accounts'. We

1 Existing letters show that Tertius Galton's other sons, e.g. Erasmus, although much older than Francis, were at the same time returning equally elaborate accounts 
learn that the expenditure of $£ 1.2$ on the great coat and frock coat at Cartwright's must have been patcrnally sanctioned. Other interesting items are " $\mathrm{Pr}$ of Foils and Handles," 14s.; "Medicine (\& enough of it too)," 8s.; "Head, neck, leg and arm," $£ 1.6 s$. ; "Magnetic and Galv. Apparatus," 5s. 6d.; "Rattletrap, stationery, etc.," 5 s.; "Larks, etc., etc.," $12 s .6 d$.

There is also a paragraph in the letter bearing on the coming change to ${ }^{\circ}$ Cambridge :

"As to Blakesly please say that I wished to give my time prineipally to Mathematies and was entircly ignorant of the eourse usually pursued with regard to a private Tutor-whom he should recommend, whether Hopkins or another-and what steps I ought to take to enter mysclf under one."

A letter of April 8th is worth citing at length. It contains a neat drawing of the Coddington lens, with details of its construction and parts; that lens had been invented by Brewster in 1820, but brought into general use by Coddington's paper (Camb. Phil. Trans. vol. iii. p. 421) of 1830 , so that it was new commercially.

\section{My dear Goveryor,}

I have taken your places. I have not matrieulated. I wish that you would send the enelosed paper to Mr Frederiek Ledsam to ask him to nominatc me, as I do not know him ${ }^{1}$; there is no partieular hurry. We are beginning to expect no. Easter Holidays and consequently no Paris for me, as Partridge is dreadfully bchindhand in his lectures. However, it ean't be helperl. The Sliding Rule was 12 shillingswood, beautifully marked in every possible direetion and of very great use. I invested yesterday in a Coddington Lens, as I very much wanted something of the sort. It admits at lcast 6 times as mueh light as the inieroseope that you gave me--though it does not magnify so highly-and is a hand lens-18 shillings certainly, but so very useful, they are just the size and shape of picture; it slides into its case with a huge joint $(a)$.

Fras. Galton.

In ease you cannot (like mysclf) read one word on the tieket, it means that you start from Boulogne at 12 o'eloek and that I have paid $£ 2.9$ s. and that you will have to pay $£ 1$ at Boulogne.

to their father. He had eertainly the banker's sense of order in this natter, and must have had a great share in his father's and grandfather's power of elaboration and organisation to be able to bear in mind, criticise and often correct these individual details. The nature of the entries in these aecounts also demonstrate the affectionate freedom of expression and expenditure that governed the whole relationship.

1 A student at King's College nominated by one of the members of the body was allowed a reduetion of about $\tau$ per cent. in fees. 
The visit to France did come off', but Tertius Galton and Emma started first, and on April 13 Francis was to have his second near chance of losing his life by drowning. The event is described in the following letter to his sister Bessy ${ }^{1}$ :

Thursday, April 14th, 1840.

17 New Spring Gardens.

\section{MY dear Bessy,}

Yesterday at 17 minutes and 45 seconds to 5 (I know the time because my watch was stopped), just when you werc puzzling yourself over some cross-stitch pattern and whilst Delly was trying to find out a type in the Old Testament for the fact that St Paul left his cloak behind at Ephesus-well, as you were both amusing yourselves at that said time-I, your humble servant, Lord Torment and Tease, clothes and boots on, was floundering under the wheels of a Stean Packet, the paddles of wlich were bumping upon ny head with a 15 -horse power, and some short time afterwards I found myself kicking about some 8 or 10 feet decp, rising to the top, which instead of reaching, I merely knocked my head against a huge piecc of wood and sank down again, at the same time gulping in water like a fish and bublling out air like at blacksmith's bellows, my life worth "a littlc less than nothing at all," as the sailors say. Wcll, I am alive, which is a great deal more than I had expected, but desperately beaten about my head. I can't lie in bed, so I'll write you all about it.

I went in a Steam Boat to Putney to see the Oxford and Cambridge rowing match. As we were returning, very fast and with the tide, through Battersea Bridge, we ran foul of the middle pier. I, who was behind the paddle-box, saw low we were going just before we struck, and caught tight hold of one of the paddle-box steps, expecting a general smash and deternined to have a swim for it. Well, the body of the packet cleared, but the paddle-box, belind which I was, cane full crash against the sides of the arch. It split open just before me by the shock. I was thrown head foremost through the cleft, right amongst the paddle wheels, which were still going round, they not having touched the pier, owing I suppose to the recoil from the smash of the paddle box, though when they did, they were doubled up and rendered useless immediately. Well, this regularly stunned me. Thank heavens my neck was not broken in the wheel (Escape No. 1). I was quitc insensible, and how I cleared the bridge I have not the slightest conception. I must have been beaten down by the paddle wheels beneath the bottom of the bout-and fortunately enough, otherwise from the shape of the packet which heeled over I must have been jammed between it and the pier [illustrative sketeh of packet and pier in elevation], and of course squashed. That

1 'The first event oecurred in 1833, when Francis was 11 years old; he had been taught to swim. He went to pay a visit to lis sister Lucy at Smethwick. He was walking by the canal at the bottom of the garden, when he saw a bird's nest on the branch of a tree and fell into the water in trying to get it. His legs got entangled in the tree so that lie was held with lis head under water, and no one near to help lim. At last with a vigorous effort he made himself loose and swam to shore. (Mrs Wheler's lieminiscences under 1833.) 
makes Escape No. 2. Well, as I said, I was insensible, and when I knew where I was, I found mysclf under a large piece of woorl which proved to be the outer sirlo of the paddle box, with part of the top still attached, thus uaking an angle in whiel after some floundering I got stuck, and though I dived as well as I coukl, for I was nearly spent and had swallowed a great deal of water, I still on rising humped against the wood. [Illustrative sketch of floating portion of packlle-wheel, showing sulmmerged angle under which F. G. was caught.] I of course gave myself up, but determined to have a regular good push for life. I felt the wood round me and could see a little, and at last I made out the edge of the top part of the paddle-box, grasped tight hold of it, and pulled inyself from underneath and cleared it. I then rose rapidly towards the surface, when I bumped against another pieeo of wood, which, however, I easily pushed asidc and rose; but I rose too high and conscquently sank again, but I lad had a good breath of air and was a little refreshed. I did not sink I daresay a foot below tho surface, but I got entangled in some long bits of wood, which as I was all but spent nearly drowned me, and when I got to the surface they were too heavy to givo me any real support, so I looked round and saw the side of the paddle-box, which had before becn so nuch in my way, floating down with the tide. I struck out and soon reached it -and I did feel happy. I climbed onto it and it was a perfect raft. (Escape No. 3.) On looking about me I found that the steamer was 300 yards or so in front and could not stir. I was quite 200 yards and nearly 300 from the bridge, the whole of whicls distance I had floaterl down head under water (only one other nian went overboard and he merely got a ducking, swam to a bit of wreck and was quite safe). Well, I was in the nickst of the river, plenty of boats and watermen werc at the slore, those nice dear fellows who when they sec you struggling, look on, and never dream of rowing to you till you are either safe or dead-yes, and if safe, they swear they saved your life, mareh off to the Royal Humane Soeicty and get a gold medal for their pains, with a long paragraph in the I'imes about "unparallelcd bravery," and so forth. Well, after waving iny hat, for I don't know how long, ofl" some half-dozen came in a body. I was pullerl into a boat and felt very seedy, I was clizzy and very sick. However, to put the captain out of his fright, I took an oar, deelared nothing was the natter with me and pulled mechanically.

I was so dizry that I scarce knew what I did. On getting to the packet everybody looked horrified, one or two ladies held up their handkcrchicfs before their eyes. I couldn't make out what at, but on getting ashore and to an inn, with a lookingglass I found my faee, ear's and whiskers, shirt, ctc., all covered with blood. One nail had hookerl me by the side of the nosc, another lad "sarved" out my face and I had as many cuts on my ear" as a Christmas pig. I got to bed, half dried clothes and walked to London. Now don't faney I am ill. I took enough calomel and salts to do anything, and except a rather torn face and broken head, I really have nothing the matter with me. I have walked out to-day and am going to Lecture in half an hour. I have gained great glory by iny splashes under water and it is a very good tale to tell-at lcast when the pain goes off. I now know something of what drowning is-I felt no pain, but rather dreamy-and. I also know what my feeling will be when I am dying, as I firmly belicved I was then.

Tell Dar that if he had not taught me to swim I should have been stiff by this 
time and a cofliu in process of being made. I an most grateful to him-and if I have clitdren l'll make them amphibious.

Now don't fancy that I am ill-onee again. Just send an epistle sorn-all about journey to Isle of Man and everything. N.B. The dueking has eured a eold.

$$
\text { Yours, ete., }
$$

Francis Galton.

I have got a relic from the wood which saved my lifc. It stuck into my waistcoat pocket and broke off as I was getting into the boat, and I scnd you some enclosed ${ }^{1}$. My wateh is muclı hurt.

In the account Sir Francis gives in his Memories (p. 46) of this event, the reason for his strong feeling about the watermen is manifest-the men in the first boat asked a sovereign to take him in, but being in comparative safety he was able to resist this extortion!

'Ten days later Francis' examinations are over; he feels he has done well, and, ready for his holiday, he sets out a free man to overtake his father in Paris:

\section{Boulogse, Hôtel de Griraltar.}

\section{Dear Pater,}

Couldn't write before on account of the Examination in Anatomy and Chemistry. I will tell you why when I come, but I am too lazy now. Mr, one young Mr, and 3 Miss WW _ (Civil Engineers), wcre in the Steam Packet with me from Dover to Boulogne. I eame very "strong" with one of the Miss W__, who says that they are going to stay a week at Paris. I think that we shall travel together tomorrow at 9 o'elock. I being "dished" for this evening and they, I bclieve, ditto.

Hang their Vin Ordinaire, it has diluted iny gumption, till it is as weak as their vermacelli soup, which hang also. Travellel by night from London to Dover; got there at 6 a.m., walkerl without interruption for 5 hours up the cliffs and in every direction, set off at 12; got here at 3. I have no particular' news worth telling. 'Tell Enma that I have two views of Dover and one of Boulogne (having invested in a small board Sketching Book). There is nothing to be seen in Boulogne, so $\mathrm{I}$ am going to dress and promenade!!!

\section{Good-bye.}

Fra. Galton.

N.B. It is the custom in France to write on thin paper and with a vafer, and not to direct epistles which are written on something very like millboard and sealed with a seal sueh as a Cardinal would affix to a Pope's Bull to London; and thereby make the postage 2 shillings and 4 penee. Such was the case with a certain letter I received.

N.B. to N.B. (or $\left.1 / \mathrm{NB}^{2}\right)$. I am not sure whether the letter was 1 shilling and 4 penee or 2 shillings and 4 pence. I think the latter. All inistakes to be referred to Vermacelli soup or Vin Ordinairc.

${ }^{1}$ I imagine this is the shaving of wood which has been prescrved with a small triangular pieee of lcad in this bundle of letters. 
None enjoyed the frolic of a holiday more than Francis, althongh no one could work harder at the proper time. 'The tour' went by way of Paris to Nancy, Strasburg, Baden-Baden, Stuttgart, Heilbron, Heidelberg, Frankfurt, Schlangenbad, Coblentz, Bonn and Antwerp, Mr Galton and his danghter reaching England on June 4th. A sketch of the tour seems to have been made ont by Francis at some Rhenish town on April 30th, and accords fairly closely with the route ultimately described by Emma Galton in her diary. But Francis was back at King's College on May 7 th, and there is no record of how far he accompanied the party. On his way home he appears to have called in at Jersey and seen his old adversary, Dr Jeune of the Free School, now Dean of Jersey. His great news on arrival home is conveyed to his sister Delly ${ }^{1}$ :

Dear Delly,

17 New St., Spring Gardens,

London, May $71 h$ [1840].

Hurrah! Hurrah!! I am 2nd Prizeman in Anatomy and Chemistry. I had only expceted a certificate of honour. Hurrah! Go it, ye cripples.

An undated letter of a few days later to his sister Bessy puts the circumstances of the prize in more detail :

17 New StREeT,

Spring Gardens, London.

My deAR Betsy,

Thank you for your letter, and thanks innumerable for your congratulations. I am excessively glad that I have gained this prize, as it is such a good introduction; it was the only prize open to me, else I hoped that my name would have appeared in another place as well; however look again, about the first week in August in the papers and in the meantime wish me sucecss in Botany and Forensic Medicine.

Had I gained the first prize instead of the second it would have been an improvement, but if you consider that the class consists of between 70 and 80 , and that Anatomy and Chemistry are the Sciences which students principally follow, and again that of these 70 or 80 students, about 30 were 2 nd year men, that is had dissccted for two years, whilst I had only dissected for one, you will see that it was plenty for me to do; however I was within a very few marks of being first, but a miss is as good as a mile.

1 This letter has upon it the first postage stamp on any of Francis Galton's lettcrs, and an endorsement on it states that it is the first the home circle had secn. Francis stuck the stamp in the top left-hand corner at an anglc of $45^{\circ}$, head downwards. Ten days later he has adopted the now usual method. 
My books are, one folio Seneca, printed Antwerp 1652, very scarce, good type and very valuable; D'Israeli's Essays, which originally appeared in three volumes, now printed in one ; Songs of England and Scotland, 2 vols. small 8vo, all gilt stamped with College arms and so forth, - they are well worth having.

I nm quite glad that you like Tenby so much, and the good memory of the Larly at the Post Office is highly laudable1. I had capital fun in Frnnce, I do love travelling. Oh, Betsy, if you could but see Mr Y., poor man, so down in the mouth whenever Mrs Y. contradicts lim. He was talking to $\mathrm{me}$ of his nanservant who had married a housemaid and said, "That fellow John, like a great fool, has just been married, the idiot! A inan is good for nothing after marrying; he would do so though in spite of all that I could say." Poor Y. There is however one thing in him highly commendable, which is that unlike the tame elcphants who delight to clecoy wild ones into their own statc of captivity, he loudly declaims against all marriage in all circumstances.......He bcgan once during dinner to argue, and after his old stylc was debating whether "Cause should be considered as the precursor of Eiffect, or Effect as the conscquence of Cause," when the baby, who was sitting on his knec, haring previously unobserved insinuated its paw into a wine-glass of Port, splashed a volley of the wine right upon Y.'s white tic, and then upset the glass and what remained in it over Y.'s knees. I did so pity him, he is irrevocably a family man.

Write occasional epistlcs. Yours, ctc.,

Fraxcis Galton.

P.S. I think my old sclroolfellow $\mathrm{C}-$ is at Tenby; he is dying of consumption, poor fellow; he was the kindest boy possible and very talented. Should you find out that he is there, please tell me. I saw Dicky Doyne yesterday.

How little we grasp at 18 , what we shall sigh for at 50 as incomparably more weighty than many soiled shirt fronts!

'The few days' holiday in France enabled Galton to return to his work with renewed vigour. He was taking several new subjects, and as is the case with each man of original power, they came to him as new worlds to be discovered and conquered afresh.

$$
\text { May 17, } 1839 \text { [? 1840], }
$$

17 New St., Sprisg Gardens.

My neÁr Motmer,

When you next write to my father, please tell him that a letter which I directed to him shortly after my arrival in London at Baden-Baden, was returned to me the other day, opened from the Dead Letter Box, owing to my not having previously paid the sum of $1 s .8 d$, which it sccms is necessary, and of which I was not aware. Please tell him this in order to account for his not having received a letter from me. I would writc, but as of course by this time he lias left Baden-Barlen, I do not know lis address. As I suppose that by this time you have heard from him,

Sce the first footnote, p. 83 . 
plcasc write slortly and tell me all the news and his prescnt plans. I shall also want $£ 10$ (the Governor told me to apply to you), which please send soon as I am in somc want of it. I have to invest in several new books owing to my attending perfectly new subjects for lectures. Don't forget to tell the Governor in your next letter that you have given it to me. Also please tell him that the lectures that I am attending arc 1. Botany at King's Collegc, 2. Forensic Medicine, 3. Chemical Manipulation, 4. Surgical Operations, and 5. Botany under Lindley ${ }^{3}$ at the Chclsea Botanical Gardens, only twice a week. I do not attend the Civil Engineering Classes as it would be too much I think to do well ${ }^{2}$; neither do I dissect as I had previously intended, because I can only get pickled subjects, and also because there is an immense deal of microscopifying required in Vegetable Physiology, to which, it seems to me, that I had better at present give my time. I like my summer course very much indeed, it is not lialf such hard work as the Winter Course, and much more amusing, and two good prizes open to me at the end of the course, riz. Botany and Forensic Medicine.

I received a letter from Bessy the other day, who told me that she had just had a letter from Delly, who assumed the honour of sending her (Bessy) the first glutinous stamp, but Dclly not being very expert, the stamp did not stick on, and so Bessy had to pay double Postage.

Oh, Delly! Delly! your congratulatory letters with regard to the reduced Postage System have been singularly unfortunate; in case of any fresh alteration, please don't write to me.

Good bye, Your affectionate son,

Fras. Galton.

P.S. Mrs and Miss Hodgson are just gone to Brighton to reeruit from the Hooping Cough (no vicious w, you observe, to my Hooping $\mathrm{Cough}^{3}$ ). How are Darwin and Claverdon getting on?

On Tertius Galton's return in June there was a good deal of correspondence about expenses. Francis had not been really extravagant, but he had taken his accounts to Paris to show to his father, he had not shown them and then he had lost them! Further, he did not always promptly acknowledge the receipt of remittances and Tertius' training as a banker demanded absolute punctuality in these matters.

${ }^{1}$ Lindley was Professor of Botany at University College (1829-1860), and attracted large classes. He was also lecturer on Botany to the Apothecaries Company at Chelsea (1836-1853). He was a botanist of great distinction, and it is pleasant to think of Galton attending his Chelsea lectures.

2 This is the first evidence of Francis Galton's interest in Engineering. No earlier reference to the possibility of attending these lectures has been found, and it is probable that mechanical rather than civil engineering would have specially interested him.

${ }^{3}$ Francis Galton appears to have hit off the older form (sce on the point Skeat and Johnson). Or was it the Frencli tour?

P. (:) 


\author{
WEDNESDAY, [June] 10th, 1840, \\ 17 New St., Sprivg Gardens.
}

MY dear Governor,

You aro the most delectable Governol going in the early part of your letter, but in tho last not a man of business (!!!). Now to support my charge. When I clined with you at tho Euston did not you, the defendant, say that if the 40 pounds did not come that it would be my business to look after them,-thereby leaving me to mine own resources, and dependent upon them alone to obtain the said forty pounds? Under such order I acted and accordingly under my "auspices" the 40 pounds appeared in iny pocket. There was nothing mole evidently for me to say. $\therefore$ I said nothing. Q.E.D.

Now as to the other part'. My holidays will begin on the $21 . .28$ of July. I certainly should not disapprove of 70 days journey; indecd I have no doubt but that I should see a very great deal very well wortl seeing in that journey, and see it well too.

The route I propose taking is Hamburg, Copenhagen, Esteborg, Stockholm (by Gotha canal) (St Petersburg by Abo ?), Stockholm to Sundsvall, Trondheim (this is beautiful scenery), Bergen (splendid), Christiania (by Vøringsfoss and the Hardanger Fjeld (Pørgnis) [? word not readable], Christiansund [? Christiansand], Hull, or else going exactly the opposite way and landing from Hull at Göteborg, thence to Christiania and so on, and thus I shall be able to judge more correctly about St Petersburg. There is reindecr shooting !!!! and only 4 hours night at Bergen, Eternal Snow in the forn of glaciers 300 feet high!! In fact I am raving mad about it. I have of course taken care that Cambridge shall not suffer in anyway by it.

Please to make enquiries for a companion. I am not yet sure of one. Would you let me have the liberty of taking one book at a time from Saunders and Ottley and give me the necessary instructions, that I may cram up about Sweden, Norway and Finland?

Please tell Emma that that lady with an illegible name something like Oh law ! has sent me no seals.

Your affectionate, half-cracked son,

Fras. Galton.

The Wanderlust was seizing Francis, another factor becoming almost dominant, and the blood of Buttons and Colyears manifesting its influence. We know our Norway now as we do our Switzerland, but it was not so usual for a boy of 18 in those days to plan a tour through Norway, especially with the three days' fjeld journey across the Hardanger Vidda from Vik to the Hallingdal. It was, I know, a fairly lonely track 25 years ago, and more than 70 years back it would indeed be an unusual route, probably taken only by a few reindeer hunters. Francis gives no clue as to the source of his

"The "most delectable Governor" in the early part of his letter had clearly been proposing ten weeks of travel. 
projected journey. But his letter a week later to his father shows Francis still wholeheartedly for the Norwegian tour.

June 15, 1840,

17 New St., Spring Gardess.

\section{Dear Father,}

Thanks innumerable for intended tour and for book order. [There follows an explanation as to non-acknowledgement of a remittance.] I have just reccived from Leonard Horner a report "On the Employment of Children in Factories and other Works," to be transmitted to you by the next opportunity. N.B. Though I know that an opportunity won't present itself, I writc to ask what I am to do, that I may have time to read it before your answer comes. Now acting life to the maxim of business first and pleasure arter'ards-and having pitched into business, here goes for pleasure-about my tour, I mentioned 70 days, though I believe that 50 days will do, just to take the outside, as, in case of a good wind and in casc of a boat sailing that way when at Trondheim, why $\mathrm{I}$ may just as well go to the Lofoden Isles, which rise sevcral thousands of feet bolt upright from the water's edge and are superb-and besides close to them is the Malström. My chief expenses are in getting to Norway and back, when in the country they are but slight and will be mucl less with a companion.

I shall be free in the 3rd week of July. Poor $\mathrm{Di}^{1}$ - when will she be buried? How is your asthma?

Your affect. son,

Fras. Galton.

The next few letters are chiefly occupied with the distressing subject of accounts. After giving details of his expenditure, which are chiefly of interest for us as showing the nature of Francis's occupations-two botanical excursions with Professor Lindley, two visits to the Opera, etc.-Francis continues (June 16):

"I own that I have not kept my accounts, especially my Paris ones, at all carefully. I have generally set my expenses down, but on scraps of papers and consequently lost them afterwards from carelessness. I do not think that I have wasted any money, though I doubt if I could account for all. I am sure that I could not accurately. I don't owe anything except 32 shillings for a pair of boots and I cannot get the bill. My present riches are $£ 14$. 8 s. I shall have to get a frock coat and waistcoat. The frock coat being the $3 \mathrm{rd}$ that $I$ have had in London.

As my journey to Norway and Sweden can scarcely be less than $£ 50$, I shall not grumble at giving it up 'in toto,' but an quite ready to do so. I expect a good row from you by return of post, and as I deserve it, am resigned.

And now having to the letter followed the example of our Ministers, and when the Budget must come, having made a clean breast of it-what is to be done? It

${ }^{1}$ His cousin Diana Galton, daughter of Hubert Galton. Emma Galton, who had been staying with the Gurneys, writes on June 7 of the grave illness of Diana. 
is no use on nyy part to blarney about 'full of contrition' and so forth, but beginning from to-day, I will send you by every Monday's post my accounts for the week preceding; and in case of omission, I wish that you would write and blow me up. Please tell me by return of post-how much I am in arrear, as not understanding your figures I cannot calculate it.

Good Bye, and bclieve me ever,
Your affectionate son,
Fras. Galton."

How we should have valued the answer of Tertius Galton to this letter of his son Francis! How few young men at College now-adays would satisfy their father's desire for a weekly account of all expenditure, and how neat and elaborate are the little weekly accounts we find sent to Tertius after this date! To us it would have seemed more reasonable to grant a fixed allowance and to make no inquiry, if it were not exceeded, as to the details of expenditure. But Tertius Galton had his own views, and he insisted on the most elaborate system of petty cash accounts. Can we assert that Francis Galton's business habits and his full appreciation of the value of money arose from his father's training? Is it not rather probable that the instinct of elaboration and organisation was already there, for we find it taking strange forms in several of Francis Galton's relatives ${ }^{1}$ ?

A further letter about expenses is dated June 24 (by the recipient Tertius!).

"I am very glad indeed to find that my private expenses have not been extravagant.

On consideration I have determined to give up Norway and Sweden for the following reasons. First that although I should otherwise have enough time for

1 Thus onc of Tertius Galton's sisters had a triple inkstand with three coloured inks, triple penwipers and pens; evcry conceivable apparatus for writing, printed envelopes for her various banks and business correspondents; printed questions for her grooms, "Has the marc had her corn?" etc., etc.; a dozen or more cash boxes elaborately arrangcd to receive in separate labelled compartments cach kind of coin from each type of her property. The apparatus for the instruction and relief of the poor-tracts, ounces of tea and sugar, worsted stockings, bundles for mother's aid, etc., etc., were arranged in separate indexed presscs, with records of all transactions relating thereto. The crockery ware of the storc-roon and housekceper's room was all lettered, and all metal articles, pans and pots were duly labelled, as were the garden tools, and there were corresponding labels on the pegs on which they were hung. As many as 100 painted labels have been counted in a flower bed of hers of 12 square feet. In short, we appreciate what Francis Galton meant when he said that the desire to classify and organisc which cxisted in lis family, he felt at times as almost a danger in limself. 
Cambridge-yet an increase of 6 wceks would give me abundance. Secondly, I have already been the cause of so much expense that I have made up my mind not to incur a greater.

I called upon Leonard Horner to tell him what I had determined, and to thank him for having made enquiries for a companion, but he was not at home, nor expected till the middle of next month; so I should be obliged if you would write to him.

The cause of the cheapness of the envelopes is this-The stationer who sells thein lias an advertising sheet printed on their inside, which of course will enable him to sell them at a great reduction. This man has, however, not found them to answer, as he has no more, but I hear that they are to be got for $8 d$. the dozen. I will make enquiries. I call to-morrow on the Huberts. I have not had time owing to Hospital engagements. Everything, including accounts, getting on flourishly. There will be very near play whoever gets the prize for Forensic MLedicine. I do not make mysclf sure of it.

Good bye.

Your affectionate Son,

Fras. Galton:"

In his next letter (June 29) Francis tells his father that he fully understands and appreciates his arguments about the money: "I am most obliged to you for your liberality; however I think that for many reasons, I had better give up Norway and Sweden and go elsewhere." He suggests a month in Paris, boarding in a family who don't understand a word of English-

" a large family, as good a class of life as possible-and the most complete innocence of anything like the knowledge of the English language. In case of several equally qualified that those who can talk the most gossip be the chosen enes. This will explain my taste pretty well, - of course if the daughter's are comely-why tant gagné."

Friday, 10 th (I think), 1840,

17 New St., Sprivg Gardens, London.

MY deAr Father,

Thanks for your unanswered letters-that one which you wrote to Paris really was a perfect specimen of English composition-had it been a will and had $£ 50,000$ a year depended on it, I am sure a lawyer could not have picked a Hlaw in it.

...Everything gets on capitally, especially accounts. When I want to know if $\mathrm{I}$ have any coppers in my pocket to give to a begging crossing sweeper $\mathrm{I}$ do not condescend to feel but pull out my pocket-book add up and the result is sure to be correct. I shall want some more money, not enough though for the Paris expedition, as I propose to come to you at home first-then Rassy', and then Paris. Shall I send you my account book or an extract?

[Here follow accounts.]

1 Erasmus Galton, who had given up the Navy and settled down to farm at Loxton. Darwin Galton was farming at Claverdon. 
So much for business. Went to the Opera last night, Taglioni, last appearance -am quite hoarse with bellowing out "bravo." Aunt Gurney ${ }^{2}$ has been out of town for 3 weeks, just returned. I went to sce Courroisier hung, and was close to the gallows, poor fcllow. I went professionally for death by hanging is a medico-legal subject of some importance.

Tell Delly that I have not seen a scrap of her handwriting for ages and that she must send me a letter. What does she do without her school? I am glad that she is going to Somersetshire [Loxton], it will do her back so much good. Nothing is so bad for health, such as hers is, as a sedentary (lying-down-in-a-school-all-day) habit of living and one without variation. If she divides her attention between two sets of objects-to both of which she is attached-school and farm-her health will be wonderfully improved, Frampton's pills of health discarded and steel mixtures thrown down the sink.

My accounts shall be sent by return of post, if you will tell me in your next letter how you would like me to send them.

Good bye.

Your affectionate Son,

Fras. Galton.

This is wrapped in an " 11 . a dozen" cover.

The Paris trip was not destined to come off. A new direction was to be given to Francis Galton's plans; but the goal reached was far from the direction indicated at the start. The Wanderlust had seized Francis, although he was little conscious of it, and laboratories and lecture-rooms were incapable of holding him back.

\section{Monday, July [13], 1840, 17 New St., Spring Gardexs.}

\section{Dear Pater,}

Thanks for letter, I am in a great hurry for the post, so I will send accounts to-morrow.

Please write an answer and send it with all the speed a penny envelope is capable of.

Wm Miller is going to Giessen in Germany, to Liebig's Laboratory-Liebig is the 1st Chemist (in organic chemistry) in the world. In his Laboratory there is every opportunity for getting on, in addition to the certainty of a knowledge of German being acquired. The terms are very low, not more than $£ 5$ for admission, though of course there are many more expenses in the way of tests and other documents. Wm Miller tries to persuade me to go with him. I should like to go. Have you any objection? I write to Hodgson by this post to ask his opinion. Miller is as you know exceedingly talented and will in all probability rise high. My acquaintance with Bowman has proved to be most useful-a similar acquaintance with Miller promises to be so. Liebig's assistance will of course be invaluable to me in after life; and as his immediate pupil, more especially as I am a foreigner and come with an introduction from Daniell, I shall have every opportunity of acquiring his friendship. Again Daniell

\footnotetext{
'Mrs Hudson Gurney: sec Plate XLVII.
} 
will necessarily be much pleased with one of his class, more espeeially lis prizennn, following up so good an opportunity of working at practical chemistry; le will of course give me introductions to Liebig and will take more interest in me. Liebig's season begins next week and ends Sept. 8th nearly, all which time I shall be with him. My going there will not interfere with my Forensic Medieine Examination. I am sure that it is the best thing that $T$ can do. I sliall not. gain refinement most certainly-but will have every advantage possible for obtaining Chem. Knowlerlge, and will return as clirty and as clever as ean reasonably be expected.

$$
\text { Your affectionate Son, }
$$

Glad very, about asthma.

Fras. Galton.

In Captain Donellan's ease you used to tell a story of a Mr. Somebody who lent Capt. Donellan some book or other containing a deseription of the manufaeture of laurel water, this book after the Capt.'s execution was found always to open in the place where the proeess was deseribed. Please give me the names.

Attached to the neat account which followed next day, duly headed by the receipt for the last cheque, are a few lines in which Francis states that he should not have time to write to Liebig and wait for an answer, and that if Liebig cannot take him, what is he to do- "Go to Paris or to Switzerland?"

The next letter from Spring Gardens acknowledges the receipt of a credit on Barclay and Co. for $£ 100$. Hodgson approved of the visit to Liebig. Francis is in his holiday mood:

$$
\text { July } 16,1840 .
$$

... You enjoin me not to smoke eigars. I will not, but I will buy a neersehaum with a pipe 4 feet and a half long, and with a bowl that will contain an ounce of Tobaeeo at a time. Shall I get one for you ?

I have got my money ehanged into cireular notes at Herries, Farquahar \& Co. I land at Ostend, railroad Liége, diligence Aix and Cologne, steam Coblenz; diligenee or voiturier, if I must, to Giessen. Does not Bessy return to-day? How is his worship the farmer at Claverdon getting on?

Good bye.

Affeetionate Son,

Fras. Galiton.

I will write again. Loves and all that sort of thing.

The last letter from the old environment is written on July 22, just before the start for Giessen:

\section{My dear Father,}

\section{Tuesday.}

I am 2nd in Forensic Medicine. There is only 1 prize and so I get a Certificate of Honour. I am much vexed at not being first, but there was more competition than usual. One of the men ( $\mathrm{am}$ above him) got a Certificate of Honour 
last yenr. As you understand the cireumstances in which $\mathrm{I}$ was placed as regards juniority, I shall not attempt any further to justify my failure. If it is not infra diy. after a Cambridge degree, I shall of course go in again....

I lave sceured my berth in the Ostend steamer and start to-morrow at 12. I will send you my medical books in a parcel. Don't let them be opened. My other books I will pack up separntely. My ehemicals too I had rather were not touched. I have becn unavoidably prevented from calling on Leonard Horner. Will you write to him and tell him of my proceedings? I saw the Gurneys to-day. She talks about coaxing Bessy or Emma to Chiswick. As I have much to do, I will wish you good-bye. Loves to all.

Your affectionate Son,

Fras. Galton.

Of this "stay in Giessen" Francis's letters must themselves speak. There are two dated Giessen, the others are from Vienna, Buda Pest and Constantinople! A sketch-book diary shows that Francis, then 18 years of age, went down the Danube to Vienna, thence to Constantinople, thence to Smyrna, Syra, Athens. Beyond this records are obscure. Sketches show that he was at the Bay of Navarino on Sept. 13, and at Missolonghi on Sept. 14. A projected itinerary in the early part of the book gave a return by Rome, Pisa, Genoa, Marseilles and Paris. But he was still in Ithaca, when he should have been near Pisa, and from Constantinople he requested money to be sent to Trieste. The brief notes ceased after Sept. 14, and I do not know how Francis got home!

Those who had seen the Wanderlust rising to full intensity in the planned Norwegian expedition might have been fairly sure that Liebig would not_hold him. His diary tells only the external side of the attack:

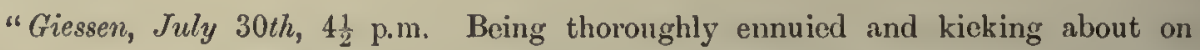
the sofa, I suddenly thought of a voyage to Constantinople and made up my mind in a quarter of an hour and sent off my passport to be viséed to Frankfurt; then went to Herr Prof. Adrian for my grammar lesson, who it seems went the same route last year, and who gave me several good hints. Wrote a penitent letter home begging for absolution, and without waiting for an answer packed np."

$$
\text { MONDAY, } 27 \text { July, 1840, }
$$

My dear Fatuer, Giessen, 1 o'elock.

I arrived yesterday at Giessen in the afternoon. I find that Liebig's laboratory is under quite different arrangements to those which $\mathrm{Mr}$ Daniell, Mr Miller and myself had expected. The plan with which it is conducted is as follows: A number of men (30 at present), who have long studied practical Chemistry, wish 
individually to examine certain organie substances. Now in analysing bodies of this elass mueh taet is required in devising the mode of treating them, and in udupting trains of experiment to the individual ease. These men go to Liebig who gives his opiniou as to how they are to set to work. He las a room where there are tables and sinks and some furnaees, about a yard's length of table is allotted to eaeln man and there he experimentalises (he brings his own apparatus and tests). Liebig looks up the men onee or twice a clay, telling them how to go on, etc. ete. Their investigations are all published with the name of the experimentalizer attached. Licbig therefore presupposes delieaey of manipulation, and professes to teach the application of it to partieular eases. It is the first part that I wish to praetise and, not having clone so sufficiently, of eourse instruction in the after part is useless. Under these eireumstanees and with the adviee of Mr Miller I have determined not to enter the ehemistry elass, but shall work nt learning German instead. My arrangements I will tell you at the end.

I set off from London at 12. Motley assemblage of passengers. Iady Noel on board ; and with the exeeption of treading upon a little poodle-dog's tail by aeeident, and making it squeal horribly, and of tumbling against a lady who was trying to drink unobserved a glass of wine, and so eausing her to spill it over her neighbours, I got on very well. Calın passage, not sick, good berth, in which I didn't sleep, and splendid appetite. Ostend at $3 \frac{1}{2}$ in the morning, shore at $4 \frac{1}{2}$, tooled about, got passport viséed ete., breakfast and railroad at 6 . Very agreeable companions they had eome with me in the steamboat, and were travelling for their first time, a lady and her Governor; there were other English also in the same earriage. Stopped an hour at Malines just looked about me. Liége at $4 \frac{1}{2}$; ran about with one of my fellow-travellers, saw everything-dined and set off for Aix at 10 at night; a eouple of Englishmen still sticking to me, one of whom tried to inveigle me into acting as a sort of courier, ete. " "Speed Malise speed," but I dished him nicely. Aix at $4 \frac{1}{2}$ in the morning, warm bath ete.; ran ahout the town, Charlemagne's throne, ete., etc. Goorl breakfast and set off for Cüln at $7 \frac{1}{2}$, arriverl there at $3 \frac{1}{2}$; bolted to the bankers; just liad time to look at the eathedral and off in the steumer; we eame opposite Drachenfels about $\frac{1}{2}$ past 11 at night. I disembarked at Königswinter; ran to the top of the Drachenfels and waitecl to see the sun rise (the steamer would have been in Coblentz by 4 o'eloek), bolted down again in 13 minutes and $\frac{3}{4}$ ters, grabbed a breakfast, and off for Coblentz; found that I eould not get off to Giessen till 3 o'clock next morning, so I walked up the Chartreuse, and in every possible direction till I was thoroughly tired (boiling sun); reinvigorated myself with a brace of iees ete. The men at the inn (Hof zum Riesen) very uneivil, so I knew that if I went to bed they would not awake me at 2 in the morning; eonsequently I took my luggage to the Selnellpost office, tolcl the man my unfortunate condition and asked him to let me sleep in a diligence. He immediately took compassion on me and bundled about for the keys of the Passagierstube, but the keys were not to be found so I pieked out the most eomfortable Postwagen and fell asleep most eosily. However the choeolate iees, bonbons, and coffee that I had taken not exaetly agreeing in my inside, $\mathrm{I}$ had a desperate nightmare, fancying that 2 vipers were daneing the "Cachuea," whilst an old rattlesnake was posturising in the "La Gitana." At this I squealed awfully and being thoroughly awakened by a desperate rattling at the door,

$$
\text { P. (:) }
$$


I found the Sentinel standing with a fixed bayonet. I however kept still and soon went to sleep. Set off at 3 in the moming (Sunday) and got to Giessen at $4 \frac{1}{2}$ p.m., tooler to the inn and on inquiry fortunately found Miller thcre. In the evening walked about the town round the ramparts ete, etc. Miller introdueerl me to Playfair, latc chemical assistant to Graham, to Gilbert, also assistant to Thompson, and to Herr Bcttenlaneher, a Vicnna professor, all studying at Licbig's. Went to bed, slept gloriously, up at 6 this morning, went to the Laboratory, heard Liebig leeture, saw all that was going on. Made arrangements with the German Professor for daily lessons. My present plans are as follows. Work hard at Giessen for a fortnight till I ean speak it tolerably. I shall then expeet letters from you with Berlin, Dresden or Hanover introductions; go to one of these places, and mix in soeiety and lark for 3 weeks at least, and shall be in England on the 14th of September.-Please write to Hodgson and tell him about my alteration mentioning that Miller thinks it the best thing that $I$ ean do. Writc an answer please by return of post and anotler letter with introduetions (if you approve of the plan) as soon as you ean get them.

I am most eomfortably housed ete., eating, drinking and sleeping eost 3 shillings a day. I dine with the ehemiealizers at 6 o'eloek. There are great top-sawyers amongst them. We always speak German. I am much vexed at losing my Chemistry, but I shall gain far more by stewing away at Gernan, than I should had I worked at Chemistry, Liebig's arrangements being as I had expected. I have enjoyed myself exeessively,

Good bye.

$\mathrm{Y}^{\mathrm{r}}$ affectionate Son,

Fras. Galton.

Miller and myself are great ehums and we talk German to cach other most unintelligibly. I have no doubt that the linguists at the table d'hote will lave much discussion on what the tongue is in whieh we eonverse.

Of the men mentioned in this letter several reached distinction later. William Allen Miller-also a Birmingham General Hospital man-became Professor of Chemistry at King's College, London, and later, especially in conjunction with Huggins, made noteworthy chemical investigations. Playfair, afterward Lord Playfair, was well-known to our generation both as chemist and politician. But the mood of Francis Galton was at this moment neither for research nor intellectual society. He could not possibly have settled down to either chemical analysis or "stewing at German." The roving lust had seized him and it was to hold him for many years, until indeed it should itself become subservient to his love of scientific inquiry. 


\section{My dear Fatuer,}

Gizsskn, July 30, 1840.

Being thorouglily cmuied at Gicssen and having nothing to do from moming to night ${ }^{1}$, I have determined to make a bolt down the Danubo and to see Constantinople and $\Lambda$ thens. I have made all the calculations of time and cost and they are very favourable. Can I take any messuge to the Skcys? I do not wait for an answer before I start for two reasons, $1^{\text {st }}$ that I have not time and $2^{\text {atlly }}$ as you promised me at goorl summer's tour to Sweden and Norway, of course you can have no objection to a comparatively civilised trip. I am getting on in German capitally, and shall lcarı almost as much of it in these my travels as if I had settled in the midst of Bcrlin-1nuch more than by stayiug in Giessen. Another reason for my unlesitating bolt is that as I shall have very little time after I an settled at Cambridge, I had better make the most of the present opportunity. So I will fancy that I have received a favourable answer, and so thank you very much indeed for your consent. My conscience being thus pacified, I will tell you something of Giessen.-It is a scrubby, abominably paved little town-cran full of students, noisy, smoky and dirty. Of these students, by far the best are the Chemicals, they being all firstrate men, wot write books and so fortlı; they are one shade less dirty than the others, that is to say they are of the colour of umber; the others being Bt Sienna. They have a table d'hôte to themselves at 6 o'clock (at which I join) and they drink inuch sour wine and Seltzer water. Every now and then they dissipate, i.e. send for a quart bottle extra of Rauenthaler, and drink healths and sing songs. To drink healths you clink your glass with everybody elsc's glass at table, thereby spilling much wine on the table-cloth and over your neighbours' necks-over which you are stretching. As there were 30 sitting down together at the one which I witnessed, by the simple rule of combinations ${ }^{2}, n(n-1)$, or $30 \times 29$, the glasses must have clinked 870 times for each lealth that was drunk say (at a low computation 20 were drunk) then 17,400 clinks must have ensued!! If one student calls out to another: "Sic sind Doctor," it is a challenge to drink 2 glasses of wine with him; if "Sie sind Professor," then 4 and so on. They have also a very uncomfortable custom for foreigners which is this-one man walks up to another (whom le knows) and asks him if he has any objection to drink "Schmollens" with him; the conscquence of which cercmony is the calling each other "du" ever after instead of "sie," and in fact making them perpetual chums. The way in which it is performed is by drinking a glass of wine, the arm which holds the glass being put through the corresponding "arm of the other-and then saluting each other on both cheeks; this last part to be continually repeated after any absence! I have not seen it performed, but I was in great fear and trepidation, even more so than when before Mary Luard at a Christmas party.-The

1 Our hero forgets that in his last letter to his father he had arranged to work hard at German for a fortnight! I do not think that Francis Galton ever obtained more than a working knowledge of German, i.e. that ho spoke it fluently or read its literature from inclination.

${ }^{2}$ Francis's mathematics seem to have failed him, or the Giessen custom differed from that of Heidelberg forty years later; cach pair clink only oncc, not twicc. Perhaps he counted a clink to each glass! 
Professor who gives me lessons is a deleetable old man, quite an origiual, who has 17 (!!) pipes in his room and who smokes to a corresponding extent. Tell Pernmy that there is a splendid eathedral at Limburg, almost unknown to Euglishmen,-and Byzantinc architecture with a touch of Gothie, just like the church of the apostles at Cöln, only mueh more splendid. By the bye in case that you slould faney any part of this letter to be a "take in," I can assure you that I never was more in earnest in my life. Having nothing more to say - with many thanks for your kind eonsent to my travels. I remain

Your affeetionate son Fras. Galton.

P.S. I have just opened to say that $I$ have seen one of the professors here who went a similar tour last year, and the one that wc have together concoeted is Frankfort, Würzburg, Ratisbon, Passau, Linz, Vienna, Constantinople, Sinyma, Athens, Patras, Ancona, Rome, Livorno, Pisa, Florenee, Livorno, Genoa, Marseilles and Paris. I have plenty of time. I could sce this all very well, quarantines \&c., and be back on the 18th Sept., but I will take more time. [In pencil.] I start tomorrow at 7 in the nurning. In case of a letter from you crossing this Miller will take eare of it.

Francis actually set off on July 31st with Dr. Meyer for Frankfort, the Doctor having parted "Schmollens" fashion from several of his fellow-students. The picture the diary provides for us is that of an intensely happy boy-full of fun and feeling himself out for a bit of a frolic truant fashion. At Frankfort, Francis began to drop the unnecessary: "Left in a parcel 1 coat, 1 p trousers, Liebig's Chemistry Part I., Liebig's Organic Chemistry and the handbook for Northern Germany (1836) with the map torn out." He had time, however, to "scetch" (sic!) ver'y neatly in pen and ink the Katharinen-Kirche and a general view of the town. The next stage is Wurzburg, with some careful pencil work sketches of the town, and here Galton fell in with a travelling companion :

"Aug. 2. Went to slecp on the sofa in the eoffee room and on awaking a scrubbylooking little Hungarian addressed me in bad English, asked me my route and said that we should be fellow travellers to Wien. Set off at 12 for Niirnburg, a Lady being the only other person in the diligence. The little Hungarian no sooner perceived a petticoat in the diligence than he bellowed out for lauterns most furiously, but notwithstanding his exertions eouldn't get one, so cursing awfully sat down with his eyes 3 inches from the girl's face. On passing out we caune elose by a light whieh exposed the physiognomy of the girl, and the Hungarian being satisfied commenced a most vigorous courtship. He toll me that it was quite necessary for me to unake ny'self mu adept in the art, and so I tried and with some success fell fast aslcep.

Any. 3. Awoke and found him liolding both lands of the girl and singing love songs. I aecordingly burst out laughing in which they botlı joined. I then began uy flirtation with much more success than my rival, at which his mustachios clesponded and looked sad. Arrived at Nüruburg at 12. Marie, for such she said was her name, gave me a lit of an artificial flower that she wore, but would not let me crib some of her 
hair, hecause I had only a penknife to eut it with, though sho said hal I had a pair of scissors it would have been different."

Ratisbon and Walhalla followed, the sketchbook showing various details of buildings, rafts, and country folk. At Passau the steaner is found to be injured and on Aug. 6 Galton set out with Major Parry in a boat with one rower to go down the Danube to Vienna, which was reached on the 7th. In Vienna there was sightseeing, opera and gaiety. Then down the Danube to Buda Pest and on to Semlin, reached on August 13th.

"The natives beastly dirty, sheepskin clothes, wide full trousers, long greasy hair, turned-up hat. Passed Peterwardein, anything but picturesque. Slept at Semlin having first walked about the dirty town and up to the ceinetery, whence is a very good view of junction of the Save and Danube. It was too dark to sec Belgrade well. [T'here is a picture of Belgrade from Semlin by moonlight, Aug. 13.] Sang 'God save the Queen' and went to bed loyal."

'Then by way of Sistova, Kustendje, Castle of Europa to Constantinople, reached on August 22nd. There is little in the diary here but a youthful traveller's impressions, a long description of the first 'Turkish bath, the slave-market and the mosques, only seen from outside. From this first section of Galton's tour three home letters remain. 'The first is from Vienna:

\section{Vienna, Hurrah!!! Aug. 7, 1840.}

Stadt Frankfort Hotel.

Iy dear Pater. It has just struck me (i.e. after having taken my place to Constantinople-not before) that this expedition of mine is about the coolest and most impudent thing that $I$ have done for a long time. But I remember when about 6 yrs old you telling Darwin and Erasmus of an exploit of yours in kindly oflering to escort some young lady (I forget whom) from Birmingham for a mile or two, and somelow or other when once in the carriage you thought it better to go on to Bromsgrove merely as a protection to her; at Bromsgrove of course the same reason held good and so on to Worcester. I thought it then a very naughty thing. Now from Birmingham to Worcester is at least 40 miles and from Franfort to Constantinople is only 2075 (I have carefully counted them) a leetle more certainly, but not enough to matter, so please be lenient. How I shall get scolded when I return! But there is one consolation, viz. that I go too fast for any letter to overtake me and disturb my serenity; when once started from here on Monday next the 10th. Now for iny diary...... [Then follows the account of the flight from Giessen and the journey to Linz.]

Splendid scenery, dark lovely pinc-wood forests, many rapids and boiling sun. Here you feel that it is the sun, it puts life into one and warms one quite into the sublime. Bye the bye $I$ am as nearly nad in that way as a person can possibly be imagined to be, who does not actually turn down his shirt collar and go about without his cravat. On arriving at Linz found that the steamboat was, as a waiter who tried to 
speak French said to an Englishman who was with me, "malade," i.e. injured in one of the rapids and obliged to lie by. I accordingly unade an agrecment with this Englishman whom I had picked up the day beforc to hire a boat between us and to get down as we could to Vicnna. Well a boat we got, i.e. a punt of unplaned boards kept together with wooden spikes and in this we set off at 3 a.m. It was horribly cold and a strong wind in our teeth, but we luckily got on, bailing out continually. On leaving the hills the wind troubled us less and about 2 o'clock wc passed Mölk having gone down all the rapids; here the wind freshencd. I accordingly took an oar, i.e. a tip of a fir-tree with a bit of board nailed to onc end and rowecl as hard as I could to Stein (look in the map), it was very hard work. At Stein we changed men and got two rowers and arrived at Vienna at 2 o'clock this morning. Being not allowed to cross the barriers we had to walk two miles with baggage to the Police Station and then another mile to a slecping place, 13 beds in onc room. Got up at 7 and have becn walking about secing sights, till about an hour ago $9 \frac{1}{2}$ p.m. The Englishman is a Major Parry, has seen some Canadian service, and in an eternal fuss and flurry, clubs with me and as he does not know one word of German is always full of gratitude. I lave just come from hearing Strauss play. I have had the pleasantest possiblc royage, nice companions-very nice indeed in some cases. N.B. Linz is univcrsally famous for the beauty of its fair sex, and so is Würzburg, and everything prospcrous. I have never enjoyed myself morc. I shall be back in quite time enough to Cambridge ( $I$ liave altered my return route) so don't be at all uneasy about that-and I shall be in Constantinople on the 23rd. Don't write after me because I am not quite sure of my return route, but I will write, if I havc time from Constantinople. I would have given anything to see your physiognomies, when you received my letter from Giessen. Didn't Bessy say: "What a monkey"? Well, Good bye and believe me ever

Your affectionate son Fras. GaLton.

Dear Pemmy, I have been sketching away. I wish that I had you with me, you would so enjoy the journey. You certainly nowhere see such universally happy faces as in Germany, it puts one in the best possible humour. I am laughing half the day, and I am tanned as red as mahogany, perfectly independent and in the best good humour imaginable. Then in the evenings I tooled with a diligence friend to the coffee gardens where all the fashionable of the town are assembled, and flirt furiously; really I feel quite at home everywhcre. I saw such splendid etchings and sketches today by all the first masters. Every style from Albert Dürer to Raphael, the trees are done beautifully (Ah! Mr Francis!) I wish you could see them they are the Archduke Charles' Collection and 35,000 in all-and how is Bessy, I suppose as fat and healthy as possible after Tenby, and Delly and Mammy and Lucy and brothers? I should like just to have a peep at all your pretty faces again, it seems at least a month since I left Frankfort and I do not know how long since I saw you last. Well, Good bye. I think of you all surnctimes. Firas. Galton.

Oh, the joy of it all, when the roving lust is on you, and all men reflect the happiness that radiates from yourself! The writer can recollect a three months' journey on foot alone from Heidelberg to the gates of Vienna and back when only a little older than Francis Galton; 
and the same strong impression received that the race of men from the Neekar to the Danube must be the happiest population on earth! But if the Wronderlust grips a man, he runs grave risk of never settling down again in this life; it is one of the faseinating features of Galton's career, that with all the means and tastes to become a wanderer, he yet settled down--after fourteen years-to steady seientifie work. Might it not well have been a ease of :

"What's become of Waring

Since he gave us all the slip,

Chose land-travel or seafaring,

Boots and chest or staff and serip,

Rather than pace up and down

Any longer London town?"

From Buda Pest Francis Galton writes to his father for a remittanee to place him on the safe side on his journey home:

"Would you therefore send me to Trieste $£ 15$; if the correct way of sending it be in letters of credit please make them payable at scveral of the places about therc, Venicc especially. Should you, lowever, have clisinherited me or forbidden my reading mathematics or some equally severe punishment, then please send duplicates of that lettcr to Malta, Syra, Athens etc., ctc., bccause after that I have read one of them I shall be sure not to enquire after the others, and they will so amusc the postmasters. Well here I am in the most Hungarian town of Hungary, and already fully entitled to the Travellers' Club. There is such a capital spccimen of an Hungarian opposite that I must scetch [sic!] him. The hair and mustachios are no exaggeration [skctch of the Hungarian]. I never fully understood what a hot day was till I came here, in truth sight sccing opens the mind and the perspiratory pores also. The water that I drink oozes through as fast as through a patcnt filtering machinc. I must really invest in a parasol to-day, the heat at midday is absolutely awful. This morning I actually saw a live cow not half-roasted, but really and truly quite duen. I have got a mosquito net of which I shall find the full benefit, shortly, about Skela Gladova (pronounced Skêla Glādరră). A water coat pea-coat is the greatest comfort imaginable. Yestcrday in a storm of rain on the rivcr, which by the byc was much more violcnt than any Scotcli storms, and which looked just as in the scetch [sicl], I coolly posted myself on the top of the paddle box, looking quietly and comfortably with my hands in my pocket at the poor miserable-looking passengers for whom thcre was not roon in the cabin and who umbrcllas leeing useless, posted themselves as well as they could under the tarpaulin, their exposed parts suffering considerably. I was considered a maniac or something like it, but two or threc Newfoundland-dog-like shakes made my peacoat half dry and not an atom of rain had gone through it...... In 11 days more I am in Istamboul, hurrah! I remember a bit of advice of Darwin's when I was climbing up a ladder to the cistern in the yard at the Larches, - not to look down, but only upwards aucl sce what was left to be climbed; just so with my present tour. I fancy mysclf not mueh farther than Bclgium, quite at home and only calculate what I have to do." 
The last letter we have is that from Constantinople:

Śtanboul, Aug. 22nd, 1840.

Mr (not Madame) Josephine's Iuonguvg House.

My dear Fatuer, Here I am at Constantinople-among Turks, Armenians, Greeks, Jews and Franks, in a goorl Lodging House, as well as possible and happier and happier every day. The Golden Horn is just in front of me, erammerl full of mosques and minarets, Seraglios and Towers. Seutari to my left on the other side of the Bospliorus and on bona fide Asia, and I myself in Pera on the top of the Giaour's Hill (remember the " $\mathrm{G}$ " in that word is pronounced lard, and it is only two syllables, thus ( $\left(\begin{array}{c}\text { ow ar } \\ \text { ) }\end{array}\right.$ ) the "ia" is just audible). I never in my life had a more pleasant royage than down the Danube. The funny costumes, and languages, viz. German, Wallachian, Selavonian, Illyrian, Turkish, Russian, Italian, French and English were all spoken around me. We eat water melons and grapes. I scetched (sic !) a good deal, walked on the land wherever the steamer stopped and really saw an immense deal. Tell Bessy that I passed by the cave where St George killed the Dragon, and sketched too-and that the putrid body of the Dragon gives birth yearly (so says tlie legend) to myriads of mosquitoes, very many of whom bye the bye bit me. At Orsova I went to the baths of Mehadia (see Murray-as you have got my "Southern Germany Murray" you must read up my route) the rapirls and between Alt Mordrva and Skela Gladova are very fine rough brown mountains on each side, a good deal of wood, a swift stream below, whirlpools oceasionally, and splendid eagles soaring about. 'The Iron Gate is a humbug, the rapid is swift enough but the scenery nothing particular. At Orsúva (Ōr-shưwa) on stepping into the boat we were tabooed for 10 days quarantine had we returned, and we were in a minute among turbanned Turks. The Quarantime laws are a great bore. A Turk has 3 days Quarantine in Wallaehia and 10 in Hungary, a Wallaehian 7 days in Hungary. So there are 3 nations close together none of whom can tride ifc, to any extent, with the other. See Murray as to the way of making exchange, and passing the money through water. Stopped at Czernabōda (that is a Russian name) and went overland to Kustendje-3 other English with myself made the first English party who lard ever done it with the exeeption of one solitary Englishman about three weeks since. We arrived at Kustendje and the Black Sea (!!) all comfortably (exeept one breakdown of the axle tree), and found a rery good inn and actually Barclay and Perkins' porter, a bottle of whieh I drank to the health of all at home. Steamer was to set off next norning at 12. Was lent a gun by an inhabitant and so went out a-shooting. Slot a couple of Sea Gulls first, then broke the leg of a heron, when flop flap flap up got an eagle, bang! Mr Fagle lay a subject for dissection on the ground. Aceordingly I did disseet him, at least skin him to the adniration of all belolders (I had ny disseeting knives with me)-and I shall bring him to England. It is not a large one, not above $3 \frac{1}{2}$ to 4 feet from tip to tip of wings, bnt a very powerful one. (Dinner's ready so I must stop.) Set off in a steamer on the Black Sea having first bathed therein. Very windy-cross sea worst passage since Mareh. My breakfast and dinner were soon food for fishes, if they could digest them-I could not, in fact I was horribly squeamish at last having during my short time of health seen a splenclid storm, lightning as bright as in the most vivicl illumination, a luroar glare of sheet lightniıg 
extending along a quadrant of the horizon concentrated itself togcther in the middlc to a broad band of forked lightning, it was splendid. The Black Sca is really very black, I do not know to what it is owing-roeky bottoin?. [We] sailed down tho Bosphorus through the Symplegades. Egad the Bosphorus beats any thing in the way of a view I have ever set my peepers upon. The kiosks are so opera-scene-likc, so white and so much trellis work about them, tho nountains are so grand and the Bosphorns so broad and blue, that (I am stuck fast in tho mud about how to finisl the sentence being afraid of verging on the romantie).

Arrived at Stamboul seeing as Byron says

$$
\begin{aligned}
& \text { "The selfsame view } \\
& \text { That eharmed the charming Mary Montague." }
\end{aligned}
$$

The seraglios are splendid, ditto palaccs, such a groat deal of trellis work about them, and then there arc cypresses, and the veiled ladies just looking out [sketelı of one] between folds of gauze and very pretty eyes they have too; then there are the Greeks, I never saw sueh blaek eyes in all my life. I should like to put one of them in a rage; they nust look splendid then. I saw the women's slave-market today-if I had had 50 pounds at my disposal I could have invested in an exeessively beautiful ono, a Georgian. Some of the slaves had their nails dyed in henna. Most of the black ones were fettered, but they seemed very happy dancing and singing and looking on complacently whilst a eouple of Turks were wrangling about their prices. I took a Turkish bath today, such a shampooing and lathering and steaming. Now about getting home. These plaguy quarantines have been extended, thougl therc is no plague now in Turkey (a great bore for I wanted to see some cases) and that at Syra with that at Triestc will be, I fear 24 days I therefore sliall seareely be ablc to see you before going to Cambridge. If I ean get books I will read away in quarantine at mathematies and classies if I ean't why I must learn Turkish or something desperato of that sort. In my last letter (from Pest) I asked you to send me $£ 15$ to Trieste-if you have not done so already please send it now-as I shall then have no possible anxicty about money matters. Good bye, loves in all direetions.

Your affeetionate son,

Fras. Galton.

Those who have had the privilege of examining Sir Francis Darwin's journal of his tour in Turkey and Greece, and comparing it with Francis Galton's diary and letters of more than 30 years later, must at once be struck by the close resemblance of the two men; they sketch much the same objects, in much the same style, and they are both interested in the same sort of things, especially the plague. The impression of the marked hereditary resemblance between uncle and nephew is much strengthened when we read these diaries.

Beyond Constantinople the diary-and it is very fragmentary-is all that tells us of Francis's further progress :

P. G. 
"Arg. 26. Set ofl" from Constantinople in the Crescent at 4 p.m. Italian captain, English mate. One English gentleman, 4 ditto Ladies; French, Greeks, etc. and imnumernble Turks, lying about, men and women, smoking and drinking coffee. They are a great nuisance; tho clenr space on the quarter deck is not 18 inches broad and the consequence is that when tho ship rolls you aro almost sure to tumble over their feet, right into the middle of them, and as they are mostly women, such a position is very indelicate, and as they are all sea sick highly disagreeable also. Very rainy on setting out; it was soon dark. Entered the Dardanclles at 8 next morning.

"A ugust 27.......Came to the place where Troy was, thoroughly disappointed. There is no truth in the proverb 'Ex nihilo, nihil fit,' for Honer has shown its fallacy. He must havo had a brilliant imagination to make a little bit of plain 2 miles long and 1 inile broad the scene of all the manoeuvres of a ten years' war. The idea too of fighting ten years for a woman! Catch me doing such a thing for the fair Mary Anne, but the days of gallantry have passed. Achilles' tomb, a little hillock; as for 'Tenedos opposite which the Greek toiled a couple of days to reach, I would bet anything that I could row over in 40 minutes (supposing the marsh on which Troy stood to have been increased by alluvial deposit, still Mount Ida and the rocks of 'Tenedos are necessarily stationary and so there cannot be much mistake about relative distances). Tenelos is rocky and barren, has a large stone fortress built on it. Mytelene rocky and barren also; if it used to be in the same state Orpheus must have been a dab hand to find beasts to charm with his lyre. Anchored off Smyrna at 11 p.m......"

In Smyrna Galton bought two pistols and a rifle barrel and he was "as happy as possible" with his purchase. On August 28 he walked out to the Aqueduct, practising shooting with his pistol and sketching the Aqueduct.

"Caught a splendid locust which I keep for Delly; got to the Aqueduct at last. having had previously to walk up the middle of the stream on natural stepping stones for about 200 yards and trespassing in orchards immumerable. The Aqueduct is a very large one, I should guess 500 yards and only from 3 to 5 feet wide. I walked on the top from one side to the other, a feat which my valet de place had told me had been once accouplished at great peril by an adventurous Englishman......

"Aug. 29. Set off on board a French man of war steamer Dante for Syra; very large and roomy, very slow sailer. Eat a fearfully large breakfast of meat and fruits, drowsiness and some symptoms of inultigrub supervencd. Passed Scio, rocky and bare. Eat an enormous dinner, tcrrible cholera, stomach-ache and nausea all night."

On Sept. 3 we find Galton in the Quarantine House at Syra, of which he provides a sketch. Here on the 6th he records a dream of ill omen to a friend, Miss Hawke, and adds, "I can't help fancying this true." A note is added at a later date, "which signified nothing." Most persons record such dreams after the event and only when they come off. In this Quarantine House Galton stayed 10 days, then he passed to Athens with a brief visit and so to quarantine at Trieste. 
He has himself in his Memories (p. 55) told us how he escaped three or four days' quarantine at 'Trieste by the quaint process of making Spoglio. The assumption made is that an apparently healthy human body passed through water is not as dangerous as the clothes it carries. Accordingly a few days before termination of the usual quarantine there is a medical iuspection and the doctor directs those who satisfy lim, and wish to "make Spoglio," to a covered quay; opposite to this, at a distance of about 20 feet, is a second quay, the two being separated by a strip of water four or five feet deep. On the second quay are vendors of clothes.

"A bargain had to be made with one of the old-clothes men by shouting across the water. I," writes Galton, "was to leave everything I liad on me, cxcepting coin or other metal, and papers which were about to be fumigated, in exchange for the offercd clothes. When the bargain was concluded, I stripped, plunged in, and enierged on the opposite quay stark naked, to be newly clothed and receive freedoin. The clothesman got my old things in due time-that was his affair. The new clothes were thin, and the trousers were made of a sort of calico and deficient in the faslionable cut of my old ones; but as it was not then late in the year the thiuness mattered little in those latitudes, and I did not care about the rest."

From Trieste Galton returned by way of Venice, Milan, Geneva and Boulogne. We have no record of the home-coming beyond what Galton himself has told us :

"My dear kind father took my escapade humorously. He was pleascd with it lather than otherwise, for I had much to tell and had obviously gained a great deal of experience." Memories, p. 57.

But the seed had been sown; the first attack had run its triumphant course, and the Wanderlust would manifest its power year after year in Galton's life. He himself says :

"This little expedition proved an important factor in moulding my after-life. It vastly widened $\mathrm{my}$ views of humanity and civilisation, and it confirmed aspirations for travel which were afterwards indulged." 


\section{CHAPTER V}

\section{LEIIRJAIIRE AND WANDERJAIIRE}

\section{Part II. Mathematical Studies and Cambridge Pleasures}

Is October, 1840, we find Francis Galton established in Trinity College, Cambridge. It was, he says, a notable day in his life when, escorted by his father, Tertius, he arrived on the top of a stage coach in the town of Cambridge. No man was ever a more loyal son of Alma Mater than Galton, and nothing gave him greater joy in later life than the honours conferred on him by his College and University. That the portrait of him-a mere pollman-should hang with those of great heroes in the dining-hall, that he could once again order audit ale and dine by right at the Fellows' table were matters which gave him inexpressible delight. Those who have never left the University have little knowledge of how very tender, and largely unreasoning is the affection of the old Cambridge man to his University. The existing life of the place he feels has nothing to do with him, it is transient, interloping. 'The permanent and substantial is the old environment, peopled with many familiar forms, with the wonted figures crossing the court, the friendly shout from the windows, the tones of voices long silent or now grown unsympathetic, the midnight fireside, the enthusiasms of youth (our youth, of course!), and the seniors with their failings, which have grown to be essential virtues, landmarks of that time, with their indulgent tolerations, and their moulding affectionate sarcasm of our certainties. We own the place, we people it; the present population are but lessees of our ancestral halls, intrusive, alien, anomalous. 'The magic fascination of it all is merely thwarted by the reality; for us "the ideal shall be the real." And when two Cambridge exiles talk togrether of the place-they unconsciously mingle in one same environment, two races of men separated, perhaps, by a generation. We know them all: Harry Hallam", "with his singular sweetness and

\footnotetext{
'Brother of 'Tennyson's Arthur Hallam.
} 
attractiveness of manner, with a love of harmless banter and paradox"; F. Canpbell", who set for himself "an ideal of public life too high for" his powers" yet who had a disposition unalloyed by pettiness, and when consulted about difficulties "put things in fiesh lights, and always with noble intent"; Johnson" of King's, the active member of the Epigram Club-of which more anon; Maine ${ }^{3}$ of Pembroke, one of the few men as thoroughly at home in Trinity as in his own college; Kay, the idler of the staircase, but the effective man in later life; Charles Buxton, with none of the exceptional brilliancy of the others but with "manly virtues and as much common sense as was consistent with a charming dash of originality"; W. G. Clark 4 ,-who like many men gave promise of high achievement, but failed to fulfil, and could but sing:

"Truly there's something wanting in the world";

Mathew Boulton, the boy known from the old school and from home (see p. 77), and the relative, Cousin Theodore ${ }^{5}$, to complete the circle. Galton tells us of these friends ${ }^{6}$ in his Memories (pp. 65-70) with a few brief lines of characterisation. Surely they are not more his friends than our own? Are they not types that we ourselves have known thirty to forty years after Galton? types which, under other names, yet haunt to-day, thirty and more years later still, the old staircases, and even now assemble to express in new language the old dreams and ever new ambitions round the ancient fireplaces, where they seem to our generation intruders, and where we seem to them shadows of a profitless past, which they dismiss as mid-Victorian!

Galton knew and loved his Cambridge right well ; it gave him friends and some mental training. He appreciated the thoroughness of its

1 Afterward Lord Campbell ; he was son of the Chancellor.

2 Willian Johnson Cory, the Eton master.

3 Afterwards Sir Henry Maine. Among Galton's personalia I have come across Maine's undergraduate visiting card.

- Public Orator of the University and Vice-Master of Trinity College.

${ }^{5}$ Theodore Howard Galton, see Pedigree Plate A.

${ }^{6}$ They were, apart from degree standard, in many respects a brilliant group. Maine in 1842, Johnson in 1843, won the Chancellor's English Medal; Clark got the Porson in 1843, and the Greek Ode in 1842 and 1843, and the Epigrams in 1842; Haine the Latin Ode in 1842 and 1843 and the Epigrams in 1843, and the Camden in 1842; M. Boulton the Epigrans in 1841; Johnson the Camden in 1844. Maine got the Craven in 1843, Johnson in 1844, Maine and Clark the Chancellor's Classical Medals in 1844 and Hallam got them in 1846 . 
studies, but complained-even bitterly-of their narrowness. Luckily for him his medical studies had. supplemented them at the very point where they were most defective-the training in observation and experiment. In 1840 there was no Natural Science Tripos, and of course Moral Science and History had not been thought of. There were Professors of Chemistry, Botany, Geology, Natural Philosophy and Mineralogy, but as the honours students must read for either the Mathematical or Classical Tripos, these professors did not attract the able students who were working for fellowships. Indeed Laboratory and Museum accommodation was very limited in Cambridge in 1840, and the modern idea of laboratory training may be said to have been practically unknown. In a certain sense Galton's training had been of a far more modern character in London than it could be in Cambridge, but at the same time the intensive study of mathematics was a distinct gain and one which was of great help to Galton. His first letter to his father, after the latter's departure from Cambridge, runs as follows:

Trin. Coll. Cambridge. Monday, Oct. [19], 1840.

\section{MY dear Father,}

Thank you for your letter. Six silver teaspoons will be amply sufficient. If you camnot send wine easily from Leanington, the best plan will be to write to your London wine-merchant as there is a carrier direct from there. There are no letters for you from the post, but $I$ enclose one from Adèle which I received today in a letter to me from her. I have had as yet no answer from Leonard Horner. O'Brien has not yet returned to Cambridge, but was expected today. He fell desperately in love at Inverary where he went with a party as tutor. I will write to you on completing my arrangements.

My rooms are very comfortable. Emma's pictures are quite at home, as usual, in ny bedroom, and I an going to invest in a plaster bust of Newton and get it bronzed over and put up opposite the fireplace [see Plate LI]. I have got everything except my linen which is not quite got ready. I shall however be able to send you my accounts in two days. Theodore has returned, but I cannot find him, he arrived about an hour since.

Perry ${ }^{1}$ gave us lis first lecture today; what a pleasure it is to hear a real senior wrangler speak. My organ of veneration is so very strong that I doubt when I shall dare to address him. What a fine sight a surplice night is, the briglit light of the wax candles and the white dresses so well contrasting with the dark panelled oak behind gives no slight rescmblance to a scene in Revelations...... am as happy as possible and «nI preparing for a long and strong pull at reading. Love to Mater and all.

\section{Your affectionate Son Fras. Galton.}

1 Senior Wrangler in 1828 , Tutor of Trinity, 1837-1811, and afterwards Bishop of Melbournc, 1847-1876. 
The following letters provide a more intimate picture of Galton's life at college :

\author{
Oct. 23rd, 1840, Thinity, Cambridge.
}

\title{
My deAr Father,
}

I did not write lefore, as I wished to hear whether Mr O'Brien ${ }^{2}$ would have me or not, before sending my letter: However I have just learnt that he will aull I legin witl him on Monday next; he reeominends me not to go over with him now my old subjeets, but to start off and read as I ean of Differentials and their application to Staties and Dynamies, and after this term to read over again what $I$ have done against my first examination in May by which I am elassed. Thanks for your letter reeived 2 days since. Port wine not arrived. The eommunieation between the intellectual nueleus of Cambridge and the Boeotian town of Leanington is exeessively tardy. I really think that our present eeonomising Government must have made a contraet with the carvier for the transmission of the mail-bag, as, if the postmaster at Warwiek was not seized with an apoplexy and thereby oceasioned a delay, your letters take 3 days to get here. Yesterday I lad a letter direetel to you in my mother's handwriting (the enelosed letter) sent me which must have slept on the road many days. I for a wager any day would undertake to be on the top of the Drachenfels by Bonn before a letter put in the post at Cambridge at midday, would reach Leamington. I waste paper fearfully, i.e. seribble over both sides of it innumerable $x, y$ 's and funny looking triangles. Mrs Hoppit says that: "It's a great comfort to her to have a reading gentleman, beeause there is then always plenty of stuff to light the fires with." Theodore looks blooming, he hangs up pietures of Cerito ${ }^{2}$ in his rooms and talks of the O-pey-ra. I tea with Boulton tonight; he is not mueh altered, but very shy. Talking of tea, please send me some soon, as there are many sloe leaves in the Cambriage. I have proved this by mieroseopieal observation. $\mathrm{H}$ - is very goodnatured and has introdueed me to some nice men; he was officious at first, wanting I think to make me as dependent on him as $Z$. is, but there was then a differenee of opinion between us, and now we are great allies.

\section{Good bye, your affeetionate son, Fras. Galiton.}

The letter is followed by the usual accounts, which this time include most of a freshman's needs-cap and gown, ironmongery, crockery, linen, etc. There are also a few lines on a little strip of paper somewhat characteristic of the man and rather hard on his father. Leonard Horner had clearly written to Tertius Galton praising the character of his son Francis-how we should like that letter now!-and Tertius had forwarded it to Cambridge. "Now I don't like being soaped; in that letter there were 3 words or so on the subject of introductions; why

${ }^{1}$ O'Brien was 3rd Wrangler in 1838 and afterwards Professol of Mathematies at the Royal Military Aeademy. He has given his name to one or two mathematieal demonstrations.

"See The Ingoldsby Legends, "A Row in an Omniluus (Box)." 
not copy them then? If I do not as yet like blarney, why try to make me fond of it by large doses?"

The next letter is endorsed by Tertius Galton, Nov. 3, 1840 :

\section{MY dEAR FATHER,}

I should have sent a letter to you yesterday if it had not been that the one that $I$ had written was spoilt by an accident in my Gumption-Reviver machine which eovered it witl water. 'This machine as it has perhaps comc into use sinee your time ${ }^{1}$ I will describe to you.

[Sketch of the Gumption-Reviver machine: a student sits reading at a table, elbows on table and hands support head, lamp in front to right; funnel dripping water which runs off a cloth bound round head to left. Additional sketches of gallows to carry funnel and of method of arranging cloth.]

"A large funnel is supported on a double stand about $6 \mathrm{ft}$. high, it has a graduated stopcock at the bottom by which the size of the aperture can be regulated. This as you read is placed above your head and filled with water. Round the hearl a napkin is tied, dependent on one side where the bow and end is so [arranged] that the water inay drop off. Now it is caleulated that as the number of hours of study increases in an arithmetic ratio, so will the weariness eonsequent on it inerease in a geometrical ratio, and the stream of water must in that ratio be increased. The gcometric ratio used in the lst year, i.e. for freshmen is 2, in the 2 nd year 3 and iu the term before taking the degree 5 . At that time the gyp has to call every quartcr of an hour to refill the funnel; the elothes are then also not protected as damp shirts do not invite repose. We generally begin to use this machine about 10 at night and eontinue it till 1 or 2 ; it is very useful. My private tutor rccommended it to me as the first thing; it is in fact quite indispensable to a high wrangler. I have reeeived wine, spoons and tea, for all of which thank you. So Fanny Broadley is going to be splieed-I congratulate her heartily. Mr Burrows may think himself uncommonly lucky, for I think she was the prettiest girl I almost ever saw.

"You mention the case of $\mathrm{Mr} \mathrm{H}$ - of Catherine Hall. I hear that he had worked himself almost to madness, but was quite unable to sueeeed on account of his natural powers; poor fellow he did the best thing that he could do though. As to who werc plucked nobody knows except the pluckers and the plucked; it is done very quietly. I have been reading very hard and am accordingly very dull. On going to O'Brien my private tutor (a 3rd Wrangler) he set me about Conic Sections, which I had not read before. He opened the book from which I was to learn them (Boucharlat Lv pages elose print ${ }^{2}$ ) and asked me with a sort of grin if I could get it up by the next lesson in $2 \frac{1}{2}$ days. I took it in earnest and did get it up, but I verily bclieve that I never worked so hard hefore. I got up the bookwork pretty well, but 1 own that I was not able to

1 These words seem to confirm the view that Tertius Galton actually went up to Trinity : see the first footnote, p. 52.

¿Boucharlat, J. L.: Théorie des courbes et des surfaces du second ordre.... 2 $2^{e} \mathrm{~cd}$. Paris, 1810. 
work problems and of eourse not having had time to aeeustom myself to a new subjeet. I will write to Hodgson.

"Distribution of Time. Up at Chapol at 7 ; ditto to $7 \frac{1}{2}$. Reading and breakfast to 9. Tectures to 11 . Reading by myself and with O'Brien to 2 , walk to $4-a 4$ mile walk-Hall to 4.20. Read $10 \frac{1}{2}$ ineluding tea. Leetures 2 hours a day, Reading (full tide) $101 \frac{1}{2}$ hours. I shall eut this down to 6 , as it is really too mueh. Tell Bessy that there is the most extraordinary possible chango in my eomplexion, the tan having quite disappeared. Breadth of phiz on the wane. Loves universally.

Fras. Galton."

\section{On the 5 th of November Galton writes home:}

"I progress salubriously. Bye the bye in ease any laughs are direeted against Theodore I shall most pugnaciously take his part, as he certainly has got a very great deal of knowledge in Modern History ete. I have been quite surprised with tho extent of his infornation on Hungarian, Turkish and other out of the way worthies. And though mathematies are most deeidedly not his forte, yet still he las a great deal in him. Goodbye tell Mater I am mueh obliged for her house-keeping advice."

\section{The salubrious progression was not of long duration :}

\section{My deAR Father,}

[November 26, 1840.]

Thanks for letter reeeived yesterday. I am mueh obliged to you about getting ne nominated to the Athenaeum, please thank Unele Howard for me. As he explained to me on a former oceasion it will be mueh better to make use of his assistance than for me to get Daniell or Partridge to nominate me, in whieh latter ease I should be sure of a professional opposition. I hope Bessy will get better soon....The reason why I write in peneil is as I am lying on my back I ean't get a pen to write; I have been eonfined to my bed for some days, rheumatism not over reading but will shortly be released. It has put a pro tempore clead stop to Maths. I have just received a letter from Horner, he offers to get me an introduetion to any men I may like, said lie did not write before to give ine time to settle and to find out the most desirable quarters for introduetions. I must make many enquiries before answering his letter.

Goodbye, affeet. Son, Fras. Galtos.

Hurra for the Queen's Kinehin'! I have ordered 3 dozen of "audit ale" on a venture for you at Leamington but am afraid that it will not be ready for $\mathrm{X}^{\text {tmas }}$. I shall be with you certainly not later than the 18 th Deer.

But the illness had been more serious than Francis had revealed. On Dec. $3^{2}$ he writes to his father:

\section{My dear Father,}

Would you please send me by return of post some money as I do not know what my doetor's bill will amount to. I was released part of Monday from bed (the

1 Prineess Vietoria, Empress Friederiel of Germany, born Nov. 21, 1840.

${ }^{8}$ Like his cousin Charles Darwin, Franeis Galton was singularly remiss in dating his letters ; we have to trust to Tertius Galton's endorsed dates.

1. (i. 
12th day of my rigid confinement thereto). As I had been extremely ill, the Doctor came 4 times in two days (fever and touch of delirium). I an in a great hurry for the post. Shall not be with you before the 18 th as I have some things to do in Iondon; we are free for $5-7$ weeks beginning on the 12 th. Shall begin lectures again on Monday next. Fras. Galton.

A letter of Dec. 8th discusses continuing to read with O'Brien for the following term:

"Next term he tells me that I had better go over the early part of Maths. with him, where he would certainly be of the greatest use to me with reference to my approaching examination. For though I believe that I know these subjects very well in the way that I was taught them, yet a Cambridge gloss makes much difference in the marks.......

"P.S. I forgot to say that I am getting on well. Shall not I think dissect in London, but give up my time to Maths. and Classics."

The next day a letter is sent, showing that Francis haid been up and about far too soon:

$$
\begin{aligned}
& \text { Wednesday 9th, } 1840 . \\
& \text { Trin. Coll. Cambridge. }
\end{aligned}
$$

Please, bed made, warming pan in trim, plenty of hot and cold water by seven and a half o'clock Saturday Evening 12th.

Too ill for London, in bed again, cold in lecture room this morning, get out again tomorrow. Fras. Galton.

Of the influence of this serious illness of Galton in his first term at Cambridge upon his work we have little direct information. He undoubtedly worked too hard, and this probably contributed to his ultimate breakdown. But his mind must have been very active during all this period, and it is singular how closely his lines of thought even in little details followed ancestral tendencies. Francis Galton began-exactly as his grandfather Erasmus Darwin had done-to design simple mechanical contrivances, and Erasmus's Commonplace Book with one page covered with mechanisms and the next with medical lore might well have been the product of Francis himself. Nay, the very rhyming aptitudes of Erasmus were reiterated in Francis during the whole of his Cambridge career. Long and short poems occur not infrequently among his papers, and without the facility of Erasmus, he had still considerable power of producing a sonorous line. It would not be possible to say that the true instinct of the creative poet was behind the versification of either ; Galton probably realised this as I have not come across any poetry later than 1844.

Already in November Francis had been writing to his father about hot oil lamps: he was interested in the question of the best 
temperature at which the oil feeding the flame should be kept in ordel to give a maximum of illumination.

On Jan. 25, Galton is in London, at 17, New Street, Spring Gardens, again; he writes to his father:

\section{My dear Father,}

I set off at 2 this afternoon for Paris, where I intend to stay till tho end of the Vacation,-that is to say I should have done, but that plaguy thing conscience preventecl inc. The placards about Boulogne steamers looked very tempting. I have just been to Bramalı about my lock, was more than $1 \frac{1}{2}$ hour with his top-sawyer man, who was in raptures and most deferential; he thinks about it today and I call again on Monday to explain anything that he may not fully understand. I enter my caveat for lamp on Monday. Now for proceedings.

Arrived at Brum at $8 \frac{1}{2}$ p.m., theatre and whiskey grog till $12 \frac{1}{2}$. Was shut up in the coach with a frowsy fat old gentleman and a fast young gentleman whose lungs were, judging by his breatl, entirely composed of full-flavoured cubas and the Cream of the Valley. The latter was not a very pleasant companion for vinous fumes ascending into his cranium displaced what reason had existed there, and showed their presence by causing him primarily to carol forth Nix my dolly pals - 2mily to sing a very sentimental song, and at last to open the window and afford me a very convincing proof that gin and cigars act as a strong emetic.-Fell asleep and awoke about 10 miles from Bristol. Cross couch had had an aceident, waited an hour till it was mencled, occupying my time in eating 2 eggss, 4 slices of beef, 2 plates of muffins and half a quartern loaf and then sallied forth and studied St Mary Le Port. Went to Cross, box-seat, a provincial medical man sitting behind with 2 friends, we got into a dreadful quarrel about lomocopathy, and as he was giving in and I was blarnying about Hippoerates, a gust of wind carried my patent gossamer hat down a steep hill into the middle of a pond (what was more natural than that beaver should take to water). The guard reclaimed it, but it presented the appearance of a chemical filter [sketcl]], as woll it might for on inspection I found that its substance was composed of brown paper. The day was beautiful. Arrived at Cross, Erasnus had been in the morning to meet the first coach, and had gone away again. I gigged it to Loxton. Sun shone, quite mild. Somersetshire is really the most beautiful country I have ever seen, north of the Alps (for Bessy), and of all dull pig-headed stupid bipeds the Somersetshire clown stands preeminent. Arrived at Loxton the manor house commodious but not gaudy ${ }^{1}$. Eras: girth visibly increased, Delly all smiles and lawn collar, the last mentioned article being as whitewash to a sepulchre or as charity, covering a multitude of deficiencies. They really both look as happy as possible; don't clash at all being separate all the morning, and in the evening whilst Delly writes letters for 4 hours and reads others for 1 quarter, Rassy pulls Track (the dog) by his tail and ears alternately, causing hin to growl ferociously for 1 hour, then sleeps $3 \frac{1}{\ddagger}$; and after that both adjourn to the dinner room to edify 3 maid-servants and a small boy with a learned commentary on the psalns, giving the true interpretation, pronunciation, and critical dissertation upon the most difficult Hebrew or Chaldee words. Was knocked up next morning at 6, of course fell

1 See Plate XXIX. 
asleep again, but was awoke at $6 \frac{1}{2}$ by a cracked dinuer bell in hysterics, when the furming nien go to their work. Got up and the small boy afore-mentioned brought me a pair of shoes [sketch] witl nails at the bottom liko the tecth of the cog wheel attached to the fly of a 10-horse steam engine; this I found was truly necessary to Sonersetshire walking. I am in a great hurry, will finish to-morrow-but must say that Rassy and Delly were most kind. I enjoyed my visit greatly. Rassy works liard at his farm and evidently takes the greatest interest in it. I went to Bath to call upon my earlicst flame Douglas Hunter ${ }^{1}$. I have no time to write inore. How is Charlotte?

Fras. Galton.

Another letter of nearly the same date describes the lainp and lock attempts :

\section{My dear Father,}

Lamp and lock both dished but have come off honorably in both. Capt. Basil Hall, aided by Wheatstone had lit upon the sane idea a short time since, and has since been making experiments. The light appears not advantageous as regards illuminating rooms, though it is useful for lighthouses. $\Lambda$ s regards my lock, Bramah complinented it and spoke very sensibly about it, he said it was certainly much more difficult to pick than any one of the same size and of a different construction, but the chances were quite great enough for security against a chance key in either the Bramal or Chub, the only thing to be feared was a model being taken of the original key when accidentally left about. Now mine being merely a piece of bent wire could be imitated from the impression left on almost any substance, or traced on paper-whilst his (here he grew coxy) required a very careful modeller and much time to imitate-my lock would also be expensive. This was very true, and I quite agree with him; but as regards the security of his lock when the key lrad been left in the hands of a pickpocket, I offered to make a falsc key in 5 minutes, if he would leave the original key in my liands for 5 seconds. He of course stood up in defence of his own key, so I got 10 knitting pins 5 large and 5 small and one wooden one which was central, the others surrounding it. On passing the central one down the bore of the key, the other ones were variously depressed according to the teeth in the key, as in the drawing, the other end $B$ of course exactly represents the key $(A)$; the ward $(C)$ is al ways the same distance from tho end and could therefore be fixed to one of the pins. Knitting pins are of course clumsy, but with a little contrivance a perfect picklock can be made (the breadth of the slits is of no consequence only the depth). Bramah was very fierce, I told him that I had some intention of patenting the picklock, and advertising "Inportant to Thieves, Housebreakers and others." I enclose a model of one of his show locks by five pins. Bramah who was called down to see my knitting pins looked angry.

Fras. Galton.

On Jan. 31 Galton is back at Trinity and writes home as follows:

\section{MY deAr Father,}

Thanks for letter. Lectures begin tomorrow (Monday) Poor $\mathbf{H}-$ !, Charlotte's cousin, was unable to stand the exannination more than 3 days on account of

1 Another letter describes this visit with Galton's usual flow of satirical humour, but conclucles with the P.S. "Douglas is a very nice girl." 
health ind so got an honour aegrotat. I was very much vexed about my lamp, but am now trying other things. I have I think a neat plan of making any balance weigh (by double weighing) to the greatest aceuraey. I do it by fixing the balanee near its eentre to a bar of steel (nagnetie) perpendieularly. The upper end of this carries a steel point which works against an iron plate, which plate can be screwed up against one of the poles of a fixed magnet, downwards, through a small space......

Galton's sketches show more clearly what he means-the main idea was a pivot or knife edge with very little friction because gravity was largely balanced by magnetic pull. Any very rough balance might be used as he proposed double weighing, and a fairly crude bearing, "a steel point against an iron plate," as there was a minimum of pressure. He probably did not intend to deal with any but very light weights and balances, otherwise the magnet would need to be very powerful.

...I think that in this way a very accurate balanee might be eonstructed for 10 shillings, which would be a desideration. I will make one.

I am having a Bramah piekloek made. I smoke my Turkish or German pipe nightly with somebody else, and give Theodore eau sucrée to drink with it-bless his innocence-it comes uncommon cheap-no man can drink nore than three tumbler's full, or it would make him sick.

O'Brien begins on Thursday.

Fras. Galton.

The fourth page of the letter has a rough sketch of Galton's room"recent improvements"- "sofa drawn out before the fire." Above the fireplace is a long low glass, and above this hang two pistols-clearly those purchased in Smyrna (p. 138), - crossed foils, - those purchased for practice at Angelo's (p. 109) - and what has the appearance of a lance, which might well have been used in the famous wild boar hunt at Sydnope in 1837-when the last boar was killed, Darwin Galton despatching it ${ }^{1}$ : see Plate LI.

Francis Galton's rooms were on the right-hand side of the ground floor of staircase B of New Court, that is the staircase to the left of the archway leading to the Avenue. The sitting-room looks east into the

${ }^{1}$ Sir Francis S. Darwin led the elase riding " a coal black steed, of mettle high and noble breed," others present were Miss Emma Darwin his daughter, his nephew Darwin Galton and Frank Jessopp, who celebrated the hunt in a poem (see Derby Mercury, A uril 8, 1874):

"Then yelped the dogs, halloed the men, Till Sydnope's echoos rang again.

The beast is roused with wrathful eye

Surveys his foes, yet seorns to fly."

etc. etc. etc. 
court, and the bedroom looks west towards the river bank, the willow tree and the lime trees of the Avenue; there is a small slip of a gyp-room next the bedroom. The rooms were sinall, and, being on the ground floor and not far from the river, may have contributed to Galton's bad health in Cambridge. Of their internal appearance we have the rough sketch just referred to, and also a picture of the last meeting of the "Caseo-Tostic," 1843; apparently it was drawn when the New Year, 1844, was five minutes old. (See Plate LIV.) Dalyell is in the chair, before what appear's to be a punch bowl, Stewart and Clark are on the sofa in front of the fire and Galton's feet only are visible-he is sitting facing Dalyell'. It is a New Year's Eve celebration. The whole is drawn hastily upon a sheet of scribbling paper which had been used on the reverse for studying geometrical optics. The picture we get of Galton throughout his college career is of a man who cared about many things, who enjoyed equally work and social life, and had not yet learnt that human powers are limited.

Three days later than the date of the "balance" letter-on February 3, Galton writes :

My dear Father,

$$
\text { Wednesulay [Feb. 3, 1841]. }
$$

'́rin. Coll.

Atwood ${ }^{2}$ came down this morning and breakfasted with me and I have left him in the hands of Boulton to lionise, as I am invalided from a relapse of my old illness which came on on Saturday without any cause to which I can assign it. I am all but well, it has not confined me to my bed, but only to my room. Thanks for lecture per post. . I am rather mad about a rotatory steam engine which I have been contriving. Boulton thinks it will do. Advantages being: $1^{\text {st }}$ The whole power being avaitable cranks being absent. 2nd The momentum of the piston increasing the effect and $\therefore$ the rapidity of working being unlinited, $3^{\text {rl }}$ consequently very small cylinder, $4^{\text {th }}$ no $f$ flywheel, $5^{\text {th }}$ exceedingly light.......

'The principle involved is similar to that of pumps now used for air and water; the direct action of steam on a vane causes rotation of the shaft to which the vane is attached. There is an ingenious mechanism for admitting the steam first to one half and then to the other of the pressure chamber; and there are numerous sketches. Galton's claims for his rotatory engine are possibly unsound, but very little as to rotatory engines could have been done before 1840 and that little could hardly be known to Galton. The letter is evidence of Galton's

' For refcrence to Dalyell see ILemories, p. 78.

${ }^{2}$ His old schoolmastcr: see p. 77 . 
Plate III

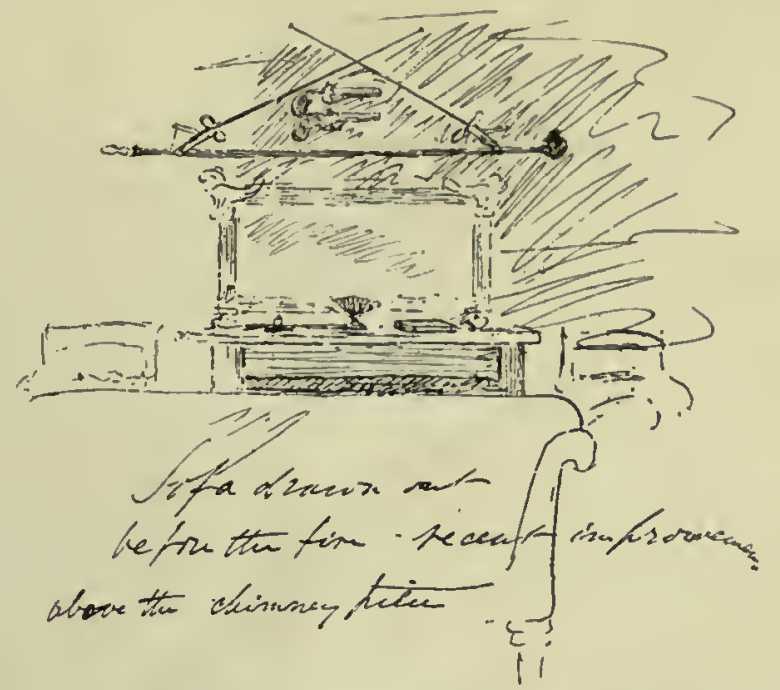

The fire-place with the foils, smyrna pistols, an! native lance.

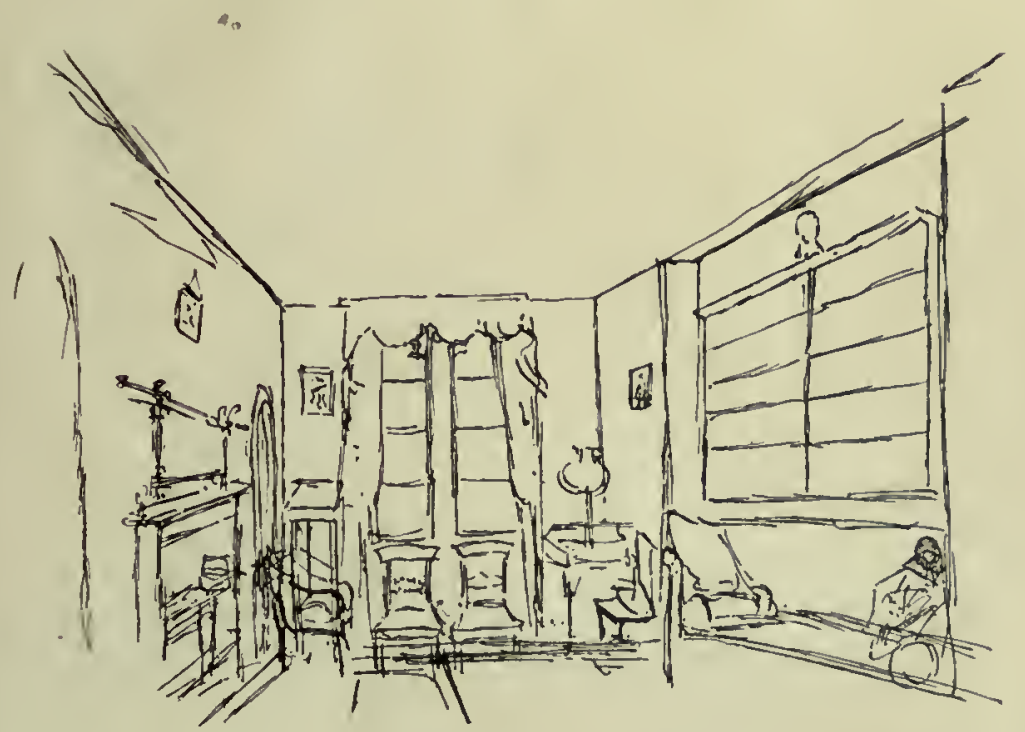

The living-room before the removal of the sofin to the tire-place.

( ialton's Rooms in 'Trinity college.

Sketches from (ialtoils Camhrilge letters. 

mechanical originality and his general interest at an early age in mechanical problems.

But teeming as young Galton was at this time with ideas, he was still equally eager for and markedly impressed by new experienees. His mind was rapidly developing, and each new eonquest, as it is made, is at once reported to his home eirele. The readiness with which he communieates everything which oceurs to his father-absolutely eonfident of sympathy and suggestion-suffices to demonstrate a very rare and perfeet relationship between parent and ohild?.

\section{Dear Euma,}

[Nrurch? 1841.]

I send 17 shillings worth of etchings etc. some of them by C. Sehub are exceedingly good. I was unable to get some outlines by Rembrandt, whieh I was anxious to have done.

I am very sorry that my Father is so unwell; perlaps this attack will do for asthma and all.

Yesterday I made my ippearanee before the cyes of wondering Cantabs, where do you think? Why right in the midst of a den containing 1 Lion, 1 Lioness, 1 hugc Bengal Tiger and 4 Leopards in Wombwell's menagerie. The Lion snarled awfully. I was a wee frightened for the Brute crouched so. The keeper told me that I was only the fourth that had entered that den. Nothing like making oneself a "Lion" at Cambridge. My Turkish tour and medical education does wonders and my late van Amburg performance promises to crown my reputation.

F. G.

P.S. I send a view I had of a street in Smyrun-thinking that it would make a very good picture à la Prout.

A few days later Francis writes to his father in a hand showing much sign of emotion :

$$
\text { Sunday [21 March 1841]. }
$$

Trin. Coli.

\section{My dear Father,}

Thanks for your letter. Tomorrow I will see if Mortlock has received the £20. I will send niy aeeounts. Thanks greatly about Aberystwith.

I am rather eut up by the sudden death of a College friend of mine. Poor fellow he wined with ine last Tuesday, walked with me next day, complaining only of a slight headache. I heard that he was ill yesterday Saturday morning, and going to see him after hall at 5 p.m. found him dying, with what I took to be typhus; called again at 9 , he was much worse and evidently could not hold out 6 hours. An eruption of searlet

1 It must have existed in earlier generations of the Galton family, for it is evideneed in the story of Samuel Galton's appeal to one of his sons: "Tell your frieud, Sammie, all about it, and he will take good eare your father does not hear a word of it." 
fever had broken out. He died at 12. He was one of the most kind-hearted fellows I ever met with; he had just taken his degree and was going into orders and had begun hospital attendance that he might be of use in his parish. He thus caught the scarlet fever and is dead. He was a very great friend of Hughes'.

It is curious that $I$ have as yet lost only $\tau$ schoolfellows or fellow-collegiates that I really eare for and every one of these have died of scarlet fever or typhus, and all except one within three days warning. How fearfully death intrudes in the midst of enjoyment like the skeleton at the Egyptian's feast. It is remarked by D'Israeli (I think) that the shock from the sudiden loss of a friend is the only fceling which the mind cannot become callous to. The frequent sight of death seems in no way to diminish it. Patients in a hospital one looks upon as doomed men and their death takes place as in the natural order of things. A friend appears part of oneself, ancl when he dies, one contemplates the grave where he is laid in as ready to receive oneself ; we then know that we are mortal. However this kind of language is out of place to you at home in the midst of marriage festivities, etc. I received no cake with your letter!

Good bye, Yours truly,

Fras. Galton.

During the Easter vacation, Francis Galton consulted both with Hodgson and Booth in Birmingham, who appear to have given diametrically opposite advice, but the nature of their proposals is not clear. They most probably concerned Francis's prolonged study of mathematics and his neglect for the time being of medicine. He writes to his father, April 8th, 1841 :

"I have on reconsidering, reconsulting, etc., ete., determined to abide the Trinity Examination, as I should be sure not to get the Caius prize as they have two very superior men there, and as they take up slightly different subjects-but to do my best for a Trinity first class and to migrate afterwards......"

It is impossible now to say, but probable that the "Caius prize" referred to may have been a Tancred studentship. There is a good deal of discussion later about the position in the May examination, but no further reference to this migration proposal, it probably arose from Galton's Birmingham medical sponsors urging concentration on medical studies.

Later in the same month, with the Darwin omission of exact dating, comes a characteristic letter:

My dear Father,

Trin. Coll. April, 1841.

No letter of yours, whether reeeived at sehool, announeing that I might come home a wcek before my time, or whether containing a cheque on Barelay, Bevan, Tritton and Co., ever came more gratefully than the one I have just reccived to say that 
my Mathematical M.S.S. were at Claverdon. I have been latterly in despair owing to their loss. I harl hunted for them before leaving Claverdon, but found them not. I looked everywhere in Cambridge and was equally disappointed. They are invaluablo; all the talent of Perry, O'Brien and Mathison ${ }^{1}$ aro condensed into those papers. Thereforc pleasc take the greatest care of them. Burn tho Duddeston titledeeds if you will, hut preserve these manuscripts. If you havo even the compassion that glimmers in a butcher's breast whilst he sticks a pig, or in Majendie whilst he runs necdles into the brain of a living dog, send them immediately. Till I receive them I am desperatc. I am very glad to hear Holland's report of Bessy; please tell me all you hear about her.

DON'T FORGET THE M.S.S. PAPERS; if you do, may the spirit of gout tweak your remembranco!!!

P.S. Please remember the Manuseripts-send them immediately.

Good bye, Yours truly,

Fras. Galton.

\section{MY dear Father,}

Srturday, May 1 [1841].

I received 2 or 3 days since your letter with good news about Bessy and bad news about yourself, for which thanks (I don't mean specially the latter part). I have also received 1 dozen of port marked "very old."

O'Brien told me the day before yesterday that I must certainly read with Hopkins next October, and on my saying that I would rather remain with him he strongly recommended me not. I own this has made me very bumptious; it does great credit to O'Brien for his openness, as of course tutors prefer to keep the better men. As lie stays in Cambridge during the Long Vacation (poor man, he is married), which is very dull and hot during summer, I go with Mathison our Mathematical Lecturer to Keswick in Cumberland with a party to read. The terms are $£ 30$ for about 3 months, and the life we lead a very pleasant and inexpensive one, certainly much cheaper than in College. By the bye we are turned out of our rooms during the Long Vacation. I have been obliged to take a half-elassical coach for the approaching College examination (in about $4 \frac{1}{2}$ weeks).

Now you must not expect me to be first Mathematic in Trinity ${ }^{2}$. I do not expect it inyself, as amongst other very good men, there are somo who have already read

1 Perry was senior in 1828 , Mathison fifth Wrangler in 1839 , both were ultimately tutors of Trinity and Perly Bishop of Melbourne.

2 Galton's year (1844) was not a very strong one in mathematics; there was no one who has left a namc in that field; and in particular it was not strong at Trinity ; that College got 6th, 7th and 8th Wranglers only, with men who did not take Trinity fellowslips. Of Galton's friends, Hughes was 22nd Wrangler, Stewart and Maine were low Senior Optimes, but first classes in the Classical Tripos; Dalycll, very nearly "wooden spoon"; Clark was 18th Senior Optimc and second Classic to Mainc's Senior Classic. Dalycll also took the Classical 'Tripos. On the whole Galton's friends were on the literary side. With what we know of lis mathematical powers, he miglit easily have led thc Trinity contingent.

P. G. 
exceedingly high and who know their early subjects very well. I hope to do better in each succeding examination, but ill health, for I scverely overstraincl mysclf my first term, - and I fcel convinced that to have read cluring the $\mathrm{X}^{\mathrm{m} \text { max }}$ Vacation would have been madncss, - has necessarily kept me back. But with no morc excuses, as there is much in what Dr Jcune uscd to say. Good byc, Your affectionate son,

Fras. Galton.

Galton appears to have taken only a third class in the Trinity May examinations, but apparently the class was determined not only by mathematics but also by classics:

\section{Friday, Old Humuas [11. June 1841].}

\section{Covent Garden.}

Left Cambridge on Tuesday, - the classes are just out.

My dear Father,

I am not jet aware what my place is in all the math. subjects. I was fourtl in Trigonometry (Mathison told me) and as I did comparatively better in Geometry and Algebra, I probably am higher in those two. Having done but little classics and that badly $\mathrm{I}$ am in the third class...... I care scarcely at all about being where $I$ am as $I$ am as high in maths. as $I$ expected. You must not forget that, as regards Classics more especially, I have to compete with men who have spent that time on them which I have employed in medicine, and it is thereforc improbable that I should take a good place amongst them.

The Math. papers were exceedingly easy this year so that everybody, who knows anything about them, must of necessity do three fourths, hence there was little roon for a man to distinguish himself in them.

In the Algebraical paper there werc absolutcly only 3 questions not bookwork, that is problcms. This is too bad, it is also unusual.

I am moving about town, doing onc thing or another, dined with the Huberts and Horners. I stay here till Tuesday morning to hear Madame Rachel on Monday. I expect to be in Leamington Tuesday afternoon.......

I have had to invest in a frock coat and two pair of trousers.......

[P.S.] Hence as you observe I have not paid my Classical Tutor $£ 7$, who had left Cambridge without an address. I have not paid for my Frock Coat which will be about £5. I should be obliged for $£ 5-£ 10$ as my bill at the Old Hunmums will bc for a week and I take one meal daily. My stock in hand is $£ 6$. 19., there being a mistake somewhere of 3 shillings in my account.

Somewhere about the October of this year Tertius Galton sent his son Francis an "Essay on Book Keeping." It is a very simple description of how to keep accounts in an orderly manner, but it is of interest as showing us that from July 1st Francis was given a regular allowance, payable in advance quarterly, and thus the minute details of expenditure hitherto transmitted to his father cease. The allowance 
was a generous one, $£ 300$ per annum and apparently an extra sum for private tuition. Tertius Galton was no doubt right in impressing upon his son the necessity for accurate record of expenditure-even to mistakes of three shillings. But the almost weekly rendering of accounts without a definite allowance does not provide a young man with the same training in monetary affairs as a dcfinite income with fieedom to spend within its limits. We cannot help considering that this statement: "Francis Galton, Esq. in account with his Treasurer," must have been a considerable relief to the undergraduate mind.

The summer vacation spent at Keswick was a very happy one; Francis Galton was in a most merry frame of mind. The final part of the vacation was overcast by the illness of Tertius Galton, who came down to join his son, and caught a severe cold, which caused his first bad illness, lasting four or five weeks. The tutors were Mathison of Trinity, and Eddis, first Chancellor's medallist and fourth classic in 1839, and well-known later as a Queen's Counsel. The members of the reading party besides Galton included Blomefield, Atkinson, Strickland, Young and Cooper ${ }^{1}$. The house Galton stayed at was Browtop, which stands well upon the Thirlmere road before the old turnpike at the junction with the steep road down to the church is reached. Galton had visited at the end of June the Hodgsons and Booths in Birmingham, and he had made a flying visit with his Aunt Booth to his sister, Lucy Moilliet, at Selby Hall. On July 1 he writes to announce his safe arrival at Keswick to his father:

"I set off [from Birmingham] by the $\frac{1}{4} 2$ o'clock train in the night and slept without once awaking until we were near Preston, we got to Lancaster at $7 \frac{1}{2} \ldots . . .$. I set off at 8 by mail to Kendal. The town was in a bustle owing to the nomination, flags, trumpets and so forth. I had a very entertaining fellow-traveller; he had a hooked nose, gold spectacles, was a meinber of the Reform Club, and a nc-plus-ultra radical; he had travelled, and had also been a rowing Cantab. We had a red hot argument on politics, which I firmly believe neither of us knew anything alout, but he would talk about them, and as I must answer yes or no, even Bessy will excuse my not assenting to a radical's ideas; he knew the lakes very well and told me many legends about them. Windermere is said to be a beautiful lake. Wordsworth asserts that it is superior to anything abroad, but I lumbly conceive that he thereby shews his patriotism

${ }^{1}$ Blomefield was about the middle of the Junior Optimes in 1843, Atkinson 27 th Wrangler in the same year and afterwards Director of Public Instruction, Calcutta, Young was Third Class, Classical Tripos and Junior Optime also in 1843; Cooper was a Senior Optime in 1844; Strickland was one of the well-known Yorkshire family of Howsham Hall, his tragic end is deseribed in the Ifemories, p. 64. 
rather than his taste. It is eertainly pretty but very narrow in comparison with its length, and the high mountains on each side apparently reduce this width still more, so that it looks like a river, and not a particularly broad one. [Then follows an account of the well-known road from Windermere to Keswick with slight sketches.]......To-day is horribly misty; Skiddaw is covered with clouds that reaeh low down as a Quakeress's dress, but those on the chain opposite are more à la Taglioni. I had intended walking up Skiddaw last niglit to see the sun rise but it began to rain....... Browtop is a very nice house, the habitable part is quite separate from the kitchen and outhouses; it is one story high and the passagre down the middle witl 4 bedrooms on one side, and 4 sitting-rooms on the other side; thus the whole house is $\mathscr{E} 5$ per week, so I pay 25 shillings. I have a beautiful view ; I should have sketched it for you, but there is nothing but elouds this morning. I am the first of the party that lias come; the rest are expeeted tomorrow.

Good bye, Your affeetionate son,

Fras. Galtox.

Thursday, July 8 [1841].

Browrop.

My dear Fatner, Being upon ny own allowance you must excuse letter paper. In answer to your question: The Apothecaries' bill I owe, though differing some shillings from the one sent to Blakesley. The Hosier's Bill is not mine probably's Theodore's. I do not want the boots at Keswiek, certainly not at present, as I always walk in thick shoes. I am very glad to hear about your asthma's want of punctuality this year; should you have an opportunity I wish you would enquire whether the other asthmatic Leamingtonians, I think 3 in number, have got off equally well, as it would be interesting to find out whether some years are more favourable than others as is apparently the ease in typhus and influenza.

I never enjoyed myself so thoroughly as at present-Mathison and Eddis are thoroughly goodnatured. When it is fine we walk out in a body from 2 to 5 ; when wet play at battledore and shuttleeoek or at fives in a most unstudious manner. Eddis you know is a senior medallist. Blomefield is the other undergraduate staying at Biowtop. The St Quintins are very kind and their son (Charles) very agreeable, he rattles off about the Himalaya Pusses and the scenery of Thibet, and totally condemus Howqua's Mixture. T'hey introduced me to the Parson, a Mr M.__ who again introduced me to a Count O..... (I purposely write the word illegibly and that for an obvious reason, it consists of "three sneezes and a ski"), who is the lion of these parts, being Chemist, Botanist, Zoologist, etc., etc., and last not least a top-sawyer Animal Magnetiser. I need scarcely say that we got the greatest allies imuediately, he is a very gentlemanly man, he shewed me through laboratories, hot-houses and monkey cages....... He has morcover got me patients to magnetise, lent me books and in short we are the greatest possible allics. He married a rich hciress...... who is a very pretty girl 18 years old, he is about $40 \ldots . .$. I ought to say that as I walked with the Count through his laboratory he introduced me to a Dr Schmidt who was staying with him and working there. T thought I knew both the face and name, and found out that he was one of Liebig's chass at Giessen, and we had great amusement in talking over the wine-parties, etc. after 
the table d'hôte. He was a great phrenologist and I got lim to paw uny head, he gavo me I think a very true character (self-estecm was remarkably full). I havo not now the bump of constructiveness very large though he says it is large. Mary's bump is firmness, I described her character and he immediatcly said that he had obscrved cqually well developed cases ${ }^{1}$. I have just descended from Skiddaw, it is a very seedy mountrin to go up, there being no difficulty whatever, the view is very extensive including the Isle of Man and Ben Lomond. It was very hot and we pitched into much whisky, and on the strength of it cheered 3 times 3 for God save the Quccn, Trinity, ctc. Whatever Father Mathew may say there is nothing likc vast quantitics of whisky on a mountain top, it would be a splendid way to subject a convert to temptation. - Please address in future Browtop as an oblique-eyed intimato of our skullion having nothing clse to do brings up the letters. Love to all and each; may the critical spirit of Bessy smilc on this epistle.

Good Bye, Your affectionate son,

Fras. Galton.

The Keswick letters show such joy in life, such healthy vigour and a nature bubbling over with such fun that those who read them must feel at once on terms of intimacy with Galton's genial personality. I have allowed his criticisms of Whewell to remain, for they are only the opinions of a boyish undergraduate on the Master of his college ${ }^{3}-$ and most of us remember what fair game the Master must ever be to the world of junior members of his college!

My dear Father,

Brow Top, Keswick.

July 18, Sunday, 1841.

Thank you for your letter. I am very glad that you talk of coming towards the lakes, as they are well worth seeing, and as a long course of fine weather almost

I Galton's interest in phrenology was a precursor of his later system of headmeasurements. While Francis was a boy at King Edward School, Birmingham, a Cambridge cxaminer fond of phrenology asked to be allowed to inspect the boys' heads to test his phrenological opinion against the results actually found in the following day's examination. He went into the school-room and was much struck with Francis' head and sent for him for' a second inspection. He then said to Dr Jeune, "This boy has the largest organ of causality I ever saw in any head but one, and that is the bust of Dr Erasmus Darwin." "Why," said Dr Jeune, "this boy is Dr Darwin's grandson." Owen, the Lanark Utopian, also noted Galton's had when an infant and predicted from its peculiarity that he would not be a common character. Tho large organs of causality, i.e. a good temporal development in ordinary parlance werc noted by the professional phrenologist, Donovan, who gave in 1849 an amusing estimate of Francis Galton's character as wonderfully correct in some respects as it was absurdly incorrcet in others. I shall citc some part of it later.

"Whewell was made Master this very autumn. 
invariably sets in about this time. I do not know of any house in Keswick which you could take (bona fide) as they are all small and mostly dark and dirty. The inn is very good, good leedrooms ete., and has been honoured by Queen Adelaide's slceping in it, if that be any inducement to you, but $\Lambda$ mbleside has many good lodging houses. I received the enclosed letter from Christian the day before yesterday. We have had beautiful weather the last 4 days, and have already been inaking several excursions, to Buttermere, where the celebrated beauty whom Hatfield the robber eloped with some 20 years since, lived, and where several uncommonly pretty girls keep up the character of the place still. We have also been up Helvellyn. They said it would take us 3 hours to reach the top, but it occupied only 23 to get up, stay $2 \overline{5}$ ininutes at the top, and be at the bottom on the other side. The country people are exceptionally hospitable, they give us no end of milk, oatcakes, home-made cheese etc., and it is diffieult to make them take anything in return, so our plan is to ask if they have any children and pick out one of the curly headed young serubs, and visibly slip a shilling or two, according to the probable extent of our united appetites, into his hand. Yesterday after taking a stroll up Skiddaw we went to the perfection of a farm house. A very pretty Creole niece of the farmer chatted, smiled, gave us milk etc. and set off a musical snuff-box playing, then brought a nosegay, and lastly sat down with us to grub. She asked if we were any of the Cambridge gentlemen, and on our saying that we were she told us that 2 or 3 years ago there was a large party at Keswick who were a "sad set of seamps." So you see what a reputation Cambridge has got. Whewell, wonderful to say, has fallen in love with an Ullswater beauty, Miss Marshall, and is going to mary her. She is very rich and of very good family, hence our continual conversation at Browtop is in surmises as to how Whewell would set to work to make love, he is nearly 50 , she a little more than 20......

We like Browtop excessively, the only fault in the situation of Keswick being that it is in a wide valley, so that there are but few walks within a short distance. The hills are all quite green so that we can run down them at a capital pace. Mathison tried sliding down one of them, but he reached the bottom a complete cherub having searcely whereon to sit, owing to the friction.......

We hear that a party of Cantabs at Ambleside think of migrating to Keswick, it will be a great bore if they come as we are enough already. Armitage the to-be senior wrangler of the February after next is one of them.

Dear Bessy I know that this letter is a stupid one but I really have nothing to say for myself. Write soon and tell me about Searborough.

Good-bye and believe me ever your affectionate $\left\{\begin{array}{l}\text { Son } \\ \text { Brother }\end{array}\right\}$,

Firas. Galton.

Buowtrop.

MY DEAR FATIER,

Sunday, Aug. 1st, $18+1$.

I received this morning $£ 15$ all correct enclosed in an envelope stamped "too late"; for which thanks. The letter before this one was dated from "N.g. cliff." 
Do they ticket the houses as cabinet curiositios? It is ccrtainly novel and decidedly literary. I suppose that Lucy and James lave already arrived, what with them and my two uncles, the Galton family will inundato the place, and if the ordinary appetite that accompanies the several branches of the family be present at Scarboro' it will givo a very satisfactory interpretation of the $\mathrm{N}$.g. ticketing. Whewell is undoubtelly under the guardianship of Hymen, though an oyster may be aficeted by love, a Whewell can't, for he has (I understand) been so involved in the metaphysical line that lie looks on the approaching event with the most philosophical indifference. In 3 wccks Keswick is to be turned topsy-turvy with amusements. Inprimis a 4-oared race in which your liumble servant is to pull, as we get up a boat for the honour of Cambrilgc. (The names of the crew are Atkinson, Strickland, Young, Galton and Cooper stecrsman) $\dot{E}^{\prime} 12$ prize. We really shall have a very fair chance, for though the Keswick boatmen are trained to pulling from their sash and petticoat age yet they are more in the cart horse line, whilst the description that I heard given of our crew was that they are "intensely plucky." We have great amusement here in scrambling about. Mathison is a capital walker but not a dab at climbing, consequently he occasionally sticks amongst the rocks like a saint in a niche and immovable without a miracle. We get on capitally at Browtop. The order of the day is-Breakfast finished as the clock strikes 9. Reading till 1 or $1 \frac{1}{2}$. Lunch, walk till 5, dine and chat till 8, Read till 10, tea to $10 \frac{1}{2}$, Read to 11 or 12 .

When a long walk is taken we eschew dinner put our leathern whisky flasks in our pockcts, which I am convinced is the true interpretation of "seven lengued boots," and walk from 1 to 8 or 9 . We certainly do great things in the walking line instead of "managć-ing nos forces" after the Swiss régime. IVe scanpcr up the hills and somchow or other don't get tired. To-day I ascended more than $\frac{2}{3}$ ds of the height of Skiddaw (driven back by mist) in 35 minutes, about 2200 fect, this was in Sunday costume and without puggyfying to any extent.

Dear Bessy. How's the bathing? and how are Emma's freckles? The amount of sunshine here is by no means dangerous to beauty as the sun has generally a mass of mist rather thicker than Skiddaw is high to shine through. It has been miscrably cold so that I real with a pea-coat on and with my feet on the fire hob. In your lettcr in a quotation from Aunt Hubert a word occurred "odm...ts." I have looked in Johnson's Dictionary but can find nothing corresponding to it, so I presume that it must have becn coined since his time.

Again, there was a passage in your letter ending with 4 notes of admiration combined. This is an excess.

Thirdly, I should recoinmend a more refined choice of phrases than such as the "weather taking up" and others of a similar nature. You state "The air is delightful, and a beautiful walk along the cliff." I am not aetherial enough to enter into your delights-(I inust bully you). How has Lucy's bazaar gone off? Pleuse write oftener. Tell me what you had for dinncr if you can think of nothing clse, but to write.

Good-byc,

your affect. Brother,

Fras. Galton. 
Keswick Browtop,

My dear father,

August [13] 1841.

......Y You talk of "fear of annoying me with a formal visit" etc. I can assure you that I slould enjoy nothing so much as Atwoodizing you over the eountry. We ean give you dinner oeeasionally at Browtop. You will find Fddis and Mathison very agreeable, and I really think that the very best thing that you can do is to settle in Keswiek for a fortnight or 3 weeks. If you will give me a commission for lodgings, I will make every enquiry. Our boat-racing seleme has been given up for on enquiry we find that the eompetitors must pull on pins, not in rollocks [sketehes]. To pull in that manner we unanimously deereed was below the dignity of a Cambridge "oar" as all the beauty of and skill of rowing consists in eorreet feathering which of eourse is impracticable with pins. It is altogether a ridieulous pieee of business. There aetually is no pruetising on the lake and consequently the pulling at the raee must be wretehed.......

Poor Chance my old sehoolfellow and ehum is dead. He was my chicf friend at Dr Jeune's and also at King's College, where he read elassies. He was one of the best fellows that I have met with; he was expected to have distinguished hinself. Poor fellow-he died of consumption.......

Yesterday morning I walked up Skiddaw to see the sumrise. I got to the top of the eastern peak which is not 150 feet lower than the highest one in 40 minutes. Of course saw nothing but mist. I shall, however, try it again tonight-We have got some sails to our boat at Keswiek, it is eurious how frightened all the boutmen here are of them, they never use them. Even the attendant "ead" upon the party, a man ready to poach, knoek down, do anything on an emergency, refused to go into the boat on the ground of having a "wife and 5 small children"."

The postscript to sister Bessie propounds on this occasion a problem in etiquette. Galton and others had dined with the Russian Count, and the Countess had not received them in very friendly fashion. Meanwhile "the Count (a very punctilious man) had left the town, leaving the Countess behind." Galton had not called since the dinner, ought he to do so? The final story of the "Count" is told in the Memories, p. 63.

\section{My dear Father,}

Browtop, August 19 1 , 1841.

Thank you for your letter which I have reeeived this evening. I hope that you will not give up your plans as regards the lakes, for if your only fear is about rainy weather, I do not think you will suffer more in travelling through Westmoreland than elsewhere, since on comparing the state of the weather here with that which a Canbridge

1 'The danger' to sailing boats on Derwentwater frou sudden gusts of wind coming down between the mountains is well known to the inhabitants: I remember a fatal aceident to a sailing boat oceurring during a stay near Keswiek. 
party las liad in Devonshire we find that we have liad tho fewer rainy days. This of eonrse does not include misty days. I have been rleluded enough lately to climb inountains to scc the sunrise, it is certainly the best regimo that I know to curc romance. I for my part never felt less spiritual or more eorporeal than I did when I got to the botton of them. I had a long walk in that manner tho day before yesterday. Happening to look out of the window about 12 after reading, I found that it was the inost beautiful niglit that we had yet laad. So pocketing my whisky flask and putting on iny pea-coat and plaid, I walked to the town and got up a party to go, slcpt under a table for 35 minutes, drank some whisky puneh, and then walked up Blencatlurn, ignominiously called "Saddlebaek," stayed on the top about an hour and then got baek by 7 a.m., it was about 16 miles. As the morning was splendid 1 then got up another party for Ennerdale. Then slept 25 minutes and walked off, and we walked the whole day, up two high mountains. I got back by $8 \frac{1}{2} \mathrm{p} . \mathrm{m}$. and after all I really was not so very tired. Keswick is at the present moment all wrestling and daneing. The ehampion in the former has been declared, having thrown some 10 opponents, but even he is now taken off his legs under the influence of brandy and water.

In the daneing department of eourse I assisted, and had for my partner a damsel whom I had observed in the morning employed in the unpoetical position of all fours, scrubbing stone steps with great diligenee.-I have today committed a most dreadful offenee in the eye of the law. I happened to be walking in a field when I saw a bull looking intensely ferocious, so I picked up a stone of a size corresponding to my fears which was therefore very large. Thus armed I ran to the nearest gate for escape; when up jumped a hare. All thoughts of the Game Laws vanished, as also of the bull. I threw the stone with a most lueky aim, and knocked the gentleman over and then I soon got over the gate and gave him the coup-de-grace with my shillelah. I shall eat lim tomorrow or the next day. We are getting very dull; we read the Times through, advertisements and all everyday, and often ask for the eatalogue of the circulating library. Undcr these cireumstances, Good bye and bclievc me ever

\section{Your affectionate soll, Fras. Galton.}

The letters to Tertius from Keswick cease with this date. The Galtons were staying at No. 9 on the Cliff [N.g. cliff of Francis's letter: see p. 158], Scarborough, and Emma Galton states in her diary that on Sept. 3 she rode from Castle Howard Park to the Iakes. 'Tertius Galton was fond of riding expeditions with his daughters, and he probably took a chill on this occasion. But we have no details of the illness at Keswick. The party got home to Leamington on Sept. 21, and on Sept. 26, Miss Galton records in her diary "Papa very ill indeed." Francis Galton, in the "annual register" of his life, speaks of his father's first serious illness occurring at Keswick. Doubtless much help was given by the Gurneys at Keswick, for we find from this time the intimacy between Gurneys and Galtons extended and visits are paid to Keswick as well as to St James's Square.

P. G. 
The next letter is dated, or should be, October 20, 1841 :

My dear Father,

\author{
Wednesday $20 t h, 1841$.
}

Trin. Coll.

I left Leamington the only Cantab on the coach by the side of a jolly old Coacliman who had been a horsedealer at Northampton and had soll loorses to Uncle Hubert; he made sundry enquiries after you. On arriving at Weedon a complete sloal of Cambridge men poured out from one of the trains amongst whom was Theodore and three or four other allies of mine; how they all were to find places was a problem too deep for the minds of anybody there except the coachman's to surmount. However they hung on the coach like crows on carrion, and a jolly drive we had recounting our adventures to each other. The coach top was unpolluted by a freshman.-I called on Mathison this morning, who skipped about through excess of animal spirits in talking over Keswick, and was as jolly as ever. I then called on Hopkins who takes me, and I begin with him on Monday. My Keswick friends are all up, two of them full of gratitude for wonderful effects produced by preseriptions which I had left them and I lave got a new patient. I. cannot express the bumptious state I am in, looking at poor bashful unsophisticated "cubs" so carefully pulling their gown to make it sit well and fidgety at finding how uncomfortable their cap is which they have unconsciously put on the wrong way; all over as "fresh" as paint-bless their innocencies.-So Whewell is Master; I suppose he will soon come into residence.

In haste for chapel,

Your affectionate son, Fras. Galton.

Francis was in all the glory of the Junior Soph. Energetic beyond measure, but hastening, alas! towards a catastrophe.

Excuse my blots as I am

T'uesday [Nov. 10, 1841].

in a great hurry.

My dear Father,

I am very sorry that from having been either too lazy or too much oceupied, I have not written sooner, though I consider you too little of an invalid to be further anxious about your health. Emma has probably given you a full account of her proceedings in Cambridge ${ }^{1}$ and I trust reseued me from Mr Hodgson's malicious chargc. She was most active and tired down both Theodore and myself. Thank you very much for your statement of my accounts; they were certainly most beautifully written out and quite a model. In one point, however, they were not quite as useful as otherwise they

1 According to her diary Miss Galton went on Nov. 4 "via Cambridge to Keswick" and returned on Nov. 28 to St James's Square with the Gurneys. Emma Galton shared many of the characteristics of her brother Francis; she was restlessly energetic and rushed not only about England but the Continent. She had a strong business instinet and recorded almost to shillings and pence the amounts received by all members of her family by inheritance, settlements and gifts. She published a noteworthy little book which has run through many editions, A Guide to the Unprotected; it gives directions for single women in business matters, and is still of value. 
might have been for after reading them through carefully 5 timcs I abandoncd all hope of making out the meaning of any one single line in utter despair. The words appear all bewitched for I can't make out which is substantive and whicl is nominative caso ctc. etc. As a specimen "Debtor to balance agreed $£$. .- Should you have spare time, would you be so kind as to write two or three lines in account book style with their interpretation in popular English and then I have no doubt but that I slaall make out the rest of the papcr, which you so kindly sent me.

My box arrived safely and the books inside in good preservation, with the cxception of one book right through which, like Sisera's temples, a hobnail was driven-lowever it was only sume temperance tracts bound up and therefore it is quite immatcrial. Finnia was not sure whethel my D'Israeli's Curiosities of Literature was packed up-it is.

I like Hopkins more and more every day, and I never enjoyed Cambridgo so thoroughly. Love to all.

\section{Goodbye, Your affectionate Son, Fras. GaltoN.}

The following letter gives a vivid picture of a famous mathematical coach and enables us still better to realise the Cambridge life of those days :

\section{Trinity, Thursclay Evening, \\ MY dear Father, Nov. [11] 1841.}

Thanks for the second edition of my accounts which I received this morning, and still greater tlianks for the explanatory notes by Bessy thereunto attached'

Hopkins progresses capitally. I had forgotten to tell you that I find that his charges are only $£ 72$ per annum instead of $£ 100$ as currently reportcd: this will make a jolly difference to my finances. Hopkins to use a Cantab expression is a regular brick; tells funny stories connected with different problems and is no way Donnish; he rattles us on at a splendid pace and makes mathematics anything but a dry subject by entering thoroughly into its metaphysics. I never enjoyed anything so much before. I made my first acquaintance with Laplace today, in one of his theorems, greatly to my satisfaction.

H - has not returned to Cambridge. He is an utter Puseyite, ho dances much and instructs his partncrs in the "Fathers" and in their controversies. Eddis and Mathison both bloom. I wined with the former last night, who decidedly has not recovered from tender impressions received at Keswick. He spoke on walking in the cloisters by moonlight, and quoted Byron. He is therefore hopeless.

I am going to become a member of the Camden Antiquarian Society as being a gentlemanly thing and really very amusing. The subscription is 7 shillings a term until $£ 3$ has been paid when the subscriber becomes an honorary member, and is relcased from further subscription retaining the same privileges. Whcwell is expected next week in Cambridge. He is not Vicc-Chancellor this year as Dr Archdall of Emmanuel has been elected to that office.

1 "Lord Torment and Tease," as he had heen called at an earlier date, neither deserved that sccond edition nor the commentary; the accounts were beautifully simple ind clear, and we inay shrewdly suspect he understood them. 
My cake las long sinee gone. $\Lambda \mathrm{s}$ it disappeared it looked like a girl dying of consumption, pining away and retaining its swcetness to the last; it was very good. I ingratiated myself mucl with Mrs Hoppit by sending for her scvenfold offspring and arranging them round the table, when I made an equable division of the remains of the cake between myself and them, and afterwards sent them away laughing, eating and digesting like steam. Twelve out of the fourteen jampots still remain free from the encroacliments of the enemy, but decidelly in ustate of predestination thereunto.

How is my Mother's foot? and Mary? Love to all and good-bye and believe me ever your affeetionate son,

Fras. Galton.

P.S. I suppose you all know that the meaning of the F. G. on the outside of my letters is that they ure family letters to be opened by anybody and merely addressed to some particular person for the satisfaetion of the postmaster.

I do not know how or where the Christmas vacation was spent, presumably at Leamington, yet on Jan. 21, Francis is up at Trinity and from there a few days afterwards joins his sister Emma, who had gone down from London to Keswick with the Gurneys on Dec. 31st. He probably only stayed a few days there, as the results for his "LittleGo" were sent to his father on March 9th from Cambridge, and that examination must have taken place some weeks earlier:

"Hurral-I'm through.

Fras. Galton, Wed. 1842."

[March 9].

The list shows him to have taken a second class; J. Kay and another of Hopkins's pupils were also in the second class, seven of them, including Buxton, were in the first. Maine, Clark, Cooper, Dalyell, Stewart and others of Galton's friends appear in the same list.

The earlier letter of Jan. 21 is of some historical interest:

$$
\text { Jan. 21, } 1842 .
$$

Mx dear Father,

Trin. Coll.

Thank you for your letter which I reeeived this morning. The Math. Examination for degrecs is just over and as you will see by the recompanying paper Cayley is 1st and Simpson 2nd wrangler; these were very far superior to the rest. Hopkins told me today that Simpson was 1000 marks ahead of the 3rd wrangler and the getting of 500 marks only entitles a man to be a wrangler. The 1st and 2nd wranglers are considered to be the most superior men, for at least many years that Cambridge lias produced ${ }^{1}$. The rest of the Tripos as usual. The exanination papers this year are much easier than usual.

${ }^{1}$ How difficult it is to see at close quarters! Stokes had been Scnior in 1841, Adums was Senior in 1843, and Thomson (Lord Kelvin) second in 1845. 'They were the nost brilliant years of Cambridge mathematical productivity and 1842 did not stand alone. 
The Glaciarium is composed of a mixture of earbonato and sulphate of potass which deliquesces in their watcr of crystallisation and afterwards hardens. 'This Miller told me, who hinsclf had heard it from Faraday. I have not seen the specilication. I shall bo quite dissipated next week. Monday I dine with Dr Fisher and go to an evening party at Hopkins; Tuesday, Bacholors' Ball; Wednesday, I go to Keswick etc. Good bye, your affectionate Son,

Fraxcis Galton.

In this letter Galton returns to his original and later usual form of signature, but it took a long time to re-establish it.

The letter of March 19 th tells us more details of the Little-Go and Galton's work at mathematics :

\section{Trinity, Cambridge,}

March 19, 1842.

\section{MY dear Father,}

I enclose you the Little Go list. I ought to have sent it yesterday, but was not in my rooms till after post-time. I liave I consider had 3 grand escapes in my lifetime: $1^{\text {st }}$ walking into a Lion's den and coming out undigested, $2^{\text {ndly }}$ bathing in a frosty stream at moonlight and not remaining at its bottom in an apoplexy, $3^{\text {rully }}$ going into the Little Go when I had not read over half my subjects and coming out unplucked, not, however, that the pluck would be of any consequence. I have never the less been the gainer by this examination for calculating the advantage of being in the first class to be estimated at sixpence, I went to a man yesterday and bet a shilling I would be in the $2^{\text {nd }}$, thus leaving 2 sixpenny pieces to luck, which as you see $I$ have won. I am much obliged to Bessy for the melaneholy news about Miss H. I was, however, aware of my misfortune the same week that the cngagement took place, but had not been informed who $M \Gamma^{r}$ E. was; there is one thing that acts as a poultice to iny wounded feelings which is that that small chimpanzee $\mathrm{MI}^{\mathrm{r}} \mathrm{S}$. is not the happy man. Time has done wonders for me in soothing etc., but, oh Bessy!! Miss D. has done much nore; she is without exception the most beautiful etc., etc., etc. I have ever scen. I was at a hop at her Ma's house the other night (I know most of the fanilies in Cambridge now), I was dancing with her (the daughter not the mama) in a quadrille with one of my Little Go-Lxaminers for a vis-a-vis. Today as the sun was shining beautifully I decked myself ont in resplendent summer apparel, light trowsers, light waistcoat (those that I had last year) to make a call upon this fair creature, but as I was fast finishing my toilette, and was "throwing a perfume over the violet" in the way of arranging my cravat ties, the wind blew and the rain fell horribly, and the streets were one mass of mud. I was in despair, but reflecting that if Leander swam the Hellespont for Hero, I was duty-bound to wade as far as the Fitzwilliam for Miss D., off I set. When, however, I arrived at their door, I wisely reflected on the splashed statc of my trousers before I knocked, and then retreated crest-fallen. Tonighlit I hang out (otherwise give a spread) in oysters; I have been all anxiety to get a dish of frogs as an adjunct and yesterday I made tremendous efforts to eatch some with the annexed apparatus [sketch of triple hook attached to a line pendent to a walking stick] 
but quite unsuccessfully. I could not see one although with another man I patrolled every imaginable ditch within reach. I firmly believe $\mathbf{S}^{\mathrm{t}}$ Patrick had got the start of mc, for Cambridge without frogs is quite an anomaly. Hopkins gave up for the term on Wednesday; before he left he called me to him and complimented me no end on my mechanics, which has made me quite jolly. I wish though that I were a better analyst. Buxton and Kay are going to leave his class as their health won't stand it. I shall certainly stay with him during the Long Vacation, and if the Dons won't let me stay in Cambridge I propose quietly taking lodgings in Grancester [sic/] (11 miles off) and coming over to him every morning. For want of room Good bye and believe me ever

Your affectionate Son,

(It's vacation tinc now.)

Fras. Galton.

But how was Francis Galton's own health standing the strain is the question which arises in our minds as we read this letter? A letter written a few days later shows that the strain was beginning to tell :

My dear Father,

Trinity, Tuesday [March 22, 1842].

On thinking over about the approaching Scholarship Examination, I so plainly see that I have no chance whatever of getting one this year that I really think it quite useless to compete. The mere going into an examination for a few days is a thing of no great labour, but I am of course anxious that if examined I should do the mathematical part as well as I am qualified to, and not place myself below iny level for want of preparation as would be the case witl me now. I have at present read 14 different mathematical subjects ${ }^{1}$; now to get up all these sufficiently well to undergo a good examination in them would necessarily require very considerable application, which would be better bestowed on the subject (Mechanics) that I have now in hand, inasmuch as the fact of having them now well prepared would in no way assist me in any future examination, after a year's interval for instance. I spoke to Hopkins about it a fortnight ago; he strongly recommends me not to put myself out of the way for the examination, should I be inclined to go in for it. I find that it is impossible to get up my subjects without doing so and therefore think it preferable not to go in at all. I would, however, have possibly tried my best, but my head is already rather bad from having overworked myself in attempting to get up these subjects as well as doing what Hopkins las set us for this vacation, so that in the short time that is left I could do but very little. There is one other reason remaining numely that $I$ should not know my standing in Maths. in the College from the result of this examination any better than

1 In a postscript Galton says: "The subjects I have read are : (1) Algcbia Parts I and III (2) Algebra Part II (3) Euclid (4) Trigonometry, Plane (5) Spherical (6) Conic Sections (7) Theory of Equations (8) Newton (9) Differential Calculus (10) Integral Calculus (11) Differential Equations (12) Statics (13) Dynamics (not finished) (14) Geometry of 3 Dimensions."-Astronomy and Optics (of which he had certainly read some) were needed to complete the old two years' course, leaving the physical subjects for the third year. 
$16^{6^{a}}$ 


$$
\text { Sta calludrel riatjalla }
$$

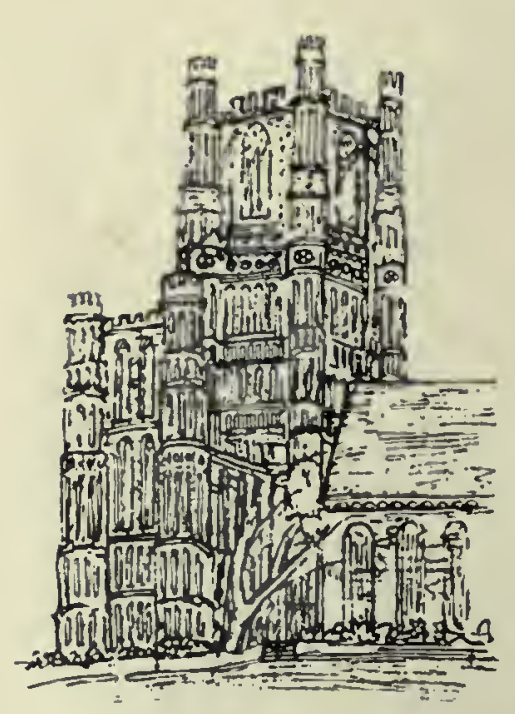

P'en and ink sketch of Ely Cathedral from a letter of Francis (Galton to his Father. 1842.

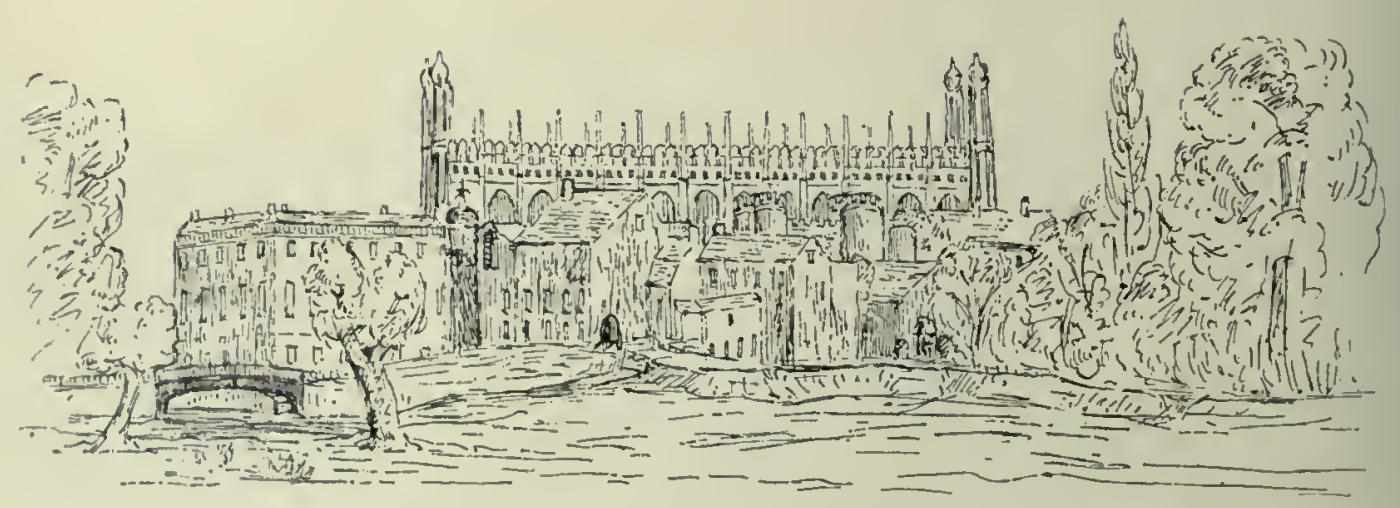

Pen and ink sketch of King's ('ollege Chapel from the field ly the Mill, 1843.

Sketches from Galton's Cambrilge Letters. 
I do now as those with whom I have to compete read with Hopkins, - viz. Wnlker, Hotham and Bowring' (Kay, and Buxton and Edwards have been obliged to leave off). I should thereforo much prefer not to go in at all, subject however, of course to your wishes. I can easily get off on the plea of ill health which will be in a considerable degree a true one and can leave Cambridge for 5 or 6 days cluring tho time of the examination. Should you agree with mo will you let mo know your plans for eertain, that I may make mine accordingly. I have no news to tell you at present, so I remain,

\section{Your affectionate Soll, Fras. Galton.}

This letter indicates much to those that read between the lines. In the first place Galton was staying up during the Easter vacation; in the next there is little doubt that he was or had been seriously overworking. Galton could not work under pressure, he had to do his work leisurely, and this he was to learn by sad experience before it became the practice of his later life. He was so keenly excited by many things that he could not repress his instinct to carry on numerons pursuits at once. Of the relics of this Easter vacation I note a visit to Ely Cathedral and a careful sketch of its western tower (see Plate LII), sent to his father; there is also a long poem on the birth of the Prince of Wales (Nov. 9, 1841), with the motto Tu Marcellus eris; it is dated March 31, 1842, and was probably composed for the Chancellor's medal. The Chancellor's English medal is for a subject given out at the end of the Michaelmas Term, and exercises are to be sent in on or before March 31st following. The subject for 1842 was actually Galton's theme, and the medal was obtained by H. S. Maine, of Pembroke, one of Galton's friends and afterwards the distinguished Master of 'Trinity Hall.

Galton's poem has rather the roll of Erasinus Darwin's poetry and its theme the infant prince considering the deeds of his ancestors, some of whom-Edward I, and Edward II, first Prince of Wales-were as much Galton's ancestors as King Edward VII's :
"How different is thy lot to Edward's son,
Born in the land his sire had searcely won,
'Midst warriors rucle within that turret tall
That beetles o'er Carnarvon's massive wall,
Coldly through grated loopholes streamed the day
Lighting the couch where Eleanora lay."

1 Walker was 8th Wrangler, Bowring 23rd Wrangler in 1844. Hotham graduated in the same year, but, I think, must have taken a poll degree. 
From April and May of this year no letters have survived; we do not know whether Galton went on reading with Hopkins or went in for his College May. We lose also all account of how he came to join a reading party under Cayley and Venables ${ }^{1}$ which went in June to Aberfeldy, in Perthshire.

On June 15 he is staying with the Kays at Terrace House, Battersea, and writes to his father that he is leaving by boat for Dundee in an hour and a half. He describes his journey to town, how he has dined with Partridge, seen the Missourian (which he holds to be falsely articulated in order to increase the apparent height), and heard Robert le Diable - all told with the usual quaint humour. The first letter from Aberfeldy is five days later and some of it may be given here:

ABerfeldy, June 19, 1842.

My dear Fatier,

My proceedings liave gone on splendidly but the voyage from London to Dundee was all that could be horrible; instead of taking 36 we were 50 hours, a swell of a most abominable deseription inclined slightly to our course so that the rolling was dreadful. Everybody (104 in all, 30 was the usual number) was wretchedly sick. I as usual dreadfully so. - Otherwise we had a jolly royage; most of our party on board and the two tutors. Cayley is unanimously voted a brick and a most gentlemanly-minded man. Some of the passengers too had seen much life. One was a traveller in the interior of Africa, shot elephants, lions, ete. ete...... Perth is beautiful to a degree, ditto the lady inhabitants....... hear Sir Neil Menzies is a most hospitable person, but I have not yet sent my letter of introduetion. In laste

\section{Your affectionate son, Fras. Galton.}

The reading party on this occasion consisted of the two Kays, Fowell and Charles Buxton, Galton and Yeoman². We may reasonably expect that play rather predominated over work. The reading party gave a ball :

The Cambridge party requests the honour of _- eompany on Wednesday the 31 st instant. Dancing will commence at 8 o'cloek.

Breadalbane Arms, Aberfeldie.

There were 29 "Dancing Ladies" and only 22 "Dancing Gentlemen," but as "7 Cantabs" are included in the latter we may safely

1 Venables, afterwards Canon of Lineoln, was 33rd Wrangler and in the second class, Classical Tripos.

2 Yeoman was 27th Wrangler, and third class, Classical Tripos in 1845, I think thr Buxtons and Kays took poll degrees. 
conclude that Cayley did his duty on the occasion. A draft programme prepared on a rough piece of paper by Francis Galton, giving the names of the guests, the dances and music, the supper menu (somewhat substantial), the flower decorations, the directions- " many candles," "polish the coffee pot," "pins, necdle and thread, and looking glass," etc., showing how completely and carefully he provided for all contingencies, has survived to the present day. It was wrapped round some fishing hooks and flies, and enclosed with a piece of ribbon worn at the Highland wedding of Margaret Carmichael, described in the letter below.

\section{My dear father,}

$$
\text { Aberfaldy, Monday [Aug. 1, 1842]. }
$$

We are enjoying ourselves very mueh at Aberfeldy, there is unfortunately mueh monotony in the walks, as the village is situated on the side of a broad strath through whieh runs the Tay, and itself formed by high barren moorlands. We have just witnessed a true Highland wedding, and absolutely daneed with only $1+1$ hours altogether intermission from 3 in the afternoon till 4 the next morning. I myself was pretty eonsiderably knoeked up, but several of the villagers did not go to bed at all and really did not seem mueh the worse for it the next clay. The Seoteh reels are great fun, for after every one is ready and before the reel is played, a partieular squeak is given on the fiddle and every one kisses his partner, and if they are obstreperous there is a fine ehase and seramble. We are really very nuch liked at Aberfeldy, and have been huzza'ed nore than onee as we walked up the town. When we were invited to the wedding, we eaeh subseribed 2 shillings and so bought the bride a very good looking tea tray, 2 jolly brass eandlestieks and snuffers, whieh overwhelmed the lady. The Seoteh air has done wonders for my general health, but my head seareely improves. I have been ahle to do but little reading sinee I lave been here and altogether am very low abont myself...... Lady Menzies has been most kind to me and other neighbouring residents have been exeeedingly hospitable to the party. Will Bessy thank Mrs Cameron for the note of introduetion when next she sees her. Goodbye, Your affeetionate son,

Fras. Galton.

The next letter is from Edinburgh after the rending party had broken up:

Mí dear Father,

Edinburgh, The Queex's Hotel [Sept. 14, 1842].

I left Aberfeldy very early yesterday morning with Eben $\mathrm{Kay}^{1}$ and went thro' Crieff and Stirling to Edinbro', really quite sorry to part with the Highlands. We left in high featlier, knowing every family well in the Strath, some of them intinately and altogether have, I really think, left a very good name for Cambridge. Our balk went off superbly. I wrote a deseription of it to Emma who has possibly forwarderl it on to

"Afterwards Justiee of Appeal; Joseph Kay was the "Travelling Baeliclor" who wrote on elueation and elallenged Whewell. He was later a Q.C.

p. fi. 
you. We went to the Queen's reception at Taymoutlı'. Major and Mrs Menzies took mo with them in their carriage. The Highlanders looked very well, drawn up in files round a large quadrangle in 4 bodics dressed in the Campbcll and Menzies dress and hunting tartans respectively. The Queen and Prince Albert looked most gracious, but were not cheered lialf enough. I ain sure we Cantabs did all we could, but evoryborly elsc did nothing but gape with astonishment. The evening illuminations were most perfect, everything in such perfect taste....... saw $\mathrm{M}_{1}$. Dalrymple in a splendid highland dress among the lookers on; he did not recognise me and as I scarcely knew lim, I dicl not address him. Wc "hung out" fireworks the other night and liad several persons to come and see them; they went off very well. We subscribed 10 shillings each and got about 30 rockets, a dozen and a half Roman candles, many wheels, etc., etc.

I will write to you again from Inch Dairnie (where Aytoun of Trinity lives), he has written to ask me to stay as long as I possibly can, and I am thinking of spending a few days there; it is near Kirkcaldy to which place there are steamers every 2 hours from Edinburgh. Goodbye, Your affectionate son,

Francis Galton.

For those who have carefully read these Aberfeldy letters, there will I think be little doubt that Galton was nearing a breakdown; the uncontrollable joyousness of the Keswick correspondence has gone ; there is little about work or long expeditions, there is a sub-tone indeed of depression. This finds its full utterance in the first letter that has been preserved from Galton's third Cambridge year. It seems to me as powerful an indictment of the competitive examination system as Galton's earlier attack on a classical school education. Before studying these Cambridge letters, I had imagined Galton's breakdown to be individual and due to his own constitution, but these letters directly show it to be the outcome of a pernicious examination system (superposed on great social and mental activities), which ruined the College career of men who distinguished themselves in later life, and whose University work ought to have been not only a delight to them, but of real service as a training for the future.

Trin. Coll., Nov. 2, 1842.

MY deAr Father,

I forgot in my last note to go into proper rapturos about Stultz; he really is a wonderful man. I had no idea that it was in human power to make such extraordinary improvements in my personal attire as the combined geniuses of Stultz and Gobby have cffected. Consultations of course liad to be frequent during the course of the Friday and Saturday that I was in Town, but $I$ at length emerged from my chrysalis crust of Cartwright and Janes' manufacturc to the butterfly adornments of Messrs Stultz.

My head is very uncertain so that I can scarcely read at all; however I find that I am not at all solitary in that respect. Of the year above me the first 3 men in their College examinations are all going out in the poll, the first 2 from had health and the

1 'The seat of Lord Breadalbanc. 
third, Boulton, from tinding that he could not continue reading as he used to clo without risking it. Fowell Buxton is quite knocked up and goes out in the poll, so docs Bristed one of the first classics in our year, in fact tlio whole of Trinity is crank. 'T'wo other men Hotham and Edwards who read with Hopkins and at the same time were very superior classics (Hotlam was Newcastle scholar at Eton, which is the highest classical honon' they can get there) have both given up classics finding their two subjects are too much for them. It is quite melancholy too to see the men who stood high in the College, but did not get scholarships this year in May; they seem most of them quite broken spirited. Our man Stokes who was considered sure of being Senior Classic of his year, who used to be the merriest fellow going, lost his scholarship from not doing his Mathematies, he scarcely ever perpetrates a laugh and so also with the other men. Johnson also (Adèle knows Mrs Johnson) is quite cut up. Joe Kay has left from illness produced by reading and won't come back till next term. I feel more convinced every day that if there is a thing more to be repressed than another it is certainly the system of competition for the satisfaction enjoyed by the gaincrs is vel'y far from counterbalancing the pain it produces among the others ${ }^{1}$.

I have not after all entered a boat club but patronise hockey and made my first debut yesterday at it. Montague Bonlton is a very nice fellow and uncommonly slarp, I do not know what his chance is considered to be in Honours. Charley Buxton's and my debating club gets on famously. We have just enrolled Hallam ${ }^{2}$ (the youngest and

1 To go out in the Poll was according to Bristed (Five Years in an English University (1840-5), 3rd ed. p. 216) the course which many a man took at that date out of pride when from early idleness, ill health or other cause his degree would not bo equal to what he thought his abilities deserved. Of the men mentioned Hotham inust have finally taken a poll degree, but he was elected to a Trinity fellowship in 1845; Edwards was a very low wrangler; Stokes did not graduate at all or took a poll; Charles Astor Bristed was an American, he is referred to in the Memories, p. 77, and was a great friend of Henry Hallam. He gave an obituary notice of Hallam in the New York Literary World, which is cited by Maine and Lushington and carries us back into the circle of the "Historical."-_He was the neatest extempore speaker I ever heard; his unprepared remarks were more precisely and elegantly worded than most men's elaborate written compositions. He had too a foresight and power of anticipation uncommon in such a youth, which enabled lim to leave no salient points of attack and made his arguments very difficult to answer. He was always most liberal in his concessions to the other side and never committed the fanlt of claiming too much or proving too much. His was not a passionate oratory that carried his hearers away in a whirlwind, but a winning voice that stole away their hearts, the ars celare artem, the perfection of persuasiveness."-These lines are $\boldsymbol{u}$ striking testimonial to the powers of Hallam, but also indicate the nature of Galton's personal circle. Bristed was next but one to "wooden spoon " in the mathematical and second in the second class of the Classical Tripos in 1845. I have already referred to Fowell Buxton and the Kays.

2 This is the "Historical Socicty," and we may fairly assume it was founded by Galton and Buxton. In the Menoir of Henry Fitzmaurice Hallam by Henry Sumner Maine and Franklin Luslington, which is published in the Remains in Verse and Prose of Arthur Henry Hallam (new ed. 1862, p. lii), it is said of Henry Hallam: "In the first year of his College-life he became the virtual founder of the 'Historical' debating 
only surviving son of "Middle Ages") among our members and spout away most learnedly once $\Omega$ week on subjeets in the cthical line. There are 9 of us altogether and I shall be president next week and shall array myself in Stultz for the occasion. We keep it very seeret and meet in each other's' rooms in rotation under the pretext of a wine party; then the man who gives the spread is president and at $\frac{1}{4}$ before 5 sports his door and the debate begins. The president of one meeting has to propose a subject and open the debate on it in the meeting a week after. Mr Hodgson sent me my certificate for degrading the lay before yesterday. I will let you know how the proceedings about it progress in my next letter. I have invested in sueh a jolly seeond-hand arm chair. I really believe it is the most eomfortable in Cambridge, it eost $£ 3.10 \mathrm{~s}$; the seat is only 10 inches from the ground so it is thoroughly luxurious. [Sketch of said chair.] How is Capt. B-, wedded or single? By the way one can imagine the following seene:

Scene. Interior of a cliureh, marriage proeession, bridesmaids, ete., rather an elderly bride and bridegroom.

Priest. Wilt thou have this man to be thy wedded husband?

Bride. Not a doubt about it.

How are the various family ailments? Does Mater find bannocks lie very lightly on the stomach? Thank you for taking eare of the papers; there were some books also that I left, Guizot's Civilisation, etc., and thcre are some at Claverdon. Now if Mater had such a redundancy of preserves and jams from the garden that she was really obliged to manage with them as she used to with the cats of old, viz. give sixpence to whomsoever would take them, then the strength of my filial affection would rejoiee at the opportunity of being useful and of taking 2 or 3 pots out of her way. And should all this be the case it would be worth while to put them with the books in a box and send them at once to Cambridge, where they would be severally eaten and read.

I am learning singing after the Hullah fashion, but alas notwithstanding maternal prophesies I find the Galton ear is as slightly developed inside my skull as it is largely on the outside, and although I keep up the credit of the family failing, yet I am afraid I shall not at the same time qualify for the professorship of music.

I read with no tutor at all at present, as I question the advantages of doing so, but slall attend the University lectures on mechanics by Willis, which begin on the 10th.

Theodore is reading hard for his degree which eomes off in about 10 weeks. Goodbye and believe ine, Your affectionate son,

Fras. Galton.

The next letter does not tell us whether Galton has given up the idea of degrading, but it shows that there was little hope of any immediate improvement in his health.

\section{My dear Fatiner,}

[circa November 28, 1842.]

Thank you much for your and Bessy's letter which last I reccived yestcrday. I am quite ashamed at not having written oftener but my head generally is not as well

club, established to eneourage a more philosophieal habit in style, argument, and ehoice of subjects, than was in vogue in the somewhat promiscuous theatre of the Union." Galton's letter of Nov. 2 and that of Feb. 17 of the following year seem to indicate that Hallam, although possibly an early member, was not the virtual founder of the "Historieal." 
as might be at the orthodox letter writing time, namely about 7 a.m. I find nyself quite unable to do anything in reading for loy really dcep attention to Matlis. I can bring on my usual dizziness ctc. almost immediately though generally I feel mucl better than I used to do. Palpitations of the heart have lately come on when I read more than I ought to do which I am rather glad of than otherwise, as it saves my head. Wliat annoys me most is that my powers of reading vary so mucl on consecutive days, at one time being able to l'ead some hours, at another not half one, and the dizziness etc. when it does come on, comes on so rapidly that I have no fore-warning symptom to tell me when to stop, except occasionally the palpitations. I have been rather diffusc a la Leamington about my health so by way of change do thank Hiner particularly for the cake and tell her that if the quickness of its disappearance be any sign of excellence that it decidedly must rank annong the very best that culinary science has produced. It was capital and at least 20 individuals concurred in that remark.......

The breakdown in Galton's health must have been so complete that he determined to give up reading for mathematical honours (not to degrade) and to enter for a poll degree only. He now spent much of his time in literury and social pursuits, and towards the end of his stay at Cambridge resumed there his medical studies. That he was a popular man at Cambridge appears from the societies he founded or assisted to found; he was also active in various undergraduate movements as the following letters will indicate.

\section{My dear Father,}

Sunday $\left[\begin{array}{lll}17 & \text { Feb. 1843]. }\end{array}\right.$

Thank you very much for all three of your letters, which were certainly very amusing. All my time lias lately been taken up by canvassing and afterwards by a most unfortunate collision between two of my friends witl one of whom I was much interested and in some degree involved. $\mathrm{P}$ - and $\mathrm{C}$ - are the two men. The first you have heard me mention before. The last is a son I believe of Sir Thos $\mathrm{C}$ __ and was a fellow commoner. $\mathrm{P}$ - is a man whose whole object was to make a very cxtended acquaintance, in which he certainly succeeded, but at the same time was very unpopular from being a pushing sort of man and often mixed in quarrels, and a very noisy arguer at the Union. He was a great friend of Theodore's at one time, who afterwards was rather offended at lim. To proceed, on Monday night the candidates for the Union Officcrs were proposed. $\mathrm{P} \longrightarrow$ proposed one and $\mathrm{C}-$ seconded $^{3}$. In some private business

${ }^{1}$ Galton, Mr Harold Wright informs me, was elected a member of the Library Committee by 152 votes. Mr Wright has most kindly extracted from the minute-books for me the references to Francis Galton; they show that he was a frequent speakcr-tlius on March 15, 1842, he opened a debate on tho negative side of the question: "Would the method of voting by Ballot in returning members to Parliament be an improvenent upon the present system?" The negative was carried by 26 to 4 . He was less fortunatc on April 12 th when he opened a debate against Sir Robert Peel's financial proposals and the voting in favour of them was 32 to 9 . When on Dec. 7 of the previous year he had spoken in favour of a repeal of the Coln Laws, however, only 7 voted for repeal with 23 against. 
that followed $\mathrm{P}$ _ unade a great disturbance-calling out, groaning, etc., etc. in which he urged on 4 or 5 Magdalene men to support him. I on meeting him that evcring assured him that had I becn president I should have fined or expelled him, but he secmed to look upon the whole matter as a joke, and assured me that with 4 or 5 supporters he would break the Union lamps and upset anything like order. The reason of his anger was that a different man was elected President from the one he supported. The next day he apologised for the disturbance he had made. When that very cvening on Gibbs, the ncw President taking the cliair he was so shamefully uproarious that nothing could go on. At one time I heard him cry out three groans for the President, which he and his unen gave. I then went to the President and requested him to ccusure or expel him for the whole Union was in an uproar. The President shortly after seeing one of his supporters $\mathrm{X}$ — crying out fined him a sovereign. P__ rushed across the room crying out "infamous," and was neither fined nor expelled as he ought to have been. I then spoke to some other members of the Historical about his imnediate expulsion out of that society; which they cordially agrecd to, but we determined to talk it over next day, Wedncsday. On Wednesday morning I met P-, who told me he was highly vexed at his conduct the night before; when by all that is shameful that very night at a lecture which was given in the Union and [at which] Mr Thorp the tutor of Trinity kindly took the chair (he had been when an undergraduate a Prcsident), $\mathrm{P}$ — was more uproarious than everurging on several Magdalene men, who stood behind the furthest benches and kept up continually stamping so that nothing could go on. Thorp threatened twice to leave the chair and was going to do so, when C__ jumped up and rushed into the midst of them, confronted P_ and told hin that his conduct was disgraceful and blackguardly as it had been the night before, he then turned round and said his observations applied to all who had assisted in the row. When turned $\mathrm{C}$ - felt a pusl on the shoulder of which he took no heed, but turning again repeated his observations to $\mathrm{P}-$. He then spoke to all the men who had left their seats (about 200) and were crowding round, and said is it your wisl these men should be turned out; they all cried Turn them out, turn then out. Cries of Chair, Chair recalled the men to their places, and $\mathrm{P} \longrightarrow$ and his associates left the room.-I immediately drew up a requisition to $\mathrm{P}$ - to leave the Historical ${ }^{2}$, which was signed by all who saw it about 17 , and then began to take steps for expelling him the Union'. Whell going to $\mathrm{C}-$ _'s room I found him half-mad hearing that $\mathrm{P}$ had spread a report that he had struck $\mathrm{C}$ _ in the Union, who was too cowardly to return it. $\mathrm{C}-$ then put a horsewhip in his pocket and went everywhere in search of $\mathrm{P}$ - but could not find him. Late in the evening le returned to his rooms with his two friends where he found $\mathrm{P} \_$with $\mathrm{X} —$ and $\mathrm{Y} —$ of Magdalene, who said I have heard that you have been looking for me all day, here $\mathrm{I}$ am. C_— said he wished to speak with him by himself. On his demurring he gave his word that he need be under no

1 Galton has misplaced the foundation of the Historical in the 1 lemories, p. 76. No doubt the violent behaviour at the Union strengthened the Historical.

: On Feb. 20 a inotion to expel Mr P_—_ was brought forward at a special mceting, and on its being carricd a poll was demanded; this resulted, next day, in 246 for expulsion and 76 against. On the report stage another poll was demanded with the result of 236 for expulsion and 103 against, so that the notion was lost, a three-fourths majority being apparently neclful. 
bodily fear. So they went down into the eloisters. On arriving there C-_ asked him if it was true that lie had spread the above report. P_ replied that he had struek him in the Union. C__ drew out his horsewhip and held it over lim and said: Consider yourself horsewhipped. $\mathrm{P} \longrightarrow$ said: You have not struck mo. $\mathrm{C}-$ dropped the whip on his shoulders. P_ drew out a life-preserver and struek $\mathrm{C}$ - feroeiously over the temples which quite confused him; he however closed in when $\mathrm{X}-$ and $\mathrm{Y}$ —— actually pinioned $\mathrm{C}-$ and whilst $\mathrm{C} \longrightarrow$-'s two friends were trying to tear them off, $\mathrm{P}-$ - deliberately hit $\mathrm{C} \longrightarrow$ several times on the hearl. $\mathrm{P}$ — trotted away and said I have witnesses that you first struek me. He sinee owned that the whole affair was prearranged. All $\mathrm{C} \longrightarrow$ 's friends were of course almost mad. It was beneath his dignity to ehallenge him $^{1}$. To skip over all the different plans that were proposed and laid aside it has enderl in laying the inatter before the College authorities who have rusticated P_— "sine die," which is the same as expelling him, for they take his name off the boards and they have not allowed $\mathrm{C}$ _ to reside this term which is almost a nominal punishment as ho is a bachelor scholar, and in no way to be injured by such sentence. I need not add that $\mathrm{P} \longrightarrow$ is universally eut and I understand that he has threatened being revenged on me.

$\mathrm{C}$ - was a good deal hurt. A large committee of whom I am one are always together either at $\mathrm{C} \longrightarrow$-'s or some others' rooms. He breakfasts with me tomorrow before going down and the whole of Trinity will probably see him off. The motion for P__'s expulsion comes on tomorrow evening. Denman, son of Lord Denman, and senior elassic takes the chair. A printed statement will be published as soon ns the Magdalene men have been punished and I will send you onc.

The tests, for arsenic are very casily applied and quite chenply, but the 4 pounds is I believe the Chenist's fee. Your affectionate son,

Fras. Galton.

I fear the shortness of the above statement will not give you a very clear notion of the way matters stand.

There are no further letters relating to this remarkable episode in the life of the Union ${ }^{2}$, but a few verses-apparently by Galton-among his papers show that he saw the humorous as well as the serious side of the matter. 'They rum:

IJorsevehip and Life-preserver.

P__ I'll face it out and 'stearl of dawdling

Go and sce my friends at Magdalene

I On the proposal to challenge: see the Memories, p. 75 .

${ }^{2}$ Among Mr Harold Wright's gleanings from the minutes we find a motion by Galton "That the restriction by whieh the Library Committeo are prevented from purchasing novels be done away witl." (Uctober 29, 1843). The motion was lost. His name also appears (March 28, 1843) at the end of a report of a committee appointed to consider the question of the Union giving a ball. The Committee strongly opposed the suggestion. Galton was proposed on Jan. 31, 1842, by Housman of St John's for the office of President, but was defeated on a poll by Crawshay of Trinity. Some account of this disturbance at the Union will be found in Bristed, loc. cit. p. 169. 


\author{
My friends I've told you once that really \\ I did hit $\mathrm{C}$ - most severely \\ Who answered nothing when I whaeked him, \\ But now some plucky friend has baeked him, \\ And made hin threaten me a dipping \\ Or a sanguinary whipping. \\ $\mathrm{X}-$ and $\mathrm{Y}$ - together \\ $\mathrm{D}-\mathbf{n}$ it if he don't deserve a \\ Licking with a Life-preserver, \\ Up! and, when your coat is put on, \\ Buy the instrument at Mutton.
}

Versification was indeed very much in Galton's mind at this tine and on April 5, 1843, he writes to his father :

\title{
My deAR Father,
}

TriN. CoLI.

I am having the greatest fun inaginable in getting up an "English Epigram Society" which is to meet 3 times a term, the members are to send in their epigrams anonymously and they are to be read by some one chosen by lot. The subject is to be chosen out of those proposed by a majority. I have got the first in the University among the rising men to join it, two young Fellows of Trinity and bachelors, ete., so I cxpect that some of the Epigrams will be first rate. The soeiety eonsists of 12. All the men I have spoken to have jumped at the idca, and I have great hopes of its working exceedingly well.

I think I shall be able to conne down this week, when I would eoaeh it to Hatton and then walk on. I send you a poem, $I$ have just sent it for the Camden medal and fear it will not interest you much as it is all relative to the present great controversy as to whether man has a conseience (innate I mean) or not. Paley and Locke and many Greek philosophers as you know against it, Plato and Bishop Butler and some German inetaphysicians and Whewell on the other side. Stewart seems to be for it, lut does not give a decided opinion one way or the other. The mottoes I have chosen explain the point of the whole; I take the paraphrase of the one from Plato to be: "They have ever in their soul a specimen of the Divine nature, lasting and bright as silver or gold." I was obliged to print it before scnding it in. I leave it on the honor of the Fanily that it be not shown to any besides themselves I mean iny Father and Mother, Bessy, Adèle, Emma, nor in any way to be spoken of to others.

Your affectionate son, Fras. Galton.

The poem is of deep interest-not as a poem, it gained no prize ${ }^{2}$ but as evidence of Galton's faith and view of life at this period of his

' See Bristed, loc. cit. p. 214.

2 The prizc was won by Galton's friend, W. Johnson of King's. As Mrs Browning puts it:

Many fervent souls

Strike rhyme on riyme, who would strike steel on steel

If steel liad offered, in a restless lieat

Of doing something.

Aurure Leigh, 2 ?nd ed. p. 34. 
career. He had not yet realised that the social virtues were the products of a long evolution, he considered that mercy, justice and truth were absolute ideals, and that a knowledge of what they consist in was divinely planted in every human breast. 'The world for him was a degenerate world:

"The heart of man is intellectualized,

"And the high souls of other days are gone."

Its salvation depended not on a forward progress, but on a return to some earlier ill-defined state, where conscience had held more complete sway, and Divine rule had been more fully recognised.

"Well may we loathe this world of sin, and strain

"As an imprisoned dove to flee away;

"Well may we burn to be as citizens

"Of some state, modelled after Plato's scheme,

"And overruled by Christianity,

"Where justice, love, and truth, and loliness

"Should be the moving principle of all,

"And God acknowledged as its prop and stay.

"I am no ingrate foster son to thee,

"Granta, revered mother, in thy lap

"Have good men grown to their maturity,

"Nourished and strengthened by thy wholesome lore,

"And thence have proudly walked before the world

"As statesmen, poets and philosophers.

"Still thou art but a corner of the earth,

" Wherein a penitent may weep and pray,

"While all abroad is rouglr disquietude."

There is no doubt that Galton was at this time in a depressed frame of mind, and therefore too much stress must not be laid on such opinions as those conveyed above or in the words:

"How foolish and how wicked seems the world,

"With all its encrgies bent to amass

"Wealth, fame or knowledge."

But the poem does form an index to his standpoint at that time, and enables us the better to appreciate those fetter's from which, be tells us, Dar'win's Origin of Species emancipated him (see p. 6). The time was yet distant when he too would hold that to increase the bounds of knowledge was, perhaps, the "most respectable task" a inan could set himself in life, or when he would settle down to

P. G. 
ascertain how the social virtues arose from the evolution of the herd or endeavour to inquire statistically into the efficacy of prayer.

The following letter must have been written shortly before the Long Vacation, which Francis was planning to pass in Germany with his sister Emma.

\section{My deAr Father,}

\section{Trinity [Date ?].}

I do not think I can get any Weimar introrluction from my London medical friends though they may have some acquaintances in Jena. Jena is I find a stage from Weimar. I am making all enquiries I can, and from all I can gather Weimar is decidedly the place for us. The Historical Society flourishes. I speechified there the last meeting. The Epigram Society appears most prosperous, we had its first mceting last night. A great many were sent in, and 5 chosen out of them by ballot. Then we have sulsscribed for a superb manuscript book with AMOENITATES CANTABRIGIENSES on it, in which such epigrams as are chosen are inserted. I have not time to write out for you the five in question, but they were very fair. I ought to say that we take the word epiyram in its most general sense, that is any poem of any character on a given subject with or without point. The subject was Via trita, via tuta (the worn way is the safe way) the Duke of Norfolk's motto. The verses I sent in, they were one of the five, were:

\footnotetext{
"A plucky lad was he,

"Who fastened quills together,

"And tried to cross the sea,

"In spite of wind and weatler.

"Though better to have wept

"In silence Minos" ire,

"Facts only prove he leapt,

"From frying pan to fire.

"Shareloolders save your load,

"Save money, save material,

"So kecp the turnpike road

"And sell your steam aerial."
}

Your affectionate son, Fras. Galton.

The last letter from Cambridge this term is undated but it must have been written in the first few days of June:

My dear Fatiler, Wednesday Evening [Date ?].

Thank you very much for your kind present to me which will be very acoeptable as I do not doubt but that my journey will be somewhat expensive. I will be with you on Monday Evening, as I propose to leave Cambridge for Claverdon by the Eagle on that day. Then I was thinking of staying witl you there until Wednesday or Thursd:y and then joining Emma in London and starting off witl her on Monday.

I cannot write a longer letter now as we are heing plagued with an Examination, in which, howcver, I am not trying to do unuch, as I am quite indifferent as to iny place. 
in the Classes and only want to avoid being posted whieh is a bore beeause the nane is published in the newspapers as such and relations me generally ignorant of the nature and elaraeter of these exaninations. I have prepared literally nothing but trusted to the light of nature which has been very useful so far, and I think I have al ready avoided a post ${ }^{1}$. If it had not been so, I should only lave had to eram for any ono of the later papers over night and that would have done perfeetly.

Henslow the botanieal leeturer has heen very grood-natured to me about Saxe Weimar; he says he would have given me introductions, but he has never hinself been abroad, but he advises me to ask at once if there be any resident botanist, to go to him and to state my ease, and to ask him what are the valuable flowers in the neighbourhood, ete. He says there is a kind of freemasonry among naturalists, that it is very little trouble for a professor to open his herbarium and to shew a few leaves of it, and it may be of great service and therefore they never hesitate a moment about doing so. I shall eertainly follow his advice.

Goodbye, my dear Father and with many thanks for your kind letter, I remain

Your affeetionate son, Fras. Galton.

The next letter finds Galton in London (June 10, 1843) preparing to go to Dresden with his sister. He has seen "the farce of Fortunio at Drury Lane, which is certainly most absurd and contains more puns than it has hitherto fallen to my lot to listen to even from yourself [S. T. G.]." There are a few days of seeing friends-Partridge, Kays, Horners, and relations Hubert Galtons, Charles Barclays, Gurneys-and a new acquaintance, Denham Cookes, is made. "He has the funniest head I ever saw, is exceedingly agreeable, and at his ease; nobody except his lawyer knows where he lives, under cover to whom all communications are addressed. His hair is yellowish red; his face something like this [sketch of a face with bizygomatic much greater than minimum temporal breadth]. He told us a great deal." Then brother and sister are off via Hamburg to Dresden. In Dresden they appenred to have stayed till August 16, but only one joint letter of Francis and Emma to "Father, Mother, Bessy and Delly" has survived. Emma writes: "We enjoy ourselves much, it is most kind of you allowing me this journey, I feel most obliged to you for it. Francis has been busy with his Doctors lately. He asked Dr Todd of London and his brother to tea; Fras. makes a capital host, and we hang out tea, bread and butter and cherries. We leave on Thursday for Tetschen to stay till Saturday at Mr Noel's.......The Hallams and ourselves are prodigious friends. They leave on Monday." Henry

1 Galton got a fourth elass in the May Examination, 1843. 
Hallam and his sister had also gone to Dresden. Francis himself writes in something of his old light style on people and customs:

"We are in full preparation for leaving Dresclen early the day after tomorrow. We go by steamer to Tetschen to the house of $\mathrm{Mr}$ Noel, Mr Woolness's friend; lie called upon me the other day whilst I was snoozing in hed at 9, and was very good-natured to Pem and asked us to stay in his house on our way to Prague. Accordingly we go to him on Thursday and stay until Saturday, which time he wrote to say would suit him. Coombe, the phrenologist, is I believe staying at Tetschen; at least Mr Noel came to Dresden to mcet him and afterwards returned with him in the steaner home. Mrs Noel is a Bohemian lady of very good birth and sister to Count Thun, who is a great man in these parts. His face is plain, but the bumps on her head are undeniably gool, Mr Noel himself being an authority on that subject ${ }^{3}$. Emma suggested that Lecky who was second in the late duel might be my old sehoolfellow at Boulogne; have you any means of aseertaining whether such be the case? I do not remember him personally, though I remember passing a Sunday at Colonel Lecky's. The Hallams go on Monday but we have made arrangements for meeting them two or three times on our way southwards and then they will stay 10 days at Munich."

There exists only Emma Galton's diary, which tells us that the party went to Prague (August 22), Carlsbad, Regensburg, Munich (September 2), Augsburg, Constance, Höllenthal, Cologne, Ostend and so to London (September 31). Miss Galton notes that there was a fearful storm; Francis Galton records that he was nearly drowned off the Goodwin Sands, but I can find no details. Galton was back in Cambridge on October 20 begging his father and Emma to come down there for the visit of Queen Victoria. "Mrs Hoppet is all anxiety to see you." Miss Galton's diary does not refer to the visit so that probably it did not come off. The following letter indicates that Tertius at least was not present.

\section{My dear Father,}

Trin. Col.t. [31 Oet. 1843].

I have been talking with $\mathrm{Dr}$ Haviland about the lectures I have to attend. He tells me that if I put a "spurt" on and go to 4 lectures a day, that I shall be able to finish with Cambridge by the end of next terin; he absolves me from hospital practice in Cambridge and accordingly I shall be able to practice (if I like) next June 2 years. I have without hesitation adopted his plan. I must pass an examination by each of the Professors separately and the examination takes place at the close of their lectures. Whether I shall fecl myself strong enough to go in for all four or any of them at the end of the eourse I attend I do not know; if not I shall clo so next year. I am working

$1 \mathrm{Mr}$ Noel formed a fine collection of casts from living heads-taking those of men noteworthy for either ability or erime. This collection has reccntly been presented to the Galton Eugenies Laboratory by Lady Lovelace. 
Plate $1.1 / 1$

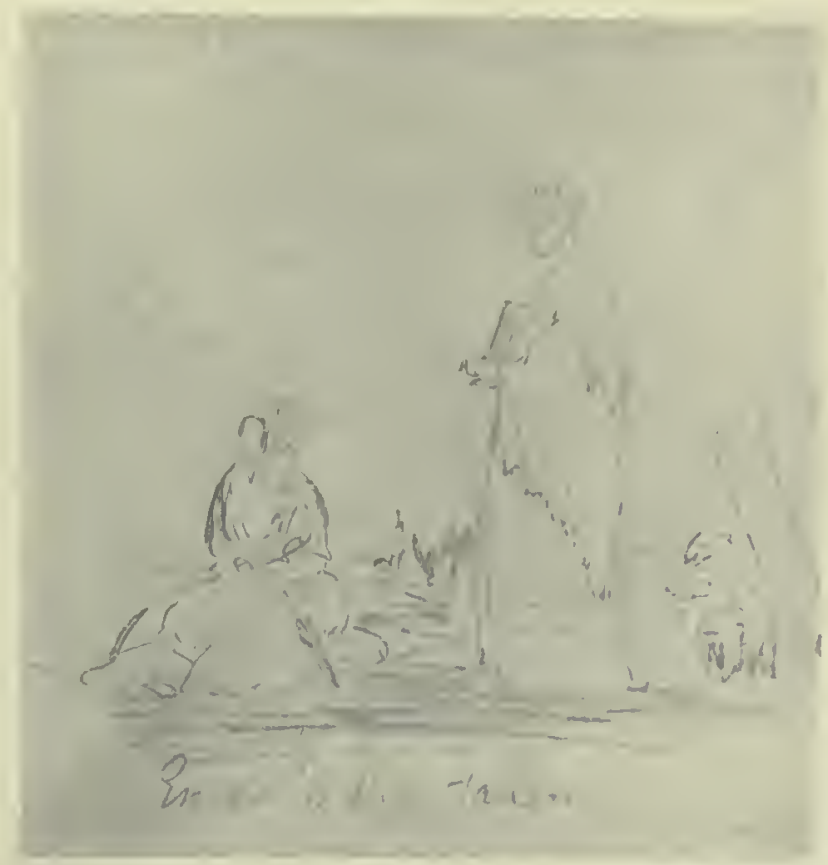

Emma Galton and Julia Hallam.

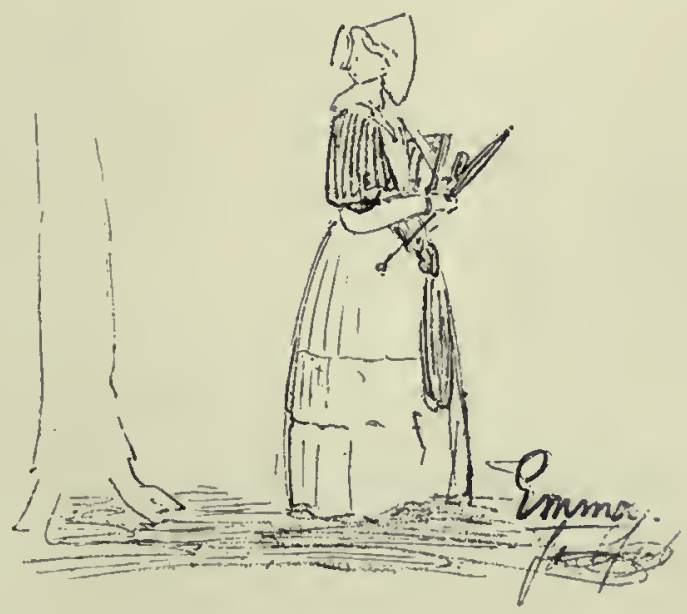

"Sister Emma."

From Francis Galton's sketehbook of the German tour in 1843. 

$180^{\circ}$ 
Plate LIV

Mus dear fatten-

Lour affectionate fou ci.

BAt. the cerenusey having tares

trace the keonering annul it now

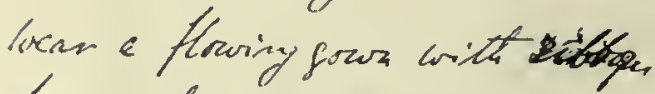

rang in front over siltier arm.

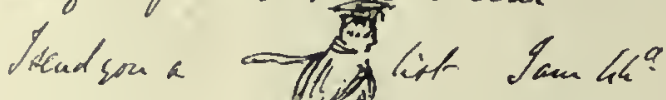

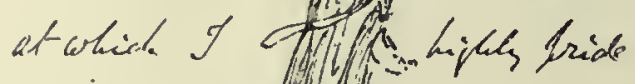

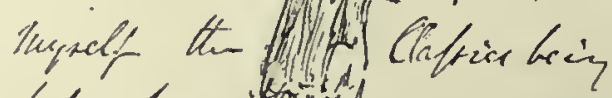

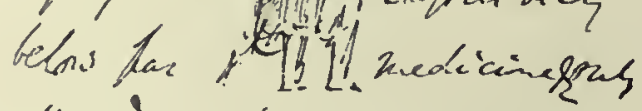

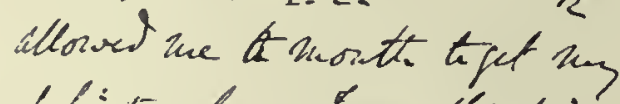

subedit of. Four tend is.

Letter of Francis Galton to Tertius Galton announcing his graduation.

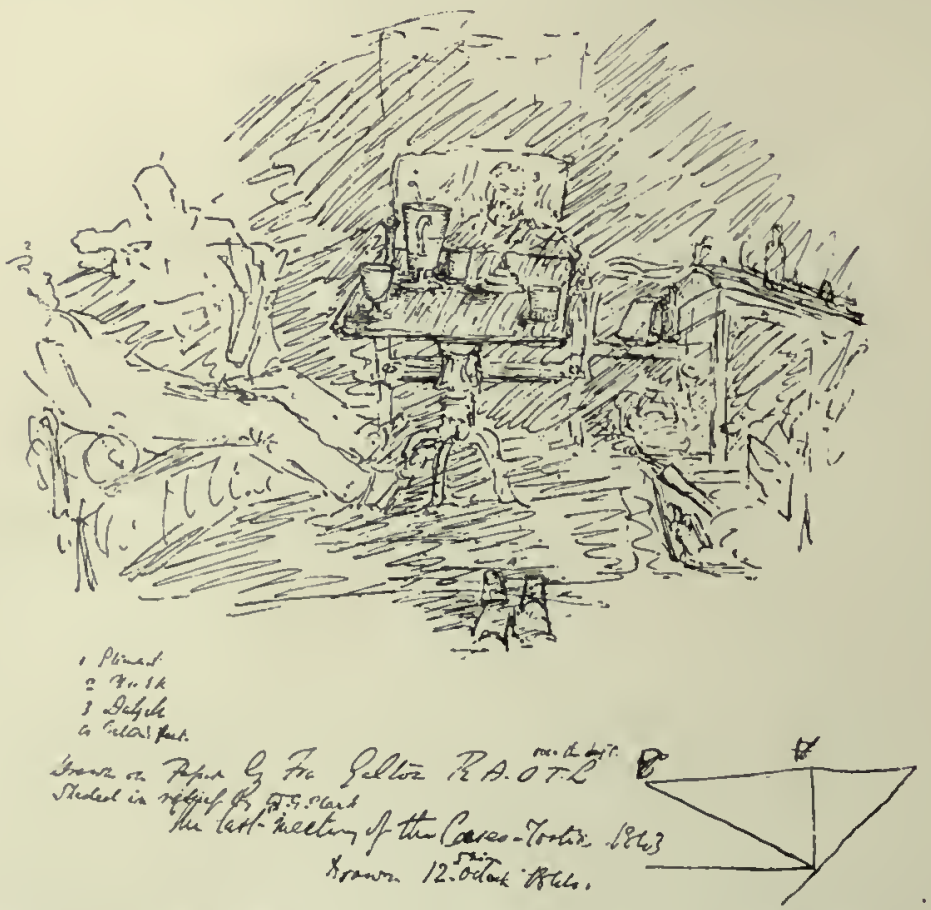

'The last meeting of the Caseo-Tostic Club, 1843, Present: Stewart, Clark, Dalyell and Galton.

last Days in Cambridge. Sketches found in letters. 
feroeionsly at present. First for my degree and secondly on the 4 diflerent subjeets, Anatony, Praetiee of Medicine, Chemistry and Forensic Medieine. I did at one time know these same suljeets wcll enough, but they slip in nu cxtrnordinary degree out of the mind. I am writing in the Union and waiting for some motions to come on that I was pledged last term to open. I wrote you a note by this morning's post. My gown was not among the number thrown down for the Queen to walk upon and eaught up before the maicls of lonor (bless their pretty feet) could do so, as I had no inelination to nssimilate my loyalty to that of the Aldermen of Southampton.

Goorlhye, Your affeetionate son,

Fras. Galton.

'The postscript of this letter contains a long description with sketches of "the jolliest dodge imaginable to supersede the old plan of bolting the left door into which the right door locks" of any two-door cupboard. 'The contrivance is one in which the shutting of the right door antomatically fastens the left.

In November Galton found that he would have to stay in Cambridge till June to complete his medical work. He proposes to go to St George's Hospital to complete his medical education. He considers that London would be the best place after leaving Cambridge and before the winter medical session begins he could learn Botany and Materia Medica, together with some degree of hospital practice. "If not, I could dissect in Paris, though, after all, minute anatomy is really useless to a practitioner who does not operate, and I think I know quite enough of general anatomy." He thinks of taking rooms in King's College as more suited to a medical student than lodgings. A letter without date of Jannary 1844 contains on the first page a sketch of a handsome young bachelor.

\section{Mr dear Father,}

Your affectionatc son is B.A., the cercmony having taken place this morning and I now wear a flowing gown with ribbons hung in front ovcr cither arm. I send you a list. I am $44^{\text {th }}$ at which I highly pride myself, the Classics being below par and Medicine etc. only allowed me a month to get my subjects up. I was third in Mathematics but would have been first only for a misunderstanding in onc question which lost me fifteen marks. The place howcver in the Poll signifies nothing.

I see Hopkins occasionally who often asks me out; le has asked me to dinner tonight and again on Tuesslay night.

Thank you very much about the earriage to the Stratford ball. It will be most convenient and capital for me. Please tell Emma that I foar iny Schiller will not do for her on account of the type, besides I think that I had rather keep it. Tell her I was much obliged for her remembering my ofler of selling it.

Your affectionate son,

Fras. Galton. 
Apparently shortly before taking his degree Galton drew up a petition concerning the badness of dinner "at Hall." The fate it met with-if ever presented-I do not find recorded".

\section{To the Mraster and Seniors of Trinity College.}

We being the whole of the undergraduate pensioners of Trinity College who are now in resilence, beg to call your attention to the very uncomfortable character of the dinners at Hall. It lad been intended last year that a memorial to this effect should have been sent. But it was understood that the Steward of the College expresserl his wish that such a measure should not be resorted to, as he was then preparing a report in his othcial capacity, one which we hoped could not fail of meeting with attention as the evil arose not from the smallness of the sum we pay for our dinner, but from the nismanagement of it. On this account the memorial of last year was not proceeded with, but the Steward's report laving failed in producing any improvement we take these means of calling your scrious attention to the subject as strongly as is consistent with the respect we owe you. We complain of the dirtiness of the waiters, the bad state of the eutlery, and the pewter dishes, which with the character of the meat give the tables an appearance far from gentlemanly and very inferior to that of most of the Cambridge smaller colleges and all of the Oxford ones. And this appearance has created a very general feeling among visitors to the prejuclice of Trinity, which for the honour of our College we would gladly see removed. We make no petition for unnecessary luxury at Hall, but only desire that our meal there should not be inferior to what is usual in society at the present day and to which therefore as gentlemen we feel ourselves entitled, and more especially so when it is acknowledged that the sun we now pay for it could by management fully satisfy our requirement.

Possibly a hunt in the Trinity minute books might provide the reply of the Master and Seniors to this petition. Such a body has generally a ready answer, as when at the beginning of the centnry the undergraduates of another large Cambridge College petitioned for dinner at 1 o'clock instead of 12 , stating, for one reason, that it would give an hour longer for the morning's work, and the Master and Seniors replied that they thoroughly approved of their reason and that to meet their views in future chapel would be at 6 a.m. instead of 7 !

'Bristerl writes: "The tables of the Undergraduates, arranged according to their respective years, are supplied with abundance of plain joints and vegetables, and beer and ale ad libitum, besides which, soup, pastry, and clreese can be 'sized for,' that is, brought in portions to individuals at an extra cliarge; so that on the whole a very comfortable meal might be effected but for the orowd and confusion, in which respect the lall dinner much resembles our steumboat meals. The at tendance also is very deficient and of the roughest sort." Five Year's in an English University (1840-5), 3rd erl. p. 35 . 
A whole series of epigrams and verses touch on the fun and frolic of this last year of Galton's College career. 'The first, I quote, refers to the Historical Debating Society founded by Galton and his friend Charles Buxton.

On the cursed Gift of Oratory.

Within the Black Bear's aneicnt walls,

Sit the young Historieals.

Sambo Sutton once fought there,

Once a meeting met for prayer,

Once a Tory there did try

Election bribes successfully.

But now worthier than all

Sits the Sage Historical.

Look at him that now is pleading, Gravely, carnestly,

His hands against his lips applied,

Swaying about from side to side,

Ever with uneven motion,

Like a barrel on the ocean.

The while some one idea he lays

Before the club in many ways.

Or, there was satire of some well-known member of the circle:

Nature when she built you Taffy,

Made a lion too,

For whom she found a soul so gruft

And one so meek for you.

She had in the live-coal

Far too many irons,

So the beast got Taffy's soul

And Taffy got the lion's.

'Tafly's heart of stccl

Knows not fear at all,

But the lion he must feel

Particularly small.

Towards the end of his Cambridge time Galton became for a short while a teetotaller, and possibly the following lines commemorate the episode:

\section{Ode to Wilk Punch.}

When first I met thee warm and young

There slione sueh truth about thee,

Such fragranee o'er thy surface hung

I did not dare to doubt thee. 
I sipt and next a bumper tried, My friends' prediction scorning, Then reeled and told them all they lied, But ah! the following morning.

Then go, Deceiver go,

Thoso tongues whose lust could make them

Trust one so false, so low

Deserve salines to slake them.

A way, thy cliarms their bloom have shed, Now failing to adorn thee, While men who loved theo once have fied And teach the world to scorn thee.

Milk Punch, bland liypocrite be gone

And my worst wishes to ye

You ne'er do good to any one,

But serew the hands that brew ye.

Then go, Deceiver go, etc. etc.

Some of these points are again illustrated in Galton's six months as a bachelor at Cambridge. He returned there on Feb. 13, 1844, and reports to his father that he is working hard at medicine and that Dr Bond has offered him a clinical clerkship on the next vacancy. He encloses the following Bulletin:

\section{Case of Francis Galton.}

Year. 1844.

Month. Feb.
Trade. Cantab.

Disease. Extreme appetite.

The patient states that he left Leamingtun by the coach on Feb. $3^{\text {rd }}$ : the day was cold and rainy. At Southran he purchased some captain's biscuits which he continued eating till Northampton, at which place he invested in a pork pie. His appetite continued extreme even more so than natural. Present state. Fice flushed, which he accounts for by a violent walk, appetite remarkable.

\section{My deAr Father,}

$[$ March 6, 1844.]

Will you tell Bessy that I received her letter just after I had put iny last into the post and thank her much for it. I see young Barclay occasionally we have breakfasted at each other's rooms and are good friends when we meet, but I have now so little spare time at ny disposal being the whole morning in attendance on inedical lectures etc., that $I$ have been unable to go out much lately and consequently have raroly met him. I get more and more fond of medicine every day. I an trying some new ways of taking cases, or rather the outlines of cases by lines drawn under each particular symptom and varying according to its severity, every day or every 
second day as the case may be. In fact like the ordinary plan of statistical charts? It seems of great use for noting cases quiekly, since you can do all you want by the bedside of the patient and when going rouncl with the physician which w' be quits out of the question in the ordinary way of proceeding, and then many cases are noted which would otlerwise be neglected.

Do you remember my mother and myself talking about the connection of gout and astlima? I asked several medical men whether they liad over observed any and they all silid no, when curiously enough yesterday Dr Haviland stated in lis lectures that "from a wide olservation he $\mathrm{c}^{\text {'l }}$ not help thinking that gout and astlma had certain connections which lave not yet been investigated." I sliall certainly look out for cases that way, for it would be very curious if such apparently unlike disenses were after all related. Dr Haviland spoke much of very strong coffee as often being of very great scrvice in asthma;-that or tea, which is unch the same, for their active principles are identicut, I know you have found good only you don't take the former streng enough.

Does my nother still adhere to her intention of accompanying me to Slinewsbury next Easter, will you ask her to write about it? I slall have I lope nearly a fortnight altogether, bit must spend a week at home to talk over our future plans and Bols Snwyer dodges, for getting into practice and so on, with your?

You will probably have heard fron Emma, who found it out tbrouglı the Hallams, that I am a tea-totaller of abont a month's standing. It suits with my constitution gloriously-but warm advocate as I am of the cause, wliatever you do, iny dear Father, don't lower yourself, as wine is a most necessary medicine for you. I an very glad I have taken the pledge. I told Delly my reasons, who will tell them you. It was not done without a term's previons consideration.

$$
\text { Your affectionate son, } \quad \text { F. G. }
$$

Tertius Galton was slowly failing in health during these years and very tender and playful are the letters of his medical son. On March 9, 1844, he writes:

\section{My deAr Father,}

Saturday morning.

As I was not able myself to enter into learned consultation with Pritchard and Dr Jcphson I cannot altogether give up my privilege of "family doctor," and so will write this letter full of prescriptions. But first I must truly congratulate you on your convaleseence which Delly tells me is in capital progress; and as I presume

1 The suggestion becomes clear when one has seen the elaborate statistical cbarts of the grandfather-Samuel Galton-covering most complete records of his household economy.

2 From about this date have survived two plans, onc an elaborate arrangement of the inside of a doctor's carriage with sleeping things, escritoirc, pots and pans of all sorts; the other a description of a physician's waiting room with a number of devices to impress the patients with the scientific cliaracter of the consultant and some humorous items as "folio works of various authors, too large to be alsstracted."

P. G. 
only wanting a litule hospital patient discipline to make it perfect. Now my prescriptions are:

1st. That the Hospital Patient do on no uccasion feel his pulse.

2nd. That the H. P. do never look in the glass to see whether lis cyes are red.

3ri. That the II. P. do never examine his own liealth with a view to self-loctoring.

ftl. That the H. P. do make improvements at Claverdon, and commit prisoners at Leamington when so inclined, but that lie never attend eanal-meetings, nor put himself to inconvenience or anxiety.

5th. That the H. P. do henceforth enjoy an "otium cmu dignitate" and leave hard work to younger heads for whom it is a duty.

And now ny dear Father I have finished doetoring for the present, but shall go on writing doctor's letters until I hear that you obey my rules, and that you treat your own constitution with the respect it descrves for liaving brought you through astlima, hard work at banking and anxicties of all sorts for so long. Indeed it is a highly meritorious constitution and fairly deserves rest. - I hope to be with you in alout a fortnight but the exact tine is not yet fixed, lowever I shall know before another thrce days, when I will writc. At present 1 still continuc full work at medieine. I an reading Hippoerates and Arctaeus in which we are examined for the M.B. degree. It is now my lecture time, and so not to lose a post I send my letter unfinished but will write again on Monday.

\section{Your very affectionate Soln,}

Fras. Galton.

During the Easter Vacation following Francis Galton went to visit his uncle Dr Robert Darwin and there is a letter dated Shrewsbury, Wednesday, and endorsed by Tertius Galton, April 10, $1844^{1}$.

At 3 p.m. yesterday I arrived at my Uncle's gates; the palms of my hands were deeidedly moist-the eourage was oozing. 'The fly drove up to the door and I was heartily welcomed by my cousin Susan. I made many apologies which were directly stopped short as everything was made up and exeused. And then I was taken into the dining room to eat luncheon and then in came iny uncle who welcomed me if possible 5 times more heartily and who also stopped short all apologies, having, however, first shewn me the delinquent letter, which was wonderful free froun all dates. Not a word have I heard of my iniquities since then up to the present time. And they have all been as goodnatured and as warm-hearted as possible. They wanted me much to stay, but I thought I had better not, lest my uncle should feel the excitement too inuch ${ }^{2}$, and also because they wanted me to have some anusements all day, and Shrewsbury does not afford any, and so I fear they may be afraid that thcy arc

1 There is a letter from Violetta Galton to her son Francis from alsout March of this year, saying how the health of both Tertius and herself has failed: "I dare not make any positive engagement to take you to Shrewsbury, but if I cannot do so, I propose, as soon as you come home, to write to my Brother and say how anxious I am to introduee my youngest son to him."

${ }^{2}$ Dr Darwin was then 78 years of age; he died four years later. 
not as hospitable as they might lo which is far from the ease, but still they might think it. My unele is very much better and stronger than I expecterl, and I lasve enjoyed my visit extremely. Your affeetionate son,

F. Gatito:.

At the beginning of May, Galton was back in Cambridge full of his medical studies and pointing out the value of a Cambridge degree for a medical man.

"Robert Frere who was my senion at Partridge's, and who has indeed taken a surgeon's degree has had this fact so much urged upon him by different Londen Doetors that he intends coming to Cambridge as a fresluman next tern. So I was right after all, notwithstanding Hodgson's forebodings, in wisling for a Cantab. edueation....... 'Tell Delly that as soon as I came up, and through the medium of Tooke I served a writ for total alsstinence on Selwyn. He professes himself not quite decided as yet, though uncloubtedly in favour of the cause. Tooke introdueed me to him the day after. The Epigram Society flourishes in great vigour, we meet next time to write epitaplss on the various dons now in authority. Selwyn I hear desires to join us. The Kays come up next wcek to take degrees in Frecmasonry ${ }^{1}$, and then they are to tcll me about any lodgings near them thcy have found out for me in town." [May 1, 1844.]

Only two more letters of the Cumbridge period have been preserved-indeed we shall soon reach the end of our material of this kind; for with the death of Tertius there was no other member of the family who preserved Francis' letters with the same tender care. At the risk of wearying the reader, I give them both.

\section{Mv loar Father,}

$$
\text { Monulay Morming [May 6, 1844]. }
$$

'Thank you very much for your two letters and I have just received Emma's also with the account of Miss E. I should think Mr T. Was not a person of very sauguine temperament. What is the correct thing for a lady to do uncler those circumstances? I always thought that the bridegroom was made to breakfast with the lnidal party before the cerenony, and never lost sight of till after it was over, lest he might holt. It seems so odd to make an appointment to meet and be married at a given hour at a clurel. Had Mr. T. only been a disciple of my l'ather's, he would have leen shivering at least half an hour lefore his time waiting for the chureh-door to open, and not be so grievously latc. I am glad Mrs Onslow is getting better, did you say the ball went right through her? My old friend, Joe Kay, is in Cambridge and he tells unc of several lorlgings about where I should like to be in London. I lave not actually

1 Francis Galton himself was initiater on February 5, 1844, into Scientific Lodge No, 105 of the Ancient, Free and Accepted Masons, helk at the Red Lion Hotel, Cambridge, and on Mareh 12, 18.5, he was registered on the looks of the Grand Lodge, Iondon. 
tixerl upon the street but certainly should prefer one of those running out of Park Lane, for then I shall be near St George's Hospital and the Park, and elose by the Kays, Campbells, C. Buxton and not far from Mr. Hallam, and indeerl some others. I faney that I shall get from Kay's description quite as good rooms as I slakll want $f()^{\circ}$ 20 shillings a weck....... We had sucls a glorious May day herc. I determined to improve upon my last year's one and together with two other men raised a shilling or sixpenny subscription to $£ 3$. With this we got 80 buns, 240 oranges, 600 small l,iscuit cakes and materials for 8 gallons of tea (to be made ready sugared etc. in cans); then we got a maypole 9 fcet above the ground [picture], with a great wreath on the top and two flugs one on either side fastened to sticks and held loy boys. Then an arch through which only 2 could pass at a time, reeeiring each of them a bun or 2 or three biscuits and an orange (in transitu). Then we chose a Queen of the May, the prettiest little girl I evcr remember to have seen [portrait] and Mrs Hoppit took her in charge and washed her and attircd her in a royal diadem and then the undergraduates present, about 60 shoved their way in to the maypole and took hands and spread out leaving a large vacant ring, in the centre of which was the maypole and the Qneen of the May. She choose her partner and with five other girls and thcir partners clanced the College hornpipe. Then we let in a number of other smaller girls who took hands and dancerl in a wide ring round them and the maypole, and after that another ring concentric that danced the opposite way round, so all three were going at once. We had onc of those street hurdy-gurdy things for the music. So the plan of the proceedings was thus: [Diagram of the dancing circles, the outermost sketehed below in clevation consisting of undergraduates in caps and gowns with stretched linked hands and outstretched legsoutside these a crowd of undergraduate onlookers]. 'There were more than 200 children and the undergraduate arms were at full stretch. The maypole was put up in the college green.

Riddle. If a man wants to obtain a vegetable time piece at what hour should he rise?

Answer. He must get "up at eight o'clock" (nust get a potato clock).

Goodbye. Your affectionate son,

Fras. Galton.

P.S. I will always write on Mondays as on this and last weck.

Trrax. CoLs. [May 13, 1844].

My dear Father, Tuesduy (instead of Monduy).

Pray exeuse this small shect of paper, for $T$ have so much of it on hand that I can find no way for its disposal. A number of my old college friends have come up during the past week, and most of them gone down again. Mathew Boulton just appeared for two days and a night to take his clegree. He asked me much to come to Tew, and I have aecepted his invite gladly for some far future time as I am afraid that I shall have no time for holidays in London. Evcrybody is making up long vacation parties and I have had carnest entreaties to travel with different allies to St Petersburg, to Madricl and I don't know where else, but after all it is satisfactory to have something better to do than to jnin them. Fowell Buxton has also been herc, 


\section{Lehrjahre and Wanderjahre}

he is working at the brewery in London but unfortunately keeps a long way ofl from where I shall. The 2 Kays eanic up, one to be made a Frecmason, the other to lse passed to the $2^{\text {ux }}$ degree and I was raiserl to tho third on the same night. Frelerick liristowe has been in Cambridge the last week to see his brother, who takes his degree next year. At the Epigrum meeting last time we had the most ammsing colleetion that as yet we have been favoured with. One slort one was on Griflin, n Johninn Senior Wrangler, who has written the most stale, abstraet and uninteresting books on optics it is possible to conceive and quite spoilt the beauty of the science. I ought to say the subject given was "An Epitapl." It was:

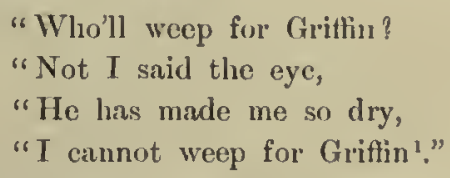

Bessy wrote to me the other day, it was principally on good advice.

The Kays tell me that they are going to build a splendid street in London longer than any at present existing and closed at eitler end with large metal doors and archways; it is to be by Kensington Gardens. Westmaeott has nearly finisluet his bas-reliefs for the basement of the new Royal Excliange; they are said to be splendidly executed. I do not know how the figures are grouped, but they form an allegory relating to Commerce, and the figures are in modern not ancient dress and I believe not unlike those on the old penny postage envelope. The British and Foreign Institnte is going to build extensively; there are now 1.250 menbers, the priees for dining are the same as those of the Athenaeum, which are high. A very fair librnry has suddenly sprung up by all the principal publishers giving very handsome presents of looks to Buckingham as a return for his exertions in that part of the copyright bill by whicls the number of copies of each publication that must be sent to different librarics has been diminished, and thesc books lie has made over to the Institute. Are Lucy's kinehins still with you? Give my love to them, if they are and also to Isucy. Your very aflectionate son,

\section{Francis GaLton.}

How is my mother's healtlı? and do you still teach Adèle's scliool-children? Yonr chess-board is invaluable; we lie lazily on the banks of the river in the sun playing chess after hall, which is luxurious to a degree. I didn't read the specch of Sir Robert you mentioned but should have been very glad to have been alle to lave cheered lim for the passage in question.

${ }^{1}$ N. W. Griftin: A T'reatise on Optics, Cambridge, 1842. The last information as to the Epigram Club I can find is in a letter of Nov, 10, 1844, received by Francis (ialton on Dec. 16th. It is from Charles Evans who hopes Galton has not lost all interest in his old protégée, which is flourishing satisfactorily. The subjects for the next meeting were "Much cry and little wool," "Fools enter in where angels fear to tread" together with the "current epitaphs." Evans states thiut they miss Galton very" much in the colony, for though his old rooms are occupied by a man known to loth of them, he being a fellow-commoner and rather antique did not assoeinte much with them. In the postscript comes the query, "Is the pledge still in violate?" 
'The following dateless letter is written soon after Galton had settled in London again:

Monday.

\section{My dear Father,}

I am afraid that I have two unanswered letters on the score against me, and thank you much for the letter of introduction to $\mathbf{M r}$ Walker contained in the last. I will tell you the result after I have taken it. I meet with numbers of my Cambridge friends so that I am pretty' sure of a call every day and this with working till about 4 at merlicine, and again before going to berl makes my existence about as jolly and as cozy as I ever expect to aspire to. Mr Hallan gave me a ticket for the private vicw of the fresco-paintings now in Westminster Hall (on Saturday). They arc said to be decidedly inferior to what was expected, and nearly half of them were rejected as unworthy of exhibition. The two hest (and I harl come to the same conclusion without hearing it before) are considered to be "Rachcl and Jacol," by Cope and a study by Armitage, a female figure looking something like Britumia'. Armitage and Cope were two of the three that got $£ 300$ prizes for their cartoons last year.

Dr Todd is very good natured to me. He las invited me to spend next Sunday with him at a country cottage of his near Streatham Common.

I enclose you two scrawls on one piece of paper intended respectively to represent different views of iny room. Tell Bessy that since she was in it, my landlord has allowed me a glorious damask green little bit of a sofa which fits as snugly as possible into the room. [Picture of a most uncomfortable-lonking, philistine piecc of furniturc.]

Sir Arthur Brooke saicl he would take me to see Alexis the mesmeriser abont whom so much has been written in the Fimes, Chronicle and IIerald by and in reply to Colonel Gurwood. I thought I had better go as he is said to be by far the most successful clairsoyant; lie won't exhibit publicly and this time Mr Ramsay Clarke had him in his room. It was entirely a failure, he certainly played at cards with his eyes blindfolded but that is not conclusive; but in not one instance could he read words written aside, and put into boxes, which lie professed to loc able to do.

Will you be so kind as to let me know on what days Warwick Castle is visible as Mr. Hallan spends a day next week over Warwick, Coventry and Kenilwortl, not Leamington. If you have any thin guide book to those places which might loe sent casily by post I shouk be much ol,liged if you would send it to me, as I want to do everything ohliging for the "Antik Vogel." Fnma will explain.

\section{Your affectionate son,}

F. G.

[P.S.] Dear Emma, She is sweeter than cver. F. G.

We know that Francis was in Cimbridge on May 13, probably June, July and August were the extent of his stay in London and the limit of his medicil studies at St George's. His address seems to have

1 It may comfort some of my reader's to know that Francis Galton thrice wrote this name and erossed it out, beforc he reached the above spelling. 
been 16 King's Street, Covent Garden'. Francis Galton had many friends ahout him in London; the friendship with the Hathons had strengthened since the Gernan visit. Ennma Galton was staying with the Gurneys in St James Square in February, and hat visited the British Musenm with Mr and Miss Hallan, meeting there Miss Edgeworth, Samuel Rogers and Maeintush, and in July of 1845, she was staying at Nailsen with the Hallams. 'Tertius and Violetta Galton were in London in February and calling on the Hallans. But the friendship of Francis Galton and Henry Hallan seems to have ripened nost in the latter part of 1844 and in 1846, from which years several very affectionate letters from Hallam to Galton have surviverl, to which some reference will be made in the following chapter.

Very tender are the letters from Tertius to his son Francis during the last nine months of his life. He was clearly very anxious that Francis should concentrate himself on medicine and should follow a definite profession in life. Nor does he fail to remind him of family claims.

"I hope you will go to Shrewsbury at Easter as you ought to see Uncle Bob before he dies"--is the prompting that comes from home before the Easter visit (see p. 186), which had doubtless bcen scveral times postponed.

On Feb. 4th, 1844, T'ertius writes:

"As Bessy has no doubt given you nuch salutary advice as to exclusive atcention to medieine, I forbear repeating to you all that Horner said to me on the importance of it to success in London practice as founded upon his own observation and the remarks of many leading medieal men of his aequaintance."

And again on March 9th :

"I am extremely glad that you take so fondly to your profession upon every accuunt, as an occupation useful to yourself and to others, and as a souree of pecuniary indepenclence, which, after all, it is among the number of our duties to promote......I admire your courage in taking the pledge, and your motives for it, and am glad that the plan agrees with you. Adèle tells me that in your easc unlike that of the gin-drinking lady, resolution was rewarded beforeliand."

Emma Galton, writing on March 4 of the failing health of her father, T'ertius, says, "My father has said over and over again 'Give

1 A letter from Tertius Galton to Franeis, dated June 30, 1844, and enelosing the last Cambridge College bill is thus addressed. Tertius speaks of himsclf as still weak and restless. 
my affectionate love to my dear Francis!."' There can be little doubt that Francis was his Benjamin, and when on September 9 Tertius goes to St Leonards in the hope that a change of air may effect some good, Francis was chosen as his companion and nurse. 'The picture of father and son together in the last few weeks of the former's life has been preserved for us in the letters of 'Tertius to his home circle. They went by way of T'unbridge Wells, whence 'T'ertius writes to his daughter Emma of a drive round the rocks with Francis. From St Leonards we hear:

Francis has sketched a little. He is an excellent travelling Plysician and does not buckle on the muzzle too tightly as he used to do. You know my detestation of being valetted, so when John eomes in the morning for orders, I. tell him to make himself scarce; he employs much of his timo in fossil-hunting and for ought I know the rest of it in taking private lessons in the Polka to qualify him for dancing with Buswell and the rest of the maids on his return.

I have not heard from Claverdon or of Mrs Cameron. I hope tomorrow's post will bring me a letter. I am getting wonderfully stronger and can climb liills à la chamois. If it were not for the dread of Hodgson blowing me up, I should plunge into the seabut Prudenee and gout dictate that 1 should remain altogetler a terrestrial animal. Franeis sends his love.

$$
\text { Your affectionate Father, }
$$

\section{S. Tertius Galtox.}

Give my kind regards to Mr and Mrs Gurney [Lmma was at St James Square]...... We are just returned from the aforesaid Meliboeus [Fairlight Glen trip], but eould not quite distinguish Louis Philippe on the other side of the Channel.

\section{A few days later Tertius writes cheerfully again :}

"I'le sea air has done wonders with me and tells every day-so do not be surprised if you see my name in the paper's as liaving gained a prize at a cricket match. Francis and myself have an oecasional game at ehess, but have not yet put the pack of cards into requisition."

These last weeks of affectionate intercourse remained a life-long memory to the son. When 65 years later he received the Copley Medal of the Royal Society, his first thought was how the news would have delighted his father. It seemed a justification for deserting a profession his father had chosen for hin.

From the date of these letters onwards 'Tertius' health failed rapidly. On September 30 Enma Galton joined her father and

"Emma Galton writes again: "It would please lim very much, if in a day or two ...you would write him an affectionate letter...a letter from you is as good as a dozen draughts." 
brother. On October 9 the party moved to 57 Marina, where Mrs Galton and her daughter Bessy joined them. A fortnight afterwards (October 23) Tertius Galton died, and to Francis Galton foll the melancholy task of accompanying his father's coffin to Claverdon, where the funeral took place on October 31. Bessy, writing to her aunt Hubert Galton soon after her father's death, says :

"Yet none but his children can know what a daily, what an hourly loss lie is to them. All our occupations and pleasures were so connceted with him, that cverything now scens a blank and it will be a very long time before we shall cease to be constantly reminded of hin in everything we do."

Such losses leave always a deep impress on our feelings, and often a still deeper impress on our careers, but as in the case of the death of Samuel Galton the loss meant a shifting of responsibilities and the members of the younger generation stood free to follow their individual bents. Some changes bearing on Francis Galton's future life must here be noted. The home at No. 29 Lansdowne Place was given up; Mrs Galton went in the May of the following year to live at Claverdon. On May 13 Adèle Galton, "Sister Delly," was married to the Rev. Robert Shirley Bunbury, only to be left a widow in the following year with one child, Millicent, afterwards Mrs Lethbridge, Francis Galton's much loved niece. On December 31, Elizabeth Galton, "Sister Bessy," was married to Mr Edward Wheler, and on November 13, 1845, Emma Galton started on extensive French, Italian and German travels which lasted till June 5, 1846. She was again abroad from May to November of 1847, thus illustrating the hereditary Galton Wanderlust. The independence that had come to each member of the family with the death of Tertius influenced not less the life of Francis. There can be little doubt that had Tertius lived Francis would have followed the strong desire of his father and would have had a profession in life ${ }^{2}$. To those at that time viewing his actions, there must have been some hesitation in judgment; the next five or six years were to be spent without definite object, apparently in the pursuit of rather idle pleasures,

${ }^{1}$ Bessy Galton writes emphasizing the gravity of ber father's illness in 1844. "He rcgrets not hearing from you so do, dearest Francis, write immediately a nice steady letter telling him what you are studying etc., and talk of your profession with pleasure, it would do him more good than anything, and make a point of writing at least once a fortnight." The home letters to Francis Galton show how kecn Tertius Galton was that his son should follow a definite profession, and how anxious the family circle had become about lis roving tendencies - both in space and in mind.

P. G. 
and those who loved the open-hearted joyous youth best must have felt, if they did not give expression to the feeling, that the loss of his father was an irreparable loss, which had spoilt Galton's career. Knowing what we now do of Galton's later work, we can see that this period of freedom may not have been wholly without value. Yet we may wonder whether had his medical education been completed and the freedom come later, Galton might not have entered on his life-work with somewhat more knowledge and with even greater insight into its scope and the possibilities of his mission to his fellow-men.

It would be difficult to sum up the balance of good and ill which flowed to Galton from his Cambridge career. He went to Cambridge keen to observe and measure, full of the creative, inventive, contriving spirit. In these directions Cambridge gave him little or nothing. The mathematical tripos was the only door to an honours degree, and he never passed fully through the analysis, which should have led him to the physical branches, where he would have profited most highly. Even there he would have met theory alone-no observation and no experiment. Hopkins and Cayley were not the teachers for a man like Galton-such a man would have developed rapidly under a Franz Neumann, a Helmholtz, or a Kelvin. As it was his thoughts turned largely into other channels than the routine work of mathematical honours. He became a centre of much social life, of literary ambitions and of varied and somewhat scattered purposes. I do not think that we can fairly say that the competitive work for the mathematical tripos was the sole source of Francis Galton's breakdown at Cambridge. It had largely to do with his mathematical studies, but it was the impossible attempt to combine those studies with a very wide range of other interests and occupations, which finally led to his academic failure. The men with whom Galton associated, the Kays, Buxton, Johnson, Hallam, and Maine were not men of one interest or a single idea. Galton, as well as his friends, strived to cram too much into the brief years of undergraduateship-hard work, hard play, late hours and conviviality all told:- the renunciation of honours, the eager return to medical studies, the pledge in the last year of college life, were not isolated factors, but symptoms of a growing restlessness, not one thing alone accounted for his breakdown. He tried too much and he failed. Cambridge had not given him the training he needed, it did not bring him in touch with the helpful older mind, that it 
provided for his cousin Charles Darwin, but it stirred an already too active mind intensely, and brought it into touch with many young, keen and sympathetic spirits. The long period of fallow years which followed Galton's Cambridge career, was partly due to a mind recovering from overstrain, partly natural in a youth to whom pleasure was possible, but who had not yet measured its insufficiency. We have so little evidence bearing on Galton's mental evolution during the next six years of his life, that we can but speculate on what those years did for' him, and what might have bcen, had school and college training been individualised. The "Sturn- und Drang Periode" of our lives are claimed by Alma Mater, and she ever afterwards is glorified in our minds by their enchantments, but it is possible that the child gives more than the mother, and that the more brilliant her children, the less she regards their individual needs. Why should she make so little attempt to chart the course, which would lead the adventurous mind to those fragrant isles, whose enticing scents ever summon it, luring but illusive, across a barren sea? Why is the personal influence of the older on the younger mind, the unwritten experience, which lies so far above all regular tutelage, and which the sympathetic mastermariner alone can give to the apprentice hand, so rare an item in the debt her more famous children bear to Alma Mater? Is it due to the want of a thought-out system of education, to the want of the right men, or to an inherent principle in human nature which asserts that real 'education' is only attained during the solitary cruise " by chartless reef and channel"?

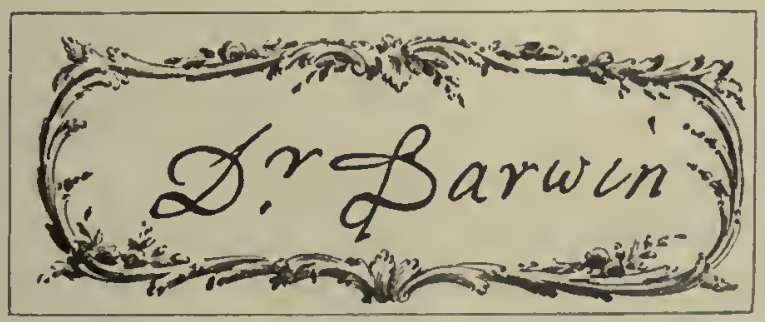

Visiting Card of Dr Erasmus Darwin. 


\section{CHAPTER VI}

FALLOW YEARS, 1844-1849

ON October 23rd, 1844, Tertius Galton had died. Francis Galton returned to town and took rooms at 105 Park Street in association with W. F. Gibbs, who afterwards became tutor to Edward VII when he was Prince of Wales, and with H. Vaughan Johnson, who had lived on the same staircase with Galton at 'Trinity, a man whom Galton describes as singularly attractive and with quaint turns of thought. But we have no letters of these years to guide us; the letters to his father of course ceased; the letters to his mother and sisters have perished, and even the letters of his sisters to him, which would have given clues to what Galton was thinking and doing-letters which Galton included in an index to his papers made late in life-have been destroyed before his papers reached the hands of his biographer. We have no evidence of what this young man of twenty-three, with ample means and intensely vigorous mind and body, was either doing or thinking, reading or observing. Yet we can be certain that in these fallow years, when nothing was published, nothing even written that has remained, there was much ferment and much change. Francis ceased any longer to be "little Francis," the controlled of older brother's and sisters. His desertion of medicine, a profession, hereditary on the maternal side and ardently desired for him by his father,- -his gradual change from orthodoxy towards agnosticism, were probably disapproved by his family; his brothers and sisters were settling down to their own individual lives and in more than one case their ideals were not his ideals. As Galton himself expresses it: "I was therefore fiee, and I eagerly desired a complete change; besides I had many 'wild oats' yet to sow."

1 Memories of my Life, p. 85. 
Not a single letter is available, not a record of the winter $1844-5$ in Park Lane; but in the later part of 1845, the Red Guds' call reached Galton, the spring-fret was on him ${ }^{2}$ :

Velvet-footed, who shall guide them to their goal?

Unto each the voice and vision: unto eacl his spoor and sign-

Lonely mountain in the Northland, misty sweat-bath 'neath the LineAnd to each a man that knows lis naked soul!

Let him go-go-go away from here!

On the other side the worlds he's overdue.

'Send your road is clear before you when the old Spring-fret comes o'er you

And the Red Gods call for you!

The Red Gods called, but for Galton the road was not clear before him, not for another five years did he know his soul! Galton's visits to Egypt and later to Syria were aimless, they were the restless visits of the well-to-do young man, seeking travel-pleasure in the routine way, without scientific object and without archaeological or linguistic knowledge. Yet there were epochs in them-as the meeting with Arnaud and the death of the faithful Ali-which influenced Galton permanently. Above all he gained two experiences-first that mere travel without aim does not give the highest pleasure, and secondly that travelling is itself an art.and needs training-training in what to take and what to observe, training in how to meet and how to handle men. Think only of the Galton, the boy of 23 years, who set off to Khartoum without a map and without purpose, and who in Syria wished to sail down the Jordall on a raft based on inflated waterskins without thought of current or season of the year-think of these things, and then of the cautious preparation, the thought-out purpose of the African journey of six years later by one who after six fallow years had become a man in bearing and in power of achievement!

The young medical student of the Birminghan General Hospital and the fieshman at Cambridge impress us with the power of observation and the capacity for action. 'The last year at Cambridge, the year in Egypt and Syria, the years to come of social life, hunting and shooting, bring before us another aspect of a many-sided nature, which had under the influence of the "spring-fiet" to test many things before it knew its "naked soul." As Galton himself has said, there were

"Rudyard Kipling: "The Feet of the Young Mcn" in The Five Nations. 
"many wild oats yet to sow." Yet in the sowing of them a transformation took place from the pleasure-seeking boy of unformed character controlled by any of many inherited tendencies, to the purposeful man seeking to extend human knowledge and with a character inoulded firmly to opinions, which changed relatively little during the remainder of life. How sad it seems that all power of tracing the transformation of these fallow years has perished with the letter's from and to him of this period!

The account Francis Galton has provided in his Memories of the travel in Egypt and Syria was written in 1908. It is more elaborated than the few simple notes he put together in 1885 , twenty-three years earlier, of the same journeyings. In Chapter VI of the Memories Galton gives no date to his departure for Egypt. In the account of 1885, he states that he "started for the East in September (I think) 1845." But there is in existence a playful letter from his friend Henry Hallam, dated Wraxall Lodge, Thursday, October 3rd, without year. The contents of this letter seem to indicate that Galton had asked Hallam to accompany him to Egypt, and if this be so, Galton did not start till somewhere near the anniversary of his father's death ${ }^{1}$, and thus we have lost the record of one whole year of his life. The letter from Hallam runs :

My dear Galton,--I have becn deliberating since I received your letter on the desirability of joining you, and though finally overcome by the prospect of minor and highly conventional difficulties relating to degrces and other matters equally contemptiblc, I envy you exceedingly. The pleasure of shooting at so large a mark as a hippopotamus of respectable size is peculiarly attractive to the mind of the infant sportsman, who like mysclf has been vainly endeavouring to rid creation of an orthodox number of partridges during the last month. I trust, however, that the terror of my arms is beginning to be spread in the neighbourhood, as I have been given to understand that a number of highly respectable pheasants, the fathers of families whose custom it has becn for many years to insure their lives on the first of October have this year been either totally refused or accepted only on the payment of such an extravagant sum by their respective offices as must obviously lave reference to the introduction of some new element into the sporting world to which it would be indelicate in me to refer more closely. Still, as I said, I gasp after the blood of Pachydermata, and under proper encouragement would direct my artillery with great hope of success against any inoffensive animal of large size, and easily vulnerable whom I might find sitting on the banks of the Nile.

1 It may be doubted whether the legal business of winding up an estate like that of 'Tertius Galton could be completed much under a year. 
Duty, however, calls on me to be serious. It is incumbent on me to point ont the vast moral responsibility you incur, to warn you of the irretrievable disgrace in which all your friends will hold you, if when you are fairly eonmitted to the pellueid strenns and bracing atmospliere of an Egyptian river you stop short of penetrating to the Court of the Negus and reposing for awhile under the shadow of the Asylum of the Universe. If you will follow my adviee you will go right ahead till you reach the Mountains of the Moon, then taking the first turning to the riglit eontinue your course until you find it necessary to ask your way; by which means you may immortalise yourself by the discovery of the great Central Sca, and by whieh time I hope to be able to join you there or anywhere else.

As you are anxious to lave your dignity supported at foreign courts you may rely on a handsome case of briekbats with "Robert Peel " or "By Her Majesty's command," "From the East India Company, private" etc., addressed to you at every largo town, postage of course not paid. Are you going before the end of "next week? On Friday the 10th or Monday the 13th at latest I shall make ny transit over the London disk, and will attempt to find you, if possible. I am sorry you never came into this part of the country as we should have been deliglited by a visit. I an grown trenendously agricultural, and intend to come out strongly on the Potato disease next term. Yonrs most sincerely, H. T. HALLA I.

One wonders how the Egyptian and Syrian journeys woukl have worked out had Galton had Henry Hallam for his comrade. As it was Galton started alone. In the following memorandum we see how forty years later he described the events of those days:

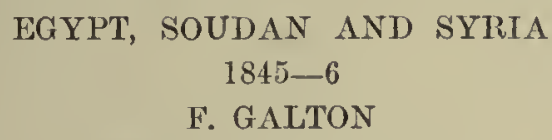

written from memory 1885 .

After my Father's death, October 1844, finding I had a competent fortune and lating the idea of practising medicine, also being disheartcned by the sense that the medical knowledge to which $I$ had access was very lax and that its progress scemed barred-I don't do justice I know to the state of the case, but only describe my foclings fresh from the rigorous methods of proof.at Cambridge-that I determined to give it up. My passion was for movement and travel and I ultimately starterl for the East in September (I think $\left.{ }^{1}\right)$, 1845. On going by diligence south from Paris, I found myself with Denham Cookes as a companion. He was charming and full of aneedote and fun; we travelled together to Avignon, where we stayed some days and there I left him. He was killed at a steeplechase in Florence soon after. Stopped at Malta where Temple Frere was with his Uncle Hookliam Frere? ${ }^{2}$. On reaching Alexandria, (or was it

1 From what has been said above this is probably incorrect and the middle or latter laalf of October more likely.

2 In his Memories, Galton regrets not having, owing to Frere's ill-health, been able to talk to the wan whose Loves of the Triangles had given the "coup de grace to the turgid poctry that had bccouve a temporary craze in my grandfather's time" (p. 85). 
en route after Malta?) I met with Montagu Boulton and his travelling companion, Hedworth Barclay, intending to go up the Nile; they having just toured in Greece. We went together to Cairo in barges, towed up the Nile by a tug--a most luxurious and eharming night. $\Lambda$ t Cairo we three agreed to make a party together up the Nile. Barclay had a eourier, a Greek, Christo, who would act as cook. Boulton had a very sinart courier, Evard by namc, who had been once groom of the chamber, he said, to Lady Jersey. He would be butler and I undertook to engage a dragoman as my special servant and he was Ali (Mohammed,- Sureyal = the little).

We spent one day boar shooting, got no boar but wounded one and when among the tall reeds holding my gun vertically above my head, as tho only chance of making way, a litter of wild pigss ram through at my very feet. I was quite helpless, could not get down my arms, but the sow did not pass me. Wo had to give a name to our boat and register it with its flag, and Boulton suggested an Ibis with the notto "Tutissimus," whieh we adopted. Barclay had a pointer for quail shooting. My impressions of the Nile were those that so many have expressed. Especially the pleasure of living all day barefoot and only half chessed, and of waking oneself by a header into the river, clambering back by the rudder. We lived in style and state. I think the awfulness of the Old Tcinples impressed me most at Carnac, going among them alone by moonlight and the silence broken rarely by the jackal. The feeling was so strong that it nearly made me faint away. A little above the first cataract, when near Korosko, the stream being swift, we went as usual by virtue of Barclay's firman to impress men to tug our boat, but found they had all been already impressed by the owner of a small and dirty looking Egyptian boat, who they told us was a Bey. We went to him and spoke impudently, like arrogant Britishers and diseussed loudly in English together whether we should not pitch him into the river. He shortly astonished us by speaking perfect Freneh and after a while cliscovered he was a much more interesting person than we had dreant of. He was Arnaud, a St Sinonian exile, in service of Mehemet Ali, who had lately returned from Sennaar where he had been sent to look for gold. He invited us to lis mud house, at which I was charmed. Perfectly simple, clean, matted, with a barometer and thermometer hung up and other scientifie gear, books, ive., like a native philosopher. He then, after we had become friends, explained to us, that though he spoke English badly, lie quite understood what we had said among ourselves when we first met him and made me feel very small indeed. However, we got on very well and made him talk of his travels and tell us of the country ahead, we had then no map and knew nothing hardly. He said : "Why do you follow the English routine of just going to the 2nd cataract and returning? Cross the desert and go to Khartoum." That sentence was at division of the ways in my subsequent life. We caught at the idea, he diseussed it and said that the chicf of the Korosko desert was then actually at the place with camels, that he knew lim and would send for him to us that afternoon or evening, when we might finally settlc matters. We asked Arnaud to dinner, received him in the grand style, Evard doing his best, and gave our good friend and ourselves quite as much wine as was good for us. When in the midst of the carouse the door of the cabin opcned, the cool air cane in, and with the cool air, the dignified eold presence of the Sheikh, with the band of sand on his forehead, the mark of his having just prostrated himself in prayer. He did look disgusted, but we got over him and finally all was arranged. We were to start the 
very next afternoon. We settled to lave the bont, her captain and crew under the charge of Bob, our Arab pipe boy, as our representative, who rose easily to the position and they had orders to take the boat to Wadi Halfa and await us therc. This was in mid January, we expected to return, as we did, early in Mareh. We got off on camol back in the afternoon and encamped 3 miles from Korosko and next morning started fairly off. It was a desert, like the skeleton of the earth, with sand blown clean away from the bare stones, or lying here and there in drifts, table topped hills. Fvard had some sort of eruptive fever and was frightfully depressed and lamenting, then Boulton got it and bore bravely up. It was hard lines for them. The water 4 days from Korosko, the only wells on the route, was braek and undrinkable; that in our water skins was horrible with the taste of leather. The waste of desert was terrible, and the way was marked hy bones of slaves and eamels. Often a dead camel was desiecated; it looked fairly right but when touehed broke and erumbled into dust, all the inside was blown away, or eaten away by the ants leaving the skin and part of the bones. These desieeated bodies were so light, that I onee held up what appenred to be half a camel when first seen and as it lay untouched. Our guide, a son or nephew of the Great Sheikh, was a jovial gay fellow and we all beeame excellent friends. Others joined our caravan ; a man, his wife, baby and donkey, just like Joseph's flight. Also another man on foot, with no possessions but an old French cuirassier sword, wherewith he was going to join slave raids in Abyssinia. In 8 days from Korosko, we reached Abu Hamed-the sight of the Nile most refreshing, but we soon tired of the midges and air, and were glad to travel on a little inland by eamel to Berber. On the way we stopped at the 5th cataract, where we waded with our guns across the river anong the many islands. At Berber the Pasha received us in state and gave us lemonado from his own limes and it seemed delightful. He also lodged us in a mud house and gave us permission to hire a boat for Khartoum. The people were troublesone when we tried to start, and seized the rope and wanted to detain us. Barclay behaved with much pluck, cast off the rope and made the 2 or 3 men who were on board hoist the sail. We got away and after a little, the rest of the crew ran along the bank and swam to us, and we got off. It was quite a small one-masted boat, cabin 4 feet high, cockroaches all about but we made shift well enough. I recollect little of the sail to Khartoum, except the mud pyramids of Meroë by the way. At Khartoum wo got (I suppose through the captain of our boat) a mud house facing the Blue Nile aeross whieh the dust columns were seen in numbers dancing on the plain. We heard of the existence of a wonderful Frank, possibly an Inglese; so we went to see. We knocked and walked in and there was about the most magnificent physique of a man $I$ have ever seen, half-dressed in Arnaout costume, looking quite wild, and he turned out to be Mansfield Parkyns recently arrived there after years in Abyssinia. He had been at Trinity College as well as ourselves and having taken part in an awkward row, found it best to leave, and had travelled ever since. He put us in the way of all the "life" in Kliartoum and introduced us to the greatest scoundrels I think, that could be found anywhere in a room, men who were too rascally for the Levant or even Cairo. They were slavedealers, outlaws and I know not what else. Full of stories about how $A$ had been poisoned by $B, B$ having just left the room before the story was told ice. Parkyns with perfect sang-froid and with all his wits well about

P. (i. 
him, held his own unscathed in this blaekguard Bohemia, not a bit sullied by it and mueh amised. We arrangerl with our Captain to take us all together a little way up the Nile. We could not spare time for more than a very few days. So up we went. The mournful character of the big, slow, marsh-like cxpanse of river was very depressing. The air was heavy and seemed to be pestiferous and I was heartily glad to get away from it. The hippopotami were in great numbers, I blazed at 40 different ones (at absurd distanees though) in one day. Boulton went out one night with Parkyns and shot a poor eow by mistake for one. There was no pereeptible current in the river, the offal and eook's messes that were thrown overbourd each night when the boat anehored, hung about her all night and were still there in the morning, so that we had to send a man wading to a distance to fetch clean water. The river lapped over the sloping banks like a flood over a meadow. There were vast flights of flaningoes, \&c. and the aspect of the river was weird and strangely inclancholy. We turned baek short of the Shilluk country, and returning to Khartoum, where wc dropped Parkyns, sailed on to Meteinneh. There we engaged camels to cross the Bayuda desert. It hardly ranks as a desert as there are many watering plaees, we only took 2 or 3 days rations of water with us and travelled 14 and even 16 hours a day. I started equipped in native dress, just a white cloth wrapped round with arm and shoulder bare. The effect was I got fearfully blistered by the sun, all my baek and arm was covered with minute blisters side by side. It was fearfully painful at night for some days. We travelled late into the night and the tail of the great bear was the index of our 24 hour cloek. We met Prince Pukler Muskaw (? spelling) by the way. I saw nothing of any wells, for wc camped at night away from them and the camel nen fetched the water. The ground had not at all the utter desert look of the Korosko. Rain falls there pcriodically and there are plenty of shabby mimosa trees. We were 6 days in getting to Meraweh. There we stopped a few days wondering at the white ants. Everything had to be laid on "angarebi," frames with

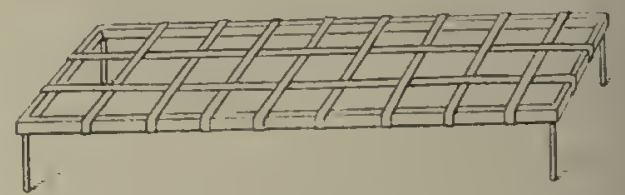

strips of hide aeross, and on legs, otherwise the white ants got at them. I went up Jebel Barkal bare-footed as a bravado, and the sharp edges of the sehist like rocks severely puuished my feet. There I got the vase, with what I now know was the representative of the God Bess upon it (given to the British Museum). From Meraweh we went a short 3 days ride aeross the desert to New Dongola where the Pasha was a mueh grander person than any hitherto seen. He had a review in our honor and mounted us on thoroughbred ponies with their queer Arab seats with the eruel curbs. We all made a great mess of our riding with so unusual a seat, and if we touched the curb up went the plaguy ponies' heads, who were always at a gallop or a sudden stop. The Pasha gave a monkey, to add to the two I had got at Berber and which were my constant companions in travel sitting on the camel with me or if not, with someone else. From Dongola we rode along the left bank of the Nile to Wadi Halfa, passing that wonderful Semneh. The Nile was then low and ran in a sluice between two low roeky banks that are under water at other times. It was so narrow that we thought we night throw a stone across it and tried liard to do so, but filied, some 
throws (not mine for I can't throw a bit) nearly succeding. The river whenever we looked down upon it during our joumey seemed totally umavignblc, scething annong jutting rocks that were thickly set in its bed. At Wadi Halfa to our joy, wo found our boat all right and Bob lording it with undisputed sway. He had actually orderecl the Captain to be flogged for some offence, and the men obeyed Bob and flogged the Captain accordingly. Such a difference between the Berbers and the Egyptians. You can not strike a Berber but may flog as many Egyptians and beat them with sticks as mueh as you likc, they are thoroughly slavish.

The voyage back, though March, became unpleasant from the Khamsin wind. It was uneventful except in the usual Nile expcriences, at Cairo we hired a house in one of the quartcrs of the town with a big wooden key and liverl there a week, conforming of course to the native ways of being in-doors by a specified and not late hour. Finally we scparated-Barclay returned straight to England, Boulton by the short desert to Syria and I not being particularly well, by steamer to Beyrout. The awakening in the early norning when sailing along the shores of Syria and seeing the Holy Land for the first time, is one of the living pietures in my memory. Here my menory fails me. I was somehow in quarantine at $\mathrm{Akka}$ and made great friends with the Pasha therc.-On the other hand I faney I went straight to Beyrout. Such a change from Egypt. The people seemed so much less sedate and disagreeably go-ahcad, and the verdure and hill slopes were so great a novelty to the eye. I lived rather stylishly, bought 2 good horses and a pony and jobbed a native groom, Ali remaining as my personal scrvant. Furnished with introductions from my Akka friend, I stayer a night with the great Druse ehief in his stronghold, who fêted me with distinetion believing evidently that I was a much greater personage than I was, which rendered the stay embarrassing. I went to Damascus and boarded in the house of the English Doctor ('Thompson) thenee as the heat was inereasing I moved to Salahieh, when I took a house and set up an establishment in which figured my two Soudan monkeys and a pet iehneumon. I lived a very oriental life and became a fairly fluent talker in common Arabic, thougl nothing of a scholar; in faet, I am ashamed to say, I never read it or even deeiphered it fluently. It was before I went to Salahieh and while still in Dr Thompson's house that faithful Ali was seized with dysentery. After an evening of parched skin and low delirium he died with iny money belt, that was under his charge still round his body. We had the washers in and all the Moslem ceremonial duly attended to and I followed him to his grave, standing of eourse far off so as not to pollute. It was a great and serious loss. I was sincerely attached to him and eondoned willingly heaps of small faults in regard to his great merits. One cold night in the desert when he and I were both chilled through, he pushed over me his rug. I did not know it till morning. I got many rides from Salahieh and spent many pleasant afternoon hours in Arab caffées sitting by the flowing waters. Colonel Churehill lived with much display near by, with his Syrian wife and I had a pleasant stay there. Finally, when the summer heats had passed I went to Lebanon and stayed a week with the Sheikh of Aden, a riglt good fellow. The first morning I counted 97 flea bites on the right lower arm and up a little way above the elbow. There were Druse rows going on while I was there and we had to stand a bricf attack, shots being fired and the house temporarily barricaded. Going thence to Tripoli I saw the most beautiful view on which my eycs have ever rested. It was of the 
Mediterranean through a gorge. At 'I'ripoli I did a foolish thing, viz. slept in the low marshy laud and caught an ague that plagued me until $I$ wholly lost it in 1851 in Africa. Riding along the shore towards Beyrout I met Boulton-a joyous meeting. We crossed and parted and I never saw him again. He went eastwards and finally being an onlooker at the siege of Mooltan, with General Whish, took up a post of observation through a loophole in a deserted turret and when there a matchlock ball passed through his eye and brain. He was singularly gifted and amiable; an epicurean in disposition, that is to say a philosophical pleasurc seeker and of sterling merit. At Beyrout I fou ud my groom and horses had got into scrapes and I sold the latter. Being unwell with ague I felt unable then to ride to Jerusalem, so I took a place in a common collicr sailing to Jaffr, making myself supremely eomfortable with rugs \&c., on a eleaned corner of the deck. At Jaffa I found baggage camels and in defiance of usage rode one into Jerusalem. The time when the Akka episode occurred and my stay in Mount Carmel has quite escaped me. It was there that $\mathrm{Mr}$ - 's baby died and I performed some share in christening it just before its death. Also a Jesuit priest (as I bclieve) got hold of me and took great pains to convert me. Also I had a scramble at night to find, as I ultimately did, a wretched piece of humanity, a converted Jew, who had wandered about the hill and contrived to get himself into grief and lost himself and was become rather desperate when found. At Jerusalem I planned an expedition, eommon enough now but then quitc uew, with one fatal exception of a year or two previous namely, to follow the valley of the Jordan all the way from Tiberias to the Dead Sea. Until Costagan's time (brother' of Mrs Bradshaw of Leamington) from that of the Crusader, I believe there was no record of a Christian having attempted the journey owing to the wars of the tribes and the impossibility of getting safely from cach to its neighbour. But a time of peaec had set in and I availed myself of it. The plan was to get water skins at Jerusalem, take them on horseback to Tiberias inflate and make a raft of them and on it to float down the Jordan. Starting from Jerusalem escorted with spcarmen and all mounted, including my native cook and I think one or two others, we ultimately slept at ........... overlooking the valley of the Jordan, half way along its course (there was a row at night and some of the horses tails were cut off in derision by the attackers) thenee I descended to the valley and rode up to Tiberias. After a few days stay I started back, rigged out my raft just below the bridge where the Jordan issues from the lake, to the great amusement of the escort, who had orders to ride by the side, and off I floatcd, the stream was far too narrow and I got capsized twiee. Theu came a more serious nisadventure for the current swirled in a narrow channel under overhanging boughs nearly touching the water and I was knocked off and got into difficulties. I soon saw that the raft projeet was not feasible at that season and took again to my horse. It was really a picturesque group. I had to ride in Arab head dress with a fillet and my men with their clump of long spcars with ostrieh feathers at the top looked very well indeed. After a while we came to a great Arab eneampment, that of the Euir Ruabah whose sister, a relative of some kind of my own escortcr, Sheikh Nair Abu Nasheer (of Jericho or thereabouts) had married. He was civil but wary and punctilious, and wherever I went I was watched. He had a quantity of old chain armour, beautiful Saraeenic coats of mail. It was a somewhat uneasy visit to me and I was glad to be off. We finally got to Jericho and thence to Jerusalem, I making various plans with my Sheikh 
for bringing a boat from Jaffa and with his permission navigating the Dead Sea, as Costagan had done, but poor fellow he had died in the aet. On returning to Jerusalem I found letters urging me to return home prineipally on aceount of some trust business for Iny sister Adèle. I went, hardly thinking it was a final parting witlı Syria, but so it was and the next year Lyneh the Ameriean eame, subsidized my Sheikh, surveyed the Jordan and Dead Sea very thoroughly and published the results in a big and valuable book, which by the way does not eontain a word of allusion to mysclf, his predeeessor.

Francis Galton.

A perusal of this sketch of Galton's tours in Egypt and Syria will indicate to the reader that the $W$ anderlust, lowever keen, had not yet ripened into the desire for scientific travel. Galton was still touring for the boyish fun of movement and of new scenes. He had not yet thoughts of the language, habits or archaeology of the people he mingled with. It was, as far as we can judge, still possible for him to settle down as a sporting country gentleman after finishing the somewhat extended "grand tour" of the day. The significant inciclents of the Egyptian and Syrian tour, which seem most markedly to have weighed with him in after life, were the meeting with Arnaud-of which he wrote that his words were "a division of the ways in my subsequent life "-the incident with the Sheikh on the same day", and the death of the faithful Ali. Galton reached England in November; 1846. One longs for the graphic letters of the earlier tours, or still better for a sample of such as came later from Africa, but none have survived. The following letter addressed to Beyrout shows that Galton must have been in continuous correspondence with some of his Cambridge friends :

\section{Wilton Crescent, June 24, 1846.}

MY Dear Galton,-Your letter was such an enormons time renehing me that if this be similarly long in arriving at its destination, I entertain serious doubts as to your getting it, partieularly as I have been lazy and have put off writing till the day before I start for Ostend, amidst the infinite lurries of paeking. I own I ought to have written or brickbatted earlier but Kay positively told me that it was useless as you never acknowledged his, and that he did not know where to direet. Your letter is a great work of art, worthy to be ranked with the most ingenious productions of modern times; of course I don't believe it, and am inelined to think you have been all the time in 105 Park St eoneealed, and examining the map of Afriea. If I really eould put my

1 " The eabin reeked with the smells of the recent earouse, when the door opened and there stood the tall Sheikh marked with sand on his forehead that indicuted recent prostration in prayer. The pure moonlight flooded the Baeehanalian eabin, and the clear cool desert air poured in. I felt swinish in the presenee of his Moslem purity and inposing mien." Memories, p. 88. 
faith in what you tell mo I should look upon you as the real Carlylese hero, the "coming man" of whom Tooke used to talk at the Union, and I should prepare to fall down and kiss your slippers, or perform any amount of ritual observance. As it is, I waver in thinking you either destined to be the greatest man of your age, or as lhaving been the perpetrator of a gigantic hoax. So I give you conditional but unbounded adniration and I express humble but ardent gratitude for the monkey, on the hypothesis I fear a most improbable one, of the dear animal not turning out a monkey of the mind, a simious Harris, a bcautiful delusion, etc. If you have taken me in, it beats the fanous Campbell hoax, for proud in my confidence of your veracity, I have been ensnaring everyone at dinner, breakfast, evening party, man, woman or clild to commit themselves to an opinion on the sources of the Nile, when I have been fortbwitl down upon them with geographical facts, and lave by means of them tyrannised over sundry meek and respcetable membcrs of scientific societies. Whenever there is a pause in conversation I never fail to say in a calm manner "I liad a letter from Abyssinia the other day, very hot season at Dafour I believe," whereat the Horners, Murchisons, Sam Rogrers ctc. gape with respectful micn.

I suppose you want to know what is going on here (always on the supposition that you have not been daily to Silk Buckingham's Institute' to read the papers). In public matters, great things, corn laws repealed, ministers expected to go out in a weck; in Cambridge things very little; Evans got the University Scholarship; Lushington head of the Tripos, of course; your humble servant 9 th, a tremendous shave off the second class; however; fortune favoured me and I got the 2nd medal. Since this I have been three wecks at Paris, and a month reading at History. Tomorrow I start for the Rhine, Gencva, Venice and Milan-family party-alarm about cholera which the papers say is coming westward with great rapidity, and cases of death in London last week. If you have got Kay's letter you will have hearl that he published a volume costing 148 , nominally at the desire of the University, whereat Whewell waxed greatly indignant and had him "u before the Senate ${ }^{2}$. Campbell has nearly given up P.E. and now talks nothing but uncompromising Evangelicalism to the great annoyance of lis friencls. It is even becoming a matter of doubt whether the chief end of education is to impede population. But no doubt the perusal of the Poor Law articles in the "Times" will soon fan the dormant flame. My Paris trip was eminently successful, I went with Luslington, Mansfield and Bartwick, and for 3 weeks we ate the most glorious dinners in the world, at 18 francs a head, went 14 nights running to the play, and polished off sonie French evening parties, whereof my opinion is that they are eminently trumpesque. I take it for granted that you will come leisurely back through Italy, and therefore hope to catch a glimpse of you at Venice or Milan, monkey and all. I an afraid the amiable animal must be a source of considcrable inconvenience to you when you return to civilisation. I can fancy a few more comfortable positions than that of looking after an ape in a railway train! You had better pack him up in brown paper, cover lim (I believe her, I beg her pardon) with postage stamps and direct her to my gyp, or to Wilton Crescent,

' For James Silk Buckingham, see Dict. Nat. Biog.

2 Galton gives some account of Joseph Kay's book, The Education of the P'oor in England and Europe, 1846, written by the "Travelling Bachelor of the University of Cambridge" and bearding Whewell, in his Memories, pp. 68-9. 
where I trust every satisfaction will be afforded. I find of course on the eve of departure that all one's German lias vanished as usual, and I shall have to begin the old story again with Ollendorf, satisfying a morbid anxiety as to the hunger of the good baker's dog, etc. I shall expect lessons in 'Tigheree, and the scimitar excreise. Your giving uy mediculeizing is a great blow; who is henceforth to tell me pleasant storics about lupus, and purpuristic elephantiasis of the pia mater; you had much better not become a parson, but come with me to Maimachtin in 3 or 4 yeurs.

Ever most sincerely yours, H. F. HALLAM.

There is little doubt that Galton's view of life was indirectly widened by his residence among and friendship with Mohammedans. He had in later days a great respect and admiration for them; during his stay in Syria he conformed largely to their way of life and possibly, in a measure, to their religion'. Experience of another great religious faith, the devout followers of which compared in conduct at many points favourably with his own co-religionists, led Galton to a wider view of the origin and function of religion in general, and there is little doubt that from this period he ceased to be an orthodox Christian in the customary sense. Writing in 1869 (see Plate II), Galton says that " the Origin of Species formed a real crisis in my life; your book drove away the constraint of my old superstition, as if it had been a nightmare, and was the first to give me freedom of thought." I think this really means that Galton owed to Darwin a positive faith; his negative attitude towards the old views had arisen thirteen or fourteen years before the publication of The Origin, and had formed to some extent a division between Francis and the more orthodox members of his family. The first blow to orthodoxy came fiom the experience that more than one religion helped men efficiently in the conduct of life, and brought the ideal into closer touch with the actual as a controlling and purifying factor. Galton taught absolute toleration, both in religious belief and in formal observance; he was prepared for family prayers, if they aided anybody in his household, and he would have accepted a fetish, had he thought the fetish-worshipper thereby better able to face the moral difficulties of life; he had none of the intellectual hatred of Huxley or Clifford for what their minds recognised

'Bosworth Smith, who advanced the riew in 1874 that Mohammedanism was in some respects better suited than Christianity to the Oriental races and to the negro, writes to Galton in 1875 : "Your view of Islam as compared with Cliristianity would, I fancy, from what you said to me, be cven more favourable than minc." 
as unreasoning. Speaking on lis own initiative to the present writer about a friend who had then recently joined the Catholic Church, he said: "Yes, I think it will be a real help, a controlling factor in X's conduct," and then he added: "How impossible it would all be for you or me!" It appears to the writer that the recognition of the relativity of religion and its individual temperamental value was attained at this time, if a positive view of life which suited his own teinperament only came to Galton with the Origin of Species. Much light would doubtless have been thrown on this point had the Egyptian and Syrian letters been preserved. But the fact that they did contain evidence of Galton's religious developinent may be the very reason why they have wholly perished.

The years which succeeded Galton's return from Syria are a blank except for what he has himself told us in his Memories, Chapter virr. The four years in question, he himself entitled "Hunting and Shooting." He writes :

"I returned to my mother and sister, who then occupied claverdon, much in need of a little rest. I was also conscious that with all my varied experiences, I was ignorant of the very $\mathrm{ABC}$ of the life of an English eountry gentleman, such as most of the friends of my family had been familiar with from childhood. I was totally unused to hunting, and I had no proper experience of shooting. This deficiency was remedied during the next three or four years" (Memories, 1'. 110).

We find Galton for the following three years spending part of his time in Leamington, hunting with a set chiefly noteworthy for their extravagance and recklessness; part of his time on Scottish moors, shooting grouse, or sailing in the Hebrides, and lastly part of his time -which amounted to weeks and months-in London, walking and riding with friends or attending meets of the Royal Stag Hounds. A few letters of Henry Hallam, spared apparently from the holocaust, indicate the thoughts most prominent in the minds of both young men-their ambition was to shoot 100 brace in a day, to kill 87 hares in a quarter of an hour, to avoid the tailor-like habit of putting a bullet into the haunch of a stag; the most provoking thing was to fail in a shot,-- "I would have given my eyes to have brought the animal down." Landseer was not the man and the artist, but "the crackshot never missing and quite up to all the dodges of the sport; he had got and shot and killed his animal very neatly." The shooting experience was undoubtedly of value to Galton in his later 
African work, but the strange thing is that it seemed to absorb his whole nature, and to be done not for the sake of the experience, but in the pure pursuit of occupation. He tells us himself that he "read a good deal all the time, and digested what I read by much thinking about it" (Memories, p. 119). But Galton was never a great student of other men's writings; he was never an accumulator like his cousin Charles Darwin; and the most well-read and annotated books in his library certainly belong to a later date and to periods of definite lines of research. Perhaps the words which follow the above quotation, "It has always been my unwholesome way of work to brood much at irregular times," better explain his development during these fallow years. Be this as it may, Galton's pursuit of travel and sport for pure amusement's sake lasted fully five years, but came to an end almost as suddenly and inexplicably as it commenced; Galton-to use his own words-had finished sowing his "wild oats" by the summer of 1849 , and was returning once more to those scientific pursuits, which had been his delight in 1840, and which he was never again to desert except under stress of ill-health.

Nearly all record of developmental influences during this period having perished, we are thrown back on surmise and hypothesis to account for these fallow years in the life of a man who both before and after was conspicuous for intellectual activity. Naturally we turn in the first place to the many hereditary strands blended in his character. On the one side we have the manifold scientific tastes of the Darwin stock, combined, however, with love for purely country pursuits and with sporting tendencies which have dominated not a few members of both the Darwin and Galton families; on the other side we have the social aptitudes and the keen love for the pleasures of life, which marked and led to the downfall of the Colyear and Sedley stocks, strangely united with the business aptitude and disciplinary sense of the Quaker blood of Farmer and Barclay. If we examine most of Galton's relatives we find one or at most two of these very different hereditary strands manifest in the same individual; but in Galton himself, and probably as source alike of his mental width and of his charm of character, we find these various strands commingled-the word is here better than blended-in a single nature. To speak for a moment in the crude language of a current theory of heredity, it is as if opposite allelomorphs could be united in the same zygote and alternately dominate

p. G. 
its characteristics. These fallow years show the dominance of determinants of which we are fully conscious in tracing Galton's family history, but which after 1850 play only a subordinate, albeit a graceful part in his character and activities. In 1849 Galton's mechanical tastes revived and his scientific bent came once more to its rights. When the "spring-fret" again came o'er him, he knew his "naked soul" and had found a congenial purpose in life.

In the failure of any record of environmental influence', we can only attribute the difference between the Soudanese and the Central African journeys to the not unfamiliar experience of different hereditary tendencies developing potency at successive stages of an individual's growth. Charles Darwin was a student and naturalist from his College days; Francis Galton's six fallow years threw back his work in life, so that much of it was achieved at an age when most minds grow quiescent. But the delay was not greatly to his, nor, in the long run, to the public disadvantage. His earlier papers on the improvement of the human race by conscious selection were nearly stillborn, they faced a world quite unripe for the ideas Galton had to teach. The acceptance of the principle of Natural Selection and the recognition of science as a capital authority in human affairs had to make marked progress before Galton's teaching could reach its audience, and produce its effect.

1 We know how the publication of the Origin of species moved Francis Galton. At first it seemed to the writer of this biography that the voyage of the "Beagle" might have turned Galton's thoughts to scientific travel, but the Journal of that voyage appeared in 1837, five or six years after the voyage, and there is no reference to it in Galton's letters of that date or later. The famous Linnaean Society publication madc jointly with Wallace dates from 1858 , when Galton had already settled down to scientific work. 
Plute I.I

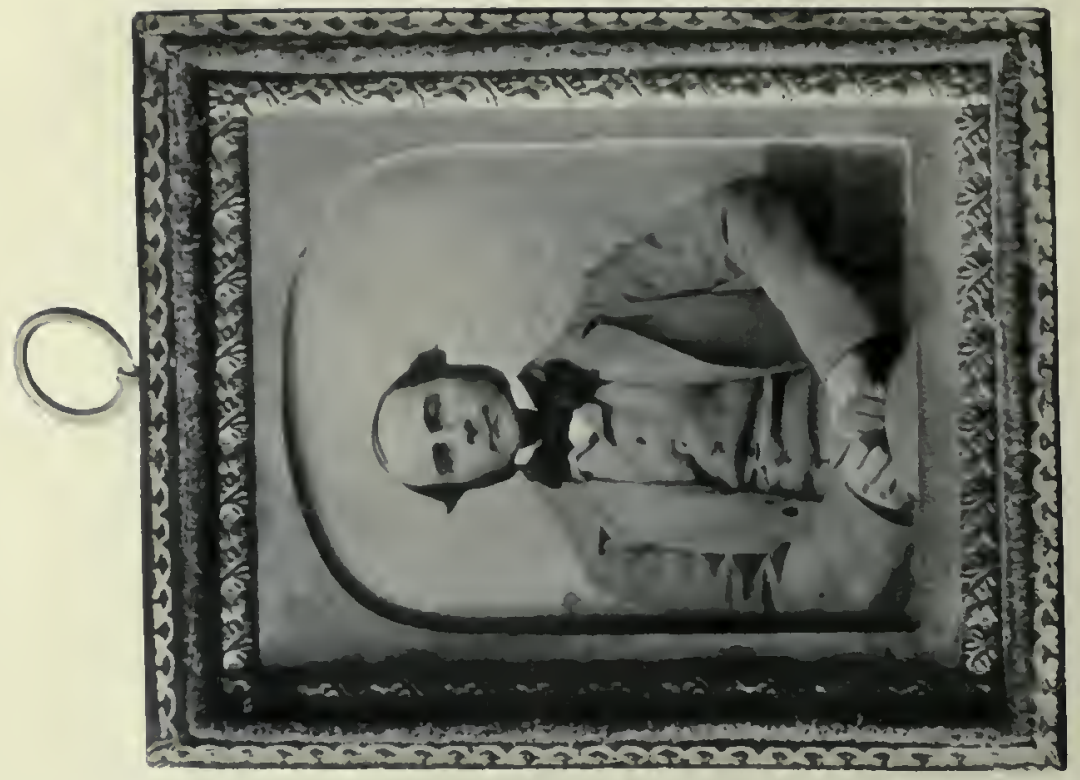

章 


\section{CHAP'TER VII}

\section{THE REAWAKENING: SCIEN'TIFIC EXPLORATION}

In the absence of records for the period 1844-9 we are unable to trace the outside influences, if any, which again stirred Galton's latent scientific tastes, awakening once more those instincts for the production of work of social value, which for six years had been lying fallow. We do not suggest that these years were without any profit for Galton's ultimate career. The accumulation of experience-however apparently aimless-is always capital of a final interest-bearing value to the man who has by heredity a receptive mind and an unusual power of storing observation. The knowledge gained hap-hazard in the Soudan and Syria, the pursuit of grouse on the Scottish and Yorkshire moors ${ }^{1}$, the shooting of seals in the Hebrides, the observation of bird and beast, the ready presence of mind, which the hunting field encourages? ${ }^{2}$ the knowledge of human motive and human weakness in the gambling, wine-loving, tale-capping ${ }^{3}$ set of the Hunt Club at Leamington, whose typical representatives were the Jack Myttons, father and son",-all these experiences were not without profit in later life. Even their value in African travel was not to be despised; it is only their incongruity with the youth of 1840 and the man of 1850 ,

1 Well for Galton that it was before the days of the modern "drive"!

" In later years Galton with eharacteristie modesty and the love of a joke even at his own expense, would say that he had learnt by experience to reduce falling off to a fine art.

3 The relief at hearing the simple truth told in simple words was, Galton once remarked, one of the new and pleasurable experiences assoeiated with the family circle which his marriage introduced him to.

" The life of Jack Mytton, Senior, has been written by "Nimrorl" (J. C. Apperley) under the title: The Life of John Mytton Esq., of IIalston, Shropshive, with his IIunting, Rrcing, Shooting, Driving and Extravagant Explouts (with colour illustrations by Alken and Rawlins). Jaek Mytton, Junior, inherited his father's reeklessness; le also got through a fortune and clied prematurely. "There was no question of his ability or power over others," wrote Galton in his .Memories, p. 110. 
which must puzzle the onlooker unacquainted with that strange mixture of Stuart and Barclay, of Colyear and Darwin blood.

The first sign of the reawakening of the old tastes is the endeavour of Galton in 1849 to design a printing telegraph. The account of this instrument was printed in 1849 , but post-dated in the publication June 1850, two months after Galton had left for Africa. The pamphlet gives very extensive details of the mechanical parts of the apparatus. In order to appreciate what the "telotype" meant in those days, we nust remind the reader that telegraphy, then recently introduced into this country, was not carried on by the Post Office but by a number of commercial companies, and a printing telegraph had not yet been achieved. Galton's instrument looks cumbersome with our modern experience of tape instruments, but there are some ingenious ideas involved. How far it was ever actually constructed it is now perhaps impossible to say, but from the wording it might be supposed that portions at least had been actually made; Galton speaks of the instrument as the result of many experiments ${ }^{1}$, and dealing with his method of intensifying the mechanical effect of the slight touch of a needle he writes :

"It is very interesting to watch such a series in operation; how the delicate, scarcely perceptible touch of the first arm causes an influence that travels on, almost as if by instinct through the whole series; how each arm hands it to the one beyond it; its available power increasing at each delivery ${ }^{2}$."

If the whole or parts were constructed, they do not appear to have been preserved, or at least to have reached the Galton Laboratory with the long series of his models and other instruments, which we possess. Galton's telotype involves three wires to connect sending and receiving stations. The needle of a galvanometer may remain stationary, turn to right or turn to left. Thus each wire can send three signals, or the system of three wires 27 signals, enough for the complete alphabet. Now consider a lever in the form of a rectangular frame balanced about a median line or axis; suppose a key slightly longer than the parallel sides of the rectangle turning on the same axis, then if the frame be horizontal and the key pass over the perpendicular edge of the side of the frame it will depress it, when itself depressed. The depression causes contact

1 The T'elotype: a printing Electric T'elegraph, by Francis Galton, Esq., M.A., Trin. Coll., Cambridge. John Weale, 1850, p. 32.

I Ibid., p. 10. 
2120 
Plate LV bis

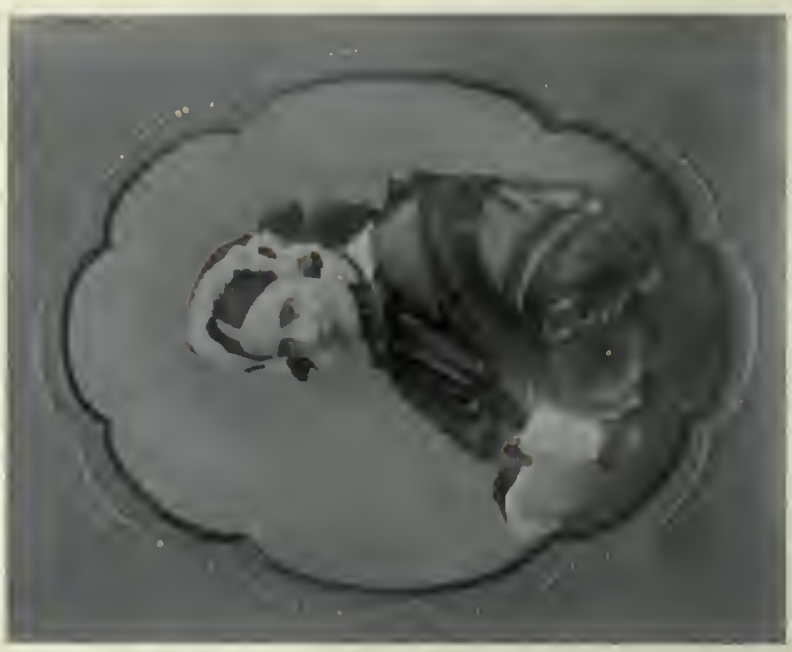

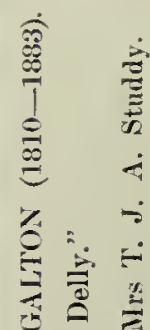

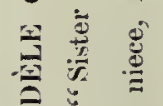

दे

空

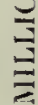

产

$\cong$

$\equiv$

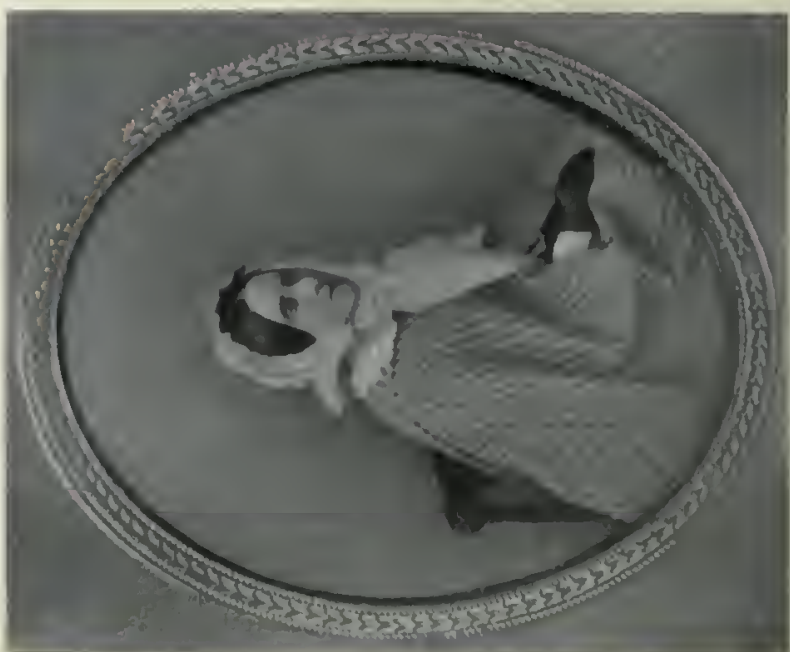

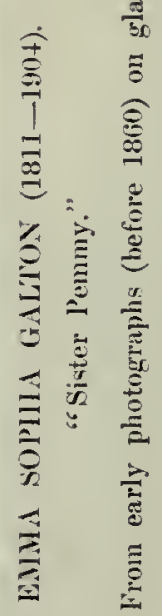


and a positive current is transmitted. If a piece of the breadtl of the key be cut out of the edge of the frame of depth equal to the play of the key, no motion of the lever takes place. A second similar rectangular frame inside the first may be depressed and give a negative current, or again may have a piece cut out and give no current at all. 'Thus one key depressed can give any of the three possible signals on the first wire. With three pairs of such rectangular frames and 27 keys all the possible combinations of signals can be sent through the triple wire. The keys may be given any letters or numbers, four wires and eight rectangular level frames on the same axis would give 81 signals. Elsewhere in the paper (p. 29) Galton indicates how with eight frames, two wires only, but two battery strengths for each wire, five signals might be got on each wire and so twenty-five signals in all. This roughly describes his third section, the determination of the proper movements of the needles for any given letter by touching a key. In his first section he considers how the weak movements of a needle nay govern the movements of a heavy arm. He does not achieve this, as we night anticipate, by electromagnets, but, discarding these, by a somerwhat elaborate mechanical device, which directs in a given manner the energy of wheels kept rotating as nearly uniformly as possible. We must refer the reader for the details of this part of the telotype, as well as for those of the manner in which the appropriate letters are to be actually printed, to the pamphlet itself; they have now only historical interest, but they suffice to indicate a mechanical versatility which was later to come to fuller fruition. Various additional possibilities are then indicated, thus, on making certain signals, mechanical effects other than printing letters, e.g. the sounding of a bell, can be obtained; methods are given by which the combination of one signal followed by a letter shall print a capital or a figure; and again processes for messages to be printed in cipher are indicated.

Lastly Galton's concluding words may be cited here, for they anticipate much that was to come later-the transference of the telegraphs to the Post Office, and the modern developinent of the telephone:

"If telegraphs, that worked and printed satisfactorily were ouce found prncticable, most large houses, public and privatc, would soon become supplied with them. The communication being so immediate, answer following question as soon as it is put, affords much more nearly the advantage of a personal communication than the best regulated post office ever could. Any schene to introduce telegraphs generally; would 
probably be first confined to London. There would be central offices, and from these bundles of wires would radiate to numerous branch offices; from the branch offices again wires would pass along the adjacent streets, and supply houses as they passed. The expense of distributing wires in this way could not be extreme, for, if the branch offices were as numerous as the branch post offices now are, the distance that the wires to each private house would lave to traverse would never be great" ( $p$. 32).

The perfect system of house to house telegraphy will probably only be reached when we return to the recorded signal, to the true telegraph, to the written instead of the spoken word. But in a large measure Galton's anticipation of 1849 has been realiser. Before, however, the world could express any opinion on the value of his telotype, the "spring-fret" had again seized him. Galton was oft' for the "misty sweat bath 'neath the line," but this time with a definite end to his travels - the exploration of a little known tract of Tropical Africa. When and how the idea of a journey of exploration in Africa occurred to Francis Galton we cannot now ascertain; the reader will remember his boyish admiration for Captain Sayers (see p. 113), which was doubtless not without permanent influence. Oswell, Murray and Livingstone had just reached Lake Ngani, proceeding from the Cape, while ten years earlier Captain (later Sir) James E. Alexander, starting also from the Cape, had twice traversed the country of the Great Namaquas, and travelling almost due east and west along Lat. $23^{\circ} \mathrm{S}$. had linked Walfisch Bay with the country of the Damaras of the Hills. North of $23^{\circ} \mathrm{S}$. fiom Walfisch Bay to Lake Ngami, of the land of the Damaras of the Plains and of the Ovampos, but little was known; it was to this land that Galton's attention was ultinately directed. Oswell and Livingstone were already at work to the north of Lake Ngami, and there seems little doubt that Galton for a considerable time had in mind the linking up of the districts traversed by them with the West Coast. But this was hardly his original project; that appears to have been to reach Lake Ngami from the Cape and then proceed northward by means of the rivers flowing into that lake $\mathrm{l}^{1}$. For this purpose his equipment contained originally two boats which were discarded at the Cape. Galton's friend, Dalyell, was acquainted with Sir Roderick Murchison, at that time President of the Royal Geographical Society; Galton's cousins Charles Darwin and Captain Douglas Galton were

1 Colborne's New Monthly Magazine, November 1850, p. 350. 
$214^{\circ}$ 


\section{SKETCHES FROM GALTON'S ALRICAN MARIES.}

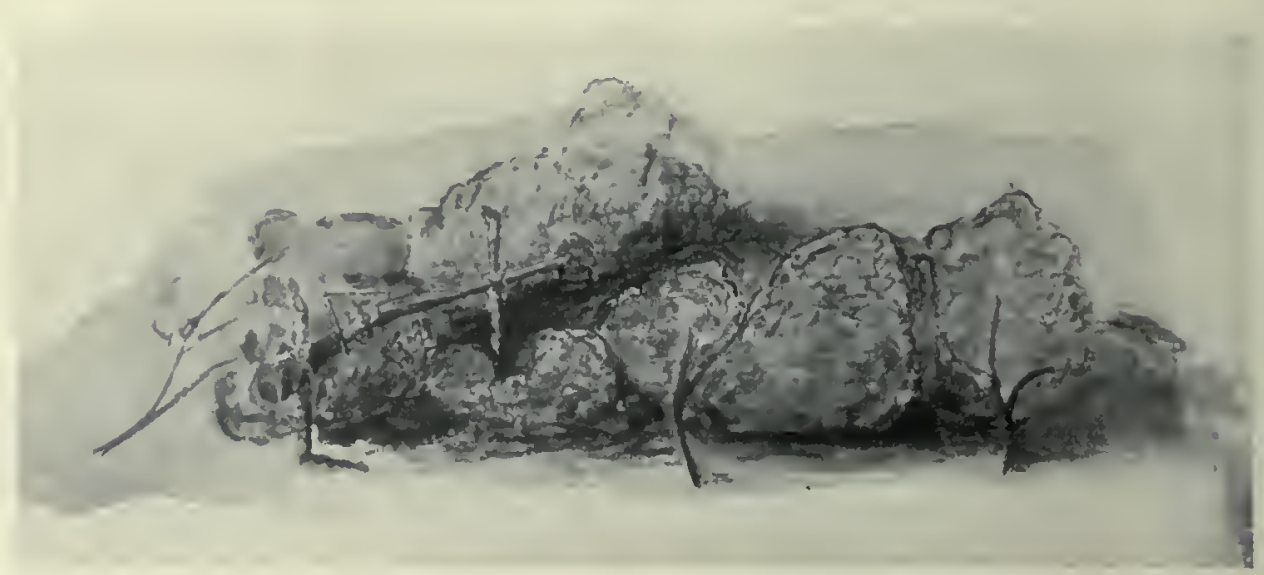

l'hotograph of a rough water-colon sketch of gun set as a trap for a lion; the beast in pulting off the lump of meat at the muzzle diwcharges the gnu.

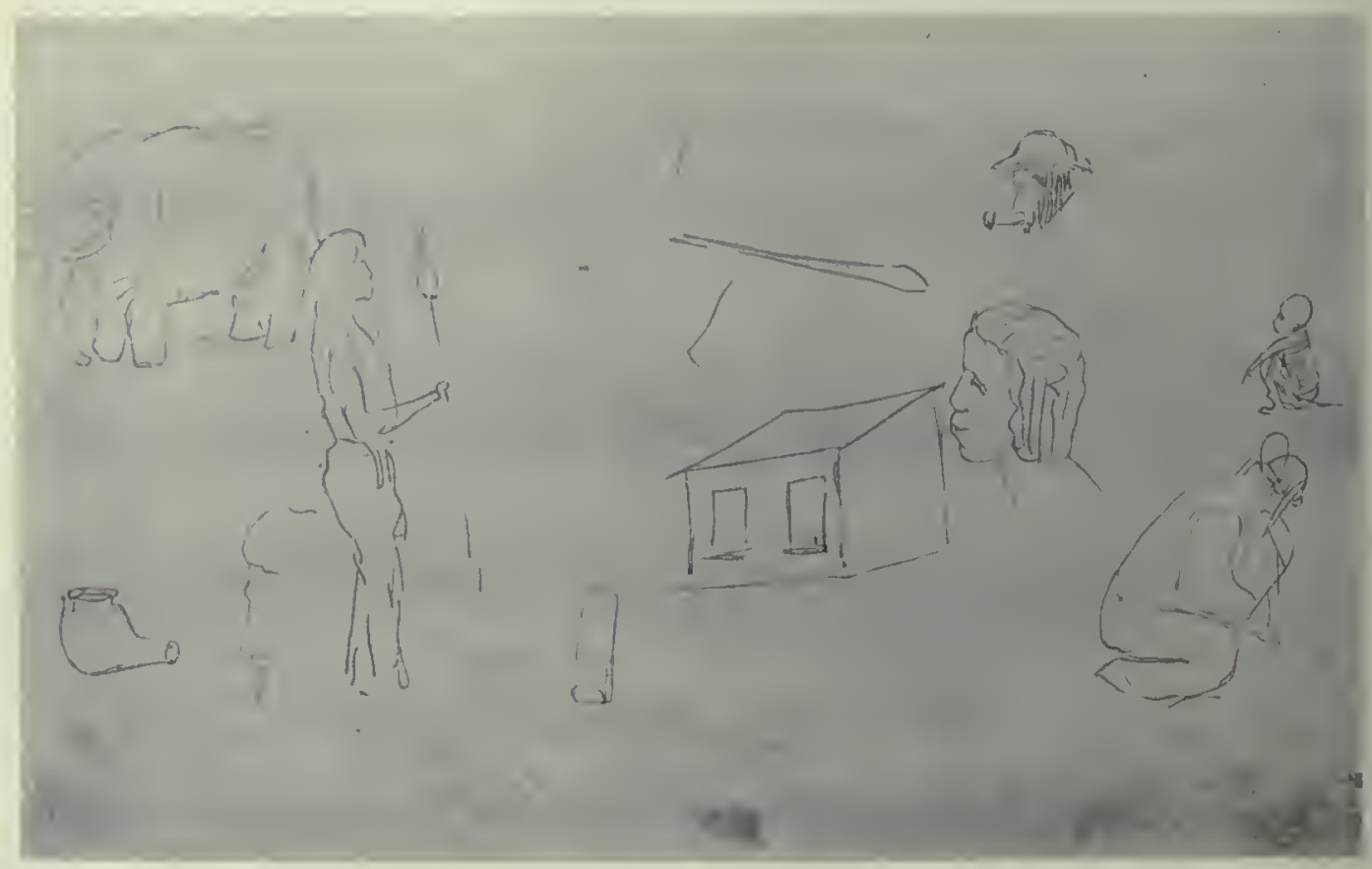

Sample page of one of Galton's dliary-sketchlooks, illustating lis pencil snapshots. 
fellows, and at the suggestion of the latter, Galton consulted the officials of the Society as to his journey. He was elected a member in the spring of 1850 and thus begun his relationship to the Royal Geographical which lasted so many years. According to the minutes of the Society Galton submitted, on March 25, 1850, a scheme for his journey to the South African lake and the route he proposed to take. 'This paper was not published in the Society's Journal and it has not been possible to obtain access to the papers of that period in the Society's archives ${ }^{1}$. The matter is probably of sinall importance, for had Galton grone up fiom the Cape to Lake Ngami, he would have found Livingstone already at work exploring the district he had thought of, and it was probably therefore providential that on his arival at tle Cape he found himself cut off" firom $\mathrm{Ngami}$ by the great trek of the emigrant Boers, who had "wrested the whole breadth of the habitable country north of the Orange River" and cut off all communication northward. After some doubts as to proceeding to Lake Ngani from the Portugivese settlements on the east coast, Galton determined on starting from Walfisch Bay on the west and crossing Damaraland. This roughly enabled him to fill in the unknown district between Alexander's west and east line, Livingstone's Lake Ngami work and the Portuguese possessions on the west coast, that is to say the upper half of the present German South-west African colonies. The account of Galton's journey was published by Murray in $1853^{3}$, and a new edition by Ward, Lock \& Co. in the Minerva Library of Famous Books in $1889^{3}$. A succinct account of the journey-Recent Expedition into the Interior of South-Western Africa-was given at meetings of the Royal Geographical Society, Feb. 23 and April 26, 1852, and is published in their Journal, vol. xxII, pp. 140-163. The paper which immediately follows this is by Livingstone and Oswell giving an account of their explorations to the north of Lake Ngami. A common map of the Galton and Livingstone explorations (p. 141) is of much interest

${ }^{1}$ I have to thank Dr. J. Scott Keltio for most kindly examining the minutes of the Royal Geographical Society for the year's 1850-2 for references to Frucis Galton.

2 The Narrative of an Explorer in Tropical South Africa, with colourcd Maps, Plates and Woodcuts. One of the maps gives a most valuable scheme of the routes of various explorers up to 1851 . The cuts are after sketches in Galton's note-books.

3 This edition has a most interesting Appendix by Galton on the later history of cxploration, etc., in Damaraland. It wants, however, most of the cuts of the original and the small unap is inferior. 
as showing the approach to Livingstone's ground that Galton macle in his journey to 'Tounobis. The Geographical Society's Journal gives also his astronomical observations for six longitudes and the latitudes of 53 stations. The map was based chiefly on triangulation with an azimuth compass. The positions thus obtained were tested with the longitudes and latitudes taken astronomically. The agreement was on the whole fair, the longitudes (by lunars with a small circle) being least satisfactory; a result which will not surprise those who have used this method and remember that Galton's experience was chiefly, if not wholly, gained on board ship after sailing for the Cape. Galton's diaries, sketchbooks and observation books are now in the Galton Laborator'y ${ }^{1}$,

1 Among the hooks in the Galton Laboratory are (i) a small note-book with MIs. native grammar, abstracts of Vardon's and Oswell's travels, lists of right ascensions and declinations of stars, a small table of logarithms, etc. It records that Professor Owen wanted the heads of wart-hogs of various ages to study their teetl, also dried heads of ostriches, especially young ones. Receipt for preserving skins and note for making expcriments why a water bird's plumage gets immediately wet after being slot, etc. (ii) A quarto book of triangulations, also latitudes and longitudes. It is started by a pen and ink sketch of a saddled ox, "Ceylon-the best hack in Africa." (iii) A folio book containing route distances, bearings, itineraries, sketches. History of the Namaqua atrocities hefore arrival of Galton; letters to or from Jonker, Swarthoy, Amiral, Cornelius and other Hottentot and some Dannara leaders. Jonker's signature to his "Apology," and the laws laid down for him, both in Dutch; fragments of diaries and other notes. A good deal might be of service to a future historian of Germain Southwest Africa. There is a fairly extensive vocabulary. (iv) Ten small pocket note and sketch books. Sketches of native women and utensils, rougl bearings and itinerury notes, journals, notes of necessarics, of talks, further vocabularies, rough drafts for Galton's law-code for the Namaquas, etc., etc. (v) A tracing of a nap of whieh the original was said to have been left at the Cape " 7 years before," by the Rev. Mr Hahn of New Barmen, missionary. It shows a big lake, the "Demboa Sea," in Lat. $18^{\circ} \mathrm{S}$. and about Long. $18^{\circ} \mathrm{E}$. This is the lake to which Galton's letters scveral times refcr but which he never really identified. If we were to trust the missionary's map, it would be as large as Lake Ngami itself! In a letter to Lord Campbell he supposes it Omanbonde, which is too far soutlı. It might represent the Elosha saltpan in the wet season, then "a rathel pretty lake," much displaced and inmenscly exaggerated in area, but it was probably Onondova.

In (iii) is a loose pencil sketch of a small lake with steep cliff-like banks surmounted by trees, and entitled: Omutchikoto, June 25, 1851. 'This must be, I think, the Otchikoto, of Galton's map, reached at that date on the return journey. It is noted on the map as a small pond $400 \mathrm{ft}$. in diameter and $180 \mathrm{ft}$. deep. Galton writes: "Thero wo took a day's rest, and amuscd ourselves in bathing. I made some tishhooks out of necdles, and caught about a hundred small fish, which we eat" (Tropical South Africu, 1st cdn. p. 238). Otchikoto was reached on May 26, 1851, on the 


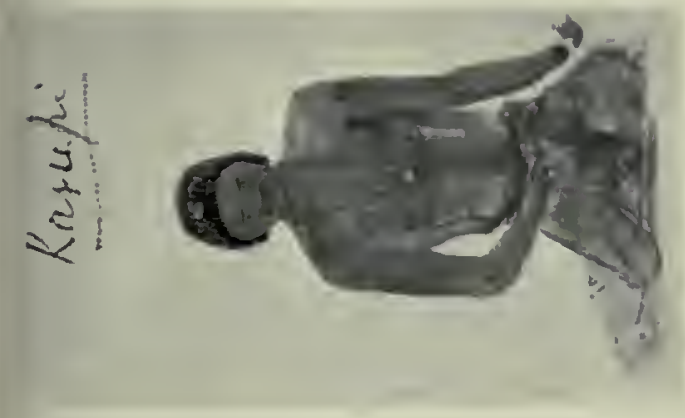

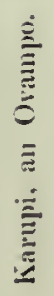

ב

सर

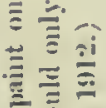

를

$\because \equiv$

$\equiv \bar{\vdots}$

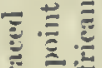

$\pm \approx$

紊突

.

光

总䓀

*.

章五

至

三

邹

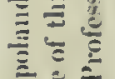

实

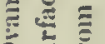

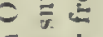

.

象

三 년 $\div \equiv$

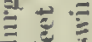
$\overline{5} \div$ 气 $\equiv \div$

$\approx \equiv$

$\stackrel{\Xi}{\Xi}$ $\equiv$ 

and before the writer of these lines; they indicate very fully the thoroughness with which he now went to work. Of the sketches we reproduce some in the Plates of this chapter, but it is not our intention here to rewrite or even to abstract the account of the African journey; we propose to bring the reader again in touch with Galton himself, chiefly by printing in part his letter's home. They bear the mark of the immediate impression made upon him by his environment, and are largely written in the old playful strain of the Cambridge days. Individual occurrences are coloured with the feeling of the moment and by the writer's relation to the recipient, in a manner which must be set aside, when a serious narrative is written a year afterwards for the public eyes.

We now turn to the letters of this period.

$$
\text { Friday night [22nd March, 1850]. }
$$

DeAREST Mother, I shall turn up some day next week but I cannot tell when. The "Dalhousie," ny ship, is at anchor in the river now. The Captain's name is Butterworth and my books are at the Pantechnicon, Belgrave Square. Ever in great haste, Affectionately, F. (T.

\section{The Dalhousie.}

\section{Plymoutil Harbour, Tuesday [April 2].}

Denaest Mother, I sha'nt, hang the ship, be off till Friday I fear, so I will write again. I came down from London by last night's mail train and an now fairly settler on board. It's blowing hard. Ever affectionately, Frank Galton.

\section{Off Plymouth Harbour, A pril 5, 1850.}

Dearest Mother, At length we are off. You will soon receive 4 copies of my Telotype; keep one, send one to Darwin, one to Emma, and one to my most useful amanuensis and draughtswoman Anne Broadley'. The weather has been very wild here, but has now reformed. Good bye for $4 \frac{1}{2}$ months when you will get my next letter. Ever affectionately, Frank G.

outward journey (p. 200). The superstitions about it are like those of the Muminelsee in the Schwarzwald-i.e. no living thing which gets in ever gets out again. Galton, Andersson and Allen swam about the lake and astonished the natives, who had never seen swimming before. "We had great fun at Otchikoto, there was a cave there full of bats and owls, which we swam to and explored." The position appears to be about Long. $17^{\circ} 5$ E. and Lat. $19^{\circ} \cdot 25$ S. Professor H. H. W. Pearson of the South African College, most kindly reported to me in 1912, that the name GALTON liad been recently found painted on a rock, only accessible by swimming, above a small lake in Damaraland. The letters appeared still quite fresh. I think this must be at Omutchikoto, otherwise Otchikoto: see Plate LVII.

1 See p. 98.

P. G. 
Lat. 16 N., Long. 20 W. May $9 t h, 1850$.

Dearest Mother, As there is a ehanee of our shortly meeting some ship homeward bound I write a few lines. I never enjoyed myself mueh more than I lave done. Glorious weather, and to my unnitigated astonishnent $I$ find that a ship is not always in this position [sketeh of a three-master going bow first down the flank of a wave of $30^{\circ}$ ] or in this [same three-master going up the front of a wave of $45^{\circ}$ ]. The faet is that a large ship like the one $I$ am in hardly moves at all exeept in very bad weather and the sea seareely ever washes over her. At starting we had very bad weather and were about 10 days in the Bay of Biseay. A poor girl, a passenger, a clergyman's daughter, who was going out to settle with her brother at the Cape eaught a severe inflammation of the lungs and died there. Our passengers make a very amusing party, and the time passes as pleasantly as ean be. I am quite a goord hand at taking observations ${ }^{1}$ and have learnt about 600 Sichuana words" (the language I shall have to speak). Andersson is a very good fellow. I keep him in exeellent order. He rammed a harpoon almost through his liand the other day, but he is a sort of fellow that eouldn't eome to harm. He had an old gun burst whilst firing it last week and only shook himself and all was right. I don't know if I told you that I ealled on his aunt just before starting. She knew Adèle at Swansea. Miss Elizabeth Lloyd tea-ed with her there. We passed under the sun the day before yesterday. It's not a bit hot. Thermometer has never been more than $80^{\circ}$ in the shade. I should like yachting, I think, and I should go to Teneriffe and then the Verde Islands, dloing Lisbon on the way; they looked so uneommonly pretty. Teneriffe would not be on an average 19 days from England. Suggest it to Darwin, if he is seized witl a mania that way this spring. I was only siek three days.

May 10. Lat. $9 \frac{1}{2}$ N., Long. $24 \mathrm{~W}$. There is a sail just reported ahead, and they are bellowing out to get ready and board her. It's very odd how few ships one sees, this is only the first homeward bound we have yet come across; however the tracks outward and homeward are different on aceount of the winds. The enigrants are rather fun than otherwise. I introduced the game of bob-eherry for the boys and every evening we filled our poekets full of things at dessert and fish away. We have made them sing together, ete., ete., but on the whole they are an uninteresting set of culss. I have got to polish up to go on board, as I have been in slippers and a leather coat for the last fortuight. So good bye, and witl love to all at Edstone ${ }^{3}$, Suitterfeld, and Adèle. Ever affectionately, Fraxk G. Tell Emma that I am working hard at drawing.

The latitudes suggest the "Dalhousie" was off the Gold Coast and had not yet passed the line.

1 The advantages of a sailing ship orer a modern steamer for a traveller of those days will be obvious.

${ }^{2}$ Several pages of the diary eontain long lists of words.

${ }^{3}$ The home for a time of Darwin Galton, who had married Mary Elizabeth, eldest daughter and eoheiress of John Phillips, Esq., of Edstone.

4 The home for a time of sister Bessy, Mrs Wheler. 


\section{The Reawalicning: Scicmific Explonation}

Cape Town, Capl of Good Hope. 8th July, 1850.

Dearest Mother, Wo arrived here safely and all well a fortnight ago-and this is the first mail that has left since then, so that what with our very long passage and the other delay, you will I fear have wondered where in the world I am. I found I had letters of introduetion to everybody wortl knowing in Capo Town. Sir Harry Smith is most civil, and I feel just as muel at home here as in Leanington. Andersson is a right good fellow and partieularly well. He desires to be very kindly remembered to all of you. I found out an old Leamington aequaintance of yours, or rather she found me out, a Mrs Menzies, who was there in 1840 and kncw Admiral Cliristian well. Sho is the wife of the Chief Justicc here and is a partieularly niee person. I daresay Eimma will recollect her. My old ally, Hyde Parker is here in command of a ship and has just taken some prizes-another friend also, a Cantab whom I had my Xmas dinner with, on the Nile, is scttled here. The news as regards my future plans, is somowliat chequered: Four days after I arrived news came from the frontier, that the Rebel Dutehmen (Boers they call them) had entirely stopped evcry route, and werc on the point of themselves, going inmediately to the Lake in order to keep it for thenselves and had stopped parties of English Travellers and robbed them. My plans have been therefore changed. I intend either to go round by Natal ncar Dclagoa Bay, or else on the western coast by Walfisch Bay, so as to turn their flank. Government, i.e. Sir H. Smith, desires me to take some letters to the Chiefs about, with reference to this movement of the Boers-in order to resist them. It has beell, and still may be for auglit I know, seriously eontemplated to annex this wide country to the Colony. Anyhow I shall know all about it in two days. I have offered to do whatever Government wishes, and I should not be surprised if I had orders of some importance to carry out. Till then as my plans are so unsettled I cannot say more but I am ready for a start any day and as soon as a deeision is come to shall very likely be packed off at once; so I may lave to leave Cape T'own this week.

I have received no letter from England as yct. Please direct them, Cape TounCape of Good Ilope, unless I write again to the eontrary as I have no chance whatever of going within 500 miles of Colesberg. Andersson is deliglited at the prospect of anything like a scrinmage-and the fact of there having been $£ 1000$ offered for the capture of one Boer, and $£ 500$ for another-on account of previous enormities quite unconnected with the present business gives an extra zest to the fun of his present destination.

If I go to Natal, I shall reeolleet to enquire about Darwin's protégé Mr Hume, anrl will report on the state of his farm. Sir H. Smith has a glorious team of beagles-they don't run half as fast as those at Edstone did, and if possible make more noise. They run about in front of Government House and have been trained to chivy any strange dog that may approach too near, which they do at full cry. Give my love to everybody - babies and all. I will write by next mail, which must lcave in 10 days I should think.

\section{Ever your affectionate son, Frank Galto.s.}

\section{Welch's Hotel, CAPE Town. August 5th, 1850.}

My Dear Darwin, In an hour more and I shall be off, with I think nearly as efficient a lot of men and eattle, as could possibly be net witls. I have been obliged to 
freight a small Schooner to take me and my traps about 1000 miles up the Coast to Walfisch Bay where I land and go towards the interior. The assistance and kindness in cvery possible way, both of Government here and of all the people, has been extreme. I take out credentials for establishing friendly relations between our Government and different tribcs, in opposition to the movement of these Dutch Boers, and they have given me an inmensc parchment passport, engrossed and in English, Dutch and Portuguese, with a hugh seal 8 inches in diameter, set in a tin box and dangling on to it, so I go as a great swell ${ }^{1}$. Sir Harry made a long speech to me the other day after dinner at Government House, to say, I was a good fellow-and he spoke very kindly indeed.

Andersson is a right good fellow, and does whatever he is told, which is particularly convenient. My head-man is one of the best known servants in Cape Town. He is Portuguese-has travelled all lis life, speaks Dutch and English perfectly and has always been liked by everybody. Then I have a Black, to look after my nine mules and horses. He calls me "Massa" and that also, is very pleasant. He is a tall athletic well built fcllow, who has worked uncommonly well in Kaffir land. Next comcs a smart lad to help him, and then I have 2 Waggon drivers and two leaders for the Oxen. One of the Drivers has worked 4 years together at a blacksmith's and waggon maker's shop here, and is a very good workman, so that hc can repair anything that gocs wrong in my waggons, and one of the leaders can also drive. Our party therefore consists of seven servants Andersson and myself, and except Juan, the head-man, their wages run from $£ 3.10 .0$ to $£ 1.10 .0$ a month. I have been obliged to lay in a very great quantity of stores, for the place where I am going to land, has no communication established with any other port, and nothing that is forgotten carr be replaced, of thesc things about lialf go to exchange for oxen, of which there are plenty there, and to get me guides and so on, of the rest I leave one half as a depot at a nissionary Station, so that $I$ have always a place to fall back upon. If the roads are good, $I$ go with my waggons and my cart, if there is doubt about water ahead, I send on my cart alone with the mule-and if the road is execrable, I hunt about for a better one, using my mules as pack animals. The country is utterly unvisited by any White, after the first 300 miles, no traveller or sportsman has cver been there at all, only a few missionaries and traders-but the universal account from the Natives is, that the further you go, the richer it becomes. There is this large reported lake, Lake Demboa, only 200 miles from the furthest missionary Station. It will be my first object to reach this, and trace the river that flows out of it, and which is said to be a branch of the Cunene to the sea, and if the river be as large and the country as fertile and healthy as it is declared by the natives to be, it will most assuredly rise soon to great importance. The Cunene is the river that bounds the Portuguese possessions on the West coast, to the South. I daresay I shall bring back a lot of ivory and gold dust from there, for I shall certainly swop any of my stores for them, if I can do so to advantage. I am comfortably provisioned, barring incat, for two years and have an immense quantity of the things, that these

1 This remarkable document is now in the Galton Laboratory. According to Galton's owu account the seal had originally been attached to a royal mandatc creating a deputy or lieutenant-governor of the colony. Sir H. Sinith wanted something to impress the natives, so he cut it off and attached it to the aforesaid parchment! 
savages are understood principally to fancy. All this has eost a lot of moncy, but like buying a ship, unless she is wrecked, you will sell her again. I have been obliged to draw a bill on Barclay for $£ 400$ beyond my letter of credit, at 30 days sight, and I leave behind me about $£ 350$ in cash, to pay the wives and mothers of my mcn, in case of any possible emergeuey. I wrote dupliente letters to Barclay, which I gave nyy Bankers here, to send with the bills, to ask them to advance what balanee there may be against me, at a usual rate of interest, but that if it was not convenient for them to do so, I had left a power of attorney with you, to sell out some shares and requested them in that case to communicate with you. But I hope they will advance the tin, as it is a bore selling, and I cannot draw any more money, till I eome back. I tako $£ 50$ in my poeket in case of any possible aeeident, but I am assured that inoncy is no earthly usc where I am going, everything is done by exchange for cloth and iron or something else. My two large boats I am compelled to leave behind as my present route lies over a hilly country, where I could not possibly take them. But, if I make out the Cunene satisfactorily, they may yet have to carry me. I shall be able to write one more letter, that you will get in a reasonable time and that will be when the vesscl leaves me in Walfiseh Bay. After then I will leave one or two with the Missionaries, and when I quit them, if all goes well I may soon get within messenger reach of the Portuguesc settlements. I have of course to write to Sir H. Smith and I think I will do so to Jord Palnerston and to the Geographical Society, so that letter sending will he a great object to me and I will do all I can to contrive it suecessfully. Well, I have now dono with myself. It is no good asking questions about home beeause $I$ do not expect to receive a letter until I return. I have had none from England yet, your hunting season will be just beginning when you get this, I suppose. I am curious to know if you have been yachting this yea: I think if you were suddenly transported here, you would like the place anazingly so many horses all with a deal of blood in then. Every cart goes at a trot and is driven 4,6 , or even 8 , in hand. Sometimes you see a set of tearing horses and a young strip of a lad only, with an immense whip to manage them. I have only 4 doggs. Well the sheet is out, so goodbye. I often think of you all at Edstone and Claverdon and regret the Sunday evening rides. Give my love to my Mother and all, and send this letter as a cireular to them. I will give you pictures in my next. When you write, address to ne care of Messrs Van der Byl and Co., Cape Town, Cape of Good Hope. Goodbye old fellow.

\section{Frank Galton.}

\section{WALisch Bay, Soutu West of AFrica. 27th August, 1850.}

Dearest Mother, At last I am fairly on the desert with everything before me quite elear and apparently easy. I have, I tind, mado a most fortunate selection of men. They work most willingly and well, and nearly all know some kind of trade. When I arrived here some 3 days ago, the Missionaries came down to meet me, and have been most eivil. I an sure I have selected a far better route than my first one, for now I am quite as near the undiseovered country as I should have been after 3 months land journey from Algoa Bay. Ostriches are all about round here, though I have seen none yet. We got 5 eggs and ate them the other day. Lions infest the country about 30 miles off; if they don't eat my nules I shall have delightful shooting. The ship unexpecteclly is on the point of starting, so my dear Mother, a long intended letter is 
spoilt. It appears the weather glass has unexpectedly fallen, and the vessel is obliged to be off some liours before her time. Many of my intended letters are therefore stopped, pray tell Douglas and Uncle Hubert I had intended writing to them, you will liear no nore from me, for I fear a very long time. I explained the reason why in full to Darwin, in my letter to him. Goodbye then, give my affectionate love to all the family. I start into the country in 4 or 5 days.

Ever your affectionate son, Frank Galtox.

Andersson is an excellent fellow and desires to be remembered to you.

\section{Lat. 22.7, Long. 17. About Decr. 1850.}

DEAlest Mother, This letter cannot I think be less than 6 montlis on the road, as it is pretty far by land from the Cape. In the first place we are all in excellent healtl, high spirits and thorough travelling order, though we have had an immense deal of trouble ancl some hardships. The weather too is warm, $157^{\circ}$ (one hundred and fifty seven degrees) Fahrenheit in the sun at midday and from $90^{\circ}$ to $100^{\circ}$ in the coolest shade, under thick trees and that sort of shade about $110^{\circ}$ to $115^{\circ}$. This appeared quite incredible to me, but $I$ have eompared 7 thermoneters of 5 different makers and they all agree, so there can be no doubt about it. The air is not oppressive at all-we are at the furthest missionary station and not further, and now I will tell you all the story in order: The slip sailed away from Waltisch Bay which is 3 miles of heavy sand from fresh water; we were employed about 10 days in getting every thing thence to the water in the eart with the mules. When there we were 18 miles from a Missionary Station. It took nearly 3 weeks to get everything there. It is the only liveable place in that part, as the water at the first place was exeerable, so bad that I had to distill every drop we drank. I kept a still going night and day and so we were supplied. After resting the mules we packed plenty of iron things, guns and so forth, making a very heavy load in the cart, to buy oxen with about 180 miles up country. I got 3 oxen here on the backs of which, some more things were packed and with a good sort of ruffian, originally a Tailor, subsequently a kind of Missionary, and now a ruined cattle dealer for a guide away we went. The men had all to walk. Andersson crossed 40 miles of desert in great style and made another 24 miles journey after, when the mules were sorely knocked up; we were obliged to let thein and the horses feed at night in the river and seeing no traeks of lions about, we did so without mueh fear. What was our horror the next morning on going down-when we saw, not a mule or a horse, but their traeks going full gallop in a drove, and by their side, the tracks of six lions, full ehase. A little further on, my pet mule lay dead, and a lion eating it; by the side a wolf waiting for his turn, again a little further my biggest horse just killed and nothing more to be seen. We ran up to where the cart and encanpment was, 2 miles off at the top of the steep banks of the river; provisioned and armed 4 men for two days and sent them off after the mules, and the rest of us hunted the lions, but unsuccessfully all day. They had got annong the rocks and we eould not track them. In the evening we went down to get the flesh to eat, for all our live stoek had perished and we were very liungry and then Andersson (who is the best fellow in the world) and myself went up well armed, to watch the carcass of the mules from a eliarning place in the rocks just over it, and which we agreed no lion could possibly climb and made sure of making a good 
bag without any danger, however as wo wcre busied about the flesh, it was getting dark, and we saw what wo thought was a quantity of antelopes running about the rocks, however they canc nearer, and as I was lifting up a shoulder of the mule, I hearcl a sudden exclamation from the men and thero were these annoying vermin of lions, just above in the very place we were going to sit, it was very clark and they just put their heads over tho stones, like big watch dogs. I thought it bettcr not to fire in volley, but to keep guns in reserve, in case they canne on us-so the Tailor fired first, but missed and the brutes were away. It was of course unsafo to watch whero we haul intended, especially as the night became very dark and so we went away, thoroughly vexerl. I had polished off a lion in great style at the Missionary station of which I spoke; it was a one eyed brute that had done an infinity of mischief and had been hunted, I really am afraid to say how often. He came growling amongst the horses and frightening the oxen, three nights when I was there and ate up a nico little dog that I much wanted to buy. We started, the Missionary, the Tailor ancl mysclf with a great possc of natives who tracked him beautifully; when we found, lie was about 80 yards off and bounding about, so tliat as I had but one barrel and was on horseback, I did not like then to venture niy reputation on a shot, so we cantered after liin, dogs and men full cry and after 3 hours got him niccly among the heavy sandlills, a loose lion is eertainly a fine beast, so I cantered to about 40 yards behind him, pulled up and placed a two ounce ball very nicely in his stern. It was great fun to see him growl and lash his tail. Well on he went and turned into a bush in a towering passion. Here wo dismounted and walked up the next sandhills, about 30 yards from him and the first bullet (from the Missionary) shot him stone dead, and the little dog was undigested in his insirle, hardly at all chewed.-Well going back to ny story we found the rest of the mules unhurt and we pushed ou. Water' was now to hand continually, and Andersson and myself alternately rode. We had great ill luck with game, seeing none. I had however a very pretty gallop after a giraffe and after wounding him, drove him to a tree in front of the cart and there shot him. I had only my little rifle with 32 bore but I fired conical bullets, steel pointed, and he dropped just like one of the oxen at Edstone on a Monday morning. This was a very welcome addition to our food, for we were very wcak from hunger, it was near a native village and I exchanged the flesh for ostrich eggs, milk, swect gum (to eat) \&c. \&c. and we stopped and gorged ourselves for two days. So wo went on, and on the fifteenth day reached Rehoboth?. The men were tired and partly mutinous, and the Namaquas (a sort of Hottentot) had driven every native away and all their cattle, and not one was to be got. Fortunately an American lived there, who had 50 uxen to sell. I took him into my service and bought his oxen at $25 \mathrm{~s}$. each-half of them being broken in. To break in the remainder was a dreadful labour, but now all 47 (3 being killed in the process) are excellent draught oxen-6 or 7 of them good riding oxen-and wc think nothing of packing the wildest beast. The men have been tossed ahout a little, and I got a vicious poke made at me, when on horseback, but turned the horse

${ }_{1}^{1}$ In January, 1909, Professor H. H. W. Pearson met at Rehoboth an old woman, Mrs Bassingthwaite, who remembered distinctly Galton visiting her father's house when she was a girl, seven years old. He was the "very intelligent Englishman, a blackmith," Dixon by name, mentioned in Tropical South Africa, 1st edn., p. 117. For a lifetime she had wondered what had become of him and why he never came back! 
just in time to receive it only slantingly, so that the skin was not lyroken. All this breaking work my new man Hans, under Andersson's management did. Of the three meu who were chiefly mutinous and who also were eonvicted of stealing, one wcnt away, and Audersson flogged the two others most severely-and with the best effect-and now everybody works well and willingly. Waggons and all are brought here, and we shall soon start. The unurdering and stealing of the Namaquas against the Damaras is horrible, they cut of the hands and feet to get the iron bracelets. About 25 thousand head of eattle have just been stolen. I have been diplomatising, in pursuance of iny instructions, but with very little effect, and must now pusl my way between all these ruffians. The only fear I have is of the oxen being stolen at night, when we should have to walk, which is very severe work in this weather, but go I will, and we are strong enough to astonish a great number of the natives, if we blaze at them. My remaining horse and 3 mules have died of the horse distemper. I have now 5 mules and 51 Oxen. My eart I shall leave behind as it is hardly strong enough. Andersson went down to fetch the waggons with most of the men and shot a rhinoeeros-but there is very little game, and now, as I have to hunt entirely on foot, I seldom go out, it is no joke in this weather. I have picked up a little of the Ovalierero language, whieh is spoken most extensively I find. I go northwards and shall thence probably get a lctter to you, through the Portuguese. Every step now is exploring. The season is now unfortunatcly at its dryest, but I think I shall get on. Ten days journey to the North, will put me beyond all desert and among kindly negroes who garden and plant. My black man speaks very fairly the language, it is so like to his own. Where I shall next be heard of, if not through the Portuguese, I can give you no idea. I have of course received no letter whatever from England, since I left it. This goes by a kind of elubbed up post, from Missionary Station to Station. The map I scnt you, turns out to be simply traced from an English nap made by a theorising map maker, which the Missionary had.- He adopted the outline, just to put in what he conceived to be the positions of the Stations and for no other purpose. It is therefore totally valueless. You know I write this letter to all the family. It is quite a round robin-and therefore I send no special message to anybody. Andersson desires particularly everything eivil, dec., dc., it's a long message but I have no room for it.-Ever most affeetionately, Frank GaLtos.

\section{Iat. 22.7, Long. 17. Dec. 5, 1850.}

My dear Campbell', We have been now three months among the savages and I find an opportunity of sending letters by clubbing together with some missionaries on the road. The letter will have a three months land journey to make to get to the Cape so that in England it will give rather antiquated intelligence. I like the work amazingly although we have had some real hardship. It is a curious feeling the being really weak from starvation, and I have had the pleasure of experiencing it more than once, but then it is such a luxury to get something to cat that all taken together leaves nothing to complain. Once six lions came down and ate part of my favourite horse and my nicest mule; we had to live on the rest for some time, the meat was tough but strengthening. Another time we were sadly off when to my delight I saw great tracks quite fresh, as broad as a plate, of a cameleopard and we eneaniped after we had shot him near his carcass and lived like wolves upon him. It is a barren country hereabouts. I must

1 The Hon. W. F. Campbell, M.P., afterwards Lord Campbell. 
try to get to the north and start in a fortnight; wo have got un distauco as jet as I had first to buy the oxen and then which is no joke to break them in. Fancy having two heavy wagons on the one hand and fifty wild oxen on the other that toss and kick and roll and are as vicious as young "thorobreds" it took time lefore we conld inake them pull kindly.

The plan is to drivo the oxen together all in a lieap, and then one man, who must understand the work takes a long cord with a loop at one end and this ho holds twisted round a stick and two or three others hold the loose end, then he creeps up behind the ox tbat he wants and as the ox is shufling about he slips the noose round his leg, and then such a confusion! The ox pulls frantically, runs at the men who have hold of the rope and they hold on all the same, at last they pull him down and catch tight hold ( 3 or 4 of tbem) of his tail and turn him on his back and then they tie all four legs together and leave him, so they treat as many as they want, then they yoke them as they lie and let them loose. My horses and most of my mules are dead so we hack oxen; my hunting saddle fits an ox's hack excellently, but it is not a sporting beast to put it on. I don't like the horns, an ox is a difficult beast to have a firm seat on as tbeir skin is so loose, they also kick and jump very short so that a rider's seat is severely tried; if you fall the horns are much in the way, especially as they usually butt at you as you fall, and kick afterwards. Tho country here is in the wildest disorder, murdering and cattle robbing are of every day occurrence; I picked up a poor wretch with his neck cut down behind to the backbone, and did what I could but he died. A set of lawless ruffians many of whose leaders were born in the Cape Colony do all this; they destroyed a missionary station 9 miles from here a few days since. I have been making all use I could of the instructions Sir Harry Smith gave me to stop this, but with no avail. Inincdiately after I wroto to these men (the Namajuas) they set out, attacked twenty-five different villages took very many of tbe women and children as slaves and all the cattle, which last can hardly be reckoned at less than 18 thousand in number. The scoundrels ton cut off the hands and feet of any of them that tbey catcl in order to get off the iron bracelets that they wear and which otherwise would take them 4 minutes to do. I have seen two wretched women who crawled here for refuge thus mutilated, they told me that they stopped tbe blood by poking the limb in the sand. All the natives here believe every white face to be their enemy, and very naturally too, I shall have to force my way through them in a fortnight as I best can. We should make a fair resistance to a very large body of natives and to a good-sized force of Namaquas; so that if they don't steal our cattle and leave us a wreck on the plain we shall do. 14 days journey North will carry us tbrough all this and to a much better country bordering on the Portuguese where the blacks garden and have kings; licre the chiets have no power, there is no union among the people, but each does what he likes. You can kill any man you like (not a chief) if you pay 6 oxen to his heirs and poor men arc much cheaper. Is it not horrible? My men I had much trouble with at first, they did not like hard work and a hot sun; they thieved and were almost mutinous. At last two cases occurred that called for strong measures, open theft and an attempt to stab, tbe men were flogged about as severely as they could be and with the very best effect. I think one and all of them would now go with mo almost P. G. 
anywherc. Andersson has uniformly been of the greatest assistance. If all goes right I think I shall be able to send a letter through the Portugnese settlements. Remember mo to all my friends and believe me ever sincerely your Frank Gairon.

Feb. 2\&th. After I had written the enclosed letter and sent it off I starterl but after going a short distance all my native servants were so alarmed on account of the fightings that werc going on that they ran away. Besides that, there harl not been rain sufficient for our journey insomuch that the letter carrier came back. So I determined to employ my time by riding straight down with my double barrellerl rifle on the Namaqua captain and seeing whether I could not bring him to reason. I saddled my ox with the largest lorns, and in my pink hunting coat and jack boots the identical ones that have more than once been in your company to Slough, I lacked over the three days journey that separaterl us and then going cautiously to the very edge of the little hill round the corner of which his place lay let my oxen get their wind and then together with the men I had with me rammed my spurs into the beast's ribs and shoved him along right into the captain's house, at least as far as his horns would let him go. The captain was at rest, he was smoking his pipe. It was the cool of the evening. Fancy the effect. I made the man as subnissive as a baby. I made him solemnly pledge his word before his people that he would leave off all oppression towards the Damaras. I had all the other Captains from a wide extent of country up to his place and made then promise to do the same. To the missionary whose station was destroyed I made then write a most submissive apology, and it is really a fact that $I$ got these scoundrels to like me. They made me umpire in their own disputes. I laid down laws for them, simple concerns certainly but they had none before. And these are in force along 250 miles of frontier, and then having settled all to my satisfaction I told them to be careful as I should certainly return that way and then went back to my waggons. The Damaras are charmed, I shall have no difficulty now in travelling. I could almost worship my red coat and jack boots that have done all this. I had not conscience enough to put on that huge cocked hat of mine-no, I patronised my hunting cap. This is a very inportant land for future commerce from the large quantity of cattle and its neighbourhood to St Helena, which is the great store for homeward bound ships. I have of course sent all particulars to Cape Town and I really think that what I have done in the way of making peace will be followed up. Our waggon road is determined on ahead. I am now at the very furthest point Europeans have ever renched and tomorrow we start. I expect to come back here in about 6 months. There is a large lake "Omanbonde" about 10 days N.W. from here. I have myself seen hills that can descry it, and there I hope first to go.

Once again good bye and believe me ever yr's sincerely Frank Galtow.

Galton's position was a very difficult one; he found the Namaquas headed by Hottentot chiefs - to whom indeed the British Government had given "captain's sticks," and who were British subjects-massacring Damaras and stealing their cattle. His sole official instructions, as sent to Jonker, "were to offer friendly relations on the part of the British Government to nations living in a certain specified tract of country in her 


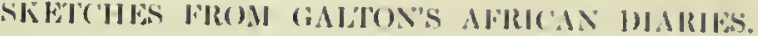

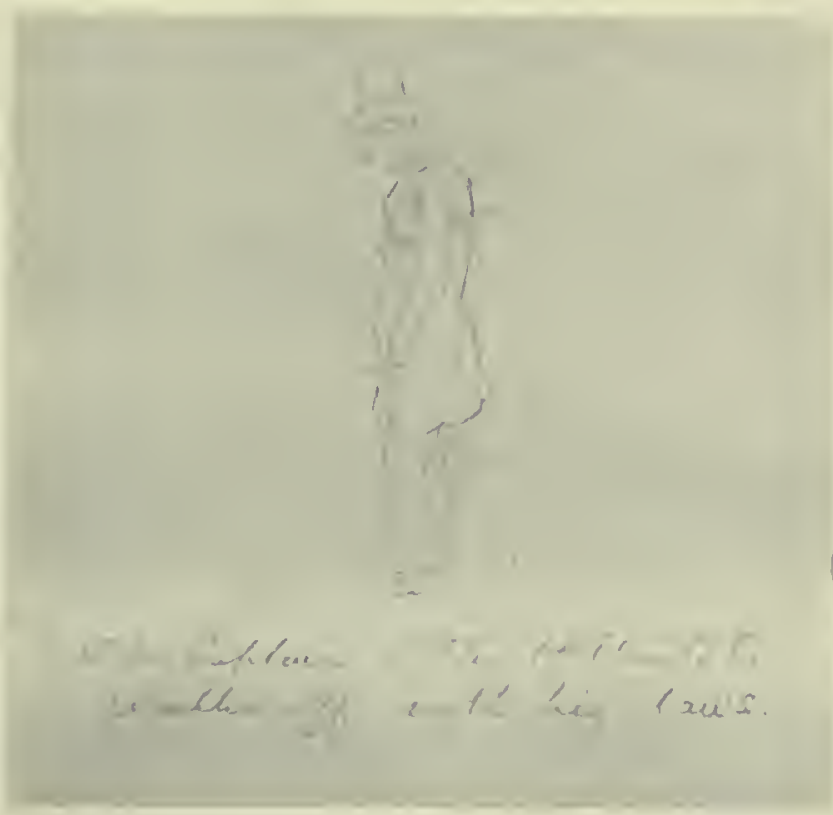

The Captain of the Hottentots walks off with the laws drawn up for him by Fancis Galton.

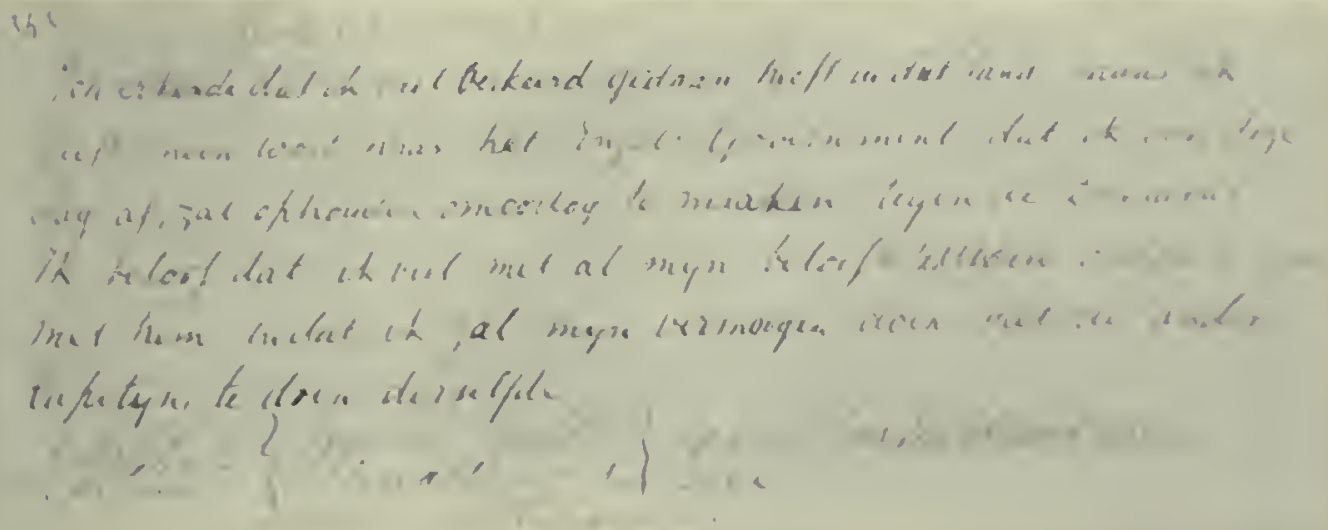

Facsinile of the original promise of Jonker Afrikaner to keep the peare in Jamamand. 'J'he promise is in Dutch and signed by the Chief, witnesses Francis (ialton and Jinotluens Surewe. 

neighbourhood, and within the probable reach of her future commerce, and which were understood to be in danger of oppression from certain British subjects and others who are in no way connected with your [Jonker's] people. Now this specified tract of country includes Damaraland and my instructions are of so general a character that although not framed with a view to oppose Namaqua oppression in particular, yet in so far as it is oppression, carried on in part by British subjects and in this part of South Africa it becomes iny immediate duty to act upon them." [Letter to Captain Jonker Afrikaner from Barmen, Nov. 25, 1850.] Even while Galton was waiting for the answer to this letter to Jonker-which answer the latter sent 300 miles roundthe Hottentots burnt eleven of the remaining 15 werfts of Kaitchené and eleven others belonging to other Damara chiefs, corresponding according to Galton's calculations to about 18,000 head of cattle raided. Galton could not possibly go forward through the middle of this ravaging, and with characteristic pluck, and probably disregarding entirely his very nebulous instructions, he determined to frighten Jonker into more orderly behaviour. His fairly stern letters had produced no effect. Such was the origin of the "red hunting-coat" expedition as described in the above letter. The end might have been very different, but Galton faced the danger, got abject apologies to the missionary Kolbe and to the British Government signed, and laws proclaimed by the Hottentot chiefs to rule their relations to the Damaras. We reproduce Captain Jonker Afrikaner's promise to the British Government: see Plate LVIII. 'Translated freely by Galton it runs :

I acknowledge that I have done much wrong in this land, but I pledge ny word to the Fnglish government that from this day forward I will abstain from all injustice to the Damaras. I promise that I will with all my power keep pence with them and that I will use iny influence as well as I can to persuade the other Captains to do the same.

Witnesses to this signature:

[Signed] I am, Jonker Afrrikanen.

Francis Gatton.

Timotueus Sneewe.

Interesting are the notes Galton, then aged 29, wrote for the speech he made as first lawgiver to this lawless crew. They run as follows:

Speak about the signatures, strength of England, could furnish every Danarn with a gun, çould cut off trade to soutl.

(1)' What is "justice," explained by these laws. 15 laws camnot meet every cise, but they will lay down a base on which very many cases may be treated. If

' The numbers refer to the remarks on the special laws which follow this. 
J. acts wcll on the whole, it will be known, if ill, also. No enquiries need be made into special cases. It is the office of a Captain to take the labour and anxiety of judging on himself. A man who does not do so is not fit to be a chief.

(3) Better ten guilty escape than one innocent suffer.

(4) Against the practice of retaliation (indiscriminate).

(5) Speak very strongly about this-it shows the Numaquas are cowards-say they are drunkards too.

(6) Very much punishment must be left to the discretion of the judge; this explains the principles on which it is regulated. Crime is never checked by severe and uncertain punishment. If too severe it raises sympathy on bchalf of the criminal and the laws are hated.

(7) Speak much on the advantages of certainty and quickness of punishment towards checking crime.

(8) J.'s simple justice. J. must not keep the [stolen] cattle for himself, but retm'n the stolen-and half the "Regt's Beesten" to the Damara.

(9) I conceive that in the long run the "Regt's Beesten" will defray the costs of justice. A sufficient number of the stolen cattle must of course be found to warrant acting under this law.

(11) To receive oxen in compensation for punishment would be in most cases simple bribery in order that oxen might be stolen. J. might be glad to have a watcher killed that he might demand oxen.

(12) Great honesty must be shewn in regard to the "Pand Ossen" and simple suspicion must never warrant their being taken. Culprit must be brought to Jonker's place to cnsure a cool enquiry into the case and proven identity.

N.B. For frequently repeated thefts stronger measures must of course be taken.

(15) Allude again to No. 11. Police Badge.

Here follows Galton's code ${ }^{2}$ put into the mouth of Jonker and read out in Dutch to the assembly:

(1) I have pledged my word to the English Government that I will act lienceforth according to law towards the Damaras.

(2) Now I give these laws for myself and for iny people.

(3) I will not treat the innocent as I treat the guilty.

(4) I will not fire off an innocent werft to make amends for stolen cattle.

(5) I will not allow that women and children have their hands and feet cut off and suchlike mishandlings.

(6) I will not punish a thief with death, and I will not give heavy punishments for small offences.

(7) But I shall do my best that no offence against me or my people shall remain unpunished.

(8) I will also punish iny own folk, who do injury to the Damaras, with the same penalty and law as I punish the Damaras with, who do injury to me or my people.

1 I.e. the judicial fine measured in oxen.

2 The Dutch version is in the folio volume; a much overwritten and rewritten English original in one of the pocket-books in Galton's hand. 
(9) But when beasts or enttle are stolen from me or my people, I will take two-fold as many from the thief, or from those who have aided the thief, when it is froven. That it to say, I will take again the beasts which have been strolon, or when $\mathrm{I}$ cannot find all, so many as the number is. And I will also take the same number as "Regt's Bcesten" (that is to say, cattle taken to pay for the trouble und costs).

(10) Also I will punish the thief with forty lushes.

(11) When one of my wateliers on the feldt has been murlerecl, and my cattlo stolen, then shall the murderer be brought to my place and put to death. I will take no payment from the murderer in any form whatever.

(12) From him who hides a thief, I will take 10 oxen as pledge oxen (Pand Osseu), and retain them until the thief is brought out to me. I will take 20 pledge oxen from those who hide a murderer. I will give these back when the evil doer is brought to ine.

(13) If the thieves drive my eattle away to a werft, and the werft will not give the thieves up when my men go there and ask for them, then $T$ will not fire that werft, neither will I take all their oxen, but I will take back the loasts that are stolen, and from their beasts will drive out "Regt's Beesten" for the werft is gnilty, and besides these I will take the pledge oxelı. I will not take more.

(14) Furthermore if the men of the worft have fled when they see my men coming and have left their cattle loose on the feldt, then I will not take all beasts that they have, but I will take the stolen cattle out from among the others, and then over and above the "Regt's Beesten" and the pledge cattlc. I will take no more.

(15) The half of the "Regt's Beesten," shall go to him from whoin the cattle have been stolen. The other half groes to me. The pledge oxen I take in clinrge.

A primitive law code it must be admitted! But this Galtonjustice ruled for many months on the borderland of the Nanaquas and Damaras, and half-a-dozen honest Englishmen with fifty Cape mounted police could have maintained order and developed trade for many years in that district after Galton's visit. As it' was the Britisl Government idled and faltered, until Germany stepped in to reap where Galton had sown.

Imagination dwells pleasantly on the youthful law-giver fresh from his fallow years of shooting and hunting facing this population of "O'erlams" - a mixture of Boer and Hottentot blood-the greater part of whom according to him had the common "felon face." A note made on Jan. 24, 1851, in one of the pocket books is, however, worth reproducing:

"Jonker is deeidedly a talented man and seems in full vigour, his shrewd remarks, concise deseriptions and keen observation shows him to be no ordinary man. He came out quite as a diplonatist in the long conversation I had with him about the interior, artfully contriving to turn the conversation to his own ends." 
Galton's influence not only over Jonker, but over Cornelius, Swartboy and Amiral, was marked, and it is characteristic of the man that but little of it is manifested in his published book. The whole episode of his attempt to establish order in Namaqua and Damaralands must be studied in the MS. notebooks.

The following is the bare account which reached the press of that day of Galton's proceedings.

\section{Cape Newspaper. 22nd August, 1851. Mr Galton's Expedition.}

Letters have been received from the enterprising travellcr Mr Galton who our readers will remcmber started for the Great Lake via Walfiseh Bay in September last. Mr Galton writes, under date the 1st Marcl from Lat. 22 Soutl, Long. 10 $40^{\circ}$ East. M. Galton arrived in the Damara Country in October, he reports constant fighting and wars of reprisals between the Damaras and the Namaquas, which eommenced 4 years ago but lad lately increased in ferocity and extent; Jonker Afrikaner being a principal mover. The destruction of the village of Damaras, gatlered around $\mathrm{Mr}$ Kolbe's mission station reported in the papers at the time, and the purchase of plundered cattle lyy white men, had led to difficulties in the way of $\mathrm{Mr}$ Galton's progress, and to the prospects of commerce. Mr Galton, on his arrival in that eountry wrote to Jonker Afrikaner, acquainting him with the instruction he had received from the Governol to establish friendly relations with the native tribes on the route to Lake Ngami, with a view to prepare a way for future commerce and to warn them against ally attempts to dispossess them of their country; and intimating the displeasurc of the British Governor at the oppression of the other tribes by the Namaquas. Jonker's answer was delayed a month and was unsatisfactory, and Mr Galton then rode straight to him with an escort of only three followers, and succeded in thoroughly alarming him. He nuade Jonker write a most ample acknowledgment of his wrong to Mr Kolbc ; and adrised him also to make the same aeknowledgment to the British Governor, which he did, and sent it by a messenger forthwith to the colony. Mr. Galton also macle Jonker send for a neighbouring captain of the red people, and made lim also solemnly undertakc to leave off oppressing the Danaras, and wrote out a few simple laws to meet cases of cattle stealing, which were eordially agreed to. One of these laws provided for the cqual punishment of Namaquas with that of Damaras for stealing. Some of their own disputes wcre also voluntarily referred to $\mathrm{Mr}$ Galton as umpire. Mr Galton has received much valuable and interesting information respecting the transactions in that part of the country for some years past, from the diary of $\mathrm{Mr}$ Halnn, the longest resident missionary among the Damaras. Mr Galton, at the date of his letters, was to start for the interior in two days, but intimates his intention of returning that way in about six montlss. A considerable impression las been made on the native minds by Mr. Galton's visit, and a way appears to be preparcd for the progress of Europcan commerce and civilisation in that direction at no very distant period : but very much will depcnd on the conduct of those here, who hereafter attempt to open ont further relations witl the natives.

We shall cndeavour to proeure for our reaclers if possible, further details of these nost interesting communications. 
We may now return to the home letters.

DEAREST Mother,

$$
\text { Feby. } 22 u d[1851] \text {. Iat. } 22, \text { I Alng. 18" 50". }
$$

......We are all well provisioned here, I have ahout 85 wxen mol $: 30$ small cattle. Still, eating notling but meat, and laving so many mouths to feerl, an ox hardly lasts 3 days. I allow 4 lbs. of meat to eaeh man. I luve quite lost all care for vegetables, and I have only drank wine (or ratlier brandy) onee since landing at Waltisch Bay. We have had admirable health und now although the sun is ligh yet the rainy season has brought its clouds and the climate is really very plensant. I an hecoming a stnnning shot with miy rifle, and always shoot plenty of clucks, partridges and guinea fowl with it. Andersson is quite invaluable, and I lave a very good set of servants now, some I picked up in the country. Three I turned away-me of these committed some barefaced robberies, but the natives were afruid to take him prisoner: T happened to be at Rehoboth shortly after he left it, where I lieard of what he hal done, and I rode very hard to the Southward for a night and day-changing oxen after him, but a stern chase is a long one, and he had too mueh start, so that I could not catch him.-Oxen are certainly cheap among the Damaras-you recollect my guns that I gave $9 s .3 d$. each for-well I get 5 large oxen for each gun-I heartily wish I had more.-I do not think that I shall be more than 6 montlis from here, as I must keep my eye on the Namaquas. If fortune favours me, I slall be able, I have no doulst, to make an entirely open load for future commerce here-where people may travel and trade without any danger. I have taken great pains about mapping the country.-It is a great anusement, and the Government at the Cape, expressed so much anxiety about creating a cattle commeree here, that I have no doubt that what I have clone will be soon followed up. We have found that there really is a lake, corresponding to what was placed down as Demboa, in the map you had from me-its name is Omabonde-there I am first going. I have several blacks in my service who lave been there. I'lic Ovampo Blacks live close by. They are a good set of people, everybody spenks well of them. For interpreters I am right well off and on the whole, all looks very favouralsle. I fear my letter is very dull-when I can write again I do not know, but do not expect to hear from me at any fixed time.-There are so many difticulties in sending letters that it is impossible to be punctual but in 6 months I dare say you will get one. Give my best love to each and all of the Family and believe me ever, Your affectionate son,

\section{Frank Galtos.}

\section{Dear Darwin,}

Lat. 22, Long. $16^{\circ} 50^{\prime}$. Feby. 23rd, 1851.

......We had such a chivy after a hyena two nights ago, the dogs found hinı just as we had all turned in to sleep. I jumped up, had only time to put my shoes on and dressed in them, my shirt and my gun and nothing else, had a scamper up and down, through thorns and over hills for ever such a way. I could have speared hin two or three times, but could not shoot for the darkness and the dogs. - At last he stood at bay in an open place where I shot him through the back bone. Talking of back bones, as I have just left the land of the Hottentots, I am sure that jou will be curious to learn whether the Hottentut Larlies are really' endowed with that shape which European 
milliners so vainly attempt to imitate. They are so, it is a fact, Darwin. I have scen figures that would drive the females of our native land desperate-figures that could afford to seoff at Crinolinc, nay more, as a scientifie man and as a lover of the beautiful I have dexterously even without the knowledge of the parties concerned, resorted to actual measurement. Had I been a proficient in the language, I should liave advanced, and bowed and smiled like Goldney, I slould have explained the dress of the ladics of our country, I should have said that the earth was ransacked for iron to afford steel springs, that the seas were fished with consumnate daring to obtain whalebone, that far distant lands were overrun to possess ourselves of caoutchouc - that these three products were ingeniously wrought by competing artists, to the utmost perfection, that their landiwork was displayed in every street corner anil advertised in every periodical but that on the other hand, that great as is European skill, yet it was nothing before the handiwork of a bounteous nature. Here I should have blushed bowed and smiled ugain, handed the tape and requested them to make themselves the necessary measurement as I stood by and registered the inches or rather yards. This however I could not do-there were none but Missionaries near to interpret for me, they would never have entered into iny feelings and therefore to them I did not apply-but I sat at a distance with my sextant, and as the ladies turned themselves about, as women always do, to be adnired, I surveyed them in every way and subsequently measured the distance of the spot where they stood-worked out and tabulated the results at my leisure. I have been measuring other things all the time I have been here, for I have been working hard to make a good map of the country and au quite pleased with my suceess. I can now calculate upon getting the latitude of any place, on a clear night to three hundred yards. I have fortunately got very good instruments and have made simple stands $t_{1}$ mount them upon, so that I can in a few minutes set up quite a little observatory. My little tent has been of great use in making excursions witl ride and pack oxen. It is perfectly waterproof and is still as good as new. My establishmont now consists of 9 white or whitish people, including myself and two blacks but they are men who have lived with Whites all their lives and about 10 natives-86 Oxen and 30 small cattle, and some 6 or 7 dogs; together with two waggons. We start on wards the day after tomorrow. Now we are at the furthest point Whites have ever reached and we steer about N.W. to a lake we have heard of about 200 miles off. I shall then make a short tour and return here to keep the Nanaquas in order. I want to explorc this country thoroughly. It is a very important one for future commerce, and I should prefer exploring it well, rather than quickly going over a long line of country. I have learnt a great deal about the place and people and all that, but it is a long story about which you could feel little interest and therefore I spare you the history. We live on nothing but meat and eoffee-and it suits us all admirably, there is quite enough to do to keep us from being dull-though I certainly should like to be dropped for a week in civilized society and then be taken back again....... I of course have heard nothing from Home sinee 1 left it.Give nuy best love to everybody and believe me Ever affectly. yr's. Frank Galton.

If $\mathrm{I}$ get smashed I have told Andcrsson he may take all my things in Africa, and also that the wages of the men, which are $£ 17$. 15. 0 . a month shall be continued for three months beyond the time that is reasonably neccssary for the expedition to reach Cape Town. I have given him and also sent my Bankers a paper about it. 
(The lake I had licard about I went to; it proved to be a nucre nothing, Ommubonde is the name of it'. I did not try to get to Lake Ngami.)

Mr dear Casipbeld. I have just returned to tho most advanced missionary stations after my exploring journey, which indeed led me through a country inost desolate, tborny and uninteresting. But the end of it quite repaid iny trouble, for I came to a pcculiarly well eivilised (if I may use such a word) nation of blaks where I was received most kindly but beyond whose territory I was not permitted to pass. I lisul arrived within 4 days of a vast river, the wonder of these parts, and to which the Portuguese traders reach, but it was impossible for me to go on. My waggons were broken and left bchind with half my party to guard them anongst a large trile of savages. My slaughter cattle were almost all consumed, and there was not nearly game enough to support us. I had ridden forward the last 200 miles on oxen, and these were knocked up and quite unable to stand more travel, so that I was in quite an unfit condition to foree my way further. It was therefore with no ordinary reluctance that, like so many other African travellers, I was, when at my most interesting point, obliged to turn back. Still I consider that I have completed the road from the Portnguese boundaries to the Cape, for the small intervening traet of land which $I$ have not seen is well inhabited and well watered. My furthest point was Lat. $17^{\circ} 58^{\prime}$, Long. $17^{\circ} 45^{\prime}$. The nation I reaehed was the Ovampos, governed by a fat stern king. I crowned him with all solemnity. His country is most fertile, broad plains, half corn, half pasturage. $\Lambda$ bundanee of palms and other fruit-trees of magnificent size; they have poultry and pigs and live right well. I did not see a single person anong them who shewed the lcast appearanee of poverty. They have more than one sort of corn; that which they prize the most is, I believe, unknown in Europe; it is eertainly unknown in the North and the East of Africa. I have of course brought plenty of it with me. Their fowls too are nice like Bantaus, so I put a cock and two hens in a basket and madc a man carry it all the way back; they thrive very well and are always laying eggs, which I am distributing among the missionaries so as to ensure extending the breed. I eannot say that we have had any real hardship, though the annoyances havo bcen very great. We were mistrusted from the first as spies and could get no guides; the roal was horrible for waggons, dense thorns curved like fisb hooks cruelly tore our clothes and lands, the oxen dare not face tbem. However I got them on 300 miles, and then the best waggen broke down. It was mended on my return from Ovanipo-land and we got back safely. I have learnt is great deal about the interior of Afriea which will much interest those who care about such things. Now I have my hands full of Namaqua Hottentots. I told you how I had been setting the affairs to right in these parts before I left, and all have continued in admirable order up to my returu. One tribe had however just broken out, so as soon as I came to the first Namaqua chief and heard all about it 1 rode straight away 100 miles in a day and a half to the next chief (where I am now) and tomoriow I take hin back with me and the two cliefs are to ally together and compel the rebel one to restore all that he has just robbed with mucli loss of life. The barbarities that occur daily in these parts are most horrible and disgusting. It was quite a relief getting beyond them to the Ovampos. If all turns out well I go ill

' See remark, ftn. p. 216.

P. G. 
a few days about 300 miles to the East for a little Elephant slooting. I cin get horses now, and after all my trouble I want a little amusement, and I expect to gain some information that $I$ want in that direction. A ship comes to Walfisch Bay in January and by it I sliall go if all is right to St Helena on my roal home. I canuot express the intcrest I feel to hear about England. No post has come here since I alrived but the ship is to loring everything. We have been most fortunate as regards lealth none of us liave ever as yet suffered from illness, and everybody did his duty with the greatest good liumour. For myself I fcel in better health than I ever did in Iingland, I hope that your occupations have not induced you to abandon the noble sport of fox hunting. I have now tried many sorts of hunting but I cand[idly asscrt] that fox hunting will bear comparison with any. 'T[here may be] greatcr excitement (but not mucls) in going after a large and vicions be[ast, but] the excellent horses of England, the music of the hou[nds and the nice] society are wanting in this country. I don't know that I have had any particularly hair breadth escapes; perhaps the one that was most so was in running up a hill I was quite blown and jumped up on a ledgc of rock, when I had a little lost my balance. It happened that I had lcapt on a large serpent's tail. one said to be of the most venomous kind, a black creature 7 feet long. He was up in an instant as high as my face in a fearful wrath, and drew back lis head to dart at me ; but I had recovered my balance, and did not wait for him, for I leapt clean down the steep rock near. He came down too, but when I at last found a stick he was going best pace among the bushes, and though I had a long chivy after the rascal, I could not kill him. Pray remember me to Lady Stratheden, and to your party and believe me ever sincerely yours, FraNK Galton. I legret much that I could get only a bag of the new corn for the Harmonicon that I was cntrusted with.

\section{Eiknams, Namaqua Land, S. Africa. Augt. 16th, 1851.}

Dearest Mother, I have a long story to tell, so long that $I$ think it will tire you to read it, all about captains and chiefs and all that sort of thing, which interests people in these parts, but about which you cannot be expected to carc. I lave returned after a journey not so long as $I$ had hoped to have made, lout still extensive enough to save my credit as a traveller. Of bran new country $I$ have explored about 500 miles out and then went back again by much the same route. The Portuguese and the magnificent intervening river, of which the Cunene is but a branch, I did not quite reach. Those abominable waggons have been like a drag chain upon me. All has ended wcll and wc have had no sickness whatever. Andersson is a right good fcllow and I have had plenty of occupation in mapping the country, so that altogether the time las passed pleasantly. Of game there is next to nothing, my guns have been quitc idle.-A fter leaving the farthest Missionary Station, I got just betwcen the two principal Black chiefs, who wcre on the point of fighting. I managed to get myself and party clear of the massacrc, and without guides had the good luck to find a sufficient quantity of water from place to place for ourselves and oxen, so that we had no hardship that way. The country was a dense mass of thorns, not simple straight thorns like a quickset of hedgc, but curverl like fish hooks, the oxen would not face them, it was terrible work getting them on. I often tried the strength of thesc thorns by fastening a bit of rag to it spring balance and pulling till the thorn broke-onc thorn stood a pull of $27 \mathrm{lbs}$. - just conceive. Our 
clothes were in rags and at first our skins were very painful, from being torn abrout so mucli, espeeially as the scratehes generally festered, but we got hard in time. IVell I found my way to the reported lako Omanboude, which was as dry as dust, not a drop' of water in the reeds, quite a sell. From the natives' leseription wo hinl reekoned on a sheet of water about 30 miles by 8 . It was just a bit of a water course 300 yards broad and might be in the rainy season 2 miles long-Lake Ngani I luve not tried for. Well I went on to the North. We moved very slowly-the waggons hal to erush through everytling, and the oxen would not pull through the thorns. After 300 miles altogether I got to the end of the eomntry of the Ovahereros and to a large village. Henee I tried to get guides to the Ovampo, the ehief would not give them, so I set ofl again, for we would not be beaten. Just at starting the oxen were frightened and sot off on a trot, there was a rotten looking stump in frout, but really a liard strong treethe near fore wheel of my best waggon came against it and erash went the whole coneern. There was a fix; we set to work, brouglit the other waggon alongside-ntade a hedge of thorns, eleared the ground and at onee a party went off, to eut down trees to mend it. The road had bcen so stony and execrable in every way, that it would ho folly to venture witl an axletree of green wood, and so the waggons must stay some weeks there, while the trees seasoned a little. I halved my party, and Andersson and inyself saddled our oxen and went to the North. We got a man who said he could take us the 15 days' journey on to the Ovampo, he led us all wrong, and we were hard put to it for water. All sorts of little disasters oceurred, we made three pushes to try and get on; the third time most fortunately we met an Ovampo trading party, who harl come down to buy eattle, so we went back with them, waited 3 long weeks till they were ready to return and then went to their eountry with them. After 200 miles, the bushes and thorns suddenly ceased, and the charming eorn country of Ondonga, with its palms and fruit trees, was before us. I rode to the King and erowned lim straiglitway with that great theatrieal crown I had. He was a brute, fat as a tub, but his people were most hospitable. The journey had been longer than I thought, my oxen were in a sad state, footsore and galled baeks. I had to buy and earry back provisions, for we laad but little eattle left. The Cunene river was 4 or 5 days a head, but Nangoro (the King) would not let us go; had I been able to stay 3 or 4 weeks, I might have persuaded him or frightened him, for he had a strong dislike to gunpowder, but it was impossible. My waggons and the men with them, were in a preearious situation. I could not wait, so I paeked $500 \mathrm{lbs}$. of corn flour, beans and so forth, on my oxen's backs and returned. All was right-the waggon well mended, axletree better than before, and about 60 more sheep and a few oxen, had been bought while I was away. We got back without aeeident of any sort by a slightly different road, and I am now at the Namaqua chief's place. I told you in my last letter how I made peace over the eountry, and it has been adınirably kept during my absence. I have therefore given Jonker, the ehief, a coeked hat, and an old Ambassador's coat of M. Sampayo's-that he gave me when in London. He is highly delighted. I go now to the Last to get a little elephant shooting and shall swop everything I have for ivory, of which the Nimaquas there lave plenty, take it down to Walfiseh Bay and start by the missionary ship for the Cape or for St Helena, eitler in December or January. If however there uffer a good opportunity of going far, I may stop in the country. A trading party of 
Blacks, froon the Portuguese country, were at Mondonga, when I was there, but I eould not send letters by them. The people are very superstitious and would have nothing to do with written things. I have of eourse heard nothing from home since I left England. I neerl not say with what anxiety I look forward to the arrival of the missionary ship whieh will bring my post from Cape Town. I have of eourse picked up much about the country, whieh will be of great interest to the people, who care about thesc things. A posse of missionaries are going to follow iny road. The Ovampo are a charming set of niggers, but almost all the other nations I have heard of, are brutal and barbarous to an almost incredible degree. The Ovahereros, a very extended nation, attacked a villagr the other day for fun, and after killing all the men and women, they tied the children's legs together by the ankles, and strung them head downwards on a long pole, which they set horizontally between two trees; then they got plenty of reeds together and put them underneath and lighted them; and as the children were dying, poor wretches, half burnt, half suffoeated, they danced and sung round them, and made a fine joke of it. Andersson desires to be particularly remembered to all. With my best love to all the family, relations and friends eollectively and individually. Ever affectly. yours,

Frank Galtos.

Ondonga is Lat. $17^{\circ} 57^{\prime}$, Long. $16^{\circ} 44^{\prime}$ (my farthest point).

The waggons broke down Lat. $19^{\circ} 30^{\prime}$, Long. $18^{\circ} 20^{\prime}$-the furthest part seen by Europeans before is Lat. $22^{\circ}$, Long. $15^{\circ} 50^{\prime}$. Ondonga is the corn country of Ovampo land; the lat. and long. given above, are of Nangoro's plaee, the capital.

P.S. On further consideration I shall be almost sure to sail for St Helena in Deeember or January.

Walfiscil Bay. 8th Decr., 1851. Reed. 27 th March, 1852.

Dearest Mother, I have just returned from my travels to the Sea Coast, and have now to wait there until the vessel comes to fetch me and bring my letters, Sc. This note I send by a ship now in the Bay and I wish much that I could go with her but I have to look after my men and I had ordered all my money to be transferred from the Cape to St Helena, but whether the letter has been received or not I cannot tell-so I must wait here a little longer, it may be a day, or it may be two months. I have made a pleasant journey this time and pushed on very far and to my satisfaction reached the traeks of people who had gone on to the great Lake. This year has been unusually dry, the driest that is known and so all along we have had great difficulty with water. Now as I went this time it was six months sinee any rain whatever had fallen, the cattle were dying of thirst, even at the regular watering plaees, so that you ean fancy it was not easy to get on in travelling. However I eane very well to the furthest point that the Hottentots hereabouts had ever reaehed to the Lastward, and there I heard a great many stories about the great waters a little further on (some ten days) from the Bushmen. There was a broad plain 63 miles aeross, with no water now, which made the next stage; so I got Bushmen guides and started. These distanees which are nothing to a camel take a great deal out of an already tired ox; I had only 7 ride aud pack oxen with me, two of them died on the road and a third was crippled he is since dead. However we got there all right and magnifieent shooting there was. All the Bushmen and beasts of the country were collected there and any number almost of the 
$26^{6}$ 
SKFICHES FROM GALTON'S AFRICAN DLARES.

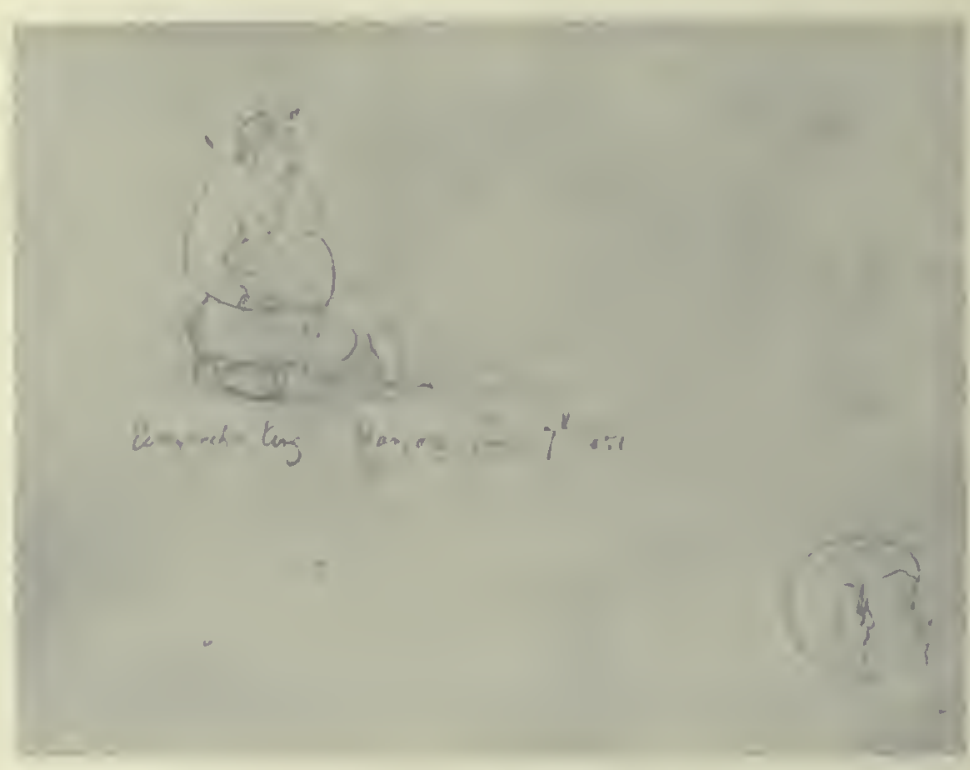

Nangoro, King of the Ovampo, origiual sketch, June $\tau, 18.51$, of his Majesty erowned with the theatrical tinsel crown purchased in Drury Lane. Cf. Plate Xxxvill.

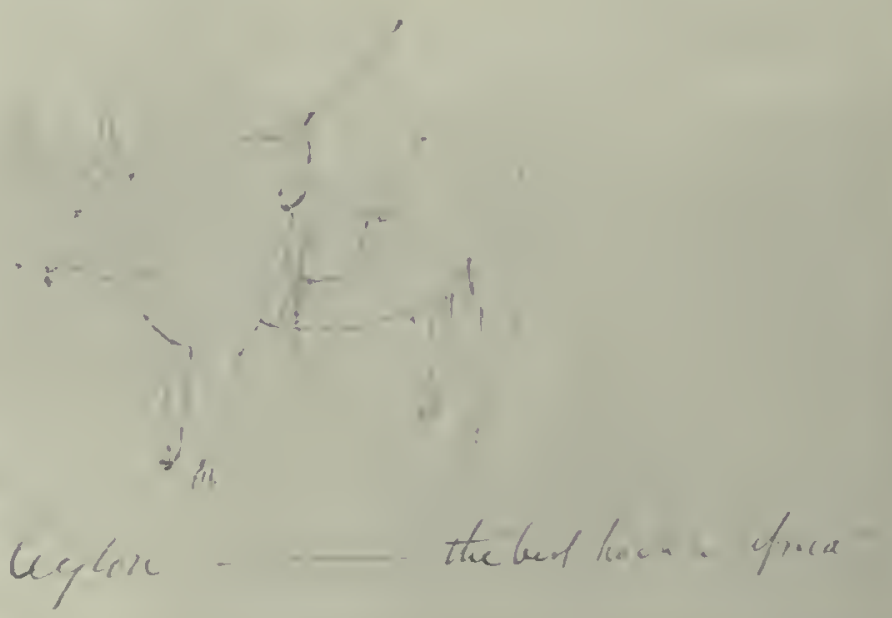

Galton's farourite hack in Danaraland. 
latter could have been killed. We got tircd of shooting and after banging thirty rhinoceroses in a week, left them alone. The Bushmen wero in ecstasies, they drick every bit of the meat and wasted none. There were herds of elcphants there luut what could be done! The country was perfectly open and without horses it would have leen madness to have gone after them. They look inmense beasts in the night time. Wo sat up in the night in little places built round with loose stones. The walls about 3 feet high, and a circle of some six feet across, close by the water and there waiterl for the rhinoceroses. Many were shot 8 paces off-most about twelve. They very seldom drop on the spot, but as soon as wounded run about most viciously-orre found out Andersson and knocked down his screen however he juuped out on the other side. They are extremely quick beasts-the largest shot was 16 feet long and about 6 feet high. I forget his girth, but it was enormous. I put a bullet clean through one, in at one side, and out at the other. It is very seldom that this happens, as the hide is so thick. Well at this place we came on the tracks of people who had reached the Lake on ride oxen, and great scoundrels they were too. The story is a long one, it is this. The year after Mr Oswell discovered the Lake, some Griquas explored a direct road to it, from the Southward and just after they had gone a party of the Kubabees (also from the South but more to the West than the Griquas) also went up the country on a plundering excursion. They reached 'Tounobis the place where we shot the rlinoceroses, and there hearing of the Griquas, they got Bushmen guides and reached their waggon tracks in four days, three days more brought them in sight of the Lake, and to the borders of a river that runs out of it to the eastward; there they attacked a small village. The Natives (the Mationa) all had their throats cut and the cattle were driven off: Another very large village was near, so the Kubabees dared not fire, for fear. of being heard, so they only cut the throats of the people in the small village, and then went quickly back. They got, I hear, some very pretty carosses and all the Bushnren assure me that the unicorn is found here. I renlly begin to believe in the existence of the beast, as reports of the animal have been received in many parts of Africa, frequently in the North. Anyhow the skins which were stolen werc quite new to all those who saw them. The guide of the Kubabees was one of my many irfornunts. Last rainy season another party of 4 waggons and plenty of horses went to the Lake to shoot elephant. I do not know whether they have been murdered there, or returned some other way but nothing more has been heard of them. I could not find out, whether they were Griquas or Europeans-one of the Bushmen had got one of their iron cooking pots, a broken one.-I woulcl have pushed on with my 4 remaining Oxen that were in travelling condition, but the next stage which intervened, between where I was, and the Mationa, was said to be a still longer one than that which $I$ had just come. It was risking too much. My time was very limited, and as it is, after my return to iny waggons, I have come down at such a pace that my remaining oxen are quite unfit for the shortest journey (I was so afraid of missing the ship that I expected). The rainy season will now soon come on and in April there will be water everywhere. My remaining things I have divided in two parts, with one I have paid $£ 100$ of wages \&c. to Hans (my head man) who wants to stay in the country, the other half I have given to Andersson, who has entered into partnership with Hans, to trade in cattle and ivory. Andersson has been a right good fellow and has gone through very hard work. I have 
thus fairly made out a roarl perfectly praeticable in the rainy season from Walfisch bay to the Lake, and what is morc I have thoroughly identified the river that runs to the North of the Ovampo witl one that runs out of the west corner of the Lake, and which very likely will beforc long, prove a lighway to the interior.-Andersson will gro to the Lake next April. A posse of missionaries will go to the Nortl about the same time, so that discovery liereabouts will still be going on. This coast is the only one by which a praeticable eommunieation with the interior can be marle-and I expect that beforc long it will prove of much inportance. I have got a little ivory, about $300 \mathrm{lbs}$. weight. It will depend a good deal on the letters I receive, whether I go straight liome henec or. not. But I have had almost enough of knocking about, and should much like a little civilized life and a bed to sleep in. We have all had excellent healtll. It is now nearly two years sinec I have heard anything of any description whatever from lome, so that I an getting very anxious for my letters. I wonder if you have received any of mine. I wrote in Feby. and in Augst. 1851. St Helena is now my first point, it may be even 3 months before I an therc, though I hope it will be mueh sooner. I will write iny next letter from thence. Goodbye now, with my best love or regards to every relation, eonneetion or friend. Believe me ever Yr. Affeetionate son, F. Galton.

\section{Ema Schooner, en route to St Helena. Janry. 8th, 1852.}

Dearest Mother, Thank Heavens I an safe away from the Savages, in better health and all that, than $I$ think $I$ have ever been. We are just half way from Africa to St Helena where $\mathrm{I}$ trust that we shall arrive in less than 5 days. I write this to be posted as soon as I land there, though I myself shall stop a little to get what information I ean upon some points that interest me a great deal from the niggers. I was most delighted when this vessel hove in sight at Walfiseh Bay where I had been stopping for a month waiting here, and considerably in doubt whether ol no, she would have brought me my letters \&c. from Cape Town. All however turned out right, and a fine packet of letters and newspapers made their appearanee, being the first news of any description that I had reeeived from home sinee leaving Plymouth Dockyard, and most thankful was I, that all of you at home were in the same good health as when I left you. Many happy new years to you all. Poor Hallam ${ }^{1}$ ! I feel as nuch grieved at his deatl as if I had lost a near relation, it makes a sad blank among my oldest friends. Walfisch Bay usually quite deserted, has been thrown into the greatest exeitement by no less than 5 Vessels - 3 of which where Whalers and one a man of War brig, coming in whilst I was there. I was in a nicely ragged state to pay my respects on board the Brig, but was most hospitably received. It was the "Grecian," Captn. Keane, who knew all the Howards and who was most civil. There had been a rumour that gunpowder was intended to be taken overland to the Kaffirs from there and she came down to reeonnoitre I of course was able to give all information as to how it could be stopjed, ire., if any arrived, and sent letters to the Native Chiefs telling them to stop the waggons if any came icc. I have brought these gentlemen into a considerable fear of ine, Heaven knows how, but principally by bullying them. They made me their umpire in all weighty questions and do anything for me. Only think of the Chief one amongst

' Galton's friend Henry Hallam had dicd. 
thcm, an old man, riding a long ten days' journey right across an alooninable country, just to wish me goodbye before I left. Andersson I have left behind as trader, and set him up with my remaining provisions \&e., on eondition that he makes a gookl try, straightaway to reaeh the Lake, in this he will have I believe but little difliculty, as we have already so fully explored the more diffieult parts of the roads there. The Missionaries go in a posse with 20 guns in another direction due north to the grcat river, at my request, and now I am trying to find out where this river most nearly joins the sea, and if I can arrange affairs so as to get a cruiser to take ine there, which I do not think improbable, I will make a fortnight excursion to it and then return homc. I havo an excellent interpreter in my man Timboo and now knowing all the tribes adjacent to tho river, I shall have I think very little diffieulty in getting the necessary information at St Helena. To the Governor there I have a Government lettcr so I daresay that he will stretch a point to help me in my schene. I have traeed a water communication from a great lake if not the lake to the westward and so if I ean only find out its mouth, a great step will be gained towards opening a roarl to the interior. But you will be tired of hearing about these things, which though they are my hobby, cannot be expected to be yours. - So Douglas and Herman have both gone and got married; if it was not so late, I would have written to them to have offered my best eongratulations. The missionaries here have a very funny way of gctting married; when one wants a wife, he writes to the President of the Society who turns the matter over in his mind and picks out a likely young lady to suit him and packs lier off. The most extraordinary thing is, that the young ladies are quite willing to go, whether they have ever seen their future spouse or not. 1 wife came out by this vessel for one of thell. A middy on board the "Greeian" told me that he had lately met a German missionary at Sicrra Leone who had had no less than thirteen wives. The climate killing the poor creatures as fast as they came out. This Bluebeard was just married to his fourteenth. I shall be very glad of a fortnight's rest at St Helena. Potatoes and bread I have been worrying at ever since I have been on buard. They taste so nice after living for suel a very long time on tough meat and hides, and a house with a roof to it and glass windows will be a real luxury, right glad too I shall be to get on the back of a horse, aftcr plorlding inore than a hundred days' journeyings on that of an execrable ox. My saddle tree and stirrups I shall keep and use them in England. I shall of course write to you again from St Helena and so now, Goodbye and with ny best love to every individual of the family, Believe me, Ever your affectionate son, F. GaLToN.

Galton reached England on April 5, 1852, two years after his departure on the same day of the same month by the "Dalhousie." A sketch map of his route from Walfisch Bay to the interior had reached the Royal Geographical Society two months earlier. 'The paper describing his journey was read on Feb. 23 and on April 26, 1852, i.e. partly before and partly after his return. The preface to his Tropical South Africe is dated April 27, 1853-a year later. During that year he was awarded a gold medal of the Royal Geographical Society, followed in 1854 by the silver medal of the French Geographical 
Society. Of the chief friends and acquaintances of Galton on this tour, Andersson ultimately followed the Galton northern route to the Cunene, the border river of the Portuguese possessions, and the Galton eastern route by "Tounobis to Lake Ngani. Later he undertook commercial expeditions and tried a mining settlement in Damaraland; he had a stormy time with the Namaquas and an adventurous life, and ultimately died not far from Nangoro's capital. Nangoro's people cane in 1858 into a controversy leading to much bloodshed with an expedition of the missionary Hahn, and Nangoro himself died some say foully or some say in fair fight at the same time. Galton himself expressed much regret at this attack on Nangoro's folk. The disastrous expedition of the missionary Hahn led incidently to the discovery of a lake said to be 25 to 30 miles long, by name Onondova, in lat. 21 and long. $19^{\circ}$; this is probably the origin of the mysterious Demboa Sea for which Galton vainly sought. Since the days of the German protectorate the resources, geography and people of Damaraland have been often and copiously illustrated and studied.

The publication of Galton's Tropical South Africa led to a letter from Charles Darwin, the first of a fairly long series, and marking the resumption of an old acquaintance. It runs as follows :

13, Sea Houses, Eastiourne, Sussex. July $24 t h, 1853$.

Dear Galton,

You will probably be surprised, after the long intermission of our acquaintance, at receiving a note from me; but I last night finished your volume with such lively interest, that $I$ cannot resist the temptation of expressing my admiration at your expedition, and at the capital account you lave published of it. I lave no doubt you lave received praise, from so many good judges that you will hardly care to hear from me, how very much I admire the spirit and style of your book. What labours and dangers you have gone througli: I can hardly fancy how you can have survived them, for you did not formerly look very strong, but you must be as tough as one of your own African waggons!

If you are inclined at any time to send me a line, I should very much like to hear what your future plans are, and where you intend to settle. I so very seldom leave home, owing to my weakened health (though in appearance a strong man) that I had hardly a chance of seeing you in London, though I have often heard of you from members of the Geographical Society.

I live at $a$ village called Down near Farnborough in Kent, and employ myself in Zoology; but the objects of my study are very small fry, and to a man accustomed to rhinoceroses and lions, would appear infinitely insigniticant.

We have come to this for a few weeks for sea-bathing with all our children, now numbering seven. 
$240^{\circ}$

.




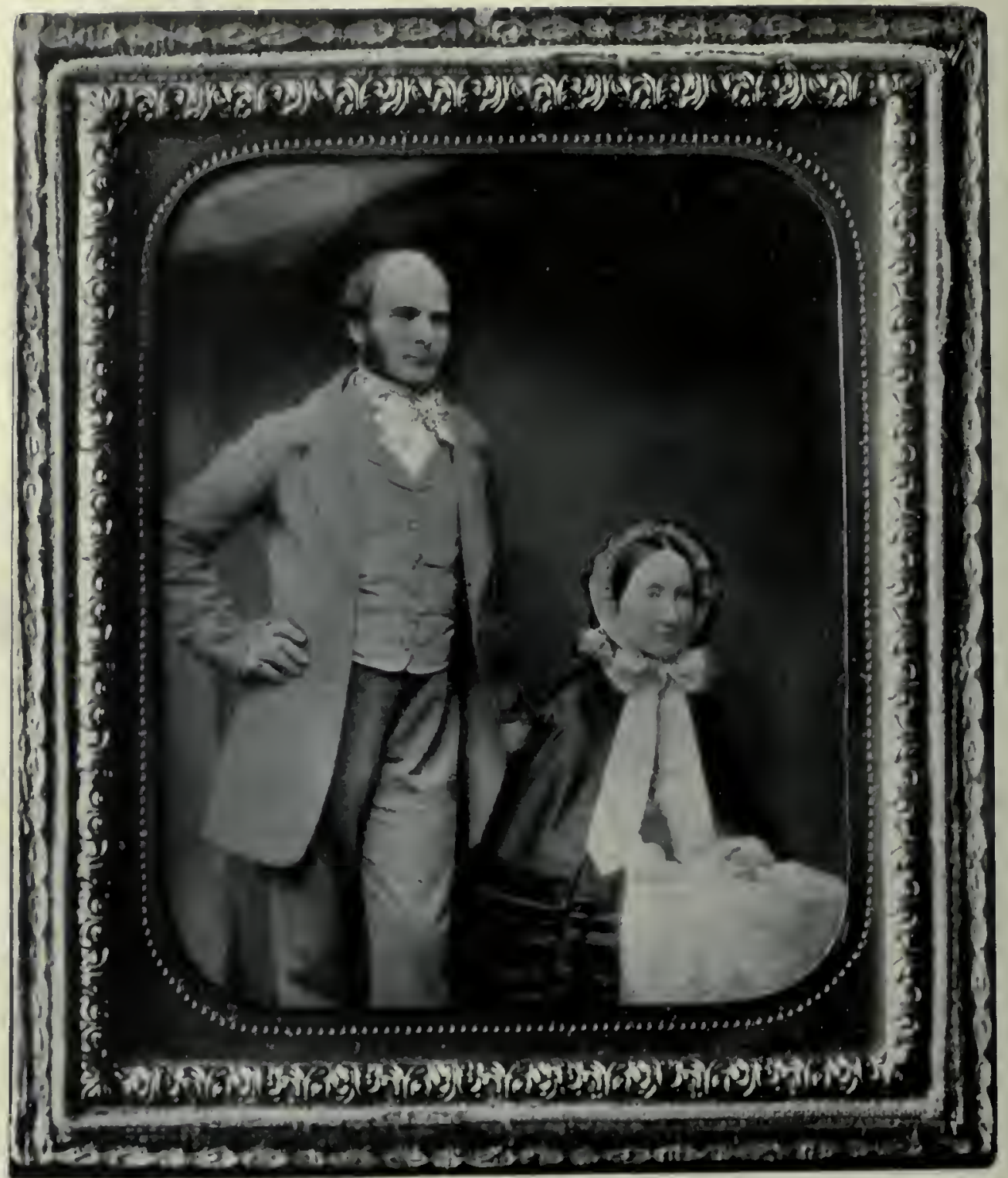

FIRANCIS GALTON AND HIS WIFE (Louisa Jaue Butler). lis early marriel life. lirom a photorriple in the possesion of Nh Wheler Galton at Claverdon. 
I should very much like to hear something about your brothers Durwin and Erasmus: I very distinctly remember a pleasant visit at the Larches, Heaven knows, how many years ago, and having inany rides with them on ponies, without stirrups. The only nember of your family whom $I$ have seen for years, is Enma, who guvc myself and wife a very cordial greeting at the British Association at Birminghan, some few years ago.

I do not know, whether. T ought not to apologise for troubling you with this notc, but the spirit whieh makes me write, must be my excuse. Pray believe me,

Yours sincerely,

C. Darmin.

In the summer of 1852 (June 14) Galton wrote it letter to the Royal Geographical Society urging the' want of proper instruments for travellers, and. we note therein the development of his interest in the study of the art of travel, to which we must return later. But he needed rest and he appears to have suffered from low fever, which was not completely dispelled by a yacliting tour with Sir Hyde Parker to Scotland and Norway. The winter was therefore spent at Dover, his mother and sister Emma nursing him. Here at a Twelfth Night party in 1853 Galton met for the first time Miss Louisa Butler. Early in March Miss Emily Butler writing to her brother A. G. Butler reports that "the lion-killer certainly seems smitten." "Galton returned in March and Miss Butler in April to London, where they again met, went together to the Crystal Palace, and returned engaged. On the day-April 27 -of Miss Butler's return to Peterborough, Galton finished his Trupical South Africa; three days later the Dean, her father, died suddenly at luncheon, and Francis Galton arrived the same evening to look only on the dead face of the man, who should have welcomed his daughter's future husband. There is little doubt that this sad initiation bound with unusual closeness the links between Galton and his wife's family.

Only one other characteristic picture of the Galton of these days has reached my hands. It is again in a letter of Miss Emily Butler to her brother of May, 1853.

"Mr. Cialton's book is very jolly, and gives one a high idea of bis resotve and prudence; the latter quality is so strongly developed that he has to have hats made for him! He has got such a tine medal from the $R$. G. S. When it was given him, the President said very fine things of him, but regretted that so spirited an adventurer was going to be spoilt and married. Mr G. says it was very well put or he would have thrown the decanter at the worthy President.

P. 1:. 
"Ml. G. came yesterday fresh from the Derby 1 I felt so plensed to have such " sportive relation. It was a splendid day at Epsom, and he was rery happy wanclering among the gypsies etc. He tells such rich stories and very neatly. He has been to spirit-rappings ${ }^{1}$ and had another eonversation in Damara with a deceased chief of that tribe. Is not that wonderful, for Mr Galton is the only man in Europe who knows Damara. The chief promised to go abroad with him, which is a pleasant look-out for Loui !"

The marniage of Francis Galton and Louisa Butler took place on August 1, and was followed by a tour in Switzerland and Italy, the winter being spent partly in Florence and partly in Rome. The return to England in March, 1854, was largely followed by visits, and on August 6 the Galtons again left for an extended tour in France. Hardly till the summer of 1855 did Galton settle down to stearly research, but from that year onwards there is scarcely a year which does not bring its definite piece of noteworthy research, and Galton's scientific production now becomes the story of his life. The extended continental tours continued throughout a long life, but they were holidays, and, however they extended his field of observation, they had no longer to do with scientific exploration. But what Galton had learnt in his African journeys, became the fund on which he drew for lis Art of Travel, 1855, and for those lectures at Aldershot on- the dit.s of Camparining (1855-6), by which he endeavoured to supply the "helplessness of our soldiers in the most elementary matters of camp-life," a helplessness the Crimean War was emphasising in the most potent and cruel of mammers. These suljects will be dealt with in the following chapter.

1 Francis Galtun enters under the events of 1853 - "spirit-1"upping mania." 
$2.42^{\alpha}$

Plute L.SI

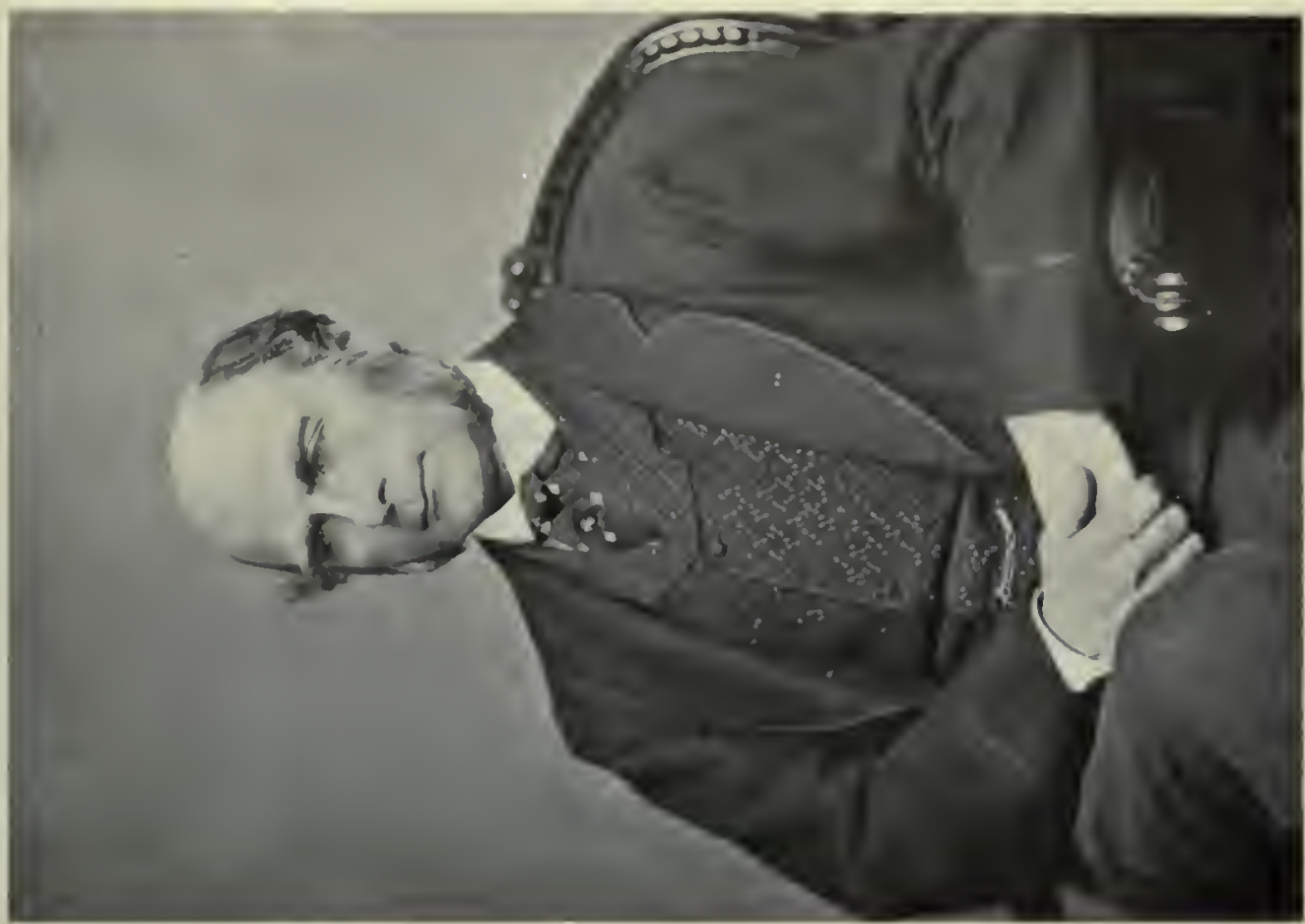

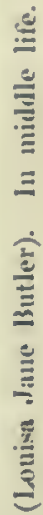

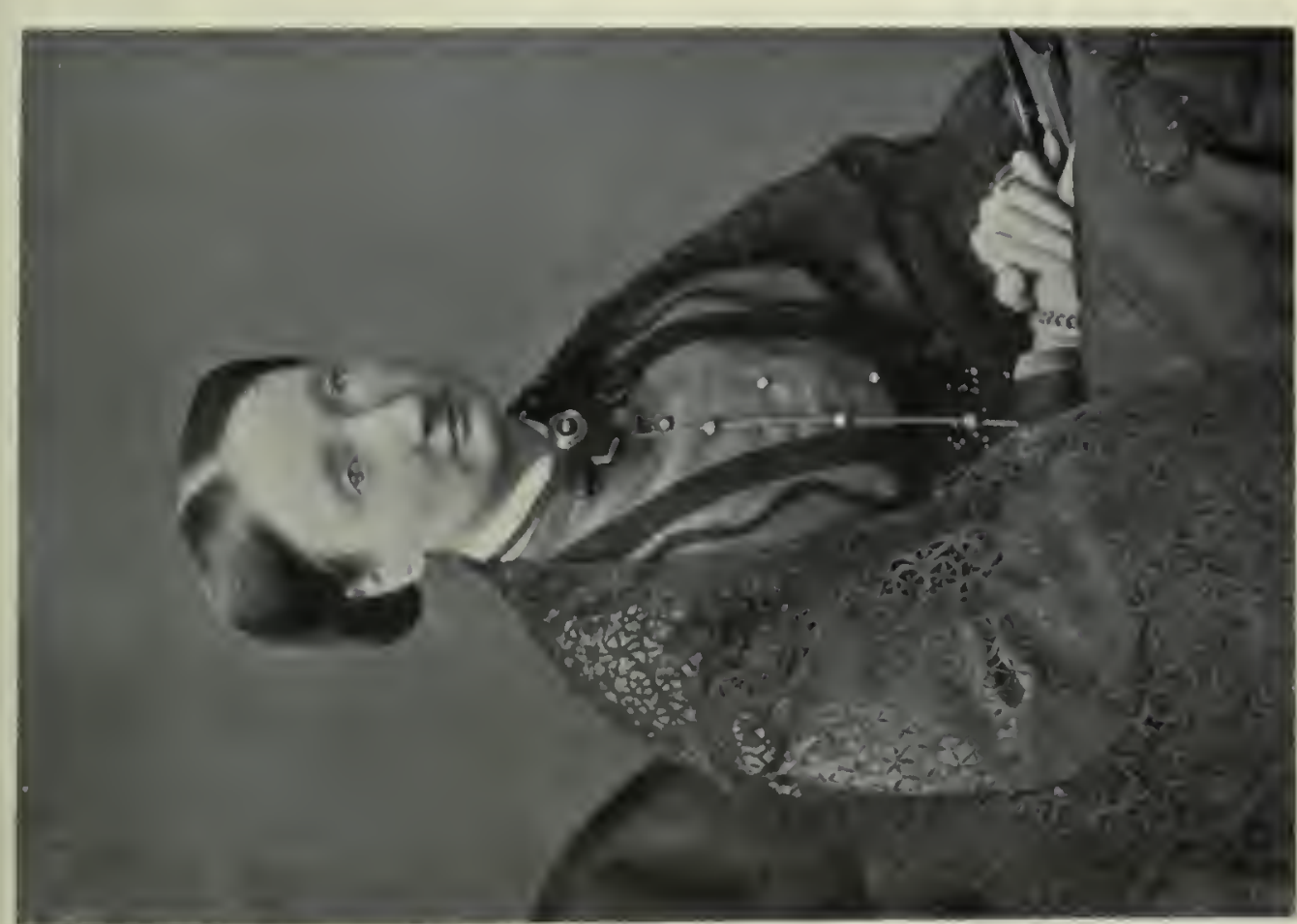

ב⿱ 
$242^{k}$ 
Plate IAII
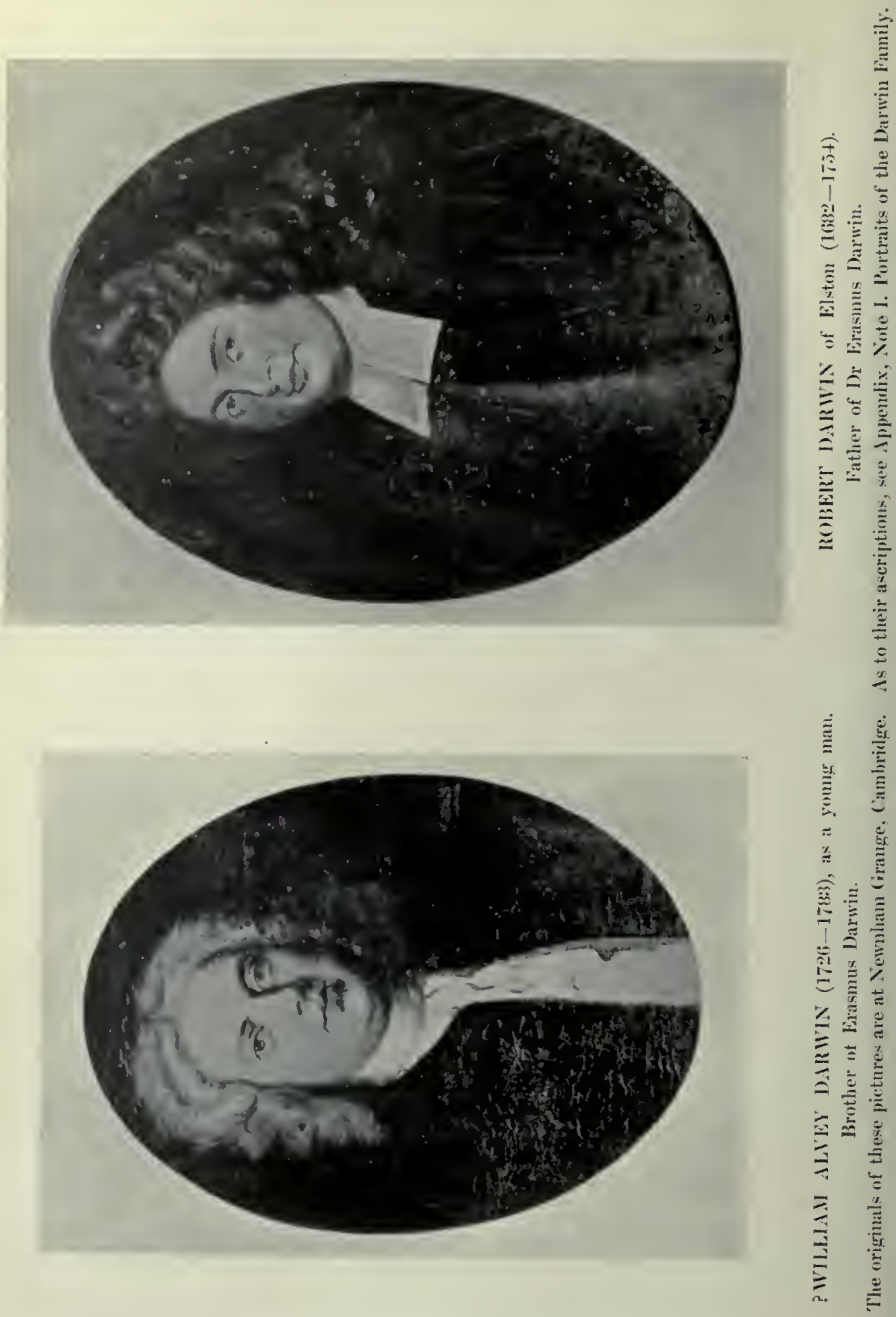


\title{
APPENDIX
}

\author{
NO'TE I
}

\section{Portraits of the Darivin Family}

Porrraits of the more immediate aneestors of Charles Darwin and Francis Galton exist at Creskeld Hall, the seat of Franeis Darwin, Lsq., and at Newnham Crange, Cambridge, formerly the home of Sir George Howard Darwin. Of tho pietures at Creskeld, the most noteworthy are those of Robert Darwin (1682-1754) supprosed to be by Riehardson about 1717, and of his tinee sons: Willian Alvey Darwin (17261783) by Wright of Derby, Robert Waring Darwin (1724-1816) aged 51, painted hy John Borridge, 1775, and Ernsmus Darwin (1731-1802), painted hy Wright also. See our Plates VI, VI $I^{\text {bis }}$ and VI ${ }^{\text {ter. }}$ I have heartily to thank Colonel C. W. Darwin for photographs of the pictures of the elder and younger Robert, and Mr William Erasmus Darwin for a photograph of that of William Alvey Darwin. The general resemblanee to Erasmus of these portraits is striking.

Some of the Darwin portraits at Elston Hall were sold by Willian Brown Darwin, and in part have been repurehased by inembers of the family. Sir Franeis Sachererell Darwin had a eony made of the portrait of his grandfather, Rolert Darwin, and he further purehased, ahout 1850, from a dealer in Newark, a Darwin portrait with which he had been familiar in his youth as part of the Fiston colleetion. These two portruits rescenderl to his grandson, Saeheverell Darwin, by whom they were left to Sir George Howard Darwin. They passed for many years tirditionally as those of Robert 1)arwin (1682-1754), and of his father, William Darwin (1655-1682), and photographs of them formerly in the possession of Sir Franeis Galton are so entitled. An exanination of the photographs eonvineed me, however, that the portrait of the so-called William Darwin must be of a later date than that of Robert Darwin, and eould not possibly represent his father. By the kindness of Larly Darwin I was enabled to examine botls pictures at Newnham Grange, and also to see various eorrespondence eoneerning then. Sir George Darwin, I then learnt, had himself felt in doubt as to the William Darwin portrait. The Robert Darwin portrait is rightly aseribed and its ascription agrees with that of the original at Creskeld; the eopyist has, however, lost something of the delieaey of the original. The history of the "William Darwin" pieture is very definite; it includes a written statement by Reginald Darwin' as to his father, Sir Franeis, finding the pieture at Newark, and its being then identitied as "William Darwiu." The Direetor of the National Portrait Gallery has most kindly examined a photograph of this

1 Letter to George Howard Darwin, Esq., Nov. 5, 1890, and also a footnote to a MS. memoir of the Darwins in the possession of the Rev. Darwin Wimot. 
"William Darwin" for me, and he dates the painting from the wig as belonging to the periorl 1730 to 1745 . 'The only "Williams" possible are therefore William Darwin of Cleatham (1681-1760), elder brother of Robert Darwin and uncle of Erasmus Darwin, - who would have been 49 in 1730 and rather old for the portrait-Willian Morgan Darwin, his son (1710 - 1762) - who would have been much the right age, but little likely to have a portrait at Elston-and William Alvey Darwin (1726-1783), as a very young man. The latter is the only alternative that seems probable, and the portrait is not wholly unlike Wright's portrait of a later date. It seems therefore reasonalble to aseribe this "William Darwin" portrait to William Alvcy Darwin although probably no certainty will ever now be possible. The Newnham Grange portraits are reprodueed on Plate XLII.

There is a miniaturc at Creskeld Hall of Ann Lascelles, that is, Ann Waring (1664-1722), whose first husband was William Darwin (1655-1682), the mother of Robert Darwin (1682-1754), and grandmother of Erasmus. $\Lambda$ portrait of the Rev. John Darwin (1730_1805), another brother of Erasmus and Rector of Elstonartist and date unknown-is at Elston Hall. Finally wc may note that there exists in Mr William E. Darwin's possession a very fine portrait, also said to be of a "William Darwin." This portrait, an undoubted Romney, is dated by the Director of the National Portrait Gallery $1780-1783$; it represents a very young man. There appears to be no "William Darwin" of this date; and the only Darwins at all of an appropriate age would be the sons of Dr Erasmus Darwin by his first wife. The portrait bears no marked resemblance to Erasmus or Robert Waring, nor is there any kuowledge of a portrait of Charles. Its history before purchase appears to be unknown. The ditliculties that have arisen in this case may emphasise the importance of returning to the good old custom of painting on the canvas itself the name of the subject.

\section{NOTE II}

\section{On the Howard Ancestry of Charles Darwin}

(See Pedigree Plate E)

While working on the Darwin side of Francis Galton's pedigree, I came across a good deal of material bearing on the noteworthy ancestors of Charles Dirwin, and it occurred to me that, as it might be many years beforc any one else again went through the same material, it would be worth while forming a pedigree of the noteworthy ancestors of Charles Darwin. Accordingly I detcrmined to put together a perigree for Charles Darwin similar to the one already issued by the Galton Laboratory for Francis Galton. In this task I have received great assistance from letters to me of the late Sir George Howard Darwin touching on points I had asked him about witl regard to the latter pedigree, and referring to papers in his possession bearing on family history. Through the kindness of Lady Darwin and Mr. William Erasmus Darwin and with the permission of Mr Charles Galton Darwin I have been able to examine a variety of documents bearing on the matter; the most valuable of these documents were drawn up many years ago by Erasmus Darwin, son of Dr Erasmus Darwin; he must have had a very extended antiquarian and historical knowledge of genealogical faets, which more than a century 


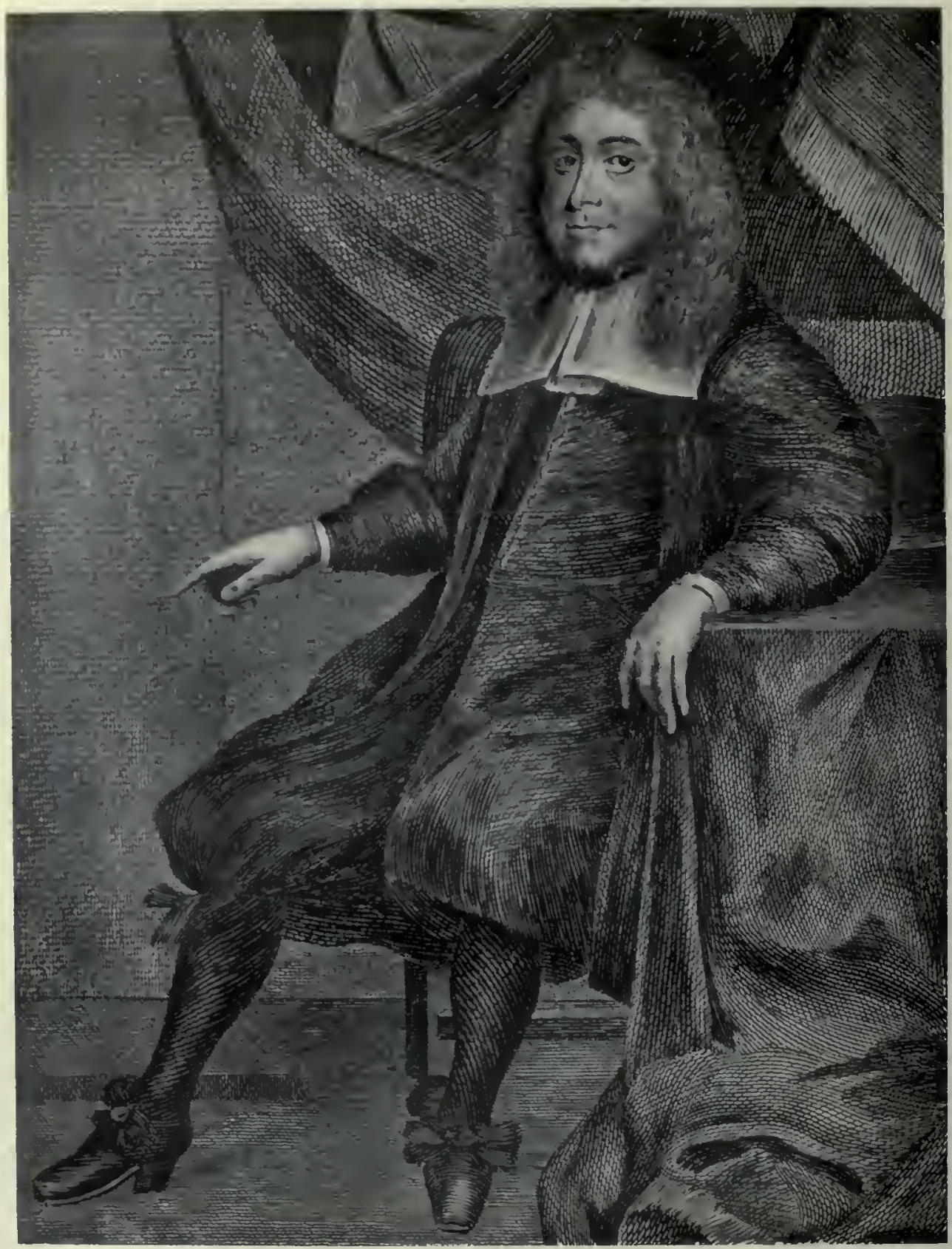

THOMAS FOLLY (1617-167\%).

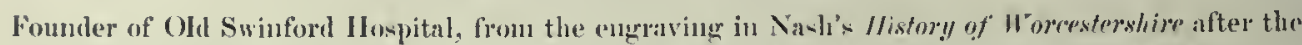

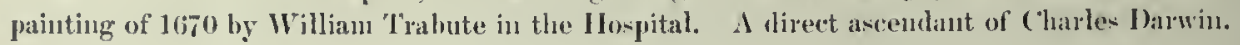


ngo ${ }^{1}$ was much lauder to nequire than at present. Ilis nccurmey is often grenter clan that provided in the more claborate perligrees of the present clny. I have harl, of eourae, to judge occasionally between conflicting statements, lut if tho realer finds uny preligrero differs at points from otler versions, it has not heen dono without inguiry and considerntion. It is impossible here to defend in dotail tho version actually providesl, of conrse the present work differs absolutely in eharacter from the oxccllent, privately printerl, Pedligree of the Fumily of Dururin, 1888, compiled by the Sumersot llermld, H. Farnhan Burke. The object of that work was to trace as completely as possible all the descendants of William Darwin of Marton (who died c. 15.42) without regarl in their achievements. The scope of the present pedigree is to follow back from Charles Darwin himself those lines which lead us to persons noteworthy in the listory of this country, or noteworthy from the standpoint of Europenn history. It is neelless to say that in a certain sense such a pedigree cannot be complete. Further resenrch would lor certain to lead us to still further instances of notewortly men or women. Incerd to keep the pedigree within anything liko rensonable bounds I have laul to indicate occasionally only final ancestors, and in other cases to entirely onit lines I perfectly well knew to be of distinction, but for which no spaco was available.

The reader who studies this pedigrec nlongside that of Francis Galton will lee struck with many similarities, but some murkerl differences. The turning point, of course, lies in the Howard marriage of Erasmus Darwin. That inarringe brought into the larwin stock the sound conmercial energy of the Foleys (see Plate LXIJT), who like Galtons aurl Farmers had amassed large wealth by iron-foundries. It gave also to the Darwin stock their share of aristocratic and ultimately royal bloorl through Pagets and Deverenx, an aequisition which the Galtons had made through the Barclays; it supplied also a pleasure pursuing element in Lettice Knollys and Penelope Devereux, which may be paralleled in the Colyear strain of Francis Galton; but it failed to provide anything of the strong religious nature that we find the Quakers contributing to Francis Galton's stock. Wr. largely miss tho the strong arlmixture of Scottish bloor, thongh pussibly the Butlers, de Burghs and Fitzgeralds may supply Celtic imagination. It is of interest in note that Galton and Jarwin were linkerl together by common bloorl in a variety of ways wholly independent of Erasmus Darwin. I should not wish the reader to look 11 pon a pedigrce like the present as an amusing tour de force. I think, on the contrary, that it illustrntes a principle expressed by Galton himself on more than one occasion, namely that thoso who have chiefly made the history of this country, we nay indeed say of liurope, fall into relatively few strains and these strains are closely linked together by bloml relationship.s?. Jistinguished leaders of men-judges, Spenkers of the Honse of Commons, leaders of commerce, warriors, cliplonatists, and men of affairs-are all there in the backgrouml and linkerl by ties of blood with the modern leaders of men-the originators of ideas which govern human progress-with men like Darwin nud Galton.

I have not rcproduced fully Mary Howard's immediate relntives. They belonged to a strain almost as plysically delicate as the Buttons (see p. 36 above). Charles Hownrd, Mary Howard's father, died at 64 , her mother at 40 , their daughter Flizabetl liverl

1 His single pedigrees of various lines do not reach back to the same clistant ancestry as inine do, but they have been very helpful.

? See the quotation from a letter of Galton's to Suture given on 1). 6 nlove. 
three years, Penelope one year, Mary herself lived to be thirty, his son Charles died at 48 years, his daughter Francus lived six years and his son Thomas only a few months. The Howard line has heen solely preserved through the one child of Mary, Robert Waring Darwin, that survived to have children, and through her brother's child, Mary Ann Howard, who married Sir Robert Wilnot of Osmaston. In botl these lines there has been noteworthy achievement.

Thave filled in at the hottom of the peligre two connections of some interest, namely, first the pedigree of the Earles of Heydon (sen Plates LXIV to IXVVT) as far as kunwn to me, and seeondly a perligree showing how the Sacheverells, through the Warings, link Darwins, Poles and Howards together. It has been suggested that Erasmus Darwin met Mrs Pole, his second wife, solely as a medical attcndant. I think there was a recognised Sacheverell relationship. In the first place Charles Howard, grandfather of Dr Erasmus Darwin's wife, made Mary Sacheverell, the wife of the famous Dr. Henry Sacheverell, an executrix of his will. This lady was the sister of Erlward Wilson, a former hailiff and (1687) mayor of Liehfield, and is said to have been a first cousin of Charles Howarl's wife, Mary Bromley. She tirst married George Sacheverell, High Sheriff of Derbyshire, 1709, and sccondly his distant relative, the funous Dr Henry Sachevereli. Elizabeth Collier's first husband, Edward Sacheverell Pole, was a son of Elizabeth Sacheverell of Morley. Elizabeth Sacheverell and Erasinus Darwin were distant cousins by common descent from Robert Waring, who died in 1662 . 'L'hus Erasmus Darwin probahly appears as medical adviser to the Poles owing to the Sacheverell or Waring relationship, and in marrying Mrs Pole as his second wife, he was linking himself to a family already eonnected by marriage with both Warings and Howards. I am inclined to take the view that Erasmus Darwin gave the name of Francis Sacheverell to his second son by Elizaheth Pole, not after her first hushand, but after the fanily, which itself dying nut, had yet linked lyy intermarriages Darwins, Wilmots, Poles, Howards and Waringrs.

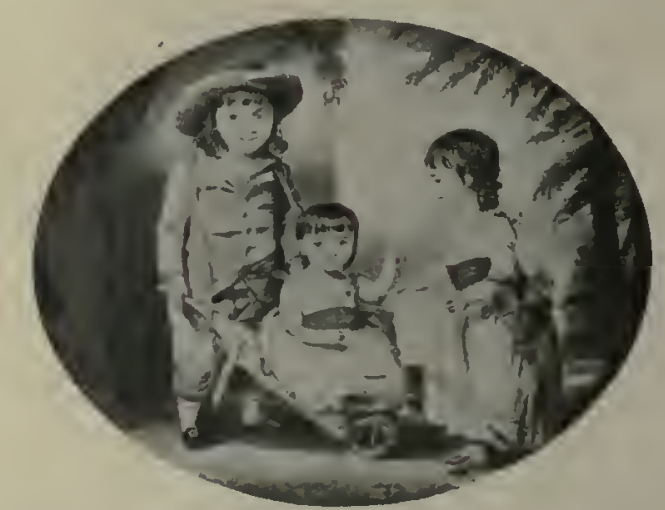

Lidward, Emma and Violetta Darwin (mother of Francis (ialton, on the right), children of Erasmus and Elizaheth Darwin, Derby, 1800. From a pieture in the possession of $\mathrm{Mr}$. Wheler (ralton at ('laverdom.

CAMBRIDGE: PRINTED BY JOIN CLAY, M.A. AT THE UNIVERSITY PRESS. 
Mute $1 . \mathrm{X} / \mathrm{P}$

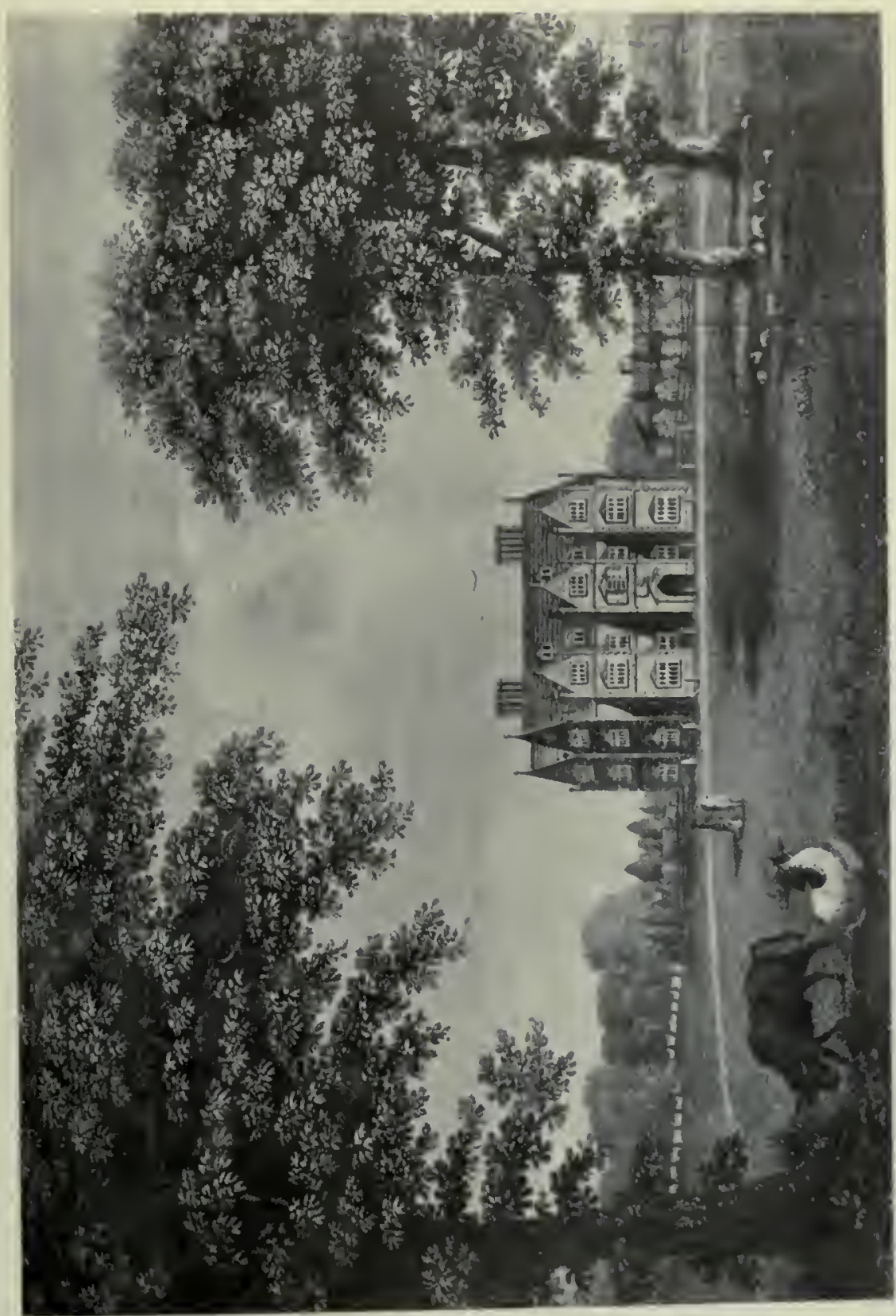



$1811161.17^{\circ}$

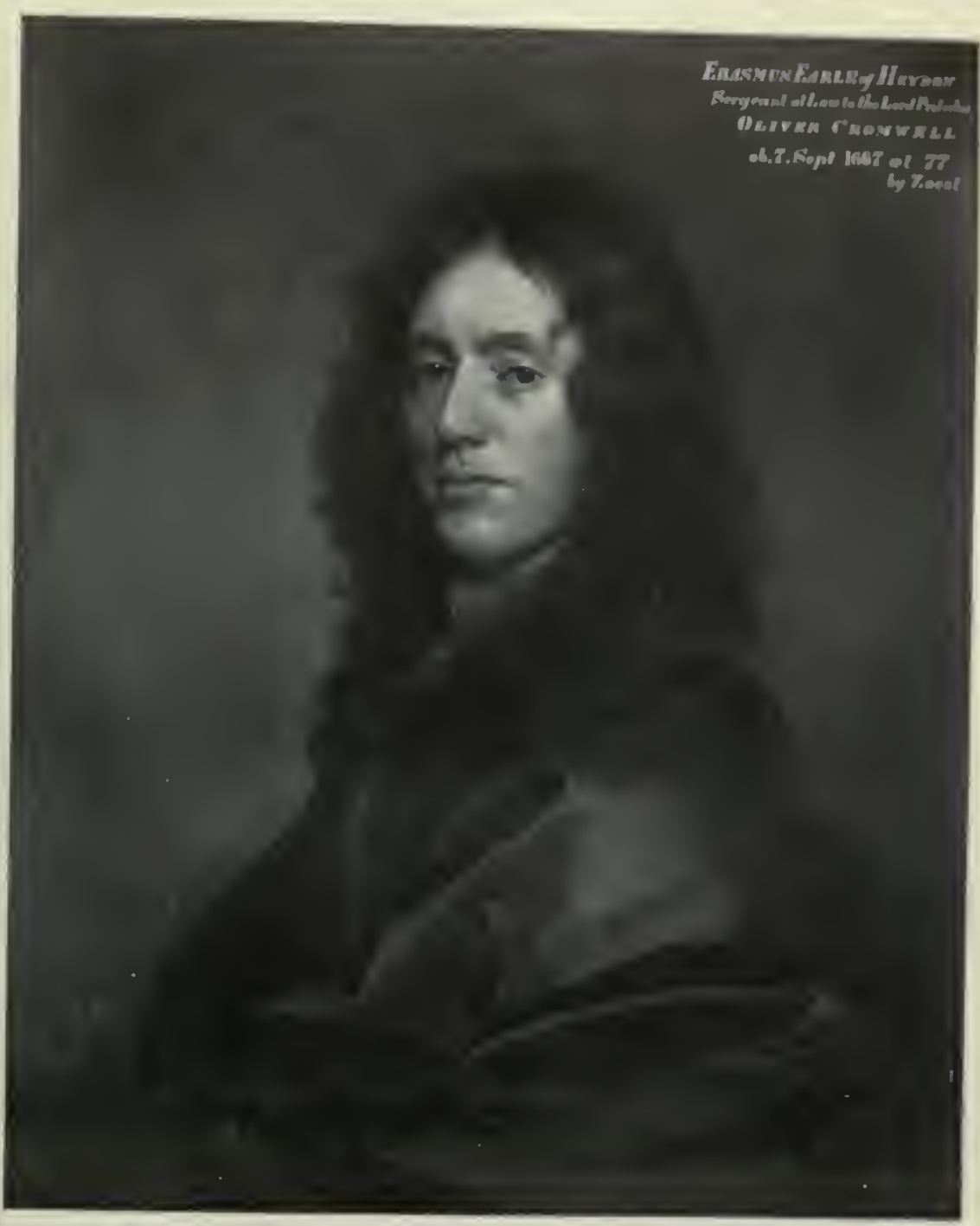

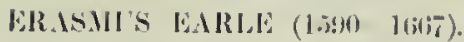

Great-great-grandfather of linamus Darwin. From the portmit ly Koest at Ileydon Hall in the possession of $\mathrm{W}$. D). Bulwer, Hisy. 

Plote I.II'I

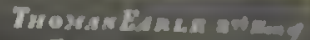

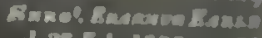 d.21.Dos I0AB of C}

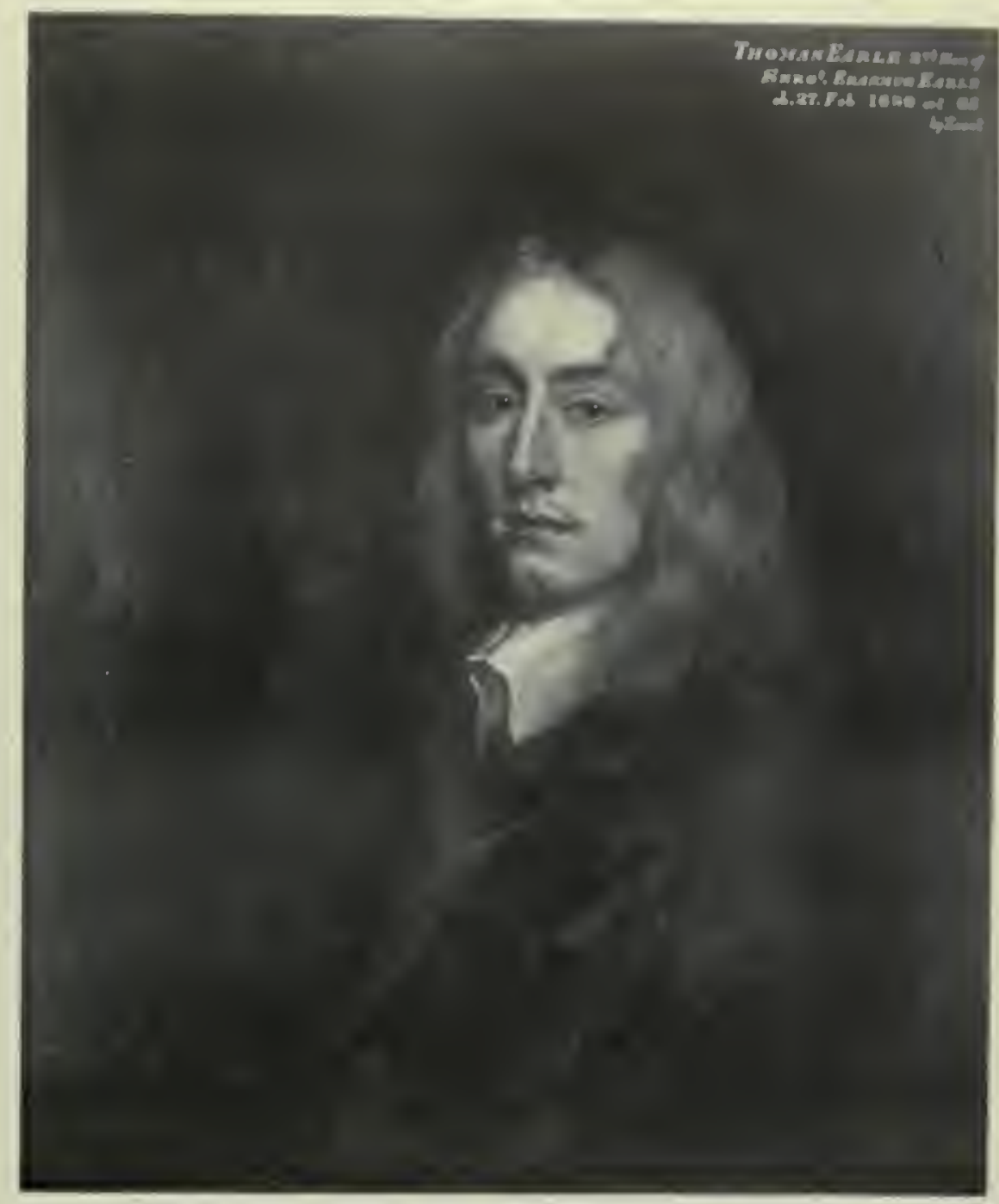

TIIOMAS EARIA (I6:-1-1683!1).

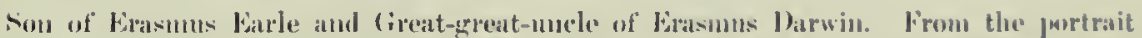

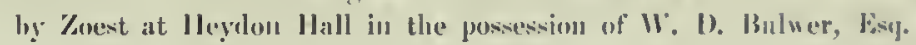





\title{
BIOMETRIKA
}

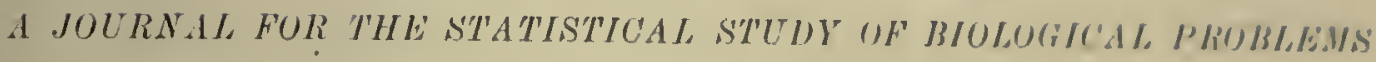

FOUNDED $13 Y$

\section{W. F. R. WELDUN, KARI PEARSON ANI FRANCIS GAITON}

G.)ITED $\mathrm{BY}$

\section{KARL PEARSUN}

\begin{abstract}
Biometrike appear's abuut four times a yonr. A whme emtaining nivut 500 pages, with plates and tables, is issued anmally. The sulsscription price, pravalle in advanee, is 30 s. net $(\$ 7.50)$ per volume (1ost free); single parts $10 \mathrm{~s}$ net $(\$ 2.50)$ each. The current volume is Volume $\mathrm{X}$, the first pert of which has just apperred.
\end{abstract}

Volumes 1-1X (1902-1913) cumplete, 30s. net per volume; bound in luekram, 34s. fid. net per volume. Till further notice new subseribers to Biometrike may obtain Vols. 1-IX together for \&10 net, or in buekram for . $\$ 12$ net.

some iden of the seope of the jommal naty loe ohtained from the following list if topies which have been disenssed annmg others in the first nine volumes of Bionetrike :-

Cranionetry. Prehistoric Figylutian Crania (Fancett), 17th century English Crania (Macdonell), IJoug and Round Barrow Skulls (Schiister), Negro Cranin fron (taloon and Congo (Jenington), Pigmy ('muia (Sinith), Cranial Tyje Contoms, Internal Cupacity from External Measurements, Study of Special Cranial Bones, Namal Contours, Craniological Notes, ctc., ete.

Anthopometry. Of Criminals in New sonth Wrales and in Eingland (Powis, Macdonell, etc.), of Scottish lusane (Tueher), Survey of Sehool Children of Scotland (Tocher), Influence of l'ignentation on Disease, Measurements of Brain IVeight (Pearl, Gladstone, Blakeman), Correlation of Hair, Eye Colour, and Age (Pear'son), Expectation of Life in Ancicnt Egypt and in Rome, Relation of Intelligence to Physical Claracter's (Pearson), Correlation of Bones of the Hand, Heasureruents from Oxford and Cambridge Anthropometric Laboratories, Fertility and Degeneracy, Anthropometric and obstetrie Studies of the fenale Pelvis, ete., etc.

Medicine. Vaceination and Recovery, Heasure. ments of Severity of Disease, Cancer and Diabetes, Multiple cases of discase, 'Cancer Houses,' Incidence of Syphilis, Mlosquitos and Malaria, Number of
Erythrocytes and the Altitude, split-fixst Deformeties, Albinism-histological and chassificntory, Antityphoinl hoculation, the Oprensic ludex, Weights of liuman Viscers, Pielalds, otc., etc.

Ilevedity. Of Durntion of Lifo in Mlu, of pertility, of Health, of 1'hysical and Mental Charnetery, of Eyo and Skin Colour sund of Special Deformition of Cont Colour in mice, in greyhonnds, in eattle and horses, of size of litter in mice and sows, of proxlue:tion of Intter-fit in colv, of eharacters in shirley Poppy and in Benus, Payners on .Menclelism, Iaw if aneestmal Heredity and determinumtal Therorjes, cte., cte.

Therearemuncrous papersunstatistical purblens in \%oology and Botany dealing with satural selection, variation and growth in tadpole, tront, cucken, wisy ps and lees, carthworms, paranecia, telmites, domestic

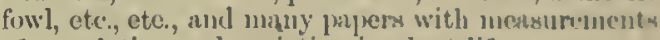
of correlation and variation in plant life.

Prantice and Theory of Stutistics. Bimmetrike

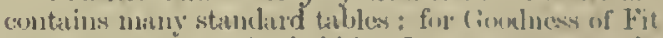
(Eldertou), of the Prolability Integral (Nheppural), Powers of Natural Nimbers, I'-finctions, (irmler and Deviates, of Prolable Errors, Tetrachoric Functions and incomplete. Moment Functions ete., oft: There are many papers on the 'Theory of Correlation, of Association and of rumlom Sampling, (n) lnter. polation, the comstruction of Jortality mul sickness Trables, lndex-distributions, etco, ote. Aneng thowe who have contributed are A. O. Powy, W. li. R. Weldon, E. Warren, O. 11. Latter, $\mathrm{F}$. Ludwig, IV. R. Maedonell, Francis (ialton, Karl Pearion, IV. F. Sheppard, L. H. Schüister, David Ilerun, IV. 1. and E. II. Elderton, (i. Lüncker, R. Penrl, G. II. Shull, Geof. Snith, Ilajor (ireenwerel, \&. II. Jenkinson, F. Y. Edgeworth, J. F. Tucher, (. 1). Faweett, A. Lee, A. K. Galloway, h. J. Gladstone, J. Brownlee, $\%$ de Helguerv, R. C. Pumet, Edmund Gain, F. E. Lutz, k. T'velıepourkowsky,

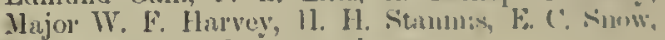
J. A. Harris, and inany others.

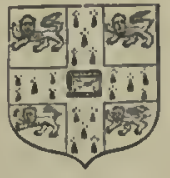

\section{Cambridge University Press}

C. F. Clay, Manager

Lundun: Fetter Lane, E.C.

Chicano: 'The University of Chicrgo Press 
THE FRANCIS GALTON LABORATORY FOR NATONAL ELUENTC

\section{EUGENICS LABORATORY LECTURE SERIES}

1. The Scope and lmportance to the State of the Science of Nitional Lugrenies. By Kan1. Peansos, F.R.S. Issieel. Third Edition. Price ls. net.

IT. The Grountwork of Eugenies. By Kan1, Pkarsox, F.R.'. Iswed. Price 1.s. net.

111. The Relative Strength of Nurture ant Nature. By Ernit M. lisistrox. Issued. Price 1s. net.

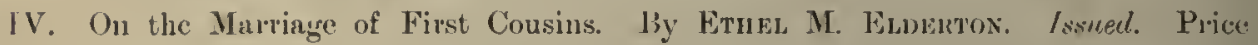
1s. net.

V. The Problem of Practical Eugenics. By KanL PEassox, F.R.s. Issued. Second Edition. Price 1s. net.

VI. Nature and Nurture, the Problem of the Future. By Kak, Pransos, F.R.s. Issileed. Price 1 s. neet.

VII. The Academic Aspect of the Science of National Eugenics. By KanL Pratsox, F.R.S. Issued. Priee 1s. net.

VIIT. Tulscrculosis, Heredity, and Enviromment. By Kan Planson, F.1R.S. Issmed. Price 1s, net.

1X. Darwinism, Medical Progress, and Eugenios: The: Cavendish leeture, 191. By Kakl Pealsox, F.R.S. Issued. Price 1s, net.

\section{QUESIIONS OF THE DAY AND OF THE FRAY}

I. The Influence of Parental Alcoholism on the Physique and Ability of the Offipring: a Reply to the Cambridge Ecomomists. By Kard Pliaksox, F.I.S. lssued. Price Is, net.

1I. Mental Defect, Mal-Nutrition, and the 'Teacher's appreciation of Intelligence: a Reply to Criticisms of the Memoir on "The Influence of Defective Physique and Unfavourable Home Environment on the Tntelligence of School Children.' By David Heros, D.Sc. Issued. Price 1s. net.

1II. In Attempt to correct some of the Nisstatements made by Sil Victur Horshex; F.R.S., F.R.C.S., and MaRY D. STURge, M.D., in their Criticisms of the Galton Laboratory Memoir: 'A First Study of the Influence of' Parental Alcoholism,' de. By Karl Pearson, F.R.S. Issued. Plice 1s. net.

1V. The Fight aganinst Tuberculosis and the Death-1ate from Phthisis. By K.ık. Pearson, F.R.S. Issued. Price 1s. net.

V. Soeial Problems: Their Treatment, Past, Present, and Future. By KARL Pearson, F.R.S. Issued. Priee 1s. net.

VI. Eugenics and Public Health: Lecture to the York Congress of the Royal Sanitary Institute, By Karr Pealson, F.R.S. Issued. Price ls. reet.

VI1. Mendelism ind the Prohlem of Mental Detect. I. A Ciriticism of Recent American Work. By Darid Herox, D.Sc. Issued. Price 28. net.

VIII. Mcndelism and the Problem of Mental Defect. II. The Continuity of Mlental Defect. By Karl Pearsoy, F.R.S., and Gustay A. Jaknerholm. Is*merl. Price 1s. net.

Published by Dulau \& Co., Ltd., 37, Soho Nquare, London, W., from whom complete lists of Galton Laboratory Publications may be obtained. 


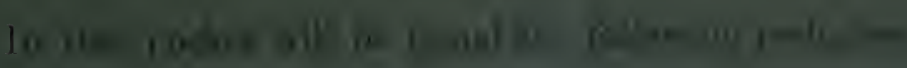

is

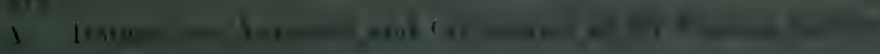

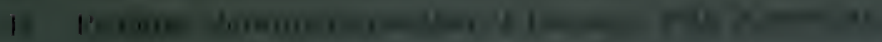

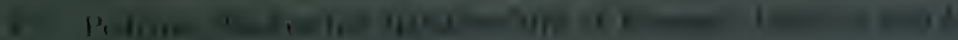

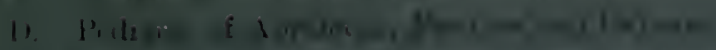

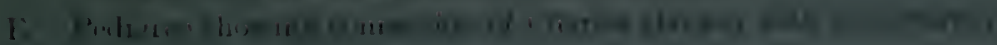

\section{The Chances of l beath and nollor Studices in Evolution}

li) hill, I'I IIV, I I, S

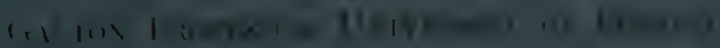

$101 \quad 1$

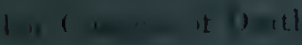

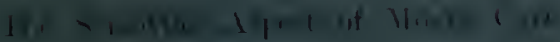
IR i i

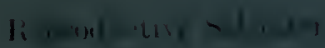

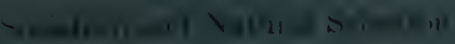

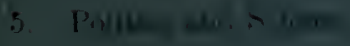

h) Li... In

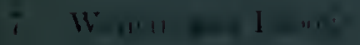

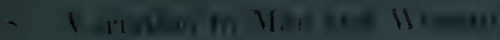

$$
\text { Ri. }, \quad r+27^{\prime} \cdot
$$

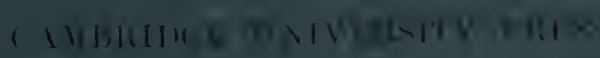

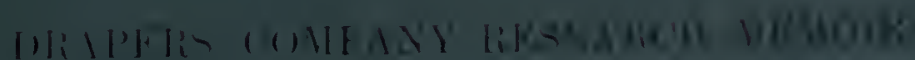

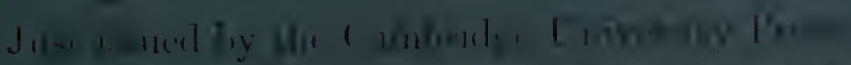

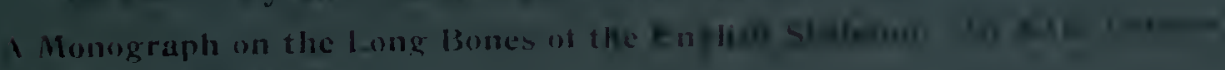

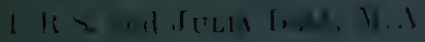

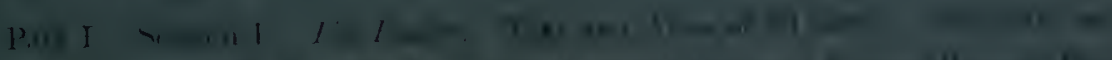

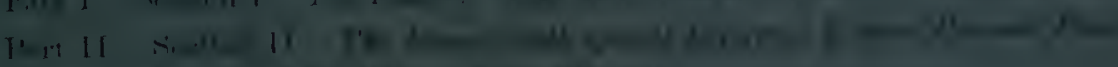

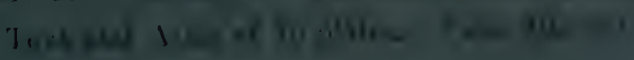

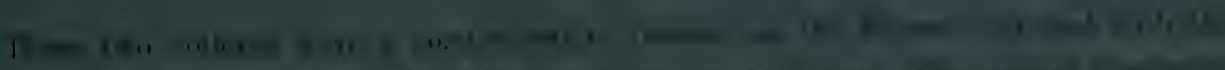

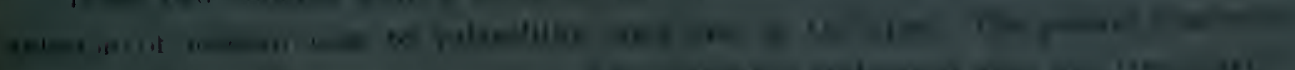

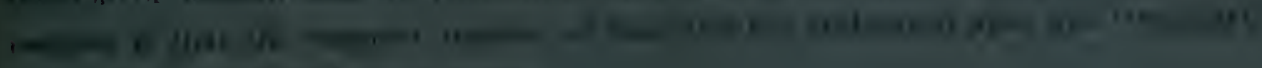

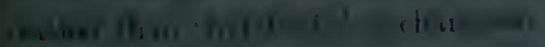



?

$0 .+1$
$i,+\infty$ $+2+x+8$ 


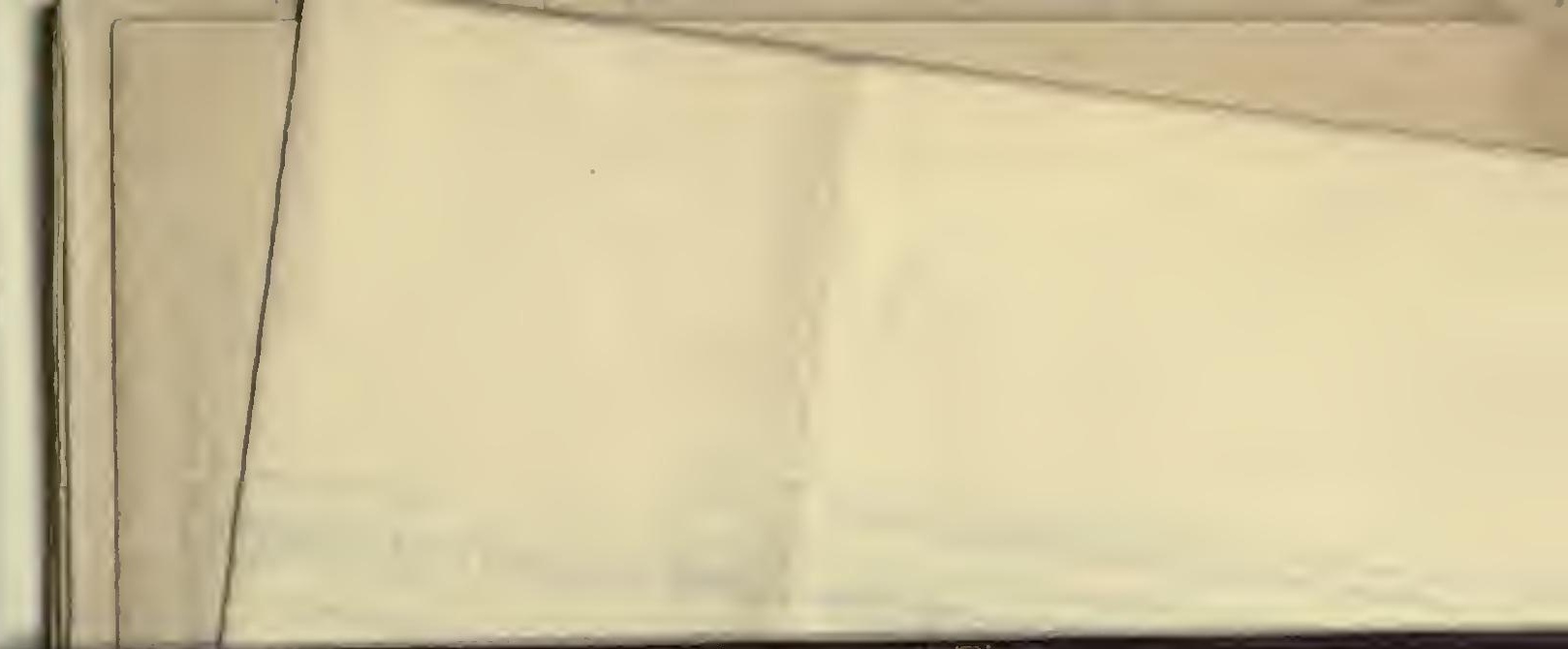

\section{PLEASE DO NOT REMOVE} CARDS OR SLIPS FROM THIS POCKET

\section{UNIVERSITY OF TORONTO UBRARY}

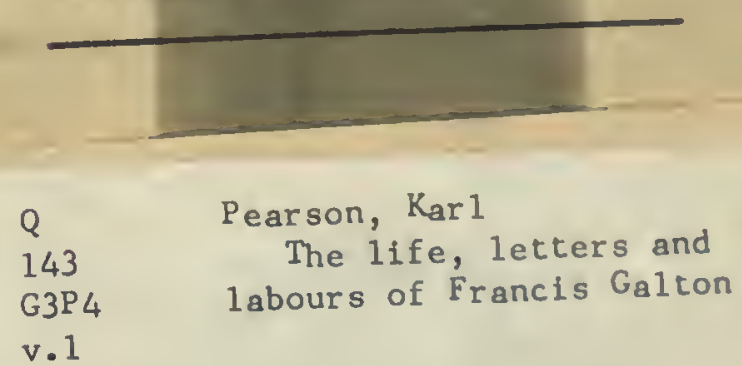

P\&ASci 
